ҚАЗАҚСТАН РЕСПУБЛИКАСЫ БІЛІМ ЖӘНЕ ҒЫЛЫМ МИНИСТРЛІГІ МИНИСТЕРСТВО ОБРАЗОВАНИЯ И НАУКИ РЕСПУБЛИКИ КАЗАХСТАН MINISTRY OF EDUCATION AND SCIENCE OF THE REPUBLIC OF KAZAKHSTAN

Қорқыт Ата атындағы

Қызылорда университетінің

ХАБАРШЫСЫ

\author{
ВЕСТНИК \\ Кызылординского \\ университета имени Коркыт Ата
}

\title{
BULLETIN \\ of the Korkyt Ata Kyzylorda University
}

№3 (58) 2021 
ISSN 1607-2782

Республикалық ғылыми-әдістемелік журнал Республиканский научно-методический журнал

Republican Scientific and Methodical Journal

1999 жылғы наурыздан бастап шығады

Выходит с марта 1999 года

Published since March 1999

№3 (58) 2021

Жылына төрт рет шығады

Выходит четыре раза в год

Published four a year

Корқыт Ата атындағы Қызылорда университетінің ХАБАРШЫСЫ

\author{
ВЕСТНИК \\ Кызылординского университета имени Коркыт Ата \\ BULLETIN \\ of the Korkyt Ata Kyzylorda University
}

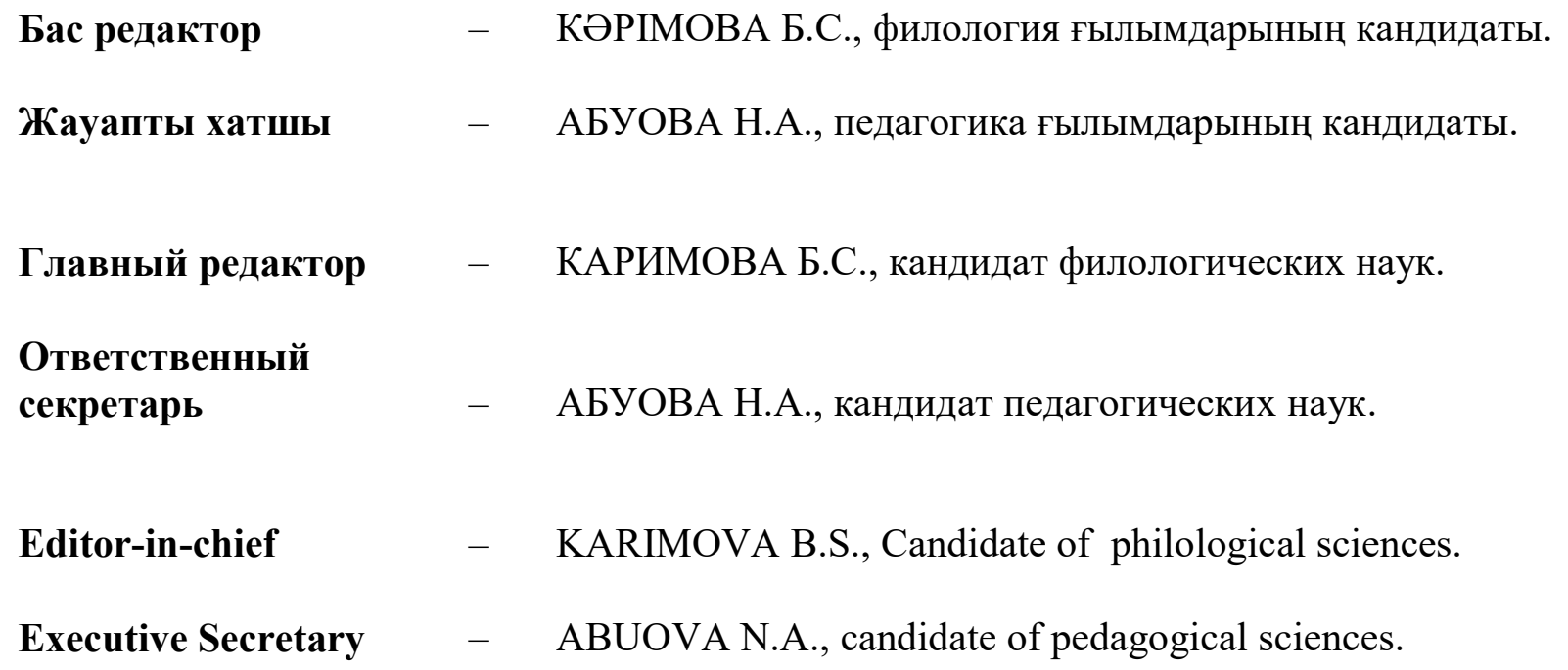




\section{АУЫЛ ШАРУАШЫЛЫҒЫ ҒЫЛЫМДАРЫ СЕРИЯСЫ}

Л.А.Тохетова -жауапты редактор, ауыл шаруашылывы выльммдарының докторы, доцент

Редакция алқасы

\section{Ауыл шаруашылығы ғылымдары}

К.Н.Тодерич

Ш.С.Рсалиев

Б.А.Дуйсембеков

А.С.Рсалиев
$\mathrm{PhD}$, Тоттори Университеті, Жапония;

биология ғылымдарының докторы, доцент, ҚР БҒМ ҒК «Қазақ егіншілік және өсімдік шаруашылығы ғылыми-зерттеу институты» РМК, Қазақстан Республикасы;

биология ғылымдарының кандидаты, доцент, «Агропарк Оңтүстік» ЖШС, Қазақстан Республикасы;

ауыл шаруашылығы ғылымдарының кандидаты, ҚР БҒМ ҒК «Биологиялық қауіпсіздік проблемалары ғылыми-зерттеу институты» ЖШС, Қазақстан Республикасы. 


\section{ЖАРАТЫЛЫСТАНУ, ТЕХНИКАЛЫК ҒЫЛЫМДАР СЕРИЯСЫ}

Н.О.Аппазов - жауапты редактор, химия вылымдарының кандидаты, профессор

\section{Редакция алқасы}

\section{И.А.Тайманов}

Ж.Искаков

Ә.Т.Төрешбаев

А.М.Мұхамбетжан

А.Р.Бурилов

С.Б.Любчик

Б.Ж.Джиембаев

H.O.Аппазов

Н.И.Ақылбеков

А.Е.Филонов

С.Т.Тулеуханов

А.М.Мыңбай P.Х.Курманбаев

Б.Б.Абжалелов

\section{1. Жаратылыстану ғылымдары}

\section{1.Физика-математика ғылымдары}

физика-математика ғылымдарының докторы, профессор, Новосибирск мемлекеттік университеті, Ресей Федерациясы; техника ғылымдарының кандидаты, доцент, Г.Дәукеев атындағы Алматы энергетика және байланыс университеті, Қазақстан Республикасы;

физика-математика ғылымдарының кандидаты, Қорқыт Ата атындағы Қызылорда университеті, Қазақстан Республикасы; физика-математика ғылымдарының кандидаты, Қорқыт Ата атындағы Қызылорда университеті, Қазақстан Республикасы.

\section{2. Химия ғылымдары}

химия ғылымдарының докторы, профессор, А.Е.Арбузов атындағы Органикалық және физикалық химия институты, Ресей Федерациясы; $\mathrm{PhD}$, профессор, Лиссабон Жаңа университеті, Португалия; химия ғылымдарының докторы, профессор, Қазақ ұлттық қыздар педагогикалық университеті, Қазақстан Республикасы; химия ғылымдарының кандидаты, профессор, «Ы.Жақаев атындағы Қазақ күріш шаруашылығы ғылыми-зерттеу институты» ЖШС, Қазақстан Республикасы;

$\mathrm{PhD}$, Қорқыт Ата атындағы Қызылорда университеті, Қазақстан Республикасы.

\section{3. Биология ғылымдары}

биология ғылымдарының докторы, профессор, Ресей ғылым академиясы Г.К.Скрябин атындағы биохимия және микроорганизмдер физиологиясы институты, Ресей Федерациясы; биология ғылымдарының докторы, профессор, әл-Фараби атындағы Қазақ ұлттық университеті, Қазақстан Республикасы;

$\mathrm{PhD}$, Назарбаев университеті; биология ғылымдарының кандидаты, қауымдастырылған профессор, Қорқыт Ата атындағы Қызылорда университеті, Қазақстан Республикасы;

биология ғылымдарының кандидаты, Қорқыт Ата атындағы Қызылорда университеті, Қазақстан Республикасы. 


\section{ЖАРАТЫЛЫСТАНУ, ТЕХНИКАЛЫК ҒЫЛЫМДАР СЕРИЯСЫ}

А.Ж.Сейтмұратов - жауапты редактор, физика-математика вылымдарының докторы, доиент

\section{Редакция алқасы}

\section{2. Техника ғылымдары және технологиялар}

\section{1. Кұрылыс}

Н.А.Машкин

Қ.А.Бисенов

C.А.Монтаев

С.С.Удербаев

А.И.Дивеев

М.Ж.Айтимов

Н.Б.Конырбаев

И.С.Ибадулла техника ғылымдарының докторы, профессор, Новосибирск мемлекеттік техникалық университеті, Ресей Федерациясы; техника ғылымдарының докторы, профессор, Қорқыт Ата атындағы Қызылорда университеті, Қазақстан Республикасы; техника ғылымдарының докторы, профессор, Жәңгір хан атындағы Батыс Қазақстан аграрлық-техникалық университеті, Қазақстан Республикасы; техника ғылымдарының докторы, доцент, Қорқыт Ата атындағы Қызылорда университеті, Қазақстан Республикасы.

\section{2. Ақпараттама, есептеу техникасы және басқару}

техника ғылымдарының докторы, профессор, Ресей халықтар достығы университеті, Ресей Федерациясы;

$\mathrm{PhD}$, КР Президенті жанындағы мемлекеттік басқару академиясының Қызылорда облысы бойынша филиалы, Қазақстан Республикасы; $\mathrm{PhD}$, Қорқыт Ата атындағы Қызылорда университеті, Қазақстан Республикасы.

$\mathrm{PhD}$, Қызылорда облысы әкімдігі «Ақпараттық технологиялар орталығының» директоры, Қазақстан Республикасы 


\section{БІЛІМ, ГУМАНИТАРЛЫК ЖӘНЕ ӘЛЕУМЕТТІК ҒЫЛЫМДАР СЕРИЯСЫ}

Л.А.Казбекова - жауапты редактор, экономика вылымдарының кандидаты, доцент

Редакция алкасы

П.Н.Осипов

Н.Ю.Фоминых

Г.С.Саудабаева

Ш.М.Майгельдиева

С.К.Абильдина

О.Оджал

Х.Ч.Касапоглу

Р.С.Тұрысбек

К.С.Сарышева

С.І.Садыбекова

Т.И.Кеншінбай

Ғ.Ә.Тұякбаев

\section{1. Білім}

1.1. Педагогика ғылымдары

педагогика ғылымдарының докторы, профессор, Қазан федералды университеті, Ресей Федерациясы;

педагогика ғылымдарының докторы, профессор, Г.В.Плеханов атындағы Ресей экономикалық университеті, Ресей Федерациясы; педагогика ғылымдарының докторы, профессор, Абай атындағы Қазақ ұлттық педагогикалық университеті, Қазақстан Республикасы;

педагогика ғылымдарының докторы, доцент, Қорқыт Ата атындағы Қызылорда университеті, Қазақстан Республикасы; педагогика ғылымдарының докторы, профессор, Е.А.Бөкетов атындағы Қарағанды мемлекеттік университеті, Қазақстан Республикасы.

\section{2. Гуманитарлық ғылымдар \\ 1.2. Филология ғылымдары}

филология ғылымдарының докторы, профессор, Қажы Байрам Вели университеті, Түркия Республикасы; $\mathrm{PhD}$, профессор, Қажы Байрам Вели университеті, Түркия Республикасы; филология ғылымдарының докторы, профессор, Л.Н.Гумилев атындағы Еуразия ұлттық университеті, Қазақстан Республикасы; филология ғылымдарының кандидаты, Қорқыт Ата атындағы Қызылорда университеті, Қазақстан Республикасы; филология ғылымдарының кандидаты, доцент, Қорқыт Ата атындағы Қызылорда университеті, Қазақстан Республикасы; филология ғылымдарының кандидаты, Қорқыт Ата атындағы Қызылорда университеті, Қазақстан Республикасы; филология ғылымдарының кандидаты, Қорқыт Ата атындағы Қызылорда университеті, Қазақстан Республикасы.

3. Әлеуметтік ғылымдар және бизнес, қызмет көрсету

\section{1. Экономикалық ғылымдар}

\section{Д.Н.Силка}

Ү.Ж.Шалболова

А.Ш.Абдимомынова

Н.С.Товма экономика ғылымдарының докторы, доцент, Мәскеу мемлекеттік құрылыс университеті, Ресей Федерациясы; экономика ғылымдарының докторы, профессор,Л.Н.Гумилев атындағы Еуразия ұлттық университеті, Қазақстан Республикасы; экономика ғылымдарының кандидаты, доцент, Қорқыт Ата атындағы Қызылорда университеті, Қазақстан Республикасы экономика ғылымдарының кандидаты, доцент, әл-Фараби атындағы Қазақ ұлттық университеті, Қазақстан Республикасы. 


\section{СЕРИЯ СЕЛЬСКОХОЗЯЙСТВЕННЫХ НАУК}

Л.А.Тохетова - ответственный редактор,доктор сельскохозяйственных наук, доиент

Редакционная коллегия

\section{Сельскохозяйственные науки}

К.Н.Тодерич $\quad \mathrm{PhD}$, Университет Тоттори, Япония;

Ш.С.Рсалиев доктор биологических наук, доцент, РГП «Казахский научноисследовательский институт земледелия и растениеводства» КН МОН РК, Республика Казахстан;

Б.А.Дуйсембеков кандидат биологических наук, доцент, ТОО «Агропарк Оңтүстік», Республика Казахстан;

А.С.Рсалиев кандидат сельскохозяйственных наук, ТОО «Научноисследовательский институт проблем биологической безопасности», КН МОН РК, Республика Казахстан. 


\section{СЕРИЯ ЕСТЕСТВЕННЫХ, ТЕХНИЧЕСКИХ НАУК}

Н.О.Аппазов - ответственный редактор,кандидат химических наук, профессор

Редакционная коллегия

1. Естественные науки

\section{1 Физико-математические науки}

\section{И.А.Тайманов}

Ж.Искаков

\section{А.Т.Турешбаев}

А.М.Мухамбетжан
А.Р.Бурилов

С.Б.Любчик

Б.Ж.Джиембаев

H.O.Аппазов

Н.И.Акылбеков

А.Е.Филонов

С.Т.Тулеуханов

А.М.Мынбай

Б.Б.Абжалелов

P.Х.Курманбаев доктор физико-математических наук, профессор, Новосибирский государственный университет, Российская Федерация; кандидат технических наук, доцент, Алматинский университет энергетики и связи имени Г.Даукеева, Республика Казахстан; кандидат физико-математических наук, Кызылординский университет имени Коркыт Ата, Республика Казахстан; кандидат физико-математических наук, Кызылординский университет имени Коркыт Ата, Республика Казахстан.

\section{2 Химические науки}

доктор химических наук, профессор, Институт органической и физической химии имени А.Е.Арбузова, Российская Федерация; $\mathrm{PhD}$, профессор, Новый университет Лиссабона, Португалия; доктор химических наук, профессор, Казахский национальный женский педагогический университет, Республика Казахстан; кандидат химических наук, профессор, ТОО «Казахский научноисследовательский институт рисоводства им. И.Жахаева», Республика Казахстан;

$\mathrm{PhD}$, Кызылординский университет имени Коркыт Ата, Республика Казахстан.

\section{3 Биологические науки}

доктор биологических наук, профессор, Институт биохимии и физиологии микроорганизмов им. Г.К.Скрябина, Российская Академия наук, Российская Федерация; доктор биологических наук, профессор, Казахский национальный университет имени аль-Фараби, Республика Казахстан; $\mathrm{PhD}$ доктор, Назарбаев Университет; кандидат биологических наук, Кызылординский университет имени Коркыт Ата, Республика Казахстан; кандидат биологических наук, ассоциированный профессор, Кызылординский университет имени Коркыт Ата, Республика Казахстан. 


\section{СЕРИЯ ЕСТЕСТВЕННЫХ, ТЕХНИЧЕСКИХ НАУК}

А.Ж.Сейтмуратов- ответственный редактор,доктор физико-математических наук, доиент

Редакционная коллегия

\section{2. Технические науки и технологии}

Н.А.Машкин

К.А.Бисенов

C.А.Монтаев

С.С.Удербаев

А.И.Дивеев

М.Ж.Айтимов

Н.Б.Конырбаев

С.И.Ибадулла

\section{1. Строительство}

доктор технических наук, профессор, Новосибирский государственный технический университет, Российская Федерация; доктор технических наук, профессор, Кызылординский университет имени Коркыт Ата, Республика Казахстан;

доктор технических наук, профессор, Западно-Казахстанский аграрно-технический университет имени Жангир хана, Республика Казахстан;

доктор технических наук, доцент, Кызылординский университет имени Коркыт Ата, Республика Казахстан.

\section{2 Информатика, вычислительная техника и управление}

доктор технических наук, профессор, Российский университет дружбы народов, Российская Федерация;

$\mathrm{PhD}$, филиал Академии государственного управления при Президенте Республики Казахстан по Кызылординской области, Республика Казахстан;

$\mathrm{PhD}$, Кызылординский университет имени Коркыт Ата, Республика Казахстан.

$\mathrm{PhD}$, директор Центра информационных технологий акимата Кызылординской области. Республика Казахстан. 


\section{СЕРИЯ ОБРАЗОВАНИЯ И ГУМАНИТАРНО-СОЦИАЛЬНЫХ НАУК}

Л.А.Казбекова- ответственный редактор, кандидат экономических наук, доцент

Редакционная коллегия

\section{1. Образование}

П.Н.Осипов

Н.Ю.Фоминых

Г.С.Саудабаева

Ш.М.Майгельдиева

С.К.Абильдина

О.Оджал

Х.Ч.Касапоглу

Р.С.Турысбек

К.С.Сарышева

С.И.Садыбекова

Т.И.Кеншинбай

Г.А.Туякбаев

\section{Д.Н.Силка}

У.Ж.Шалболова

А.Ш.Абдимомынова

\author{
Н.А.Товма
}

\section{1. Педагогические науки}

доктор педагогических наук, профессор, Казанский федеральный университет, Российская Федерация; доктор педагогических наук, профессор, Российский экономический университет имени Г.В. Плеханова, Российская Федерация; доктор педагогических наук, профессор, Казахский национальный педагогический университет имени Абая, Республика Казахстан; доктор педагогических наук, доцент, Кызылординский университет имени Коркыт Ата, Республика Казахстан; доктор педагогических наук, профессор, Карагандинский государственный университет имени Е.А.Букетова, Республика Казахстан.

\section{2. Гуманитарные науки}

\section{1. Филологические науки}

доктор филологических наук, профессор, Университет Хаджи Байрам Вели, Республика Турция;

$\mathrm{PhD}$, профессор, Университет Хаджи Байрам Вели, Республика Турция;

доктор филологических наук, профессор, Евразийский национальный университет имени Л.Н.Гумилева, Республика Казахстан;

Кандидат филологических наук, Кызылординский университет им.

Коркыт Ата, Республика Казахстан;

кандидат филологических наук, доцент, Кызылординский

университет имени Коркыт Ата, Республика Казахстан;

кандидат филологических наук, Кызылординский университет имени Коркыт Ата, Республика Казахстан;

кандидат филологических наук, Кызылординский университет имени Коркыт Ата, Республика Казахстан;

\section{3. Социальные науки и бизнес, обслуживание}

\section{1. Экономические науки}

доктор экономических наук, профессор, Московский государственный строительный университет, Российская Федерация; доктор экономических наук, профессор, Евразийский национальный университет имени Л.Н.Гумилева, Республика Казахстан; кандидат экономических наук, доцент, Кызылординский университет имени Коркыт Ата,Республика Казахстан;

кандидат экономических наук, $\mathrm{PhD}$, доцент, Казахский национальный университет имени аль-Фараби, Республика Казахстан. 


\section{SERIES OF AGRICULTURAL SCIENCES}

L.A.Tokhetova - Executive Editor, Doctor of Agricultural Sciences, Associate Professor

\section{Editorial Board}

\section{Agricultural sciences}

K.N.Toderich

Sh.S. Rsaliyev

B.A.Duisembekov

A.S.Rsaliyev
$\mathrm{PhD}$, Tottori University, Japan;

Doctor of Biological Sciences, Associate Professor, Committee of Science of the Ministry of Edication and Science of the Republic of Kazakhstan «Kazakh Research Institute of Agriculture and Crop Production» RSE, Republic of Kazakhstan;

Candidate of Biological Sciences, Associate Professor, "Agropark Ontustik " LLP, Republic of Kazakhstan;

Candidate of Agricultural Sciences, Committee of Science of the Ministry of Edication and Science of the Republic of Kazakhstan «Research Institute of Biological Safety Problems» LPP, Republic of Kazakhstan. 


\section{SERIES OF NATURAL, TECHNICAL SCIENCES}

N.O.Appazov - Executive Editor, Candidate of Chemical Sciences, Professor

\section{Editorial Board}

\section{I.A. Taymanov}

Zh. Iskakov

\section{A.T.Toreshbayev}

A.M.Mukhambetzhan

\section{A.R.Burilov}

S.B.Lyubchik

B.Zh.Dzhiembaev

N.O.Appazov

N.I.Akylbekov

A.E. Filonov

S.T.Tuleukhanov

A.M.Mynbay

B.B.Abzhalelov

R.Kh.Kurmanbaev

\section{Natural Sciences}

\subsection{Physical and mathematical sciences}

Doctor of Physical and Mathematical Sciences, Professor, Novosibirsk State University, Russian Federation; Candidate of Technical Sciences, Associate Professor, G.Daukeyev Almaty University of Power Engineering and Telecommunications, Republic of Kazakhstan; Candidate of Physical and Mathematical Sciences, Korkyt Ata Kyzylorda University, Republic of Kazakhstan; Candidate of Physical and Mathematical Sciences, Republic of Kazakhstan.

\subsection{Chemical sciences}

Doctor of Chemical sciences, Professor, A.E.Arbuzov Institute of Organic and Physical Chemistry,Russian Federation; $\mathrm{PhD}$, Professor, Nova University Lisbon,Portuguese Republic; Doctor of Chemical Sciences, Professor, Kazakh National Women's Pedagogical University, Republic of Kazakhstan;

Candidate of Chemical Sciences, Professor, LLP "Kazakh Scientific Research Institute of Rice Cultivation named after I. Zhakhaeva", Republic of Kazakhstan; PhD, Korkyt Ata Kyzylorda University, Republic of Kazakhstan.

\subsection{Biological Sciences}

Doctor of Biological Sciences, Professor, Skryabin Institute of Biochemistry and Physiology of Microorganisms The Russian Academy of Sciences, Russian Federation;

Doctor of Biological Sciences, Professor, al-Farabi Kazakh National University, Republic of Kazakhstan;

$\mathrm{PhD}$, Nazarbayev University;

Candidate of Biological Sciences, Korkyt Ata Kyzylorda University, Republic of Kazakhstan;

Candidate of Biological Sciences, Associate Professor, Korkyt Ata Kyzylorda University, Republic of Kazakhstan. 


\section{SERIES OF NATURAL, TECHNICAL SCIENCES}

A.Zh.Seitmuratov-Executive Editor, Doctor of Physical and Mathematical Sciences, Associate Professor

\section{Editorial Board}

\section{Technical Sciences and Technologies}

\subsection{Construction}

N.A.Mashkin

K.A.Bisenov

S.A.Montaev

S.S.Uderbaev
Doctor of Technical Sciences, Professor, Novosibirsk State Technical University, Russian Federation;

Doctor of Technical Sciences, Professor, Korkyt Ata Kyzylorda University, Republic of Kazakhstan;

Doctor of Technical Sciences, Professor, Zhangir khan West Kazakhstan agrarian - technical university, Republic of Kazakhstan; Doctor of Technical Sciences, Associate Professor, Korkyt Ata Kyzylorda University, Republic of Kazakhstan.

\subsection{Informatics, Computer Engineering and Management}

A.I.Diveyev Doctor of Technical Sciences, Professor, Peoples' Friendship University of Russia,Russian Federation;

M.Zh.Atimimov $\mathrm{PhD}$, branch of the Academy of Public Administration under the President of the Republic of Kazakhstan in Kyzylorda region, Republic of Kazakhstan;

N.B.Konyrbayev $\mathrm{PhD}$, Korkyt Ata Kyzylorda University, Republic of Kazakhstan;

S.I.Ibadulla $\mathrm{PhD}$, Director of the Information Technologies Center of the Akimat of the Kyzylorda Region, Republic of Kazakhstan. 


\section{EDUCATION, HUMANITIES AND SOCIAL SCIENCES SERIES}

L.A.Kazbekova - Executive Editor, candidate of economic sciences, Associate Professor

\section{Editorial board}

P.N. Osipov

N.Y.Fominych

G.S.Saudabayeva

Sh.M.Maigeldieva

S.K.Abildina

O.Odzhal

\section{H.C.Kasapoglu \\ R.S.Turysbek}

K.S.Saryshova

S.I.Sadybekova

G.A.Tuyakbaev

T.I.Kenshinbay

D.Silka

U.Zh.Shalbolova

A.Sh.Abdimomynova

N.A.Tovma

\section{Education}

\subsection{Pedagogical Sciences}

Doctor of Pedagogical Sciences, Professor, Kazan Federal University, Russian Federation;

Doctor of Pedagogical Sciences, Professor, G.V.Plekhanov Russian University of Economics, Russian Federation;

Doctor of Pedagogical Sciences, Professor, Abai Kazakh National Pedagogical University, Republic of Kazakhstan;

Doctor of Pedagogical Sciences, Associate Professor,, Korkyt Ata Kyzylorda University, Republic of Kazakhstan;

Doctorof Pedagogical Sciences, Professor, E.A.Buketov Karaganda State University, Republic of Kazakhstan

\section{Humanitarian Sciences}

\subsection{Philological science}

Doctor of Philology, Professor, Haji Bayram Veli University, Republic of Turkey;

$\mathrm{PhD}$, Professor, Haji Bayram Veli University, Republic of Turkey;

Doctor of Philology, Professor, L.N.Gumilyov Eurasian National

University, Republic of Kazakhstan;

Candidate of Philological Sciences, Kyzylorda University Korkyt Ata, Republic of Kazakhstan;

Candidate of Philological Sciences, Associate Professor,, Republic of Kazakhstan;

Candidate of Philological Sciences, Korkyt Ata Kyzylorda University, Republic of Kazakhstan;

Candidate of Philological Sciences, Korkyt Ata Kyzylorda University, Republic of Kazakhstan.

\section{Social Sciences and Business, Services}

\subsection{Economic Sciences}

Doctor of Economic Sciences, Professor, Moscow State University of Civil Engineering, Russian Federation;

Doctor of Economic Sciences, Professor, L.N.Gumilyov Eurasian

National University, Republic of Kazakhstan;

Candidate of Economic Sciences, Associate Professor,, Korkyt Ata

Kyzylorda University, Republic of Kazakhstan;

Candidate of Economic Sciences, PhD, Associate Professor, al-Farabi Kazakh National University, Republic of Kazakhstan. 


\section{ОҚЫРМАНҒА!}

Қорқыт Ата атындағы Қызылорда университетінің Хабаршысы - «ҚУ Хабаршысы» 1999 жылғы наурыздан бастап жылына төрт рет шығады. «Хабаршы» - ғалымдардың жүргізген зерттеулерінің маңызды тақырыптарын қамтитын, мақалалары мен материалдары көпшілікке танымал, беделді ғылыми басылым. Оның беттерінде елімізді экономикалық және рухани жаңғыртудың өзекті ғылыми мәселелері, халықаралық деңгейде бәсекеге қабілетті мамандар даярлау тәжірибесі мен болашағы талқыланып, білім беру, ғылым мен өндіріс салаларын интеграциялаудың озық үлгілері жарық көреді. Сонымен қатар үздіксіз білім беру жүйесіндегі инновациялық және ақпараттық технологиялар мен оқу-әдістемелік жұмыстар жарияланып отырады. Еліміздің, алыс және жақын шетел ғалымдарының еңбектері, ғылыми конференциялардың материалдары, танымдық-тәрбиелік мақалалар, жастардың ғылыми шығармашылығы, университетіміздің тыныс-тіршілігі туралы да ақпараттар мен жаңалықтар көпшілік назарына ұсынылады.

«ҚУ Хабаршысы» ғылыми журналы профессор-оқытушыларға, мұғалімдерге, ғылыми қызметкерлерге, жас ғалымдар мен студенттерге, сондай-ақ Қазақстанның білім және ғылым саласындағы жаңалықтарымен танысқысы келетін зиялы қауымға арналған.

Құрметті қауым, Сіздерді журналдың белсенді авторы және оқырманы болуға шақырамыз!

Редакиия алқасы

\section{ЧИТАТЕЛЮ!}

Вестник Кызылординского университета имени Коркыт Ата - «Вестник КУ» издается четыре раза в год с марта 1999 года. «Вестник» - авторитетное научное издание, статьи и материалы которого освещают важные темы исследований ученых. На его страницах обсуждаются актуальные проблемы экономической и духовной модернизации страны, опыт и перспективы подготовки конкурентоспособных специалистов на международном уровне, освещаются передовые модели интеграции в области образования, науки и производства. Также публикуются работы по инновационным и информационным технологиям и учебнометодические работы в системе непрерывного образования.

На страницах Вестника будут представлены труды ученых страны, ближнего и дальнего зарубежья, материалы научных конференций, познавательно-воспитательные статьи, информация и новости о научном творчестве молодежи, жизни университета.

Научный журнал «Вестник КУ» предназначен для профессорско-преподавательского состава, учителей, научных работников, молодых ученых и студентов, а также для творческой интеллигенции Казахстана, желающей ознакомиться с новостями в сфере образования и науки.

Уважаемые коллеги, приглашаем вас стать активными авторами и читателями журнала!

Редакционная коллегия

\section{TO THE READER!}

Bulletin of Korkyt Ata Kyzylorda University - «Bulletin KU» is published four a year since March 1999. The "Bulletin" is an authoritative scientific publication, whose articles and materials cover important research topics of scientists. On its pages are discussed topical problems of economic and spiritual modernization of the country, experience and prospects of training competitive specialists at the international level, are highlighted advanced models of integration in education, science and production. Works on innovative and information technologies and educational and methodical works in the system of continuous education are also published.

On the pages of the Bulletin will be presented the works of scientists of the country, near and far abroad, materials of scientific conferences, cognitive and educational articles, information and news about the scientific creativity of young people, the life of the university.

The scientific journal "Bulletin KU" is intended for the faculty, teachers, researchers, young scientists and students, as well as for the creative intellectuals of Kazakhstan, who want to get acquainted with the news in the field of education and science.

Dear colleagues, we invite you to become active authors and readers of the journal!

Editorial board 


\title{
АУЫЛ ШАРУАШЫЛЫҒЫ ҒЫЛЫМДАРЫ СЕРИЯСЫ \\ СЕРИЯ СЕЛЬСКОХОЗЯЙСТВЕННЫХ НАУК \\ SERIES OF AGRICULTURAL SCIENCES
}

\author{
Ауыл шаруашылығы ғылымдары \\ Сельскохозяйственные науки \\ Agricultural science
}

ГРНТИ 68.29.25

https://doi.org/10.52081/bkaku.2021.v58.i3.066

\section{ЭФФЕКТИВНОСТЬ ПРИМЕНЕНИЯ АДАПТИРОВАННОЙ МАЛООБЪЕМНОЙ ТЕХНОЛОГИИ ДЛЯ ВЫРАЩИВАНИЯ ТОМАТА В ТЕПЛИЦАХ ПРИАРАЛЬЯ}

Кудияров Р.И. ${ }^{\mathbf{1}}$, кандидат сельскохозяйственных наук kri_2030@mail.ru, https://orcid.org/0000-0002-4973-2371

Дямуршаева Э.Б. ${ }^{1}$, магистр сельскохозяйственных наук elinaa20@mail.ru, https://orcid.org/0000-0002-4606-4654

Сауытбева Г.3. ${ }^{2}$, кандидат педагогических наук gul.s.58@mail.ru, https://orcid.org/0000-0002-9297-5790

Дямуршаева Г.Е. ${ }^{2}$, заведующая тепличным хозяйством korkyt.green@mail.ru, https://orcid.org/0000-0002-4385-7616

\footnotetext{
${ }^{1}$ Гуманитарно-технический институт «Акмешит», г.Кызылорда, Республика Казахстан

${ }^{2}$ Кызылординский университет им. Коркыт Ата, г.Кызылорда, Республика Казахстан
}

Аннотация. В данной работе приведены результаты исследований по эффективности применения адаптированной к условиям Приаралья малообъемной технологии выращивания томата. Установлено, что применение данной технологии способствовала интенсификации процессов роста и развития растений гибрида Lilos F1, и как результат увеличению урожайности и качества производимой продукции. В результае наблюдалоась более ранняя закладки 1-ой кисти, ускорение на 4 и 6 дней соответственно наступления цветения и плодоношения, увеличению количество плодов на первых 3-х кистях с 8-ми до 9,6, увеличение на 10 дней периода плодоношения. Выход ранней продукции составил увеличился 2,45 кг $/ \mathrm{m}^{2}$, общей 28,16 кг $/ \mathrm{M}^{2}$ что на $0,33 \mathrm{\kappa г} / \mathrm{M}^{2}$ и на $3,71 \mathrm{\kappa г} / \mathrm{M}^{2}$ больше, чем в ранее проведенных испытаниях ( 2,12 и 24,45 кг/м ${ }^{2}$ ). Применении адаптированной к региональным условиям и сортовым особенностям гибрида Lilos F1 технология позволила на $78,2 \%$ реализовать потенциал продуктивности данного гибрида, что на 9,4\%, чем предыдущих исследованиях $(68,8 \%)$. Качество полученной продукции полностью соответствовало требованиям ГОСТов, а содержание нитрат-ионов составило от 85,1 до 103,4 мг/кг, что значительно ниже ПДК 300 мг/кг.

Ключевые слова: малообъемная технология, субстрат, томат, продуктивность, качество продукиии.

Введение. Система беспочвенного культивирования все чаще используются в качестве основного технологического компонента в современной тепличной промышленности. Ее основным преимуществом является независимость культуры от почвы, которая, как естественная среда, является неоднородной, содержит патогены, имеет тенденцию к разложению в монокультурных системах и может быть малоплодородной и засоленной.

За последнее десятилетие наиболее широкое распространение в мире получила малообъемная технология выращивания овощных культур с использованием различных субстратов и системы капельного орошения и фертигации. Эта технология является 
одним из лучших способов преодоления местной нехватки воды, а также получения высококачественной продукции даже в районах с низкоплодородными почвами и проблемными природно-климатическими условиями [1] .

Технологии беспочвенного выращивания экологически чистой растительной продукции в малообъемных гидропонных модулях являются плодом многолетних фундаментальных и прикладных исследований целого ряда зарубежных фирм и российских ученых. На сегодняшний день проделана большая работа по повышению продуктивности и эффективности беспочвенной технологии выращивания различных культур, включая разработку беспочвенных питательных сред с оптимальными физическими и химическими свойствами. Но, несмотря на разносторонне исследование проблем эффективности овощеводства защищенного грунта в условиях рыночной экономики, территориальная специфика производственного процесса тепличного производства изучена не в полной мере. Создавая типовой проект технологии, исследователи не имели физической возможности осуществлять его адаптацию к условиям конкретных регионов, так как эту работу можно выполнить только на месте, и она имеет длительный характер [2]. В недостаточном объеме ведутся исследования и по минеральному питанию растений, а различные технологические системы внедряются без предварительного изучения и адаптации к местным условиям [3]. В результате при использовании этих технологий на практике возникает ряд проблем, главная из которых, это ее адаптация к региональным условиям. О том, что все имеющиеся на сегодняшний день рекомендации по малообъемному выращиванию растений в теплице носят обобщенный характер и требуют доработки технологии с учетом производственных и климатических факторов отмечают в своих работах и многие зарубежные ученые $[4,5]$.

Анализ возможных направлений развития тепличного овощеводства Приаралья показал, что основным сдерживающим фактором широкого внедрения прогрессивной технологии малообъемного выращивания томатов с использовании систем капельного полива в тепличных хозяйствах региона является слабое научное обеспечение и отсутствие исследований по адаптации к местным условиям.

Практическая важность вопроса повышения эффективности производства тепличной продукции и недостаточный уровень разработки и актуальность проблемы определили направление исследований, проводимых на базе тепичного хоязйства НАО Кызылординский университет им. Коркыт Ата. Цель проводимых исследований заключалась в создании опытного образца малообъемной технологии выращивания томатов на субстратах из древесных опилок и рисовой шелухи, адаптированной к климатическим факторам и условиям производства, с целью дальнейшего внедрения в фермерских хозяйствах региона.

Материалы и методы исследований. Исследования включали последовательное проведение лабораторных, полупроизводственных и производственных опытов с использованием общепринятых методических рекомендаций по проведению опытов с овощными культурами в сооружениях защищенного грунта.

Одним из основных факторов, определяющим систему выращивания и эффективность производства является выбор сорта (гибрида), продуктивность которого тесно связана с его генетическими признаками. Генотип должен обеспечивать достаточную степень надежности и защиты от неблагоприятного воздействия биотических и абиотических факторов окружающей среды. Вместе они определяют желаемый уровень производительности [6-7]. Поэтому для проведения исследований был отобран индетерминантный ранний гибрид Lilos F1 (Riik Zwaan, Нидерланды), показавший высокие и стабильные результаты продуктивности в проведенных ранее

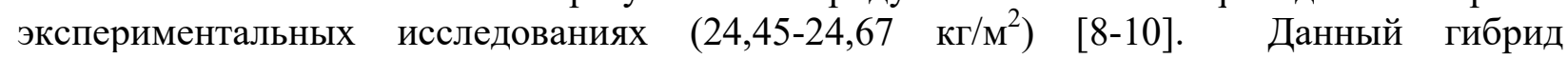
высокоурожайный, идеально завязывает плоды массой 150-160 г и, которые не мельчают в 
течение всего сезона даже в стрессовых условиях. Растение открытое, идеально сбалансированное, что облегчает уход, сильная корневая система. Благодаря хорошей силе роста завязывает много плодов отличного качества на всех кистях. Плоды округлые, однородные, поверхность блестящая без зелёного пятна вокруг плодоножки,ярко-красные, плотные, хорошо хранятся и транспортируются. Как нижние, так и верхние кисти сильные, с короткой осью, не заламываются. Устойчивый к болезням: вирусу тобачной мозайки (ToMv/F1-5), фузариозному увяданию (Fol:0,1), фузариозной гнили верхушек и корней (For), вертициллезному увяданию (Va), галловой нематоде (Mi).

Образцом для сравнения эффективности адаптированной технологии малообъемного выращивания томата являлась применяемая ранее технология выращивания гибрид Lilos F1 на субстрате из древесных опилок.

В адаптированной технологии для выращивания гибрида в условиях продленного оборота использовали композиционный субстрат из древесных опилок и рисовой шелухи с соотношением компонентов и 75:25, при выращивании на котором данный гибрид

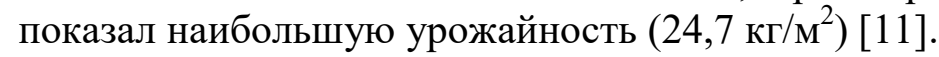

По результатам предыдущих исследований были изменены и другие технологические элементы: срок посева и посадки [12], густота размещения растений в теплице [13], состав и концентрация питательного раствора, способ формирования растений и другие. Параметры технологий приведены в таблице 1.

Таблица 1 - Технологические параметры томата

\begin{tabular}{|c|c|c|}
\hline Параметры & $\begin{array}{l}\text { Применяемая } \\
\text { технология }\end{array}$ & Адаптированная технологии \\
\hline Срок посева семян & 15 июля & 1 августа \\
\hline Субстрат & Древесные опилки & $\begin{array}{l}\text { Древесные опилки и рисовая } \\
\text { шелуха в соотношении 75:25 }\end{array}$ \\
\hline $\begin{array}{l}\text { Густота размещения растений, } \\
\text { шт/м² }\end{array}$ & 2,3 & 2,5 \\
\hline $\begin{array}{l}\text { Состав питательного раствора, } \\
\text { ppm }\end{array}$ & \multicolumn{2}{|c|}{$\begin{array}{l}\text { до плодоношения: } \mathrm{N}-107, \mathrm{P}-114, \mathrm{~K}-114, \mathrm{Ca}-38, \mathrm{Mg}-20, \mathrm{Fe}- \\
0,25, \mathrm{Cu}-0,018, \mathrm{Mo} \mathrm{-} \mathrm{0,004,} \mathrm{Mn} \mathrm{-} \mathrm{0,15,} \mathrm{Zn} \mathrm{-} \mathrm{0,012,} \mathrm{В} \mathrm{-} \mathrm{0,034;} \\
\text { в период плодоношения: N - 200, P- 55, K - 300, Ca - 200, Mg- } \\
55, \mathrm{Fe}-3,0, \mathrm{Cu}-0,5, \mathrm{Mo}-0,12, \mathrm{Mn}-0,125, \mathrm{Zn}-0,2, \mathrm{~B}-0,9\end{array}$} \\
\hline $\begin{array}{ll}\text { Концентрация } & \text { питательного } \\
\text { раствора (ЕС) }\end{array}$ & $1,7-3,0$ & $0,7-2,7$ \\
\hline рН питательного раствора & \multicolumn{2}{|l|}{$5,5-6,0$} \\
\hline Формирование & \multicolumn{2}{|c|}{ В один стебель с укладкой на стеллажи } \\
\hline
\end{tabular}

Для проведения испытаний была разработана технологическая карта, включающая весь комплекс технологических операций возделывания томата Lilos F1 в малообъемных гидропонных модулях на субстратах из древесных опилок и рисовой шелухи в условиях продленного оборота с описанием их особенностей и порядка проведения. Вся агротехника эксперимента проводилась в соответствии с данной технологической картой.

Согласно технологическим требованиям рассаду томатов выращивали с пикировкой: 1 августа семена высевали в кассеты с торфяной смесью, а через 14 суток после появления всходов растения пикировали в горшки $\varnothing 10$ см. Для выращивания рассады использовали готовый торфяной субстрат Агробалт $-\mathrm{H}$, нормализованный по кислотности рН 5,5 и содержащий необходимое количество макро- и микроэлементов.

Рассаду выращивали без досвечивания и, чтобы создать оптимальные условия освещения, постоянно изменяли густоту стояния растений: после пикировки по 28 
растений на 1 м²; на 5-ой неделе - по 20; на 6-ой- по 15; - на 7-ой - по 14; на 8-ой - по 12. Для подкормки рассады использовали растворы комплексных удобрений N-P-K: 10-52-10 и 14-11-25, кальциевой селитры и гумата натрия (ЕС 1,5-5,0). А также проводи профилактические мероприятий против вредителей и болезней обработкой рассады $0,1 \%$ раствором псевдобактерина от корневых гнилей и $1 \%$ раствором Гаучо (иммидокларирид) против вредителей.

Перед высадкой рассады проводили дезинфекцию теплицы в и размещали систему капельного орошения. Подготовленный субстрат помещали в полиэтиленовые мешки объемом 30л, и укладывали в теплице на стеллажи. В мешках вырезали посадочные лунки, в которые устанавливали капельницы. На шпалере размещали крючки с веревкой для подвязывания растений. В теплицу рассаду выставляли 15 сентября, при этом горшки с субстратом пока не соединяли, а ставили на мешки рядом с отверстиями и подсоединяли к системе капельного орошения и подвязывали к вертикальному шпагату.

Перед высадкой рассады мешки с субстратом увлажняли с помощью системы капельного орошения питательным раствором (Е.С - 3,0-3,5) до полного насыщения. Затем на обращенной к дорожке стороне мешка делали по 2 дренажных отверстия. В фазе начала цветения 2- ой кисти растения перемещали в субстрат. Температурный и влажностный режим в теплице поддерживали в соответствии с технологическими требованиями для каждой фазы роста и развития растений: до плодоношения днем в солнечную погоду $20-22{ }^{0} \mathrm{C}$, в пасмурную $-19-20{ }^{0} \mathrm{C}$ и ночью $15-17^{0} \mathrm{C}$, влажность $60-65 \%$, в период плодоношения соответственно $24-26{ }^{0} \mathrm{C}, 20-22{ }^{0} \mathrm{C}$ и $17-18{ }^{0} \mathrm{C}$, влажность $65-70 \%$.

Для питания растений использовали питательный раствор, полностью сбалансированный по элементам питания и дифференцированный в соответствии со стадией развития растений (таблица 1). Концентрацию питательного раствора устанавливали по электропроводности в зависимости от фазы развития растений от 1,7 до 2,7, нужный уровень $\mathrm{pH}$ - 5,5 - 6,0 питательного раствора поддерживали применением раствора азотной кислоты.

Поливы и подкормку растений проводили капельным способом каждый час с 7.00 до 17.00 так, чтобы определенный процент питательного раствора был отведен из субстрата через дренаж с каждым поливом: в 7.00-0\%, в $9.00-3 \%, 10.00-6 \%, 11.00-12 \%$, $12.00-30 \%, 13.00$ и $15.00-20 \%, 17.00-10 \%$

Ежедневно проводили мониторинг режима полива и питания измерением объемов и ЕС дренажного и питательного растворов и на основании результатов измерений вносили корректировки в работе автоматических элементов системы: на инжекторе - для изменения концентрации питательного раствора и на таймере - для увеличения или уменьшения объема полива.

Формирование растений томата вели в один стебель с удалением всех о боковых ответвлений («пасынки») с приспусканием стебеля вдоль стеллажа под наклоном. Для улучшения циркуляции воздуха в приземной зоне и предотвращения развития инфекции проводили постепенное удаление нижних листьев. Сбор урожая начинали, когда томаты достигали бурой и розовой степени зрелости.

Во время проведения эксперимента проводили фенологические и биометрические наблюдения, регистрацию основных параметров микроклимата, мониторинг режимов полива и питания растений, учет урожая и качества производимой продукции.

Оценку качества выращенной продукции проводили по следующим показателям: органолептическая оценка (ГОСТ 1725-85) [14], содержание сухих веществ (ГОСТ ИСО 2173-2013) [15], общее содержание сахара (ГОСТ 8756.13-87) [16], титруемая кислотность (ГОСТ ИСО 750-2013) [17], концентрация аскорбиновой кислоты (ГОСТ 24556-89) [17] и содержание нитрат-ионов (ГОСТ 29270-95) [18]. 
Результаты и обсуждение. Получение высокого урожая зависит от экологической адаптивности выращиваемого гибрида, определяемой биологическими характеристиками и выражающаяся в скороспелости и силе растения, размере плодов, их качестве и, конечно же, общей продуктивности [20- 24].

Результаты фенологических наблюдений показали, что применение адаптированной технологии для выращивания гибрида томатов Lilos F1 способствовало интенсификации процессов роста и развития растений: так цветение наступало через 41 день после всходов, плодоношение через 56 дней после цветения, что соответственно на 4 и 6 дней раньше, чем в предыущих исследованиях, в результате срок плодоношения увеличился со 196 дней до 206 дней. (рисунок 1).

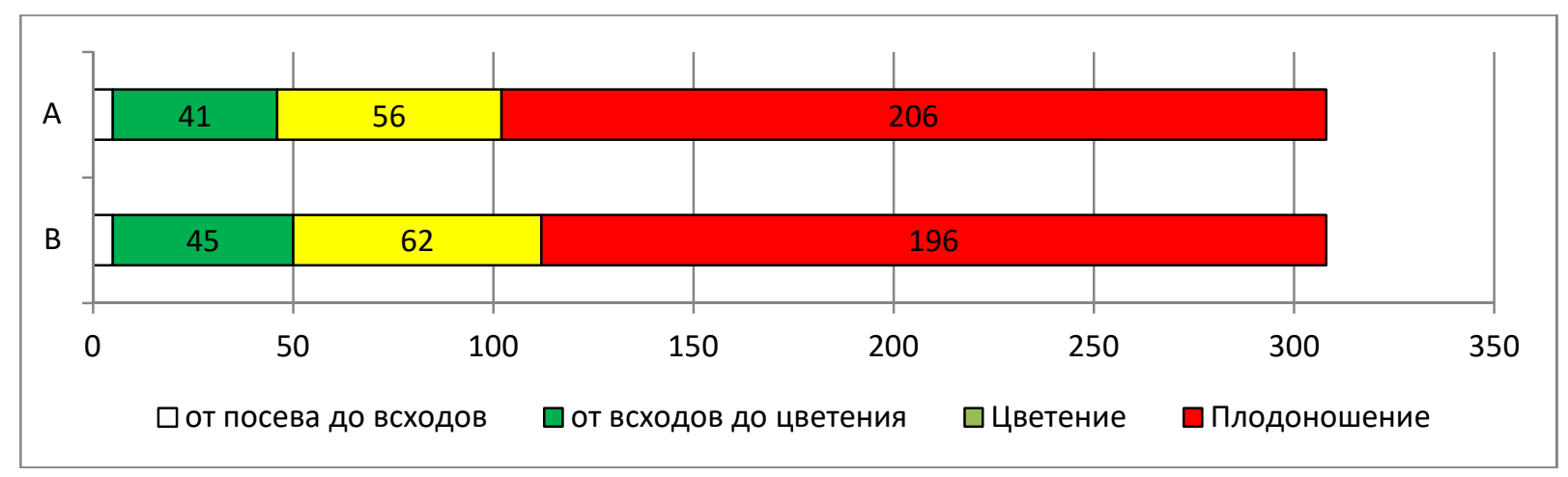

Рисунок 1 - Влияние адаптированной технологии малообъемного выращивания томата на интенсивность процессов роста и развития растений ( А- адаптированная технология, В- применяемая ранее технология).

Показатели эффективности адаптированной технологии малообъемного выращивания томатного гибрида Lilos F1 приведены в таблице 2.

Таблиц 2 - Показатели эффективности адаптированной технологии малообъемного выращивания томатного гибрида Lilos F1.

\begin{tabular}{|c|c|c|c|c|c|c|c|}
\hline & \multirow[b]{2}{*}{ 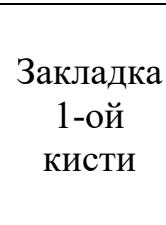 } & \multirow{2}{*}{$\begin{array}{c}\text { К-во } \\
\text { плодов } \\
\text { на пер- } \\
\text { вых 3- } \\
\text { кистях } \\
\end{array}$} & \multicolumn{3}{|c|}{ Урожайность, кг/м² } & \multirow{2}{*}{$\begin{array}{c}\text { К-во } \\
\text { плодов } \\
\text { с } 1 \text { рас- } \\
\text { тения }\end{array}$} & \multirow[b]{2}{*}{$\begin{array}{c}\text { Масса } \\
1 \text { плода, } \\
\Gamma\end{array}$} \\
\hline & & & Ранняя & Общая & $\begin{array}{c}\text { Стандарт- } \\
\text { ная }\end{array}$ & & \\
\hline $\begin{array}{l}\text { Ранее применяе- } \\
\text { мая технология } \\
\text { (контроль) }\end{array}$ & $\begin{array}{l}\text { после } \\
\text { 9-го } \\
\text { листа }\end{array}$ & 8,0 & 2,12 & 24,45 & 96,8 & 103 & 103,2 \\
\hline $\begin{array}{l}\text { Адаптированная } \\
\text { технология }\end{array}$ & $\begin{array}{l}\text { после } \\
8 \text {-го } \\
\text { листа }\end{array}$ & 9,6 & 2,45 & 28,16 & 99,2 & 96 & 117,3 \\
\hline в \% контролю & - & 120,0 & 115,6 & 115,20 & 102,5 & 93,2 & 113,7 \\
\hline
\end{tabular}

В результате биометрических наблюдений было установлено, что интенсификация процессов роста и развития растений сособствовала более ранней закладки 1-ой кисти после 8-го (в предыдущих испытаниях после 9-го листа), а также к увеличению количество плодов на первых 3-х кистях с 8-ми до 9,6. 
Биометрические наблюдения, проводимые в течение всего периода вегетации, включали регулярный подсчет количества листьев и кистей на растении, необходимы для проведения формирования растений с целью обеспечения их сбалансированного развития: в осенне-зимний период на растении оставляли 15 листьев и 5-6 кистей весенне-летний 18 и 6-7 соответственно.

В адаптированной технологии срок посева семян был сдвинут на 2 недели позже, поскольку температурные условия с середины июля до середины августа в регионе являются настолько экстремально высокими, что культивирование без искусственного охлаждения становится невозможными. Посев семян 1 августа позволил избежать температурного стресса, который сильно тормозит рост и развитие растения и получить

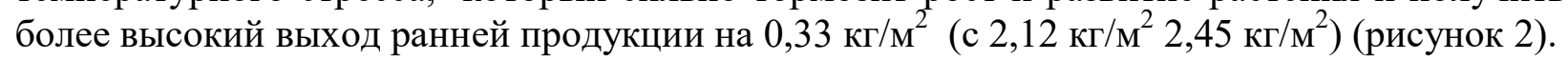
Анализ динамики поступления урожая, представленный на рисунке 2 показывает, что общая тенденция формирования урожая в течение вегетационного сезона сохранилась: наименьший урожай был получен в феврале и марте, поскольку его формирование приходилось на период с наименьшей продолжительностью светового дня и наименьшей интенсивностью солнечной радиации (декабря, январь), наибольший - с апреля по июнь, когда свет переставал быть лимитирующим фактором.

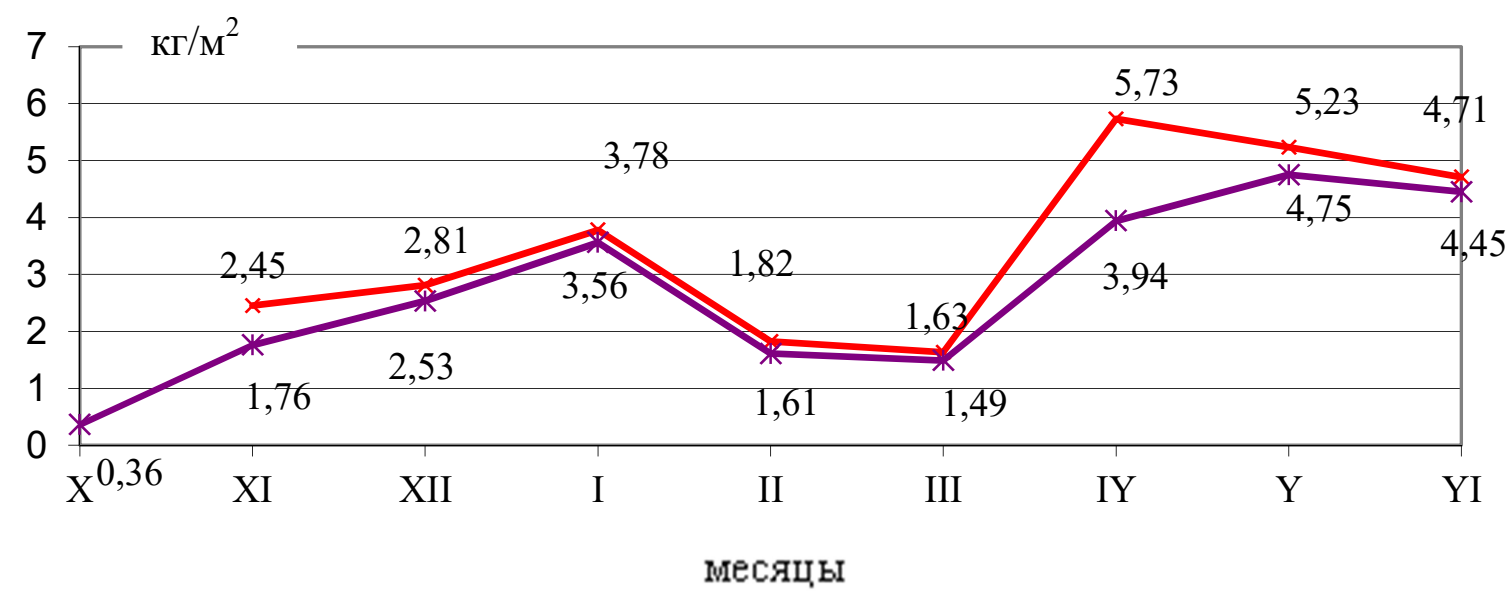

*-Адаптированная технология $\quad$ *-Предыдущие испытания

Рисунок 2 - Влияние адаптированной технологии малообъемного выращивания томата на урожайность томатов

За вегетационный период на растениях томатного гибрида Lilos F1 сформировалось в среднем по 96 плодов, средняя масса 1 плода составила 117,3 г, выход стандартной продукции составил 99,2\%. В ранее проведенных исследований эти показатели были следующие: 103 плода с 1 растения со средней массой 103,2 г, выход стандартной продукции - 96,8 \%. Масса и количество плодов являются количественными компонентами, которые определяют урожайность и зависят как от генетических фактров, так и от фактов окружающей среды [20-24].

Результаты исследований показали, что при применении адаптированной технологии что на растениях гибрида Lilos F1 формировалось меньшее количество плодов (96 плодов/ на 1 раст.), но их средняя масса при этом увеличилась на 13,7\% и составила 117,3 г. В ранее проведенных исследованиях эти показатели составили 103 плода с 1 растения по 103,2 г. Общая урожайность томатного гибрида Lilos F1 при применении 


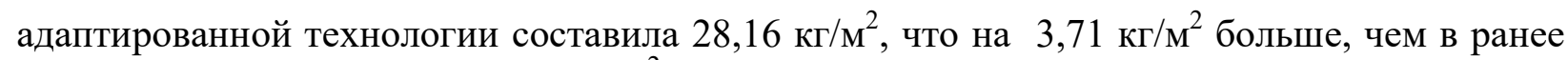

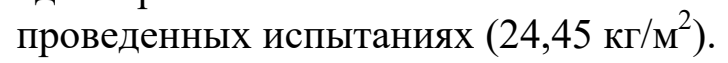

Таким образом, применении адаптированной к региональным условиям и сортовым особенностям гибрида Lilos F1 технология позволила на 78,2\% реализовать потенциал продуктивности данного гибрида, что на 9,4\%, чем предыдущих исследованиях $(68,8 \%)$.

Результаты анализ качества урожая показали полное соответствие органолептических показателей качества требованиям ГОСТа: по внешнему виду все плоды были свежие, целые, чистые, здоровые, плотные, красной, розовой и бурой степени зрелости , без каких-либо повреждений, с плодоножкой, имели приятный запах и вкус, свойственный данному гибриду, выход стандартной продукции составил 99,2 \%.

Твердость плодов томатов, оцененная по шкале от 1 до 10, была очень хорошей и составила 8,9-9,3. Твердость плодов является очень важным показателем для реализации продукции, так при таких показателях твердости плоды могут быть собраны на более поздних стадиях зрелости и иметь при этом лучший вкус.

Важными критериями высококачественных томатов являются вкус и аромат, которые зависят томатов от соотношения между сахаром и кислотой. Более высокий уровень сахара и содержанием органической кислоты улучшает качество томатов $[25,26]$.

Результаты биохимического анализа плодов томатов, приведенные в таблице 3, показывают, что приприменение адаптированной технологии удалось сохранить высокие скусовые качества плодов данного гибрида, а в отдельные периода сезона даже улучшить.

Высокие биохимические показатели качества плодов в проведенных ранее исследованиях определяются главным образом применением питательного раствора с более высокой концентрацией, что подтверждает результаты исследований, которые утверждают, что содержание сухого вещества, растворимых твердых веществ, титруемой кислотности, летучих соединений, минералов, каротина и витамина С в свежих плодах увеличиваются с увеличением солености [26-28].

Таблица 3 - Биохимический состав плодов гибрида Lilos F1.

\begin{tabular}{|c|c|c|c|c|c|}
\hline Месяц & $\begin{array}{l}\text { Сухое } \\
\text { вещество, } \\
\% \\
\end{array}$ & $\begin{array}{l}\text { Общий } \\
\text { сахар, } \\
\text { \% }\end{array}$ & $\begin{array}{l}\text { Аскорбиновая } \\
\text { кислота, } \\
\text { мг/100 г }\end{array}$ & $\begin{array}{l}\text { Титруемая } \\
\text { кислота, } \\
\% \\
\end{array}$ & $\begin{array}{l}\left(\mathrm{NO}^{-}\right) \\
\text {мг/кг }\end{array}$ \\
\hline \multicolumn{6}{|c|}{ Адаптированная технология } \\
\hline XI & 6,05 & 2,87 & 15,38 & 0,54 & 95,3 \\
\hline XII & 5,98 & 2,73 & 15,22 & 0,54 & 98,1 \\
\hline $\mathrm{I}$ & 5,95 & 2,70 & 15,21 & 0,55 & 98,7 \\
\hline II & 5,89 & 2,67 & 15,06 & 0,57 & 103,4 \\
\hline III & 5,97 & 2,79 & 15,22 & 0,54 & 94,0 \\
\hline IY & 6,07 & 2,91 & 15,39 & 0,53 & 89,2 \\
\hline $\mathrm{Y}$ & 6,19 & 2,96 & 15,47 & 0,53 & 84,6 \\
\hline YI & 6,21 & 2,97 & 15,46 & 0,53 & 84,7 \\
\hline \multicolumn{6}{|c|}{ Ранее применяемая технология (контроль) } \\
\hline & 6,20 & 2,91 & 15,38 & 0,59 & 84,6 \\
\hline
\end{tabular}

Содежание нитрат-ионов составило от 85,1 до 103,4 мг/кг, что значительно меньше ПДК для плодов тепличных томатов 300 мг/кг.

Заключение. Результаты исследований показали, что повышение эффективности тепличного производства томатов определялась высокой экологической адаптивностью 
томатного гибрида Lilos F1 и взаимодействием между его генетическими особенностями с технологическими условиями адаптированной технологии малообъемного выращивания. Применение данной технологии способствовала интенсификации процессов роста и развития растений гибрида Lilos F1, и как результат увеличению урожайности и качества производимой продукции.

Исследования финансируются Министерством образования и науки Республики Казахстан (грант № АР08956053 ).

\section{Литература:}

[1] Малообъемное выращивание культур [Электронный ресурс] // Промгидропоника.ру: сайт. - URL: https://www. promgidroponica.ru/vsjo-o-gidroponike/maloobemn_virash_kultur.

[2] Луценко, E.B. Перспективы выращивания томатов на закрытом грунте по технологии малообъемной гидропоники // Научный журнал КубГАУ. - 2005. - №10. - URL: https://cyberleninka.ru/article/n/perspektivy-vyraschivaniya-tomatov-na-zakrytom-grunte-po-tehnologiimaloobemnoy - gidroponiki.

[3] Пфаненштиль, В.И. Адаптация технологии и оборудования капельного полива к условиям зимних теплиц Западной Сибири: дисс...к.с-х.наук: 05.20.21/АГАУ. - Барнаул, 2004. C. 3

[4] Schwarz, D. et al. Guidelines to use tomato in experiments with a controlled environment. Frontiers in Plant Science, doi: 10.3389/fpls.2014.00625. - URL: http://journal.frontiersin.org/Journal /10.3389/fpls.2014.00625/abstract .

[5] Poorter, H. et al. The art of growing plants for experimental purposes: a practical guide for the plant biologist // Functional Plant Biologe. - 2012. - Vol.39. - P.821-838.

[6] Бакулина, В.А. Сорт - основа технологии // Картофель и овощи. -1988.- №1 - С. 14-20. 8-10.

[7] Тараканов, Г.И. Сорт - основное звено технологии // Мир теплиц. - 1997. - №.6. - С .

[8] Дямуршаева, Э.Б., Кудияров Р.И., Сауытбаева Г.З., Дямуршаева Г.Е. и др. Перспективные гибриды томатов для малообъемного выращивания в зимних теплицах Приаралья // Современные проблемы науки и образования. - 2015. - № 2. URL: http://www.scienceeducation.ru/122-21343

[9] Dyamurshayeva, E.B., Kudiyarov R.I., Dyamurshayeva G.E. et al. Efficiency of use of the rice peel and wood sawdust as the substratum for cultivation of tomatoes // Papers of the International Research Journal. - Екатеринбург, 2017. - C.63-66 (AGRIS) http://research-journal.org/wpcontent/uploads/2017/02/02-2-56.pdf

[10] Dyamurshayeva, E.B., Kudiyarov R.I., Bobrenko I.A., Sauytbayeva G.Z., Dyamurshayeva G.E. et al. Variety trial on tomato hybrids in greenhouse conditions of the Prearal Area of Kazakhstan// OnLine Journal of Biological Sciences. 2017.- Vol.17, Issue 2. - P.26 - 34. -

D OI: 10.3844/ojbsci.2017.26.34. -URL: http://thescipub.com/PDF/ ofsp.11143.pdf

[11] Kudiyarov, R. I., Dyamurshayeva E. B., Sauytbayeva G. Z., Dyamurshayeva G. E. et al.. Influence of various substrates on productivity and economical efficiency of cultivation of tomatoes by the method of low-volume hydroponics // Bulletin of national academy of sciences of the Republic of Kazakhstan.- Almaty, 2021. - Vol. 2. - P .6-11.

[12] Дямуршаева, Э.Б., Кудияров Р.И., Сауытбаева Г.З., Дямуршаева Г.Е. Влияние различных сроков посадки на урожайность томата в условиях защищенного грунта Казахстанского Приаралья // Современные проблемы науки и образования. - 2015. - № 2. URL: http://www.science-education.ru/122-21321.

[13] Дямуршаева, Э.Б., Кудияров Р.И., Дямуршаева Г.Е. Агроэкономческое обоснование технологических приемов выращивания томатов в теплицах Приаралья // Сб.трудов XX Междунар.научно-практ. конф.«Тенденции и инновации современной науки». - Краснодар: «Априори», $2017 .-$ С .62.

[14] ГОСТ 1725 - 85. Томаты свежие. Технические условия.

[15] ГОСТ ИСО 2173 - 2013. Плодоовощная продукция. Рефрактометрический метод определения содержания растворимых твердых веществ. 
[16] ГОСТ 8756.13 - 87. Плодоовощная продукция. Методы определения сахара.

[17] ГОСТ ИСО 750 - 2013. Плодоовощная продукция. Определение титруемой кислотности.

[18] ГОСТ 24556 - 89. Продукты переработки фруктов и овощей. Методы определения витамина С.

[19] ГОСТ 29270 - 95. Плодоовощная продукция. Методы определения нитратов.

[20] Dhaliwal, M.S. et al. Genetics of yield and its components in tomato. Ann. Biol. - Vol.4. 1998. - p $.75-80$.

[21] Zdravković, J., Pavlović N.V., Girek Z. and Cvikić A.D. Generation mean analysis of yield components and yield in tomato (Lycopersicon esculentum Mill.). Pak. J. Bot. - 2011. - Vol. 43. - 2011. - P. $1575-1580$.

[22] Hussain, S.I.et al. Yield potential of some exotic and local tomato cultivars grown for summer roduction. Pak.J.Biol.Sci. - 2001. - Vol.4. - P.1215 - 1216. DOI: 10.3923/pjbs.2001.1215. 1216.

[23] Singh, T. et al. Performance of tomato (Solanum lycopersicum L.) hybrids for growth, yield and quality inside polyhouse under mid hill condition of uttarakhand. Am. J. Drug Discovery Dev.

- 2 014. - Vol.4. - P. 202 - 209. DOI: 10.3923/ajdd.2014.202.209.

[24] Rajasekar, M.T. et al. Influence of weather and growing environment on vegetable growth and yield. J.Horticulture Forestry. - 2013. -Vol.5. - P.160 - 167.

[25] Vesseur, W.P. Tomato tasting and consumer attitude. Acta Horticulturae. - 1990. - Vol.259. - P. 83-89. DOI: 10.17660/ActaHortic.1990.259.7

[26] Davies, J.N., Hobson G.E. The constituents of tomato fruit-the influence of environment, nutrition and genotype. CRC Critical Rev. Food Sci. Nut. - 1981. - Vol. 15. - P. 205 - 280. DOI: $10.1080 / 10408398109527317$

[27] Tuzel, J.H., Tuzel Y., Sul A. et. a1. Effects of EC level of the nutrient solution on yield and fruit quality of tomatoes. Acta Horticulturae. - 2001. - Vol.559. - P.587-592. DOI: 10.17660/ActaHortic.2001.559.86

[28] Dorais, M.R. et al. Improving tomato fruit quality by increasing salinity: Effects on ion uptake, growth and yield. Acta Horticulturae. - 2000. - Vol. 511. - P. 1109 - 1100. DOI: 10.17660/ActaHortic.2000.511.21

\section{References:}

[1] Maloob"emnoe vyrashchivanie kul'tur [Elektronnyj resurs] // Promgidroponika.ru: sajt. URL: https://www. promgidroponica.ru/vsjo-o-gidroponike/maloobemn_virash_kultur.

[2] Lucenko, E.V. Perspektivy vyrashchivaniya tomatov na zakrytom grunte po tekhnologii maloob"emnoj gidroponiki // Nauchnyj zhurnal KubGAU. - 2005. - №10. - URL: https://cyberleninka.ru/article/n/perspektivy-vyraschivaniya-tomatov-na-zakrytom-grunte-po-tehnologiimaloobemnoy - gidroponiki.

[3] Pfanenshtil', V.I. Adaptaciya tekhnologii i oborudovaniya kapel'nogo poliva k usloviyam zimnih teplic Zapadnoj Sibiri: diss...k.s-h.nauk: 05.20.21/AGAU. - Barnaul, 2004. - S.3

[4] Schwarz, D. et al. Guidelines to use tomato in experiments with a controlled environment. Frontiers in Plant Science, doi: 10.3389/fpls.2014.00625. - URL: http://journal.frontiersin.org/Journal /10.3389/fpls.2014.00625/abstract .

[5] Poorter, H. et al. The art of growing plants for experimental purposes: a practical guide for the plant biologist // Functional Plant Biologe. - 2012. - Vol.39. - P.821-838.

[6] Bakulina, V.A. Sort - osnova tekhnologii // Kartofel' i ovoshchi. -1988.- №1. - S. 14-20.

[7] Tarakanov, G.I. Sort - osnovnoe zveno tekhnologii // Mir teplic. - 1997. - №.6. - C . 8-10.

[8] Dyamurshaeva, E.B., Kudiyarov R.I., Sauytbaeva G.Z., Dyamurshaeva G.E. i dr. Perspektivnye gibridy tomatov dlya maloob"emnogo vyrashchivaniya v zimnih teplicah Priaral'ya // Sovremennye problemy nauki i obrazovaniya. - 2015. - № 2. URL: http://www.scienceeducation.ru/122-21343

[9] Dyamurshayeva, E.B., Kudiyarov R.I., Dyamurshayeva G.E. et al. Efficiency of use of the rice peel and wood sawdust as the substratum for cultivation of tomatoes // Papers of the International Research Journal. - Ekaterinburg, 2017. - C.63-66 (AGRIS) http://research-journal.org/wpcontent/uploads/2017/02/02-2-56.pdf 
[10] Dyamurshayeva, E.B., Kudiyarov R.I., Bobrenko I.A., Sauytbayeva G.Z., Dyamurshayeva G.E. et al. Variety trial on tomato hybrids in greenhouse conditions of the Prearal Area of Kazakhstan// OnLine Journal of Biological Sciences. 2017.- Vol.17, Issue 2. - R.26 - 34. -

D OI: 10.3844/ojbsci.2017.26.34. -URL: http://thescipub.com/PDF/ ofsp.11143.pdf

[11] Kudiyarov, R.I., Dyamurshayeva E. B., Sauytbayeva G. Z., Dyamurshayeva G. E. et al.. Influence of various substrates on productivity and economical efficiency of cultivation of tomatoes by the method of low-volume hydroponics // Bulletin of national academy of sciences of the Republic of Kazakhstan.- Almaty, 2021. - Vol. 2. - R .6-11.

[12] Dyamurshaeva, E.B., Kudiyarov R.I., Sauytbaeva G.Z., Dyamurshaeva G.E. Vliyanie razlichnyh srokov posadki na urozhajnost' tomata $\mathrm{v}$ usloviyah zashchishchennogo grunta Kazahstanskogo Priaral'ya // Sovremennye problemy nauki i obrazovaniya. - 2015. - № 2. URL: http://www.scienceeducation.ru/122-21321.

[13] Dyamurshaeva, E.B., Kudiyarov R.I., Dyamurshaeva G.E. Agroekonomcheskoe obosnovanie tekhnologicheskih priemov vyrashchivaniya tomatov v teplicah Priaral'ya // Sb.trudov XX Mezhdunar.nauchno-prakt. konf.«Tendencii i innovacii sovremennoj nauki». - Krasnodar: «Apriori», 2017 . S .62.

[14] GOST 1725 - 85. Tomaty svezhie. Tekhnicheskie usloviya.

[15] GOST ISO 2173 - 2013. Plodoovoshchnaya produkciya. Refraktometricheskij metod opredeleniya soderzhaniya rastvorimyh tverdyh veshchestv.

[16] GOST 8756.13 - 87. Plodoovoshchnaya produkciya. Metody opredeleniya sahara.

[17] GOST ISO 750 - 2013. Plodoovoshchnaya produkciya. Opredelenie titruemoj kislotnosti.

[18] GOST 24556 - 89. Produkty pererabotki fruktov i ovoshchej. Metody opredeleniya vitamina

S.

[19] GOST 29270 - 95. Plodoovoshchnaya produkciya. Metody opredeleniya nitratov.

[20] Dhaliwal, M.S. et al. Genetics of yield and its components in tomato. Ann. Biol. - Vol.4. 1998. - r. $75-80$.

[21] Zdravković, J., Pavlović N.V., Girek Z. and Cvikić A.D. Generation mean analysis of yield components and yield in tomato (Lycopersicon esculentum Mill.). Pak. J. Bot. - 2011. - Vol. 43. - 2011. - P. $1575-1580$.

[22] Hussain, S.I.et al. Yield potential of some exotic and local tomato cultivars grown for summer roduction. Pak.J.Biol.Sci. - 2001. - Vol.4. - P.1215 - 1216. DOI: 10.3923/pjbs.2001.1215. 1216.

[23] Singh, T. et al. Performance of tomato (Solanum lycopersicum L.) hybrids for growth, yield and quality inside polyhouse under mid hill condition of uttarakhand. Am. J. Drug Discovery Dev.

- 2 014. - Vol.4. - P. 202 - 209. DOI: 10.3923/ajdd.2014.202.209.

[24] Rajasekar, M.T. et al. Influence of weather and growing environment on vegetable growth and yield. J.Horticulture Forestry. - 2013. -Vol.5. - P.160 - 167.

[25] Vesseur, W.P. Tomato tasting and consumer attitude. Acta Horticulturae. - 1990 - Vol.259. - P. 83-89. DOI: 10.17660/ActaHortic.1990.259.7

[26] Davies, J.N., Hobson G.E. The constituents of tomato fruit-the influence of environment, nutrition and genotype. CRC Critical Rev. Food Sci. Nut. - 1981. - Vol. 15. - P. 205 - 280. DOI: $10.1080 / 10408398109527317$

[27] Tuzel, J.H., Tuzel Y., Sul A. et. a1. Effects of EC level of the nutrient solution on yield and fruit quality of tomatoes. Acta Horticulturae. - 2001. - Vol.559. - P.587-592. DOI: 10.17660/ActaHortic.2001.559.86

[28] Dorais, M.R. et al. Improving tomato fruit quality by increasing salinity: Effects on ion uptake, growth and yield. Acta Horticulturae. - 2000. - Vol. 511. - P. 1109 - 1100. DOI: 10.17660/ActaHortic.2000.511.21 


\title{
THE EFFECTIVENESS OF THE ADAPTED LOW-VOLUME TECHNOLOGY FOR GROWING TOMATOES IN GREENHOUSES IN THE ARAL SEA REGIONANNOTATION
}

\author{
Kudiyarov R. I. ${ }^{1}$, candidate of agricultural sciences \\ Dyamurshayeva E. B. ${ }^{1}$, master in agriculture sciences \\ Sauytbayeva G. Z. $^{2}$, candidate of pedagogical sciences \\ Dyamurshayeva G. E. ${ }^{2}$, head of greenhouse facilities
${ }^{1}$ Humanitarian and Technical Institute "Akmeshit", Kyzylorda, Republic of Kazakhstan
${ }^{2}$ Kyzylorda University named after Korkyt Ata, Kyzylorda, Republic of Kazakhstan

\begin{abstract}
Annotation. This paper presents the results of research on the effectiveness of using a smallvolume tomato growing technology adapted to the conditions of the Aral Sea region. It was found that the use of this technology contributed to the intensification of the processes of growth and development of plants of the Lilos F1 hybrid, and as a result, increased productivity and quality of products. As a result, the first brush was laid earlier, the onset of flowering and fruiting accelerated by 4 and 6 days, respectively, the number of fruits on the first 3 brushes increased from 8 to 9.6 , and the fruiting period increased by 10 days. The early production yield was approximately $2.45 \mathrm{~kg} / \mathrm{m} 2$, with a total of 28.16 $\mathrm{kg} / \mathrm{m} 2$, which is $0.33 \mathrm{~kg} / \mathrm{m} 2$ and $3.71 \mathrm{~kg} / \mathrm{m} 2$ more than in the previous tests $(2.12$ and $24.45 \mathrm{~kg} / \mathrm{m} 2)$. The application of the technology adapted to the regional conditions and varietal characteristics of the Lilos F1 hybrid allowed $78.2 \%$ to realize the productivity potential of this hybrid, which is $9.4 \%$ more than in previous studies (68.8\%). The quality of the obtained products fully met the requirements of GOST standards, and the content of nitrate ions ranged from 85.1 to $103.4 \mathrm{mg} / \mathrm{kg}$, which is significantly lower than the MPC of $300 \mathrm{mg} / \mathrm{kg}$.
\end{abstract}

Keywords: small-volume technology, substrate, tomato, productivity, product quality.

\section{АРАЛ ӨНІРІНІҢ ЖЫЛЫЖАЙЛАРЫНДА ҚЫЗАНАҚ ӨСІРУ ҮШІН БЕЙІМДЕЛГЕН АЗ КӨЛЕМДІ ТЕХНОЛОГИЯНЫ ҚОЛДАНУ ТИІМДІЛІГІ}

\author{
Кудияров Р. И. ${ }^{1}$, ауыл шаруашылығы ғылымдарының кандидаты \\ Дямуршаева Э.Б. ${ }^{1}$, ауыл шаруашылығы ғылымдарының магистрі \\ Сауытбева Г.3. ${ }^{2}$, педагогика ғылымдарының кандидаты \\ Дямуршаева Г.Е. ${ }^{2}$, жылыжай меңгерушісі
}

${ }^{1}$ «Ақмешіт» гуманитарлық-техникальқ институты, Қызылорда қ., Қазақстан Республикасы
${ }^{2}$ Қорқыт Ата атындавы Қызылорда университеті, Қызылорда қ., Қазақстан Республикасы

Аннотация. Бұл жұмыста Арал өңірі жағдайларына бейімделген қызанақ өсірудің аз көлемді технологиясын қолданудың тиімділігі бойынша зерттеулердің нәтижелері келтірілген. Бұл технологияны қолдану Lilos F1 гибридті өсімдіктердің өсуі мен даму процестерінің күшеюіне және өнімнің өнімділігі мен сапасының артуына ықпал еткені анықталды. Нәтижесінде, 1-ші щетканың ертерек төселуі, гүлдену мен жемістердің басталуына тиісінше 4 және 6 күнге жеделдету, алғашқы 3 щеткадағы жемістер санының 8-ден 9,6-ға дейін өсуі, жеміс беру кезеңінің

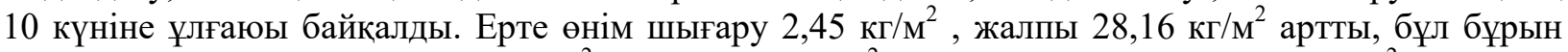
жүргізілген сынақтардан $0,33 \mathrm{\kappa r} / \mathrm{m}^{2}$ және $3,71 \mathrm{\kappa r} / \mathrm{m}^{2}$ артық $\left(2,12\right.$ және $\left.24,45 \mathrm{\kappa r} / \mathrm{m}^{2}\right)$. Өңірлік жағдайларға және сорттық ерекшеліктерге бейімделген Lilos F1 гибридін қолдану технологиясы осы гибридтің өнімділік әлеуетін 78,2\% - ға іске асыруға мүмкіндік берді, бұл алдыңғы зерттеулерге қарағанда 9,4\% - ға (68,8\%). Алынған өнімнің сапасы Мемлекеттік стандарт талаптарына толық сәйкес келді, ал нитрат иондарының мөлшері 85,1-ден 103,4 мг/кг-ға дейін болды, бұл ШРК 300 мг/кг-нан едәуір төмен.

Кілт сөздер: аз көлемді технология, субстрат, қьызанақ, өнімділік, өнім сапасы. 


\title{
БИОЛОГИЧЕСКИЕ ПРИЗНАКИ ПРИСПОСОБЛЕНИЕ МЯСНЫХ ПОРОД СКОТА В УСЛОВИЯХ ЮГО ЗАПАДА КАЗАХСТАНА
}

Баринов В.Э. ${ }^{1}$, кандидат сельскохозяйственных наук ucity3@mail.ru, https://orcid.org/0000-0003-0010-1832

Длимбетов М.К. ${ }^{2}$, кандидат сельскохозяйственных наук dilimbetovm1964@mail.ru, https://orcid.org/0000-0003-2499-3783

Кенжебаев С.А. ${ }^{2}$, кандидат ветеринарных наук kenzhebaev_serik@bk.ru, https://orcid.org/0000-0002-8740-3448

\author{
${ }^{1}$ Калмыцикий государственный университет имени Городовикова, г.Элиста, \\ Российская Федерачия \\ ${ }^{2}$ ТОО «Казахский научно-исследовательский институт рисоводства им. Жахаева», \\ г.Кызылорда, Республика Казахстан
}

\begin{abstract}
Аннотация. Впервые, в условиях резко континентального климата юго-запада Казахстана изучены акклиматизационные и адаптационные способности, завезенных в регион калмыцкой, Санта-Гертруда и казахской белоголовой пород.

Результаты исследований показали, что во все сезоны года у калмыцкой породы двигательные и пищевые поведения были более активными поисками кормов, быстрой реактивности на раздражителей, стадностью на пастбищах, нежели породы Санта-Гертруды и казахской белоголовой, также высоким материнским инстинктом. Калмыцкая порода стойко переносила низкие и высокие температуры воздуха и коэффициент теплоустойчивости, в среднем, составил 2,39+, а индекс холодоустойчивости был в пределах $59,70+$.

За три года физиологическое состояние животных с небольшими отклонениями соответствовал норме, а в крови было большее количество эритроцитов и гемоглобина, у сверстниц казахской белоголовой породы и Санта-Гертруды были относительно низкими, что свидетельствует о благополучно проходящей акклиматизации и адаптационной пластичности этой породы в новых условиях обитания. В статье доступно и понятным языком описана биологическая характеристика мясного скота в условиях юго-западного региона Казахстана.
\end{abstract}

Ключевые слова: окружающая среда, климат, порода скота, акклиматизация, адаптация, наследственность, потомство, продуктивность.

Введение. В Кызылординской области Республики Казахстан, расположенной примущественно на юге-западе страны, мясное скотоводство развит слабо. Здесь отгоннопастбищное скотоводство представлено в основном мелкотоварными хозяйствами (96 \%), где фермеры на условные 100 коров ежегодно получают не более 47-50 телят, при этом яловость репродуктивных маток составляет 12-15 \%, аборт и мертворождаемость плода 7 \% и отход телят до года -5 \% в среднем. Слабая зоотехнические работы за последние 20 лет привело к измельчению скота с низкой живой массы тела (не более 380-400 кг), соответственно и с меньшим выходом туш при убое 200 кг или (46-48 \%).

В хозяйствах области из всего 367 тыс. голов скота всего лишь 14,9 тыс. (4,1%) разных пород имеют племенной статус и в области пока что, не разработана региональная программа развития мясного скотоводства. Завоз в область племенного скота разных мясных пород по 50-200 голов с дальнего и ближнего зарубежья и с других регионов республики осуществляется без учета местных природно-климатических условии, что привело к негативным последствиям. Так, мясные породы герефорд, аулиекольская к местным условиям среды оказались вовсе не приспособленными. Об ошибках при закупке импортного скота и его последствиях было сообщено ранее [1]. 
Климат региона резко континентальный, жаркое,сухое лето и холодная с неустойчивым снежным покровом зима, а осадки в виде дождя и снега не превышает 123135 мм в год.

Цель исследований - изучение протекающих процессов акклиматизации и адаптации калмыцкой, Санты-Гертруды и казахской белоголовой пород.

Для достижения намеченной цели было решить следующие задачи -изучить состояния здоровья и анализа крови завезенного молодняка названных пород:

изучить двигательного, пищевого поведения молодняка названных породв новой среде обитания в сравнении;

Материалы и методы исследований. Объектами для определения акклиматизации и адаптационных признаков скота в регионе служили калмыцкая, казахская белоголовая и Санта-Гертруда породы скота.

Данные о климатических условии, природы и другие данные Кызылординской области РК изложены по [2].

Состояния здоровья животных указанных пород определяли методами клинических исследовании ветеринарии с измерением температуры тела, частоты дыхания и пульса согласно методике [3] из десяти голов от каждый породы по сезонам года, с учетом температуры воздуха на момент исследования а количества эритроцитов на ФЭК, содержание гемоглобинов в них по Сали, лейкоцитов и тромбоцитов подсчетом в камере Горяева и СОЭ по мм/час. в лабораториях по методике [4].

Двигательные и пищевые поведения, повадков скота, изменения жизненных функции организма и признаков приспособления названных пород в условиях региона изучали методами наблюдения с биометрией хронометражно в разные сезоны года.

Сбор первичных, последующих и окончательных результатов исследования выполнены по методике [5], и обработаны методом вариационной статистики, биометрии в биологии [6].

Результаты и их обсуждение. Физиологические состояние и анализ крови молодняка калмыцкой, казахской белоголовой и Санта-Гертруда пород изучали на момент завоза их в регион. Температура тела, частота дыхания и пульса 7-8 месячных телок названных пород показали, что они с небольшими отклонениями соответствовали физиологической норме, присущей их возрасту (таблица 1)

Таблица 1 - Клиническая картина 7-8 месячных телок на момент завоза в регион

\begin{tabular}{|l|l|l|l|l|l|}
\hline \multirow{2}{*}{$\begin{array}{l}\text { п/п } \\
\text { № }\end{array}$} & Показатели & $\begin{array}{l}\text { Единица } \\
\text { измерения }\end{array}$ & \multicolumn{2}{|l|}{ Порода скота } \\
\cline { 5 - 6 } & калмыцкая & $\begin{array}{l}\text { казахская } \\
\text { белоголовая }\end{array}$ & $\begin{array}{l}\text { Санта- } \\
\text { Гертруда }\end{array}$ \\
\hline 1 & Температура тела & \multicolumn{1}{|c}{${ }^{\circ} \mathrm{C}$} & $38,4-38,6$ & $38,5-38,7$ & $38,6-38,8$ \\
\hline 3 & Частота дыхания & $\begin{array}{l}\text { количество } \\
\text { мин }\end{array}$ & $29-30$ & $28-29$ & $28-29$ \\
\hline
\end{tabular}

Результаты анализа проб крови у молодняка названных пород показало, что количество зритроцитов и количество гемоглобина были больше у телок калмыцкой породы (соответственно, 6,2 и 118) нежели этих показателей у их сверстниц казахской белоголовой (соответственно 5,8 и 110) и породы Санта-Гертруда (соответственно, 6,2 и 118). Количество лейкоцитов, трамбоцитов и СОЭ с небольшими отклонениями соответствала физиологической норме (таблица 2). 
Двигательная и пищевая поведение молодняка названных пород в новых природных условиях региона.Изучение поведения и реактивности на раздражителей телок указанных пород в условиях региона показали существенные различия. Так, у молодняка калмыцкой породы Ростовской и Бурятской селекции после ночной выгрузки со скотовозов, была сильная жажда, беспокойство, напряжение и дрожь тела, громкие мычание, раздражительность, вероятно обусловленные с длительностью дорожной транспортировки (2700-3000 км), незнакомой местностью и влиянием раздражителей (свет прожекторов, звук сигналов, голос людей и др.).

Таблица 2 - Анализ проб крови 7-8 месячнных телок на момент завоза

\begin{tabular}{|c|c|c|c|c|c|}
\hline \multirow{2}{*}{ № } & & Единица & \multicolumn{3}{|c|}{ Порода скота } \\
\cline { 4 - 6 } & Показатели & измерения & калмыцкая & $\begin{array}{c}\text { казахская } \\
\text { белоголовая }\end{array}$ & $\begin{array}{c}\text { Санта- } \\
\text { Гертруда }\end{array}$ \\
\hline 1 & Эритроциты & $10^{12}$ л & $7,2 \pm 0,51$ & $5,8 \pm 0,48$ & $6,2 \pm 0,49$ \\
\hline 2 & Гемоглобин & Г.л. & $130 \pm 1,30$ & $110 \pm 1,22$ & $118 \pm 1,25$ \\
\hline 3 & Лейкоциты & $10^{9}$ л. & $6,7 \pm 0,52$ & $6,6 \pm 0,51$ & $6,3 \pm 0,50$ \\
\hline 4 & Тробоциты & $10^{9}$ л. & $296 \pm 6,16$ & $270 \pm 6,18$ & $282 \pm 6,15$ \\
\hline 5 & СОЭ & мм. в час & $0,90 \pm 0,05$ & $0,96 \pm 0,06$ & $0,92 \pm 0,05$ \\
\hline
\end{tabular}

По истечении 3-5 суток они заметно успокоились в новой среде, все же еще держались обособленно, избегали присутствия человека, но охотно, паслись группами на пастбище, подходили водопоям. В целом, по результатам наблюдении можно считать, легко приспособились к новой среде обитания. В последующие месяцы у этой породы выявлены явно выраженное стадное поведение. Утром они поголовно вместе вставали с мест ночлежек, также шли к водопоям, затем на пастбища. Со временем в стадах сформировались лидеры групп, возникали борьба за добычи кормов, иногда с признаками агрессивности к близким, где сильным доставались больше, а слабые уходили на другое, более безопасное место и последние больше тратили время на поиск кормов и довольствовались меньшим источником кормов, паслись по краям, либо в конце стада, но скот этой породы были всегда вместе. Ответная реакция этой породы на раздражителей были достаточно на высоком уровне. На посторонний резкий звук, на сигнал автотракторов, на громкий голос человека они поголовно, поворачивали головы, быстро реагировали на угрозы и группами уходили, либо принимали оборонительные позы защиты. Во всех случаях они оказались очень свободолюбивыми животными, неохотновходили в загоны, коровники, в тесноте громко мычали, проявляли беспокойства, бодали соседей, а в расколах проявляли даже буйства.

Активность двигательного поведения, этой породы ранее были изучены $[7,8,9,10]$. При этом [11] установили, что активность двигательного поведения, физиологическая реактивность скота зависела от сезонов года и температуры внешней среды и они были более активными зимой, нежели летом, что согласуются с результатами наших наблюдении.

Телки казахской белоголовой породы по характерам поведении в новых условиях региона существенно отличались. Завезенные с племенных репродукторов ЗападноКазахстанской области они за первые сутки были утомленными и ослабленными на раздражители реагировали без особого напряжения, явно были в стрессе от транспортировки. Спустя 10-12 дней телки физиологически восстановились, на пастищах активно паслись, но было заметно, что они поедали больше мягких стебельков, чем грубых трав. Стрессы животных вызванные транспортировкой указали и $[12,13]$ которые схожи с данными наших наблюдении. 
Стадное поведение этой породы по сравнению со скотом калмыцкой породы был посредственным. Так, при возникновении на пастбищах раздражителей (гудки, сигналы, крики, громкие удары и т.д.) они уходили подальше, чаще всего не группами, а в рассыпную. В спокойной обстановке они больше проявляли в отношении к сверстницам по стаде покладистый характер, обнюхивали тела, облизывали головы и шеи близких, часто лежали группами во время жвачки на ночлегах, но они всегда не теряли осторожность. Следует отметить что во все времена изучения характер поведения этой породы животных были близки к флегматичному типу темперамента, при этом у них не замечены угрожающие, агрессивные повадки в отношении сверстницам по стаду, не проявляли боязнь человеку.

Молодняк породы Санта-Гертруда, завезенные с племенного репродуктора Алматинской области по хронометражным наблюдениям обладал более активным темпераментом движения, чем казахская белоголовая порода, а по характеру реагирования на раздражителей они были сходны калмыцкой породе скота, но их степень реактивности оказались менее выраженными и несколько в ином виде. Например, на крик, на громкие звуки и сигналы они проявляли больше пугливости и боязни, нежели защиты или агрессивности. Животные этой породы предпочитали пастись в тугайных, тростниковых зарослях, чем равнинных просторах степных пастбищ, чаще всего мелкими группами (3-5 голов), эти признаки позволяют считать, что стадность поведения этой породы скота развит меньше, чем калмыцкой породы.

В целом, результаты изучения показали, что калмыцкая порода на природных пастбищах по поиску, добычи кормов затрачивали в сутки 14-15 часов (60 \%), тогда как их сверстницы казахской белоголовой и Санта-Гертруда на это затрачивали соответственно 9-10 (42 \%) и 12-13 (52 \%) часов времени в среднем. При этом калмыцкая порода быстро приучилась к местным кормам, добывали пастбищных трав более активно и свободно уходили по поиску кормов на длительные расстояния (до 20 км), тогда как казахская белоголовая порода паслась в радиусе не более 8-10 км. Сообощение о влиянии пищевой активности [14] и пищевого взаимодействия с репродуктивными показателями скота аналогичны с нашими наблюдениями.

Характерные признаки групповой активности калмыцкой породы по сравнению с другими породами, вероятно обусловлены генетической природой животных, проявленный имеющихся у родителей наследуемых признаков, которые управляет поведенческих механизмами и можно считать, что животные хорошо акклиматизировались к условиям резко континентального климата региона. Известно, что порода многими столетиями формировалась в суровых условиях Западной Монголии, Восточной Сибири и Алтая вначале путем естественного отбора, где выживали только приспособленные животные, которые выработали исключительную приспособленность к неблагоприятным факторам природы, сохраняя при этом ценные хозяйственные особенности.

Исследования генетических и экологических связей между хозяйственными признаками [15], генетического разнообразия и генных признаков пород скота из Сибири и Восточной Европы [16] и породных различии и генетических параметров скота [17] дают основание считать, что о вероятности присутствия генетической природы калмыцкой породы здесь. Влияние температурных факторов на поведение скота [18] и [19], адаптация и стресс при разведении животных [20] в общих чертах коррелируют с данными наших наблюдении по поведению скота,но авторы проводили исследования иными методами и с другими породами скота.

Выводы. Нами установлено, что увсех исследуемых животных пищевое поведение с увеличением возраста усиливалась, движение скота по поиску и добычи кормов 
становились более активными и в результате скот на пастбищах потребляли болшее количество кормовых трав, жвачными актами, что и согласуются с сообщениями [21].

Таким образом, приведенные данные наших исследовании по определению двигательного и пищевого поведения исследуемых пород скота свидетельствуют о разности активности, характера поведения и отражает сам процесс адаптации и степень приспособленности животных к природо-климатическим условиям региона.

\section{Литература:}

[1] Кучеренко, А. Ошибки при закупке импортного скота. /А.Кучеренко // Животноводство в России. - 2009, № 3.

[2] Система сельскохозяйсвенного производства Кызылординской области. ТОО «Бастау», 2002.

[3] Howard, J.T., Kachman S.D., Snelling W.M., Pollak E.J., Ciobanu D.C., Kuehn L.A., Spangler M.L. Beef cattle body temperature during climatic stress: a genome-wide association study. Int. J. Biometeorol. 2014;58(7):1665-1672. DOI 10.1007/s00484 - $013-0773-5$.

[4] Ковалев, С.П., Курденко А.П., Братушкина Е.Л., Вояков А.А. Клиническая диагностика животных. «Лань», 2016.

[5] Азаубаева, Г.С.. Картина крови животных и птицы. Курган. Зауралье, Россия, 2004.

[6] Чернышев, Н.А. и др. Методика сбора материалов, выполнения экспериментальных работ в животноводстве. Мичуринский аграрный университет, 2006.

[7] Плохинский, Н.А. «Руководство по биометрии в животноводстве». - М.: 1969. № 3 .

[8] Амерханов, Х., Хайницский В., Каюмов Ф. // Молочное и мясное скотоводство, 2011,

[9] Басангов, Н.П., Баринов В.Э. Калмыцкий скот. Монография. Элиста, Россия:ММП «БоТКН», 1992.

[10] Гармаев, Д.Ц. Технология калмыцкого мясного скотоводства: Монография . УланУдэ. Бурятская гос. с.-х. акад. -2007.

[11] Еременко, В.К., Каюмов Ф.Г. Калмыцкий скот и методы его совершенствования: Монография. М.: Вестник РАСХН, 2005.

[12] Отаров, А.И., Каюмов Ф.Г., Третьяков Р.Ф. Влияние климатических факторов на гематологические показатели калмыцкого скота в горных условиях Кабардино-Балкарской Республики. Известия Оренбургского гос. аграрн. Университета. - 2020, № 2 (82)

[13] Бондарь, А.А. Породные особенности поведения и стрессоустойчивости коров / А. А. Бондарь // Тезисы докладов Всесоюзного научно-практического семинара. - Харьков, 1989. С. 24 25.

[14] Browning, R., Leite-Browning M.L. Comparative stress responses to short transport and related events in Hereford and Brahman steers. J. Anim. Sci., 2013, 91: 957 - 969.

[15] Butler, W.R. Nutritional interactions with reproductive performance in dairy cattl / W.R. Butler // Animal Reproduction Science. - Special Issue 60 - 61, 2000. - P. 449 - 457.

[16] Bock, R.M. Genetic and environmental relatooushin among economic characters in beet cattle- J.Amin.Sci. - 1955. - V.14. - P. $24-27$

[17] Iso-Touru, T, Tapio M, Vilkki J, Kiseleva T, Ammosov I, Ivanova Z, et al. Genetic diversity and genomic signatures of selection among cattle breeds from Siberia, eastern and northern Europe. AnimGenet. 2016;47:647 - 57.

[18] Marshall, D.M. (1994). Breed differences and genetic-parameters for body-composition traits in beef-cattle. J. Anim. Sci. 72(10), $2745-2755$.

[19] Караваева, Е.А. Влияние температурных факторов поведение коров в условиях средней полосы РСФСР. Е. А. Караваева // Адаптация на разных уровнях биологической организации. -Сыктывкар: АН СССР. - 1982. С - 189.

[20] Young, B. Thermal influence on ruminants / B. Young, A. Degen. - Environmental Aspects of Housing for Animal Production. - 1981.-p. $167-180$.

[21] Чередниченко, Л.К. Природные факторы среды и их влияние на организм / Л. К. Чередниченко // Экологическая физиология животных. - Л.: Наука, 1979. 
[22] Василенко, Т.Ф. Возрастная динамика формирования пищевого поведения у телят при свободном движении и гиподинамии / Т. Ф. Василенко, А. А. Мартынов, Н. П. Монголов, Н. И. Чувьюрова, Л. Ю. Рубцова // с.-х. Биология. - 2010, № 2. С. 95 - 99.

\section{References:}

[1] Kucherenko, A. Oshibki pri zakupke importnogo skota. /A.Kucherenko // ZHivotnovodstvo v Rossii. - 2009, № 3.

[2] Sistema sel'skohozyajsvennogo proizvodstva Kyzylordinskoj oblasti. TOO «Bastau», 2002.

[3] Howard, J.T., Kachman S.D., Snelling W.M., Pollak E.J., Ciobanu D.C., Kuehn L.A., Spangler M.L. Beef cattle body temperature during climatic stress: a genome-wide association study. Int. J. Biometeorol. 2014;58(7):1665-1672. DOI 10.1007/s00484 - $013-0773-5$.

[4] Kovalev, S.P., Kurdenko A.P., Bratushkina E.L., Voyakov A.A. Klinicheskaya diagnostika zhivotnyh. «Lan'», 2016.

[5] Azaubaeva, G.S.. Kartina krovi zhivotnyh i pticy. Kurgan. Zaural'e, Rossiya, 2004.

[6] Chernyshev, N.A. i dr. Metodika sbora materialov, vypolneniya eksperimental'nyh rabot v zhivotnovodstve. Michurinskij agrarnyj universitet, 2006.

[7] Plohinskij, N.A. «Rukovodstvo po biometrii v zhivotnovodstve». - M.: 1969.

3.

[8] Amerhanov, H., Hajnicskij V., Kayumov F. // Molochnoe i myasnoe skotovodstvo, 2011, №

[9] Basangov, N.P., Barinov V.E. Kalmyckij skot. Monografiya. Elista, Rossiya:MMP «BoTKN», 1992.

[10] Garmaev, D.C. Tekhnologiya kalmyckogo myasnogo skotovodstva: Monografiya . UlanUde. Buryatskaya gos. s.-h. akad. - 2007.

[11] Eremenko, V.K., Kayumov F.G. Kalmyckij skot i metody ego sovershenstvovaniya: Monografiya. M.: Vestnik RASKHN, 2005.

[12] Otarov, A.I., Kayumov F.G., Tret'yakov R.F. Vliyanie klimaticheskih faktorov na gematologicheskie pokazateli kalmyckogo skota v gornyh usloviyah Kabardino-Balkarskoj Respubliki. Izvestiya Orenburgskogo gos. agrarn. Universiteta. - 2020, № 2 (82)

[13] Bondar', A.A. Porodnye osobennosti povedeniya i stressoustojchivosti korov / A. A. Bondar' // Tezisy dokladov Vsesoyuznogo nauchno-prakticheskogo seminara. - Har'kov, 1989. S. 24 25 .

[14] Browning, R., Leite-Browning M.L. Comparative stress responses to short transport and related events in Hereford and Brahman steers. J. Anim. Sci., 2013, 91: 957 - 969.

[15] Butler, W.R. Nutritional interactions with reproductive performance in dairy cattl / W.R. Butler // Animal Reproduction Science. - Special Issue 60 - 61, 2000. - P. 449 - 457.

[16] Bock, R.M. Genetic and environmental relatooushin among economic characters in beet cattle- J.Amin.Sci. - 1955. - V.14. - P. $24-27$

[17] Iso-Touru, T, Tapio M, Vilkki J, Kiseleva T, Ammosov I, Ivanova Z, et al. Genetic diversity and genomic signatures of selection among cattle breeds from Siberia, eastern and northern Europe. AnimGenet. 2016;47:647 - 57.

[18] Marshall, D.M. (1994). Breed differences and genetic-parameters for body-composition traits in beef-cattle. J. Anim. Sci. 72(10), $2745-2755$.

[19] Karavaeva, E.A. Vliyanie temperaturnyh faktorov povedenie korov v usloviyah srednej polosy RSFSR. E. A. Karavaeva // Adaptaciya na raznyh urovnyah biologicheskoj organizacii. Syktyvkar: AN SSSR. - 1982. S - 189.

[20] Young, B. Thermal influence on ruminants / B. Young, A. Degen. - Environmental Aspects of Housing for Animal Production. - 1981. - p. $167-180$.

[21] Cherednichenko, L.K. Prirodnye faktory sredy i ih vliyanie na organizm / L. K. CHerednichenko // Ekologicheskaya fiziologiya zhivotnyh. - L.: Nauka, 1979.

[22] Vasilenko, T.F. Vozrastnaya dinamika formirovaniya pishchevogo povedeniya u telyat pri svobodnom dvizhenii i gipodinamii / T. F. Vasilenko, A. A. Martynov, N. P. Mongolov, N. I. CHuv'yurova, L. YU. Rubcova // s.-h. Biologiya. - 2010, № 2. S. 95 - 99. 


\title{
ҚАЗАҚСТАННЫН ОНТУСТІК БАТЫС АЙМАҒЫНА ІРІ ҚАРА МАЛЫНЫН БИОЛОГИЯЛЫК БЕЙІМДЕЛУ ЕРЕКШЕЛІКТЕРІ
}

\author{
Баринов В.Э. ${ }^{1}$, ауыл шаруашылығы ғылымдарының кандидаты \\ Длимбетов М. К. ${ }^{2}$, ауыл шаруашылығы ғылымдарының кандидаты \\ Кенжебаев С. А. ${ }^{2}$, ветеринария ғылымдарының кандидаты \\ ${ }^{I}$ Городовиков атындавы Қалмақ.мемлекеттік университеті, Элиста қ., Ресей Федерациясы \\ 2"ЫI. Жақ̧аев атындавы қ̧азақ̧ күріш шаруашылывы ҒЗИ" ЖШС, Қызыллорда қ̧., ҚР
}

\begin{abstract}
Андатпа. Алғаш рет Қазақстанның оңтүстік-батысындағы қатал континентальды климат жағдайында аймаққа әкелінген қалмақ, Санта-Гертруда және қазақтың ақ бас тұқымдарының жерсіну мен бейімделу қабілеттері зерттелді. Зерттеу нәтижелері көрсеткендей, жылдың барлық мезгілінде қалмақ тұқымының қимыл және тамақтану мінез-құлықтары Санта-Гертруда мен қазақтың ақбас тұқымдарына қарағанда азық іздеуде, тітіркендіргіштерге жылдам реактивтілікте, жайылымдарда жайылу барысында белсенді болып және де бұзаулаған сиырлардың табиғи аналық сезімі өте жоғары болатыны анықталды. Қалмақ тұқымы ауа-райының төмен және жоғары температурасына төзімді болатыны байқалып, ыстыққа төзімділік коэффициенті орта есеппен 2,39+ құрады, ал суыққа төзімділік индексі 59,70+ аралығында болды.Үш жылғы зерттеулер барысында бұл тұқымның малдарының физиологиялық жағдайларында аздаған ауытқулар болғанымен нормаға сай болды. Қандағы эритроцит пен гемоглобиннің мөлшері оларда қазақтың ақ бас және Санта-Гертруда тұқымдарындағы қатарластарына қарағанда мол болып, жаңа тіршілік ету аймағының жағдайларына жақсы жерсініп, бейімделетіні байқалды. Мақалада Қазақстанның оңтүстік-батыс аймағы жағдайындағы етті ipi қара малының биологиялық сипаттамасы барынша түсінікті тілде және жан-жақты баяндалған.
\end{abstract}

Кїлт сөздер: окружсюющая среда, климат, порода скота, акклиматизация, адаптация, наследственность, потомство, продуктивность.

\section{BIOLOGICAL SIGNS ADAPTATION OF MEAT BREEDS OF LIVESTOCK IN THE CONDITIONS OF SOUTHWEST KAZAKHSTAN}

\author{
Barinov V.E. ${ }^{1}$, candidate of agricultural sciences \\ Dlymbetov M. K. ${ }^{2}$, candidate of agricultural sciences \\ Kenzhebaev S. A. ${ }^{2}$, candidate of veterinary sciences \\ ${ }^{I}$ Kalmyk State University named after Gorodovikov, Elista, Russian Federation \\ ${ }^{2}$ LLP "Kazakh Scientific Research Institute of Rice Growing named after Zhakhaeva" \\ Kyzylorda, Republic of Kazakhstan
}

\begin{abstract}
Annotation. For the first time, acclimatization and adaptation abilities of Kalmyk, Santa Gertrude and Kazakh white-headed breeds imported to the region have been studied in the sharply continental climate of southwestern Kazakhstan. The results of the research showed that in all seasons of the year, the Kalmyk breed's motor and eating behaviors were more active in the search for food, rapid reactivity to stimuli, herding on pastures than the Santa Gertrude and Kazakh White-headed breeds, as well as high maternal instinct. The Kalmyk breed steadfastly endured low and high air temperatures and the coefficient of heat resistance, on average, was 2.39+, and the cold resistance index was within 59.70+. For three years, the physiological condition of animals with small deviations corresponded to the norm, and there were more erythrocytes and hemoglobin in the blood, the peers of the Kazakh white-headed breed and Santa Gertrude were relatively low, which indicates that acclimatization and adaptive plasticity of this breed in new living conditions were successfully passing. The article describes in an accessible and understandable language the biological characteristics of beef cattle in the conditions of the southwestern region of Kazakhstan.
\end{abstract}

Keywords: environment, climate, cattle breed, acclimatization, adaptation, heredity, offspring, productivity. 


\title{
FUNDAMENTALS AND SOCIO-ECONOMIC RESULTS OF THE PLACEMENT AND DEVELOPMENT OF AGRICULTURE IN THE SOUTHERN REGION
}

\author{
Yessimov E.K. ${ }^{1}$, candidate of technical sciences \\ esimov58@mail.ru, https://orcid.org/0000-0001-6993-9057 \\ Sultanbekova P.S. ${ }^{1}$, candidate of technical sciences \\ parida.sultanbekova@mail.ru, https://orcid.org/0000-0003-4194-1854 \\ Shayanbekova B.R. ${ }^{2}$,candidate of technical sciences \\ shbakhyt_67@list.ru, https://orcid.org/0000-0003-0399-6387 \\ Omarov K.A. ${ }^{2}$, candidate of geographical sciences \\ kaliom@mail.ru, https://orcid.org/0000-0003-3128-8206 \\ Bulanbayeva P.U. ${ }^{2}$, PhD \\ peri08@mail.ru,https://orcid.org/0000-0002-3879-0680 \\ ${ }^{1}$ South Kazakhstan University named after M.Auezov, Shymkent city, Republic of Kazakhstan \\ ${ }^{2}$ Kyzylorda University named after Korkyt Ata, Kyzylorda city, Republic of Kazakhstan
}

\begin{abstract}
Annotation. There are two main reasons for the development of cotton growing in the southern regions of the country: the first is objective, the second is subjective. An objective reason for the development of cotton growing in the southern regions of the country is the natural climate and relief of the region. The southwestern, southern part of the region is located on the plains of the Turan depression. In particular, the climate of the region has its own characteristics: dry air, predominance of sunlight and hot days, long autumn, sufficient and convenient location of water sources for irrigation. The climate of the Turkestan region is similar to that of neighboring Uzbekistan in terms of sunshine and hot days from May to October, and even higher than in a number of other agricultural countries.

The article states in detail that the only way to solve the problem of economic independence under favorable climatic conditions is the need for efficient use of agricultural land resources.

It also describes the structure of agricultural land in the southern part of the country, the relevance and development of crop production through the introduction of scientific and technological progress, the basis for the effective use of land resources and socio-economic results.

In general, in the context of the development of world market relations, the effectiveness of the reforms carried out in our country will undoubtedly allow our country to develop economically.

Keywords: land resources, agriculture, plant growing, arable land.
\end{abstract}

Introduction. There are two main reasons for the development of cotton in the southern regions of the country: the first is objective, the second is subjective. The objective reason for the development of cotton in the southern regions of the country is due to the natural climate and terrain. The territory is located in the south-west, the southern part in the plains of the Turan depression. In particular, the climate of the region is characterized by the characteristics of the weather: dry air, the success of heat and sunlight, long autumn, sufficient and location of water sources for irrigation. The growth period of crop production, including cotton) is equal to that of neighboring Uzbekistan in terms of sunshine and duration of hot days, and even higher than in a number of countries around the Mediterranean [2,3].

Materials and research methods. However, the deficit of cotton and the amount of foreign exchange earnings from the sale of ready-to-eat semi-finished products abroad are unsatisfactory and do not cover. Therefore, we believe that knowledge of the population's expenditures on the purchase of rationally scarce food products should be carried out by increasing the role of cotton production in global competition. 
The achievement of economic independence, including meeting the demand for food products at the expense of domestic opportunities, is directly related, first of all, to the achievement of grain independence.

According to the experience of other countries, in order to achieve full grain independence, it is necessary to produce one ton of grain per capita. Grain products produced in such quantities make it possible to fully satisfy all the needs of the population for food, livestock in the required quantity.

The sustain ability of crop production plays an important role in solving the problem of grain independence. To do this, it is necessary to apply an intensive approach, to increase the yield of arable land on the basis of an increase in the culture of agriculture. Currently, the average level of grain yield is very low.

The relevance of increasing the yield of agricultural crops by introducing the results of scientific and technological progress into production is explained by the following features:

- limited area of land in general and land suitable for agriculture in particular;

- shortage of waste water resources;

- Possibility of increasing the amount of arable land (arable land) through investment;

- The process of rapid population growth in the region.

Research results and their discussion. The high level among the countries of the world shows that the only way to solve the problem of economic independence is to increase the efficiency of land use. Currently, the area under crops in the region is 1158.4 thousand hectares, the distribution of crops is as follows.

Table 1 - The structure of agricultural land in Turkestan region

\begin{tabular}{|c|c|c|c|}
\hline $\begin{array}{c}\text { Composition } \\
\text { of agricultural land }\end{array}$ & $\begin{array}{r}\text { Total, } \\
\text { thousand hectares }\end{array}$ & $\begin{array}{c}\text { The share of } \\
\text { total land, } \%\end{array}$ & $\begin{array}{c}\text { The share in } \\
\text { the } \\
\text { useful } \\
\text { Agriculture, \% }\end{array}$ \\
\hline Sowing & 1107,2 & 8,9 & 10,1 \\
\hline $\begin{array}{c}\text { Perennial } \\
\text { sowing }\end{array}$ & 26,5 & 0,2 & 0,2 \\
\hline Virgin lands & 112,0 & 0,9 & 1,0 \\
\hline Meadows & 176,9 & 1,4 & 1,6 \\
\hline Pastures & 9545,9 & 77,1 & 100,0 \\
\hline $\begin{array}{c}\text { Total } \\
\text { agricultural land }\end{array}$ & 10968,5 & 88,6 & \\
\hline $\begin{array}{c}\text { House } \\
\text { foundations }\end{array}$ & 24,7 & 0,2 & \\
\hline Forests & 458,0 & 3,7 & \\
\hline $\begin{array}{c}\text { in the state } \\
\text { fund }\end{array}$ & 105,8 & 0,9 & \\
\hline Other lands & 818,9 & 6,7 & \\
\hline Total & 12375,9 & 100,0 & \\
\hline
\end{tabular}

The economy of the region is significantly affected by the general trends in agricultural development. It is well known that in the context of the development of market relations, the increase in the effectiveness of the ongoing reform largely depends on the harmonious and correct use of economic mechanisms.

Therefore, there is a sufficient productive force and an economic requirement for modern economic management, the difference of which is that the main economic achievements 
available at enterprises are the ability to strengthen them with proper use of land, the service of the national economy.

The area of land used in agricultural production - about 11.7 thousand hectares, including plowed (plowed) part - about 1107.2 thousand hectares, more than 500 thousand hectares of irrigated land. As shown in Table 1 above, 458 thousand hectares, or 3.7\% of the total land area in this area, are $6.7 \%$ of the forest area, which is mainly unsuitable for agricultural use, as it is a mountain with large ridges and deep valleys, relief lands [5,6,7].

Also, most of these lands do not have fertile soils. Only some areas can be used for grazing. This situation highlights the importance of economic valuation of land now and in the future. Because there is no reason to actively involve such lands in agricultural production.

However, as a result of the measures taken by the state in the process of agricultural reform, in recent years there have been some positive changes in the construction of land resources, and the dynamics of agricultural development has reached a significant breakthrough.

One of the regions of the country with socio-economic indicators is the South Kazakhstan region, formed in 1932 as part of the country. Its powerful productive forces, economically active population of urban and rural areas, mineral and surface resources in 2014, the gross output of large industrial enterprises (in current prices) amounted to 264.2 billion. tenge.

This strategic direction of the regional economy is a positive attitude arising from the requirements of agriculture, especially its priority sectors, to more fully meet the food needs of the population, the adaptation of rural producers to foreign markets, increasing their international competitiveness.

This includes the region's natural resources, fertile land resources, mild and short winters, sufficient sunlight and water sources, human potential, etc. These resources not only increase the production of agricultural products, but also create a favorable environment for the production of a wide range of them. For example, in the foothills, crop production, especially horticulture, dairy farming is well developed. Steppe-mountainous areas are suitable for irrigated and cultivated agriculture, in particular, for the production of grain, vegetables and technical products. In addition, the desert and steppe regions have great potential for the development of camel and horse breeding. This is evidenced by the fact that $20.2 \%$ of the processing industry of the region is food and agricultural raw materials.

In 2014, agricultural processing enterprises produced goods worth 40.8 billion tenge. tenge worth of products. Among the food products, especially fruits and vegetables, ethyl alcohol, long-lasting confectionery, crackers and cookies, etc. Production has increased 1.5-2 times only in the last 2-3 years.

Thus, the first main reserve for the further sustainable development of the agro-industrial sector of the region is the basic sector - to ensure the dynamics and efficiency of agriculture, the second reserve - the development of the manufacturing industry.

The total area of agricultural land in the region is 10.3 million hectares. hectares, including $1.1 \mathrm{mln}$. hectares of land of agricultural cooperatives and partnerships, 790.9 thousand hectares of peasant (farmer) farms, 344.6 thousand hectares of land of economic associations and joint stock companies. The land of citizens engaged in private (home-based) and community gardening is 3.8 thousand hectares.

Availability of agricultural machinery, except for farms of agricultural enterprises (peasants, farmers): tractors of all brands - 2789 units, combine harvesters 498, cotton harvesters -215 , cultivators -593 , seeders - 567 , etc. technical forces $[8,10,11]$.

In 2018, the volume of investments in fixed assets in agriculture will reach 300 billion. tenge. The income of agricultural producers due to the use of such resources is characterized by the following (Table 2). 
Table 2 - Dynamics of agriculture in Turkestan region

\begin{tabular}{|l|c|c|c|c|c|}
\hline \multicolumn{1}{|c|}{ Indicators for } & $2014 \mathrm{y}$. & $2015 \mathrm{y}$. & $2016 \mathrm{y}$. & $2017 \mathrm{y}$. & $\begin{array}{c}2018 \mathrm{y} .2014 \mathrm{y} . \\
\text { compared }\end{array}$ \\
\hline Gross agricultural output, bln. tenge & 65,4 & 77,7 & 95,8 & 90,4 & 185,1 \\
\hline $\begin{array}{l}\text { Including: } \\
\text { crop production } \\
\text { livestock products }\end{array}$ & 45,4 & 55,9 & 71,3 & 60,7 & 153,2 \\
\hline Structure of agriculture by industry,\% & - & - & - & - & 158,5 \\
\hline crop production & 73,9 & 77,8 & 81,4 & 76,4 & - \\
\hline Livestock & 46,1 & 42,2 & 38,6 & 44,6 & - \\
\hline total sown area, thousand hectares & 724,8 & 741,5 & 750,0 & 772,8 & 146,7 \\
\hline $\begin{array}{l}\text { Including: } \\
\text { raw cotton }\end{array}$ & 194,5 & 180,5 & 209,4 & 233,1 & 130,8 \\
\hline The share of raw cotton in the field,\% & 25,0 & 23,0 & 26,2 & 29,2 & - \\
\hline cereals and legumes & 219,7 & 246,5 & 241,8 & 236,5 & 148,0 \\
\hline $\begin{array}{l}\text { share of cereals and legumes in the } \\
\text { field,\% }\end{array}$ & 25,0 & 37,0 & 39,7 & - & - \\
\hline $\begin{array}{l}\text { gross yield, thousand tons: cereals and } \\
\text { legumes }\end{array}$ & 325,2 & 551,4 & 498,4 & 475,1 & 150,2 \\
\hline raw cotton & 420,5 & 364,4 & 406,0 & 470,4 & 128,0 \\
\hline $\begin{array}{l}\text { livestock products: meat (in live } \\
\text { weight), thousand tons }\end{array}$ & 110,3 & 110,5 & 115,0 & 123,0 & 121,5 \\
\hline $\begin{array}{l}\text { milk, thousand tons milk, thousand } \\
\text { tons }\end{array}$ & 390,2 & 402,9 & 429,4 & 466,1 & 116,0 \\
\hline eggs, mln. pieces & 133,6 & 155,2 & 188,6 & 196,8 & 123,3 \\
\hline wool, tons & 3611,0 & 3730,0 & 4147,0 & 4647,0 & 132,7 \\
\hline & & & & \\
\hline
\end{tabular}

At least three conclusions can be drawn from the table:

- It is true that in recent years the area under crops has been growing steadily, especially raw cotton and legumes;

- About one third of the sown area is occupied by cereals and legumes, $29.2 \%$ of the total area is occupied by raw cotton;

- low level of livestock production, especially meat and dairy products.

At present, $48 \%$ of all agricultural products are produced in peasant (farmer) farms, $43 \%$ in subsistence farms (household foundations), and only $9 \%$ in agricultural enterprises. Therefore, the prospects of agriculture in the region in the field of crop production - entirely based on private ownership, and in the production of livestock products - in the hands of private farms of the population.

From 2014 to 2018, the number of farms in the region increased from 41.8 thousand to 52.1 thousand, or $25 \%$.

However, the current situation on farms is unsatisfactory: the volume of production is insufficient, growth is insignificant, product quality and costs are not at a competitive level, labor productivity and efficiency are low.

The same can be said about the productivity, efficiency and competitiveness of livestock, which is concentrated in the private property of the entire rural population. For example, in 2014-2018. Meat production here increased by $14.5 \%, 13.6 \%$, wool by $15.6 \%$, eggs by $29.7 \%$ $[10,11]$.

$85 \%$ of the total territory of Kazakhstan is arid and insufficiently moist. In this case, the formation of an artificial irrigation system will play a key role in improving the quality of 
guaranteed production and use of land resources. In this regard, Turkestan region has more than 500 thousand hectares of irrigated arable land.

Such arable lands are planted with cereals, cotton, potatoes, vegetables and orchards. This can be seen from the indicators in Table 3 below.

Table 3 - Structure of irrigated lands of Turkestan region (thousand hectares)

\begin{tabular}{|l|c|c|c|c|c|c|}
\hline Indicators & $1995 \mathrm{y}$. & $2010 \mathrm{y}$. & $2015 \mathrm{y}$. & $2016 \mathrm{y}$. & $2017 \mathrm{y}$. & $2018 \mathrm{y}$. \\
\hline Irrigated arable land & 565,3 & 461,4 & 488,1 & 506,8 & 492,1 & 503,1 \\
\hline Including on major crops & & & & & & \\
\hline corn for grain & 19,2 & 20,5 & 15,5 & 24,7 & 22,7 & 17,7 \\
\hline fodder crops & 351,5 & 204,8 & 205,2 & 215,7 & 182,6 & 178,5 \\
\hline potatoes, orchards, vegetables & 30,2 & 46,9 & 48,5 & 53,7 & 51,8 & 51,3 \\
\hline Fig/rice/ & 13,6 & 3,6 & 1,2 & 3,6 & 2,0 & 1,8 \\
\hline technical crops & 114,6 & 164,3 & 196,2 & 185,6 & 213,5 & 235,1 \\
\hline Including: cotton sowing & 109,7 & 153,3 & 184,5 & 170,3 & 199,4 & 223,1 \\
\hline grapes & 28,7 & - & 18,6 & - & 21,0 & 21,3 \\
\hline others & 26,1 & 15,7 & 16,1 & 15,7 & 14,9 & 14,6 \\
\hline unused lands & 12,8 & - & 14,7 & - & 12,2 & 10,4 \\
\hline
\end{tabular}

Conclusion. In short, the main thing is to ensure the normal life of the rural population, to improve the quality of life of the population, to develop production, to keep up with the current trend of additional water, to give it additional impetus, to achieve high efficiency.

Over the last 4-5 years, the area of irrigated land has changed significantly compared to 1995. This is a decrease of 104.4 thousand hectares in 2010 compared to 1995, 78.7 thousand hectares in 2015 and 662.7 thousand hectares in 2018.

In our opinion, the main reason for this is the loss of fertile land due to the transfer of most of the land in the south to the market system of agricultural production.

In the case of the agricultural sector of the study region, the following should be taken into account:

- basic industry - raising the intensity of agriculture to a new level, material and technical re-equipment, attracting investment in the priority areas of social and engineering infrastructure;

- increase the productivity of the peasant (farmer) in increasing the efficiency of crop production, grouping into industry clusters, further elaboration of state support for irrigation water, fuel, mineral fertilizers, seed materials;

- Accelerate the development of animal husbandry, optimize the structure of arable land for it, increase the number of offspring, increase non-repayable funding for livestock breeding, improve specially adopted laws on the regulation of private farms of the rural population.

\section{literature:}

[1] Аймурзина, Б.Т. Государственная финансовая поддержка развития АПК РК //Актуальные проблемы экономики. - 2014. - №2 (152). - С. 87-93.

[2] Каменова, М.Ж. и др. Конкурентоспособность аграрного сектора Республики Казахстан: теория, практика и перспективы в посткризисный период. - Астана: ИП Ботабеков, 2012. $-247 \mathrm{c}$.

[3] Югай, С. Тенденции государственной поддержки сельского хозяйства Казахстана в контексте мирового опыта // Проблемы агрорынка. - 2014. - №1. - С. 150 - 157.

[4] Накипова, Г. Интеграционные процессы агропромышленного комплекса в Казахстане //Проблемы агрорынка. - 2013. - №3. - С.112 - 119. 
[5] Комитет по статистике Министерства национальной экономики Республики Казахстан [Электронный ресурc].-2018. - URL: http://www.stat.gov.kz (дата обращения: 06.05.2018).

[6] Шредер, М. Фракталы, хаос, степенные законы. Миниатюры из бесконечного рая. Ижевск: НИЦ «Регулярная и хаотическая динамика», 2001.- 528 с.

[7] Хан, Ю. Конкурентоспособность аграрного сектора Казахстана в условиях ВТО // Проблемы агрорынка.- 2017. - №3.- С. 13 - 15.

[8] Волкова, П.А. Статистическая обработка данных в учебно-исследовательских работах. - М.: Экопресс, 2008. - 60 c.

[9] Есентугелов, А.Е. Уязвимость казахстанской экономики для кризиса еврозоны // Вестник КазУЭФМТ. - 2013. - № 1. - С. 18 - 29.

[10] Бахтиярова, А.Ж. Основные проблемы и текущая ситуация в сельскохозяйственном секторе Республики Казахстан // Доклады НАН РК. - 2017. - №3. - С. 164 - 168.

[11] Есімов, Е.Қ., Карабалаева А.Д., Ермаханов Н.Қ. Оңтүстік аймақта мақта шаруашылығын орналастыру мен дамытудың негіздері және әлеуметтік - экономикалық нәтижелері. «QAZAQTANÝ» республиканский научный журнал 2(6) номер 2020 год, июнь, Шымкент.

\section{References:}

[1] Ajmurzina, B.T. Gosudarstvennaja finansovaja podderzhka razvitija APK RK //Aktual'nye problemy jekonomiki. - 2014. - №2(152). - S.87 - 93 .

[2] Kamenova, M.Zh. i dr. Konkurentosposobnost' agrarnogo sektora Respubliki Kazahstan: teorija, praktika i perspektivy v postkrizisnyj period. - Astana: IP Botabekov, 2012. - $247 \mathrm{~s}$.

[3] Jugaj, S. Tendencii gosudarstvennoj podderzhki sel'skogo hozjajstva Kazahstana v kontekste mirovogo opyta // Problemy agrorynka. - 2014. - №1. - S. 150 - 157.

[4] Nakipova, G. Integracionnye process agropromyshlennogo kompleksa $\mathrm{v}$ Kazahstane//Problemy agrorynka. - 2013. - №3. - S. 112 - 119.

[5] Komitet po statistike Ministerstva nacional'noj jekonomiki Respubliki Kazahstan [Jelektronnyj resurs].-2018. - URL: http://www.stat.gov.kz (data obrashhenija: 06.05.2018).

[6] Shreder, M. Fraktaly, haos, stepennye zakony. Miniatjury iz beskonechnogo raja. - Izhevsk: NIC «Reguljarnaja i haoticheskaja dinamika», 2001. - $528 \mathrm{~s}$.

[7] Han, Y.U. Konkurentosposobnost' agrarnogo sektora Kazahstana v usloviyah VTO // Problemy agrorynka.- 2017. - №3.- S. 13 - 15.

[8] Volkova, P.A. Statisticheskaya obrabotka dannyh v uchebno-issledovatel'skih rabotah. - M.: Ekopress, 2008. - $60 \mathrm{~s}$.

[9] Esentugelov, A.E. Uyazvimost' kazahstanskoj ekonomiki dlya krizisa evrozony // Vestnik KazUEFMT. - 2013. - №1. - S. 18 - 29.

[10] Bahtiyarova, A.Zh. Osnovnye problemy i tekushchaya situaciya v sel'skohozyajstvennom sektore Respubliki Kazahstan // Doklady NAN RK. - 2017. - №3. - S. $164-168$.

[11] Esimov, E.K., Karabalaeva A.D., Ermahanov N.K. Ontystik ajmakta makta sharuashylyғyn ornalastyru men damytudyn negizderi zhəne əleumettik - ekonomikalyk nətizheleri. «QAZAQTANÝ» respublikanskij nauchnyj zhurnal 2(6) nomer 2020 god, iyun', Shymkent.

\section{ОНТУСТІК АЙМАҚТА АУЫЛ ШАРУАШЫЛЫҒЫН ОРНАЛАСТЫРУ ЖӘНЕ ДАМЫТУДЫҢ НЕГІЗДЕРІ МЕН ӘЛЕУМЕТТІК-ЭКОНОМИКАЛЫҚ НӘТИЖЕЛЕРІ}

Есімов Е.К. 1 , техника ғылымының кандидаты Султанбекова П.С. ${ }^{1}$, техника ғылымының кандидаты Шаянбекова Б.Р. ${ }^{2}$, техника ғылымдарының кандидаты Омаров К.Ә. ${ }^{2}$, география ғылымдарының кандидаты Буланбаева П.У.', $\mathrm{PhD}$

${ }^{I}$ М.Әуезов атындавы Оңтүстік Қазақстан университеті, Шылкент қ, Қазақстан ${ }^{2}$ Қорқыыт Ата атындавы Қызылорда университеті, Қызыллорда құ., Қазақсттан 
Аңдатпа. Республикамыздың оңтүстік өнірінде мақта шаруашылығының дамуының негізінен екі себебі бар: біріншісі - объективтік, екіншісі - субъективтік себеп.

Мақта шаруашылығының республикамыздың оңтүстік өнірінде өркендеуінің объективтік себебі, аймақтың табиғи климаты және жер бедері өсімдікке қолайлы. Аймақтың оңтүстік батыс, оңтүстік бөлігі Тұран ойпатының жазықтарында орналасқан. Атап айтқанда, аймақтың климаты, ауа - райының өзіне тән ерекшеліктері бар: құрғақ ауа, күн сәулесі мен ыстық күндері басым, күзі ұзаққа созылады, суғару үшін қажетті су көздерінің жеткілікті және қолайлы орналасуы. Түркістан облысының климат жағдайы мамыр және қазан айлары аралығында күн көзінің өткірлігі мен ыстық күндердің басымдығы жөнінде көршілес Өзбекстанмен тең, ал басқа егіншілікпен айналысатын мемлекеттердің бірқатарына қарағанда бұдан да жоғары қолайлы көрсеткіштерге ие.

Мақалада қолайлы табиғи-климатттық жағдайды ескере отырып, экономикалық тәуелсіздік мәселесін шешудің бірден-бір жолы ауыл шаруашылық жер ресурстарын тиімді пайдалану қажеттігі жәйлі айтылады.

Сонымен қатар еліміздің оңтүстік аймағындағы ауыл шаруашылығы жерлерінің құрылымы, өсімдік шаруашылығының өнімділігін өндіріске ғылыми-техникалық прогрестің нәтижелерін енгізу есебінен арттырудың бүгінгі таңдағы өзектілігі мен дамыту жолдары, жер ресуртарын тиімді пайдалану негіздері мен әлеуметтік-экономикалық нәтижелері туралы баяндалған.

Жалпы айтканда әлемдік нарықтық қатынастардың дамуы жағдайында, елімізде жүргізіліп жатқан реформаның тиімділігі біздің елімізде де экономикалық тұрғыда дамуға мүмкіндік берері сөзсіз.

Кілт сөздер: жер ресурстары, ауыл шаруашылывы, өсмдік шаруашылызы, айдалван жерлер.

\section{ОСНОВЫ И СОЩИАЛЬНО-ЭКОНОМИЧЕСКИЕ РЕЗУЛЬТАТЫ РАЗМЕЩЕНИЯ И РАЗВИТИЯ СЕЛЬСКОГО ХОЗЯЙСТВА В ЮЖНОМ РЕГИОНЕ}

Есимов Е.К. ${ }^{1}$, кандидат технических наук

Султанбекова П.С. ${ }^{1}$, кандидат технических наук

Шаянбекова Б.P. ${ }^{2}$ кандидат технических наук

Омаров К.А. ${ }^{2}$, кандидат географических наук Буланбаева П.У. ${ }^{2}, \mathrm{PhD}$

${ }^{1}$ Южно-Казахстанский университет имени М.Ауэзова, г.Шымкент, Республика Казахстан

${ }^{2}$ Кызылординский университет имени Коркыт Ата, г. Кызылорда, Республика Казахстан

Аннотация. Есть две основные причины развития хлопководства в южных регионах страны: первая - объективная, вторая - субъективная. Объективной причиной развития хлопководства в южных регионах страны является естественный климат и рельеф региона. Югозападная, южная часть района расположена на равнинах Туранской котловины. В частности, климат региона имеет свои особенности: сухой воздух, преобладание солнечного света и жарких дней, продолжительная осень, достаточное и удобное расположение источников воды для полива. Климат Туркестанской области схож с климатом соседнего Узбекистана по солнечному свету и жарким дням с мая по октябрь и даже выше, чем в ряде других сельскохозяйственных стран.

В статье подробно констатируется, что единственный способ решить проблему экономической независимости при благоприятных природно-климатических условиях - это необходимость эффективного использования земельных ресурсов сельскохозяйственного назначения.

Также описывается структура сельскохозяйственных земель в южной части страны, актуальность и развитие растениеводства за счет внедрения научно-технического прогресса, основы эффективного использования земельных ресурсов и социально-экономические результаты.

В целом, в контексте развития мировых рыночных отношений, эффективность проводимых в нашей стране реформ, несомненно, позволит нашей стране развиваться экономически.

Ключевые слова: земельные ресурсы, сельское хозяйство, растениеводство, пашня. 


\title{
REPRODUCTIVE ABILITIES OF MEAT BREEDS OF LIVESTOCK IN THE CONDITIONS OF SOUTH-WEST KAZAKHSTAN
}

\author{
Dlimbetov M.K., candidate of agricultural sciences \\ dilimbetovm1964@mail.ru, https://orcid.org/0000-0003-2499-3783 \\ Kenzhebaev S. A., candidate of veterinary sciences \\ kenzhebaev_serik@bk.ru,https://orcid.org/0000-0002-8740-3448
LLP "Kazakh Scientific Research Institute of Rice Growing named after Zhakhaeva" Kyzylorda city, Republic of Kazakhstan

\begin{abstract}
Annotation. In the conditions of the sharply continental climate of the Kyzylorda region, the sexual activity of the imported Kalmyk breed from Russia, the Kazakh white-headed breed from the West Kazakhstan region and Santa Gertruda from the Almaty region of heifers and their reproductive ability of first-calf heifers have been established. The signs of sexual maturity depended on their breed characteristics and they first appeared in Kalmyk and Kazakh white-headed heifers, then in 10-12 month old heifers of the Santa Gertruda breed. Hunting in the non-bodied Kalmyk breed was observed from the age of 15 months, in the contemporaries of the Kazakh white-headed breed and the Santa Gertrude breed, they appeared, respectively, at 16-17 and 18-19 months of age and were more pronounced in the first breed. The reproductive capacity of first-calf heifers of these breeds was different. For 100 conditional queens, 68 calves were obtained from the Kazakh white-headed breed, 54 calves from the first-calf heifers of the Santa Gertruda breed, and 84 calves from their peers of the Kalmyk breed, respectively, 18 and 32 more calves per year. At the same time, it was established that the latter have a highly developed maternal instinct, expressed by the protection of the offspring, even by aggressiveness. Differences in the growth rate of young animals of these breeds were also established and they were high (750-780 g per day) than in young animals of these breeds (on average, $650 \mathrm{~g}$ per day). Thus, in the conditions of deserts, semi-deserts with a sharply continental climate of the Kyzylorda region, the Kalmyk breed, along with an exceptional ability in a new habitat, also showed a high reproductive ability of offspring with good signs of meat productivity.
\end{abstract}

Keywords: environment, climate, breed of livestock, acclimatization, adaptation, heredity, offspring, productivity

Introduction. In the Kyzylorda region of the Republic of Kazakhstan, located mainly in the south-west of the country, beef cattle breeding is poorly developed. Here, pasture cattle breeding is mainly represented by small-scale farms $(96 \%)$, where farmers annually receive no more than 47-50 calves for a conditional 100 cows, while the number of reproductive queens is $12-15 \%$, abortion and stillbirth of the fetus is $7 \%$ and the departure of calves up to a year is $5 \%$ on average. Weak zoo technical work over the past 20 years has led to the crushing of livestock with a low live body weight (no more than $380-400 \mathrm{~kg}$ ), respectively, and with a lower yield of carcasses at slaughter of $200 \mathrm{~kg}$ or $(46-48 \%)$.

The climate of the region is sharply continental, with hot, dry summers and cold winters with unstable snow cover. In the winter months (January, February), the low air temperature drops to minus $34-36^{\circ} \mathrm{C}$ on average, and in summer (July-August)the high air temperature is kept within plus $39-45^{\circ} \mathrm{C}$. The territory of the region is one of the arid regions of the republic. Here, natural precipitation in the form of rain and snow does not exceed 123-135 mm per year.

The purpose of the research is to study the ongoing processes of acclimatization and adaptation of the reproductive abilities of the Kalmyk, Santa Gertrude and Kazakh white-headed breeds and to find opportunities for breeding beef cattle with persistent adaptive qualities to a harsh continental climate.

To achieve the intended goal, it is necessary to solve the following tasks- 
-to study the physiology of sexual development of young animals;

to evaluate, in comparison, the sexual activity and reproductive abilities of the first heifers and the degree of the offspring obtained in the new living conditions.

Materials and methods of research. Kalmyk, Kazakh white-headed and Santa Gertrude cattle breeds served as objects for determining reproductive abilities.

The physiological state of animals was studied according to [1]. Sexual activity and reproductive abilities of queens in the conditions of the region were studied by their behavior, guided by [2], and their reproductive abilities were determined by the number of offspring received per conditional 100 cows annually.

The degree of adaptation of offspring obtained from imported queens, their growth and development dynamics were determined by a linear evaluation method using indices, the data were compared with breed standards, guided by the methods[3].

Results and their discussion. From the point of view of animal science, along with other signs of adaptation of livestock, the reproductive abilities of queens are important, because only parents well adapted to local conditions are able to pass on economic and useful properties to their offspring.

In the conditions of the region, the first signs of puberty of young animals depended on their breed characteristics and these signs were the first to appear in 8-9 month-old heifers of the Kalmyk and Kazakh white-headed breed, later 10-12 months in heifers of the Santa Gertrude breed.

Sexual hunting and estrus in heifers of the Kalmyk breed were manifested from the age of 15 months, more vivid manifestations of specific excitement, anxiety. In this state, they approached or allowed themselves bulls, jumped up to others, often mooed, bent their backs, lifted their tail, lost their appetite, which lasted 12-16 hours. These signs of sexual hunting in heifers of the Kazakh white-headed breed appeared at the age of 16-17 months, and in the Santa Gertrude breed peers even later (18-19 months) with less sexual activity.

In general, the sexual cycle and estrus in heifers of the studied breeds was repeated periodically every 20-21 days on average. Heifers of these breeds were inseminated with selected bulls-producers of the same breed, not lower than the first class. Pregnancy of inseminated queens for us was an important period of time related to the physiological state of the queens themselves and intrauterine fetal development, which lasted 280-285 days [4]. The importance of the gestation period of cows for the well-being of calves at the time indicated similar to our data.

When calving approached, the calves of the Kalmyk breed were worried, often lay down and got up, lifted their legs, looked back, licked their sides, retreated far away, looked for secluded places and calved. Their labor lasted an average of 40-50 minutes and was easy. After giving birth, they did not rest for a long time (7-10 min.), then they got up and actively licked their newborns, we can say, from head to toe, and after 15-20 minutes they got to their feet, found the udder and sucked the mother's colostrums. It should be especially noted that the first heifers of this breed have a strongly developed maternal instinct. They hid the newborn from strangers as much as possible, and when there were dangers, protecting the calf, they showed real aggressiveness, which persisted until the kittens were beaten.

Childbirth in the queens of the Kazakh white-headed and Santa Gertrude breeds took relatively longer (50-60 min.), sometimes with some difficulties (different rhythm city and intensity of attempts and contractions). Women in labor after giving birth lay for a long time in an exhausted state, it was difficult to get to their feet, then they also licked, sniffed and fed newborn calves. There were cases when the first heifers of the Santa Gertrude breed were frightened of their newborns after giving birth, ran away.

Conclusion. The reproductive ability of the first heifers of these breeds was also different. 66 calves were received from the first heifers of the Kazakh white-headed breed for a 
conditional 100 queens in 2020 and 68 calves in 2021, and 52 and 54 calves respectively from their peers of the Santa Gertrude breed. 84 calves per 100 queens were received from the first calves of the Kalmyk breed in 2020 and 84 calves per 100 queens in 2021. and they were ahead of their peers of the Kazakh white-headed breed by 18 and 32 calves of the Santa Gertrude breed by a conditional 100 queens. The comparatively low fertility of the queens of the latter breed was also pointed out at the time [5]. High fertility, reproductive longevity, ease of calving cows, excellent viability of calves and young animals of this breed were previously reported $[6,7,8]$.In natural and climatic conditions, the offspring of this breed inherently retained adaptive qualities, grew well and developed. We found that the growth rate of young breeds was different and it was 750-780 g per day for the Kalmyk breed. on average, while this indicator for the Kazakh white-headed and Santa Gertrude breeds did not exceed 650 g., It should be noted that the growth rate of young animals of the studied breeds mainly depended on the seasons of the year and it was high in autumn, low in summer.

In countries that are major producers and exporters of beef (Canada, Argentina, Uruguay, etc.), farmers, according to the recommendations of breeders, evaluate heifers by growth rate in stages: - at weaning and at one-year-old age $[9,10,11]$, and in the USA, on the contrary, at evaluation stations, they evaluate bulls at weaning and at 12 months of age and identify potential producers for further improvement of meat characteristics of herds [12]. The two-stage selection of beef bulls by testing them on their own productivity and the quality of offspring is also being tested in Kazakhstan [13,14], which is a subject for us to form new herds from among the most adapted and highly productive young of a particular breed according to the results of research, because the influence of production circumstances on the expected reactions to growth during selection [15], taking into account the metabolism of the organism and the body size of the young [16], is also important for us, because the prospect of preserving genomic resources [17] is important.

We did not conduct a comparative assessment of the live weight depending on the age of the studied cattle breeds, because according to the international classification, they belong to different categories in terms of body mass.

Thus, the research results obtained by us allow us to assume that in the conditions of semi-deserts and deserts of the south-west of Kazakhstan with a sharply continental climate, the Kalmyk breed of cattle is the most adapted. Measures aimed at increasing the population with breeding works using the gene pool will be an effective method of breeding this breed in the region.

\section{References:}

[1] Amerhanov, H., Hajnicskij V., Kayumov F. // Molochnoe i myasnoe skotovodstvo, 2011. №3.

[2 ]Basangov, N.P., Barinov V. E. Kalmyckij skot. Monografiya. Elista, Rossiya:MMP «BөTKN», 1992.

[3] Garmaev, D.C. Tekhnologiya kalmyckogo myasnogo skotovodstva: Monografiya . UlanUde. Buryatskaya gos. s.-h. akad. -2007.

[4] Kovalev, S.P., Kurdenko A. P., Bratushkina E. L., Voyakov A. A. Klinicheskaya diagnostika zhivotnyh. «Lan'», 2016.

[5] Instrukciya po bonitirovke krupnogo rogatogo skota molochnyh i myasnyh porod. - M.: Kolos. -1975 .

[6] Mackevich, V.V: Rekomendacii po razvedeniyu i razmnozheniyu krupnogo rogatogo skota porody «Santa-Gertruda» v Kazahstane, Alma-Ata, 1964; M., 1968.

[7] Mihajlov, N.N. i dr. Akusherstvo, ginekologiya i iskusstvennoe osemenenie s.-h. zhivotnyh. M.:VO «Agroproizdat», 1990. 
[8] Tamarovskij, M.V., Danilenko O. V. Osnovnye napravleniya selekcii v myasnom skotovodstve Kazahstana // Sbornik HYIII Mezhdunarodnoj nauno-prakticheskoj konferencii, Novosibirsk, 2015, - S. 187-190.

[9] Tamarovskij, M.F., Danilenko O. V., ZHuzenov SH. A. Osnovnye napravleniya plemennoj raboty v myasnom skotovodstve Kazahstana. // Mat. dokl. Mezhdunarodnoj nauchno-prakticheskoj konferencii «Problemy pustynno - pastbishchnogo zhivotnovodstva. Samarkand, NII karakulevodstva i ekologii pustyn', 13 - 14 avgust, 2015.

[10] Bruford, M.W., Ginja C, Hofmann I, Joost S, Orozco-terWengel P, Alberto FJ, et al. Prospects and challenges for the conservation of farm animal genomic resources, 2015-2025. Front Genet. 2015;6:314.

[11] Hirooka, H. Effect of production circumstances on expected responses for growth and carcass fraits to selection of bulls in Jpon / H. Hirooka, F. Green // J. anim. Sc.-1999.-Vol. 77, №1.- P. $1135-1143$.

[12] Kleiber, M. Body size and metabolism / M. Kleiber. - Hilgardia. 1932. 6: P. 351.

[13] Lazuda Y., Streznicka H. Beef production in the South America. // Chambers d agriculture. 1982 - V.53. № 685

[14[ Parsons, P.A. Conservation strategies: adaptation to stress and the preservation of genetic diversity / P.A. Parsons. // Biol. J. Linn. Soc, 1996. - Vol. 58. - P. $471-482$.

[15[ Stothart, T.G. Selection for yearling weight in beef cattle. - Canada Dep. Agr. Reserch station lakombe, Alberta,1969. - P. 81.

[16] System of beef production in the United States and Canada - 1986/87.

[17] Wilkinson, Y. Beef production from diary heardly. Wilkinson // Rev. ADAS. - \#24.

\title{
ҚАЗАҚСТАННЫН ОНТУСТІК-БАТЫСЫ ЖАҒДАЙЫНДА ІРІ КАРА МАЛЫННЫҢ ӨСІМІН МОЛАЙТУ КАБІЛЕТІ
}

\author{
Длимбетов М. К., ауыл шаруашылығы ғылымдарының кандидаты \\ Кенжебаев С. А., ветеринария ғылымдарының кандидаты
}

«Ы. Жақ̆аев атындавы құазақ күріш шаруашылывы вылыли-зерттеу институты» ЖШС, Қызылорда қ., Қазақсттан Республикасы

Андатпа. Қызылорда облысының қатал континентальды климаты жағдайында Ресейден әкелінген қалмақ, Батыс Қазақстан облысынан әкелінген қазақтың ақбас және Алматы облысынан әкелінген Санта Гертруда қашарларының жыныстық белсенділігі мен репродуктивті қабілетілігі анықталды.

Жалпы алғанда, қашарлардың жыныстық жетілудің белгілері олардың тұқымдық ерекшеліктеріне байланысты болды және олар алдымен қалмақ және қазақ ақбас қашарларында пайда болып, сонан соң 10-12 айлық жастағы Санта-Гертруда қашарларында байқалды.

Қалмақ қашарларының алғашқы күйлеу кезеңі 15 айлық жасында басталса, ал қазақтың ақбас тұқымы мен Санта-Гертруда тұқымының замандастарында бұл құбылыс сәйкесінше 16-17 және 18-19 айларында байқалды.

Осы тұқымдардың қашарларының көбею қабілеті (төлшеңдігі) әр түрлі болды. 100 шартты аналыққа есептегенде қазақтың ақбас тұқымынан 68, Санта-Гертруда тұқымының қашарларынан 54, қалмақ тұқымы қашарларынан 84 бұзау алынып, нәтижесінде қалмақ тұқымы қашарларынан құрбыларымен салыстырғанда сәйкесінше 18 және 32 бұзау артық алынды. Сонымен бірге, қалмақ тұқымы қашарларының төлдерін жауларынан жақсы қорғап-қоштайтын агрессивті аналық сезімі өте жоғары болатыны анықталды.

Кіллт сөздер: қормаван орта, климат, мал тұқылмы, акклиматизация, бейімделу, тұқылм қуалаушылық, ұрпак, өнімділік 


\title{
ВОСПРОИЗВОДИТЕЛЬНЫЕ СПОСОБНОСТИ МЯСНЫХ ПОРОД СКОТА В УСЛОВИЯХ ЮГО-ЗАПАДА КАЗАХСТАНА
}

\author{
Длимбетов М. К., кандидат сельскохозяйственных наук \\ Кенжебаев С. А., кандидат ветеринарных наук \\ ТОО «Казахский научно-исследовательский институт рисоводства им. Жахаева» \\ г. Кызылорда, Республика Казахстан
}

\begin{abstract}
Аннотация. В условиях резко континентального климата Кызылординской области установлены половая активность завезенных калмыцкой породы с России, казахской белоголовой с Западно-Казахстанской области и Санта-Гертруда из Алматинской области телок и их воспроизводительная способность первотелок.

Признаки половой зрелости зависела от их породных особенностей и они первыми появились у телок калмыцкой и казахской белоголовой, затем у 10-12 месячных телок породы Санта-Гертруда.

Половая охота у нетелой калмыцкой породы наблюдалась с 15-ти месячного, у сверстниц казахской белоголовой и породы Санта-Гертруды они появились, соответственно, в 16-17 и 18-19 месячном возрасте и были более ярко выражены у первой породы.

Воспроизводительная способность у первотелок указанных пород были разными. На 100 условных маток от казахской белоголовой породы было получено 68, от первотелок породы Санта-Гертруда -54 , а от сверстниц калмыцкой породы - 84 телят, соответственно, 18 и 32 телят больше за год. При этом установлено, что у последних сильно развит материнский инстинкт, выраженный защитой потомства, даже агрессивностью.

Также установлены разности в интенсивности роста молодняка указанных пород и они были высокими (750-780 г в сутки), нежели у молодняка названных пород (в среднем, 650 г в сутки).

Таким образом, в условиях пустынь, полупустынь с резко континентальным климатом Кызылординской области калмыцкая порода наряду с исключительной способностью в новой среде обитания показал и высокую воспроизводительную способность потомства с хорошими признаками мясной продуктивности.
\end{abstract}

Ключевые слова: окружающая среда, климат, порода скота, акклиматизация, адаптация, наследственность, потомство, продуктивность 


\title{
ЖАРАТЫЛЫСТАНУ ЖӘНЕ ТЕХНИКАЛЫК ГЫЛЫМДАР СЕРИЯСЫ \\ СЕРИЯ ЕСТЕСТВЕННЫХ И ТЕХНИЧЕСКИХНАУК \\ SERIES OF NATURALAND TECHNICAL SCIENCES
}

Физика-математика ғылымдары

Физико-математические науки

Physical and mathematical sciences

МРНТИ 539.3(043.3)

https://doi.org/10.52081/bkaku.2021.v58.i3.070

\section{CLASS OF PLANE PROBLEMS ON THE EFFECT OF MOVING LOADS UNDER A NONLINEAR LAW}

\author{
Seitmuratov A. Zh, doctor of physical and mathematical sciences \\ angisin_@mail.ru, https://orcid.org/0000-0002-9622-9584 \\ Kyzylorda University named after Korkyt Ata, Kyzylorda, Republic of Kazakhstan
}

\begin{abstract}
Annotation. The present work is devoted to the dynamics stability study of wave processes of plane and circular elements, and it is also being considered a class of plane tasks about moving loads effect on the surface of a layered elastic half-plane under the nonlinear law of stress versus deformation. While studying the wave processes of planar and circular elements in deformable bodies, the concept of phase velocity is introduced as the rate of phase medium change. In the case of harmonic vibrations of a cylindrical shell, the phase speed is expressed through the frequency of natural oscillations of freely supported along the edges of the shell, and therefore, the investigation of waves in plane and circular elements has the most direct relation to the problem of determining the own forms and vibration frequencies of finite length shells. If the studies are carried out taking into account the material rheological properties of considered system, there is a surrounding system environment, also generally displaying rheological properties, the use of these methods is considerably difficult. In such cases, the influence of rheological parameters on the components of the complex phase velocity is studied in definite values of the vibration frequencies. At present article, it is being considered an approximate solution of the nonlinear task about the effect of a moving load on an elastic layer lying on an undeformable base under the nonlinear stress law of depending strains from deformations.
\end{abstract}

Keywords: dynamics, waves, moving load, vibrations, deformation, nonlinear law, rheological properties, frequency, fose velocity.

Introduction. While solving the problems of wave processes of plane and circular elements in deformable bodies, the concept of phase velocity is introduced as the rate of change of the phase medium. In this case of harmonic vibrations of a cylindrical shell, the phase velocity is expressed through the frequency of natural oscillations freely supported along the edges of the shell, and therefore, the investigation of waves in plane and circular elements has the most direct relation to the problem of determine the proper forms and vibration frequencies of finite length shells. [1.2]

In many studies, two methods are usually used to determine the characteristics of waves.

It is studied the instantaneous state of the medium, corresponding to a certain fixed time moment.

It is studied the change in time of the body constant state at some fixed point.

If the studies are carried out taking into account the rheological properties of the considered system material or, there is a surrounding medium, also generally displaying rheological properties, the use of these methods is considerably difficult. In such cases, the 
influence of rheological parameters on the components of the complex phase velocity is studied for certain values of the vibration frequencies.

Materials and research methods. The physical law of stress-strain relation in a plane formulation is adopted in the form

$$
\begin{aligned}
& \sigma_{j j}=3 K \varepsilon_{0}\left[1+\alpha x_{0} \varepsilon_{0}^{2}\right]+2 \mu\left(\varepsilon_{j j}-\varepsilon_{0}\right)\left[1+\alpha \gamma_{0} \psi_{0}^{2}\right] \\
& \sigma_{i j}=\mu \varepsilon_{i j}\left[1+\alpha \gamma_{0} \psi_{0}^{2}\right], \quad(i \neq j ; i, j=x, y)
\end{aligned}
$$

где $\varepsilon_{0} ; \psi_{0}$ - average volumetric strain and intensity of strain rate $\alpha$-small parameter.

Oscillations in a layer are boundary conditions: [3]

$$
\begin{array}{lrr}
\sigma_{y y}=f_{y}(x, t), & \sigma_{x y}=0, & y=h, \\
v=0, & \sigma_{x y}=0, & y=0 .
\end{array}
$$

Due to the boundary conditions, the longitudinal displacement $u$ is an even function of the coordinate and a transverse movement $v$ odd in $x$.

Therefore, we will continue these functions on $y$ from $-h$ to 0 .

Then, instead of the problem for an elastic layer lying on an undeformable base, we obtain the task for a thickness layer $2 h(-h \leq y \leq h)$, on the surface of which $y= \pm h$ external forces are set

$$
\sigma_{y y}=f(x, t), \quad \sigma_{x y}=0 .
$$

However, in such a formulation the problem remains very complicated in the mathematical formulation and obtaining its solution presents great difficulties. This problem can be solved in an approximate formulation, considering the elastic layer as an elastic thickness plate $2 h .[4]$

Approximate equation of the longitudinal vibration of a plate in a nonlinear setting for the main part of the longitudinal displacement $U$ has the following form:

$$
\begin{aligned}
& \frac{\partial^{2} U}{\partial t^{2}}-C_{n \pi}^{2} \frac{\partial^{2} U}{\partial x^{2}}-\frac{2}{9} \alpha \frac{x_{0} k}{\rho}\left(\frac{4 \mu-\rho C_{n \pi}^{2}}{4 \mu}\right)^{4} \frac{\partial}{\partial x}\left[\left(\frac{\partial U}{\partial x}+\right.\right. \\
& \left.\left.+\frac{1}{\mu} f_{y}\right)^{3}\right]=\frac{1}{\rho}\left(\frac{\rho C_{n \pi}^{2}}{2 \mu}-1\right) \frac{\partial f_{y}}{\partial x}
\end{aligned}
$$

Let us consider a special case of an external rolling effort, when:

$$
f_{y}(x, t)=f_{y}(x-D t),
$$

where D - the speed of movement of the external load on the surface layer is considered constant.

We introduce the moving coordinate

$$
x^{\prime}=x-D t,
$$


and for simplicity $x, y$ we omit the primes.

In moving coordinates, the longitudinal vibration of elastic layer or plate with the physical nonlinearity of the law $\sigma(\varepsilon)$ with allowance for the external mobile load is described by the following nonlinear ordinary equation: [5]

$$
\begin{aligned}
& \left(D^{2}-\tilde{N}_{i e}^{2}\right) \frac{d^{2} U}{d x^{2}}-\frac{2}{9} \alpha \frac{x_{0} k}{\rho}\left(\frac{4 \mu-\rho c_{i e ̈}^{2}}{4 \mu}\right)^{4} \frac{d}{d x}\left[\left(2 \frac{d U}{d x}+\right.\right. \\
& \left.\left.+\frac{f_{y}}{\mu}\right)^{3}\right]=\frac{1}{\rho}\left(\frac{\rho \tilde{N}_{i e}^{2}}{2 \mu}-1\right) \frac{\partial f_{y}}{\partial x}
\end{aligned}
$$

obtained from the (4) when replacing (6).

Integrating (7) on $x$, taking into account the damping condition at infinity Relatively $\frac{d U}{d x}$ we obtain a cubic equation:

$$
\begin{aligned}
& \left(\frac{d U}{d x}\right)^{3}+\frac{3}{2 \mu} f_{y}\left(\frac{d U}{d x}\right)^{2}+\left[\frac{3}{4 \mu^{2}} f_{y}^{2}-\frac{9 \rho\left(D^{2}-C_{n l}^{2}\right)}{16 \alpha x_{0} k}\left(\frac{4 \mu}{4 \mu-\rho C_{n n}^{2}}\right)^{4}\right] \times \\
& \times \frac{d U}{d x}+\left[\frac{1}{8 \mu^{3}} f_{y}^{3}-\frac{9\left(2 \mu-\rho C_{n l}^{2}\right)}{32 \alpha \mu x_{0} k}\left(\frac{4 \mu}{4 \mu-\rho C_{n l}^{2}}\right)^{4} f_{y}\right]=0
\end{aligned}
$$

Substitution

$$
\frac{d U}{d x}=S-\frac{a}{3}
$$

the equation(8) is reduced to the form:

$$
S^{3}+P S+q=0
$$

where: $\quad a=\frac{3}{2 \mu} f_{y}$,

$$
P=-\frac{9 \rho\left(D^{2}-C_{i e}^{2}\right)}{16 \alpha x_{0} k}\left(\frac{4 \mu}{4 \mu-\rho C_{i e}^{2}}\right)^{4},
$$

i.e. $P$ does not depend on external load $a$

$$
q=-\frac{9\left(2 \mu-\rho C_{i e}^{2}\right)}{32 \alpha \mu x_{0} k}\left(\frac{4 \mu}{4 \mu-\rho C_{i e}^{2}}\right)^{4} f_{y} .
$$

Let us consider the case when $\alpha<0$ (similarly, the problem is solved in the case $\alpha>0$ ). 
If we consider the excess sound mode[6]

$$
D>C_{i \ddot{e}}
$$

i.e. when the perturbation in the layer before the load is absent, it is clear that $P>0$ and the equation(9) ( respectively (8)) has one real solution. [7]

If the speed of movement of an external load $D$ satisfies the inequality

$$
D<C_{i \ddot{e}}
$$

i.e subsonic mode, then $P<0$ and the equation (9) ( respectively(8)) can have another solution.

One real solution of equation (8) in the subsonic mode has the form:

$$
\frac{d U}{d x}=\sqrt[3]{-\frac{q(x)}{2}+\sqrt{\left(\frac{p}{3}\right)^{3}+\left(\frac{q(x)}{2}\right)^{2}}}+\sqrt[3]{-\frac{q(x)}{2}-\sqrt{\left(\frac{p}{3}\right)^{3}+\left(\frac{q(x)}{2}\right)^{2}}}-\frac{a(x)}{3} .
$$

Integrating (10) $\mathrm{X}$ with respect to the damping condition of the displacement at infinity, and the transition to the fixed coordinates, we obtain:

$$
U=\int_{\infty}^{x-D t}\left[\sqrt[3]{-\frac{q(\xi)}{2}+\sqrt{\left(\frac{p}{3}\right)^{3}+\left(\frac{q(\xi)}{2}\right)^{2}}}+\sqrt[3]{-\frac{q(\xi)}{2}-\sqrt{\left(\frac{p}{3}\right)^{3}+\left(\frac{q(\xi)}{2}\right)^{2}}}-\frac{a(\xi)}{3}\right] d \xi
$$

The magnitude of the voltage $\sigma_{x x}$ is approximately calculated by the formula:

$$
\begin{aligned}
& \sigma_{x x}=\rho C_{i e}^{2}\left[\sqrt[3]{-\frac{q(x-D t)}{2}+\sqrt{\left(\frac{p}{3}\right)^{3}+\left(\frac{q(x-D t)}{2}\right)^{2}}}+\sqrt[3]{-\frac{q(x-D t)}{2}-\sqrt{\left(\frac{p}{3}\right)^{3}+\left(\frac{q(x-D t)}{2}\right)^{2}}}\right]- \\
& -f_{y}(x-D t)-\alpha\left[\left(\frac{\rho C_{i e}^{2}}{2 \mu}-1\right) f_{2}(U)-f_{1}(U)\right],
\end{aligned}
$$

where,

$$
\begin{aligned}
& f_{2}(U)=\frac{1}{9} x_{0} k\left(\frac{4 \mu-\rho C_{n n}^{2}}{4 \mu}\right)^{3}\left(2 \frac{\partial U}{\partial x}+\frac{1}{\mu} f_{y}\right)^{3} ; \\
& f_{1}(U)=\frac{1}{9} x_{0} k\left[2\left(1-\frac{\rho C_{n n}^{2}}{4 \mu}\right) \frac{\partial U}{\partial x}+\frac{1}{\lambda+2 \mu} f_{y}-\frac{\alpha}{\lambda+2 \mu} f_{2}(U)\right]^{3} .
\end{aligned}
$$

From the last expressions it follows that when $\alpha \rightarrow 0$ we obtain a solution for the linear problem.

If the non-linearity parameter $\alpha$ is assumed sufficiently small, then instead of (11) we can approximately use the formula for displacement: 


$$
\begin{aligned}
& U=\frac{1}{\rho\left(D^{2}-C_{i e}^{2}\right)}\left(\frac{\rho C_{i e}^{2}}{2 \mu}-1\right) \int_{\infty}^{x-D t} f_{y}(\xi) d \xi+\alpha\left\{\frac{2}{9} \frac{x_{0} k}{\rho\left(D^{2}-C_{i e}^{2}\right)} \times\right. \\
& \left.\times\left(\frac{4 \mu-\rho C_{n n}^{2}}{4 \mu}\right)^{4}\left[\frac{\rho D^{2}-2 \mu}{\mu \rho\left(D^{2}-C_{n n}^{2}\right)}\right]^{3} \int_{\infty}^{x-D t} f_{y}^{3}(\xi) d \xi\right\}
\end{aligned}
$$

At small $\alpha$ values for the voltage $\sigma_{x x}, \sigma_{y y}, \sigma_{x y}$ formulas are obtained: [8]

$$
\begin{aligned}
& \left.\sigma_{x x}=\frac{D^{2}}{D^{2}-C_{i e}^{2}}\left(\frac{\rho C_{i e}^{2}}{2 \mu}-1\right) f_{y}+\alpha\left\{\frac{2}{9} \frac{x k C_{i e}^{2}}{D^{2}-C_{i e}^{2}} \times\left(\frac{4 \mu-\rho C_{i e}^{2}}{4 \mu}\right)^{4}\left[\frac{\rho D^{2}-2 \mu}{\mu \rho\left(D^{2}-C_{i e}^{2}\right.}\right)\right]^{3} f_{y}^{3}+2\left(1-\frac{\rho C_{i e}^{2}}{4 \mu}\right) f_{2}(U)\right\}+ \\
& +\frac{y^{2}}{2}\left\{\left[\rho D^{2}\left(\frac{\rho C_{n s}^{2}}{2 \mu}+1\right)-\rho D^{2}\left(\frac{\rho C_{n \pi}^{2}}{2 \mu}-1\right)^{2}+3(\lambda+2 \mu)\left(\frac{\rho C_{n s}^{2}}{2 \mu}-2\right)-2\left(\rho C_{n n}^{2}-3 \mu\right)\right] \frac{\partial^{3} U}{\partial x^{3}}+\right. \\
& +\frac{1}{\lambda+2 \mu}\left[\rho D^{2}\left(\frac{\rho C_{n s}^{2}}{2 \mu}-1\right)+4 \mu-3(\lambda+2 \mu)\right] \frac{\partial^{2} f_{y}}{\partial x^{2}}- \\
& \left.-\frac{\alpha}{\lambda+2 \mu}\left[\rho D^{2}\left(\frac{\rho C_{n \pi}^{2}}{2 \mu}-1\right)+4 \mu-3(\lambda+2 \mu)\right] \frac{\partial^{2} f_{2}(U)}{\partial x^{2}}-\alpha \frac{4 \mu}{4 \mu-\rho C_{n \pi}^{2}} \frac{\partial^{2} f_{2}(U)}{\partial x^{2}}\right\} \\
& \sigma_{z z}=f_{y}+\frac{y^{2}-h^{2}}{2}\left\{\frac{\rho C_{n s}^{2}}{2 \mu}\left(\rho D^{2}-2 \mu\right) \frac{\partial^{3} U}{\partial x^{3}}-\left(\frac{\rho D^{2}}{\lambda+2 \mu}+\frac{\rho C_{n s}^{2}}{2 \mu}-1\right) \frac{\partial^{2} f_{y}}{\partial x^{2}}+\right. \\
& \left.+\alpha\left(\frac{\rho D^{2}}{\lambda+2 \mu}+\frac{\rho C_{n s}^{2}}{2 \mu}-2\right) \frac{\partial^{2} f_{2}(U)}{\partial x^{2}}\right\} \\
& \sigma_{x z}=\alpha+\left(y-\frac{1}{h^{2}} y^{3}\right) \frac{x_{0} k}{192}\left(\frac{4 \mu-\rho C_{i e}^{2}}{\mu}\right)^{4}\left[\frac{\rho D^{2}-2 \mu}{\mu \rho\left(D^{2}-C_{i e}^{2}\right)}\right]^{3} f_{z}^{2} f_{z}^{1} .
\end{aligned}
$$

If $f_{z}(x-D t)$ given as

$$
f_{y}(x-D t)=\sigma_{0} \beta(x-D t) l^{-\beta(x-D t)},
$$

then, for example, with respect to the dimensionless relation $\frac{\sigma_{x x}}{\sigma_{0}}$ approximately obtain: [9]

$$
\frac{\sigma_{x x}}{\sigma_{0}}=l_{1} \xi l^{-\xi}+\alpha l_{2} \sigma_{0}^{2} \xi^{3} l^{-3 \xi}, \quad(\alpha<0)
$$


where,

$$
\begin{aligned}
& l_{1}=\frac{D^{2}}{D^{2}-C_{n n}^{2}}\left(\frac{\rho C_{n l}^{2}}{2 \mu}-1\right)>0, \\
& l_{2}=\frac{D^{2}}{D^{2}-C_{n l}^{2}} \cdot \frac{x_{0} k\left(4 \mu-\rho C_{n n}^{2}\right)^{4}\left(\rho D^{2}-2 \mu\right)}{1152 \mu^{7} \rho^{3}\left(D^{2}-C_{n n}^{2}\right)^{3}}>0
\end{aligned}
$$

Conclusion. The present work is devoted to the dynamics stability study of wave processes of plane and circular elements, and it is also being considered a class of plane tasks about moving loads effect on the surface of a layered elastic half-plane under the nonlinear law of stress versus deformation. A class of plane problems on the effect of moving loads on the surface of a layered elastic half-plane is solved. The problems of this class are of great practical interest and, in addition, can serve as a standard for the development of various numerical algorithms for solving dynamic problems.

\section{References:}

[1] Filippov, I.G., S.I. Filippov, 1995. Dynamic stability theory of rods. Proceedings of the Russian-Polish seminar. Theoretical Foundations of construction. Warsaw, pp.63 -69.

[2] Medeubaev, N.K., Seytmuratov, A.Z., Ramazanov, M.I. Solving Problems of Vibrational Processes of Isotropically Homogeneous Elastic Plates// Lobachevskii Journal of Mathematics, 2020, 41(9), 1846-1853 DOI: 10.1134/S1995080220090188

[3]Seitmuratov, A., Taimuratova, L.U., Zhussipbek, B., Seitkhanova, A., Kainbaeva, L.Conditions of extreme stress state //News of the National Academy of Sciences of the Republic of Kazakhstan, Series of Geology and Technical Sciences, 2019, ISSN 2224-5278 Volume 5, Number 437 (2019), 202 - 206 https://doi.org/10.32014/2019.2518-170X.143

[4] Seitmuratov, A., Zhussipbek B., Sydykova G., SeithanovaA., Aitimova U. Dynamic stability of wave processesof a round rod // News of NAS RK. Series of physico-mathematical. 2019 2(324): 90 - 98 (in Eng). ISSN 2518-1726 (Online), ISSN 1991-346X (Print).https://doi.org/10.32014/2019.25181726.16.

[5] Seitmuratov, A., Tileubay S., Toxanova S., Ibragimova N., Doszhanov B., AitimovM.Zh. The problem of the oscillation of the elastic layer bounded by rigid bouhdaries//News of NAS RK. Series of physico-mathematical.2018 5(321): 42 -48(in Eng). ISSN 2518-1726 (Online), ISSN 1991-346X (Print).https://doi.org/10.32014/2018.2518-1726.6.

[6] Seitmuratov, A., ZharmenovaB., DauitbayevaA., Bekmuratova A. K., TulegenovaE., Ussenova G. Numerical analysis of the solution of some oscillation problems by the decomposition method //News of NAS RK. Series of physico-mathematical.2019 1(323): 28 - 37 (in Eng). ISSN 25181726 (Online), ISSN 1991-346X https://doi.org/10.32014/2019.2518-1726.4..

[7] Seitmuratov, A.Z., Nurlanova,BM., Medeubaev N. Equetions of vibration of a twodimensionally layered plate strictly based on the decision of various boundaty-value problems// Bulletin of the Karaganda university-mathematics.2007 3(87): 109-116 . (in Eng)

[8] Seitmuratov, A., N.Medeubaev, Z.Seylova, L.Taimuratova,A.Dauitbayeva, S.Tileubay, E.Tulegenova.Oscillation equations of rectangular plates in linear approximation//Journal of Theoretical and Applied Information Technology. 2020. Vol.98. No 06. (C) 2005 - ongoing JATIT \& LLS ISSN: 1992-8645 www.jatit.org

[9] Seitmuratov, A., Dauitbayeva, A.O., Berkimbayev, K., Turlugulova, N.A., Tulegenova, E.N. Constructed two-parameter structurally stable maps //News of the National Academy of Sciences of the Republic of Kazakhstan, Series of Geology and Technical Sciences ISSN 2224-5278Volume 6, Number 438 (2019), 302 - 307 https://doi.org/10.32014/2019.2518-170X.182 


\title{
БИСЫЗЫҚТЫ ЗАН БОЙЫНША ҚОЗҒАЛМАЛЫ УСТЕМЕ ЖАҒДАЙЫНДАҒЫ ЖАЗЫҚ ЕСЕПТЕР ТОБЫ
}

Сейтмұратов А.Ж., физика математика ғылымарының докторы

Қорқыт Ата атындавы Қызылорда университеті, г.Қызыллорда, ҚазақстанРеспубликасы

\begin{abstract}
Аңдатпа: Бұл мақала дөңгелек және жазық элементтердің толқындық процсстер кезінде орын алатын орнықтылық динамикасын зеріттеуге арналған, және де осыған қоса кернеудің деформациядан сызықтық емес заңы бойынша, қатпарлы тұрқыр бетімен қозғалмалы үстеме жағдайындағы, тәуелділігінің жазық есептер топтамасын қарастырады. Деформацияланатын денелердің дөңгелек және жазық элементтерінің толқындық процсстерін зерттеу кезінде фазалық жылдамдық, фазалық ортаның жылдамдығының өзгеру шамасы деген ұғым енгізіледі. Цилиндрлік қабықшалардың гармоникалық тербелісі жағдайында фазалық жылдамдық, қабықшалардың шеттерінде еркін орналасқан өзіндік тербеліс жиілігі арқылы өрнектеледі, сондықтан дөңгелек және жазық элементтер толқынын зерттеу, қабықшаның ақырлы ұзындығының жиілік тербелісі мен дербес формасын анықтауға тікелей байланысты. Егер зарттеу жұмысы қарастырылып отырған жүйе материалдың реологиялық қасиеті негігінде жүргізілсе немесе, қоршаған орта жүйесі болса, және жалпы жағдайда реологиялық қасиеттері анықталса онда бұл тәсілдерді қолдану қыйынға соғады.
\end{abstract}

Кілт сөздер: динамика, толқындар, қзздалатын үстеме, тербеліс, деформаиия, бисызықұты заң, реологиялық қ̧асиет, жиілік, фокус жылдамдывы.

\section{КЛАСС ПЛОСКИХ ЗАДАЧ О ВОЗДЕЙСТВИИ ПОДВИЖНЫХ НАГРУЗОК ПРИ НЕЛИНЕЙНОМ ЗАКОНЕ}

Сейтмұратов А.Ж., доктор физико математических наук

Кызылординский университ им.Коркыт Ата, г.Кызыллорда, Республика Казахстан

Аннотация. Данная работа посвящена изучению динамики устойчивости волновых процессов плоских и круговых элементов, а также рассматривается класс плоских задач о воздействии подвижных нагрузок на поверхность слоистой упругой полуплоскости при нелинейном законе зависимости напряжений от деформаций. При исследованиях волновых процессов плоских и круговых элементов в деформируемых телах вводится понятие фазовой скорости, как скорости изменения фазовой среды. В случае гармонических колебаний цилиндрической оболочки фазовая скорость выражается через частоту собственных колебаний свободно опертой по краям оболочки, и поэтому, исследование волн в плоских и круговых элементах имеет самое прямое отношение к проблеме определения собственных форм и частот колебаний оболочек конечной длины. Если исследования проводятся с учетом реологических свойств материала рассматриваемой системы или, имеется окружающая систему среда, также в общем случае, проявляющая реологические свойства, использование этих способов значительно затруднено. В таких случаях изучается влияние реологических параметров на составляющие комплексной фазовой скорости при определенных значениях частот колебаний.

Ключевые слова: динамика, волны, подвижная нагрузка, колебания, деформация, нелинейный закон, реологические свойства, частота, фозовая скорость 


\title{
ҚҰРЫЛЫМЫ ӘРТУРЛІ ТЕНДЕУЛЕР МЕН ТЕНСІЗДІКТЕРДІ ШЕШУДІН ТИПТІК КЛАСТАР ӘДІСІ
}

\author{
Алпысов А.К., педагогика ғылымдарының кандидаты \\ alpysovak@mail.ru, https://orcid.org/0000-0001-7926-7493 \\ Сейтханова А.K., $\mathrm{PhD}$ \\ ainur1179@mail.ru, https://orcid.org/0000-0002-6667-4548 \\ Абишова И.Ш., математика магистрі \\ inka_bsh@mail.ru. https://orcid.org/ 0000-0001-6625-6613

\section{Павлодар педагогикалық университеті, Павлодар қ., Қазақ̧стан Республикасы}

Аңдатпа: Мақалада теңдеулер мен теңсіздіктерді шешу әдістерін беру кезінде есептерді тиімді шешу дағдылары мен іскерліктерін дамыту жолдары, теориялық білімдердің нақтылануы, практикада қолдана алу ептіліктерін қалыптастыру негіздері қарастырылған. Математиканы оқытуда есеп шығару арқылы математикалық ұғымдарды қалыптастырып, математикалық ойлауын өрістетуге, білімдерін практикада қолдануға, ізденгіштік қасиеттерін тәрбиелеуге жол ашады.

Математикалық ұғымды меңгеру үшін оның анықтамасымен қатар ерекше белгілерін, қасиеттерін білу қажет. Бұған ең алдымен есеп шығару және жаттығулар орындау арқылы қол жеткізуге болады. Есеп шығару барысында жаңа тәсілдерді меңгеру, алгоритмдерді құру, шығарған есептердің көмегімен игерген әдіс-тәсілдерге практикалық маңызы бар іскерліктерін шыңдау жолдары негізделеді. Сонымен қатар, ойлау қабілетін дамыту арқылы теңдеулер мен теңсіздіктерді түрлендіру, ортақ немесе айрықша қасиеттерді көрсетуге, дұрыс қорытынды жасауға көмектеседі. Әр түрлі есептерді шығару арқылы оның шешуі қандай жағдайда табылатынын анықтау үшін қандай амалдарға жүгіну қажеттігін және шығару жолының қандай айрықша белгілері тиімді тәсілдерді таңдауға мүмкіндік беретінін көрсетеді.

Жалпы мақаланың теориялық негіздемесі арқылы құрылымы әртүрлі теңдеулер мен теңсіздіктерді шешуге ыңғайлы жолдарды игеруге болады.

Кілт сөздер: теңдеулер, теңңсіздіктер, нысанды тапсырмалар жүйесі, функиионалдыграфиктік әдіс.

Kipicпе. Бүгінгі таңда білім беру мазмұнын жаңарту - сапалы білім, жарқын болашаққа негіздеп, бірқатар жетістіктер формуласын ұсынған үлгі және оқу-тәрбиелік үрдісті жан-жақты жаңа әдіс-тәсілдермен ұштастыру болып табылады. Білім беруді жаңаша ұйымдастыру - оның педагогикалық, психологиялық негіздерін, теориясы мен тәжірибесін тереңірек қайта қарауды қажет етеді. Осыған байланысты ұстаздар алдында оқытудың әдіс-тәсілдерін үнемі жаңартып отыру және оқу-тәрбие үдерісінде оқушының өз бетінше білім алуына бағытталып, осы мақсатта мұғалімнің тиімді іс-әрекеттің түрлі формаларын қолданылуын көздейді.

Математикада теңдеуді де, теңсіздікті де өмірде болған немесе болып жатқан құбылысты зерттеу құралы ретінде пайдаланады. Теңдеу арқылы процестің дәл шешімі зерттелсе, ал теңсіздік арқылы белгілі бір аралықтағы қозғалыс зерттеледі. Теңдеулер мен теңсіздіктерді білім қалыптастырудың тиімділігі тұрғысынан қарастырғанда, келесі проблемаларды шешу керектігі шығады, яғни құрылымы әртүрлі теңдеулердің шешімдерін табу әдістеріне үйреткеннен кейін теңсіздіктердің шешімдерін табуға үйрету және теңдеу мен теңсіздіктердің есептермелерін біріктіріп табуға үйрету.

Математикада теңдеулер шешімін табуда жүздеген әдістер қолданылатыны белгілі. Параметрлеу әдісі арқылы өзегі айныған интегралдық дифференциалдық теңдеулер жүйесіне шешім шығаруға болады, сонымен қатар, кейбір есептердің жуық және сандық 
шешімдерін табу алгоритмдері де математикалық есептеулер үшін көп қолданылады [1, 2, $3]$.

Жаңа білім беру бағдарламасында теңдеулер мен теңсіздіктерден бастап, жоғары дәрежелі теңдеулер мен теңсіздіктерді шешу теориясы мен практикалық мәселелеріне дейін кең орын берілген. Мысалы, сызықтық теңсіздіктерді шешу, екінші дәрежелі теңсіздіктер көмегімен квадраттық үш мүшені зерттеу, теңдеулер жөнінде талдау жасау, жуықтап есептеулер, иррационал сандар теориясы, сандық қатарлар сияқты мәселелер теңсіздіктер арқылы түсіндіріледі. Тек математикада ғана емес, әртүрлі жаратылыстану ғылымдарында зерттелетін табиғаттың үздіксіз процестері, әсіресе экономикалық, экологиялық және т.б. салалардағы байланыстар теңсіздіктердің көмегімен шешіледі [4, 224 б].

Әдебиетке шолу. Теңдеулер мен теңсіздіктер теориясы орта мектепте оқушылардың логикалық ойлау қабілетін дамыта алатындай, өз алдына ғылымипедагогикалық маңызы бар негізгі оқу материалы болып есептеледі. Ол оқушыларды айқын дұрыс ойлауға, шамаларды салыстыра білуге дағдыландырады, теңдеулер мен теңсіздіктерді шешу барысында шығармашылық қабілеттілік, ізденгіштілік қасиеттерді дамытудың жолдары анықталады. Соңғы кезде орта мектеп математикасында көптеген жақсы бетбұрыстарға қарамастан, теңсіздіктер жөнінде мектеп оқушыларының түсініктері мардымсыз. Осы олқылықты жою үшін теңсіздіктер теориясы мен оны үйренудің әдісін жетілдіру қажет. Теңдеулер мен теңсіздіктерді шешуді күнделікті кездестіретін айналасындағы айғақтармен байланыстыру қажет. Егерде тарихқа үңілетін болсақ, практикалық есептерді шығарудың алгебралық әдістерінің бастамасы ежелгі ғылым әлемімен байланысты. Сол кездің өзінде де теңдеулер мен теңсіздіктерді құруды талап ететін есептер пайда бола бастады. Алғашқыда мұндай есептерді шығару үшін арифметикалық әдістер қолданылды. Одан әрі алгебралық жағын қарастыру қалыптаса бастады. Қазіргі уақытқа дейінгі теңдеулер мен теңсіздіктедің дамуында әртүрлі әдістердің өзгеріп, жаңарып отыруы осы ұғымдардың нақтылануы мен басқа да математиканың бөлімдерімен байланысын атап өтуге болады. Бұл процесте теңдеу мен теңсіздіктердің алгебралық ұғымдар жүйесіндегі мәні маңызды рөл атқарады [5, 287 б]. Алгебраның дамуы теңдеуді алгебраның негізгі ұғымы ретінде үш негізге негізделеді.

a) теңдеулер мәтінді есептерді шығарудың құралы ретінде;

б) теңдеулер алгебрадағы оқу обьектісі бола алатын ерекше формула ретінде;

в) теңдеулер кеңістіктегі (жазықтықтағы) нүктелер координаталарын немесе сандарды жанамалай анықтайтын формула ретінде.

Сол себептен теңдеу жалпы математикалық ұғым жағынан көп астарлы. Теңдеу ұғымына байланысты теңдеудің маңыздылығы мен кең көлемділігіне қарап оны оқып үйрену қазіргі математикалық әдісте мазмұнды - әдістемелік негізде теңдеулер мен теңсіздіктер ұйымдастырылған. Бұл жерде мектептегі математика курсындағы теңдеулер мен теңсіздіктерді оқып үйрену, олардың аралығындағы байланыс, оларды тиімді шешудегі жалпы және жеке әдістер теңдеулер мен теңсіздіктер желісінің қалыптасуын нақтылап қарастырылып отыр. Теңдеулер мен теңсіздіктер сонымен қатар функциялық бағыттармен тығыз байланыста. Осындай байланыстардың ең негізгісі ол функцияларды зерттеуге теңдеулерді шешу, құрастыру әдістері. Бір жағынан функциялық бағыт теңдеулер мен теңсіздіктер желісінің мазмұнына және оларды үйрену түрінде де бір шама ықпал етеді. Негізінде функциялық бағыт теңдеулер мен теңсіздіктерді зерттеу мен шешу графиктік көрнекілікті де қажет етеді [6, 187 б].

Зерттеу материалдары мен әдістері. Теңсіздіктің күшін сақтау жағдайларын пайымдауға, теңсіздіктің мағынасы жойылмайтындай белгісіздердің мүмкін мәндерін айыруға дағдыландыру керек. Мысалы, алгебралық $\frac{x+1}{x-1}<\frac{x+2}{x-2}$ теңсіздігінде белгісіздің 
мәндері 1 мен 2-ден басқа сандар болуы керек. Бұл мәндерде бөлшектердің мағынасы жоқ болады. Сонымен теңсіздікті дәлелдегенде және шешкенде әріптер мен белгісіз шамалардың мүмкін мәндерін үнемі есепке алып отыру керек. Таңбасы белгісіздің мүмкін мәндерінің бәрінде де сақталатындай теңсіздік шартсыз теңсіздік деп аталады. Мысалы, $2 x+7<2(x+4) ;-(4 x+13)>x+2$ бұл арада айнымалының орнына оның мүмкін мәндерінің қайсысын қойса да теңсіздіктің мағынасы өзгермейді. Таңбасы белгісіздің мүмкін мәндерінің кейбіреуінде ғана сақталатындай теңсіздікті шартты немесе белгісізі бар теңсіздік деп атайды. Мысалы, $2 x-1>7$, мұнда $x>4$ болса ғана теңсіздіктің оң бөлігінен сол бөлігі үлкен. Барлық теңсіздіктердің қасиеттерін сандық теңсіздіктер арқылы көрсетуге болады [7, 198 б].

Енді теңсіздіктердің біраз қасиеттеріне тоқталып өтейік.

$a<b$ теңсіздігінен $b>a$ теңсіздігі шығады. Демек, тенсіздіктердің бөліктерін ауыстырғанда теңсіздік таңбасы да ауысады. Бұл қорытынды тікелей теңсіздіктердің анықтамасынан шығады.

$a<b$ және $b<c$ теңсіздіктерінен $a<c$ теңсіздігі шығады. Берілген шарт бойынша $a<b$ және $b<c$. Сондықтан $a-b<0$ және $b-c<0$. Екі теріс санның қосындысы да теріс сан болғандықтан, $(a-b)+(b-c)<0$ жақшаларын ашсақ, $a-b<0$ сонда $a<c$. Бұл қасиет есептерді шешкенде, теоремаларды дәлелдегенде теңсіздікті күшейту үшін қолданылады.

Теңсіздіктерді дәлелдеу геометриядағы сияқты оқушылардың логикалық ойлау қабілетін дамытуға, теориялық материалды терең меңгеруге, берік практикалық дағдыны қалыптастыруға көмектеседі. Соңғы кезде орта мектептегі математиканың бағдарламасында теңсіздіктерді дәлелдеуге дұрыс көңіл бөлмей келеді. Мектеп оқулықтарында бұл мәселеге арнап есептер құрастырылмаған. Сондықтан біз теңсіздіктерді дәлелдеуге көбірек тоқталуымыз керек. Енді теңсіздіктердің қасиеттеріне сүйеніп теңсіздіктерді дәлелдеудің кейбір әдістерін қарастырайық [6, 64 б].

1. Анықтама бойынша теңсіздікті дәлелдеу.

Егер $a$ мен $b$ сандарының айырымы оң болса, онда $a>b$ болады. Сондықтан $f(a, b, \ldots, k)>g(a, b, \ldots, k)$ теңсіздігін дәлелдеу үшін $f(a, b, \ldots, k)-g(a, b, \ldots, k)$ айырымын алып және $a, b, \ldots, k$ мәндері үшін оң болатынын дәлелдеу керек. (Осы тәсіл $f<g, f \geq g, f \leq g$ теңсіздіктерін дәлелдеуде де қолданылады).

1-мысал. Егер $a \geq 0, b \geq 0$ болса, онда $\frac{a+b}{2} \geq \sqrt{a b}$ дәлелдеу керек.

Дәлелдеуі. $\frac{a+b}{2}-\sqrt{a b}$ айырмасын алып оның таңбасын анықтаймыз.

$$
\frac{a+b}{2}-\sqrt{a b}=\frac{a-2 \sqrt{a b}+b}{2}=\frac{(\sqrt{a}-\sqrt{b})^{2}}{2} .
$$

$\frac{(\sqrt{a}-\sqrt{b})^{2}}{2}$ өрнегі кез келген теріс емес $a$ және $b$ мәндерінде оң болады.

Сонымен $\frac{a+b}{2}-\sqrt{a b} \geq 0$, онда $\frac{a+b}{2} \geq \sqrt{a b}$ дегенді білдіреді.

2-мысал. Егер $a b>0$ болса, онда $\frac{a}{b}+\frac{b}{a} \geq 2$ дәлелдеу керек.

Дәлелдеуі. $\left(\frac{a}{b}+\frac{b}{a}\right)-2=\frac{a^{2}+b^{2}-2 a b}{a b}=\frac{(a-b)^{2}}{a b}$ мұнда $a b>0$, онда 


$$
\frac{(a-b)^{2}}{a b} \geq 0
$$

Сонымен $\frac{a}{b}+\frac{b}{a}-2 \geq 0$ айырмасы теріс емес, яғни $\frac{a}{b}+\frac{b}{a} \geq 2$ теңсіздік дәлелденді. 3-мысал. Егер $a+b+c \geq 0$ болса, онда $a^{3}+b^{3}+c^{3} \geq 3 a b c$ дәлелдеу керек.

Дәлелдеуі. Айырмасын қарастырамыз, $a^{3}+b^{3}$ қосындысын кубтардың қосындысына толықтырамыз, сонда,

$$
\begin{gathered}
a^{3}+b^{3}+c^{3}-3 a b c=a^{3}+3 a^{2} b+3 a b^{2}+b^{3}+c^{3}-3 a^{2} b-3 a b^{2}-3 a b c=(a+b)^{3}- \\
-3 a b(a+b+c)+c^{3}=(a+b)^{3}+c^{3}-3 a b(a+b+c)=((a+b)+c)\left((a+b)^{2}-(a+b) c+c^{2}\right)- \\
-3 a b(a+b+c)=(a+b+c)\left(a^{2}+2 a b+b^{2}-a c-b c+c^{2}-3 a b\right)= \\
=(a+b+c)\left(a^{2}+b^{2}+c^{2}-a b-a c-b c\right)=\frac{1}{2}(a+b+c)\left(2 a^{2}+2 b^{2}+2 c^{2}-2 a b-2 a c-2 b c\right)= \\
=\frac{1}{2}(a+b+c)\left((a-b)^{2}+(a-c)^{2}+(b-c)^{2}\right) .
\end{gathered}
$$

$a+b+c \geq 0$ шарты бойынша, алынған өрнек теріс емес. Сондықтан берілген теңсіздік дұрыс.

Теңсіздіктің дұрыстығын дәлелдеуде синтетикалық әдіс те көп қолданылады. Бұл әдістің негізгі идеясы мынада: дұрыстығы бұрын дәлелденген не дұрыстығына шүбә келтірмейтін теңсіздікті түрлендіре отырып, берілген теңсіздіктің өзін шығарып алады (берілген теңсіздіктің дұрыстығы дәлелденбейді) [4, 68 б]. Енді мысалдар қарастырайық.

4-мысал. $\frac{a+b}{2} \geq \sqrt{a b}, a \geq 0, b \geq 0$ теңсіздіктің дұрыстығын дәлелдеңдер

Дәлелдеуі. Бұл теңсіздіктің дұрыстығын синтетикалық әдіспен дәлелдеу үшін $a>0$ мен $b>0$ болғанда, дұрыстығы ақиқат мына теңсіздікті $(a-b)^{2} \geq 0$ негізге аламыз. Оны мына түрде жазамыз:

$$
a^{2}-2 a b+b^{2} \geq 0
$$

Теңсіздіктің екі жағына бірдей $4 a b$-ны мүшелеп қоссақ,

$$
a^{2}-2 a b+b^{2} \geq 4 a b \text { немесе }(a+b)^{2} \geq 4 a b \text {. }
$$

Енді соңғы теңсіздіктің екі жағынан бірдей квадрат түбір тапсақ:

$$
a+b \geq 2 \sqrt{a b} .
$$

Осы теңсіздіктің екі жағында бірдей 2-ге мүшелеп, бөлсек, онда дәлелденілуге тиісті төмендегі теңсіздік келіп шығады:

Сонымен берілген теңсіздіктің дұрыстығы дәлелденді.

$$
\frac{a+b}{2} \geq \sqrt{a b} \text {. }
$$

$$
a+b+c \geq \sqrt{a b}+\sqrt{b c}+\sqrt{a c} \quad(a \geq 0, b \geq 0, c \geq 0)
$$

Дәлелдеуі. $a$ және $b, b$ және $c$, $a$ және $c$ сандары үшін арифметикалық орта мен геометриялық орта туралы теңсіздікті қолдансақ: 


$$
a+b \geq 2 \sqrt{a b}, b+c \geq 2 \sqrt{b c}, a+c \geq 2 \sqrt{a c} .
$$

Бұл теңсіздіктерді мүшелеп қоссақ

$$
a+b+b+c+a+c \geq 2 \sqrt{a b}+2 \sqrt{b c}+2 \sqrt{a c}
$$

бұдан

$$
2(a+b+c) \geq 2(\sqrt{a b}+\sqrt{b c}+\sqrt{a c})
$$

немесе

$$
a+b+c \geq \sqrt{a b}+\sqrt{b c}+\sqrt{a c}
$$

болып шығады. Сонымен, берілген теңсіздіктің дұрыстығы дәлелденді.

6-мысал. $a>0, \mathrm{~b}>0, \mathrm{c}>0, \quad(a+b+c)\left(\frac{1}{a}+\frac{1}{b}+\frac{1}{c}\right) \geq 9$ дәлелдеу керек.

Дәлелдеуі. 1-тәсіл. Белгілі (опорных) теңсіздік ретінде келесі теңсіздіктерді аламыз:

$$
\frac{a}{b}+\frac{b}{a} \geq 2 ; \quad \frac{a}{c}+\frac{c}{a} \geq 2 ; \quad \frac{b}{c}+\frac{c}{b} \geq 2 .
$$

(бұл теңсіздіктер мынадай жағдайда теңдікке жиналады $a=b, a=c$ және $b=c)$. Бұл теңсіздіктерді қосамыз.

$$
\frac{a}{b}+\frac{b}{a}+\frac{a}{c}+\frac{c}{a}+\frac{b}{c}+\frac{c}{b} \geq 6, \frac{b+c}{a}+\frac{a+c}{b}+\frac{a+b}{c} \geq 6
$$

Әрі қарай түрлендірулер жасаймыз:

$$
\begin{gathered}
\left(1+\frac{a+c}{b}\right)+\left(1+\frac{b+c}{a}\right)+\left(1+\frac{a+b}{c}\right) \geq 9 \\
\frac{a+b+c}{b}+\frac{a+b+c}{a}+\frac{a+b+c}{c} \geq 9 . \quad(a+b+c)\left(\frac{1}{a}+\frac{1}{b}+\frac{1}{c}\right) \geq 9 .
\end{gathered}
$$

$a=b=c$ болғанда теңдік таңбасы орынды.

2-тәсіл. Берілген теңсіздікті анықтама бойынша дәлелдеу керек.

$$
\begin{gathered}
(a+b+c)\left(\frac{1}{a}+\frac{1}{b}+\frac{1}{c}\right)-9=1+\frac{a}{b}+\frac{a}{c}+\frac{b}{a}+1+\frac{b}{c}+\frac{c}{a}+\frac{c}{b}+1-9= \\
=\left(\frac{a}{b}+\frac{b}{a}\right)+\left(\frac{a}{c}+\frac{c}{a}\right)+\left(\frac{b}{c}+\frac{c}{b}\right)-6= \\
=\left(\frac{a}{b}+\frac{b}{a}-2\right)+\left(\frac{a}{c}+\frac{c}{a}-2\right)+\left(\frac{b}{c}+\frac{c}{b}-2\right)= \\
=\frac{(a-b)^{2}}{a b}+\frac{(a-c)^{2}}{a c}+\frac{(b-c)^{2}}{b c} \geq 0 .
\end{gathered}
$$

Сонымен берілген теңсіздік дұрыс.

Теңсіздіктің екі жағы да бірдей натурал аргумент $n$-ге тәуелді болып келгенде теңсіздіктің дұрыстығын дәлелдеу үшін математикалық индукиия әдісі қолданылады. Теңсіздіктің дұрыстығын бұл әдіспен дәлелдеу үшін мына екі пікірдің дұрыстығын көрсетеді: a) алдымен теңсіздіктің $n=1$ (немесе берілген теңсіздіктегі $n$-нің ең кіші мәні $n=k_{0}$ үшін) дұрыстығын көрсетеді, б) берілген теңсіздікті $n=k$ ( $k>1$ немесе 
$k>k_{0}$ ) үшін дұрыс деп жорып, оның $n=k+1$ үшін дұрыстығын дәлелдейді [6]. Мысалдар қарастырайық.

7-мысал. $x \geq-1$ болғанда, кез келген натурал сан $n$ үшін орындалатынын дәлелдеу керек.

$$
(1+x)^{n} \geq 1+n x
$$

Дәлелдеуі. Расында да $n=1$ үшін (1) теңсіздік орындалады.

Енді (1) теңсіздікті $n=k$ үшін дұрыс деп жорығанда, яғни

$$
(1+x)^{k} \geq 1+k x
$$

болады. Оның $n=k+1$ натурал саны үшін дұрыс болатындығын, яғни мына теңсіздіктің

$$
(1+x)^{k+1} \geq 1+(k+1) x
$$

орындалатынын көрсетейік. Ол үшін (2) теңсіздіктің екі жағын да бірдей $1+x>0$ санына көбейтелік. Сонда

$$
(1+x)^{k+1} \geq(1+x)(k x+1)
$$

немесе

$$
(1+x)^{k+1} \geq 1+(k+1) x+k x^{2}
$$

болады. Соңғы теңсіздіктен $k x^{2}>0$ болатындықтан, (3) теңсіздіктің дұрыстығы келіп шығады. Сонымен, берілген теңсіздіктің дұрыстығы математикалық индукция әдісі бойынша дәлелденді.

Оқыту үрдісіндегі теңсіздіктерді шешкенде теңсіздік қасиеттерін қолдана білу дағдыларын барынша дамыту аса маңызды. Бұл болашақта мамандығы математикамен байланыста болатын студенттер үшін қажет. Себебі теңсіздіктердің қасиеттеріне сүйеніп теңсіздіктердерді дәлелдеу әдістерін игере алу дағдысы жоғары математика курсын жақсы меңгеру үшін ерекше маңызды. Жоғары мектепте теңдеулер мен теңсіздіктерді шешудің дәстүрлі емес әдістерін іске асыру нәтижесінде жұмыстың негізгі мазмұнын жете түсінуге, тақырыпты оқытудың технологиясын игеруге мүмкіндіктер анықталды [8, 267 б].

Теңдеулер мен теңсіздіктерді шешудегі графиктік әдістерді қолдану білім алушылардың ойлау қабілетін дамытып, теория мен практикада меңгерген білім мен іскерлігін оқу-әдістемелік жұмыстарда пайдалана алады. Координаталық жазықтықты пайдаланатын графиктік әдістер теңдеулер мен теңсіздіктер, жүйелерді шешуде маңызды рөл атқарады. Бұл әдістің теңдеулер мен теңсіздіктерге қолданыстағы рөлі өзгеше, мұнда бұл әдіс тек көріністің жауабын көрсету үшін жұмсалады [9, 75 б], [10, 248 б].

$f(x)=g(x)$ теңдеуін функционалды-графиктік әдіспен шешу үшін:

1) $y=f(x)$ және $y=g(x)$ функцияларының графиктері салынады;

2) графиктер қиылысса қиылысу нүктесін табады.

Графиктердің қиылысу нүктесінің абсциссасы теңдеудің түбірі болады. $y=f(x)$ және $y=g(x)$ функцияларының графигі қиылыспаса теңдеудің шешімі жоқ.

Бұл әдіс теңдеудің түбірлерінің санын және теңдеудің түбірлерін дәл немесе жуықтап анықтауға мүмкіндік береді. Егер х аралығында $y=f(x)$ және $y=g(x)$ функцияларының бірі өсетін, ал екіншісі кемитін болса, онда $f(x)=g(x)$ теңдеуінің осы аралықта жалғыз түбірі болады (1-сурет), немесе ешбір түбірі болмайды (2-сурет). 


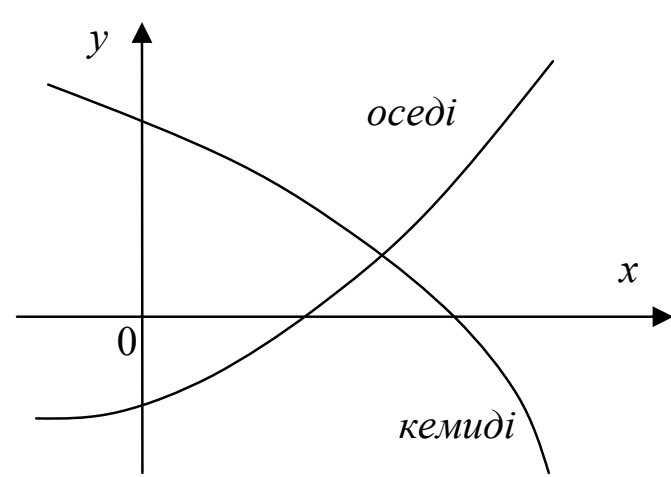

1-сурет - Бір түбірі бар теңдеу графигі

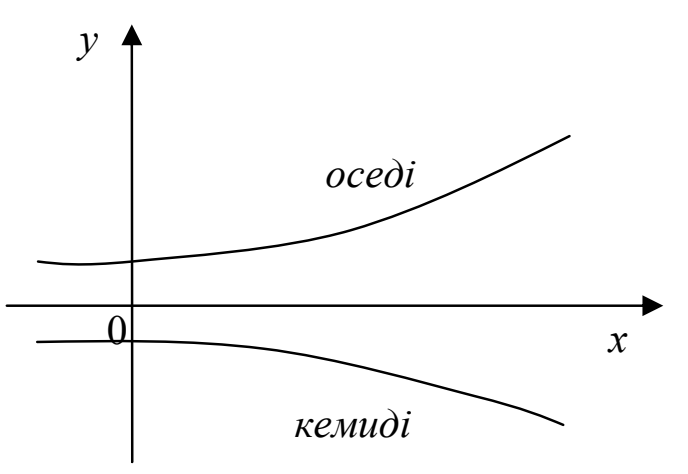

2-сурет - Түбірсіз тендеу графигі

8-мысал. $x^{2}-x-2=0$ теңдеуін шешу үшін, берілген теңдеуді $x^{2}=x+2$ түрінде жазып аламыз.

1) $y=x^{2}$ және $y=x+2$ саламыз;

2) бұл графиктердің қиылысу нүктелер (-1; 1), (2; 4) (3-сурет).

Жауабы: -1; 2.

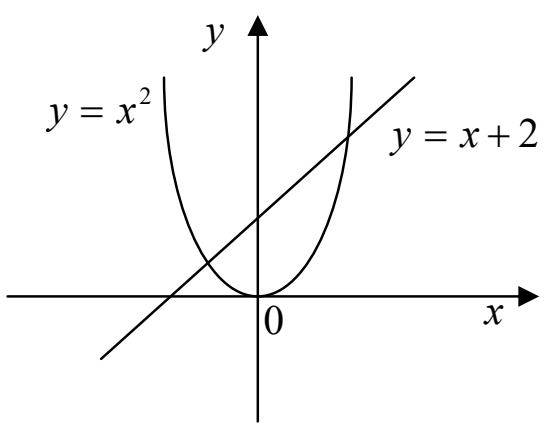

\section{3-сурет - Грфик арқылы тендеуді шешу}

9-мысал. $x^{4}-8 x+63=0$ теңдеуін шешу керек.

Шешуі. Теңдеуді шешу үшін теңдіктің сол жағын көбейткіштерге жіктеу керек. Бұл оңайға түспейді. Бірақ жіктеуге болады. Егер теңдеуді $x^{4}=8 x-63$ түрінде жазып, $y=x^{4}$ және $y=8 x-63$ функцияларының графигін ең болмағанда схемалық түрде салатын болсақ, олардың қиылыспайтындығына көзіміз жетеді (4-сурет)

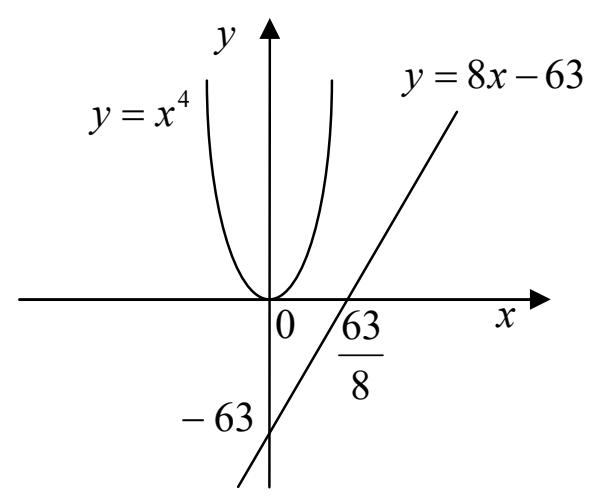

4-сурет - Тендеуге шешуге арналған график 
Егер X аралығында $y=f(x)$ және $y=g(x)$ функцияларының бірі өсетін, екіншісі кемитін болса және қандайда бір жолмен $f(x)=g(x)$ теңдеуінің бір түбірін анықтай алсақ, онда теңдеу толық шешілген, ол түбір теңдеудің жалғыз түбірі.

Зерттеу нәтижелері. Сонымен, математикалық есептерді шеше отырып, білім алушылар жаңа ұғымдарды, жаңа мәселелерді таниды, математикалық таңбаларды біледі, дәлелдеу жолын үйренеді. Есеп шарты бойынша математикалық теорияның есептер шешуге қолданылуын, есептер шешудің жаңа әдістерін танымдық немесе есептер шешуге қажетті математиканың жаңа бір саласымен танысады және т.б. Сондықтан математикалық есептерді шешу барысында теориялық материалды нақтылай отырып, жеткілікті түрде жаттығу арқылы дағды қалыптастырып, математикалық білімін көтереді. Дүниеге ғылыми көзқарасты қалыптастырудың білімдік мәні математика ғылымының негіздерін үйретуді және алған білімдерін тәжірибеде қолдануға мүмкіндік береді.

Қорытынды. Қорыта келгенде, білім алушылардың математикалық біліктілігін арттыруда тек математикалық білімдер жиынтығын игеруі ғана емес, сонымен қатар ол білімді практикада туындалатын әртүрлі теңдеулер мен теңсіздіктерді түрлі әдістер арқылы шығара білу болып табылады. Күрделі есептерді шығарғанда білім алушылардың ойлау әрекеті түрлі ғылыми әдістерден тұрады. Олар бірлікте, белгілі бір өзара байланыста болады және есеп шығару процесінде біртұтас аналитикалық - синтетикалық ic-әрекет түрінде бой көрсетеді. Орта мектепте математиканы оқыту кезеңінде математикалық білімнің жүйелігі мен күнделігінің деңгейін бағалау үшін, білім алушылардың теңдеулер мен теңсіздіктерді шешудегі оқыту әдістерін еркін таңдай білуіне, іс-жүзінде қарапайым және қолайлы жағдайды математикалық модель түрінде қарастыру біліктілігіне, күрделі есептерді шешуде математикалық әдістерді қолдана алу деңгейлеріне сүйену керек. Математиканы оқытуда теңдеулер мен теңсіздіктерді шығаруды үйрету ғана емес, ол кез келген проблеманы шеше білуде, қиындықты жеңуде, танымдық және ойлау қабілеттерді жетілдіруде маңызды рөл атқарады.

\section{Әдебиеттер:}

[1] Abdullaev, V.M., Aida-zade K.R. Numerical method of solution to loaded nonlocal boundary value problems for ordinary differential equations, Comput. Math. Math. Phys., 54 (2014), 1096 - 1109. https://doi.org/10.1134/S0965542514070021.

[2] Aida-zade, K.R., Abdullaev V.M. On the numerical solution of loaded systems of ordinary differential equations with nonseparated multipoint and integral conditions, Numer. Anal. Appl., 7 (2014), 1-14. https://doi.org/10.1134/S1995423914010017.

[3] Assanova, A.T., Bakirova E.A., Kadirbayeva Zh.M. Numerical solution to a control problem for integro-differential equations, Comput. Math. and Math. Phys., 60 (2020), 203-221. https://doi.org/10.1134/S0965542520020049.

[4] Груденов, Г.И. Совершенствование методической работы учителя математики. Книга для учителя. - М: Просвещение, 2002. - 224c.

[5] Бидосов, А. Математиканы оқыту әдістемесі. - А. 2010. - 2876.

[6] Алпысов, А.К. Математика. Теңдеулер мен теңсіздіктер. Павлодар. 2013. - 1876.

[7] Алпысов, А.Қ. Математиканы оқыту әдістемесі. Павлодар. 2017. - 1986.

[8] Рогановский, Н.М. Методика преподавния математики в средней школе. - М., ВШ, 2000. $-267 \mathrm{c}$.

[9] Колягин, Ю.М. и др. Методика преподавния математики в средней школе. Частные методики. - М., 1997

[10] Лебеденцев, К.Ф. Преподавание алгебры и начала анализа. Киев. 2005. - 248c. 


\title{
References:
}

[1] Abdullaev, V.M., Aida-zade K.R. Numerical method of solution to loaded nonlocal boundary value problems for ordinary differential equations, Comput. Math. Math. Phys., 54 (2014), 1096 - 1109. https://doi.org/10.1134/S0965542514070021.

[2] Aida-zade, K.R., Abdullaev V.M. On the numerical solution of loaded systems of ordinary differential equations with nonseparated multipoint and integral conditions, Numer. Anal. Appl., 7 (2014), 1-14. https://doi.org/10.1134/S1995423914010017.

[3] Assanova, A.T., Bakirova E.A., Kadirbayeva Zh.M. Numerical solution to a control problem for integro-differential equations, Comput. Math. and Math. Phys., 60 (2020), 203-221. https://doi.org/10.1134/S0965542520020049.

[4] Grudenov, G.I. Sovershenstvovanie metodicheskoj raboty uchitelya matematiki. Kniga dlya uchitelya. - M: Prosveshchenie, 2002. - 224s.

[5] Bidosov, A. Matematikany окуtu әdistemesi. - A. 2010. - 287b.

[6] Alpysov, A.K. Matematika. Теңdeuler men teңsizdikter. Pavlodar. 2013. - 187b.

[7] Alpysov, A.Q. Matematikany oqytu ədistemesi. Pavlodar. 2017. - 198b.

[8] Roganovskij, N.M. Metodika prepodavniya matematiki v srednej shkole. - M., VSH, 2000. 267s.

[9] Kolyagin, Yu.M. i dr. Metodika prepodavniya matematiki v srednej shkole. CHastnye metodiki. - M., 1997

[10] Lebedencev, K.F. Prepodavanie algebry i nachala analiza. Kiev. 2005. -248s.

\section{ТИПОВЫЕ КЛАССОВЫЕ МЕТОДЫ РЕШЕНИЯ УРАВНЕНИЙ И НЕРАВЕНСТВ С РАЗЛИЧНЫМИ СТРУКТУРАМИ}

\author{
Алпысов А.К., кандидат педагогических наук \\ Сейтханова А.K., $\mathrm{PhD}$ \\ Абишова И.Ш., магистр математики \\ Павлодарский педагогический университет, г. Павлодар, Республика Казахстан
}

\begin{abstract}
Аннотация. В статье рассмотрены способы развития навыков и умений эффективно решать задачи при изложении методов решения уравнений и неравенств, уточнении теоретических знаний, основах формирования умений для применения на практике. Формирование математических понятий через решение задач при обучении математике открывает путь к развитию математического мышления, применению знаний на практике, развитию навыков поиска.

Чтобы усвоить математическое понятие, наряду с его определением, необходимо знать его особенности и свойства. Этого можно достичь, прежде всего, с помощью решения проблем и упражнений. Решение проблем основано на разработке новых методов, создании алгоритмов, способах развития практических навыков в методах и приемах, освоенных с помощью задач. Кроме того, преобразование уравнений и неравенств посредством развития навыков мышления помогает выявить общие или особые свойства, чтобы сделать правильные выводы. Решая различные задачи, показывает, какие операции следует использовать для определения ситуации, в которой найдено решение, и какие особенности решения позволяют выбрать наиболее эффективные методы.

Благодаря теоретическому обоснованию общей статьи можно освоить удобные способы решения уравнений и неравенств различной структуры.

Ключевые слова: уравнения, неравенства, система объектных задач,функциональнографический метод.
\end{abstract}




\title{
TYPICAL CLASS METHODS FOR SOLVING EQUATIONS AND INEQUALITIES WITH DIFFERENT STRUCTURES
}

\author{
Alpysov A.K., candidate of pedagogical sciences \\ Seytkhanova A.K., $\mathrm{PhD}$ \\ Abishova I.Sh., master of mathematics \\ Pavlodar Pedagogical University, Pavlodar city, Republic of Kazakhstan
}

\begin{abstract}
Annotation.The article discusses the ways of developing skills and abilities to effectively solve problems when describing methods for solving equations and inequalities, clarifying theoretical knowledge, the basics of forming skills for practical application. The formation of mathematical concepts through solving problems in teaching mathematics opens the way to the development of mathematical thinking, the application of knowledge in practice, and the development of search skills.

To master a mathematical concept, along with its definition, it is necessary to know its features and properties. This can be achieved primarily through problem solving and exercise. Problem solving is based on the development of new methods, the creation of algorithms, ways of developing practical skills in the methods and techniques mastered with the help of tasks. In addition, transforming equations and inequalities through the development of thinking skills helps to identify common or special properties in order to draw correct conclusions. Solving various problems, it shows what operations should be used to determine the situation in which a solution was found, and what features of the solution allow choosing the most effective methods.

Thanks to the theoretical substantiation of the general article, it is possible to master convenient methods for solving equations and inequalities of various structures.
\end{abstract}

Key words: equations, inequalities, system of object problems, functional-graphic method 


\title{
INORGANIC CHEMISTRY PROBLEM-BASED LEARNING
}

\author{
Balykbaeva G. T., candidate of chemical sciences \\ bal_gulzhan@mail.ru, https://orcid.org/ 0000-0002-8026-5169 \\ Tapalova A. S., candidate of technical sciences \\ anipa52@mail.ru, https://orcid.org/0000-0001-7556-2380 \\ Abyzbekova G. M., candidate of chemical sciences \\ abizgul@mail.ru, https://orcid.org/0000-0003-3721-1322 \\ Espenbetova Sh. O., candidate of technical sciences \\ sholpan-sultan@mail.ru, https://orcid.org/ 0000-0002-6488-6846 \\ Arynova K. Sh., candidate of pedagogical sciences \\ karima_71_10@mail.ru, https://orcid.org/ 0000-0003-1186-769X \\ Kyzylorda University named after Korkyt Ata, Kyzylorda city, Kazakhstan
}

\begin{abstract}
Annotation. The resolution of problem situations under the teacher's guidance makes students compare, generalize, analyze phenomena, and not only memorize them mechanically. The processes of advancing and resolving problem situations are an unbroken chain, since when a problem is advanced, its solution begins simultaneously, which leads to the formulation of new problems. That is, a contradictory and continuous process of new scientific concepts active cognition is carried out. We see from the experience that using the methods of problem-based learning in the lessons that they promote development of cognitive activity, creative students' independence, the formation of their worldview, intellectual development, and as a result, the improvement of the knowledge's quality. Today, it is necessary when learning future specialists, in addition to the implementation of existing educational state standards in this specialty, to focus on the development of their creative qualities, creative thinking, which, ultimately, will promote to the formation of highly professional competent personnel.
\end{abstract}

Keywords: problem-based learning, self-development, critical thinking, independent work, active learning, cognitive activity

Introduction. Modern conditions require from education workers to set new goals and objectives which will direct the educational process to self-development, students' selfeducation, the development of critical thinking, the formation of a personality that can collect, synthesize and analyze information, understand the practical, vital significance of a process, invention, discovery. One of the conditions the modern education system meets is the person's preparation with a high level of intelligence, a qualified specialist, capable to creative work and professional growth, mastering and introducing high technology and information technologies. It is important to integrate the forms and methods of learning, but practical implementation of these principles to the learning process often causes difficulties.

The future specialist should be prepared for active, creative professional and social activity that would promote the progress of social development and be able to acquire new knowledge and make decisions independently. The role of value of students' knowledge is being rethought at the present stage of education development, because modern society needs a creative specialist who is able to orientate independently in the rapid flow of scientific and technical information, be able to think critically, develop and defend his point of view. Therefore, today it is important to teach students to learn independently and constantly, solve life and professional problems, and develop an active life position. What conditions are needed 
for this? First of all, the possibility of involving each student in active cognitive activity, constructing a dialogue between student - student and teacher - student as the main form of educational interaction, formation of students' reflective position and teachers, the use of innovative pedagogical technologies and teaching methods. The task of developing the creative abilities and professional competencies of the students is the social order of society, which leads to transfer the emphasis from transferring to students mostly finished subject-disciplinary knowledge to organize their joint active cognitive activity in the educational process.

Problem-based learning has a long development history. Even in ancient times, it was known that mental activity promotes both better memorization and deeper insight into the essence of objects, processes and phenomena. So, statement problematic questions to the interlocutor and his difficulty in finding answers to them are characteristic of Socrates's discussions, the same technique was known in the Pythagorean school. Later on, the idea of active learning was developed by such teachers and philosophers as Y. A. Kamensky, J. Zh. Russo, I. G. Pestalozzi. The scientific substantiation of problem education as a didactic system was given by M. I. Makhmutov [1].

As noted by M.I. Makhmutov, creating a problem situation and its awareness by students is possible in the study of any educational topic, since in most cases it is possible to raise a problematic question for the student to solve it independently[1]. Problematic situations can be created at all stages of learning process: during explanation, consolidating, control.

L.S. Vygotsky was the first who put forward the idea of developing learning [2]. Vygotsky put the question about the attitude of learning and child's development at the center of his research. In his opinion, the question of the attitude of learning and child's development at school age is the most central and fundamental issue, without which the problem of pedagogical psychology and the analysis of the pedagogical process cannot only be solved correctly, but even put.

At present, the most famous is the didactic system of developing education, which was developed under the guidance of L.V. Zankov [3]. It is based on the following principles:

- constructing learning at a high, but feasible level of difficulty;

- learning the material at a fast pace, but taking into account its accessibility;

- a sharp increase of theoretical knowledge volume;

- students' awareness of learning process.

D.B. Elkonin and V.V. Davydov with a group of psychologists developed another developing learning system [6]. It also aims to use students' intellectual development reserves.

There are a number of attempts to define this phenomenon in the pedagogical literature. V. Okon [5] imagines the problematic training as the totality of such actions as the organization of problem situations, the formation of problems, providing students the necessary help, the verification of these solutions and, finally, the management of systematization and consolidation of acquired knowledge. The main disadvantage of this definition is that the learning process here appears as the process of acquiring all knowledge only by solving problems.

T.V. Kudryavtsev [4] sees the essence of problematic teaching in the following: problematic education is in creating problematic situations for students, in recognizing, accepting and resolving these situations by students in the course of students' joint work with a teacher under the students' optimal independence and with the teacher general leadership. However, such a definition does not reflect the entire concept of problem education.

In my opinion, M.I. Makhmutov [1], gives the most complete definition of the "problembased learning" concept who supposes that problem-based learning is a type of developing training that combines students' systematic independent search activity with the assimilation of science ready-made conclusions, and the system of methods is built taking into account goalsetting and problematic principle; the process of interaction between teaching and learning is focused on the formation of students' cognitive independence, sustainable motives of learning 
and cogitative, including creative abilities in the course of their scientific concepts assimilation and methods of activity determined by the system of problem situations.

The phased theory of mental activity formation by N.F. Talyzyn [11] and I.Ya. Galperina [12], can be the basis for the formation of mental activity in organizing independent work of chemistry students. This theory is well reflected in the works by T. P. Rayskina [15], Z. A. Reshetova [14], and O.S. Zaitsev [13], who used effectively this theory in higher education. Also, the effective organization of students' independent work is rationally described in the works of scientific methodologists such as A.S. Tapalova [17] and K. Saduakasova [18].

Studying chemical disciplines forms as a theoretical basis for students in mastering special disciplines, as practical skills and abilities that allow future specialist to find problems' rational solutions of an applied direction. In this regard, the requirements for the knowledge quality and the level of students' training are increasing, therefore, in the process of studying chemical disciplines in the training of chemists, problematic teaching methods are used.

Teaching chemical disciplines is an essential part of chemists' professional training. Lectures on basic chemical disciplines have a large amount of information, which allow us to transfer a large amount of information in a compressed form. It is necessary to show all the positive aspects of this form of teaching in order to achieve high efficiency in mastering lecture material: teaching the audience through the lecturer's thought to the logical development of thought and through his speech to the correct construction of students 'speech [18]. However, lecturing in the traditional sense is no longer relevant today.

\section{Methodology}

At the problem lecture, new knowledge is introduced as unknown to students. Accordingly, the received information is assimilated as a personal discovery of unknown knowledge, which allows students to create the illusion of a "discovery" has already known in science. Educational problems should not only be accessible in their difficulty, but also take into account the students' cognitive abilities and proceed from the studied discipline, be significant for the assimilation of new material [7].

During the lecture, students think with the help of a teacher's creating a problem situation before they receive all the necessary information that constitutes new knowledge for them. For example, in our practice, when studying the topic "Oxidation-reduction," after determining the purpose of the lesson, students were asked problematic questions: "For compounds $\mathrm{NO}_{2}, \mathrm{HNO}_{3}$, $\mathrm{NH}_{3}, \mathrm{~N}_{2}$, students have to determine which of them can be only oxidants, which only reductants, and which oxidants and reductants (may show redox duality) "[18]. Students offer their hypotheses:

The maximum and minimum values of an element oxidation states are determined by its position in the periodic system. In these degrees of oxidation, the element shows only one function in the ORR - oxidizing agent or reducing agent.

Let's determine the oxidation state of the nitrogen atom in the compounds:

$+4 \quad+5 \quad-3 \quad 0$

$\mathrm{NO}_{2}, \mathrm{HNO}_{3}, \mathrm{NH}_{3}, \mathrm{~N}_{2}$

Compounds containing atoms of highly oxidized elements can only be oxidizing agents. The highest oxidation state of element atoms, as a rule, coincides with the group number in the periodic system of elements.

In the $\mathrm{HNO}_{3}$ compound, the nitrogen atom is in the highest oxidation state +5 , which coincides with the group number and cannot give electrons, therefore, HNO3 is only an oxidizing agent. Compounds containing atoms of elements in the lowest oxidation state can only be reducing agents. The lowest oxidation state for metal atoms is 0 , for non-metals it is the difference (with a minus sign) between the number 8 and the group number in the periodic system, and cannot be greater than four in absolute value. The number 8 is the maximum possible number $\overline{\mathrm{e}}$ at the external level of any atom in the compound. 
In the NH3 compound, a nitrogen atom of up to $8 \overline{\mathrm{e}}$ lacks $3 \overline{\mathrm{e}}$.

C.o. $(\mathrm{N})=-(8-5)=-3$.

The nitrogen atom is in the lowest oxidation state -3 , it cannot accept electrons, therefore, NH3 is only a reducing agent. Compounds containing atoms of elements in an intermediate oxidation state can also be oxidizing agents and reducing agents, depending on the redox properties of the second substance in the ORR.

In $\mathrm{N} 2$ and NO2 compounds, the sulfur atom is in the intermediate oxidation state of 0 and +4 ; therefore, $\mathrm{N} 2$ and NO2 can play the role of both an oxidizing agent and a reducing agent, i.e., they can show redox duality depending on the properties of the second substance in the ORR or type ORR.

Thus, students come to the conclusion: redox properties of various elements atoms are appeared depending on many factors, the most important of which are electronic structure of the element, its oxidation state in the substance, and the nature of the properties of other participants in the reaction. And also, students themselves try to find a solution to the problem situation. In traditional teaching, they do the opposite - at first we give knowledge, a method or algorithm for solving, and then examples on which you can practice using this method.

The components of the problematic situation are the object of cognition (lecture material) and the subject of cognition (student), the process of mental interaction of the subject with the object will be cognitive activity, the assimilation of new knowledge that is still unknown to the student, containing in the educational problem.

Lecture is constructed in the way that to determine the appearance of the issue in the student's mind. Training material is presented in the form of a training problem. It has the logical form of a cognitive task, noting some contradictions in its conditions and ending with the questions that this contradiction objectifies. The problem situation appears after detection of contradictions in the source data of the training problem.

Students' independent work (IWS) plays an important role for the implementation of modern knowledge assimilation. It is intended for deeper assimilation, deepening and consolidation of the skills acquired in classroom studies, including laboratory classes. Students' independent work suggests the development of the intellectual and creative abilities of each student. In particular, the tasks of independent work on the development of intellectual and creative students' skills in the form of tasks with a multiple option is the basis for a thorough, multi-level, systematic implementation of tasks. As evidence of our words, we give a tabular version of the tasks that we use in our practice [17].

Multi-variant tasks

Task 10.1. Describe the reactions according to the proposed schemes.

1. Determine the oxidation state of atoms of all elements in substances.

2. Determine which reactions are oxidative and reduction (ORR).

3. Balance ORR by electronic balance method. Indicate which process is oxidation, which is reduction, which substance is an oxidizing agent, and which is a reducing agent.

4. Determine the type of ORR (Table 1).

Students' independent work (IWS) plays an important role for assimilation of modern knowledge. Students' independent work (IWS) is intended for deeper assimilation, deepening and consolidation of the skills acquired in classroom studies, including laboratory classes. Students' independent work (IWS) suggests the development of the intellectual and creative abilities of each student. 
Table 1 - Multi-variant tasks for studen's independent work

\begin{tabular}{|c|c|}
\hline Variants & Reaction equations \\
\hline \multirow[t]{3}{*}{1} & $\mathrm{KMnO}_{4}+\mathrm{H}_{2} \mathrm{~S}+\mathrm{H}_{2} \mathrm{SO}_{4}=\mathrm{MnSO}_{4}+\mathrm{S}+\mathrm{K}_{2} \mathrm{SO}_{4}+\mathrm{H}_{2} \mathrm{O}$ \\
\hline & $\mathrm{Zn}+\mathrm{H}_{2} \mathrm{SO}_{4 \text { (concent.) }}=\mathrm{H}_{2} \mathrm{~S}+\mathrm{H}_{2} \mathrm{O}+\mathrm{ZnSO}_{4}$ \\
\hline & $\mathrm{AgNO}_{3}+\left(\mathrm{NH}_{4}\right)_{2} \mathrm{~S} \rightarrow \mathrm{Ag}_{2} \mathrm{~S}+\mathrm{NH}_{4} \mathrm{NO}_{3}$ \\
\hline \multirow[t]{3}{*}{2} & $\mathrm{AgNO}_{3}+\mathrm{NaOH} \rightarrow \mathrm{Ag}_{2} \mathrm{O}+\mathrm{H}_{2} \mathrm{O}+\mathrm{NaNO}_{3}$ \\
\hline & $\mathrm{Na}_{2} \mathrm{SO}_{3}+\mathrm{K}_{2} \mathrm{Cr}_{2} \mathrm{O}_{7}+\mathrm{H}_{2} \mathrm{SO}_{4} \rightarrow \mathrm{Na}_{2} \mathrm{SO}_{4}+\mathrm{Cr}_{2}\left(\mathrm{SO}_{4}\right)_{3}+\mathrm{K}_{2} \mathrm{SO}_{4}+\mathrm{H}_{2} \mathrm{O}$ \\
\hline & $\mathrm{Zn}+\mathrm{H}_{2} \mathrm{SO}_{4 \text { (diluted.) }}=\mathrm{S}+\mathrm{H}_{2} \mathrm{O}+\mathrm{ZnSO}_{4}$ \\
\hline \multirow[t]{3}{*}{3} & $\mathrm{Al}(\mathrm{OH})_{3}+\mathrm{HCl} \rightarrow \mathrm{AlCl}_{3}+\mathrm{H}_{2} \mathrm{O}$ \\
\hline & $\mathrm{Al}+\mathrm{KMnO}_{4}+\mathrm{H}_{2} \mathrm{SO}_{4} \rightarrow \mathrm{Al}_{2}\left(\mathrm{SO}_{4}\right)_{3}+\mathrm{MnSO}_{4}+\mathrm{K}_{2} \mathrm{SO}_{4}+\mathrm{H}_{2} \mathrm{O}$ \\
\hline & $\mathrm{Cu}+\mathrm{HNO}_{3} \rightarrow \mathrm{Cu}\left(\mathrm{NO}_{3}\right)_{2}+\mathrm{NO}+\mathrm{H}_{2} \mathrm{O}$ \\
\hline \multirow[t]{3}{*}{4} & $\mathrm{Al}(\mathrm{OH})_{3}+\mathrm{NaOH} \rightarrow \mathrm{Na}\left[\mathrm{Al}(\mathrm{OH})_{4}\right]$ \\
\hline & $\mathrm{FeSO}_{4}+\mathrm{KMnO}_{4}+\mathrm{H}_{2} \mathrm{SO}_{4} \rightarrow \mathrm{MnSO}_{4}+\mathrm{Fe}_{2}\left(\mathrm{SO}_{4}\right)_{3}+\mathrm{K}_{2} \mathrm{SO}_{4}+\mathrm{H}_{2} \mathrm{O}$ \\
\hline & $\mathrm{Ge}+\mathrm{NaOH}+\mathrm{H}_{2} \mathrm{O}_{2} \rightarrow \mathrm{NaHGeO}_{3}+\mathrm{H}_{2} \mathrm{O}$ \\
\hline
\end{tabular}

A set of questions and tasks has been developed to emphasize the preparation for further professional chemist's activities, including problem tasks, leading to a meaningful transfer of knowledge gained in practical and laboratory studies, to typical situations in the specialty, independent work, forming the selection of necessary knowledge, leading to creative search for new solutions as a result of an independent explanation of the proposed phenomena and facts [7] (Table 2,3).

Table 2 - Examples of tasks for an independent solution on the topic "Oxidative and reduction reactions"

\begin{tabular}{|c|c|}
\hline \multirow[t]{2}{*}{ Task 1} & $\begin{array}{l}\text { Is it possible to use } \mathrm{K}_{2} \mathrm{Cr}_{2} \mathrm{O} \text { as an oxidizing agent in an acidic medium in the } \\
\text { following processes under standard conditions: }\end{array}$ \\
\hline & $\begin{array}{l}\text { a) } 2 \mathrm{~F}^{-}-2 \mathrm{e}^{-}=\mathrm{F}_{2}, \mathrm{E}^{0}=2,85 \mathrm{~B} \\
\text { б) } 2 \mathrm{Cl}^{-}-2 \mathrm{e}^{-}=\mathrm{Cl}_{2}, \mathrm{E}^{0}=1,36 \mathrm{~B} \\
\text { в) } 2 \mathrm{Br}^{-}-2 \mathrm{e}^{-}=\mathrm{Br}_{2}, \mathrm{E}^{0}=1,06 \mathrm{~B} \\
\text { г) } 2 \mathrm{I}-2 \mathrm{e}^{-}=\mathrm{I}_{2}, \mathrm{E}^{0}=0,54 \mathrm{~B} \\
\text { Standard oxidative and reduction potential of the system } \mathrm{Cr}_{2} \mathrm{O}_{7}{ }^{2-}+14 \mathrm{H}^{+}+ \\
6 \mathrm{e}^{-}=2 \mathrm{Cr}^{3+}+7 \mathrm{H}_{2} \mathrm{O} \text { equals } \mathrm{E}^{0}=1,33 \mathrm{~B}\end{array}$ \\
\hline Task 2 & $\begin{array}{l}\text { Calculate oxidative and reduction potential for the system } \\
\mathrm{MnO}_{4}^{-}+8 \mathrm{H}^{+}+5 \mathrm{e}^{-}=\mathrm{Mn}^{2+}+4 \mathrm{H}_{2} \mathrm{O} \\
\text { If } \mathrm{C}\left(\mathrm{MnO}_{4}-\right)=10^{-5} \mathrm{M}, \mathrm{C}\left(\mathrm{Mn}^{2+}\right)=10^{-2} \mathrm{M}, \mathrm{C}\left(\mathrm{H}^{+}\right)=0,2 \mathrm{M} \text {. }\end{array}$ \\
\hline Task 3 & $\begin{array}{l}\text { For standard conditions, calculate the equilibrium constant of the oxidative } \\
\text { and reduction reaction: } \\
2 \mathrm{KMnO}_{4}+5 \mathrm{HBr}+3 \mathrm{H}_{2} \mathrm{SO}_{4}=2 \mathrm{MnSO}_{4}+5 \mathrm{HBrO}+\mathrm{K}_{2} \mathrm{SO}_{4}+3 \mathrm{H}_{2} \mathrm{O} \text { and so on. } \\
\text { Examples of tasks for an independent decision on the topic "Thermodynamics } \\
\text { of chemical processes": }\end{array}$ \\
\hline
\end{tabular}

Table 3 - Examples of tasks for an independent decision on the topic "Chemical thermodynamics"

\begin{tabular}{|l|l|}
\hline \multirow{2}{*}{ Task 1. } & Predict the sign of entropy change $\left(\Delta \mathrm{S}_{298}^{\mathrm{o}}\right)$ in each of the proposed reactions: \\
\cline { 2 - 2 } & $\begin{array}{l}\text { 1) } 2 \mathrm{KClO}_{3(\mathrm{cr})}=2 \mathrm{KCl}(\mathrm{cr}) \\
\text { 2) } \mathrm{N}_{2(\mathrm{~g})}+2 \mathrm{O}_{2(\mathrm{~g})}\end{array}$ \\
& 3) $3 \mathrm{C}_{2} \mathrm{H}_{2(\mathrm{~g})}=\mathrm{C}_{6} \mathrm{H}_{6(\mathrm{liq})}$
\end{tabular}




\begin{tabular}{|c|c|}
\hline & $\begin{array}{l}\text { 4) } \mathrm{FeO}_{(\mathrm{cr})}+\mathrm{H}_{2(\mathrm{~g})}=\mathrm{Fe}_{(\mathrm{cr})}+\mathrm{H}_{2} \mathrm{O}_{(\mathrm{g})} \\
\text { 5) } \mathrm{Ag}^{+} \text {(sol) } \\
\text { Check the correctness of conclusions made by calculation } \Delta \\
\mathrm{S}_{298}^{\mathrm{o}} \text { corresponding reactions, using reference data. }\end{array}$ \\
\hline Decision: & $\begin{array}{l}\text { I. 1) } \Delta \mathrm{S}^{\mathrm{o}}{ }_{298} \text { the first reaction is greater than zero. The entropy of a system as a } \\
\text { measure of disorder increases with an increase in the number of a substance } \\
\text { moles (the number of moles), moreover, one of the obtained substances is in a } \\
\text { gaseous state; } \\
\text { 2) } \Delta \mathrm{S}^{\mathrm{o}}{ }_{298}<0 \text {, since three volumes of gases enter the reaction, and two are } \\
\text { obtained, i.e. the number of gaseous substances particles decreases, order is } \\
\text { growing in the system; } \\
\text { 3) } \Delta \mathrm{S}^{\mathrm{o}}{ }_{298}<0 \text { for the same reason as in the case } 2 \text {; } \\
\text { 4) probably, } \Delta \mathrm{S}^{\mathrm{o}}{ }_{298}>0 \text {, since the composition of gas molecules has become } \\
\left.\text { more complicated ( } \mathrm{H}_{2} \mathrm{O} \text { instead of } \mathrm{H}_{2}\right) \text {, although as the result of the reaction, } \\
\text { the number of moles has not changed (including gaseous substances); } \\
\text { 5) } \Delta \mathrm{S}^{\mathrm{o}}{ }_{298}<0 \text {, since ions } \mathrm{Ag}^{+} \text {и } \mathrm{Cl}^{-} \text {, in solution pass into the precipitate, i.e. } \\
\text { order is growing in the system. }\end{array}$ \\
\hline \multirow[t]{2}{*}{ II. } & $\begin{array}{l}\text { Let's write down the values from the look-up table } \mathrm{S}_{298}^{\mathrm{o}} \text { the corresponding } \\
\text { substances and sign them under the formulas in the equations } 1-5 \text { : }\end{array}$ \\
\hline & 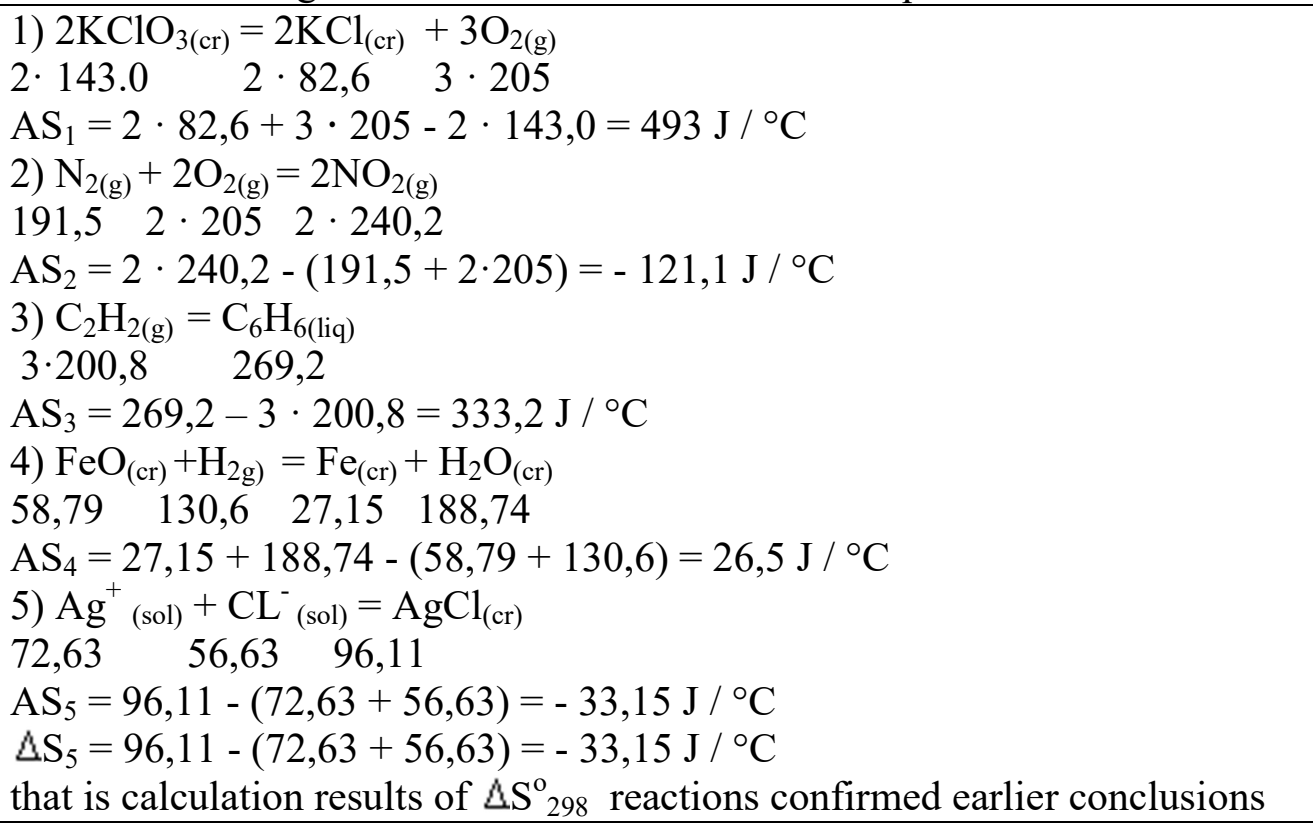 \\
\hline Task 2 & $\begin{array}{l}\text { Which of the reactions listed in Task } 1 \text { occur spontaneously under standard } \\
\text { conditions? }\end{array}$ \\
\hline Decision: & $\begin{array}{l}\text { The answer to the task question gives calculating of the change of isobaric- } \\
\text { isothermal potential or Gibbs free energy }\left(\Delta \mathrm{G}^{\mathrm{o}}{ }_{298}\right) \text { proposed reactions. } \Delta \mathrm{G}- \\
\text { function of the system state, and therefore } \Sigma \mathrm{G}^{\mathrm{o}}=\sum \Delta \mathrm{G}^{\mathrm{o}} \text { (prod.) - } \Sigma \Delta \\
\mathrm{G}^{\mathrm{o}} \text { (orig.). } \\
\text { Let's write down the values from the look-up table } \Delta \mathrm{G}^{\mathrm{o}}{ }_{298} \text { the formation of } \\
\text { compounds and we will sign them under the corresponding formulas in } \\
\text { equations } 1-5 \text {, we calculate } \Delta \mathrm{G}^{\mathrm{o}}{ }_{298} \text { corresponding reactions: } \\
\text { 1) } \Delta \mathrm{G} 1=2 \cdot(-408,0)-2 \cdot(-289,5)=-236,2 \mathrm{kj} \\
\text { 2) } \Delta \mathrm{G} 2=2 \cdot 51,5=103 \mathrm{kj} \\
\text { 3) } \Delta \mathrm{G} 3=129,7-3 \cdot 209,2=-497,9 \mathrm{kj} \\
\text { 2) } \Delta \mathrm{G} 4=-228,8-(-244,35)=15,5 \mathrm{kj} \\
\text { 5) } \Delta \mathrm{G} 5=-155,44-(83,89-184,3)=-55,03 \mathrm{kj}\end{array}$ \\
\hline
\end{tabular}




\begin{tabular}{|l|l|}
\hline & $\begin{array}{l}\text { The obtained results indicate that reactions 1, 3 and 5 can occur } \\
\text { spontaneously under standard conditions until equilibrium is established, and } \\
\text { reactions } 2 \text { and } 4 \text { under these conditions cannot occur in this direction [9]. }\end{array}$ \\
\hline
\end{tabular}

A high level of lecture material in combination with new forms of conducting practical and laboratory classes requires the introduction of modern technology, including computerization.

Particular attention should be paid to laboratory studies, namely search or partially search, role-playing games [18].

Laboratory work and practical exercises can be of a reproductive, partially search and search nature. In practical work, the future chemist is obliged to use modern chemical methods to determine harmful substances in the environment, production, using modern research methods.

The method of practical application of the studied material is used in the performance of laboratory work in order to motivate the study. It is very important to teach the student to make a specific and very short conclusion on the fulfilled work in the laboratory, which is important in practical work, as most of the conclusions are made incorrectly, for example, "in this work I learned how to determine the concentration of a substance in a given material." It is necessary to pay attention to the technique of laboratory work during the execution of laboratory work (preparation of samples for analysis, weighing on an analytical balance of a weight of up to the fourth digit, preparation of standard solutions, etc.).

Much attention is also paid to compliance with safety requirements, ability to maintain records correctly, formulate conclusions on the basis of theoretical knowledge and practically completed experiment. At a modern level laboratory works promote to a better assimilation of theoretical material presented in lectures and practical exercises, helps to form practical skills, acquaints students with modern methods of scientific research and is an effective way to form a scientific worldview system [18].

Let's consider conducting a partial search laboratory work in the discipline "Inorganic chemistry". The topic of the lesson should be relevant for the student, i.e. be motivational in nature (Table 4).

Table 4 - Tasks of laboratory work on the topic: "Electrochemical processes»:

\begin{tabular}{|c|c|}
\hline \multirow[t]{2}{*}{ Task 1.} & $\begin{array}{l}\text { Determine the values of metals in 1M solutions of their salts concerning to the silver } \\
\text { chloride electrode: 1) copper; 2) iron; 3) nickel; 5) copper. }\end{array}$ \\
\hline & $\begin{array}{l}\text { - Draw a diagram of the device. } \\
\text { - Based on the obtained EMF values, calculate the potential value of the studied } \\
\text { electrode.- Make a diagram of the galvanic element using to conduct the } \\
\text { experiment. What is the anode and what is the cathode in your case? }\end{array}$ \\
\hline \multirow[t]{2}{*}{ Task 2.} & $\begin{array}{l}\text { Compare the reducing activity of these metals in reactions with solutions containing } \\
\text { cations: } \mathrm{Fe}^{2+}, \mathrm{Cu}^{2+}, \mathrm{Zn}^{2+}, \mathrm{Ni}^{2+}, \mathrm{Ag}^{+}: \\
\text {1) } \mathrm{Sn} ; 2) \mathrm{Mg} ; 3) \mathrm{Cu} \text {;) } \mathrm{Zn} ; 5) \mathrm{Al} \text {; } \\
\mathrm{Fe} ; \quad \mathrm{Pb} \quad \mathrm{Fe} ; \mathrm{Sn} ; \quad \mathrm{Sn} .\end{array}$ \\
\hline & $\begin{array}{l}\text {-Mark the data, write the reaction equations. } \\
\text { - Write down the experimental data into the table. } \\
\text { - Arrange the metals as their reducing activity decreases. } \\
\text {-Based on the reference data, calculate the EMF of the reactions. }\end{array}$ \\
\hline Task 3. & $\begin{array}{l}\text { According to the reference data, predict the direction of the ORR flow and confirm } \\
\text { your result experimentally: } \\
\begin{array}{ll}\text { 1) } \mathrm{MnO}_{4}^{-}+\mathrm{NO}_{2}^{-}+\mathrm{H}^{+} ; & \text {2) } \mathrm{Fe}^{3+}+\mathrm{I}^{-} \\
\mathrm{Mn}^{2+}+\mathrm{SO}_{3}^{2-}+\mathrm{H}_{2} \mathrm{O} & \end{array}\end{array}$ \\
\hline
\end{tabular}




\begin{tabular}{|l|ll|}
\hline & $\begin{array}{l}\text { 3) } \mathrm{MnO}_{4}{ }^{-}+\mathrm{SO}_{3}{ }^{2-}+\mathrm{H}_{2} \mathrm{O} ; \\
\mathrm{Mn}^{2+}+\mathrm{NO}_{2}{ }^{-}+\mathrm{H}^{+} ;\end{array}$ & 4) $\mathrm{Cr}_{2} \mathrm{O}_{7}{ }^{2-}+\mathrm{Fe}^{2+}+\mathrm{H}^{+} ;$ \\
\cline { 2 - 3 } & $\begin{array}{l}\text {-Calculate the EMF of the given systems. } \\
\text {-For feasible reactions, write down the molecular equations, balance using electron- } \\
\text { ion balance. } \\
\text { - Mark the data of conducted reactions. }\end{array}$ \\
\hline
\end{tabular}

Research results and their discussion. Creative works are offered for students with a higher level of intelligence, as part of students' research, the results of which are reported at students' conferences. Such options for independent work promote to the development of cognitive interest, develop intelligence, and form skills of self-education.

Reproductive nature works are distinguished by the fact that when they are conducted, students use detailed instructions that indicate the purpose of the work, reagents and equipment, the order of the work, expected results, questions for controlling knowledge, and recommended literature. Partial-search work can be addressed to senior students and are distinguished by the fact that when they are conducted, students do not use detailed instructions; they are not given the procedure for performing the necessary actions, and require students to select equipment themselves, choose methods for performing work in the instructional and reference books and others. Works that have a search character are characterized by the fact that students must solve a new problem for them, based on their theoretical knowledge. When planning class work, it is necessary to find the optimal ratio of classical and active forms of educational process organization, and when conducting laboratory work and practical training- reproductive, partially search and search work to ensure a high level of intellectual activity [8].

Students work with educational and scientific literature independently, according to reference data they predict the direction of the course of ORR and experimentally confirm their results. Laboratory work was selected with the goal of implementing a developing personalityoriented approach to student learning. It is constructed in such a way, on the one hand, to maximize the independence of students' cognitive work in the workshop and the development of their mental abilities, and on the other hand, to create conditions for the development of communication skills which are necessary in the work of a specialist of any profile.

Conclusion. In practical work, the future chemist is obliged to use modern chemical methods to determine harmful substances in the environment, production, using modern research methods [10]. A modern graduate of a pedagogical university should be ready to work in schools of various types and profiles, be able to organize training in alternative programs and textbooks at various levels of learning. In such conditions, the future chemistry teacher needs to study material from various sources, to select the content that mostly fully corresponds to this pedagogical goal and its didactic reconstruction. Therefore, the readiness for independent acquisition of knowledge is one of the most important processes for a modern chemistry teacher.

In my pedagogical practice I use various ways of enhancing cognitive activity, the main ones among them are the variety of forms, methods, teaching aids, the choice of their combinations, which stimulate the students' activity and independence in appeared situations.

Years of practical experience have shown that situations in which students themselves:

- defend their opinion;

- take part in discussions;

- put questions to the students and teachers;

- review the students' answers;

- evaluate the students' answers and written work;

- train weak students;

- explain incomprehensible material;

- choose independently a feasible task; 
- learn to find several options for a possible solution of a cognitive task (problem); actions;

- create situations of self-examination, analysis of personal cognitive and practical

- solve cognitive problems through the integrated application of solution known methods.

Thus, as a result of using active methods in the educational process, the emotional response of students to the process of learning increases, the motivation of learning activities, and interest in mastering new knowledge, skills and their practical application increase, which promotes the development of students' creative abilities, the ability to formulate and express their point of view, activation of thinking. The issues of enhancing the students' cognitive activity are among the most actual issues of modern pedagogical science and practice. Indeed, the result of training, development and the formation of professional competencies of future specialists depend on the quality of learning as an activity.

\section{Literature:}

[1] Махмутов, М.И. Проблемное обучение: основные вопросы теории. - М., 1975.

[2] Выготский, Л.С. Психическое развитие детей в процессе обучения. - М., 1935.

[3] Занков, Л.В. Развитие студентов в процессе обучения. - М.: АПН РСФСР, 1963.

[4] Кудрявцев, Т.В. Психология технического мышления. - М., 1971.

[5] Окон, В. Основы проблемного обучения. М.: Просвещение, 1968.

[6] Эльконин, Д.Б., Давыдов В.В. Возрастные возможности овладения знаниями. - М.: Просвещение, 1966

[7] Полат, Е.С., Бухаркина М.Ю., Моисеева М.В., Петров А.Е. Новые педагогические и информационные технологии в системе образования: Учебное пособие для студентов педагогических вузов и системы повышения квалификации педагогических кадров/ - М.: Академия, 2005. - 272 с.

[8] Хилков, Н.Л. Методика преподавания при изучении химических дисциплин [Электронный ресурс]/ Н.Л.Хилков. - Режим доступа: https://e-koncept.ru/2014/55176.htm

[9] Бейорагникалық химия. Тапсырмалар мен жаттығулар7 Окулық Астана, 2014, "Сарыарқа" баспасы.

[10] Тапалова, А.С. Жалпы және бейорганикалық химия праткикумы. Астана, 2009, «Сарыарқа» баспасы.

[11] Талызина, Н.Ф. Педагогическая психология: Учебник для студентов средних педагогических учебных заведений. - М.: Издательский центр "Академия", 1998.

[12] Гальперин, П.Я. Лекции по психологии / Под редакцией и с предисловием А.И.Подольского. М., 2002.

2015

[13] Зайцев, О.С. Химия. Лабораторный практикум и сборник заданий. Москва, Юрате.

[14] Решетова, 3.А., Сергеева Т.А. Построение курса общей химии на основе систематического раскрытия ее предмета с.11-58// Системно-структурный подход к построению курса химии. - М., 1983

[15] Райскина, Т.П. Зависимость методов обучения и видов познавательной деятельности учащихся от типа предметного построения. Дисс. Канд.пед.наук. - М., 1984.

[16] Дильманов, Б.М., А. С. Тапалова. Жалпы және бейорганикалық химия практикумы. - Астана, 2020.

[17] Тапалова, А.С. Бейорганикалық химия. Нұрсұлтан. «Фолиант» баспасы, 2020 жыл 2019. - 408 б

[18] Садуакасыкызы, К. Химияны оқыту әдістемесі. «Фолиант» баспасы, Нұрсұлтан

\section{References:}

[1] Mahmutov, M.I. Problemnoe obuchenie: osnovnye voprosy teorii. - M., 1975.

[2] Vygotskij, L.S. Psihicheskoe razvitie detej v processe obucheniya. - M.-L., 1935. 
[3] Zankov, L.V. Razvitie studentov v processe obucheniya. - M.: APN RSFSR, 1963.

[4] Kudryavcev, T.V. Psihologiya tekhnicheskogo myshleniya. - M., 1971.

[5] Okon, V. Osnovy problemnogo obucheniya. M.: Prosveshchenie, 1968.

[6] El'konin, D.B., Davydov V.V. Vozrastnye vozmozhnosti ovladeniya znaniyami. - M.: Prosveshchenie, 1966

[7] Polat, E.S., Buharkina M.YU., Moiseeva M.V., Petrov A.E. Novye pedagogicheskie i informacionnye tekhnologii $\mathrm{v}$ sisteme obrazovaniya: Uchebnoe posobie dlya studentov pedagogicheskih vuzov i sistemy povysheniya kvalifikacii pedagogicheskih kadrov/. - M.: Akademiya, 2005. - $272 \mathrm{~s}$.

[8] Hilkov, N.L. Metodika prepodavaniya pri izuchenii himicheskih disciplin [Elektronnyj resurs]/ N.L.Hilkov. - Rezhim dostupa: https://e-koncept.ru/2014/55176.htm baspasy.

[9] Bejoragnikalyq himiya. Tapsyrmalar men zhattygular. Оқиlyq Astana, 2014, "Saryarqa" baspasy.

[10] Tapalova, A.S. Zhalpy zhane bejorganikalyq himiya pratkikumy. Astana, 2009, «Saryarqa»

[11] Talyzina, N.F. Pedagogicheskaya psihologiya: Uchebnik dlya studentov srednih pedagogicheskih uchebnyh zavedenij. - M.: Izdatel'skij centr "Akademiya", 1998.

[12] Gal'perin, P.Ya. Lekcii po psihologii / Pod redakciej i s predisloviem A.I.Podol'skogo. M., 2002.

[13] Zajcev, O.S., himiya. Laboratornyj praktikum i sbornik zadanij. Moskva, YUrate. 2015

[14] Reshetova, Z.A., Sergeeva T.A. Postroenie kursa obshchej himii na osnove sistematicheskogo raskrytiya ee predmeta s.11-58// Sistemno-strukturnyj podhod k postroeniyu kursa himii M., 1983

[15] Rajskina, T.P., Zavisimost' metodov obucheniya i vidov poznavatel'noj deyatel'nosti uchashchihsya ot tipa predmetnogo postroeniya. Diss. Kand.ped.nauk. M., 1984. $2020 \mathrm{zh}$

[16] Dil'manov, B.M., A. S. Tapalova. ZHalpy zhane bejorganikalyq himiya praktikumy.Astana

[17] Tapalova, A.S., Bejorganikalyq himiya. Nursultan. «Foliant» baspasy, 2020 zhyl 2019 zh.

[18] Saduakasykyzy, K., Himiyany oqytu adistemesi. 408 b. - «Foliant» baspasy, Nursultan

\title{
ПРОБЛЕМЫ НЕОРГАНИЧЕСКОЙ ХИМИИ ОСНОВА ОБУЧЕНИЯ
}

\author{
Балыкбаева Г.Т., кандидат химических наук \\ Тапалова А.С., кандидат технических наук \\ Абызбекова Г.М., кандидат химических наук \\ Еспенбетова Ш.О., кандидат технических наук \\ Арынова К.Ш., кандидат педагогических наук
}

Кызылординский университет имени Коркыт Ата, г.Кызылорда, Казахстан

Аннотация. Разрешение проблемных ситуаций под руководством учителя заставляет учащихся сравнивать, обобщать, анализировать явления, а не только механически запоминать их. Процессы продвижения и разрешения проблемных ситуаций представляют собой непрерывную цепь, так как при продвижении проблемы ее решение начинается одновременно, что приводит к постановке новых проблем. То есть осуществляется противоречивый и непрерывный процесс активного познания новых научных понятий. Из опыта мы видим, что использование методов проблемного обучения на уроках способствует развитию познавательной активности, творческой самостоятельности учащихся, формированию их мировоззрения, интеллектуальному развитию и, как следствие, повышению качества полученных знаний. Сегодня необходимо при обучении будущих специалистов, помимо реализации существующих образовательных государственных стандартов по данной специальности, ориентироваться на развитие их творческих качеств, творческого мышления, что, в конечном счете, будет способствовать формированию высокопрофессиональных компетентных кадров.

Ключевые слова: проблемное обучение, саморазвитие, критическое мышление, самостоятельная работа, активное обучение, познавательная деятельность 


\title{
БЕЙОРГАНИКАЛЫҚ ХИМИЯ МӘСЕЛЕСІ, ОҚЫТУ НЕГІЗІ
}

\author{
Балықбаева Г.Т., химия ғылымдарының кандидаты \\ Тапалова А.С., техника ғылымдарының кандидаты \\ Абызбекова Г.М., химия ғылымдарының кандидаты \\ Еспенбетова Ш.О., техника ғылымдарының кандидаты \\ Арынова К.Ш., педагогика ғылымдарының кандидаты \\ Қоркыт Ата атындавы Қызылорда университеті, Қызылорда к., Қазақстан \\ Республикасы
}

\begin{abstract}
Аңдатпа. Мұғалімнің басшылығымен проблемалық жағдайларды шешу студенттерді құбылыстарды салыстыруға, жалпылауға, талдауға мәжбүр етеді, оларды механикалық түрде жаттап қана қоймайды. Проблемалық жағдайларды жылжыту және шешу процестері үздіксіз тізбек болып табылады, өйткені мәселені алға тарту кезінде оны шешу бір уақытта басталады, бұл жаңа проблемалардың туындауына әкеледі. Яғни, жаңа ғылыми ұғымдарды белсенді танудың қайшылықты және үздіксіз процесі жүзеге асырылады. Сабақтарда проблемалық оқыту әдістерін қолдану танымдық белсенділікті, оқушылардың шығармашылық тәуелсіздігін дамытуға, олардың дүниетанымын қалыптастыруға, зияткерлік дамуына және нәтижесінде алынған білім сапасын арттыруға ықпал ететінін тәжірибеден көреміз. Бүгінгі таңда болашақ мамандарды оқыту кезінде осы мамандық бойынша қолданыстағы білім берудің мемлекеттік стандарттарын іске асырумен қатар, олардың шығармашылық қасиеттерін, шығармашылық ойлауын дамытуға бағдарлану қажет, бұл, сайып келгенде, жоғары білікті білікті кадрларды қалыптастыруға ықпал етеді.

Кілт сөздер: проблемальқ оқыту, өзін-өзі дамыту, сыни тұрвылдан ойлау, өзіндік жұмысс, белсенді оқу, танымдық белсенділік
\end{abstract}




\title{
СИНТЕЗ И ХАРАКТЕРИСТИКА НОВЫХ ДИФИЛЬНЫХ СОПОЛИМЕРОВ НА ОСНОВЕ АКРИЛАТОВ
}

\author{
Уркимбаева П.И., кандидат химических наук \\ urkimbayeva.perizat@gmail.com, https://orcid.org/0000-0001-7775-0238
}

Казахский национальный университет им. Аль-Фараби, г.Алматы, Республика Казахстан

\begin{abstract}
Аннотация. Радикальной сополимеризацией 2-гидроксиэтилакрилата (ГЭА) c метилакрилатом (МА) осуществлен синтез новых термочувствительных водорастворимых полимеров, изучены основные закономерности их образования. Методом ЯМР-спектроскопии определен состав сополимеров, рассчитаны константы сополимеризации. Установлено, что водные растворы сополимеров характеризуются нижней критической температурой растворения (НКТР), значения которой зависит от содержания МА в составе макроцепей.

2-гидроксиэтилакрилат - очень полезное сырье для химического синтеза, поскольку оно легко подвергается комбинированным реакциям с широким спектром органических и неорганических соединений, он является необходимым сырьем во многих случаях жизни человека. Поскольку 2-гидроксиэтилакрилат (2-ГЭА) используется в производстве твердых полимеров, дисперсий и растворов полимеров, качественные показатели в этой области также подробно описаны в статье. Существуют различные свидетельства того, что сырье 2гидроксиэтилакрилат широко используется в промышленности в качестве покрытия из-за его высоких связывающих, пленкообразующих, адгезионных и герметизирующих свойств.

Методами вискозиметрии и турбидиметрии изучено комплексообразование водорастворимых сополимеров ГЭА-МА с полиакриловой кислотой (ПАК) в водных растворах. Определены критические величины $\mathrm{pH}$ комплексообразования, показано с увеличением в составе сополимеров гидрофобных звеньев МА эффективность комплексообразования в системе неионный полимер-ПАК повышается.
\end{abstract}

Ключевые слова: радикальная сополимеризация, 2-гидроксиэтилакрилат, метилакрилат, дифильные полимеры; термочувствительные водорастворимые полимеры, НКТР, ЯМРспектроскопия; вискозиметрия; турбидиметрия, комплексообразование

Введение. В настоящее время среди термочувствительных полимеров наибольший интерес в научном и практическом отношении представляют полимеры, водные растворы которых обладают нижней критической температурой растворения (НКТР). Макромолекулы таких полимеров содержат в своей структуре функциональные гидрофильные группы, обеспечивающие растворимость в воде, а также гидрофобные фрагменты. С повышением температуры усиливаются гидрофобные взаимодействия и в системе термочувствительный полимер-вода реализуется возможность возникновения различного рода критических явлений: для линейных макромолекул это выражается в расслоении на две фазы - обогащенную и обедненную полимером, для полимерных сеток - в термоиндуцируемом коллапсе, то есть резком сжатии объема геля в десятки и сотни раз при достижении определенной температуры. Обычно такие полимеры получают гомополимеризацией водорастворимых мономеров, сочетающих в своей структуре одновременно гидрофильные и гидрофобные фрагменты. Многие из них уже в настоящее время начинают эффективно использоваться в биомедицине для обеспечения контролируемой доставки лекарственных веществ, в тканевой инженерии, пищевой индустрии, электронике и т.д. /1/. Однако круг доступных термочувствительных полимеров весьма ограничен, причем основная часть публикаций посвящена поли-N- 
изопропилакриламиду /2-3/, в значительно меньшей степени исследованы полимеры поли$\mathrm{N}$-винилкапролактама /4/ и поли-винилбутилового эфира /5/. Ранее нами был разработан другой подход для синтеза новых термочувствительных полимеров с использованием сополимеризации мономеров с существенным различием в гидрофильно-гидрофобном балансе химической структуры, что позволяет регулировать соотношение гидрофильных и гидрофобных звеньев в макроцепях и, соответственно, температуру фазовых переходов в системе полимер-вода в широких пределах /6/.

В настоящей работе для получения термочувствительных полимеров в качестве гидрофильного мономера был использован 2-гидроксиэтилакрилат (ГЭА), в качестве гидрофобного - метилакрилат (МА).

Материалы и методы исследования. Мономеры 2-гидроксиэтилакрилат (ГЭА) и метилакрилат (MA) производства фирмы «Aldrich Chemikal Co., США» очищали перегонкой в токе аргона в вакууме.

Полиакриловую кислоту молекулярной массой 250000 («Aldrich Chemikal Co., США») использовали без дополнительной очистки.

Сополимеризацию ГЭА с МА проводили в дилатометрах, реакционную смесь для удаления кислорода предварительно продували аргоном в течение 40 мин. Сополимеры очищали путем многократного переосаждения из спирта в диэтиловый эфир. В качестве инициатора использовали динитрил азо-бис-изомасленной кислоты (ДАК). 300 (Германия).

Спектры ЯMP( $\left.\mathrm{H}^{1}\right)$ записывали с использованием ЯMP-спектрометра Bruker ARX-

Турбидиметрические измерения проводили при длине волны 400 нм с использованием УФ-спектрофотометра Shimadzu UV-2401 (Япония).

pH растворов определяли на приборе «Ion Meter 3345» (Jenway LTD., Великобритания) и регулировали добавлением 0.1 н растворов $\mathrm{HCl}$ или $\mathrm{NaOH}$.

Относительную вязкость растворов измеряли в капиллярных вискозиметрах типа Уббелоде при $298 \mathrm{~K} \pm 0,05$.

Результаты и обсуждение. На рис. 1 представлены данные по кинетике радикальной сополимеризации ГЭА и МА, полученные методом дилатометрии. Видно, что скорость процесса снижается с увеличением концентрации МА в исходной мономерной смеси (ИМС), что свидетельствует о более высокой активности ГЭА в процессе сополимеризации по сравнению с МА.

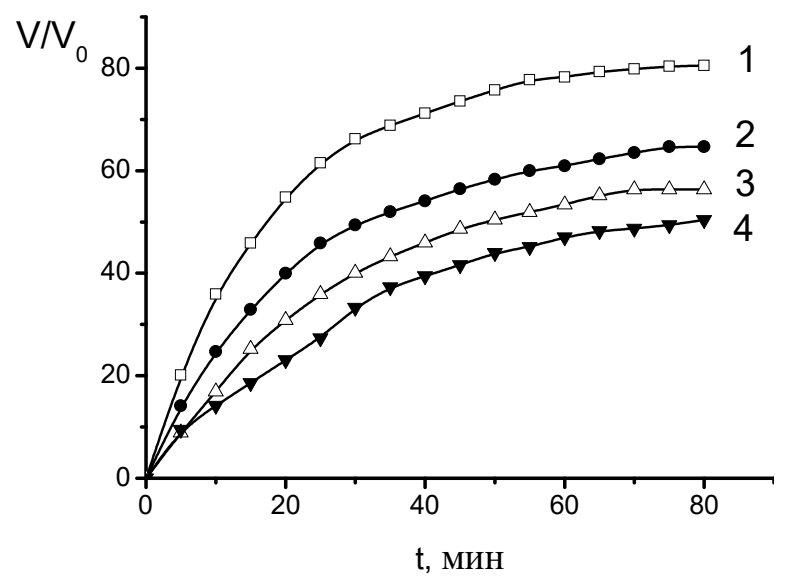

Рисунок 1 - Кинетика гомополимеризации ГЭА (1) и сополимеризации ГЭА с МА (2-4) Состав ИМС [ГЭА]:[МА] = 90,0:10,0 (2), 80,0:20,0 (3), 70,0:30,0 (4). $\mathrm{T}=60^{\circ} \mathrm{C}$. 
Для сополимеров (СПЛ), выделенных на начальных стадиях конверсии, методом ЯМР $\left(\mathrm{H}^{1}\right)$-спектроскопии был определен состав. Как видно из данных таблицы, составы СПЛ обогащены звеньями ГЭА по сравнению содержанием его в ИМС. Расчет констант сополимеризации приводит к следующим значениям $\mathrm{r}_{1}($ ГЭА $)=1,1$ и $\mathrm{r}_{2}(\mathrm{MA})=0,8$, что указывает на более высокую реакционную способность ГЭА по сравнению с МА. Для полученных СПЛ ГЭА-МА различных составов методом гель-проникающей хроматографии исследованы молекулярно-массовые характеристики. Показано, что СПЛ обладают достаточно высокой молекулярной массой (порядка $\sim 10^{5}$ ) и характеризуются низким значением коэффициента полидисперсности, что свидетельствует о высоком вкладе рекомбинации в механизм бимолекулярного обрыва растущих макрорадикалов в процессе сополимеризации.

Таблица 1 - Состав сополимеров ГЭА-МА в зависимости от состава исходной мономерной смеси

\begin{tabular}{|c|c|}
\hline $\begin{array}{c}\text { Состав ИМС, } \\
\text { моль.\% [ГЭА]:[MА] }\end{array}$ & $\begin{array}{c}\text { Состав сополимеров, } \\
\text { моль.\% [ГЭА]:[MА] }\end{array}$ \\
\hline $70,0: 30,0$ & $74,2: 25,8$ \\
\hline $80,0: 20,0$ & $82,1: 17,9$ \\
\hline $90,0: 10,0$ & $90,8: 9,2$ \\
\hline
\end{tabular}

На рис. 2 приведены результаты турбидиметрического исследования влияния температуры на растворимость СПЛ ГЭА-МА в воде. Видно, что с увеличением температуры наблюдается достаточно резкое повышение мутности раствора, свидетельствующее о фазовом расслоении, обусловленным ухудшением термодинамического качества растворителя.

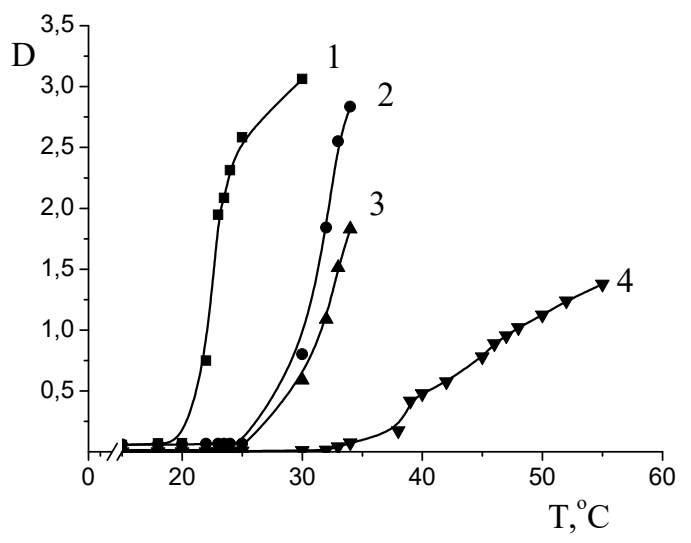

Рисунок 2 - Зависимость оптической плотности растворов сополимера ГЭА-МА от температуры;

[ГЭА]:[МА] $=74,2: 25,8$ мол.\%; 1 (1); 0,8 (2); 0,5 (3); 0,2 (4) \% раствор.

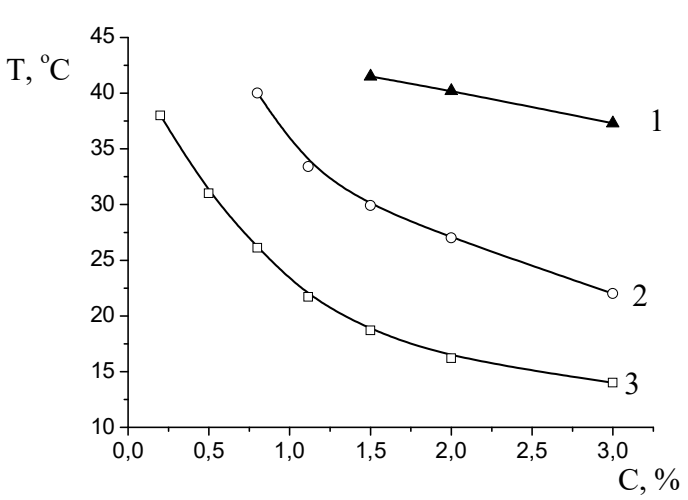

Рисунок 3 - Фазовая диаграмма растворимости сополимеров ГЭА-МА

[ГЭА]:[MА] $=90,8: 9,2(3), 82,1: 17,9(2), 74,2: 25,8$

(1) мол.\%

На основе полученных данных были построены фазовые диаграммы полимер-вода (рис.3), из которых следует, что водные растворы СПЛ ГЭА-МА характеризуются наличием нижней критической температурой растворения (НКТР). Значение НКТР 
зависит от состава СПЛ, при этом система с большим содержанием гидрофобного компонента (MA) претерпевает фазовое расслоение при более низких температурах. Необходимо отметить, что для водных растворов гомополимеров ГЭА с повышением температуры фазовое расслоение не наблюдается, а поли-МА в воде практически не растворим. Следовательно, наличие НКТР для СПЛ ГЭА-МА обусловлено определенным сочетанием гидрофильных и гидрофобных звеньев в структуре сополимера /1,6,7/. Гидрофильные звенья ГЭА обеспечивают растворимость СПЛ в воде, а звенья МА участвуют в гидрофобных взаимодействиях, которые усиливаются с повышением температуры и способствуют фазовому расслоению водного раствора СПЛ.

Для новых СПЛ ГЭА-МА изучены интерполимерные взаимодействия с линейной полиакриловой кислотой (ПАК). Как видно из данных, представленных на рис. 4, титрование водного раствора ПАК раствором СПЛ ГЭА-МА $(\mathrm{pH}=2,7)$ сопровождается экстремальным повышением мутности и снижением приведенной вязкости раствора, что свидетельствует об образовании интерполимерных комплексов (ИПК), стабилизированных водородными связями, имеющих, как известно более компактную структуру по сравнению с конформацией исходных полимерных компонентов /7/. Положение экстремумов указывает на нестехиометричность состава формируемых поликомплексов, содержащих избыток СПЛ, что, видимо, связано с эффектом нарушения комплементарности макромолекул неионного полимера.
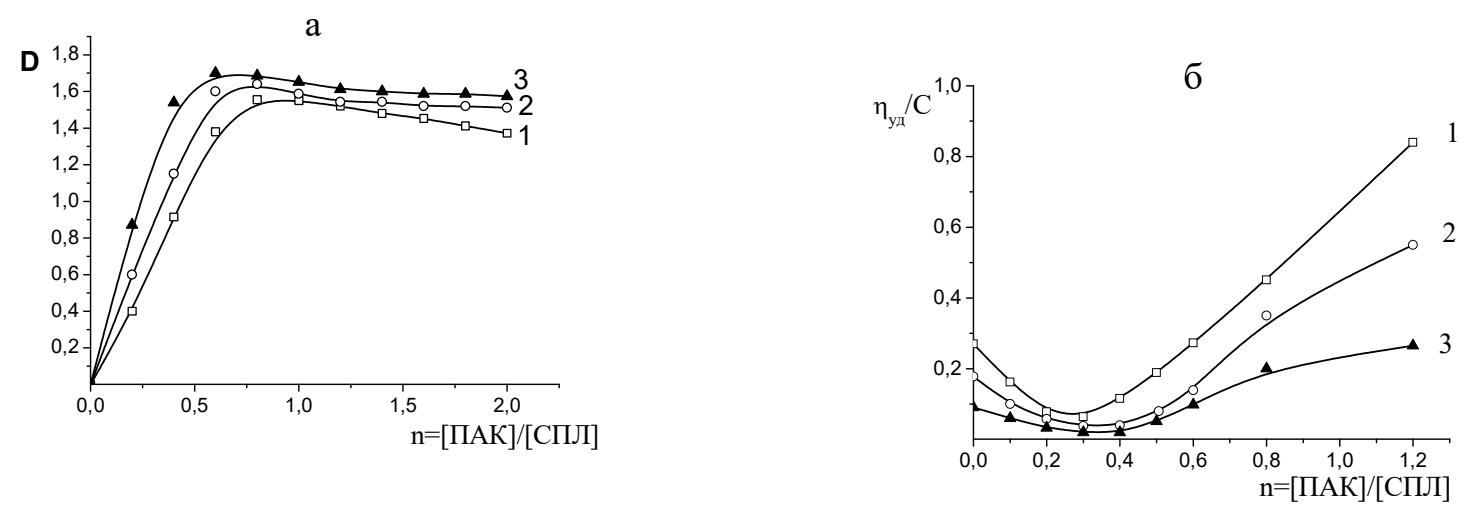

\section{Рисунок 4 - Турбидиметрическое (а) и вискозиметрическое (б) титрование растворов СПЛ ГЭА-МА раствором ПАК}

[ГЭА]:[МА ] 74,2:25,8(1), 82,1:17,9 (2), 90,8:9,2(3) мол.\%; [ПАК]=0,01M, $\mathrm{M}_{\mathrm{w}}($ ПАК)=2,5·10

Известно, что образование ИПК в водных растворах наблюдается ниже определенных критических значений $\mathrm{pH} / 7 /$. При этом величина критической $\mathrm{pH}$ комплексообразования $\left(\mathrm{pH}_{\text {крит }}\right)$ может рассматриваться в качестве количественного критерия способности системы неионогенный полимер - поликарбоновая кислота к образованию поликомплексов /8/. В данной работе методом турбидиметрии была определена $\mathrm{pH}_{\text {крит }}$ для сополимеров различного состава. Из рисунка 5 видно, что при

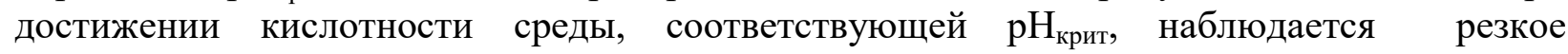
помутнение в системе полимер-вода, что свидетельствует о межфазном расслоении, обусловленным формированием ИПК. При этом с повышением содержания звеньев МА в структуре сополимера, критические значения $\mathrm{pH}$ комплексообразования в системе СПЛ ГЭА-МА - ПАК сдвигается в область больших значений. Это указывает на то, что увеличение содержания гидрофобного компонента в составе СПЛ, несмотря на нарушение комплементарности, в целом способствует повышению их комплексообразующей 
способности в системе неионный полимер-полиакриловая кислота. Эти результаты хорошо согласуются с полученными ранее данными о существенном вкладе гидрофобных взаимодействий в дополнительную стабилизацию ИПК /8-10/.

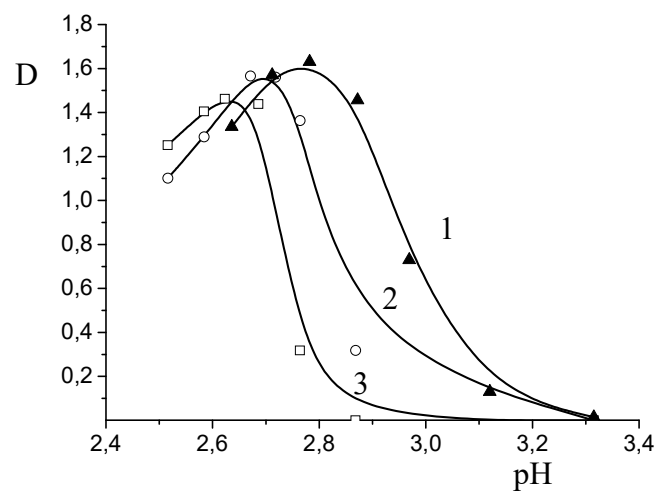

\section{Рисунок 5 - Зависимость оптической плотности смесей растворов сополимеров ГЭА-МА с ПАК от рН среды; [ГЭА]:[МА] $=74,2: 25,8(1), 82,1: 17,9(2), 90,8: 9,2$ (3) мол.\%; $[$ ГЭА-МА $]=[\Pi А К]=0,01$ моль $/ л, \mathrm{M}_{\mathrm{W}}($ ПАК $)=2,5 * 10^{5}$;}

Выводы. Таким образом, методом радикальной сополимеризации получены новые термочувствительные водорастворимые сополимеры ГЭА-МА. Определены составы сополимеров и их молекулярно-массовые характеристики. Установлено, что для водных растворов линейных сополимеров характерно наличие НКТР, значение которой удается регулировать варьированием гидрофильно-гидрофобного баланса макроцепей сополимеров. Методами турбодиметрического и вискозиметрического титрования изучено комплексообразование линейных сополимеров ГЭА-МА с ПАК.

\section{Литература:}

[1] Галаев, И.Ю. «Умные» полимеры в биотехнологии и медицине // Успехи химии. 1995. - Т. 64, №5. - С. $505-524$.

[2] Рахметуллаева, Р.К., Ахметкалиева Г.Т., Кажиева А.К., Нуркеева 3.С., Мун Г.А. Новые термочувствительные растворимые и сшитые полимеры на основе винилового эфира этиленгликоля и N-изопропилакриламида// Наука и техника Казахстана. - 2002. - №1 . - С. 118-122

[3] Kenessova, Z.A., Mun G.A., Bakytzhanuly B., Rakhmetullayeva R.K., Yessirkepova A.N., Samenova N.O. and Urkimbayeva P.I. Radiation-Chemical Synthesis of Crosslinked Films Based on NVinylcaprolactam Copolymers // Bulletin of Experimental Biology and Medicine. - 2019. - Vol. 167. No. 5. - P. 685-686.

[4] Dilmukhambetov, E.E., Shatabayeva, E.O., Urkimbayeva, P.I., Zhetpisbayev, S.R., Kaldybekov, D.B. The effect of graft copolymers based on polyethylene glycol and N-Vinylcaprolactam on physicochemical properties of cement pastes //International Multidisciplinary Scientific GeoConference Surveying Geology and Mining Ecology Management, SGEM, 2(6). - 2015. - P. 335342 ;

[5] Мун, Г.А., Уркимбаева П.И. Сополимер N-винилпирролидона и винилбутилового эфира //Патент на полезную модель МЮ РК №1515 от 16.06.2016.

[6] Nam, I.K., Mun G.A., Urkimbaeva P.I., Nurkeeva Z.S. $\gamma$-Rays-induced synthesis of hydrogels of vinyl ethers with stimuli-sensitive behavior // Rad. Phys. Chem.. - 2003. - V.66. - P.281 - 287.

[7] Tsuchida, T., Abe K. Interactions between macromolecules in solution and intermacromolecular complexes // Adv. Polim. Sci. 1982. V.45 P.1 - 119. 
[8] Нуркееза, 3.С., Мун Г.А., Хуторянский В.В. Интерполимерные комплексы полимеров виниловых эфиров гликолей и композиционные материалы на их основе // Высокомол. Соед.-2001. - Т.43.Б. №5. - С. 925 - 935

[9] Toktabayeva, A.K., Adilet Zh. Alikulov, Raikhan K. Rakhmetullayeva, Grigoriy A. Mun, Ayauzhan M. Tumabayeva, Perizat I. Urkimbayeva, Valentina K. Yu, Tulegen M. Seilkhanov. Synthesis and study of physico-chemical characteristics of novel cationic (co)polymers based on $\mathrm{N}$ isopropylacrylamide and $\mathrm{N}$-(2-vinyloxyethyl)-N-(2-cyanoethyl) amine. Journal of Chemical Technology and Metallurgy, 54, 3, 2019, 467-474.

[10] Шайхутдинов, Е.М. Влияние гидрофобных взаимодействий на комплексообразующие свойства сополимеров простых виниловых эфиров // Высокомол. Соед. 2001. - Т.43.Б. №10. - С. 1867 - 1872.

\section{References:}

[1] Galaev, I.Yu. «Umnye» polimery v biotekhnologii i medicine // Uspekhi himii. - 1995. - T. 64, № 5. - S. $505-524$.

[2] Nam, I.K., Mun G.A., Urkimbaeva P.I., Nurkeeva Z.S. $\square$-Rays-induced synthesis of hydrogels of vinyl ethers with stimuli-sensitive behavior // Rad. Phys. Chem. - 2003. - V.66. - P.281 287.

[3] Tsuchida, T., Abe K. Interactions between macromolecules in solution and intermacromolecular complexes // Adv. Polim. Sci. 1982. V.45 P.1 - 119.

[4] Nurkeeza, Z.S., Mun G.A., Hutoryanskij V.V. Interpolimernye kompleksy polimerov vinilovyh efirov glikolej i kompozicionnye materialy na ih osnove // Vysokomol. Soed. - 2001. - T.43.B. №5. -S.925 - 935

[5] Mun, G.A., Nurkeeza Z.S., Hutoryanskij V.V., Kan VA., Sergaziev A.D.,

[6] Shajhutdinov, E.M. Vliyanie gidrofobnyh vzaimodejstvij na kompleksoobrazuyushchie svojstva sopolimerov prostyh vinilovyh efirov // Vysokomol. Soed. - 2001. - T.43.B. №10. - S. 1867 1872.

[7] Tsuchida, T., Abe K. Interactions between macromolecules in solution and intermacromolecular complexes // Adv. Polim. Sci. 1982. V.45 P.1 - 119.

[8] Nurkeeza, Z.S., Mun G.A., Hutoryanskij V.V. Interpolimernye kompleksy polimerov vinilovyh efirov glikolej i kompozicionnye materialy na ih osnove // Vysokomol. Soed.-2001. - T.43.B. №5. - S. $925-935$

[9] Toktabayeva, A.K., Adilet Zh. Alikulov, Raikhan K. Rakhmetullayeva, Grigoriy A. Mun, Ayauzhan M. Tumabayeva, Perizat I. Urkimbayeva, Valentina K. Yu, Tulegen M. Seilkhanov. Synthesis and study of physico-chemical characteristics of novel cationic (co)polymers based on $\mathrm{N}$ isopropylacrylamide and $\mathrm{N}$-(2-vinyloxyethyl)-N-(2-cyanoethyl) amine. Journal of Chemical Technology and Metallurgy, 54, 3, 2019, 467-474.

[10] Shajhutdinov, E.M. Vliyanie gidrofobnyh vzaimodejstvij na kompleksoobrazuyushchie svojstva sopolimerov prostyh vinilovyh efirov // Vysokomol. Soed. - 2001. - T.43.B. №10. - S. 1867 1872.

\section{АКРИЛАТТАР НЕГІЗІНДЕГІ ЖАНА ДИФИЛЬДІ СОПОЛИМЕРЛЕРДІН СИНТЕЗІ ЖӘНЕ СИПАТТАМАЛАРЫ}

Үркімбаева П.И., химия ғылымдарының кандидаты

\section{Әл-Фараби атындавы Қазақ Ұлттық университеті, г. Алматы, Казахстан Республикасы}

Андатпа. 2-гидроксиэтилакрилат (ГЭА) пен метилакрилатты (МА) радикалды сополимерлеу арқылы жаңа термосезімтал суда еритін полимерлер синтезделген, олардың түзілуінің негізгі заңдылықтары анықталған. Бастапқы мономерлік қоспада МА мөлшерінің артуымен сополимерлеу жылдамдығы төмендейтіндігі анықталған. Сополимерлеу константалары 
есептелген. Сополимерлердің сулы ерітінділеріне төменгі критикалық еру температурасы (ТКЕТ) тән және оның мәні сополимер құрамында МА мөлшерінің артуымен төмендейді.

2-гидроксиэтилакрилат химиялық синтез үшін өте пайдалы шикізат болып табылады, өйткені ол органикалық және бейорганикалық қосылыстардың кең спектрімен аралас реакцияларға оңай түседі, ол адам өмірінің көптеген жағдайларында қажетті шикізат болып табылады. 2-гидроксиэтилакрилат (2-ГЭА) қатты полимерлер, дисперсиялар және полимер ерітінділері өндірісінде қолданылатындықтан, осы саладағы сапа көрсеткіштері де мақалада егжей-тегжейлі сипатталған. Шикізат 2-гидроксиэтилакрилат жоғары байланыстырушы, қабық түзетін, адгезиялық және тығыздағыш қасиеттеріне байланысты жабын ретінде өнеркәсіпте кеңінен қолданылатыны туралы әртүрлі деректер бар.

Тұтқырлық және УК-спектросокпия әдістерімен ГЭА-МА сополимерлерінің полиакрил қышқылымен (ПАҚ) сулы ортада комплекске түсуі зерттелген. Комплекске түсудің дағдарыстық pH мәні анықталған. Ионсыз полимер-полиакрил қышқылы жүйесіндегі комплекске түсу тиімділігі сополимер құрамында МА буындарырын артуымен үдейтіндігі тағайындалған.

Кілт сөздер: радикалды сополимерлену, 2-гидроксиэтилакрилат, метилакрилат, амфифилді полимерлер; термосезімтал, суда еритін полимерлер, LCST, ЯMP спектроскопиясы; вискозиметрия; турбидиметрия, комплекстену

\title{
SYNTHESIS AND CHARACTERIZATION OF ACRYLATE-BASED DIPHILIC COPOLYMERS
}

\author{
Urkimbaeva P.I., candidate of chemical sciences \\ Kazakh National University named of Al-Farabi, Almat city, Republic of Kazakhstan
}

\begin{abstract}
Annotation. Novel water-soluble amphiphilic copolymers have been synthesized by free radical copolymerization of 2-hydroxyethyl acrylate (HEA) with methyl acrylate (MA). It was shown that an increase in MA content in feed mixture results in lower rate of polymerization. Constants of copolymerization were calculated from data on composition of copolymers. In water these copolymers exhibit lower critical solution temperature, which depends on the content of hydrophobic methyl acrylate units.

Novel water-soluble amphiphilic copolymers have been synthesized by free radical copolymerization of 2-hydroxyethyl acrylate (HEA) with methyl acrylate (MA). It was shown that an increase in MA content in feed mixture results in lower rate of polymerization. Constants of copolymerization were calculated from data on composition of copolymers. In water these copolymers exhibit lower critical solution temperature, which depends on the content of hydrophobic methyl acrylate units. The interaction between these copolymers and poly(acrylic acid) in aqueous solutions results in formation of interpolymer complexes stabilized by hydrogen bonds and hydrophobic interactions. Critical $\mathrm{pH}$ of complexation was determined for different conditions.

The interaction between these copolymers and poly(acrylic acid) in aqueous solutions results in formation of interpolymer complexes stabilized by hydrogen bonds and hydrophobic interactions. Critical $\mathrm{pH}$ of complexation was determined for different conditions.
\end{abstract}

Keywords: radical copolymerization, 2-hydroxyethylacrylate, methylacrylate, diphilic polymers; thermosensitive water-soluble polymers, NCTR, NMR spectroscopy; viscometry; turbidimetry, complexation 
Биология ғылымдары

Биологические науки

Biological sciences

МРНТИ 612.11+612.15+612.398

https://doi.org/10.52081/bkaku.2021.v58.i3.074

\title{
FUNCTIONAL CHANGES IN THE CONCENTRATION OF TOTAL PROTEIN IN RESIDENTS OF THE KYZYLORDA REGION
}

\author{
Ibadullayeva S.Zh., doctor of biological sciences \\ salt_i@mail.ru, https://orcid.org/0000-0003-3270-8364 \\ Kyzylorda University named after Korkyt Ata, Kyzylorda city, Republic of Kazakhstan
}

\begin{abstract}
Annotation. Taking into account the ever-increasing role of prevention in modern conditions, a comprehensive understanding of the morph physiological and chronobiological organization of human life is necessary, which is most optimal for living in specific environmental conditions, in other words, the conditions for the formation of population health and its pathological deviations due to factors that exist in the very organism, as well as acting on it from the outside. The process of cleansing the body of denatured, aged proteins occurs in many organs, primarily in the liver. Degradation processes in a cell can both recognize proteins to be degraded and begin degradation, but these processes must be selective, since there is significant heterogeneity in the rates of degradation of various proteins in one cell. Proteases are usually required for the implementation of catabolic processes, and apparently, lysosomal and extralysosomal proteases are involved in the catabolism of cellular proteins. The concentration of total protein and its fractions in the blood plasma in people living in various districts of the Kyzylorda region does not depend on the severity of the action of extreme factors characteristic of the Aral Sea zone.
\end{abstract}

Key words: total protein, protein, albumin, globulin, region, environment, resident

Intoduction. The body's adaptive reactions can be subdivided into two interconnected classes, namely: into urgent adaptation reactions that are realized "from the spot", for the implementation of which there are ready-made, fully formed mechanisms in the body, and into gradually forming long-term adaptation reactions, for the implementation of which in the body there are only genetically determined prerequisites that ensure the gradual formation of such mechanisms with repeated or sufficiently long-term action of environmental factors, i.e. with repeated or prolonged use of available mechanisms for urgent adaptation. At the same time, urgent and long-term adaptation are two stages of the same process, which ensures a reliable adaptation of the organism to the requirements of the environment [1].

The content of blood plasma proteins in humans, the amount of which under conditions of a relative norm reaches 100 [95], is $65-85 \mathrm{~g} / \mathrm{L}$. These include albumin, globulins, and fibrinogen. Carrying out numerous functions, blood plasma proteins determine the value of oncotic pressure, buffering properties of blood, plasma viscosity, the ability of blood to carry out a transport function and immune defense. They are a reserve for the construction of tissue proteins and provide creative connections. They perform the function of carriers of biologically active substances - hormones, vitamins, pigments, metabolites, microelements, and having buffering properties, they take part in the regulation of acid-base balance $(\mathrm{pH})$ of the blood, being a part of lipoproteins, participate in the transport of lipids and lipoids. Blood fibrinogen is involved in blood clotting; $\gamma$-globulins perform a protective function, are a factor of specific and nonspecific immunity, and albumin can adsorb toxins on its surface [2].

Protein metabolism begins in the digestive tract, where protease enzymes such as pepsin, trypsin and chymotrypsin break mainly peptide bonds within the protein molecule. At the same time, peptidases, which include carboxypolypeptidases, aminopolypeptidases, and dipeptidases, hydrolyze polypeptides to free amino acids [3]. The obtained amino acids are used for the 
synthesis of specific body proteins, the synthesis of which (100\% fibrinogen, $95 \%$ albumin, $85 \%$ globulins) is mainly carried out in the liver. The synthesized plasma proteins constantly circulate in the blood - tissue - lymph system [4]. Over time, proteins undergo oxidative stress and various denaturation transformations, conformational changes in the macromolecule, leading to a reversible or irreversible loss of its ability to perform a certain biological function $[5,6]$ and leave the bloodstream. The process of protein denaturation also takes place under the action of various chemical and physical factors, such as $\mathrm{pH}$ shifts, heat and cold, high pressure, mechanical treatment, the action of metal ions, pesticides, alcohols, detergents, and some enzymes [7,8]. For example, it was shown that in shock caused by the action of elevated temperature, oxidation of thiol groups in proteins occurs, leading to their destabilization [9].

It is known that when the body is exposed to extreme factors of various modality, oxidative stress develops in the body, accompanied by an increased formation of superoxide radicals, hydroxyl radicals, and molecular hydrogen peroxide [10]. These compounds play an important role in living systems because easily interact with biological compounds, modify them and, thereby, change the course of physiological processes. They are called "reactive oxygen species".

The impact of reactive oxygen species on proteins leads to their oxidative modification, accompanied by conformational rearrangements and denaturation, which leads to a decrease in the antioxidant potential of cells and tissues. In this case, free radical oxidation can be considered as a possible cause of functional changes in membrane-bound enzymes [11].

Protein oxidation processes in cells have a general biological role. Oxidizing enzymes responsible for the metabolism of toxicants catalyze the inactivation of a number of enzymes. At the same time, oxidation caused by the action of oxidase systems with mixed action makes proteins more sensitive to proteolysis and, therefore, are the triggering mechanisms of protein degradation. It has been shown that the oxidation of key metabolic enzymes is associated with the bactericidal effect of neutrophils. There is also evidence that the degradation of endogenous proteins increases following the action of agents inducing the activity of mixed type oxidases [12]. Recent data indicate that various intracellular proteolytic enzymes or systems can recognize and preferentially degrade oxidatively damaged proteins to amino acids. It has been established that proteolytic systems (including proteinases, proteases, and peptidases) can function by preventing the formation or accumulation of protein aggregates damaged by oxidants. That is, many proteolytic enzymes, along with DNA repair systems, can act as systems of cellular secondary antioxidant defense [13,14,15].

Material and research methods. To solve the set tasks, a survey was carried out, which included the analysis of total protein in the blood of residents of different regions of the Aral Sea region. For clarity, we present a map of the region with the selection of the survey regions (Figure 1).

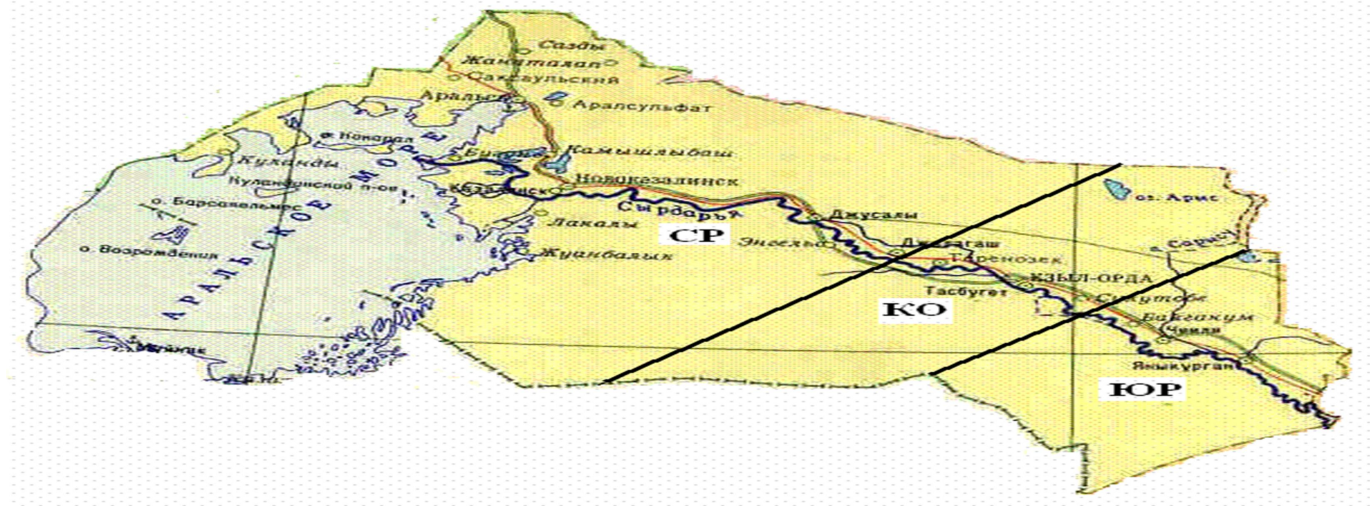

$\mathrm{CP}$ - northern regions; KO - Kyzylorda; ЮP - southern regions

Figure 1 - Map of the Kyzylorda region 
As can be seen from the results of the research, in the surveyed contingent of residents of the Aral Sea region, the dependence of the anthropometric parameters of men and, to a greater extent, women, on the area of the Kyzylorda region they live in, established earlier, remains . Thus, southerner women were higher than northerners by $4.3 \%(\mathrm{p}<0.05)$ and heavier by $12.1 \%$ $(\mathrm{p}<0.05)$, and men were $1.7 \%$ higher and heavier by $6.1 \%$. In a series of studies, the content of total protein and its fractions was monitored. After centrifugation of the blood (10 min at 1000 $\mathrm{g}$ ), the total protein concentration in the obtained blood plasma was determined by the biuret technique. To establish the ratio of albumin and globulins, paper electrophoresis was used. The data obtained were processed statistically using the Microsoft Excel computer program.

Results and discussion. Tables 1-3 summarize the data on the concentration of total protein, albumin and globulins in blood plasma in men and women from different regions of the Aral Sea region. As can be seen from these tables, we did not record significant differences in the content of total protein and its fractions in blood plasma in men and women living in different regions of the Kyzylorda region. We can only note higher rates for those living in regions remote from the Aral Sea (Table 1,2,3).

Table 1 - Concentration of total protein $(\mathrm{g} / \mathrm{L})$ in blood plasma in residents of different regions of the Aral Sea region

\begin{tabular}{|l|l|l|l|}
\hline \multirow{2}{*}{ Gender } & Region & KO & NR \\
\cline { 2 - 4 } & SR & $72,12 \pm 3,91$ & $70,89 \pm 4,01$ \\
\hline Men & $73,17 \pm 4,12$ & $71,31 \pm 4,04$ & $70,40 \pm 3,82$ \\
\hline Women & $72,20 \pm 3,83$ & \multicolumn{2}{l|}{} \\
\hline \multicolumn{2}{|l|}{ Note: SR - southern regions, KZ - Kyzylorda, NR - northern regions } \\
\hline
\end{tabular}

Table 2 - The concentration of albumin $(\mathrm{g} / \mathrm{L})$ in blood plasma in residents of different regions of the Aral Sea region

\begin{tabular}{|l|l|l|l|}
\hline \multirow{2}{*}{ Gender } & Region & NR \\
\cline { 2 - 4 } & SR & KO & $37.86 \pm 1.93$ \\
\hline Men & $39.20 \pm 2.51$ & $38.85 \pm 2.02$ & $35.90 \pm 1.51$ \\
\hline Women & $38.33 \pm 1.91$ & $37.70 \pm 1.60$ & \\
\hline Note: SR - southern regions, KZ - Kyzylorda, NR - northern regions \\
\hline
\end{tabular}

Table 3 - Concentration of globulins $(\mathrm{g} / \mathrm{L}$ ) in blood plasma in residents of different regions of the Aral Sea region

\begin{tabular}{|l|l|l|l|}
\hline \multirow{2}{*}{ Gender } & Region & KO & NR \\
\cline { 2 - 4 } & SR & $35.17 \pm 1.30$ & $34.62 \pm 1.83$ \\
\hline Men & $37.14 \pm 1.70$ & $34.61 \pm 1.71$ & $34.50 \pm 1.81$ \\
\hline Women & $35.31 \pm 1.92$ & 34 . northern regions \\
\hline \multicolumn{4}{|l}{ Note: SR - southern regions, KZ - Kyzylorda, NR - non } \\
\hline
\end{tabular}

The research results showed that there is a certain dependence of the total protein concentration in the blood plasma of residents of the Kyzylorda region on their place of residence: higher values for southerners and lower for Kyzylorda and northerners. Comparative 
analysis of the total protein content in blood plasma showed insignificant changes in this indicator.

Thus, residents from the southern districts of the Kyzylorda region in 2017 had a maximum total protein content in blood plasma and amounted to $72.32 \pm 3.11 \mathrm{~g} / \mathrm{L}$, then by 2019 their content decreased to $71.90 \pm 3.29 \mathrm{~g} / \mathrm{L}$. , with a subsequent increase by 2020 to values equal to $72.18 \pm$ $3.11 \mathrm{~g} / \mathrm{L}$.

The concentration of total protein in the blood plasma of residents of Kyzylorda changed in the same way: the maximum content was $71.89 \pm 3.18 \mathrm{~g} / \mathrm{L}$ in 2017 , and the minimum - in $2019-70.72 \pm 3.18) \mathrm{g} / \mathrm{L}$, and by 2020 reached values equal to $71.52 \pm 3.30 \mathrm{~g} / \mathrm{L}$.

In 2017, when we started the survey, in those living in the northern districts of the Kyzylorda region, the total protein content in the blood plasma was $70.51 \pm 3.02 \mathrm{~g} / \mathrm{L}$, decreasing to 68.03 $\pm 2.88 \mathrm{~g} / \mathrm{L}$ in 2019 from subsequent increase by 2020 to the maximum values equal to $70.02 \pm$ $3.05 \mathrm{~g} / \mathrm{L}$.Our data indicate that, in parallel with the change in the total protein content in the blood plasma, the concentration of albumin in the plasma also changed in the residents of different regions of the Kyzylorda region.

So, in residents of southern regions in 2017 , the concentration of albumin in blood plasma was $38.20 \pm 1.50 \mathrm{~g} / \mathrm{L}$, decreasing by 2019 to values equal to $36.81 \pm 1.42 \mathrm{~g} / \mathrm{L}$, i.e. decreased by $3.8 \%$. The maximum amount of albumin in blood plasma was recorded in 2020 $38.45 \pm 1.59 \mathrm{~g} / \mathrm{L}$. The concentration of albumin in blood plasma of people living in the city of Kyzylorda in 2017 was $37.92 \pm 2.01 \mathrm{~g} / \mathrm{L}$., increasing by $0.1 \%$ by 2019 and decreasing to 37.93 $\pm 1.98 \mathrm{~g} / \mathrm{L}$. in 2020 , the content of albumin in blood plasma reached its maximum values and amounted to $39.45 \pm 1.85 \mathrm{~g} / \mathrm{L}$.

As shown by the research results, the concentration of albumin in the blood plasma in 2017 in residents of the northern districts of the Kyzylorda region was $36.18 \pm 1.55 \mathrm{~g} / \mathrm{1}$, further decreasing to the minimum value in 2019 and equal to $34.66 \pm 1.69 \mathrm{~g} / \mathrm{L}$., with a subsequent increase by 2020 to $36.90 \pm 1.59 \mathrm{~g} / \mathrm{L}$. In the study, changes in the concentration of globulins in blood plasma in residents of different regions of the Aral Sea region in 2017-2020 changed in a similar way. So, in residents of the southern districts of the Kyzylorda region at the beginning of the survey (2017), the average content of globulins in blood plasma was $34.93 \pm 1.42 \mathrm{~g} / \mathrm{L}$. It increased by 2018 , reaching $35.35 \pm 1.50 \mathrm{~g} / \mathrm{L}$, and in subsequent years it decreased and reached minimum values equal to $33.54 \pm 1.49 \mathrm{~g} / \mathrm{L}$ by 2020 .

In residents of Kyzylorda, the average content of globulins in blood plasma in 2017 was $33.21 \pm 1.32 \mathrm{~g} / \mathrm{L}$, increasing by 2018 to $34.29 \pm 1.03) \mathrm{g} / \mathrm{L}$, followed by a decrease to values equal to $33.54 \pm 1.50 \mathrm{~g} / \mathrm{L}$ in 2019. In 2020, the level of globulins in blood plasma was $34.75 \pm$ $1.61 \mathrm{~g} / \mathrm{L}$.

In residents of the northern regions in 2017, the average concentration of globulins in blood plasma was $34.62 \pm 1.30 \mathrm{~g} / \mathrm{L}$. By 2018, the content of globulins in blood plasma increased to a maximum of $35.40 \mathrm{~g} / \mathrm{L}$, decreasing to $34.25 \pm 1.32 \mathrm{~g} / \mathrm{L}$ in 2019 and again rising to $35.10 \pm$ $1.61 \mathrm{~g} / \mathrm{L}$. in 2020 .

Thus, as the studies have shown, during 2017-2020, the concentration of proteins in the blood plasma in residents of different regions of the Kyzylorda region did not change significantly, and no patterns were revealed in these changes.

Conclusion. Acceptance of the concept of quality of life makes it possible to characterize the entire chain of development of a chronic disease: health, decreased quality of life, maladjustment state, prenosology, disease. The earlier in this chain the appropriate measures are taken, the higher the level of health preservation will be. Therapeutic and restorative measures at the final stage, as a rule, do not lead to complete recovery.

The observations confirmed the previously shown negative effect of the complex of climatic and geographic and anthropogenic factors of the Aral Sea region on the anthropometric parameters in girls [16]; young women living closer to the Aral Sea were shorter and had less 
body weight. We associate this fact with the pollution of soil, air and water with pollutants, which have a particularly pronounced effect on a growing organism [17].

Of particular importance is the fact that the main environmental pollutants are wastes of industrial and agricultural production not only of our republic, but also of those located south of Kyrgyzstan and Uzbekistan, and entering the Aral Sea region with the waters of the Syr Darya River [18].

On average, the long-term resources of river flow in the Aral Sea basin are $116 \mathrm{~km} 3 /$ year, including $37 \mathrm{~km} 3$ / year in the Syrdarya river basin. The runoff of the Syrdarya River is formed on the territory of Kyrgyzstan (75.2\%), Uzbekistan (15.2\%), Kazakhstan (6.9\%), Tajikistan (2.7\%). The Amu Darya runoff - within Tajikistan (74\%), Uzbekistan (8.5\%),

During the conditionally natural period (until 1960), an average of $56 \mathrm{~km} 3$ / year of river flow ( $48 \%$ of the total volume) entered the Aral Sea, which ensured the relative stability of its watersalt regime. In recent decades, a climatically and anthropogenically determined decrease in the resources of the river runoff formed in the Aral Sea basin has been noted, on average, to 102.2 $\mathrm{km} 3$ / year, including in the Syr Darya basin - up to $35.5 \mathrm{~km} 3$ / year. During this period, the Aral Sea received an average of about $19 \mathrm{~km} 3$ / year of river flow .

Due to insufficient inflow, the sea continued to dry up: its level decreased annually by an average of $0.4 \mathrm{~m}$, the area and volume decreased by 1 thousand $\mathrm{km} 2$ and $14 \mathrm{~km} 3$ per year. If this inflow is preserved in the near future, one should expect the formation of three residual reservoirs in the Aral Sea basin with a total area of about 20-25 thousand $\mathrm{km} 2$ [18]

The drainage of the Syr Darya delta and the drop in the Aral Sea level led to a change in the geochemical parameters of the ecosystem components of this region. At the same time, the amount of applied mineral fertilizers and pesticides on the irrigated areas of the Aral region was 10-15 times higher than the all-Union level. All this became the reason that storms of salt, pesticides and sand are formed on the vast desert expanses, which quite recently were the bottom of the Aral Sea.

In the process of adaptation to extreme climatic-geographical and anthropogenic conditions in the Aral Sea region, as in all other crisis zones, there is a decrease in the reserve and adaptive capacities of organisms. It should be noted that different organs and systems react differently to the impact of a complex of extreme climatic and geographic and anthropogenic environmental factors. Another of the possible mechanisms of the adverse effect of toxicants contained in large quantities in the water, soil and atmosphere of the Kyzylorda region is an increase in the content of conformationally altered denatured proteins in the blood under their action.

It is well known that in the course of life, plasma proteins in the bloodstream age, are exposed to toxicants that have entered the body, and become an object of oxidative stress. They are denatured, which is associated with the modification of the secondary, tertiary or quaternary structures of the protein molecule, or with conformational changes in macromolecules, leading to a reversible or irreversible loss of its ability to perform a certain biological function. The structure of proteins also changes with shifts in $\mathrm{pH}$, the action of ions of a number of metals, organic substances, some enzymes, temperature, pressure, etc.

It is known that the development of pathological conditions is associated with oxidative stress, which can be caused by tissue destruction. In this case, the accumulation of a specific group of peptides can be noted in the blood, the molecular weight of which ranges from 300 to $5000 \mathrm{D}$, which is considered as one of the mechanisms of manifestation of the general adaptation syndrome.

In accordance with the main provisions of the Address of the President of the Republic of Kazakhstan "Kazakhstan-2030", it is important to conduct monitoring, increase the reserve capabilities of the body, develop ways and means of preventing and correcting functional changes in the activity of organs and systems caused by extreme factors. A prerequisite for this is an understanding of the physiological and biochemical mechanisms of the damaging effects of 
toxic substances on the body at the cellular and subcellular levels. Under the action of extreme environmental factors, the state of the lipid component of the membrane, as well as the enzyme systems localized in it, changes, which leads to disruption of ionic homeostasis or metabolism of the cell. All of the above indicates that the problem of protecting the health of the population can be successfully solved only if there is sufficient information about the molecular-biochemical mechanisms of the action of adverse factors on the body.

\section{Literature:} P. 461-466.

[1] Plimmer, J.R. Pesticide loss to the atmosphere // Amer.J.Int.Med. - 1990. - V. 18, No. 4. -

[2] Palgova, L.K. Characteristics of hepatorenal manifestations in the population of the Aral Sea region under conditions of intensive load with pesticides. - Diss.Doctor of Medical Sciences: 14.00.07. Almaty, $1993 .-265 \mathrm{p}$.

[3] Kolbai, I.S., Kapysheva U.N., Bakhtiyarova Sh.K. The level of protein catabolism in tissues as an indicator of the body's resistance to extreme influences // Physiological foundations of a healthy lifestyle: International. scientific and practical conference, dedicated. The 60th anniversary of the Institute of Human and Animal Physiology of the Central Biological Institute of the Ministry of Education and Science of the Republic of Kazakhstan. - Almaty, 2005. - P.90 - 91

[4] Chao, C.C., Ma Y.S., Stadtman E.R. Modification of protein surface hydrophobicity and methionine oxidation by oxidative systems // Proc. Natl. Acad. Sci. USA. - 1997. - V.94, №7. - P.29692974.

[5] Kolbay, I.S., Shalakhmetova T.M. Metal accumulation, DNA, glicogen, and protein content in rat hepatocytes at the effect of Aral region alimentary factors // XXXIII Congr.Internat. Union Physiol.Sci.: Abstracts. - St.Petersburg, 1997. - P.041.19

[6] Christensen, J.M. New developments in the biological monitoring of inorganic chemicals // Biological Monitoring in Occupational and Environmental Health: Proc. Int. Sympos. - Helsinki, 1996. P. $45-46$.

[7] Murzamadieva, A.A. Regulation of circulation of denatured proteins by the lymphatic system and the liver // Izvestiya of the Ministry of Education and ScienceRK. Ser.biol. - 2003, №. 5. P.92 - 98 .

[8] Joli, M. Physical chemistry of protein denaturation / Trans. from English . - M., 1968. - 364 p.

[9] Demchenko, A.P., Orlovskaya N.N. Changes in the structure and function of proteins during aging and their possible mechanisms // Modern. biol. - 1981. - T.92, Issue 2. - S. $180-198$.

[10] Agarwal, S., Sohal R.S. Aging and protein oxidative damage // Mech. Aging. Dev. - 1994. V.75, N 1. - P.11 - 19 .

[11] Alexandrov, V.Ya. Cell reactivity and proteins. - L., $1985 .-318$ p.

[12] Cadenas, S., Rojas C., Barja G. Endotoxin increases oxidative injury to proteins in guinea pig liver: protection by dietary vitamin C // Pharmacol. Toxicol. - 1998. - V.82, № 1. - P .11 - 18.

[13] Fataccioli, V., Andraud E., Gentil M. e.a. Effects of chronic ethanol administration on rat liver proteasome activities: relationship with oxidative stress // Hepatology. - 1999. - V.29, №1 . - P .14 20. P. $8-12$

[14] Kulinskiy, V.I. Neutralization of xenobiotics // Soros Educational Journal. - 1999, №. 1. -

[15] Sies, H. Oxidative stress: from basic research to clinical application. // Am. J. Med. - 1991. - Vol.91, №3. - P.31S - 38S.

[16] Ibadullaeva, S.Zh. Functional indicators of the cardiorespiratory system, the cellular composition of the blood in the inhabitants of the Aral Sea region and their correction using hypoxichypercapnic training. - Abstract of thesis ... cand. Biologicalsciences: 03.00.13 - Almaty, 1998 . - 24 p.

[17] Binkova, B., Erin A.N., Sram R.J., Topinka J. Lipid peroxidati-on-induced changes in physical properties of annular lipids in rat brain synaptosomal membranes // Gen. Physiol. Biophys. 1990. - Vol.9, N 3. - P.311-318. 
[18] Malkovsky, I.M. Commentary on the proposal of the Japan Foundation for World Infrastructure // KazEkoPravda, №270, January 30, 2002.

\section{ҚЫЗЫЛОРДА ОБЛЫСЫНЫН ТҰРҒЫНДАРЫНДА ЖАЛПЫ АҚУЫЗ КОНЦЕНТРАЦИЯСЫНЫН ФУНКЦИОНАЛДЫҚ ӨЗГЕРІСТЕРІ}

Ибадуллаева С. Ж., биология ғылымдарының докторы

Қорқыт Ата атындавы Қызылорда университеті, Қызылорда құаласы, Қазақстан Республикасы

Аннотация. Қазіргі жағдайда профилактиканың өсіп келе жатқан рөлін ескере отырып, қоршаған ортаның нақты жағдайларында өмір сүру үшін ең оңтайлы адам өмірінің морфофизиологиялық және хронобиологиялық ұйымын, басқаша айтқанда, ағзаның өзінде бар факторларға байланысты халықтың денсаулығы мен оның патологиялық ауытқуларының қалыптасу жағдайларын жан-жақты түсіну қажет., сондай-ақ оған сырттан әсер етеді. Денені денатуратталған, қартайған ақуыздардан тазарту процесі көптеген органдарда, ең алдымен бауырда жүреді. Жасушадағы деградация процестері жойылатын ақуыздарды тани алады және деградацияны бастайды, бірақ бұл процестер селективті болуы керек, өйткені бір жасушадағы әртүрлі ақуыздардың деградация жылдамдығында айтарлықтай гетерогенділік бар. Протеазалар әдетте катаболикалық процестерді жүзеге асыру үшін қажет және лизосомалық және экстрализосомалық протеазалар жасуша ақуыздарының катаболизміне қатысатын сияқты.Қызылорданың түрлі аудандарында тұратын адамдардың қан плазмасындағы жалпы ақуыз бен оның фракцияларының концентрациясы. Өңір Арал өңірі аймағына тән экстремалды факторлардың әсер ету ауырлығына тәуелді емес.

Кілт сөздер: жалпы ақуыз, ақуыз, альбумин, глобулин, аймақ, орта, тұрвын.

\section{ФУНКЦИОНАЛЬНЫЕ ИЗМЕНЕНИЯ КОНЦЕНТРАЦИИ ОБЩЕГО БЕЛКА У ЖИТЕЛЕЙ КЫЗЫЛОРДИНСКОЙ ОБЛАСТИ}

Ибадуллаева С.Ж., доктор биологических наук

Кызылординский университет илени Коркыт Ата, г.Кызылорда, Республика Казахстан

Аннотация. Принимая во внимание все возрастающую роль профилактики в современных условиях, необходимо всестороннее понимание морфофизиологической и хронобиологической организации жизни человека, наиболее оптимальной для проживания в конкретных условиях окружающей среды, иными словами, условиях формирования состояния здоровья населения и его патологических отклонений из-за факторов, существующих в самом организме, а также действующих на него извне. Процесс очищения организма от денатурированных, состарившихся белков происходит во многих органах, в первую очередь в печени. Процессы деградации в клетке могут как распознавать разрушаемые белки, так и начинать деградацию, но эти процессы должны быть избирательными, поскольку существует значительная неоднородность в скоростях деградации различных белков в одной клетке. Протеазы обычно необходимы для реализации катаболических процессов, и, по-видимому, в катаболизме клеточных белков участвуют лизосомальные и экстрализосомальные протеазы. Концентрация общего белка и его фракций в плазме крови у людей, проживающих в различных районах Кызылорды. Регион не зависит от выраженности действия экстремальных факторов, характерных для зоны Приаралья.

Ключевые слова: общий белок, белок, альбумин, глобулин, регион, среда, резидент. 


\title{
POSSIBILITY OF PRODUCTION OF DAIRY PRODUCTS WITH STEVIA EXTRACT
}

\author{
Auezeva N.S. ${ }^{1}$, candidate of biological sciences \\ nurkuigan1971@mail.ru, https://orcid.org/0000-0002-7986-2126 \\ Ibraeva S.S. ${ }^{2}$, teacher of geography \\ ibrayevasyrg@mail.ru, https://orcid.org/0000-0002-8685-7413
${ }^{I}$ Saken Seifullin Kazakh Agrotechnical University, Nur-Sultan city, Republic of Kazakhstan
${ }^{2}$ Kyzylorda Agrarian and Technical Higher College named after, I. Abdukarimova, Kyzylorda city, Republic of Kazakhstan

\begin{abstract}
The article presents the possibility of obtaining dairy products with stevia extract and the results of the study of organoleptic, physical and chemical properties of the finished product.

Market relations require dairy producers to provide consumers with new dairy-based foods enriched with vegetable supplements. Mixed milk-based products, enriched with plant and animal products, allow you to prepare a new type of lunch with a new composition.

As a natural sweetener, stevia extract gives a special sweet taste to yogurt products, as well as not only sweetens the product, but also makes it easier to absorb. This means that the stevia plant has not only tasty properties, but also easily digestible nutrients. Natural product made during the preparation of lactic acid products is a unique type of raw material with useful, highly digestible dietary properties. After all, natural milk contains a source of nutrients: immunoglobulins, hormones, growth factors, enzymes and other biologically active substances. Lactic acid product with stevia extract provides a sweet taste, a healthy type of food that does not lag behind in quality.
\end{abstract}

Keywords: yogurt, stevia extract, sugar, milk acidity, titratable milk acidity, organoleptic parameters, physical and chemical parameters, tasting.

Introduction. Today, due to the growing global demand for healthy nutrition, it is important to develop and improve the range of products with high nutritional value, functional and biochemical properties. Dairy products are widely used by people for the prevention of various diseases, including diseases of the gastrointestinal tract.

For example, in the dairy industry of Russia there are also large enterprises, specialized workshops, etc., where there are large-scale achievements that can be exchanged with dairy enterprises of our country [1].

One of the main tasks of biotechnology is the development of foods by increasing the content of lactic acid products. Accordingly, the relevance of this article is to present the type of product made by adding stevia extract to dairy products [2].

Stevia is a perennial shrub known as a member of the genus Asteraceae. Its origin is the South American continent, Paraguay. Arya, S., Gandhi, S., et al., 2018. Although there are more than 200 species worldwide, only two species, Stevia rebaudianabertoni and Stevia phlebophylla, are recognized as valuable. After all, only these two types can produce sweet steviol glycosides.

Eleven steviol glycosides are formed along the stevia plant, which give the leaves a sweet taste. There are 3 main types of eleven glycosides, including stevioside, rebaudiazide $\mathrm{A}$ and rebaudiazide C (5-10\%; 2-4\%; 1-2\%). Rebaudioside A and stevioside are the closest glycosides to sugar in taste [3].

Material and research methods. Some steviol glycosides do not have a sweet taste, but rather a bitter taste, and the representatives of this bitter taste are the glycosides rebaudioside B and redaudioside D. Steviol glycosides are diterpene glycosides with a common aglycone, ie the basis of steviozides is steviol. Carbohydrate residues are bound to the common aglycon [4]. 
The extract of stevia leaves has antimicrobial, anti-oxidant (antioxidant), adaptogenic properties. Traditionally, plant flavonoids and polyphenols are recognized as natural antioxidants. Biologically active substances - flavonoids are formed in the range of 2 to $3 \%$ along the leaves of stevia belonging to different varieties [5].

The stevia plant, which has several hundred times more sweetness equivalent than table sugar, has a number of chemical, physical and pharmacological properties that make it widely used as a natural sweetener. Quantitative indicators of protein, fat, ash, sugar, macronutrients N, $\mathrm{P}, \mathrm{Ca}$, etc. of dried leaves and extracts of stevia differ in numerical values (Table 1).

Table 1 - Chemical properties of dried stevia leaves and stevia extract

\begin{tabular}{|c|c|c|}
\hline Indications & Dried stevia leaves & Stevia extracts \\
\hline Sugar & 6,55 & 1,77 \\
\hline Fat & 3,8 & 1,75 \\
\hline Fiber & 14,18 & 10,44 \\
\hline Carotene & 30,5 & 7 \\
\hline Hygroscopic & 7,8 & 7 \\
\hline Protein & 2,72 & 0,3 \\
\hline Cinder & 17,45 & 6,61 \\
\hline $\mathrm{P}$ & 0,34 & 0,28 \\
\hline $\mathrm{Ca}$ & 0,79 & 0,61 \\
\hline
\end{tabular}

According to Table 1, it is confirmed that the chemical composition of stevia is rich in nutrients. At the same time, the rate of transfer of chemicals to the finished product during the processing of raw materials is much higher than the percentage of waste.

In the process of obtaining stevia extract, stevia leaves are used as a primary source of raw materials. They are obtained in the form of dried, air-dried, fresh leaves. The release of biologically important substances along the leaves depends on several factors. These include: temperature, water ratio, duration of extraction.

The optimal extractant for extracting stevia is water. 1-3 $\mathrm{mm}$ of crushed leaves as a raw material is an effective volume for the production of large amounts of extractives. In the extraction process, a temperature of $90{ }^{\circ} \mathrm{C}$, a 1: 5 ratio of extractant to raw material, and an extraction time of 2 hours are optimal. In the above cases, the consumption of extractives at the cost of extracting is $46.11 \%$, the consumption of sweet glycosides is $8.17 \%$, the consumption of dry products is $10.32 \%$. The extraction process is performed with various detergents, such as butylpropionate. For long-term storage of stevia extract, the extract is dried in a vacuum dryer, sublimation dryer, lyophilic, etc.

Over the past decade, stevia has been used in many industries as a sugar substitute product or biologically active additive.

The widespread use of this plant in the food industry is due to its ability to withstand the effects of sweet glycosides and heat treatment. This is because stevia does not deteriorate in composition when exposed to different temperatures [6].

Research method and results. Samples of camel's milk, clotted yogurt enriched with vegetable extract were taken as the object of study. The plant component for the extract was selected and two different by-products were obtained. One is made by adding sugar in the 
traditional way, the other is made with stevia extract. The dose, stage and method of administration of stevia extract in milk were selected.

Cow's milk was taken as a second sample for comparative qualitative study (Table 2). The titrated acid number was determined in the phenolphthalein indicator, the active acid number was determined in the Consort C 931 analyzer.

The condition for determining the quality of samples was based on organoleptic characteristics: taste and smell, appearance, color, consistency and overall effect.

Table 2 - Comparative physical and chemical properties of camel's milk

\begin{tabular}{|l|l|l|}
\hline SOMO / KMSK & 8,30 & 8,30 \\
\hline protein, g/100 g & 2,9 & 2,9 \\
\hline Lipid amount, g/100 g & 3,75 & 3,75 \\
\hline The amount of lactose in milk sugar, g / 100 g & 4,8 & 4,8 \\
\hline Minerals, g / 100 g & 0,6 & 0,6 \\
\hline Acidity, To & 16 & 16 \\
\hline Density, g / cm3 & $1,029=29,16$ & $1,029=29,16$ \\
\hline Activeacidity, pH & $6,9-7$ & $6,9-7$ \\
\hline Temperature, oC & 19,5 & 19,5 \\
\hline Addedwater & 0 & 0 \\
\hline
\end{tabular}

As shown in the table, the chemical composition of camel's milk is high in terms of quantity and quality. In particular, the number of KMSK is 2.27 times higher, the protein content is higher by 0.23 , etc. The parameters are formed more in camel's milk than in cow's milk.

During the study, the analysis of organoleptic parameters of two lactic acid products was performed (Table 3).

Table 3 - Organoleptic characteristics of lactic acid products

\begin{tabular}{|l|l|l|}
\hline \multirow{2}{*}{ Indicators } & \multicolumn{1}{|c|}{ Yogurt } \\
\cline { 2 - 4 } Smell and taste & $\begin{array}{l}|c| \\
\text { Characteristic of a clean, lactic } \\
\text { acid product, sweet, without } \\
\text { foreign taste and odor }\end{array}$ & $\begin{array}{l}\text { Pure, lactic acid product has } \\
\text { no characteristic odor or taste, } \\
\text { no foreign taste and odor }\end{array}$ \\
\hline Colour & $\begin{array}{l}\text { Creamcolor, lightorange } \\
\text { Milky-white }\end{array}$ \\
\hline & $\begin{array}{l}\text { Medium viscous, liquid } \\
\text { consistency, uniform, with } \\
\text { bubbles }\end{array}$ & $\begin{array}{l}\text { Liquid, medium viscous, } \\
\text { slightly granular, with } \\
\text { bubbles. }\end{array}$ \\
\hline
\end{tabular}

Both samples of lactic acid products have a liquid and slightly viscous consistency. The product with the addition of stevia extract has a delicate sweet taste due to the smell and taste lactic acid and the extract. The second sample did not contain lactic acid and foreign odors in taste and odor, but no sweet taste was detected.

Conclusion. The results of the study of milk-based products, the organoleptic, physicochemical properties of the finished product, the process of adding natural sugar substitute plant extract to lactic acid products instead of sugar were carried out. According to the results of the study, the sweet taste of our lactic acid products was confirmed during the tasting assessment of organoleptic parameters. The sweetness of yogurt with the addition of stevia is not inferior to the product with the addition of sugar and has its own lunch flavor. 
As world experience shows, new milk production technologies updated annually, which are updated every year, are always relevant both for human health and for biological achievements $[7,8,9,10]$.

\section{Literature:}

[1] Николаева, М.А. Рынок молочных товаров: состояние и перспективы развития // Индустрия питания Food Industry. 2018. Т. 3. № 3. С. 78-85. DOI: 10.29141/2500-1922-2018-3-3-12.

[2] Kanareykina, S.G, Kanareykin V.I. Разработка линейки молочно-растительных йогуртов // Известия Оренбургского государтсвенного аграрного университета. 2016. № 1. Р.100 103.

[3] Kanareykina, S.G, Arslanova A.M, Kanareykin V.I. Применение растительного компонента при производстве йогурта // Наука молодых - инновационному развитию АПК. Материалы международной молодежной научно-практической конференции. Уфа: Башкирский государственный аграрный университет. 2016. Р.153 - 158.

[4] Tasturganova, E.C. Разработка технологии молочных продуктов специального назначения на основе верблюжьего молока с использованием пробиотических заквасок: дис. ... докт. философ.(PhD) - Алматы, 2019. - 148 р.

[5] Z. Farah, M., Camel Milk. Encyclopedia of Dairy Sciences - 2011. P. 512-517.

[6] Elubaeva, M.E. Қазақстан Республикасында өсірілетін түйе малының сүтін өндіру және өңдеу үшін генетикалық потенциалын зерттеу: дис. философ. докт - Алматы, 2018. - 114 р.

[7] Зенкова, А.В. Тенденции в развитии молочного скотоводства /А.В.Зенкова// Экономика сельскохозяйственных и перерабатывающих предприятий. - 2008. - № 8. - С.27-28.

[8] Формирование агропромышленнных кластеров в России //АПК: экономика, управление. - 2008. - № 3 .

[9] Белов, А.С., Воронин А.А., Жебит М.Э. Молочная отрасль России - 2017 год // Молочное животноводство. 21.08.2017. URL: https:// agrovesti. net/lib/industries/dairy-farming.

[10] Пармухина, Е. Рынок сыра после эмбарго: рост производства пошел на спад. URL: www.agroinvestor.ru/market/article/25832- rynok-syra-posle-embargo. Bibliography

\section{References:}

[1] Nikolaeva, M.A. Rynok molochnyh tovarov: sostoyanie i perspektivy razvitiya // Industriya pitaniya Food Industry. 2018. T. 3. № 3. S. 78-85. DOI: 10.29141/2500-1922-2018-3-3-12.

[1] Kanareykina, S.G, Kanareykin V.I. Razrabotka linejki molochno-rastitel'nyh jogurtov // Izvestiya Orenburgskogo gosudartsvennogo agrarnogo universiteta. 2016. № 1. P.100 - 103.

[2] Kanareykina, S.G, ArslanovaA.M, KanareykinV.I. Primenenie rastitel'nogo komponenta pri proizvodstve jogurta // Nauka molodyh - innovacionnomu razvitiyu APK. Materialy mezhdunarodnoj molodezhnoj nauchno-prakticheskoj konferencii. Ufa: Bashkirskij gosudarstvennyj agrarnyj universitet. 2016. P.153 - 158 .

[3] Tasturganova, E.C. Razrabotka tekhnologii molochnyh produktov special'nogo naznacheniya na osnove verblyuzh'ego moloka s ispol'zovaniem probioticheskih zakvasok: dis. ... dokt. filosof.(PhD) - Almaty, 2019. - 148 p.

[4] Farah, M. Z., Camel Milk. Encyclopedia of Dairy Sciences - 2011. P. 512-517.

[5] Elubaeva, M.E. Qazaqstan Respublikasynda osiriletin tuje malynyn sytin ondiru zhane ondeu ushin genetikalyq potencialyn zertteu: dis. filosof. dokt - Almaty, 2018. - $114 \mathrm{p}$.

[7] Zenkova, A.V. Tendencii v razvitii molochnogo skotovodstva /A.V.Zenkova// Ekonomika sel'skohozyajstvennyh i pererabatyvayushchih predpriyatij. - 2008. - № 8. - S.27-28.

- № 3 .

[8] Formirovanie agropromyshlennnyh klasterov v Rossii //APK: ekonomika, upravlenie. - 2008.

[9] Belov, A.S., Voronin A.A., ZHebit M.E. Molochnaya otrasl' Rossii - 2017 god // Molochnoe zhivotnovodstvo. 21.08.2017. URL: https:// agrovesti. net/lib/industries/dairy-farming.

[10] Parmuhina, E. Rynok syra posle embargo: rost proizvodstva poshel na spad. URL: www.agroinvestor.ru/market/article/25832- rynok-syra-posle-embargo. Bibliography 


\title{
СТЕВИЯ СЫҒЫНДЫСЫМЕН ДАЙЫНДАЛАТЫН СУТҚЫШҚЫЛДЫ ӨНІМ АЛУДЫН МУМКІНДІГІ
}

\author{
Ауезова Н.С. ${ }^{1}$, биология ғылымдарының кандидаты \\ Ибраева С.С. ${ }^{2}$, география пәнінің оқытушысы \\ ${ }^{1}$ С.Сейфуллин атындавы Қазақ агротехникалық университеті, Нұр-Сұлтан қุаласы, \\ Қазақстан Республикасы \\ ${ }^{2}$ И.Әбдікәрімов атындагы аграрлық-техникалық жогарвы колледж, \\ Қызыллорда қ̧аласы, Қазақ̧стан Республикасы
}

\begin{abstract}
Андатпа. Мақалада стивия сығындысы қосылған сүт өнімдерін алу мүмкіндігі және дайын өнімнің органолептикалық, физика-химиялық көрсеткіштерін зерттеу нәтижелері келтірілген.

Нарықтық қатынастар сүт өнімдерін өндірушілерден өсімдік қоспасымен байытылған жаңа сүт негізді тағам түрлерін тұтынушыларға ұсыну үдерісін талап етуде. Шығу тегі өсімдік және жануар негізді өнімдермен байытылған аралас сүт негізді өнімдер жаңа құрамға ие таңсық тағам түрін дайындауға мүмкіндік береді.

Табиғи тәттілендіргіш ретінде стевия сығындысы йогурт өніміне ерекше тәтті дәм береді, сонымен қатар өнімді тәттілендіріп қана қоймай, оның оңай сіңірілуін жүзеге асырады. Бұл дегеніміз, стевия өсімдігі дәмдік қасиетінен бөлек, жеңіл сіңімді тағамдық құрамға да ие деген сөз. Сүтқышқылды өнім дайындау барысында дайындалған табиғи өнім пайдалы, сіңімі жоғары диеталық қасиетке ие бірегей шикізат түрі болып табылады. Өйткені,табиғи сүттің құрамында құнарлы компоненттер көзі кездеседі: иммуноглобулиндер, гормондар, өсу факторлары, ферменттер және т.т биологиялық белсенді заттар. Стевия сығындысы қосылған сүтқышқылды өнім тәтті дәмі, сапасы бойынша қалыспайтын пайдалы тағам түрімен қамтамасыз етеді.
\end{abstract}

Кілт сөздер: йогурт, стевия сызындысы, қант, сүт қыышқылдылывы, сүттің титрлеу қышқылдылыгы, органолептикалық параметрлер, физика-химиялық көрсеткіштер, дегустация.

\section{ВОЗМОЖНОСТЬ ПРОИЗВОДСТВА МОЛОЧНЫХ ПРОДУКТОВ С ЭКСТРАКТОМ СТЕВИИ}

\author{
Ауезова Н.С. ${ }^{1}$, кандидат биологических наук \\ Ибраева С.С. ${ }^{2}$, преподаватель географии \\ ${ }^{1}$ Казахский агротехнический университет имени С.Сейфуллина, г. Нур-Султан, \\ Республика Казахстан \\ ${ }^{2}$ Кызылординский аграрно-технический высший колледж им. И. Абдукаримова, \\ г.Кызылорда, Республика Казахстан
}

\begin{abstract}
Аннотация. В статье представлен возможность получения молочного продукта, приготовленного на основе молока с добавлением растительного экстракта и результаты исследования органолептических, физико-химических показателей готового продукта. Экстракт стевии как натуральный сахаро заменитель придает йогуртовому продукту изумительный сладкий вкус, а также делает продукт не только подслащенным, но и легко усваиваемым. Это означает, что помимо вкусовых качеств, растение стевия также обладает легкоусвояемым питательным составом.

В процессе приготовления кисломолочного продукта верблюжье молоко является уникальным видом сырья, обладающим полезными, высоко усвояемыми диетическими свойствами. Ведь в составе верблюжьего молока содержится более 100 источников ценных компонентов: иммуноглобулины, гормоны, факторы роста, ферменты и др. биологически активные вещества. Кисломолочный продукт, приготовленный на основе верблюжьего молока с экстрактом стевии, обеспечивает здоровый вид пищи, не уступающий по сладкому вкусу и качеству.

Ключевые слова: йогурт, экстракт стевии, сахар, кислотность молока, титруемая кислотность молока, органолептические параметры, физико-химические показатели, дегустация
\end{abstract}


Техникалық ғылымдар

Технические науки

Technical science

SRSTI 86.29+68.01.98

https://doi.org/10.52081/bkaku.2021.v58.i3.076

\title{
PRODUCTION RISKS IN THE OIL - GAS INDUSTRY
}

\author{
Tanzharykov P.A., candidate of technical sciences \\ pan_19600214@mail.ru, https://orcid.org/0000-0002-6490-9972 \\ Sarabekova U.Zh., $\mathrm{PhD}$ \\ ulbolsyn.sar@mail.ru,https://orcid.org/0000-0001-9548-8333 \\ Zhienbekova Zh.E., Master student \\ zhaziko_97@mail.ru,https://orcid.org/0000-0002-3675-7473 \\ Zhumabek Zh., student \\ zhumabek.0201@mail.ru, https://orcid.org/0000-0002-6700-6912
}

Korkyt Ata Kyzylorda University, Kyzylorda city, Republic of Kazakhstan,

\begin{abstract}
Annotation. This article suggests ways to quickly assess the state of labor protection and ecology by calculating a number of indicators of industrial risk based on the information available in the modules for assessing labor protection by indicators of industrial risk. The efficiency of using the software proposed by the authors for the occupational health and safety management system based on a specific task from the modules "Personnel", "Events", "Equipment" and "Ecology", consisting of four main modules, is proved.

In addition, this paper compares the matrix methods of risk assessment in the coordinate system "probability of an event or consequences of an event" of prevention and assessment of occupational risks for employees used in domestic and foreign practice in the occupational safety management system. Work on identifying harmful factors of accidents during the extraction, use and transportation of raw materials at industrial enterprises and assessing compliance with the requirements of the standards of the Republic of Kazakhstan should be carried out continuously. The main goal of the labor protection service is to create safe working conditions for employees at industrial enterprises, as well as to prevent occupational diseases of employees. In this regard, a system of accounting, analysis and assessment of the state of labor protection, as well as labor safety management, should work.
\end{abstract}

Keywords: labor protection, labor safety management system, production risk, accident, occupational disease, quality management system, risk analysis.

Introduction.Currently, the topic "health and safety" remains very relevant in all areas. Human life and the environment can be affected by the nature of harmful and dangerous factors for a person in the process of labor activity. Underestimation of factors in production leads to the death of people, equipment failure, and pollution of the environment with harmful substances. Prevention of such events and reduction of damage from them require purposeful work on the study of the conditions of their occurrence, the use of methods of System Analysis and modeling of potentially dangerous processes in the Technosphere, scientist P. G. Belov emphasizes in his work [1].

The main goal of the policy in the field of labor protection at the industrial site is to protect the life and health of employees in the course of their activities, and defines a clear concept of labor protection. To achieve this goal, it is necessary to create a harmonious Occupational Health and safety system and ensure the real functioning of all its components. Currently, the country has developed a system of Public Administration of labor protection, replacing the system of centralized planning and financing of labor protection measures [2]. 
The tasks of the labor legislation of the Republic of Kazakhstan are to create the necessary legal conditions aimed at balancing the interests of Labor Relations, social stability, and social harmony. The labor legislation of the Republic of Kazakhstan is based on the Constitution of the Republic of Kazakhstan and consists of the Labor Code, Laws of the Republic of Kazakhstan and other normative legal acts of the Republic of Kazakhstan [3]. The purpose of the labor legislation of the Republic of Kazakhstan is legal regulation of Labor Relations and other relations directly related to Labor Relations, aimed at protecting the rights and interests of the terms of Labor Relations, establishing minimum guarantees of rights and freedoms in the field of Labor.

Literature review. In this case, it is necessary to create a quality management system (QMS) to ensure safe working conditions at oil and oil refineries. The main task in it is to carry out a lot of organizational work and create a structure of the QMS for work on labor protection at the industrial site.

In the «Occupational Health and safety management system», it is necessary to pass the certification of work on occupational health and safety management system in the shortest possible time, which meets the requirements of other international standards, such as "system of Occupational Safety Standards St RK 12.0.005-2016", "System of Occupational Safety and Health Management St RK OHSAS 18001-2008" [4, 5].

The process of integration of our country into the world community requires a comprehensive update of the management system, bringing laws, standards, and management principles to world norms. The Occupational Safety Management System (OSMS) is one of the elements of the organization's management system, and workplace certification is the basis of the Occupational Health and safety management system.

Currently, many organizations have a well-defined occupational safety management system. Work in this area is mainly carried out in the event of a clear threat to safety at the workplace, an accident or in connection with the instructions of the inspector of the supervision and control body, requiring the elimination of violations of the legislation and other regulatory legal acts on labor protection. As a result of the creation of the Occupational Safety Management System, the organization will be able to ensure its attractiveness to investors through an effective safety management system that meets international standards, reduce unscheduled economic losses resulting from accidents, accidents and occupational diseases, improve its image and increase its competitiveness in the market. The requirements of the standard apply to organizations of all types. The implementation of the Occupational Safety Management System and its functioning in accordance with the procedure provided for in the standard can only be ensured if all management links of the organization and its employees are involved. As provided for in the requirements of the standard, the management of the organization responsible for labor protection must ensure the development, implementation and operation of the system in accordance with the requirements established by this standard [4-5].

Research materials and methods. The essence of the requirements, first of all, the management of the organization should define and document the policy, goals and objectives in the field of labor protection, communicate the adopted policy to all employees of the organization, support and ensure its implementation at all levels of management, periodically review and adjust the policy in order to ensure its stable compliance with the changing needs of the organization. The policy here should correspond to the nature and scope of risks and relate to the economic goals of the organization.

Each individual organization forms its own occupational health and safety management system aimed at ensuring its safety in the implementation of labor protection requirements. The standard scheme of Occupational Health and safety management in industry is implemented as follows: 
- development of local documents on labor protection (standards for the organization of labor protection with the distribution of responsibility among the management of the organization, Heads of structural divisions, establishing their responsibility, instructions on labor protection by profession and type of work, other documents);

- Organizational activities for the implementation of the OSMS with the participation or joint participation of a trade union organization (conducting all types of instructions on labor protection, professional development and training of employees on labor protection, preparation and conclusion of a collective agreement and an agreement on labor protection, organization and conduct of preliminary and periodic medical examinations of employees subject to such an examination, etc.);

- creation and strengthening of labor protection services, training and certification of labor protection specialists;

- conducting certification of workplaces for working conditions;

- ensuring technical safety of works, reconstruction of production facilities, improvement of sanitary and household services for employees;

- providing employees with individual and collective means of protection;

- control over compliance with labor protection requirements in departments and workplaces (through two-and three-stage Control and other methods);

- maintaining documents on labor protection.

The implementation of the specified provisions of the standard in determining the policy, goals and objectives of employers in the field of labor protection and their documentation design should not cause special difficulties, since these issues are mainly within the competence of the organization [6].

The most organic and effective way to create software information support, in which the above-mentioned functions and requirements for the technological process can be met, is to use the calculation of operational values of risks, reflecting the current state of daily activities of the organization as a whole and each of its divisions as the core of the entire information complex of the Automation unit.

It is advisable to provide software for the Occupational Health and safety management system based on a specific task consisting of four main modules: "employees", "events", "equipment", "Ecology" and a number of sub-modules.

In the Occupational Health and safety management system, modern methods of prevention and assessment of occupational risks for employees used in domestic and foreign practice are compared. These methods include: matrix methods of risk assessment in the coordinate system" probability of an event or consequences of an event", the Elmeri system, the fine-Kinney method, and the expert methodology" five stages of risk assessment".

At the current stage of functioning of the Occupational Health and safety management system, it is impossible to have a single methodological approach to identifying occupational risks. There is also no universal methodology for assessing occupational risks, each of the methods used has its own advantages and disadvantages, but all of them are aimed at improving working conditions at the workplace, preserving the life and health of the employee. In the coordinate system" probability of an event - consequences of an event", matrix methods of risk assessment are widely used for risk assessment due to their simplicity [7].

Research results and discussion. Risk is defined as a two-dimensional value based on the probability of occurrence and severity of consequences. The essence of the method is that for each case, the category of probability of its occurrence and the possible damage corresponding to this situation are determined in advance. The risk is calculated using the following formula:

$\mathrm{R}=\mathrm{P} \cdot \mathrm{S}$

Where, $\mathrm{R}$ - is the value of the risk, by points; $\mathrm{P}$ - is the probability of occurrence of the risk; $\mathrm{S}$ - is the severity of the hazard effect by points. 
One of the options for assessing the probability of occurrence of a hazard is shown in Table 1

Table 1 - Rrisk probability assessment (P)

\begin{tabular}{|c|c|c|}
\hline $\begin{array}{l}\text { Value, } \\
\text { points }\end{array}$ & Probability & Description \\
\hline 1 & $\begin{array}{c}\text { very rare } \\
\text { (minimum) }\end{array}$ & $\begin{array}{c}\text { The probability of occurrence is low. It is impossible to predict } \\
\text { the occurrence of such a factor ( } 1 \text { case for every } 10,000 \\
\text { operations or } 1 \text { case for } 10 \text { years of operation) }\end{array}$ \\
\hline 2 & $\begin{array}{l}\text { medium (low } \\
\text { frequency) }\end{array}$ & $\begin{array}{l}\text { The probability of occurrence is low. Such cases occur in some } \\
\text { cases, but the level of opportunities for this is not high (at least } 1 \\
\text { case for every } 1000 \text { operations or } 1 \text { case for every working year) }\end{array}$ \\
\hline 3 & $\begin{array}{l}\text { significant (average } \\
\text { frequency) }\end{array}$ & $\begin{array}{l}\text { The probability of occurrence is average. Such cases can occur } \\
\text { realistically and unexpectedly (10 cases per } 1000 \text { operations or } \\
1 \text { case per month) }\end{array}$ \\
\hline 4 & $\begin{array}{l}\text { important (high } \\
\text { frequency) }\end{array}$ & $\begin{array}{l}\text { There is a high probability of an event occurring. Conditions for } \\
\text { this occur regularly or at certain intervals (less than } 10 \text { for every } \\
\qquad 100 \text { operations, or } 1 \text { case every week) }\end{array}$ \\
\hline 5 & $\begin{array}{l}\text { very high (very } \\
\text { often) }\end{array}$ & $\begin{array}{l}\text { The probability of occurrence is very high. Usually occurs over } \\
\text { long periods of time under normal use (one case per shift, each } \\
\text { working day) }\end{array}$ \\
\hline
\end{tabular}

Among the many areas of activity of the enterprise, the activity on the management and control of labor protection and industrial safety is of particular importance, since timely and justified actions in this area depend on the life and health of Employees [8]. The risk Impact Assessment (S) is shown in Table 2.

Table 2 - Risk Impact Assessment (S)

\begin{tabular}{|c|l|l|}
\hline $\begin{array}{c}\text { Value, } \\
\text { points }\end{array}$ & $\begin{array}{c}\text { Consequences of } \\
\text { exposure to danger }\end{array}$ & \multicolumn{1}{|c|}{$\begin{array}{c}\text { Description of the severity of the degree of impact on the } \\
\text { employee }\end{array}$} \\
\hline 1 & $\begin{array}{l}\text { minimal impact (very } \\
\text { light injury) }\end{array}$ & $\begin{array}{l}\text { There is a slight impact on the equipment or the course of } \\
\text { work, micro trauma occurs, and first aid is provided }\end{array}$ \\
\hline 2 & $\begin{array}{l}\text { moderate impact (mild } \\
\text { injury) }\end{array}$ & $\begin{array}{l}\text { The period of loss of working capacity includes 1 day. The } \\
\text { employee's life is not in danger, additional assistance is } \\
\text { required to fix the problem, or a shutdown is required }\end{array}$ \\
\hline 3 & $\begin{array}{l}\text { significant impact } \\
\text { (injuries of moderate } \\
\text { severity) }\end{array}$ & $\begin{array}{l}\text { The presence of serious injuries that are life-threatening or } \\
\text { potentially dangerous to health }\end{array}$ \\
\hline 5 & $\begin{array}{l}\text { significant impact } \\
\text { (serious injuries) }\end{array}$ & $\begin{array}{l}\text { Group accidents with serious consequences with a fatal } \\
\text { outcome also have a significant impact on the equipment } \\
\text { during Operation }\end{array}$ \\
\hline (very serious injury)
\end{tabular}

The undoubted advantage of the method is its ease of use. Its significant distribution in organizations is that risk assessment in the workplace is an obligation of the employer fixed at 
the legislative level, and its application allows you to fulfill the requirement of the state regulator in the field of labor protection at the lowest cost (Table 2).

In the course of risk assessment, it is conditionally possible to divide into four stages: identification of harmful and dangerous factors of occupational risk in terms of possible risks to the health of employees, collection of data on the frequency and severity of injuries and occupational diseases, economic assessment of the consequences of injuries and occupational diseases, "testing" of occupational risks and selection of the appropriate insurance model.

Assessment of labor protection by production risk indicators according to the information contained in the modules, it is possible to quickly assess the state of labor protection and ecology by calculating a number of production risk indicators. Production risk indicators and operational risk values are maintained [9].

All of the above indicators characterize the effectiveness of the work of divisions in timely and complete implementation of legislative and regulatory requirements in the field of Occupational Safety, Fire Safety and ecology, elimination of identified violations.

Each of the indicators should be calculated on a quarterly basis for divisions and for the organization as a whole. If the corresponding value is zero in the indicator section, then the indicator is equal to one.

Hazard analysis allows us to determine the sources of dangerous factors, possible destructive events, the sequence of events, the probability of accidents, the magnitude of the risk, the magnitude of the consequences, and ways to prevent and minimize the consequences of accidents.

All of the above indicators characterize the effectiveness of the work of departments in the field of timely and complete implementation of legislative and regulatory requirements for labor protection, fire safety and ecology and elimination of identified violations. The range of changes in the values of each of the indicators is from 0 to 1 .

Methods for detecting hazards [10-12] can be divided as follows:

- engineering methods are performed by probabilistic safety analysis using statistics when calculating frequencies;

- model methods (based on building models of the impact of dangerous and harmful factors on the individual, professional and social groups of the population);

- expert methods (includes determining the probability of various events based on a survey of experienced experts);

- sociological methods based on population surveys.

These methods are used together to represent different aspects of danger. Risk analysis qualitatively and quantitatively describes the risks and ends with planning preventive measures. It is based on knowledge of logical algebra and events, probability theory, statistical analysis, requires engineering knowledge and a systematic approach.

In the course of risk assessment, four stages can be conditionally distinguished: identification of harmful and dangerous factors of occupational risk in terms of possible risks to the health of employees, collection of data on the frequency and severity of injuries and occupational diseases, economic assessment of the consequences of injuries and occupational diseases, "testing" of occupational risks and selection of the appropriate insurance model.

For social insurance purposes, it is important to take into account that there are organizations where most accidents do not cause serious consequences, as well as a significant number of accidents lead to serious consequences for employees (partial or complete loss of working capacity). This situation leads, accordingly, to an increase in the volume of compensation payments, medical and rehabilitation services. In addition, in case of loss of working capacity (depending on the type of injury or occupational disease), various services related to the treatment of the victim, medical, professional and social rehabilitation are required 
in accordance with the situation of causing harm and the cost of services. Therefore, the economic and natural indicators of professional risks vary significantly.

From the point of view of social insurance, occupational risk refers to situations that arise from the probability of occurrence of insurance events (related to industrial accidents and occupational diseases) that work for this professional group and require expenses for reimbursement of expenses for treatment and rehabilitation.

The risk of occupational disease, risk of injury, loss of income as a result of accidents and additional costs for the treatment and rehabilitation of victims are insured.

The level of professional risk is described as follows:

- probability of occurrence of insured events as a result of industrial accidents that lead to the loss of wages (for a professional group working for a certain period of time frequency);

- types of harm to health (nosology) and duration (reduced working capacity);

- a set of compensation, medical and rehabilitation services required for a specific professional group of employees.

It should be noted that the main characteristic of compulsory social insurance covers economic and legal relations related to adverse social consequences of work from accidents and occupational diseases.

As for the statistics of injuries and occupational diseases, as well as the assessment of some occupational risk factors included in the topic of Occupational Health and safety, social insurance uses to solve the following problems: differentiation and classification of risks, development of measures to prevent them, formation of an information base, etc.appropriate infrastructure for risk management [13-15].

The object of professional risk research is the workplace. The workplace is a place where a direct risk situation arises, where a dangerous situation is visible. For example, at the workplace, an employee may be affected by factors of various degrees of chemical, physical and biological nature, as well as the risk of the labor process (labor intensity, labor intensity, and labor monotony). In this regard, it is necessary to identify and prevent possible risks based on objective data obtained as a result of conducting a subjective assessment of their condition or certification of workplaces for working conditions, instead of traditional methods of improving working conditions and programming the goals of labor protection and planning activities, their identification with respect to safety and the development of a policy in the field of labor protection in the organization. It is generally necessary to integrate Occupational Health and safety management into the organization's management system, as this is due to the technological, financial and other operational features of the organization's activities.

Conclusion. Organization of development, implementation and operation of the OEDP in accordance with the standard:

- ensure compliance with all regulatory requirements related to labor protection at all workplaces and in all areas of the organization;

- initiation of events, improvement of working conditions and labor protection, improvement of ODS, as well as prevention of occupational diseases, accidents and accidents; protection;

- registration and resolution of any conditions related to working conditions and

- Organization of work on making proposals and ensuring the implementation of decisions, improving labor protection, certification of workplaces for working conditions;

- checking the implementation of decisions taken, managing the elimination of nonconformities;

- systematic analysis of the report on the functioning of the Occupational Health and safety management system and its use by the organization's management in order to improve the specified system. 
The implementation of these functions is assigned to a specialist who has the appropriate training and qualifications. These functions go beyond the duties of an occupational health and safety engineer, by their very nature they correspond to the functions of a manager and can be performed by a person with extensive knowledge in the field of management management of an organization.

\section{References:}

[1] Belov, P.G. System analysis and modeling of dangerous processes in the technosphere: Textbook for students. higher. studies'. institutions / - M.: publishing center "Academy", 2003. - 8 p.

[2] Balandina, E.A. quality management System of labor protection in higher education: textbook. manual / publishing house of Vladimir state. UN-TA, 2008. - $72 \mathrm{p}$.

[3] Labor Code Of The Republic Of Kazakhstan. 23.11.2015, №414. - V, Almaty, 2016. -264 p.

[4] ST RK 12.0.005-2016 Occupational safety standards system. https://online.zakon.kz/ Document/?doc_id=39512126.

[5] ST RK OHSAS 18001-2008 Occupational health and safety management system. https://online.zakon.kz/document/?doc_id=30541508.

[6] Tanzharykov, P.A., Abdrakhmanov S.T., Sarabekova Yu.Z. Occupational safety and environmental protection in the oil and gas industry / Textbook - Kyzylorda, "Tumar", 2009. -352 pp. ISBN 978-601-229-097-4.

[7] The ophilus, Stephen C. Human factors analysis and classification system for the oil and gas industry (HFACS-OGI) [Text]/Stephen C. Theophilus, Victor N. Esenowo, Andrew O. Arewa, Augustine O. Ifelebuegu //Reliability Engineering and System Safety - Elsevier, 2017. - Vol. 62 . - PP. 168-176.

[8] Nosenko, A.M. Research and methodology for assessing occupational risks in organizations of the petrochemical complex [Electronic resource] // Electronic periodical "Alley of Science". - Electron. zhurn. - 2018. - No. 5. systems.

[9] Occupational safety standards system GOST 12.0.230-2007. Occupational safety management

[10] Bulavka, Yu.A. Risk assessment of the impact of harmful and dangerous production factors on the health of refinery workers (on the example of the production of lubricants, bitumen and additives): author. dis. Cand. technological. Sciences: 05.26.01 / Yu.A. Pin; Polotsk state un-t. - Novopolotsk, 2013. $-24 \mathrm{p}$.

[11] Tanzharikov, P.A., Sarabekova U.Zh.,Tanzharikova G.P. Evaluation of economic efficiency of oil waste recycling technology. Science journal of "Actual Problems of Economics". Ukraine . № 1 2014., -P. 340-346.

[12] Tanzharikov, P., Ayfer Erken, Abilbek Zh., Sarabekova U.Zh., Ermukhanova N. The technology of preparation of the oil sludge pit with polymerorganic screen for oil waste. ARPN Journal of Engineering and Applied Sciences. VOL. 13. 2018, pp. 4360-4364.

[13] Ryskaliyev, M.Z., Zharylgapov, S.M., Saktaganova, N.A., Sarabekova, U.Zh., Yerimbetov, K.A. Physico-mechanical properties of foam concrete with a keratin-based foaming agent. International Journal of Engineering and Advanced Technology, 2019, 8 (3), pp. 80-82.

[14] Ryskaliyev, M.Z., Zharylgapov, S.M., Saktaganova, N.A., Sarabekova, U.Z., Abdikerova, U.B. The influence of annealing temperature on variation of physicomechanical properties of wall ceramic tiles based on loess loam modified by oil sludge. ARPN Journal of Engineering and Applied Sciences, 2020, 15(22), стр. 2713-2721.

[15] Aldungarova, A., Sarabekova, U., Zhusupbekov, A., Tanaka, T., Tanzharikov, P. The influence of experimental studies on the stability of hydraulic structures. IOP Conference Series: Materials Science and Engineering, 2021, 1030(1), 012113.

\section{МҰНАЙ-ГАЗ САЛАСЫНДАҒЫ ӨНДІРІСТІК ТӘУЕКЕЛДЕР}

Таңжарықов П.А., техника ғылымдарының кандидаты

Сарабекова Ұ.Ж., $\mathrm{PhD}$

Жиенбекова Ж.Е., магистрант 
Андатпа. Бұл мақалада өндірістік тәуекел көрсеткіштері бойынша еңбекті қорғауды бағалау үшін модульдерде бар ақпарат бойынша өндірістік тәуекелдің бірқатар көрсеткіштерін есептеу арқылы еңбекті қорғау және экология жағдайына жедел баға беру жолдары ұсынылады. Авторлар ұсынып отырған еңбекті қорғауды басқару жүйесіне арналған бағдарламалық қамтамасыз етуді төрт негізгі модульден тұратын «Қызметкерлер», «Оқиғалар», «Жабдықтар» және «Экология» модульдерден нақты тапсырма негізінде пайдаланудың тиімділігі дәлелденген.

Сонымен қатар, аталған жұмыста еңбекті қорғауды басқару жүйесінде отандық және шетелдік тәжірибеде қолданылатын жұмыскерлер үшін кәсіби қауіптердің алдын алудың және бағалаудың «Оқиғаның ықтималдығы немесе оқиғаның салдары» координаталар жүйесіндегі қауіпті бағалаудың матрицалық әдістері салыстырылған. Өнеркәсіп орындарында шикізатты өндіру, пайдалану және тасымалдау кезінде болатын апаттардың зиянды факторларын ьалдау және Қазақстан Республикасы стандарттары талаптарына сәйкестігін бағалау жұмыстары үздіксіз жүргізіліп отыруы тиіс. Өндіріс орындарындағы қызметкерлердің қауіпсіз еңбек жағдайын жасау, сондай-ақ жұмыскердің кәсіптік ауруларын болдырма еңбекті қорғау қызметінің басты мақсаты болып табылады. Осыған байланысты еңбекті қорғаудың жай-күйін есепке алу, талдау және бағалау, сондай-ақ еңбек қауіпсіздігін басқару жүйесі жұмыс жасауы тиіс.

Кілт сөздер: еңбекті қоргау, еңбек қауіпсіздігін басқару жүйесі, өндірістік тәуекел, жазатайьм оқива, кәсіптік ауру, сапа менеджмент жүйесі, құуіпті талдау.

\title{
ПРОИЗВОДСТВЕННЫЕ РИСКИ В НЕФТЕГАЗОВОЙ ОТРАСЛИ
}

\author{
Танжарыков П.А., кандидат технических наук \\ Сарабекова У.Ж., $\mathrm{PhD}$ \\ Жиенбекова Ж.Е., магистрант \\ Жұмабек Ж., студент
}

Кызылординский университет имени Коркыт Ата, г. Кызылорда, Республика Казахстан,

Аннотация. В данной статье предложены пути оперативной оценки состояния охраны труда и экологии путем расчета ряда показателей производственного риска по имеющейся в модулях информации для оценки охраны труда по показателям производственного риска. Доказана эффективность использования предлагаемого авторами программного обеспечения для системы управления охраной труда на основе конкретного задания из модулей «Персонал», «События», «Оборудование» и «Экология», состоящих из четырех основных модулей.

Кроме того, в данной работе сопоставлены матричные методы оценки риска в системе координат «вероятность события или последствия события» предупреждения и оценки профессиональных рисков для работников, применяемых в отечественной и зарубежной практике в системе управления охраной труда. Работа по выявлению вредных факторов аварий при добыче, использовании и транспортировке сырья на промышленных предприятиях и оценке соответствия требованиям стандартов Республики Казахстан должна проводиться непрерывно. Главной целью службы охраны труда является создание безопасных условий труда работников на производственных предприятиях, а также предотвращение профессиональных заболеваний работников. В связи с этим должна работать система учета, анализа и оценки состояния охраны труда, а также управления безопасностью труда.

Ключевые слова: охрана труда, система менеджмента безопасности труда, производственный риск, несчастный случай, профессиональное заболевание, система менеджмента качества, анализ рисков 


\title{
DEVELOPMENT OF ROAD SURFACE BASED ON LOCAL RAW MATERIALS AND INDUSTRIAL WASTE
}

\author{
Titov M. M. ${ }^{1}$, doctor of technical sciences \\ agd tmm48@mail.ru.https://orcid.org/0000-0002-2894-0358 \\ Yerimbetov K. A. ${ }^{2}$, doctoral student \\ koktem1703@mail.ru. https://orcid.org/0000-0002-2894-0358 \\ ${ }^{1}$ Novosibirsk State University of Architecture and Civil Engineering, Novosibirk city, Russia \\ ${ }^{2}$ Humanitarian and Technical Institute "Akmeshit", Kyzylorda city, Republic of Kazakhstan
}

\begin{abstract}
Annotation. A review of the literature on the use of thermal power plants (TPPs) in the production of asphalt concrete was conducted. The advantages and disadvantages of asphalt concrete coatings are analyzed. According to experts, the reason lies in the violation of construction technology. And, in principle, the topics of ensuring compliance with construction standards and legislative regulation are among the most relevant in the construction of roads in Kazakhstan. The features of the use of asphaltresin-paraffin waste from oil fields and ash of the Kyzylorda thermal power plant as part of asphalt concrete in road construction are considered. The construction of the pavement with the use of asphalt concrete based on the composite binder system "Bitumen - asphalt concrete-tar-paraffin waste (ARPW) TPP ash" has been developed. Due to the stratification of the concrete mixture, the cement milk will be separated from the coarse aggregate, so the upper layer, which experiences the main loads and impacts from the wheels of cars, turned out to be without the main coarse aggregate. This subsequently led to its rapid wear and the formation of a rut. Cement concrete coating with all the positive aspects described below and obvious, and here, too, there are disadvantages of these types of coating, it is not the inability to open traffic immediately after the completion of construction and the need for expansion joints. The author reveals not only the advantages of asphalt concrete coatings, but also the disadvantage of asphalt mixtures in practical use in highways.
\end{abstract}

Keywords: asphalt-resinous-paraffin waste, asphalt concrete, road surface, ash from a thermal power plant.

Introduction. Road construction is one of the most large-tonnage industries, which makes us focus on the enormous need for raw materials, which, in turn, determines one of the directions and priorities of state activity [1]. The construction of highways of thestate significance is financed at the expense of the Republican budget or from the regional budget, if the roads are of regional or urban significance. As a result of the implementation of the subprogram, it is planned to increase the length of public roads by $50 \%$.

Today, the length of public roads of the Republic of Kazakhstan is 96 thousand $\mathrm{km}$, of which the republican network is 25 thousand $\mathrm{km}$, the local network is 71 thousand $\mathrm{km}$. In the period from 2021-2025, it is planned to build and reconstruct 12 thousand $\mathrm{km}$ of roads of the republican network in the road industry. 200 thousand people will be involved annually. By 2020, 13 thousand $\mathrm{km}$ of roads of the republican network have been reconstructed. This year, road construction works covered 4.7 thousand $\mathrm{km}$ of the republican network. Construction and reconstruction of 3.6 thousand $\mathrm{km}$ is in progress. By the end of the year, it is planned to put into operation -2.2 thousandkmand toopen traffic for 1.2 thousand $\mathrm{km}$. Major and medium repairs covered 1.1 thousand $\mathrm{km}$ of roads. To date, 15 road projects are being implemented [1].

Currently, scientists and specialists in the field of road construction pay special attention to the quality of road construction, search for new effective solutions to further improve it, as well as increase the maintenance-free service life of hard surfaces. Moreover, asphalt concrete remains the main material for the construction of road coverings. To date, there are many manufacturing companies of various types of asphalt concrete in Kazakhstan. It is also produced 
on modular installations, which significantly increases the scale of application. However, like any other material, asphalt concrete and, accordingly, coatings from it, have their advantages and disadvantages [2-3] (Figure 1).

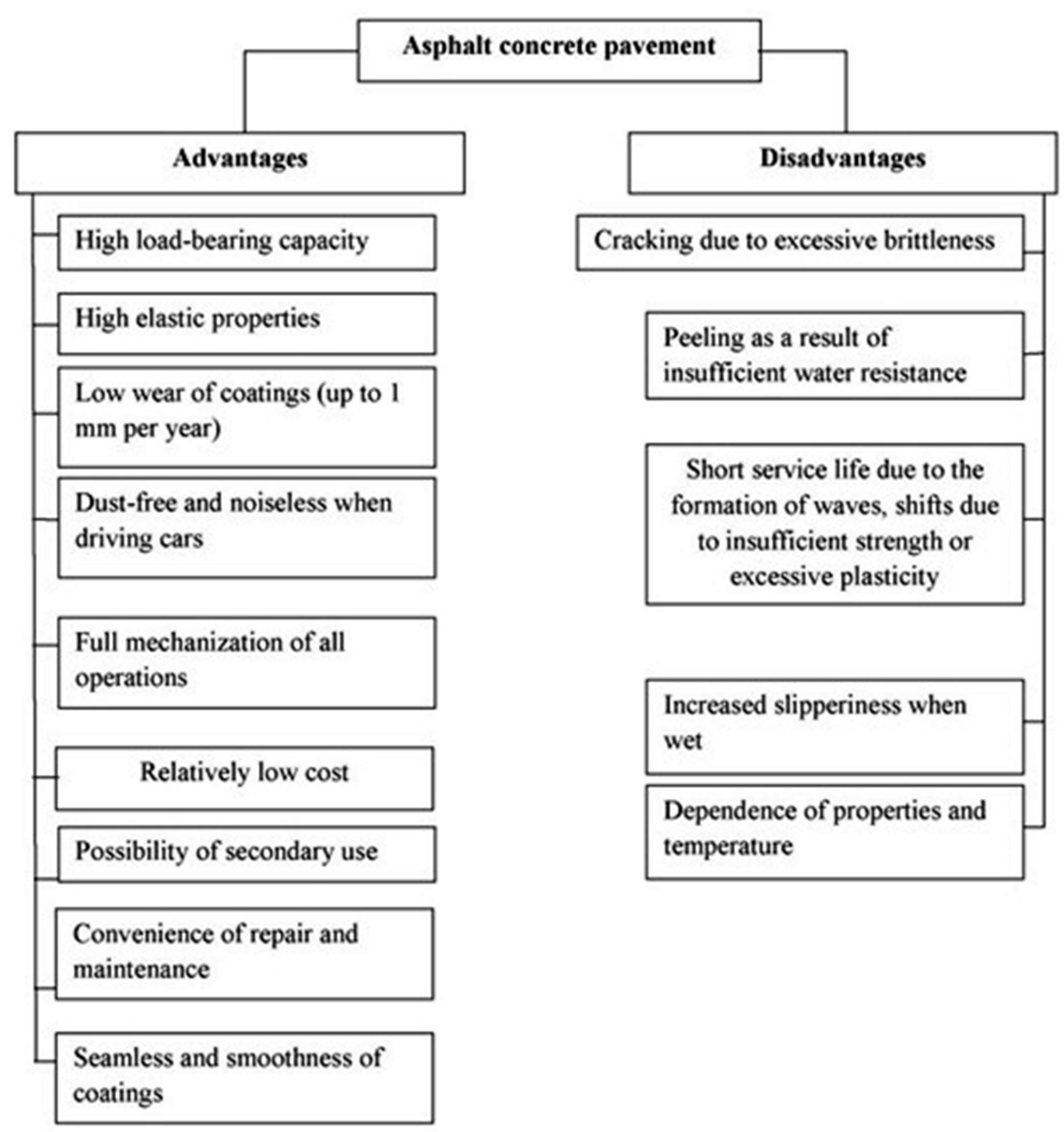

Figure 1-Advantages and disadvantages of asphalt concrete coatings

Compared with the cement-concrete coatings closest to them, they are distinguished by high evenness, good adhesion to the car wheel, and the absence of temperature seams. All this ensures the movement of not only an individual car, but also the entire traffic flow with a given standard speed of up to $150 \mathrm{~km} / \mathrm{h}$ and higher. According to the literature data, the number of roads with asphalt-concrete pavement,is about 97\% in comparison with cement-concrete analogues, on the roads of the general network. [4]. It is also a common practice to lay an asphalt concrete layer on top of a cement concrete coating after it has developed its resource instead of its major repairs, such an experience of reconstruction of roads with cement concrete coatings has found wide application both in our country and abroad [5].

Consequently, the primary task of the road industry remains to improve the quality and durability of asphalt concrete pavement [6]. The solution is the production and use of asphalt concrete with increased performance indicators and durability [7]. The improvement of the 
properties is possible both due to the influence on the characteristics of the raw materials components, and due to the influence on the properties of the composite itself.

Research methods. Determination of the specific ash surface of the Kyzylorda CHPP (Ssp, cm2 / g) was carried out on a PSX-12 (SP) device, which also makes it possible to determine the average particle size $(\mathrm{d}, \mu \mathrm{m})$. The principle of operation of the device is based on the dependence of the air permeability of the powder layer on the value of its specific surface area (Table 1).

Table 1 - Specifications IICX-12 (SP)

\begin{tabular}{|l|l|}
\hline Instrument characteristics & Values \\
\hline Specific surface measurement range, $\mathrm{cm} 2 / \mathrm{g}$ & $200-50000$ \\
\hline Measurement range of mass-average particle size, $\mu \mathrm{m}$ & $0,5-200$ \\
\hline Hardware error, no more, $\%$ & \pm 3 \\
\hline
\end{tabular}

The determination of the specific effective activity of natural radio nuclides of technogenic raw materials was carried out in accordance with GOST 30108-94, SanPiN 2.6.1.2523-09 and NRB-99/2009 [8,9] using the gamma-beta-spectrometric complex "Progress BG" 4. The complex includes: GEM-40190-S detection system based on high-purity germanium semiconductor; spectrometric amplifier and multichannel pulse analyzer 92X "Spectrum Master"; spectrum visualization and processing system.

Determination of the true density, average density, porosity, an indicator of bitumen capacity and ash moisture content as bitumen fillers was carried out in accordance with GOST R 52129-2003 [10].

Determination of the physical and mechanical characteristics of bitumen was carried out in accordance with GOST 11501-78 [11], GOST 11505-75 [12], GOST 11506-73 [13], GOST 11507-78 [14].

Rheological characteristics of bitumen using a vibratory rotary viscometer Rheotest RN4.1 and a plate / plate measuring system. For measurements, a plate with a diameter of 36 $\mathrm{mm}$ with a viscosity measurement range of $100-10 \mathrm{mPa} * \mathrm{~s}$ was used.

Determination of physical and mechanical characteristics of large and small aggregates for asphalt concrete mixture was carried out according to standard methods in accordance with GOST 8269.0-97, GOST 8735-88 [15].

The method of laboratory research of asphalt concrete provided for a series of tests in accordance with GOST 12801-2013 [24] on samples obtained by compaction of mixtures in a molding machine, followed by comparison of the results with regulatory requirements.

Rutting resistance of asphalt concrete was determined using an InfraTestPrutechnik GmbH6 wheel load tester (Germany) in accordance with the European standard EN 12697-22. This device allows you to simulate the operating conditions of asphalt concrete under the action of a load from a moving vehicle (wheel load).

Great attention is paid to the design of road construction materials, construction and repair of asphalt concrete pavements all over the world, since as a result of operation, asphalt concrete pavements are subjected to very serious external influences: the force effect of loads from the wheels of cars, atmospheric precipitation in the form of rain and snow, as well as temperature changes occurring over time, freezing and thawing, etc.

The main reasons that cause surface destruction of asphalt concrete pavement are:

- the use of low-quality raw materials;

- an overdose of bitumen, which causes an increased fat content of the asphalt concrete mixture [5]; 
- violations in the technology of preparation of asphalt concrete mixture (poor mixing in the mixer), followed by the appearance of bitumen spots protruding on the surface of the coating;

- insufficient sealing (the sealing coefficient is lower than the norm for SNiP 3.06.03-85).

Therefore, for increasing the stability of asphalt concrete to real operating conditions, it is necessary to take into account a number of circumstances. It follows from the practice of road operation that the more crushed stone and binder in the composition of asphalt concrete, the more resistant it is to abrasion. The strength of crushed stone and its resistance to abrasion also has a significant impact on the wear process. The good adhesion of bitumen to the stone material and the optimal amount of the composite binder of the "Bitumen-asphalt-resinous-paraffin waste (ARPW) - ash of the TPP" system in the mixture contribute to better retention of small fractions of asphalt concrete on the surface of the layer. However even multi-crushed asphalt concretes made of high-strength crushed stone of the main chemical and mineralogical composition on modified bitumen are not able to resist the abrasive effect of studded automobile wheels.

The most characteristic type of destruction of asphalt concrete coatings (Figure 2) are cracks, potholes, patches, ruts, coloring, peeling, destruction of edges [16].
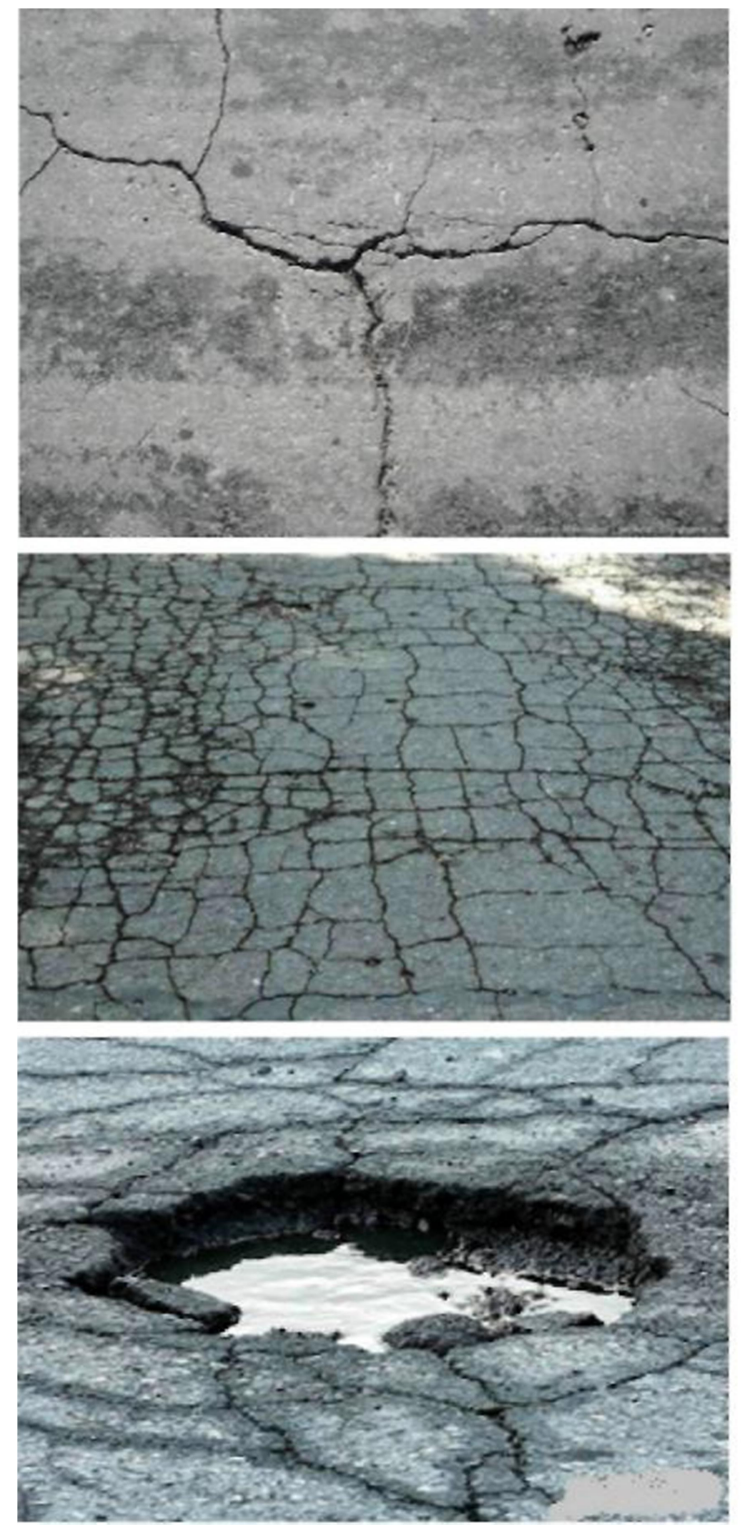
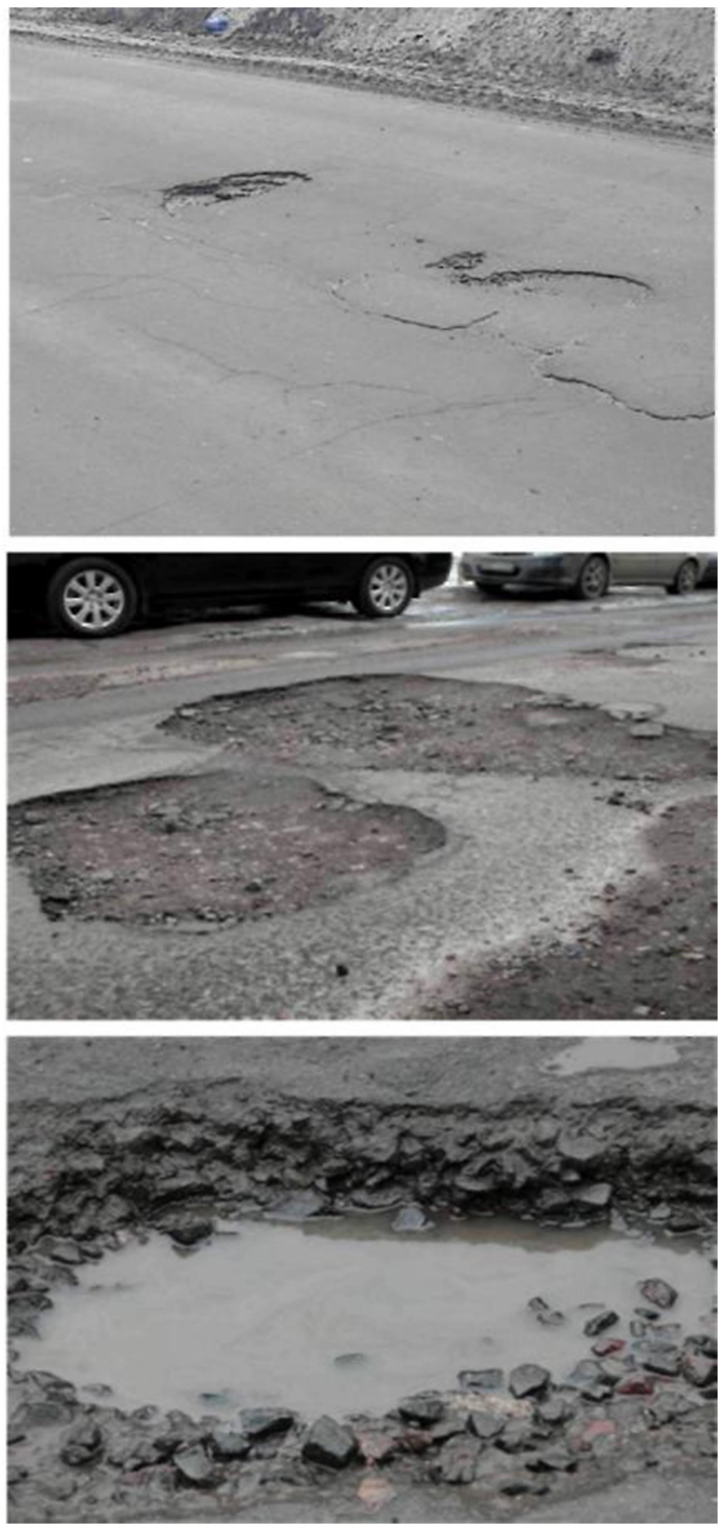

Figure 2-Types of destruction of asphalt concrete pavement 
Their appearance is associated with the impact of weather and climatic factors, transport loads and changes in the properties of materials over time and, due to untimely repair of the initial stage of damage, the damage area can reach up to $60-80 \%$ of the total coverage area [17, 18]. Therefore, the use of effective methods to combat cracking and shear resistance would increase the service life of coatings, reduce the cost of their maintenance and repair by increasing the resistance of layers to emerging cracks.

It is established that the rheological and strength properties of asphalt concrete, the types of pavement construction and operating conditions, as well as the strength of asphalt concrete are characterized by a pronounced time dependence on the degree of cracking and shear resistance of the asphalt concrete coating. And the intensity of relaxation processes during deformation and destruction of bituminous materials largely depends on the temperature and the level of acting stresses [19].

In general, the resistance of a material to the appearance of cracks and ruts of various types is determined by its following properties: thermal (coefficient of linear temperature expansion), deformation (relaxation modulus at a calculated low temperature), strength (ultimate structural strength) and fatigue (level of damage to the coating material) [20].

Study results and discussion. The analysis of a large number of scientific publications and regulatory literature allows us to conclude that there are many approaches to assessing the crack resistance and shear resistance of road surfaces. However, the dependence of the strength properties of asphalt concrete on the rheological properties of the binder forces us to focus on the influence of the components of the asphalt concrete mixture on this indicator. Since bitumen is the main rheological component of the mixture, the use of a good quality material or a modified analog will increase the defect-free period after laying the coating [21].

Thus, the study of the raw material base of road asphalt concrete must be carried out in a comprehensive manner. There are a number of problems and tasks in terms of providing highquality raw materials, from a detailed study of the properties to the consideration of the processes of interaction of the components of the mixture at the macro -, micro-and nanoscalein the modern road construction.

Turning to the discussion of the problems of raw components of asphalt concrete mix, it is worth focusing on the concept itself for a clear understanding of the existing problems of asphalt concrete and methods of their solution.

Asphalt concrete is an artificial building material obtained after compaction of an asphalt concrete mixture prepared in mixers in a heated state and including rationally selected mineral materials (crushed stone, sand, mineral powder) and bitumen [22-26]. The most valuable advantage of asphalt concrete, according to $\mathrm{Yu}$. M. Bazhenov, is the absence of water in its composition, this ensures a high density and impermeability of the material [26].

In the cost of production of asphalt concrete mixes, the material consumption of products is the largest part $-82 \%$. The annual increase in the cost of materials (including crushed stone, mineral powder and bitumen) and energy resources leads to an increase in the cost of asphalt concrete mixtures by an average of $25.2 \%$ [27]. This circumstance makes it necessary to study in detail the market of the raw material base of road asphalt concrete, and to identify existing problems and methods of their solutions.

The following components can be distinguished in the structure of the asphalt-concrete mixture: large and small aggregate, the main function of which is to create a high-strength frame of the mixture, mineral powder, the main purpose of which is to fill the pore space between the grains of small and large aggregates, as well as to bring bitumen into a film state, and binder, the essence of which consists in "gluing" the particles of the inorganic part of the asphalt-concrete mixture. 
The choice of specific components of the asphalt concrete mixture and the technical requirements imposed on them are determined by the role of the components in the structure of asphalt concrete, its purpose and properties [28].

As a large aggregate, crushed stone or gravel from rocks of igneous, sedimentary and metamorphic origin, as well as from some varieties of weather-resistant and durable slags, are traditionally used. Being a macrostructural unit, a large aggregate forms the frame of asphalt concrete. This component is fundamental, it makes up about $85 \%$ of the mass of the mixture and, accordingly, high requirements are imposed on its quality, which, in turn, depend on both the production method and the origin.

To solve the problems of recycling and the basis of the literature review, we have developed a new design [29] and compositions of an asphalt-concrete mixture based on asphaltresinous-paraffin waste (ARPW) and ash of the Kyzylorda of heat and electric central (HEC).

The compositions of asphalt concrete mixtures based on the above-mentioned secondary raw materials components are proposed, which allow producing asphalt concrete of type B with compressive strengths at temperatures of 50,20 and $0{ }^{\circ} \mathrm{C}$ of 2.2-2.9 $\mathrm{MPa}, 4.4-6.2 \mathrm{MPa}$ and 9.79.9 $\mathrm{MPa}$, respectively; shear resistance according to the coefficient of internal friction of 0.85 and water resistance under prolonged water saturation of $0.75-0.85$. Figure 3 illustrates the structure of the road surface with the use of asphalt concrete based on a composite binder of the "Bitumen - ARPW - ash HEC" system.

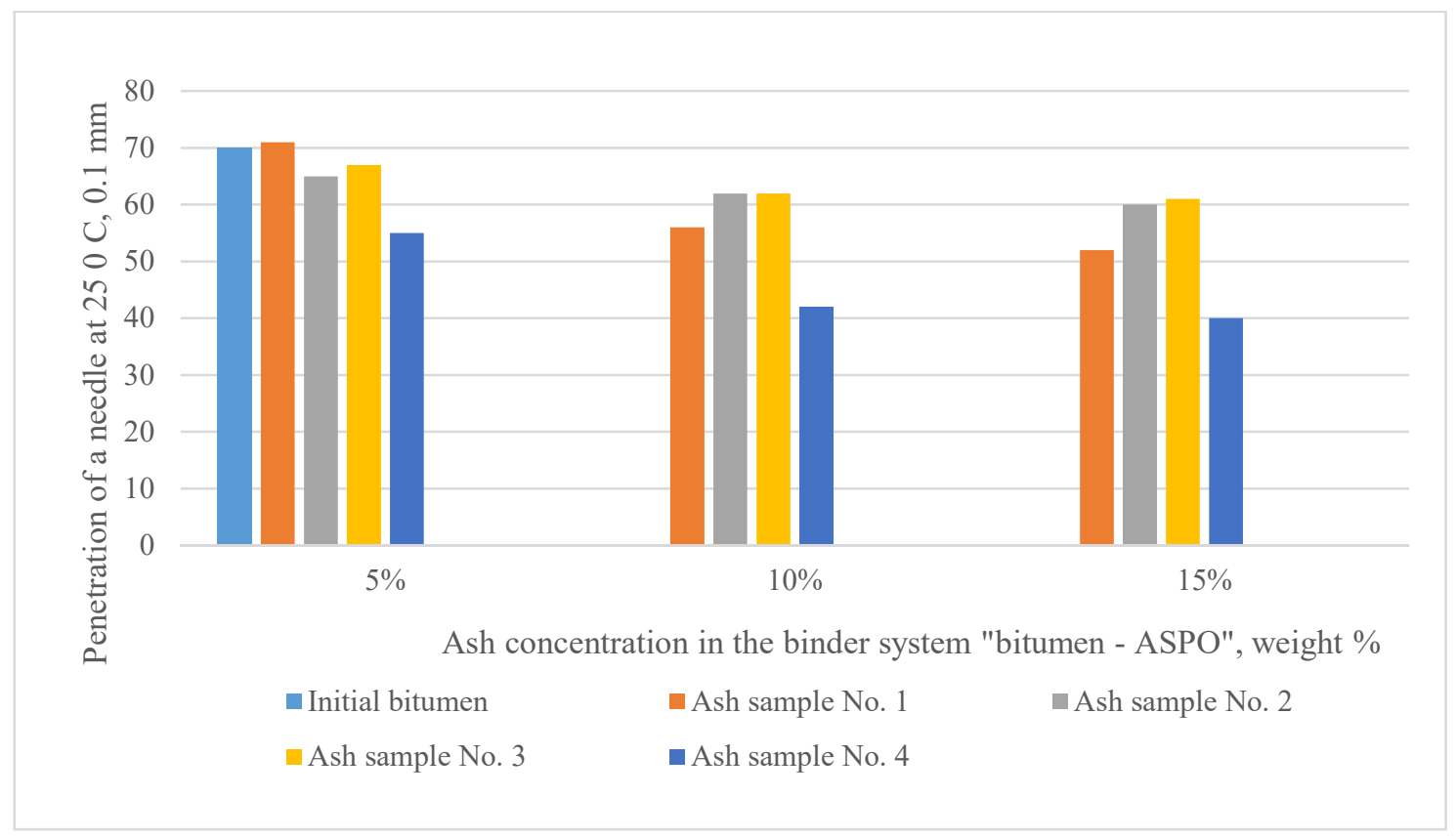

Figure 3- Dependence of the depth of penetration of the needle into the binding system "bitumen - ASPO" on the ash content

At the first stage, the physical and mechanical characteristics of the binder "ash-bitumenASPO" were studied. For bitumen used in road construction, both original and modified, a number of requirements are imposed, standardized by GOST 22245-90. The most important are the following characteristics (table 4.1): penetration depth of the needle (penetration), softening temperature along the ring and ball, extensibility (ductility), brittleness temperature, penetration index. In this work, we used road bitumen grade 60/90. 
The main characteristic of the structural and mechanical properties of road bitumen is viscosity, which depends primarily on temperature and group composition. Viscosity characterizes the ability of the inner layers of bitumen to resist movement relative to each other.

However, in accordance with GOST 11501-78 "Petroleum bitumens. The method for determining the penetration depth of the needle "determines the inverse viscosity, i.e. bitumen fluidity, characterized by a conditional indicator - the depth of penetration of the needle (penetration).

The depth of penetration of the needle into the bitumen was determined under the action of a load of $100 \mathrm{~g}$ for $5 \mathrm{~s}$ at a temperature of $+25^{\circ} \mathrm{C}$ or at $0^{\circ} \mathrm{C}$ under the action of a load of 200 $\mathrm{g}$ for $60 \mathrm{~s}$. Depending on temperature, load and duration of needle penetration, the value of penetration changes significantly.

It should also be noted that the higher the bitumen penetration at a given softening temperature and the higher the bitumen softening temperature at a given penetration, the higher its heat resistance.

With the use of the Kyzylorda CHPP in the amount of 5\%, the decrease in ash production becomes more noticeable. For ash, penetration is reduced by $31 \%$, in contrast to the original bitumen. An increase in the ash concentration of the Kyzylorda CHPP in the composition of the binder up to $10 \%$ leads to the following results. Penetration is reduced by $10 \%$ compared to the original bitumen. However, the needle penetration values continue to correspond to the 60/90 grade. When $10 \%$ ash is added to bitumen, penetration is reduced by $20 \%$, so the binder already corresponds to bitumen in viscosity of $40 / 60$, but tends to the upper limit.

After determining the rheotechnological properties of the binder system "bitumen ASPO - ash from the CHP plant", a pavement structure was designed based on the developed composite binder (Figure 4).

a)

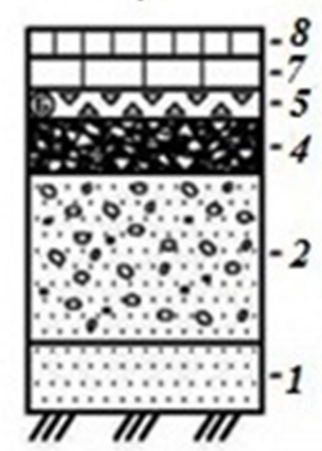

b)

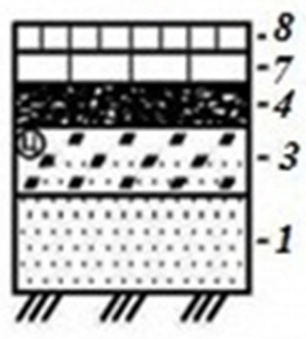

c)

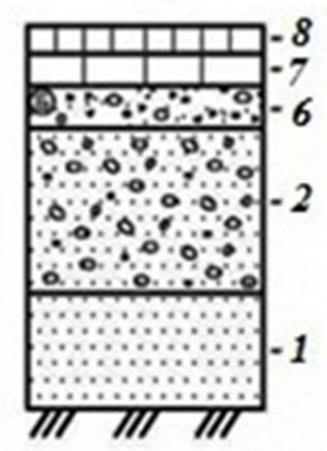

Figure 4 - Structures of road surfaces with the use of asphalt concrete based on a composite binder of the "Bitumen - ARPW - ash HEC" system

a) asphalt concrete pavement on a gravel base;

c) asphalt concrete coating on a base of crushed stone treated in the installation with organic binders, and soil reinforced with bitumen and cement concrete; c) asphalt concrete coating on a gravel base.

1 - an additional (frost - proof, draining) layer of the base made of sand, gravel, slag or frost - resistant local stone materials; its thickness is assigned by calculation; 2-crushed stone layer; 3 - soil reinforced with additives of inorganic binders; 4 - crushed stone treated with organic binders in the installation; 5 - medium - grained, fine - grained or sandy asphalt concrete; 6-gravel mixture with crushed stone additives treated with binders in the installation; 7-coarse-grained asphalt-concrete mixture based on a composite binder of the Bitumen - ARPW 
- ash HEC; 8-asphalt-concrete mixture based on a composite binder of the "Bitumen - ARPW ash HEC" system.

In parallel, the physicomechanical properties of asphalt concrete based on the binding system "bitumen - ASPO - CHP ash" were determined experimentally.

Table 2. Physical and mechanical properties of asphalt concrete using ash from thermal power plants

\begin{tabular}{|c|c|c|c|}
\hline Indicators & $\begin{array}{l}\text { Requirements of } \\
\text { GOST 9128-2013 } \\
\text { for type B }\end{array}$ & $\begin{array}{l}\text { Pure } \\
\text { bitumen }\end{array}$ & $\begin{array}{l}\text { Using ash from the } \\
\text { Kyzylorda thermal power } \\
\text { plant }\end{array}$ \\
\hline $\begin{array}{l}\text { Compressive strength, } \mathrm{MPa} \text { : } \\
\text { - at a temperature of } 50^{\circ} \mathrm{C} \\
\text { - at a temperature of } 20^{\circ} \mathrm{C} \\
\text { - at a temperature of } 0^{\circ} \mathrm{C}\end{array}$ & $\begin{array}{l}\text { not less than } 0.9 \\
\text { not less than } 2.0 \\
\text { no more than } 12.0\end{array}$ & $\begin{array}{l}1,6 \\
3,9 \\
10,1\end{array}$ & $\begin{array}{l}2,5 \\
4,22 \\
9,9\end{array}$ \\
\hline $\begin{array}{l}\text { Shear resistance by: } \\
\text { - coefficient of internal friction } \\
\text { - shear adhesion at a temperature of } \\
50^{\circ} \mathrm{C} \\
\text { Crack resistance in terms of ulti-mate } \\
\text { tensile strength during split-ting at a } \\
\text { temperature of } 0^{\circ} \mathrm{C}, \mathrm{MPa}\end{array}$ & $\begin{array}{l}\text { not less than } 0.80 \\
\text { not less than } 0.34\end{array}$ & $\begin{array}{l}0,84 \\
0,75\end{array}$ & $\begin{array}{l}0,87 \\
0,69\end{array}$ \\
\hline $\begin{array}{l}\text { Crack resistance in terms of ultimate } \\
\text { tensile strength during splitting at a } \\
\text { temperature of } 0^{\circ} \mathrm{C}, \mathrm{MPa}\end{array}$ & $\begin{array}{l}\text { not less than } 2.5 \\
\text { and } \\
\text { no more than } 7.0\end{array}$ & 4,1 & 4,2 \\
\hline Water resistance & not less than 0.75 & 0,90 & 0,98 \\
\hline Water saturation, $\%$ & from 1.5 to 4.0 & 1,8 & 1,52 \\
\hline Swelling, $\%$ & - & 0,02 & 0,002 \\
\hline Long-term water resistance & $\begin{array}{l}\text { not less than } 0.80 \\
\text { not less than } 0.34\end{array}$ & 0,78 & 0,90 \\
\hline
\end{tabular}

Conclusion. A technology for the production of asphalt concrete based on asphaltresinous-paraffin waste and ash from the Kyzylorda thermal power plant has been developed. In order to implement the obtained research results, the following regulatory documents have been worked out: recommendations for the use of ash of various compositions as additives structuring bitumen; technological regulations for the production of asphalt concrete using the indicated raw materials.

\section{Literature}

[1] https://www.primeminister.kz/ru/news/do-2025-goda-vse-dorogi-respubliki-budut-obespecheny-pridorozhnym-servisom-miir-rk-631548.

[2] Государственная программа инфраструктурного развития «Нурлыжол», 2020 г.

[3] Положение государственного учреждения "Управление индустриальноинновационного развития Кызылординской области". https:/adilet.zan.kz/rus/docs/V15L0005041. 2015. 
[4] Столяров, В.В. Оптимизация числа полос движения на сети дорог национального и регионального значения на основе требуемого уровня надежности сети / В.В Столяров, Д.М. Немчинов // Строительные материалы. - 2014, № 11. - С. 3 - 7.

[5] Ушаков, В.В. Перспективы и эффективность применения цементобетона в дорожном строительстве // Наука и техника в дор. отрасли. - 2002, № 4.

[6] Ремонт асфальтобетонных покрытий автомобильных дорог. Обзорная информация // Автомобильные дороги и мосты. - 2004, № 5. - 37с.

[7] Левитин, И.Е. Повышение эффективности строительства и эксплуатации автомобильных дорог // Совещание по вопросу повышения эффективности строительства и эксплуатации автомобильных дорог. - М. - 30.05.2011.

[8] ГОСТ 30108-94 Материалы и изделия строительные. Определение удельной эффективной активности естественных радионуклидов. - Введ. 30.06.1994. - М.: Изд-во стандартов, 1994. - 4c.

[9] Нормы радиационной безопасности НРБ-99/2009, Санитарные правила и нормативы СанПиН 2.6.1.2523-09.

[10] ГОСТ Р 52129-2003 Порошок минеральный для асфальтобетонных и органоминеральных смесей. Технические условия. - Введ. 27.06.2003. - М.: Изд-во стандартов, 2003. $-22 \mathrm{c}$.

[11] ГОСТ 11501-78 Битумы нефтяные. Метод определения глубины проникания иглы. Введ. 01.01.1980. - М.: Стандартинформ, 2005. - 5c.

[12] ГОСТ 11505-75 Битумы нефтяные. Метод определения растяжимости. - Введ. 01.01.1977. - М.: Изд-во стандартов, 1993. - 4c.

[13] ГОСТ 11506-73 Битумы нефтяные. Метод определения температуры размягчения по кольцу и шару. - Введ. 07.01.1974. - М.: Изд-во стандартов, 2003. - 5с.

[14] ГОСТ 11507-78 Битумы нефтяные. Метод определения температуры хрупкости по Фраасу. - Введ. 01.01.1980. - М.: Изд-во стандартов, 1993. - 4c.

[15] ГОСТ 8735-88 Песок для строительных работ. Методы испытаний. - Введ. 01.11.2014. -М: Изд-во стандартов, 2014. - 55 с.

[16] Леонович, И.И. Диагностика и управление качеством автомобильных дорог: учеб. пособие / И.И. Леонович, СВ. Богданович, И.В. Нестерович. - Минск: Новоезнание, 2011, - 350 с.

[17] Носов, В.П. Увеличение сроков службы дорожных одежд - стратегическая задача дорожной науки // Автомобильные дороги. - 2006, № 12. - С. 81 - 86.

[18] Гридчин, А.М. Оценка воздействия климатических факторов на асфальтобетон / А.M. Гридчин, Г.С. Духовный, А.Н. Котухов, А.С. Погромский // Вестник Белгородского государственного технологического университета им. В.Г. Шухова. - 2003, № 5. - С. 262.

[19] Волков, М.И. Дорожно-строительные материалы / М.И. Волков, И.М. Борщ, И.М. Грушко, И.В. Королев. - М.: Транспорт, 1975, - 527 с.

[20] Веренько, В.А. Деформации и разрушения дорожных покрытий: причины и пути устранения / В.А. Веренько. - Минск: БеларускаяЭнцыклапедыяімяП. Броукі, 2008, - 304 с.

[21] Поздняева, Л.В. Ловушка для трещин / Л.В. Поздняева, Л.А. Горелышева // Автомобильные дороги. - 2010, № 8. - С. $78-81$.

[22] Грушко, И.М. Дорожно-строительные материалы: учебник для автомобильнодорожных институтов / И.М. Грушко, И.В. Королев, И.М. Борщ, Г.М. Мищенко. - М.: Транспорт, $1983,-383$ c.

[23] Котлярскш, Э.В. Строительно-технические свойства дорожного асфальтового бетона: учебное пособие / Э.В. Котлярский. - М.: МАДИ (ГТУ), 2004, - 192 с.

[24] Рыбъев, И.А. Строительное материаловедение / И.А. Рыбьев. - М.: Высшая школа, $2004,-701 \mathrm{c}$.

[25] Горчаков, Г.И. Строительные материалы: учеб. для вузов / Г.И. Горчаков, Ю.М. Баженов. - М.: Стройиздат, 1986, - 688 с.

[26] Баженов, Ю.М. Технология бетона: учебник / Баженов Ю. М. - 5-е издание. - Москва : Издательство АСВ, 2015, - 528 с.

[27] Буртан, С.Т. Состав и свойства минерального остова в связи с проблемой управления качеством асфальтобетона / СТ. Буртан, С.К. Мустафин // Дорожная техника. - 2010, - С. 20 - 27. 
[28] Гридчин, А.М. Асфальтобетон с использованием гидравлически активных минеральных порошков: учебное пособие / А.М. Гридчин, В.В. Ядыкина, М.А. Высоцкая, Д.А. Кузнецов. - Белгород: Изд-во БГТУ, 2006, - 163 с.

[29] Патент на полезную модель № 4751. Дорожное покрытие. Удербаев С.С., Еримбетов К.А.. РГП «Национальный институт интеллектуальной собственности» МЮ РК, 03.03.2020 г.

\section{References:}

[1] https://www.primeminister.kz/ru/news/do-2025-goda-vse-dorogi-respubliki-budut-obespecheny-pridorozhnym-servisom-miir-rk-631548.

[2] Gosudarstvennaya programma infrastrukturnogo razvitiya «Nurlyzhol», $2020 \mathrm{~g}$.

[3] Polozhenie gosudarstvennogo uchrezhdeniya "Upravlenie industrial'no-innovacionnogo razvitiya Kyzylordinskoj oblasti". https://adilet.zan.kz/rus/docs/V15L0005041. 2015.

[4] Stolyarov, V.V. Optimizaciya chisla polos dvizheniya na seti dorog nacio $\neg$ nal'nogo i regional'nogo znacheniya na osnove trebuemogo urovnya nadezhnosti se $\neg$ ti / V.V Stolyarov, D.M. Nemchinov // Stroitel'nye materialy. - 2014, № 11. - S. 3-7.

[5] Ushakov, V.V. Perspektivy i effektivnost' primeneniya cementobetona $\mathrm{v}$ dorozhnom stroitel'stve // Nauka i tekhnika v dor. otrasli. - 2002, № 4.

[6] Remont asfal'tobetonnyh pokrytij avtomobil'nyh dorog. Obzornaya informaciya // Avtomobil'nye dorogi i mosty. - 2004, № 5. - 37s.

[7] Levitin, I.E. Povyshenie effektivnosti stroitel'stva i ekspluatacii avtomobil'nyh dorog // Soveshchanie po voprosu povysheniya effektivnosti stroi $\neg$ tel'stva i ekspluatacii avtomobil'nyh dorog. M. -30.05 .2011 .

[8] GOST 30108-94 Materialy i izdeliya stroitel'nye. Opredelenie udel'noj effektivnoj aktivnosti estestvennyh radionuklidov. - Vved. 30.06.1994. - M.: Izd-vo standartov, 1994. - 4s.

[9] Normy radiacionnoj bezopasnosti NRB-99/2009, Sanitarnye pravi $\neg$ la i normativy SanPiN 2.6.1.2523-09.

[10] GOST R 52129 - 2003 Poroshok mineral'nyj dlya asfal'tobetonnyh i or-ganomineral'nyh smesej. Tekhnicheskie usloviya. - Vved. 27.06.2003. - Mm.. Izd-vo standartov, 2003. - $22 \mathrm{~s}$.

[11] GOST 11501-78 Bitumy neftyanye. Metod opredeleniya glubiny pro $\neg$ nikaniya igly. - Vved. 01.01.1980. - M.: Standartinform, 2005. $-5 \mathrm{~s}$.

[12] GOST 11505-75 Bitumy neftyanye. Metod opredeleniya rastyazhimosti. - Vved. 01.01.1977. - M.: Izd-vo standartov, 1993. - 4s.

[13] GOST 11506 - 73 Bitumy neftyanye. Metod opredeleniya temperatury razmyagcheniya po kol'cu i sharu. - Vved. 07.01.1974. - M.: Izd-vo standartov, 2003. - 5s.

[14] GOST 11507 - 78 Bitumy neftyanye. Metod opredeleniya temperatury hrupkosti po Fraasu. - Vved. 01.01.1980. - M.: Izd-vo standartov, 1993. - 4s.

[15] GOST 8735 - 88 Pesok dlya stroitel'nyh rabot. Metody ispytanij. - Vved. 01.11.2014. -M.: Izd-vo standartov, 2014. $-55 \mathrm{~s}$.

[16] Leonovich, I.I. Diagnostika i upravlenie kachestvom avtomobil'nyh do $\neg$ rog: ucheb. posobie / I.I. Leonovich, SV. Bogdanovich, I.V. Nesterovich. - Minsk: Novoeznanie, 2011, - 350 s.

[17] Nosov, V.P. Uvelichenie srokov sluzhby dorozhnyh odezhd - strategiche $\neg$ skaya zadacha dorozhnoj nauki // Avtomobil'nye dorogi. - 2006, № 12. - S. 81 - 86 .

[18] Gridchin, A.M. Ocenka vozdejstviya klimaticheskih faktorov na asfal'to $\neg$ beton / A.M. Gridchin, G.S. Duhovnyj, A.N. Kotuhov, A.S. Pogromskij // Vestnik Belgorodskogo gosudarstvennogo tekhnologicheskogo universiteta im. V.G. SHuho ᄀva. - 2003, № 5. - S. 262.

[19] Volkov, M.I. Dorozhno-stroitel'nye materialy / M.I. Volkov, I.M. Borshch, I.M. Grushko, I.V. Korolev. - M.: Transport, 1975, - 527 s.

[20] Veren'ko, V.A. Deformacii i razrusheniya dorozhnyh pokrytij: prichiny i puti ustraneniya / V.A. Veren'ko. - Minsk: BelaruskayaEncyklapedyyaimyaP. Brouki, 2008, - 304 s.

[21] Pozdnyaeva, L.V. Lovushka dlya treshchin / L.V. Pozdnyaeva, L.A. Gorelysheva // Avtomobil'nye dorogi. - 2010, № 8. - S. $78-81$.

[22] Grushko, I.M. Dorozhno-stroitel'nye materialy: uchebnik dlya avtomo $\neg$ bil'no-dorozhnyh institutov / I.M. Grushko, I.V. Korolev, I.M. Borshch, G.M. Mishchenko. - M.: Transport, 1983, - 383 s. 
[23] Kotlyarsksh, E.V. Stroitel'no-tekhnicheskie svojstva dorozhnogo asfal' $\neg$ tovogo betona: uchebnoe posobie / E.V. Kotlyarskij. - M.: MADI (GTU), 2004, - $192 \mathrm{s.}$

$701 \mathrm{~s}$.

[24] Ryb"ev, I.A. Stroitel'noe materialovedenie / I.A. Ryb'ev. - M.: Vys $\neg$ shaya shkola, 2004, -

[25] Gorchakov, G.I. Stroitel'nye materialy: ucheb. dlya vuzov / G.I. Gorchakov, YU.M. Bazhenov. - M.: Strojizdat, 1986, - 688 s.

[26] Bazhenov, YU. M. Tekhnologiya betona: uchebnik / Bazhenov YU. M. - 5 - e izdanie. Moskva: Izdatel'stvo ASV, 2015, - 528s.

[27] Burtan, S.T. Sostav i svojstva mineral'nogo ostova v svyazi s problemoj upravleniya kachestvom asfal'tobetona / ST. Burtan, S.K. Mustafin // Dorozhnaya tekhnika. - 2010, - S. $20-27$.

[28] Gridchin, A.M. Asfal'tobeton s ispol'zovaniem gidravlicheski aktivnyh mineral'nyh poroshkov: uchebnoe posobie / A.M. Gridchin, V.V. YAdykina, M.A. Vysockaya, D.A. Kuznecov. Belgorod: Izd-vo BGTU, 2006, - 163 s.

[29] Patent na poleznuyu model' № 4751. Dorozhnoe pokrytie. Uderbaev S.S., Erimbetov K.A.. RGP «Nacional'nyj institut intellektual'noj sobstvennosti» MYU RK, 03.03.2020 g.

\section{РАЗРАБОТКА ДОРОЖНОГО ПОКРЫТИЯ НА ОСНОВЕ ПРОМЫШЛЕННЫХ ОТХОДОВ}

Титов М. М. ${ }^{1}$, доктор технических наук Еримбетов К. А. ${ }^{2}$, докторант

${ }^{1}$ Новосибирский государственный архитектурно-строительный университет, 2. Новосибирск, Россия

${ }^{2}$ Гуманитарно-технический институт «Акмешит», г. Кызылорда, Республика Казахстан

Аннотация. Был проведен обзор литературы по использованию тепловых электростанций (ТЭС) в производстве асфальтобетона. Проанализированы преимущества и недостатки асфальтобетонных покрытий. Рассмотрены особенности использования асфальто-смолопарафиновых отходов нефтяных месторождений и золы Кызылординской ТЭС в составе асфальтобетона при дорожном строительстве. Разработана конструкция дорожного покрытия с применением асфальтобетона на основе композиционного вяжущего системы «Битум - асфальтосмолисто-парафиновые отходы (АСПО) - зола ТЭС». Из-за расслоения бетонной смеси цементное молоко будет отделено от крупного заполнителя, поэтому верхний слой, который испытывает основные нагрузки и удары от колес автомобилей, оказался без основного крупного заполнителя. Это впоследствии привело к его быстрому износу и образованию колеи. Цементобетонное покрытие со всеми положительными сторонами, описанными ниже, и здесь тоже есть недостатки этих видов покрытия, такие недостатки строительства, привести в порядок до завершения строительство. Автор в статье раскрывает не только преимущества асфальтобетонных покрытий, но и недостатки асфальтобетонных смесей при практическом применении на автомобильных дорогах.

Ключевые слова: асфальто-смолисто-парафиновые отходы, асфальтобетон, дорожное покрытие, зола тепловой электростанции.

\section{ӨНЕРКӘСІПТІК ҚАЛДЫКТАР НЕГІЗІНДЕ ЖОЛ ЖАБЫНЫН ӘЗІРЛЕУ}

Титов М. М. ${ }^{1}$, доктор технических наук Еримбетов К. А. ${ }^{2}$, докторант

${ }^{1}$ Новосибирский государственный архитектурно-строительный университет, 2. Новосибирск, Россия

${ }^{2}$ Гуманитарно-технический институт «Акмешит», г. Кызылорда, Қазақ̧стан Республикасы 
Аннотация. Асфальтбетон өндірісінде жылу электр станцияларының (ЖЭО) күлін қолдану бойынша әдеби шолу жүргізілді. Асфальтбетон жабындарының артықшылықтары мен кемшіліктері талданды. Жолдарды салу кезінде асфальтбетон құрамында Қызылорда қаласының ЖЭО-ның күлі мен мұнай өндіру кен орындарынан бөлінген асфальт-шайырлы-парафинді қалдықтарын пайдалану ерекшеліктері қарастырылды. "Битум - асфальт-шайырлы-парафинді қалдықтар (АШПҚ) - ЖЭО күлі" жүйесінің композициялық тұтқыр заты негізінде асфальтбетонды қолданумен жол жабынының құрылымы әзірленді.

Бетон қоспасының стратификациясына байланысты цемент сұйығы ірі толықтырғыштан бөлінеді, сондықтан автомобиль доңғалақтарының негізгі жүктемелері мен соққыларына төтеп беретін жоғарғы қабат негізгі толықтырғыштармен қамтамасыз етілмей қалады. Бұл кейіннен оның тез тозуына және жолдың пайда болуына әкеледі. Цемент-бетон жабынының барлық артықшылықтары төменде сипатталған және нақты көрсетілген, сонымен қатар жабынның осы түрлерінің кемшіліктері де бар, мұндай кемшіліктерді құрылыс аяқталмай тұрып ретке келтіру қажет. Автор мақалада асфальтбетон жабындарының артықшылықтарын ғана емес, сонымен қатар автомобиль жолдарын іс жүзінде қолдану кезінде асфальт-бетон қоспасынан пайда болатын кемшіліктерін де ашып көрсеткен.

Кілт сөздер: асфальт-шайырль-парафинді құалдықтар, асфальтбетон, жол жабыны, жылу электр станциясының күлі. 


\title{
РЕЗУЛЬТАТЫ ПРЕДВАРИТЕЛЬНЫХ ИСПЫТАНИЙ ЗЕРНОУБОРОЧНОГО КОМБАЙНА ЛОВОЛ GМ-80
}

\author{
Мустафаев М.Г. ${ }^{\mathbf{1}}$, доктор аграрных наук \\ meliorasiya58@mail.ru,https://orcid.org/0000-0003-2071-3078 \\ Бекжанов С. $^{2}, \mathrm{PhD}$ \\ ser.bekzhanov@mail.ru https://orcid.org/0000-0002-7876-8779 \\ Дуйсембеков Б.А. ${ }^{3}$, кандидат биологических наук \\ b.duisembekov@mail.ru https://orcid.org/0000-0001-5743-1213 \\ Култасов Б.Ш.', докторант \\ bekzathan70@mail.ru, https://orcid.org/0000-0002-4682-553X \\ Шарипова Н.Е. ${ }^{2}$, магистрант \\ sn_nurai@mail.ru https://orcid.org/0000-0001-5393-4008 \\ ${ }^{1}$ Национальная академия наук Азербайджана \\ Институт Почвоведения и Агрохимии, Азербайджсанской Республики \\ ${ }^{2}$ Кызылординский университет имени Коркыт Ата, Республика Казахстан \\ ${ }^{3}$ ТОО «Агропарк Онтустик», Республика Казахстан
}

\begin{abstract}
Аннотация. В Казахском научно-исследовательском институте рисоводства имени Ы.Жахаева на полях сахарного сорго и риса при прямом комбайнировании успешно прошли полевые испытания 2 единицы малогабаритных зерноуборочных комбайнов ЛОВОЛ GM-80. Эти комбайны в основном предназначены для небольших хозяйств, имеющих небольшие посевные площади, а также уборки труднодоступных участков. Комбайн Lovol GM-80 - это комбайны новой конструкции, которые используются для уборки урожая, и изменяя некоторые специальные рабочие органы, могут убирать пшеницу, рис, рапс, сою и другие сельскохозяйственные культуры. Умный дисплей с 8 сенсорными экранами может легко отображать параметры рабочего состояния. На основании проведения предварительных испытаний ТОО «НИИ рисоводства им.И.Жахаева» рекомендует зерноуборочный комбайн ЛОВОЛ GM-80 в качестве прямого комбайнирования сахарного сорго, а также прямого комбайнирования риса в чеках, имеющие влажность почвы не более $16-18 \%$, влажность зерна риса не более $14 \%$, урожайность зерна риса не более 30 ц/га. Для дальнейшего изучения режимов работы зерноуборочного комбайна рекомендуется провести производственные испытания для диверсификационных культур (пшеница, ячмень, сафлор, соя и т.д.) рисового севооборота.
\end{abstract}

Ключевые слова: зерноуборочный комбайн, испытание, техническая экспертиза, производительность, агрофон.

Введение. Возросшие требования к обеспечению продовольственной безопасности РК и качественному возделыванию риса, требуют создания рисозерноуборочных комбайнов нового поколения. Эту важную задачу намечено решать путем внедрения современных технологий и комплексов машин для возделывания риса, что обеспечивает дальнейшее повышение качества продуктов, а также максимальную реализацию техникоэкономических показателей работы всей зерноуборочной техники [1,2].

Зерноуборочные комбайны - основное средство, применяемое в технологическом процессе традиционной уборки зерновых культур [3-7].

В Казахском научно-исследовательском институте рисоводства имени Ы.Жахаева в уборочный период успешно прошли предварительные испытания малогабаритных зерноуборочных комбайнов ЛОВОЛ GM-80 [8-10].

Роторный комбайн LOVOL GM-80 - предназначен для фермеров, малых хозяйств и уборки небольших, труднодоступных участков [11]. 
Компактность и маневренность делают этот комбайн незаменимым для эффективной работы на небольших полях. Также его габариты значительно упрощают передвижение от поля к полю.

Роторная система обмолота обеспечивает качественное и быстрое обмолачивание массы, благодаря чему комбайн, при своей компактности, имеет высокую производительность (рис. 1).

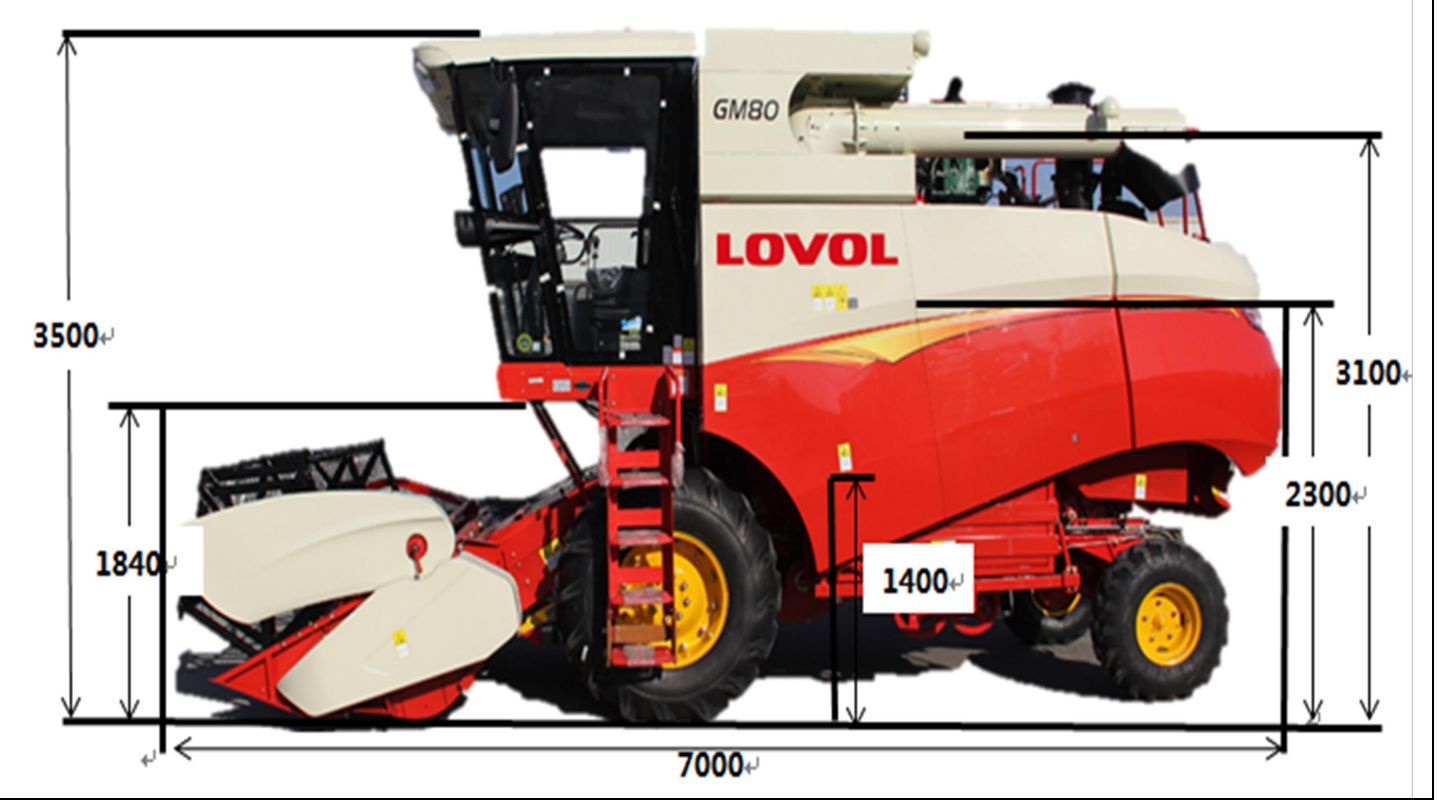

Рисунок 1 - Зерноуборочный комбайн LOVOL GM-80

LOVOL GM-80 - отличное соотношение производительности, доступной цены и небольших затрат на эксплуатацию [12].

Основные характеристики комбайна:

- комбайн рассчитан на уборку зерновых, риса, кукурузы и бобовых культур;

- $\quad$ мощность двигателя 175 л.с;

- $\quad$ зерновая жатка - 3,2 м;

- $\quad$ кукурузная жатка - 4 ряда (опция);

- $\quad$ система обмолота - роторная, с системой бесступенчатого регулирования скорости барабана;

- $\quad$ пропускная способность 8,0 кг/с;

- $\quad$ производительность до 1,3 га/ч.

Бункер зерноуборочного комбайна Lovol GM-80 составляет $\quad 2,6 \quad$ м $^{3}, \quad$ высота выгрузки - до 3 м, скорость выгрузки - 60 л/с.

Lovol GM-80 в базе комплектуется зерновой жаткой - 3,25 м, а также опционально доступна 4-х рядная жатка для уборки кукурузы. Мощность двигателя 170 л.с. передачами.

На комбайне установлена гидростатическая трансмиссия с 3-мя механическими

Достоинства зерноуборочного комбайна:

- наклонная камера шириной 90 см обеспечивает равномерную подачу зерновой массы на ротор;

- роторная система обмолота имеет простую конструкцию, которая обеспечивает бережный обмолот и высокую производительность; 
- конструкция ротора позволяет обмолотить массу без интенсивного травмирования зерна;

- система очистки комбайна имеет три каскада под обдувом, которые качественно очищают вымолоченное зерно;

- благодаря простоте конструкции роторной системы, на комбайне применяется минимальное количество приводных ремней;

- имеет простой доступ к зоне двигателя.

Техническая характеристика зерноуборочного комбайна LOVOL GM80 приведена в таблице 1.

Таблица 1 - Техническая характеристика LOVOL GM80

\begin{tabular}{|c|c|c|}
\hline № & Показатели & $\begin{array}{c}\text { Значение } \\
\text { показателей }\end{array}$ \\
\hline 1 & 2 & 3 \\
\hline 1 & Тип & $\begin{array}{l}\text { Т-образный } \\
\text { самоходный }\end{array}$ \\
\hline \multirow[t]{2}{*}{2} & Марка & LOVOL \\
\hline & Модель & GM80 (в капоте) \\
\hline 3 & Производительность по зерну за час основного времени, т/ч, не менее & $10,0-11,5$ \\
\hline 4 & Пропускная способность по хлебной массе (пшенице), кг/с, не менее & 8,0 \\
\hline \multirow[t]{4}{*}{5} & Потери зерна, \%, не более & \\
\hline & $\begin{array}{l}\text { а) за жаткой при уборке прямостоящих зерновых культур (степень } \\
\text { полеглости - до } 20 \% \text { ) }\end{array}$ & 0,5 \\
\hline & $\begin{array}{l}\text { б) за жаткой при уборке полеглых зерновых культур (степень } \\
\text { полеглости - более } 20 \text { \%) }\end{array}$ & 1,5 \\
\hline & в) за молотилкой & 1,5 \\
\hline \multirow[t]{3}{*}{6} & Дробление зерна, \%, не более: & \\
\hline & a) при уборке зерновых колосовых культур & 2,0 \\
\hline & б) при уборке зернобобовых культур & 3,0 \\
\hline \multirow[t]{2}{*}{7} & Содержание сорной примеси в зерновой массе бункера, \%, не более: & \\
\hline & - для колосовых, зернобобовых культур & 3,0 \\
\hline 8 & Ширина разбрасывания измельченной соломы, м, не более & 2,0 \\
\hline 9 & Количество обслуживающего персонала, чел. & 1 \\
\hline 10 & Коэффициент использования сменного времени, не менее & 0,65 \\
\hline 11 & Коэффициент надежности технологического процесса, не менее & 0,98 \\
\hline 12 & Рабочая скорость движения, км/ч & $1,84-11,5$ \\
\hline 13 & Транспортная скорость движения, км/ч, не более & 26,0 \\
\hline \multirow[t]{3}{*}{14} & Бункер зерновой & \\
\hline & а) конструктивное исполнение & $\begin{array}{c}\text { с автоматической } \\
\text { сигнализацией за- } \\
\text { полнения, с прину- } \\
\text { дительной } \\
\text { выгрузкой }\end{array}$ \\
\hline & б) объем, м $^{3}$, не менее & 2,6 \\
\hline 15 & Масса конструкционная (без учета транспортной тележки), кг & 7010 \\
\hline 16 & Минимальный внутренний радиус окружности поворота, м, не более & $5 ., 85$ \\
\hline 17 & Средний срок службы до списания, лет & 8 \\
\hline 18 & $\begin{array}{l}\text { Коэффициент готовности по оперативному } \\
\text { времени в основной рабочей комплектации, не менее }\end{array}$ & 0,96 \\
\hline 19 & Наработка на отказ II группы сложности, ч, не менее & 70 \\
\hline 20 & Удельная суммарная оперативная трудоемкость технических & \\
\hline
\end{tabular}




\begin{tabular}{|c|c|c|}
\hline & обслуживаний, чел·ч/ч, не более & 0,10 \\
\hline 21 & $\begin{array}{l}\text { Средняя оперативная трудоемкость ежесменного технического } \\
\text { обслуживания, чел·ч, не более }\end{array}$ & 0,10 \\
\hline 22 & $\begin{array}{l}\text { Удельная суммарная оперативная трудоемкость устранения отказов, } \\
\text { чел·ч/ч, не более }\end{array}$ & 0,02 \\
\hline 23 & $\begin{array}{l}\text { Средняя оперативная трудоемкость до сборки комбайна в условиях } \\
\text { мастерских с применением грузоподъемных средств, чел·ч, не более }\end{array}$ & 10 \\
\hline \multirow[t]{7}{*}{24} & Моторная установка: & \\
\hline & а) номинальная мощность двигателя, кВт, не менее & 129 \\
\hline & б) номинальная частота вращения коленчатого вала, об/мин & 2200 \\
\hline & $\begin{array}{l}\text { в) удельный расход топлива при номинальной мощности, г/кВт·ч, не } \\
\text { более }\end{array}$ & 250 \\
\hline & г) вместимость топливного бака, л & $260 \pm 15$ \\
\hline & д) охлаждение надувочного воздуха & в блоке радиаторов \\
\hline & е) охлаждение масла & нет \\
\hline \multirow[t]{4}{*}{25} & Молотильный аппарат: & \\
\hline & a) тип молотильного аппарата & $\begin{array}{l}\text { барабанный, } \\
\text { роторного типа }\end{array}$ \\
\hline & б) ширина молотилки, мм & 3145 \\
\hline & в) молотильный & $\begin{array}{c}\text { барабан бильный, с } \\
\text { бичами, левого и } \\
\text { правого } \\
\text { направления рифов }\end{array}$ \\
\hline 26 & Частота вращения вала барабана, об/мин & $275-1080$ \\
\hline 27 & Диаметр барабана, мм & 600 \\
\hline 28 & Число бичей & 10 \\
\hline 29 & Способ привода барабана & механический \\
\hline 30 & Способ регулирования частоты вращения & гидроуправление \\
\hline \multirow[t]{3}{*}{31} & Отбойный битер & \\
\hline & а) диаметр, мм & $400+10$ \\
\hline & б) номинальная частота вращения, об/мин & 795 \\
\hline \multirow[t]{3}{*}{32} & Подбарабанье & \\
\hline & а) тип подбарабанья & сетками \\
\hline & б) общая площадь сепарации подбарабанья, м², не менее & 2,75 \\
\hline \multirow[t]{4}{*}{33} & Выгрузной шнек & \\
\hline & а) частота вращения, об/мин, не менее & 850 \\
\hline & б) производительность выгрузного устройства, т/мин, не менее & 0,4 \\
\hline & в) высота конца выгрузного шнека, м, не менее & 3,1 \\
\hline \multirow[t]{4}{*}{34} & $\begin{array}{l}\text { Очистные устройства } \\
\text { а) площадь решет, м², не менее } \\
\text { - верхнего } \\
\text { - нижнего } \\
\text { - дополнительного } \\
\text { - удлинителя }\end{array}$ & $\begin{array}{c}14,5 \mathrm{~m}^{2} \\
14,5 \mathrm{M}^{2} \\
0,3 \mathrm{~m}^{2} \\
\text { нет }\end{array}$ \\
\hline & б) максимальное открытие жалюзи, угол & $45^{\circ}$ \\
\hline & в) длина колосовой надставки, мм, не менее & Нет \\
\hline & г) частота вращения вала вентилятора, об/мин & $990-1200$ \\
\hline 35 & Кабина & $\begin{array}{l}\text { одноместная, с } \\
\text { дополнительным } \\
\text { сиденьем }\end{array}$ \\
\hline \multirow[t]{2}{*}{36} & Жатка & \\
\hline & а) конструкционная ширина захвата жатки в основной комплектации,м & 3860 \\
\hline
\end{tabular}




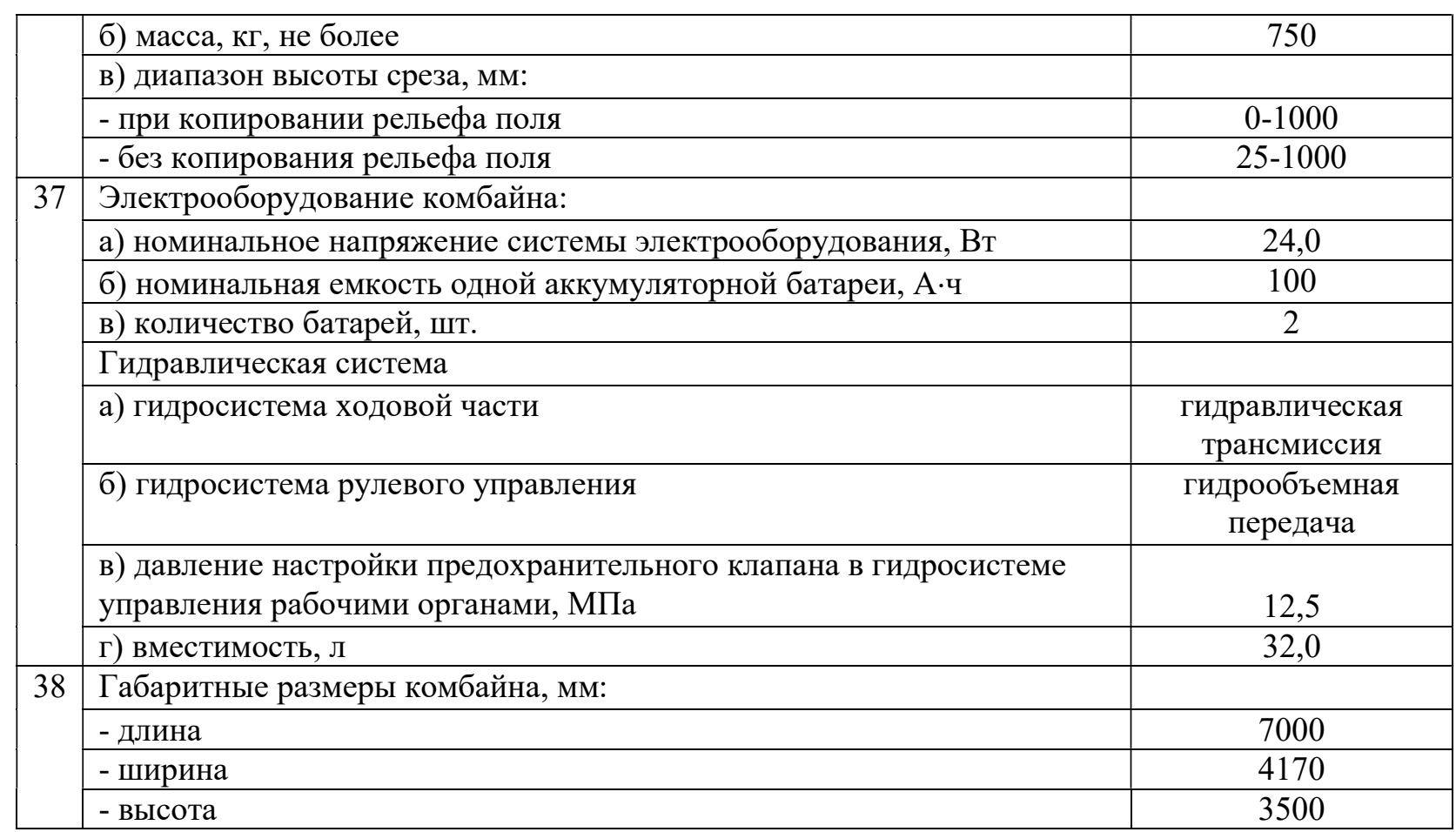

Работа зерноуборочного комбайна LOVOL GM-80 осуществляется следующим образом: при поступательном движении комбайна мотовила поднимает стебли растений, подводит их к режущему аппарату, где срезается и дальнейшим движением граблин масса подается к шнеку жатки-хедера. Шнек спиралями левого и правого направлений подает срезанные стебли к центру жатки-хедера. Пальчиковый механизм шнека захватывает срезанную массу и направляет ее в среднюю часть платформы жатки, из которого масса отбирается битером и передается в наклонную камеру. Наклонный цепочно-планчатый транспортер направляет хлебную массу к приемному битеру молотильного устройства комбайна. В молотильном устройстве хлебная масса обмолачивается с выделением большой части зерна и мелких половенных фракций через решетчатую деку.

Во время работы комбайна, необходимая частота вращения мотовила и его положение относительно режущего аппарата регулируется с помощью гидросистемы в процессе работы.Способ движения зерноуборочного комбайна челночный.

Методы и методика испытаний. Испытания проведены на соответствие машины требованиям СТ РК 1177-2003 [13-15]. Стандарт распространяется на комбайны зерноуборочные и устанавливает номенклатуру показателей условий испытаний, качества выполнения технологического процесса и методы их определения. Условия испытаний приведены в таблице 2 .

Таблица 2 - Условия испытаний (ТОО «Казахский НИИ рисоводства имени И.Жахаева»), 2020 год

\begin{tabular}{|c|c|c|c|c|c|}
\hline \multirow[t]{3}{*}{ Показатели } & \multirow[t]{3}{*}{ TY } & \multicolumn{4}{|c|}{ Значение показателей } \\
\hline & & \multicolumn{2}{|c|}{ при уборке сахарного сорго } & \multicolumn{2}{|c|}{ при уборке риса } \\
\hline & & $\begin{array}{l}\text { эксплуа- } \\
\text { тационно- } \\
\text { техноло- } \\
\text { гические }\end{array}$ & $\begin{array}{c}\text { Надеж- } \\
\text { ность }\end{array}$ & $\begin{array}{c}\text { эксплуа- } \\
\text { тационно- } \\
\text { техноло- } \\
\text { гические }\end{array}$ & $\begin{array}{c}\text { надеж- } \\
\text { ность }\end{array}$ \\
\hline Место проведения испытаний & & \multicolumn{4}{|c|}{ ТОО «Казахский НИИ рисоводства имени И.Жахаева» } \\
\hline Вид работы & & \multicolumn{4}{|c|}{ Прямое комбайнирование } \\
\hline
\end{tabular}




\begin{tabular}{|c|c|c|c|c|c|}
\hline \multirow{2}{*}{$\begin{array}{l}\text { Культура, сорт } \\
\text { Энергосредство }\end{array}$} & & \multicolumn{2}{|c|}{ Сахарное сорго } & \multicolumn{2}{|c|}{ Рис } \\
\hline & & \multicolumn{4}{|c|}{ комбайн ЛОВОЛ GM-80 } \\
\hline Максимальная мощность, кВт & 150,0 & 150,0 & 150,0 & 150,0 & 150,0 \\
\hline $\begin{array}{l}\text { Удельный расход топлива при } \\
\text { максимальной мощности, } \\
\text { г/кВт*ч }\end{array}$ & & 250,0 & 250,0 & 250,0 & 250,0 \\
\hline $\begin{array}{l}\text { Частота вращения коленчатого } \\
\text { вала при максимальной экс- } \\
\text { плуатационной мощности, } \\
\text { об/мин }\end{array}$ & & 1960 & 1960 & 1960 & 1960 \\
\hline \multicolumn{6}{|l|}{ Другие показатели: } \\
\hline - урожайность, ц/га & & 3,2 & 3,2 & 6,5 & 6,5 \\
\hline - влажность зерна, \% & & 30,1 & 30,1 & 18,0 & 18,0 \\
\hline $\begin{array}{l}\text { - влажность соломистой массы, } \\
\%\end{array}$ & & 46,2 & 46,2 & 54,0 & 54,0 \\
\hline Высота растений, см & & 260,8 & 260,8 & 94,2 & 94,2 \\
\hline Полеглость растений, \% & до 80 & - & - & 65 & 65 \\
\hline $\begin{array}{l}\text { Влажность почвы в слое 5-10 см, } \\
\%\end{array}$ & & 8,1 & 8,1 & 18,4 & 18,4 \\
\hline $\begin{array}{l}\text { Твердость почвы в слое 5-10 см, } \\
\text { мПа }\end{array}$ & & 1,70 & 1,70 & 0,76 & 0,76 \\
\hline $\begin{array}{l}\text { Густота стояния стеблей на } 1 \text { м², } \\
\text { шт }\end{array}$ & & 12 & 12 & $110-125$ & $110-125$ \\
\hline Масcа 1000 зерен, г & & 31,2 & 31,2 & 32,0 & 32,0 \\
\hline Потери от самоосыпания, г/м² & & - & - & 1,4 & 1,4 \\
\hline
\end{tabular}

Характеристику поля по длине гона, рельеф, влажность и твердость почвы, влажность зерна и соломы определяли по ГОСТ 20915.

Характеристику культур, определение урожайности зерна, естественных потерь зерна, высоту и полеглость растений определяли по ОСТ 10.8.1-99.

Результаты испытаний. Зерноуборочный комбайн ЛОВОЛ GM-80 поступил на первичные испытания 5 сентября 2020 года.

Техническая экспертиза проводилась согласно ОСТ 10.2.1-97. Определение параметров конструкции проводили по ГОСТ 28301. Определение габаритных размеров, массы, ширины захвата и минимальных радиусов поворота по ГОСТ 26025.

Техническая документация представлена на китайском языке, качество упаковки и качество изготовления удовлетворительное.

Комплект запасных частей и инструмента зерноуборочного комбайна в достаточном количестве и соответствует ТУ.

При первичной технической экспертизе были обнаружены следующие недостатки:

- отсутствуют страховочные болты для крепления жатки-хедера к наклонной камере комбайна;

- в верхней части кабины имеются механические повреждения;

- на отдельных деталях имеются отслоение лакокрасочных покрытий;

- не работает кондиционер охлаждения кабины механизатора.

Трудоемкость монтажа зерноуборочного комбайна к первому испытанию составила 1,10 чел.-час.

Показатели агротехнической оценки машины зерноуборочного комбайна ЛОВОЛ GM-80 приведены в таблице 3. 
Таблица 3 - Показатели агротехнической оценки машины зерноуборочного комбайна ЛОВОЛ GM-80

\begin{tabular}{|c|c|c|c|c|}
\hline \multirow[t]{3}{*}{ Показатели } & \multirow[t]{3}{*}{ по ТУ } & \multicolumn{3}{|c|}{ Значение показателей } \\
\hline & & \multirow{2}{*}{$\begin{array}{l}\text { при уборке са- } \\
\text { харного сорго }\end{array}$} & \multicolumn{2}{|c|}{ при уборке риса } \\
\hline & & & $\begin{array}{c}\text { ФОН-1 рис } \\
\text { прямостоящий }\end{array}$ & $\begin{array}{c}\text { ФОН-2 } \\
\text { рис полеглый }\end{array}$ \\
\hline \multicolumn{5}{|l|}{ Режим работы: } \\
\hline \multicolumn{5}{|l|}{ скорость, км/ч } \\
\hline - рабочая & $2 \ldots 8$ & 5,15 & 3,20 & 2,65 \\
\hline - транспортная & до 26,0 & \multicolumn{3}{|c|}{ до 26,0} \\
\hline Рабочая ширина захвата, м & $3,86_{-003}$ & 3,65 & 3,70 & 3,70 \\
\hline Полеглость растений, \% & до 80 & отсутствует & $25-30$ & 70 \\
\hline \multicolumn{5}{|l|}{ Сроки выполнения работ: } \\
\hline - агротехнические & & август & сентябрь & \\
\hline - фактические & & сентябрь & сентябрь & \\
\hline \multicolumn{5}{|l|}{$\begin{array}{l}\text { Показатели качества } \\
\text { технологического процесса: }\end{array}$} \\
\hline - высота среза, см & $5-40$ & & & \\
\hline \multicolumn{5}{|l|}{ - установочная, см } \\
\hline - средняя фактическая, см & & 15,5 & 8,46 & 6,55 \\
\hline \multicolumn{5}{|l|}{ Суммарная потеря зерна, \% } \\
\hline - при скашивании сорго & 1,0 & 0,58 & & \\
\hline - при скашивании риса & 1,0 & - & 0,84 & 0,96 \\
\hline
\end{tabular}

Эксплуатационно-технологические показатели зерноуборочного комбайна ЛОВОЛ GM-80 приведены в таблице 4.

Таблица 4 - Эксплуатационно-технологические показатели зерноуборочного комбайна

\begin{tabular}{|c|c|c|c|}
\hline \multirow[t]{2}{*}{ Показатели } & \multicolumn{3}{|c|}{ Значение показателей } \\
\hline & $\begin{array}{c}\text { пот } \\
\mathrm{y}\end{array}$ & при уборке сахарного сорго & при уборке риса \\
\hline Место проведения испытаний & & \multicolumn{2}{|c|}{$\begin{array}{l}\text { ТОО «Казахский НИИ рисоводства имени } \\
\text { И.Жахаева» }\end{array}$} \\
\hline Состав агрегата & & \multicolumn{2}{|c|}{ комбайн ЛОВОЛ GM-80 } \\
\hline Вид работы & & \multicolumn{2}{|c|}{ прямое комбайнирование } \\
\hline \multicolumn{4}{|l|}{ Условия работы: } \\
\hline - культура, сорт & & $\begin{array}{l}\text { Сахарное сорго - } \\
\text { Казахстанская } 20\end{array}$ & $\begin{array}{c}\text { Рис - } \\
\text { Сыр сулуы }\end{array}$ \\
\hline Влажность почвы в слое 5-10 см, \% & & 20,85 & 28,45 \\
\hline Твердость почвы в слое 5-10 см, мПа & & 1,70 & 0,76 \\
\hline \multicolumn{4}{|l|}{ Режим работы: } \\
\hline - рабочая скорость, км/ч & $2 \ldots 8$ & 5,15 & 3,20 \\
\hline - ширина захвата, м & $\begin{array}{c}3,86 \\
003\end{array}$ & 3,65 & 3,70 \\
\hline - урожайность, т/га & & 3,2 & 6,5 \\
\hline \multicolumn{4}{|l|}{ Эксплуатационные показатели: } \\
\hline $\begin{array}{l}\text { a) производительность за } 1 \text { час } \\
\text { времени, га: }\end{array}$ & & & \\
\hline
\end{tabular}




\begin{tabular}{|l|c|c|c|}
\hline - основного & & 2,42 & 1,25 \\
\hline - сменного & & 2,14 & 1,05 \\
\hline - эксплуатационного & & 2,08 & 0,85 \\
\hline Удельный расход топлива, кг/га & & 33,0 & 56,5 \\
\hline $\begin{array}{l}\text { Число обслуживающего персонала, } \\
\text { чел. }\end{array}$ & 1 & 1 & 0,950 \\
\hline $\begin{array}{l}\text { Эксплуатационно-технологические } \\
\text { коэффициенты: }\end{array}$ & & 0,950 & 0,920 \\
\hline - технологического обслуживания & 0,960 & 0,770 \\
\hline $\begin{array}{l}\text { - надежности технологического } \\
\text { процесса }\end{array}$ & & 0,865 & 0,725 \\
\hline - использования сменного времени & & 0,840 & \\
\hline $\begin{array}{l}\text { - использования эксплуатационного } \\
\text { времени }\end{array}$ & & & \\
\hline
\end{tabular}

Оценка надежности проводились согласно ОСТ 010.2.7-97, РД-10.2.8-92, ОСТ 10.2 .9-98, РД 10.2.10-91 (таблица 5).

Таблица 5 - Показатели надежности

\begin{tabular}{|c|c|c|c|}
\hline \multirow[t]{2}{*}{ Показатели } & \multicolumn{3}{|c|}{ Значение показателей } \\
\hline & по ТУ & $\begin{array}{l}\text { при уборке } \\
\text { сахарного } \\
\text { сорго }\end{array}$ & $\begin{array}{l}\text { при уборке } \\
\text { риса }\end{array}$ \\
\hline \multicolumn{4}{|l|}{ Режим работы: } \\
\hline - скорость движения, км/ч & $2 \ldots 8$ & $3,48 \ldots 5,15$ & $2,52 \ldots 3,20$ \\
\hline - ширина захвата, м & $3,86_{-003}$ & 3,65 & 3,70 \\
\hline Наработка, часы основной работы, ч & нет данных & 100 & 40 \\
\hline \multicolumn{4}{|l|}{ Общее число отказов, в том числе: } \\
\hline I - группы сложности & & 0 & 0 \\
\hline II - группы сложности & & 0 & 34 \\
\hline III - группы сложности & & 0 & 0 \\
\hline \multicolumn{4}{|l|}{ Наработка за отказ, в том числе, ч } \\
\hline I - группы сложности & нет данных & 0 & 2,0 \\
\hline II - группы сложности & нет данных & 0 & 4,5 \\
\hline III - группы сложности & не должно быть & 0 & 0 \\
\hline $\begin{array}{l}\text { Установленная безотказная наработка за } \\
\text { агрономический сезон, ч }\end{array}$ & 90 & 100 & 40 \\
\hline $\begin{array}{l}\text { Продолжительность отыскания и устранения } \\
\text { отказов, неисправностей, ч }\end{array}$ & нет данных & 0 & 17 \\
\hline $\begin{array}{l}\text { Удельная суммарная трудоемкость отыскания } \\
\text { и устранения отказов, неисправностей, чел- } \\
\text { ч/ч }\end{array}$ & нет данных & 0 &, 15 \\
\hline Среднее время восстановления, ч/отказ & нет данных & 0 & 2,60 \\
\hline \multicolumn{4}{|l|}{ Коэффициент готовности: } \\
\hline - по оперативному времени & 0,98 & 0,98 & 0,98 \\
\hline - с учетом организационного времени & 0,96 & 0,96 & 0,96 \\
\hline
\end{tabular}


Оценка безопасности и эргономичности проводились по следующим нормативным документам и стандартам ГОСТ 12.2.019, ГОСТ 12.2.120, ГОСТ 12.1.004, ГОСТ 12.2.002, ГОСТ 20062, ГОСТ 27258 (таблица 6)

Таблица 6 - Оценка безопасности и эргономичности

\begin{tabular}{|c|l|c|c|}
\hline \multirow{2}{*}{ № } & \multicolumn{1}{|c|}{ Показатели (по ТЭ, ССБТ) } & \multicolumn{2}{|c|}{ Значение показателей } \\
\cline { 3 - 4 } & \multicolumn{1}{|c|}{} & по НТД & $\begin{array}{c}\text { по испыты-ваемой } \\
\text { машине }\end{array}$ \\
\hline 1. & Удобство технического обслуживания & удобно & удобно \\
\hline 2. & Удобство технологического обслуживания & удобно & частично неудобно \\
\hline 3. & Пожаробезопасность & соответствует & соответствует \\
\hline 4. & Удобство присоединения и отсоединения машины & удобно & частично неудобно \\
\hline 5. & Удобство транспортировки по дорогам & удобно & удобно \\
\hline 6. & Рабочая поза & рациональна & рациональна \\
\hline 7. & $\begin{array}{l}\text { Максимальное усилие сопротивления перемещению } \\
\text { органов управления, Н: }\end{array}$ & & \\
\hline & $\begin{array}{l}\text { - при регулирований наклона пружинных пальцев } \\
\text { мотовила }\end{array}$ & 200 & 120,6 \\
\hline & - при натяжений транспортеров & 200 & 150 \\
\hline & $\begin{array}{l}\text { - при регулировке положения мотовила от поверхности } \\
\text { почвы }\end{array}$ & 50 & 42,5 \\
\hline 8. & Количество рабочих движении, мин & 25 & 25 \\
\hline 9. & $\begin{array}{l}\text { Удобство перевода из рабочего положения в } \\
\text { транспортное и обратно }\end{array}$ & удобно & удобно \\
\hline
\end{tabular}

Показатели технологичности зерноуборочного комбайна ЛОВОЛ GM-80 приведены в таблице 7.

\section{Таблица 7 - Показатели технологичности}

\begin{tabular}{|l|c|c|}
\hline \multirow{2}{*}{ Показатели } & \multicolumn{2}{|c|}{ Значение показателей } \\
\cline { 2 - 3 } & по ТУ & по данным испытаний \\
\hline Материалоемкость (удельная материалоемкость), кг/га & 410,2 & не установлено \\
\hline Число сортов масел и смазок, применяемых в машине & 3 & 3 \\
\hline Показатели стандартизации и унификации: & & \\
\hline - коэффициент применяемости, \% & 97 & не установлено \\
\hline - коэффициент повторяемости, \% & 98 & не установлено \\
\hline
\end{tabular}

Анализ и заключение по результатам испытаний. Зерноуборочный комбайн ЛОВОЛ GM-80 поступил на первичные испытания 5 сентября 2020 года.

Техническая экспертиза проводилась согласно ОСТ 10.2.1-97.

Техническая документация представлена не полностью (на китайском языке). Комплект запасных частей и инструмента зерноуборочного комбайна в достаточном количестве и соответствует ТУ.

Качество изготовления зерноуборочного комбайна удовлетворительное. Оперативная трудоемкость монтажа (досборки) комбайна составила 1,46 чел-ч. За период испытаний наработка составила 140 ч при плане 100 ч.

Испытания зерноуборочного комбайна проводились с 01 по 30 сентября. 
Испытания зерноуборочного комбайна ЛОВОЛ GM-80 в хозяйственных условиях проводились при прямом комбайнировании на полях сахарного сорго и риса ТОО «Казахский НИИ рисоводства имени И.Жахаева».

На уборке сахарного сорго составила 100 ч, при этом производительность зерноуборочного комбайна составила 1,1 га/ч.

Суммарные потери зерна составили 0,2\% при скорости движения 5,15 км/ч. Скорость движения зерноуборочного комбайна и производительность ограничились высотой растений на поле (в отдельных чеках высота растений сахарного сорго доходила до 320,0 см).

Условия испытаний были характерными для зоны деятельности ТОО «Казахский НИИ рисоводства имени И.Жахаева». Зерноуборочный комбайн работал на чеках площадью 1,5-3,0 га. Прямое комбайнирование культур сахарного сорго и риса в чеках осуществлялось челночным способом движения (рис. 2,3).

Агротехническая оценка зерноуборочного комбайна ЛОВОЛ GM-80 проводилось согласно СТ РК 1177.2003.

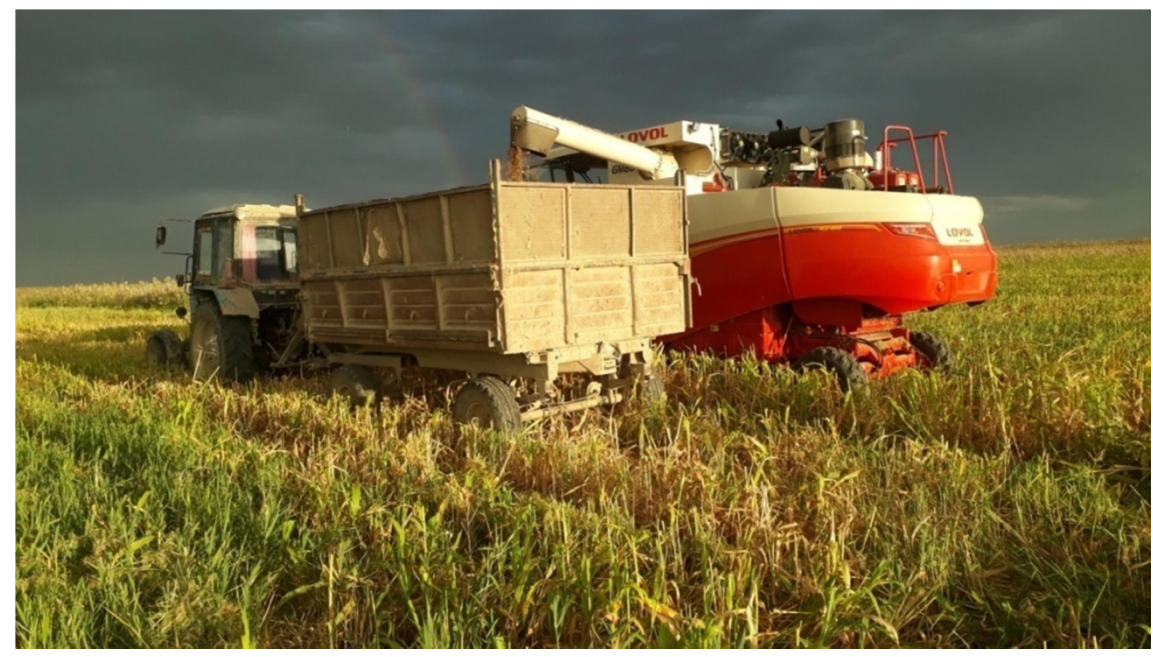

Рисунок 2 - Выгрузка зерна сахарного сорго на транспортное средство

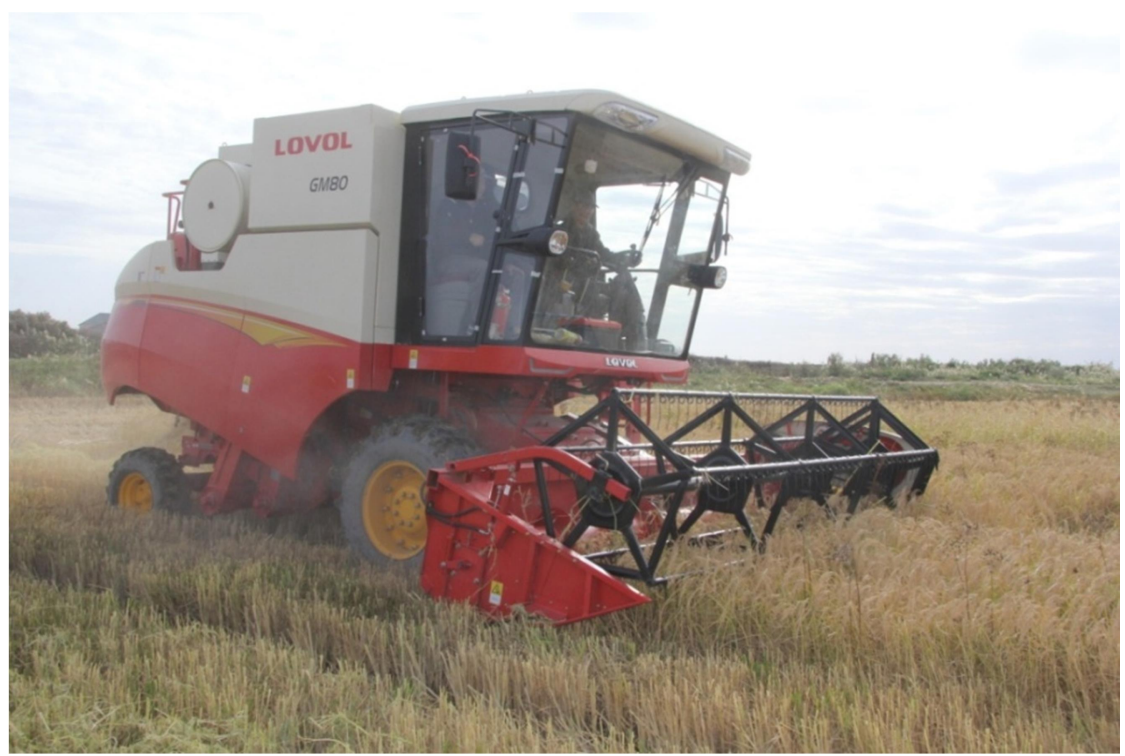

Рисунок 3 - Прямое комбайнирование риса (вид спереди) 
Показатели качества работы зерноуборочного комбайна определялись на трех фонах:

- фон 1 - прямое комбайнирование сахарного сорго;

- фон 2 - прямое комбайнирование риса стоящего;

- фон 3 - прямое комбайнирование риса полеглого до $80 \%$.

Режимы и показатели качества работы зерноуборочного комбайна приведены в разделе 3.2. Полученные результаты показывают следующие: высота среза растений находится в пределах 6,55-15,5 см, что соответствует требованиям ТУ (по $5 \ldots 40$ см).

Суммарные потери зерна при уборке риса со скоростью движения на прямостоящем $(3,20$ км/ч) и полеглом $(2,52$ км/ч) хлебостое составили соответственно 0,90 и $1,3 \%$ (допустимые потери зерна по ТУ $1,5 \%$ ).

Производительность за час основного времени зерноуборочного комбайна составляет 0,42 га/ч. При высокой влажности зерна риса (более 14\%) наблюдается увеличение количества обрушенных зерен риса за молотилкой.

В связи с предоставлением технической документации на китайском языке отдельные показатели работы комбайна по испытаниям не установлены.

Выводы и предложения. По результатам предварительных испытаний зерноуборочного комбайна ЛОВОЛ GM-80 выявлены несоответствия машины:

- по пунктам 2 пунктам ТУ.

Основные качественные и эксплуатационно-технологические показатели зерноуборочного комбайна соответствуют требованиям ТУ.

Коэффициент готовности получен 0,965 (по ТУ $\mathrm{K}_{\mathrm{r}}=0,96$ ).

На основании проведения предварительных испытаний ТОО «НИИ рисоводства им.И.Жахаева» рекомендует зерноуборочный комбайн ЛОВОЛ GM-80 в качестве прямого комбайнирования сахарного сорго, а также прямого комбайнирования риса в чеках, имеющие влажность почвы не более 16-18\%, влажность зерна риса не более $14 \%$, урожайность зерна не более 30 ц/га.

На переувлажненном участке поля (влажность почвы 24,7\%) после прохода зерноуборочного комбайн наблюдается образование колеи (рис.4).
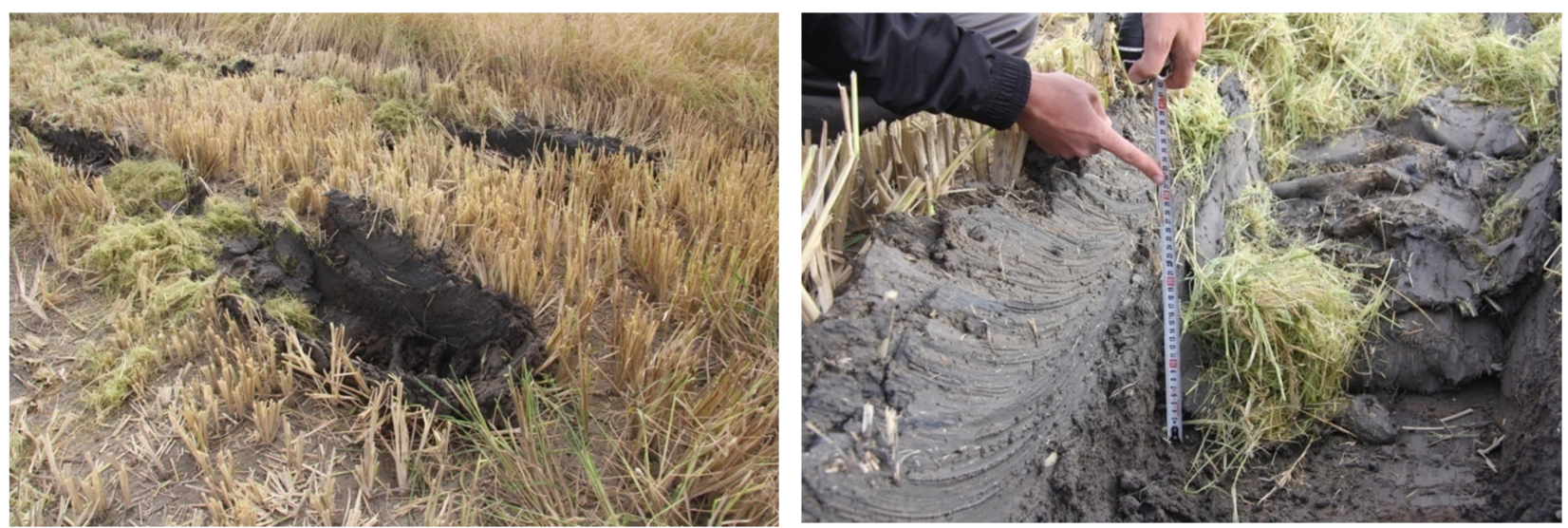

Рисунок 4 - Образование колеи на переувлажненном участке поля после прохода зерноуборочного комбайна (влажность почвы 24,7\%) 
Для рисовых полей Кызылординской области, имеющий сложный агрофон, рекомендуется более широкий профиль шин заднего и переднего колеса испытываемого зерноуборочного комбайна.

Для дальнейшего изучения режимов работы зерноуборочного комбайна рекомендуется провести производственные испытания для диверсификационных культур (пшеница, ячмень, сафлор, соя и т.д.) рисового севооборота.

\section{Литературы:}

[1] Астафьев, В.Л., Голиков В.А. Обоснование типажа зерноуборочных комбайнов и жаток, применяемых в регионах Казахстана. Сельскохозяйственные машины и технологии. 2018;12(4):10-15. https://doi.org/10.22314/2073-7599-2018-12-4-10-15

[2] Рахатов, С.3., Бекжанов С.Ж., Сактаганов Б.Ж. Методика экспериментальных исследований качественных показателей жатки-хедера // Материалы IX-й международной научнопрактической конференции. Том 25, 17-25 февраля, 2013 г. - София. - С. 18-22.

Комбайн колесный GM-80. https://agt.ge/ru/product.

[3] Кленин, Н.И. Сельскохозяйственные и мелиоративные машины.- М.: Колос, 2005. $464 \mathrm{c}$.

[4] Устинов, А.Н. Сельскохозяйственные машины. - М.: "Академия", 2007 - 264 с.

[5] Ежевский, А.А. Технологическая и техническая обеспеченность сельскохозяйственного производства России на 2013-2020 годы // Сельскохозяйственные машины и технологии. 2014. № 1. - С. 3-6.

[6] Жалнин, Э.В. Стратегия перспективного развития механизации уборки зерновых культур // Тракторы и сельхозмашины. 2004. № 9. С. 3-16.

[7] Константинов, М.М., Ловчиков А.П., Ловчиков В.П. и др. Проектирование и организация эффективного процесса уборки зерновых культур. Екатеринбург: Институт экономики УрО РАН, 2011. 144 с.

[8] В Казахстане успешно испытали малогабаритные комбайны LOVOL GM-80 https://agroinfo.kz/v-kazaxstane-uspeshno-ispytali-malogabaritnye-kombajny-lovol-gm80/

[9] Китайские комбайны Lovol проходят тестирование на уборке риса на юге Казахстана. http://russian.news.cn/2020-09/18/c_139377039.htm

[10] На Агро-2020 презентовали новый бюджетный комбайн. https:/latifundist.com/novosti /51454-na-agro-2020-prezentovali-novyj-byudzhetnyj-kombajn

[11] Роторный комбайн LOVOL GM - 80. https://technotorg.com/catalogue/view/rotornyjkombajn-lovol-gm80.html

[12] Комбайн LOVOL GM-80 с двумя жатками. https://agrobaza.kg/lovol-gm80.

[13] СТ РК 1177-2003 «Зерноуборочные комбайны. Программа и методы испытаний».

[14] ГОСТ 28301-2015 Межгосударственный стандарт. Комбайны зерноуборочные. Методы испытаний. Дата введения 2017-07-01.

[15] Чаплыгин, М.Е., Жалнин Э.В. Определение качества работы зерноуборочных комбайнов. Сельскохозяйственные машины и технологии. 2019; 13(4): 71 76. https://doi.org/10.22314/2073-7599-2019-13-4-71-76.

\section{References:}

[1] Astaf'ev, V.L., Golikov V.A. Obosnovanie tipazha zernouborochnyh kombajnov i zhatok, primenyaemyh v regionah Kazahstana. Sel'skohozyajstvennye mashiny i tekhnologii. 2018;12(4):10-15. https://doi.org/10.22314/2073-7599-2018-12-4-10-15

[2] Rahatov, S.Z., Bekzhanov S.ZH., Saktaganov B.ZH. Metodika eksperimental'nyh issledovanij kachestvennyh pokazatelej zhatki-hedera // Materialy IH-j mezhdunarodnoj nauchnoprakticheskoj konferencii. Tom 25, 17-25 fevralya, 2013 g. - Sofiya. - S. 18-22. Kombajn kolesnyj GM80. https://agt.ge/ru/product.

[3] Klenin, N.I. Sel'skohozyajstvennye i meliorativnye mashiny.- M.: Kolos, 2005. - 464 s.

[4] Ustinov, A.N. Sel'skohozyajstvennye mashiny. - M.: "Akademiya", 2007 - 264 s. 
[5] Ezhevskij, A.A. Tekhnologicheskaya i tekhnicheskaya obespechennost' sel'skohozyajstvennogo proizvodstva Rossii na 2013 - 2020 gody // Sel'skohozyajstvennye mashiny i tekhnologii. 2014. № 1. - S. $3-6$.

[6] Zhalnin, E.V. Strategiya perspektivnogo razvitiya mekhanizacii uborki zernovyh kul'tur // Traktory i sel'hozmashiny. 2004. № 9. S. 3 - 16.

[7] Konstantinov, M.M., Lovchikov A.P., Lovchikov V.P. i dr. Proektirovanie i organizaciya effektivnogo processa uborki zernovyh kul'tur. Ekaterinburg: Institut ekonomiki UrO RAN, 2011. 144 s.

[8] V Kazahstane uspeshno ispytali malogabaritnye kombajny LOVOL GM-80 https://agroinfo.kz/v-kazaxstane-uspeshno-ispytali-malogabaritnye-kombajny-lovol-gm80/

[9] Kitajskie kombajny Lovol prohodyat testirovanie na uborke risa na yuge Kazahstana. http://russian.news.cn/2020-09/18/c_139377039.htm

[10] Na Agro-2020 prezentovali novyj byudzhetnyj kombajn. https://atifundist.com/novosti /51454-na-agro-2020-prezentovali-novyj-byudzhetnyj-kombajn

[11] Rotornyj kombajn LOVOL GM - 80. https://technotorg.com/catalogue/view/rotornyjkombajn-lovol-gm80.html

[12] Kombajn LOVOL GM-80 s dvumya zhatkami. https://agrobaza.kg/lovol-gm80.

[13] ST RK 1177-2003 «Zernouborochnye kombajny. Programma i metody ispytanij».

[14] GOST 28301-2015 Mezhgosudarstvennyj standart. Kombajny zernouborochnye. Metody ispytanij. Data vvedeniya 2017-07-01.

[15] Chaplygin M.E., ZHalnin E.V. Opredelenie kachestva raboty zernouborochnyh kombajnov. Sel'skohozyajstvennye mashiny i tekhnologii. 2019; 13(4): 71-76. https://doi.org/10.22314/2073-75992019-13-4-71-76.

\title{
ЛОВОЛ GМ-80 АСТЫҚ ЖИНАУ КОМБАЙНЫНЫН АЛДЫН АЛА СЫНАУ НӘТИЖЕЛЕРІ
}

\author{
Мустафаев М.Г. ${ }^{1}$, аграрлық ғылымдарының докторы \\ Бекжанов С.ж. ${ }^{2}, \mathrm{PhD}$ \\ Дуйсембеков Б.А. ${ }^{3}$, биология ғылымдарының кандидаты \\ Култасов Б.Ш. ${ }^{2}$, докторант \\ ШариповаН.Е. ${ }^{2}$, магистрант \\ ${ }^{1}$ Азербайджан Ұлттық вылым академиясының \\ Топырақтану және агрохимия институты, Азербайджан Республикасы \\ ${ }^{2}$ Кызылординский университет имени Коркыт Ата, Қызыллорда қ,.Республика Казахстан \\ ${ }^{3}$ ТОО «Агропарк Онтустик», Республика Казахстан
}

\begin{abstract}
Аңдатпа. Ы.Жақаев атындағы Қазақ күріш шаруашылығы ғылыми-зерттеу институтының қант құмайы және күріш алқаптарында ЛОВОЛ GM-80 кіші габаритті астық жинау комбайндары тікелей ору кезінде далалық сынақтан сәтті өткізілді. Бұл комбайндар негізінен егіс алқаптары көп емес шағын шаруашылықтар, сонымен қатар техникалар жүре алмайтын учаскелердt астық жинау үшін арналған. ЛОВОЛ GM-80 комбайны - астық жинауға арналған жаңа конструкциядағы комбайндар және арнайы жұмыс құралдарын ауыстыру арқылы бидай, күріш, рапс, соя және басқа да ауылшаруашылық дақылдарын жинауға арналған. 8-сенсорлы экраны бар ақылды дисплей жұмыс күйінің параметрлерін бақылауға мүмкіндік береді. «Ы.Жақаев атындағы Қазақ күріш шаруашылығы ғылыми-зерттеу институты» ЖШС-і алдын ала сынақтан өткізу негізінде ЛОВОЛ GM-80 астық жинау комбайынын қант құмайын тікелей орып жинауға, сонымен бірге топырақ ылғалдылығы 16-18\%, күріш дәнінің ылғалдылығы 14\%-дан аспайтын, күріш өнімділігі 30 ц/гадан аспайтын алқаптарда тікелй орып жинау үшін ұсынады. Астық жинау комбайнының жұмыс режимін әрі қарай зерттеу үшін күріш ауыспалы егістің әртараптандырылған дақылдарына (бидай, тары, мақсары, соя ж.с.с.) өндірістік сынақтан өткізу жұмыстарын жүргізу ұсынылады.
\end{abstract}

Кілт сөздер: астық жинау комбайны, сынақтан өткізу, техникалық экспертиза, өнімділік, агрофон. 


\title{
PRELIMINARY TEST RESULTS GRAIN HARVESTER LOVOL GM-80
}

\author{
Mustafaev M.G. 1, doctor of agricultural sciences \\ Bekzhanov S.Zh. ${ }^{1}$, PhD \\ Duisembekov B.A. ${ }^{2}$, candidate of biological sciences \\ Kultasov B.Sh. ${ }^{1}$, doctoral student \\ Sharypova N.E. ${ }^{1}$, master's student \\ ${ }^{I}$ National Academy of Sciences of Azerbaijan \\ Institute of Soil Science and Agrochemistry, Republic of Azerbaijan \\ ${ }^{2}$ Kyzylorda University named after Korkyt Ata, Kyzylorda city, Republic of Kazakhstan \\ ${ }^{3}$ LLC "Agropark Ontustik", Almaty city, Republic of Kazakhstan
}

Annotation. At the Y. Zhakhaev Kazakh Research Institute of Rice Cultivation, 2 units of LOVOL GM-80 small-sized combine harvesters have successfully passed field tests in the fields of sugar sorghum and rice with direct combining. These combines are mainly intended for small farms with small cultivated areas, as well as harvesting areas that are difficult to access. Harvester Lovol GM- 80 is a new design harvester that is used for harvesting, and by changing some special working parts, they can harvest wheat, rice, rapeseed, soybeans and other agricultural crops. The smart display with 8 touch screens can display the working status parameters easily. Based on preliminary tests, Zhakhaev Research Institute of Rice Growing LLP recommends the LOVOL GM-80 combine harvester as a direct combining of sugar sorghum, as well as direct combining of rice in checks with soil moisture no more than $16-18 \%$, rice grain moisture no more than $14 \%$, the yield of rice grain is no more than $30 \mathrm{c} /$ ha. For further study of the operating modes of the combine harvester, it is recommended to conduct production tests for diversified crops (wheat, barley, safflower, soybeans, etc.) of rice crop rotation.

Keywords: combine harvester, testing, technical expertise, productivity, agricultural background 
FTAXP: 81.83.19

https://doi.org/10.52081/bkaku.2021.v58.i3.079

\title{
ТЕХНИКАЛЫК СЕРВИС ОРТАЛЫКТАРЫНДАҒЫ МӘСЕЛЕЛЕР МЕН ИННОВАЦИЯЛЫК КЫЗМЕТ ТУРЛЕРІНІН ПЕРСПЕКТИВАСЫ
}

\author{
Курбаналиев Б.Б., аға оқытушы \\ bkurbanaliev@mail.ru, https://orcid.org/0000-0003-1992-891X \\ Жумагулов Ж.Б., техника ғылымдарының кандидаты \\ zhandos.79@mail.ru, https://orcid.org/0000-0003-1813-902X \\ Сапарбаев Е.T., техника ғылымдарының магистрі \\ yerzhigit.saparbayev@kaznaru.edu.kz, https://orcid.org/0000-0002-9171-9453 \\ Черикбаев Р.К., техника ғылымдарының кандидаты \\ rahat_03.1980@mail.ru,https://orcid.org/0000-0002-3941-6500 \\ Қазақ ұлттыққ аграрлық зерттеу университеті, Алматы қ̧аласы, \\ Қазақсттан Республикасы
}

\begin{abstract}
Аңдатпа. Қазақстан Республикасының ауыл шаруашылығында техниканы мезгілсіз тозудан, бұзылудан және тоқтап қалудан сақтау үшін, сол техниканың үздіксіз жұмыс істеуін қамтамасыз ететін тексеру, тазалау, май құю, бекіту, реттеу жұмыстарының жиынтығы, яғни, жоспарлы сақтандыру жүйесі қолданылады. Дегенмен, осы жұмыстардын басқа техника үшін ескерілуі тиіс тағы бір маңызды операция - жөндеуден кейінгі бөлшектерді құрастыру жұмысында осы аталмыш жөндеу жұмысы кезінде құрастырма бірліктерде пайда болған өзгерістерді, ауыткуларды ескере отырып біріктіру. Өйткені кейбір құрастырма бірліктер жөндеуден кейін өзінің бастапқы зауыттық нұсқасынан сәл ауытқуға ұшырауы мүмкін. Азғантай ғана ауытқудың өзі техниканың болашақ жұмысында сенімсіздік тудыруы мүмкін.
\end{abstract}

Соңғы жүргізілген зерттеу жұмыстарының көрсеткіштері бойынша жөндеу кәсіпорындарына келіп түсетін трактор двигательдерінің 60 \% - дан көбі жөндеуді қажет етпейді, тек қана негізгі тетіктер мен тораптарды реттеп, қалпына келтіру қажет. Техниканы мезгілсіз бұзылудың алдын алу үшін оның моторлық қорын толық пайдалануды қамтамасыз ететін техникалық күйін, жеке жүйелерінің, тетіктерінің және жағдайын анықтау қажет. Шаруашылықтардың жұмыс уақыты мен қаражатын үнемдеу үшін техниканы бөлшектемей тексерудің маңызы өте зор. Жұмыс істеп тұрған машиналардың техникалық және экономикалық көрсеткіштерін бөлшектемей үздіксіз тексеру техниканың өнімділігін арттыруға және жұмсалатын шығын мөлшерін азайтуға мүмкіндік береді.

Аталмыш мақалада осы мәселелердің алдын алу, техника жөндеудегі инновациялық әдістерді қолдану мәселесі толыгымен айтылган.

Кілт сөздер: сервис, техника диагностикасы, стенд, жанармай шывыны, бүрку бұрышы

Кіріспе. Қазіргі заманауи техникалық сервис мекемелері автоматтандырылған жүйемен, роботталған кешеннен тұратын әртүрлі құрылғылар мен жабдықтармен қамтамасыз етілуі тиіс. Өйткені сұранысы жоғары өндіріс пен ауыл шаруашылығында, логистикада жабдықтардың үзіліссіз жұмыс жасауы үшін қуат, өнімділік, жүйелік нақты сәйкестік сияқты параметрлер бойынша кез келген агрегат тоқтаусыз қызмет көрсетуі қажет.

Техникалық сервис мекемесіндегі заманауи аспаптар мен жабдықтарды қолдана отырып техникаға сервис көрсету - оның бүкіл пайдалану кезеңіндегі, яғни мекеменің оны балансқа алған кезінен бастап, жарамсыз деп есептен шығарып тастағанға дейінгі уақытындағы қолдану есебі, жөндеу, ағымдағы қызмет көрсету, сақтау, тасымалдау және т.б. қызметтері бойынша жай күйі негізге алынады. Осы кезең аралығында сервис мекемесінің техника-экономикалық көрсеткіштері өздерінің қызмет көрсету жұмысын қамтамасыз ететін көрсеткішті қамту қажеттілігі бірнеше зерттеу жұмысының өзегі болып отыр $[1,2,3]$. 
Өзімізге белгілі инженерлік қызметтердің көпшілігі күрделі есептеулерді, нақты дәлдікпен орындалған нәтижені талап етеді . Есептеу нәтижесінде алынған мәліметтер арқылы дәлме дәл түсірілуді талап ететін графиктер сол техниканың жұмыстық күйіне баға беруде шешуші фактор болып табылады. Сондықтан бұрынғы қалыптасқан есептеу және миллиметрлік қағазды пайдаланып график түсіру жұмыстарында компьютерді қолдану, яғни арнайы компьютерлік бағдарламаларды пайдалану осы жұмыстағы уақыт үнемдеуге және нақты мәнді анықтауға мүмкіндік береді.

Ал кейбір зерттеу жұмыстарында техникалық сервис мекемесіндегі үзіліссіз жұмыс жасайтын технологиялық процестердің нәтижелі екендігі айтылған [4,5]. Қазіргі техника мен технологияның қарыштап дамыған кезеңінде сервис мекемелеріндегі үзіліссіз өндірістік процесті пайдалану нәтижесі орындалып жатқан операциялардан уақытты үнемдеуге мүмкіндік бере отырып өте жоғары сапада қамтамасыз етілетінін дәлелдеп отыр.

Осыған байланысты біз, инфраструктурасы заман талабына сай жабдықталған сервис мекемелеріндегі инновациялық жөндеу әдістерін бұрынғы дәстүрлі қалыптасқан әдіспен жұмыс жасайтын жөндеу мекемелері жұмысымен салыстырып көрген зерттеу жұмысының нәтижесін ұсынып отырмыз

Зерттеу мақсаты - Қазақстандағы техникалық сервис қызметін жандандыру, ауыл шаруашылығы мен тасымал жұмыстары үшін қолданылатын техниканың техникалық күйін үнемі жоғары көрсеткіште ұстап отыратын қызмет түрлерін қалыптастыру, жөндеу мекемелері қызметкерлеріне инженерлік есептеулер бағытында кеңес беру болып табылады.

Зерттеу материалдары мен әдістері. Жөндеу жұмыстарында жылдам және сапалы қызметті қамтамасыз ету үшін сервис орталықтары бәсекеге қабілеттілік критерийлері бойынша жұмыс жасауы қажет. Зерттеу мақсаты техникалық қызмет пен жөндеу жұмыстарын жоспарлаудың жаңа алгоритмін жасауды, жөндеу операцияларына жаңа бағдарлама енгізуді, диагностикалау жабдықтарына арналған әдістер мен жоспарлау ретін жасауды, жұмыс нәтижесін салыстару мен талдауды жаңа әдістермен байланыстыруды көздейді.

Мұндай міндеттерді шешу үшін көбінесе мәліметтерді статискалық модельдеу, есептік әдіс, сапалы бағалау әдісі және т.б. зерттеу әдістері қолданылады. Мысалы, техника түрі мен оларға көрсетілетін техникалық қызмет орындалу формасына қарай әртүрлі болуы мүмкін. Қазіргі заманғы мамандандырылған техникалық сервис мамандану деңгейіне, орналасу аймағына, өндірістік қуатына және еңбек нарығындағы бәсекеге қабілеттілігіне қарай көп функциялы кәсіпорын болып саналады. Сондықтан да қолданылатын зерттеу материалдары ретінде біз осы техника түрін, оның жөнделу себебін анықтап алғаннан кейін жөндеу, диагностикалау форматын таңдап, сәйкесінше зерттеу әдістерін пайдаланамыз.

Кез келген техниканың құрастырма бірліктеріндегі ақаудың себебін анықтауда оның конструкциялық ерекшелігі бойынша біраз мәліметті білуге болады. Двигательді бөлшектемей тексеру кезінде тікелей және жанама шамалар өлшенеді. Мысалы двигатель қуатының өзгерісін өлшеу кезінде жанама шамалар ретінде жанар-жағар май шығындары, цилиндрдегі қысым, газ температурасы және т.б көрсеткіштер алынып, бұл шамалар двигатель қуатын тексеруге, оның өзгерістерін айқындауға көп септігін тигізеді. Машиналардың жағдайын бөлшектемей тексеру кезінде тек қана бақылаудың жалпы әдістерін білу жеткіліксіз. Автотрактор двигателінде кездесетін ерекше ақауларды, олардың белгілерін, аппаратуралар мен оларды пайдалану ерекшеліктерін білу қажет. Двигатель қуаты мен жанармай шығындарын әр түрлі тәсілмен тексеруде компьютерлік технологияны қолдану арқылы нақты есептеулерді жүргізіп график тұрғызуға болады. Біз айтып отырған тексеру жұмыстарында двигательді бөлшектемей де, бөлшектеп те 
анықтауға болады. Бөлшектемей тексеру әдісінде техниканың жұмыс жағдайында әр түрлі құрал-жабдықтар жиынтығы арқылы жүзеге асырылады. Ал бөлшектеп тексеру әдісі көбінесе техника моторын жөндеу жұмысын жүргізгеннен кейін пайда болған ауытқулар салдарынан жүргізіледі.

Зерттеу әдісі ретінде көп қолданылатын есептік әдістің абсолютті, салыстырмалы, индексті және баланстық әдіс деп аталатын түрлері бар. Инженерлік жүйеде нақты тапсырмаларды шешу үшін техника-экономикалық талдаудың негізгі аспабы ретінде салыстырмалы есептік әдісті пайдалану өте ыңғайлы. Бұл әдіс сонымен қатар, қолда бар мәліметті жаңа бағдарламалық есептеуден алынған мәліметтермен салыстыруда, реттеуде, ерекшелігін айқындауда дәлдігі жоғары деп есептеледі. Егер есептік әдіс заманауи бағдарламалық қамсыздандыру критерийлерімен жүргізілсе онда зерттеу жұмысы үшін нақты нәтиже алуға болады [7].

Жалпы есептік әдістің экономика-математикалық деп аталатын түрін осы жұмыстың зерттеу әдістері үшін пайдалана отырып, біз сызықтық бағдарламалау мен абсолютті және салыстырмалы айырмашылықтар нәтижесін шыгара аламыз. Мысал үшін 3029DF128 дизельді двигателі бар франциялық Dohn Deere техникасына жөндеу есептерін жүргізейік.

Зерттеу нәтижесі және талдау. Двигательдің зауыттық нұсқасы бойынша жанармайды бүрку бұрышының номиналь мәні 26...28 $8^{0}$ аралығында болуы тиіс. Бірақ осы мән жөндеу жұмысы кезінде тиісті мөлшерді сақтамай жанармайды артық немесе тым аз жұмсауы мүмкін сондықтан арнайы тежеуіш - қалыптастыру стендісі арқылы номинал мәнінің артық және кеш бүрку бұрыштарын қойып тиімді мәнді анықтау қажет. Стендінің негізгі бөліктері - күш өлшеуіш механизмі, таразы механизмі, электр двигателі, жанармай және т.б. Стендінің жұмыс жасау тәртібі мынадай: тексерілетін стенд ертіндісі бар реостат арқылы жүктеледі. Иінді біліктің айналу санын реостатты ертіндіге батыру арқылы келтіреміз. 3029DF128 дизельді двигателінің техникалық сипаттамасы бойынша иінді біліктің айналу жиілігін реттеуші реостаттың арнайы тұтқасын бұрай отырып, ерітіндіге батыру арқылы қалыптастырамыз. Таразыға 100 грамм жанармай құйылып қойылады. Тәжірибе уақытын 15 секунд деп белгілейміз де жанармайды бүрку бұрышын алғашқыда номиналь мәннен $6^{0}$ ерте бұрышқа, сосын кеш бүрку бұрышына қойып, сол уақыт ішінде жұмсалған жанармай мөлшерін жазып аламыз. Тәжірибе 3 рет $\left(21^{0}, 27^{0}\right.$ және $33^{0}$ бұрыштарда) жүргізіледі.

Сонда қажет ақпарат 3029DF128 дизельді двигателі тежеуіш-қалыптастыру стендісінен алынады

Компьютерде алынған ақпарат арқылы есептеу жұмыстары жүргізіледі.

- двигатель қуаты:

$$
N_{e}=\frac{P_{m} \cdot \Pi_{m} \cdot k}{1000 \cdot \pi}, \text { кВт }
$$

- сағаттық жанармай шығыны:

$$
Q=\frac{3,6 \cdot V}{T_{m}}, \text { кг/сағ }
$$

- меншікті жанармай шығыны:

$$
g=\frac{1000 \cdot Q}{N e}, г / \mathrm{\kappa} \mathrm{B} \cdot \mathrm{caғ}
$$

мұндағы, $\mathrm{P}_{\mathrm{m}}$ - стендтің таразы механизмінің көрсеткіші, кГс; $\Pi_{\mathrm{m}}-$ тахометр бойынша электр двигателі білігінің айналу жылдамдығы, мин ${ }^{-1} ; \mathrm{k}=0,735$ - ат күші бірлігін кВт бірлігіне айналдыру коэффициенті; $\eta=0,98$ - дизельдің иінді білігінен электр двигателінің білігіне берілістің пайдалы әсет коэффициенті; V - тәжірибе кезіндегі жанармай шығыны, г; Т т - тәжірибе уақыты, с. 
Двигатель қуаты, сағаттық және меншікті жанармай шығындары стенді бойынша алынған бүрку бұрышының көрсеткіштерімен үш рет есептеледі.

1.Жанармайды бүрку бұрышының $21^{0}$-тағы мәні:

$$
\begin{aligned}
& \mathrm{N}_{\mathrm{e}}=\frac{62,4 \cdot 1750 \cdot 0,735}{1000 \cdot 0,98}=81,9 \kappa \mathrm{Bm} \\
& \mathrm{Q}=\frac{3,6 \cdot 75,5}{15}=18,16 \kappa 2 / \mathrm{caz} \\
& \mathrm{g}=\frac{1000 \cdot 18,16}{81,9}=221,832 / \mathrm{kBm} \cdot \mathrm{caz}
\end{aligned}
$$

2.Жанармайды бүрку бұрышының $27^{0}$-тағы мәні:

$$
\begin{aligned}
& \mathrm{N}_{\mathrm{e}}=\frac{59 \cdot 1750 \cdot 0,735}{1000 \cdot 0,98}=77,4 \kappa \mathrm{Bm} \\
& \mathrm{Q}=\frac{3,6 \cdot 82,1}{15}=19,7 \kappa 2 / \mathrm{caz} \\
& \mathrm{g}=\frac{1000 \cdot 19,7}{77,4}=254,472 / \mathrm{kBm} \cdot \mathrm{caz}
\end{aligned}
$$

3.Жанармайды бүрку бұрышының $33^{0}$-тағы мәні:

\begin{tabular}{|c|c|c|c|c|c|c|c|c|}
\hline 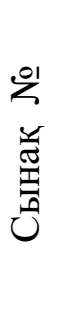 & 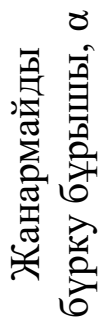 & 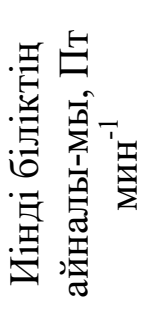 & 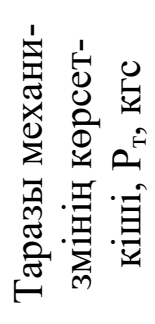 & 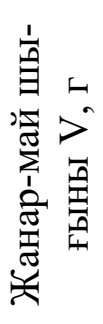 & 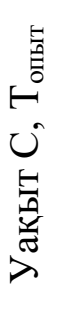 & 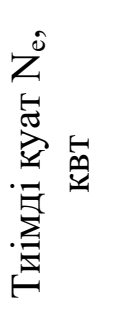 & 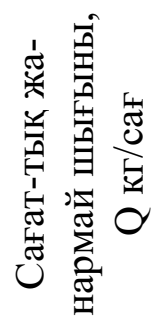 & 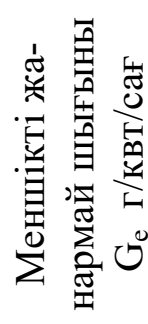 \\
\hline 1 & $21^{0}$ & 1750 & 62,4 & 75,7 & 15 & 81,9 & 18,16 & 221,8 \\
\hline 2 & $27^{0}$ & 1750 & 59,0 & 82,1 & 15 & 77,4 & 19,7 & 254,4 \\
\hline 3 & $33^{0}$ & 1750 & 61,3 & 75 & 15 & 80,45 & 18 & $223,7^{*}$ \\
\hline
\end{tabular}

$\mathrm{N}_{\mathrm{e}}=\frac{61,3 \cdot 1750 \cdot 0,735}{1000 \cdot 0,98}=80,45 \kappa B m$

$\mathrm{Q}=\frac{3,6 \cdot 75}{15}=18 \kappa 2 / \mathrm{caz}$

$\mathrm{g}=\frac{1000 \cdot 18}{80,45}=223,742 / \kappa B m \cdot c a 2$

Операцияны орындау нәтижесі кестеге түсіріледі (1-кесте).

\section{1-Кесте - Бүрку бұрышын сынау көрсеткіштері}

( Асты сызылған шамалар компьютермен есептеу нәтижесінде анықталған).

Соңында алынған ақпараттарды операциялық орындау нәтижесін шығару қажет. Қалыптасқан оқыту әдісінде бұл бөлімді жанармай бүрку бұрышының қуатқа, сағаттық және меншікті жанармай шығындарына тәуелділігі бойынша түсіріп анықталатын, сол арқылы қуаттың жоғары мәні мен жанармай шығынының төмен мәніне сәйкес келетін бұрышты анықтап қорытынды жасайтын. Инновациялық әдістер арқылы есептеуде 
болашақ маман Microsoft Excel программасын пайдаланып бұл тәуелділікті иілген диаграммамен төмендегі формада беруге болады (1-сурет).
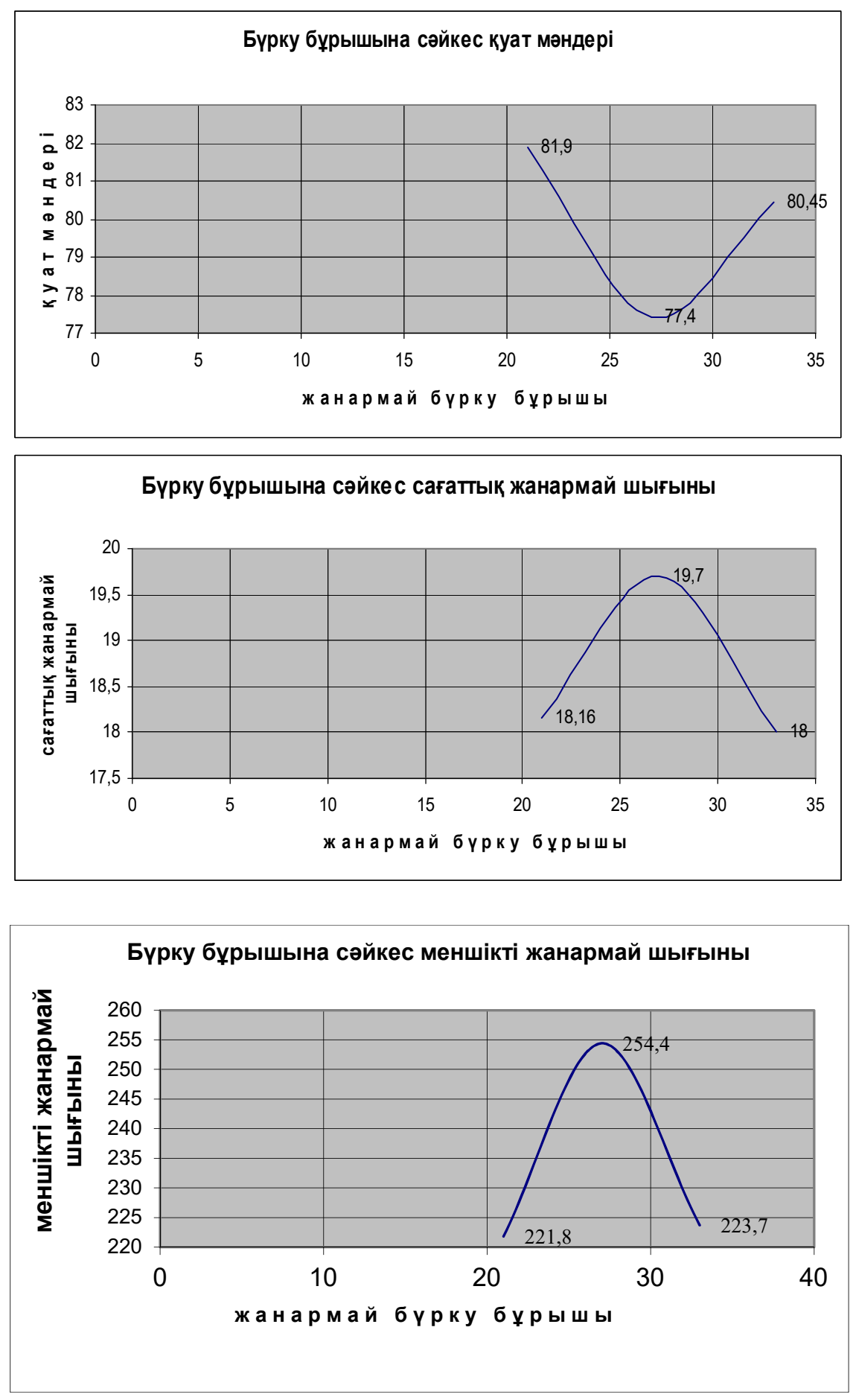

1-сурет - Дизельді двигательде тиімді жанармай бүрку бұрышын анықтау диаграммалары

Алынған график бойынша қорытынды жасайтын болсақ, 3029DF128 дизельді двигателі үшін жөндеу жұмыстарынан кейін $21^{0}$-тағы жанармай бүрку бұрышы қуаттың жоғарғы көрсеткішін, ал меншікті жанармай шығынының төмен мәнін қамтамасыз етеді 
екен, яғни двигательдің болашақтағы жұмысында жанармайды ерте бүркудің $21^{0}$-тағы мәні тиімді деп есептеледі.

Автотрактор двигательдерінің жұмысында майлау жүйесі де белгіленген мерзім ішінде диагностикалауды, техникалық қызмет көрсету мен жөндеуді қажет етеді. Автомобильдің майлау жүйесі - күрделі де құрамалы жүйе болып есептеледі [8,9]. Қысым арқылы шатун подшипниктері, таратқыш біліктің тірегі мен жұдырықшалары, білік подшипнигі мен май нососы жетегінің шестернасы майланады. Ал бүріккіш арқылы цилиндр қабырғасы, поршень поршень сақиналары, таратқыш білік жетегінің тізбегі т.б. майланады $[10,11]$.

Майлау жүйесінің негізгі техникалық күйін сипаттайтын параметрлерге басты май магистралындағы қысым мен температура болып есептеледі. Бұл параметрлерді анықтау үшін қазір жаңадан шыққан Car-Tool CT-1045 жиынтық-қондырғысы қолданылады.

Қондырғыны май магистралына жалғап жұмыс жасау үшін:

- цилиндр блогына май қысымы датчигі қойылады;

- қондырғының қосымша бөліктерінен тексеріліп жатқан двигатель маркасына сәйкес келетін түтікшені таңдап алып, оны датчикпен бірге қондырғыға жалғаймыз;

- двигательді оталдырып, жұмыстық температуралық режимге дейін қыздырамыз;

- монометр арқылы иінді біліктің минималь және қалыпты айналу жиілігіндегі май қысымын анықтап жазып аламыз.

Қазіргі қалыптасқан анықтау, салыстыру әдістерінде алынған мәндерді 2-кестедегі рұқсат етілген мәндермен салыстырып ауытқу кездескен жағдайда реттеу жұмыстарын жүргізілетін.

\section{2-Кесте - Майлау жүйесіндегі май қысымының рұқсат етілген мәндері}

\begin{tabular}{|c|c|c|c|}
\hline Автомобиль & $\begin{array}{l}\text { Температуралық } \\
\text { режим, }{ }^{0} \mathrm{C}\end{array}$ & $\begin{array}{l}n_{\text {мин кезіндегі май }} \\
\text { қысымы, мПа }\end{array}$ & 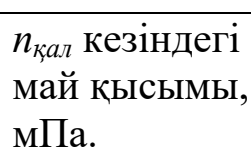 \\
\hline 1-Жеңіл көлік & 85 & 0,05 & 0,35 \\
\hline 2-жеңіл көлік & 90-ға дейін & 0,08 & 0,45 \\
\hline 3-жеңіл көлік & $80-90$ & $0,04-0,08$ & 0,30 \\
\hline
\end{tabular}

Енді алынған мәліметтерді компьютерге енгізіп, айырмашылықты анықтап көрейік. Ол үшін 2-кестенің мәндері компьютерге алдын-ала енгізіледі. Ал Car-Tool CT-1045 қондырғысы көмегімен алынған мәліметтер сол бастапқы мәліметпен салыстырылып, ауытқу мөлшері 2-сурет түрінде түседі. Автотрактор майлау жүйесіндегі тексеру нәтижесі мынадай болған.

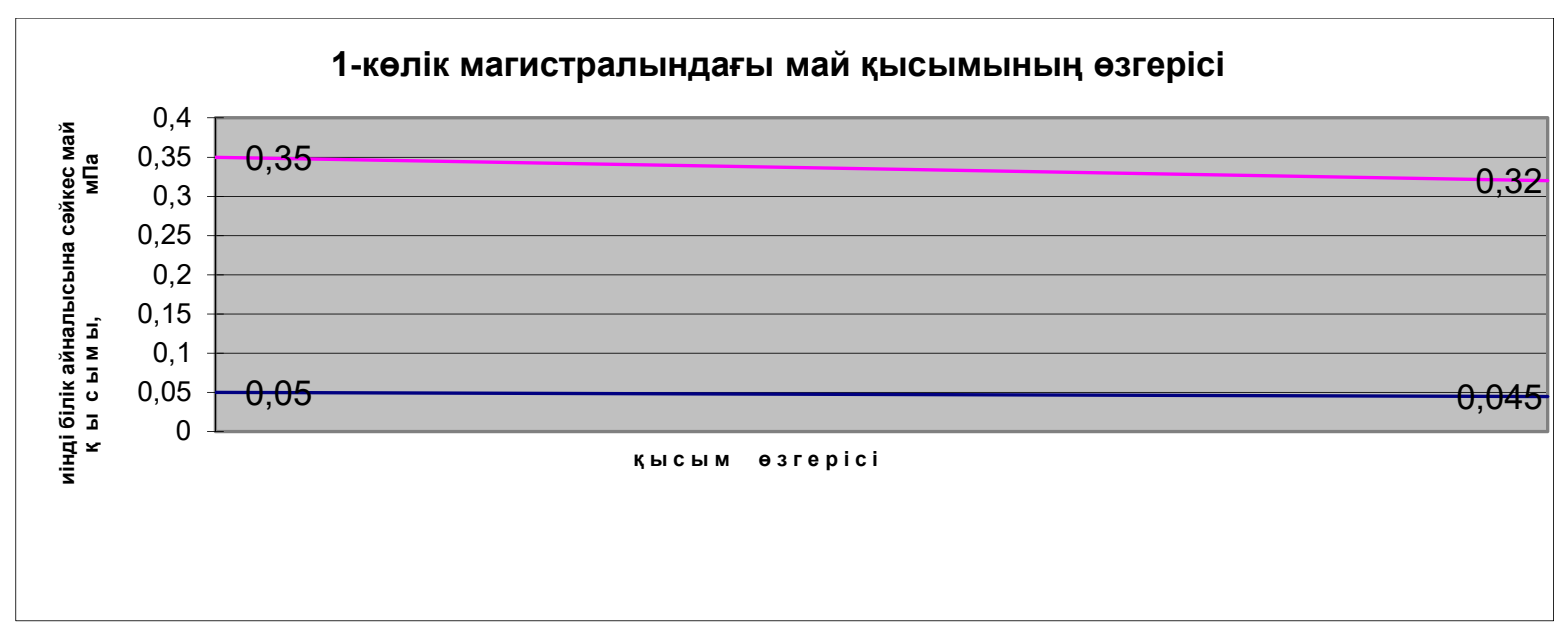




$\begin{array}{lcl}\text { 1-көлікте } & n_{\min } \text { кезінде } P=0,045 \mathrm{M} а \\ \text { 2-көлікте } & n_{\max } \text { кезінде } P=0,32 \mathrm{M} \text { Па. } \\ & n_{\min } \text { кезінде } P=0,081 \mathrm{м} \text { Па } \\ \text { 3-көлікте } & n_{\max } \text { кезінде } P=0,55 \mathrm{M} \text { Па. } \\ & n_{\min } \text { кезінде } P=0,046 \mathrm{M} \text { Па } \\ & n_{\max } \text { кезінде } P=0,4 \mathrm{M} \text { Па }\end{array}$
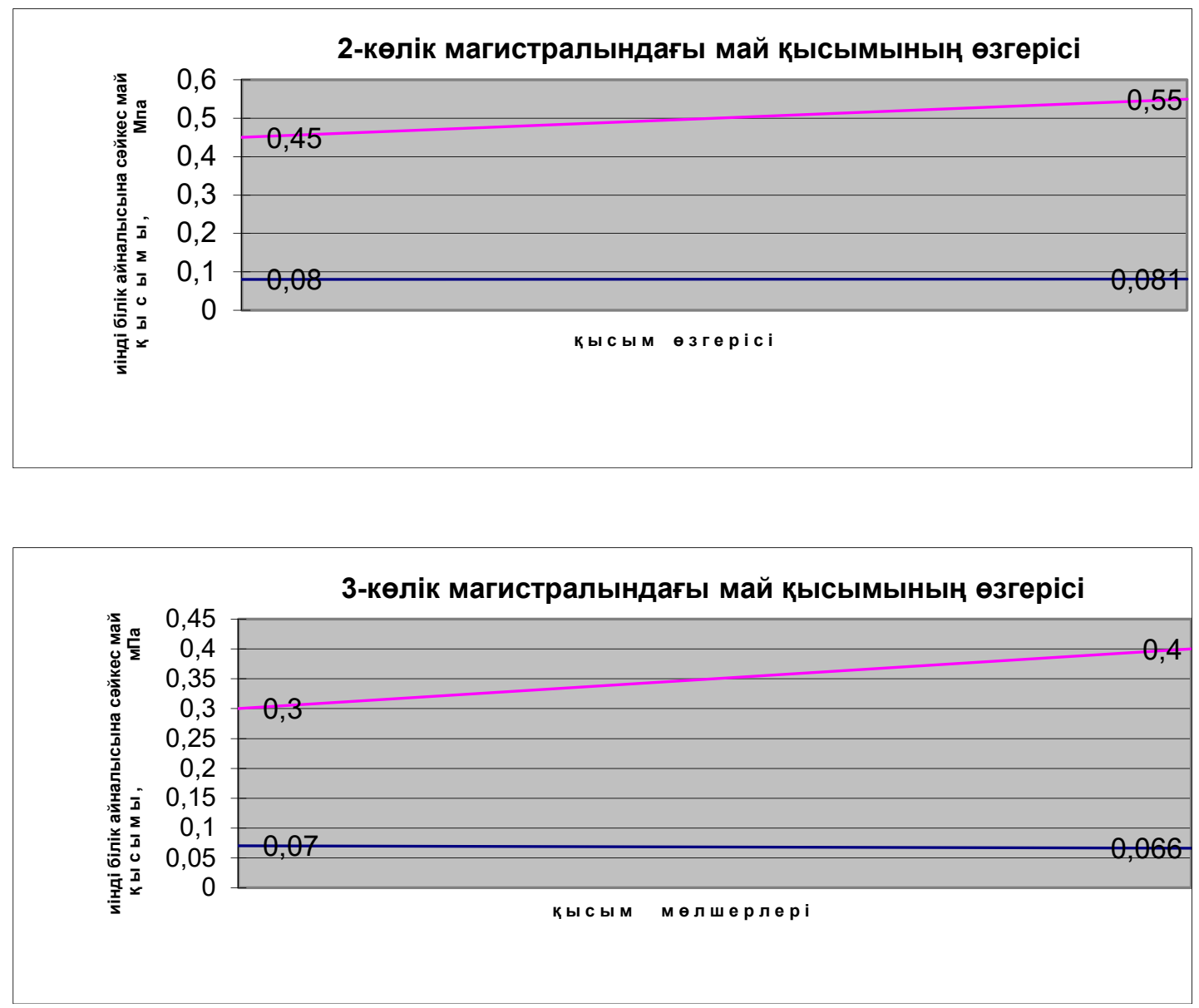

\section{2-сурет - Автомобильдердің майлау жүйесіндегі май қысымы өзгерісін анықтайтын тәуелділіктер}

Ескерту: графиктің сол жавындавы мәндер - автомобильдердің техникальқ сипаттамасындавы мәндер /2-кестедегі/, ал оң жавындавы мәндер - Car-Toоl CT-1045 құралымен тексеру кезінде анықталган қыссым өзгерісі мәндері.

Сонда 1-көліктің иінді білігінің ең төменгі айналу жиілігінде магистралдағы май қысымы белгіленген мөлшерден төмен болған, осыған сәйкес ең жоғарғы айналу жиілігінде де төмен мәнге ие болған. Сол сияқты 2 және 3-көліктерде ауытқу кездескен. Егер май қысымы шекті мәндерден төмен болса, двигательді автостетоскоп көмегімен тыңдалу қажет. Тырсыл, дыбыс пайда болса кривашуп - шатун механизмнің қосылыстары тозған деп, оны күрделі жөндеуге жібереді.

Қорытынды. Қазіргі ауыл шаруашылығы мен өндірісті, көлік тасымалы жүйесін дамытуға қойылып отырған талаптар осы салаға қатысты автокөліктерді уақытылы 
жөндеу, қызмет көрсету операцияларын өте жоғары деңгейде ұйымдастырып, жүргізуді талап етіп отыр. Ал, бұл міндеттер мен талаптарды тек қана мамандырылған техникалық сервис мекемелерінде жүзеге асыруға мүмкіндік болады. Өйткені қалыптасқан жөндеу мекемелері агрегаттар мен механизмдердің жұмыс қабілеттілігін қажетті деңгейде ұстап тұру немесе қалпына келтіру бағытындағы операцияларды 100\%-дың мөлшерде орындай алмайды. Оған кедергі болатыны - қажетті құрал-жабдықтар, қондырғылар, аспаптар мен стенділердің жоқтығы және жоғары білікті мамандардың жетіспеуі. Осыдан келіп, қазіргі ауыл шаруашылығы техникалары сенімділігін қамтамасыз ету үшін мамандандырылған техникалық сервис станциясын құру қажеттілігі айқындалады.

Жоғарыда аталған тексеру жұмыстары қазіргі таңдауға технология мен техникаға сәйкес барлық мүмкіндікті пайдалануға негізделген. Мұның арқасында техника бөлшектерінің жұмыс жасау сенімділігін арттырып, тексеруге кеткен уақытты үнемдеуге болады. Жаңадан ұйымдастырылатын техникалық сервис мекемелерінің жұмысы автотрактор двигателінің уақытынан бұрын тозуының алдын-алу, жөндеу жүргізілген жағдайда дәлдікті қамтамасыз ету, жөндеуден кейінгі жұмыс сенімділігін арттыру сияқты операцияларды мүлтіксіз орындайтын құрал-жабдықтармен қамтамасыз етілген. Сондықтан Қазақстанның экономикалық дамуы үшін бұл мәселенің де перспективалық маңызы зор деп есептейміз.

\section{Әдебиеттер:}

[1] Родионова, В.Н., Яголковская Е.Н. Организация эксплуатации и технического обслуживания оборудования на предприятии // Воронежский государственный технический университет. - ЭКОНОМИНФО. 2017. № 4

[2] Ишкина, Е.Г., Елесин С.В., Штайн Г.В., Маняшин А.В., Эртман Ю.А., Эртман С.А., Свистунова В.А., Гаваев А.С., Чижевская Е. Л. Современные технологии эксплуатации и ремонта транспортнотехнологических машин: учебное пособие / Ишкина Е.Г.,165 с.

[3] Справочник «Экология»- Управление техническим состоянием оборудования при эксплуатации [Электронный ресурс] - Режим доступа: http://ruecology.info/post/103772300020007/.

[4] Иванов, В.А., Фещенко А.А. Особенности подходов к техническому обслуживанию и ремонту оборудования в непрерывном производстве // Вестник ПНИПУ. Машиностроение, материаловедение T. 20, № 3, 2018/ DOI: 10.15593/2224-9877/2018.3.10

[5] Борисенко, И.Л., Родионова В.Н., Макаров Н.Н. Модель сервисного кластера для обслуживания промышленного оборудования // Научно-технические ведомости СПбГПУ. Экономические науки. 2017. Т. 10, № 4. С. 198-206. DOI: 10.18721/JE.10419

[6] Усуфов, М.М., Маковецкая-Абрамова О.В. Современные особенности развития автосервиса // Техника-технологические проблемы сервиса. - № 2 (20), 2012

[7] Ольшевская, Н. Экономический анализ. Шпаргалки. Расчетные методы. // Интернетpecypc https://econ.wikireading.ru/32463

[8] Масуев, М.А. Проектирование предприятий автомобильного транспорта. М.: Издательский центр «Академия», 2007. - 224 с.

[9] Ананьин, А.Д., Габитов И.И. Диагностика и техническое обслуживание машин: Учебник для студентов высших учебных заведений. М.: Издательский центр «Академия», 2008. $432 \mathrm{c}$.

[10] Радионов, Ю.В. Производственно-техническая инфраструктура предприятий автомобильного сервиса. Учеб. пособие. - Растов на Дону: Феникс, 2008. - 439 с.

[11] Власов, В.М., Жанказиев С.В., Круглов С.М. Техническое обслуживание и ремонт автомобилей. Учебник для студентов высших учебных заведений. М.: Издательский центр «Академия», 2008. - 480 с. 


\section{References:}

[1] Rodionova, V.N., YAgolkovskaya E.N. Organizaciya ekspluatacii i tekhnicheskogo obsluzhivaniya oborudovaniya na predpriyatii // Voronezhskij gosudarstvennyj tekhnicheskij universitet. - EKONOMINFO. 2017. № 4

[2] Ishkina, E.G., Elesin S.V., SHtajn G.V., Manyashin A.V., Ertman YU.A., Ertman S.A., Svistunova V.A., Gavaev A.S., CHizhevskaya E. L. Sovremennye tekhnologii ekspluatacii i remonta transportnotekhnologicheskih mashin: uchebnoe posobie / Ishkina E.G.,165 s.

[3] Spravochnik «Ekologiya» - Upravlenie tekhnicheskim sostoyaniem oborudovaniya pri ekspluatacii [Elektronnyj resurs] - Rezhim dostupa: http://ruecology.info/post/103772300020007/.

[4] Ivanov, V.A., Feshchenko A.A. Osobennosti podhodov k tekhnicheskomu obsluzhivaniyu i remontu oborudovaniya $\mathrm{v}$ nepreryvnom proizvodstve // Vestnik PNIPU. Mashinostroenie, materialovedenie T. 20, № 3, 2018/ DOI: 10.15593/2224-9877/2018.3.10

[5] Borisenko, I.L., Rodionova V.N., Makarov N.N. Model' servisnogo klastera dlya obsluzhivaniya promyshlennogo oborudovaniya // Nauchno-tekhnicheskie vedomosti SPbGPU. Ekonomicheskie nauki. 2017. T. 10, № 4. S. 198-206. DOI: 10.18721/JE.10419

[6] Usufov, M.M., Makoveckaya-Abramova O.V. Sovremennye osobennosti razvitiya avtoservisa // Tekhnika-tekhnologicheskie problemy servisa. - № 2 (20), 2012

[7] Ol'shevskaya, N. Ekonomicheskij analiz. SHpargalki. Raschetnye metody. // Internet-resurs https://econ.wikireading.ru/32463

[8] Masuev, M.A. Proektirovanie predpriyatij avtomobil'nogo transporta. M.: Izdatel'skij centr «Akademiya», 2007. - $224 \mathrm{~s}$.

[9] Anan'in, A.D., Gabitov I.I. Diagnostika i tekhnicheskoe obsluzhivanie mashin: Uchebnik dlya studentov vysshih uchebnyh zavedenij. M.: Izdatel'skij centr «Akademiya», 2008. - $432 \mathrm{~s}$.

[10] Radionov, Y.V. Proizvodstvenno-tekhnicheskaya infrastruktura predpriyatij avtomobil'nogo servisa. Ucheb. posobie. - Rastov na Donu: Feniks, 2008. - 439 s.

[11] Vlasov, V.M., Zhankaziev S.V., Kruglov S.M. Tekhnicheskoe obsluzhivanie i remont avtomobilej. Uchebnik dlya studentov vysshih uchebnyh zavedenij. M.: Izdatel'skij centr «Akademiya», 2008. $-480 \mathrm{~s}$

\section{ПРОБЛЕМЫ ТЕХНИЧЕСКОГО СЕРВИСА И ПЕРСПЕКТИВЫ ИННОВАЦИОННЫХ МЕТОДОВ}

Курбаналиев Б.Б., старший преподаватель Жумагулов Ж.Б., кандидат технических наук Сапарбаев Е.T., магистр технических наук

Черикбаев Р.К., кандидат технических наук

Казахский начиональный исследовательский аграрный университет, г. Алматы, Республика Казахстан

Аннотация. В целях предотвращения преждевременного износа, поломки и простоев сельхозтехники в Республике Казахстан применяется комплекс проверок, чисток, заправок, крепежных, наладочных работ, то есть плановая система страхования, обеспечивающая бесперебойную работу такой техники. Однако еще одна важная операция, которую необходимо учитывать для другого оборудования - это интеграция после ремонтных деталей с учетом изменений и отклонений, которые происходят в сборочных единицах в процессе этих ремонтных работ. Это связано с тем, что некоторые компоненты могут незначительно отличаться от заводской версии после ремонта. Даже малейшее отклонение может вызвать неуверенность в дальнейшей работе оборудования.

Согласно последним исследованиям, более $60 \%$ тракторных двигателей, поступающих в ремонтные компании, не требуют ремонта, только основные узлы и узлы нуждаются в регулировке и восстановлении. Чтобы предотвратить преждевременное повреждение оборудования, необходимо определить техническое состояние, отдельные системы, механизмы и 
состояние, обеспечивающие полное использование его моторного ресурса. Чтобы сэкономить время и деньги хозяйств, очень важно проводить осмотр техники без разборки. Постоянный контроль технико-экономических показателей существующих машин без разборки позволяет повысить производительность оборудования и снизить затраты.

В данной статье подробно описывается профилактика данных проблем, использование инновационных методов при ремонте оборудования.

Ключевые слова: сервис, диагностика оборудования, стенд, расход топлива, угол впрыска.

\section{PROBLEMS OF TECHNICAL SERVICE AND INNOVATIVE METHODS PERSPECTIVE}

Kurbanaliev B. B, senior teacher

Zhumagulov Zh.B., candidate of technical sciences

Saparbayev ET, master of technical sciences

Cherikbaev RK, candidate of technical sciences

\section{Kazakh National Agrarian Research University, Almaty city, Republic of Kazakhstan}

Annotation. Overall, to prevent premature depreciation, breakdown and downtime of agricultural machinery in the Republic of Kazakhstan, a complex of checks, cleaning, refueling, fastening, adjustment work is used, that is, a planned insurance system that ensures the smooth operation of such equipment. However, another important operation that must be taken into account for other equipment is the integration of after repair parts, taking into account the changes and deviations that occur in assembly units during these repairs. This is due to the fact that some components may differ slightly from the factory version after repair. Even the slightest deviation can cause uncertainty in the further operation of the equipment.

According to recent studies, more than $60 \%$ of tractor engines supplied to repair companies do not require repair, only the main components and assemblies need to be adjusted and restored. To prevent premature damage to the equipment, it is necessary to determine the technical condition, individual systems, mechanisms and condition that ensure the full use of its motor resource. To save time and money for farms, it is very important to inspect equipment without disassembly. Continuous monitoring of the technical and economic indicators of existing machines without disassembly allows you to increase the productivity of the equipment and reduce costs. This article describes in detail the prevention of these problems, the use of innovative methods in the repair of equipment.

Keywords: service, equipment diagnostics, stand, fuel consumption, injection angle. 


\title{
Ақпараттама, есептеу техникасы және басқару Информатика, вычислительная техника и управление Informatics, computer engineering and management
}

IRSTI: 20.51 .19

https://doi.org/10.52081/bkaku.2021.v58.i3.080

\section{INTERACTIVE VISUALIZATION TECHNOLOGY IN AUGMENTED REALITY}

\author{
Dauitbayeva A.O., candidate of technical sciences \\ aicos@mail.ru, https://orcid.org/0000-0002-5942-628X \\ Myrzamuratova A.A., master of engineering and technology \\ al_mansur_73@mail.ru,https://orcid.org/0000-0001-5211-5633 \\ Bexeitova A.B., master of technical sciences \\ ainur.85@list.ru, https://orcid.org/0000-0002-0346-1924
}

\section{Kyzylorda University named after Korkyt Ata, Kyzylorda city, Republic of Kazakhstan}

\begin{abstract}
Annotation. This article is devoted to the issues of visualization and information processing, in particular, improving the visualization of three-dimensional objects using augmented reality and virtual reality technologies.

The globalization of virtual reality has led to the introduction of a new term "augmented reality"into scientific circulation. If the current technologies of user interfaces are focused mainly on the interaction of a person and a computer, then augmented reality with the help of computer technologies offers improving the interface of a person and the real world around them.

Computer graphics are perceived by the system in the synthesized image in connection with the reproduction of monocular observation conditions, increasing the image volume, spatial arrangement of objects in a linear perspective, obstructing one object to another, changing the nature of shadows and tones in the image field. The experience of observation is of great importance for the perception of volume and space, so that the user "completes" the volume structure of the observed representation. Thus, the visualization offered by augmented reality in a real environment familiar to the user contributes to a better perception of three-dimensional object.
\end{abstract}

Keywords: augmented reality, interface, mobile devices, interactive visualization.

Introduction. The term" virtual reality " refers to the creation of a completely artificial environment, replacing all the audio-visual information that comes to a person from the surrounding world. In the case of additional reality, the information received from the surrounding reality is only partially supplemented by virtual content.

The relationship between man and computer is a dynamically developing branch of science. Continuous improvement of technology leads to the emergence of innovative user interface paradigms.

The globalization of virtual reality has led to a new introduction of "augmented reality" into scientific circulation. If modern user interface technologies focus mainly on HumanComputer Interaction, augmented reality (AR) with the help of computer technology allows you to improve the human interface and the real environment.

Currently, AR technology research is one of the most relevant forms.

AR technology allows you to display a model of the human interface and real environment through a Global Positioning System (GPS).

The goal is to study the technology of interactive visualization of three-dimensional objects using augmented reality tools in real time on a real scale for mass mobile devices.

Materials and methods.Photons emitted by a light source are reflected from the object, entering the retina of the eye, so that visual information enters the brain - the object becomes visible. Such lighting is called directional or direct. However, in addition to coming directly from 
the light source, photons reflected from other objects fall on the object. Such lighting is called diffused or global. This is a simulation of global lighting, which significantly increases the realism of computer visualization. Based on this, it is necessary to take into account how effective shading systems are using global lighting algorithms $[1,2]$.

It is important that the introduction of augmented reality technology requires not only a clear representation of virtual objects, but also their real integration into the real environment. This realism can be significantly improved by using the shadow of objects captured on Earth in a real environment. It is also important that the systems support reflective materials such as metal, plastic, glass, etc.

The functional capabilities of the systems were analyzed: changing the parameters of visual objects in real time, functions for managing objects in space, the ability to work simultaneously with several models, the function of stopping video streaming, the number of supported operating systems.

The organization of graphical interfaces of systems on which the speed and efficiency of interaction depends is of great importance.

Results and discussion. The implementation of mobile solutions with augmented reality was associated with the need for the user to carry a large amount of special equipment: a computer, batteries, cameras, displays. Thus, there are two main disadvantages inherent in modern augmented reality systems:

- unavailability for the mass consumer,

- the bulkiness of mobile solutions.

This leads to the almost complete absence of useful mass applications of augmented reality. Whereas when solving these shortcomings DR has a great potential for mass adoption, providing more natural ways of interacting with computer systems. To date, with the development of technologies and consumer electronics, there are serious prerequisites for changing this situation [10].

From the results of comparing systems for mass mobile devices with the use of largescale realism, interactive visualization, first of all, the shortcomings in the real representation of objects were obvious. To eliminate them, it is necessary to review the methods of organizing lighting and preliminary preparation of three-dimensional models. An important issue is the study of ways to implement the functionality of augmented reality. For example, in the process of real-time visualization, you can change various parameters of an object, such as color, material, and state. None of the considered systems allows you to change the parameters of complex composite objects.

At the same time, the organization of the user interface of systems as a whole visualization using DR is at a low level. It is necessary to develop practical recommendations for designing user interfaces of such systems.

To implement augmented reality technology, two main software components are required: tracking and visualization. Currently, researchers and specialists have developed a large-scale theoretical and algorithmic base for their implementation, both in the form of various individual components and in the form of a set of integrated programs and tools for developing additional realities. Individual components include computer vision libraries and frameworks, three-dimensional graphics movements, and other solutions.

At present, it is important to take into account that events in the field of surveillance have reached the point where it is possible to clearly observe the position and movements of a person, but, as a rule, this is achieved with the help of various special means: movement tracks, special reflectors or specially placed cameras of a certain size. This study examines the use of augmented reality technology in the mass market using tools available to a real consumer.

There are several possible ways to implement tracking on mass mobile devices. In one of the methods used in practice, the control function is not implemented. In this case, the 
collage consists of images of objects (for example, interior items). In this case, the background can be a video stream from the camera or a static image.

An important component of augmented reality is Object Recognition, which allows you to process information about the world and make it interactive, as well as computer vision. The construction, architecture and design industries have benefited greatly from the advent of DR technology. From now on, complex drawings of buildings and structures can be visualized in three-dimensional form before the customer's eyes and designed immediately at the site of their construction to understand how they fit into the landscape. In this case, you do not need additional devices, it is enough if you have a tablet or smartphone with a camera. Of course, in the video game and multimedia entertainment industry, augmented reality has been used for much longer than in the AEC (architecture, engineering and construction) industry. Nevertheless, the prospects for its implementation in the field of architecture, construction and design bring great benefits, and today there are many applications on the market that are actively used by users. In most cases, the faces of three-dimensional objects in computer graphics are represented by triangles connected to each other by their ends and common sides. Such sets are called Triangular meshes.

The division of a triangle (or network) can be determined by listing the coordinates of triangles (triplets of triangles) and vertices in three-dimensional space. Many programs that work with three-dimensional graphics save additional information related to the edges, sides, and surfaces of triangles to support textures, shadows, animations, and other operations. Most often, vertices are used to link surface parameters - they indicate the properties of the surface material, texture coordinates, and radiation intensity. These parameters are then linearly interpolated across the entire Triangle, showing a continuous function on the entire modeled surface [6].

Summary.Computer graphics the system is perceived in the synthesized image, reproducing the conditions of monocular observation, depending on the size of the image, the spatial location of objects to a linear perspective, the interference of some objects to others, the nature of Shadows and changes in tone along the image field. The observation experience is of great importance for the perception of volume and space, thanks to which the user "completes"the three-dimensional structure of the observed scene. Thus, visualization, which provides augmented reality in a real environment familiar to the user, contributes to a better perception of three-dimensional objects.

\section{References:}

[1] Афанасьева, А. Основы синтеза фотореалистичных изображений [Электронный ресурс] // Курс: Основы синтеза фотореалистичных изображений. URL: https://courses.graphics.cs.msu.ru/ course/ view.php?id=11.

[2] Благовещенский, И.А., Демьянков Н. А.Технологии и алгоритмы для создания дополненной реальности //Моделирование и анализ информационных систем. 2013. - Т. 20. - №. 2. - C.129- 138 .

[3] Визильтер, Ю.В. Обработка и анализ изображений в задачах машинного зрения: Курс лекций и практических занятий [Текст] //М.:физматкнига. -2010.

[4] Макеев, С.Н., Макеев А. Н. Генезис понятия расширенной реальности//Учебный эксперимент в образовании. - С.8.

[5] Пробуйдопокупки:сервис размещения товаров в дополненной реальности ARTOUCHER [Электронный pecypc] //ARNext.ru - Bсё о дополненной и виртуальной реальности. URL: http://arnext.ru/interview/probuy-do-pokupki-servis- razmeshheniya-tovarov-v-dopolnennoy-realnostiartoucher-15718.

[6] Чанг, Б.Т., Хоанг Ф. Н., Спицын В. Г. Распознавание лиц на основе применения метода Виолы-Джонса, вейвлет преобразования и метода главных компонент //Известия Томского политехнического университета. - 2012. - Т. 320. - №.5. 
[7] Bay, H., Tuytelaars T., Van Gool L. Surf: Speeded up robust features //Computer vision-ECCV 2006. - Springer Berlin Heidelberg, 2006. - C. $404-417$.

[8] Bimber, O., Raskar R. Modern approaches to augmented reality //ACM SIGGRAPH 2006 Courses. - ACM, 2006. - C. 1.

Cook J. et al. Real-time photo-realistic augmented reality for interior design //ACM SIGGRAPH 2003 Sketches \& Applications. - ACM, 2003. - C. 1 - 1.

[9] Иванова, А.В. Технологии виртуальной и дополненной реальности: возможности и примененияhttps://doi.org/10.17747/2078-8886-2018-3-88-107

[10] Bay, H., Tuytelaars T., Van Gool L. Surf: Speeded up robust features //Computer visionECCV 2006. - Springer Berlin Heidelberg, 2006. - C. 404-417.

[11] Bimber, O., Raskar R. Modern approaches to augmented reality //ACM SIGGRAPH 2006 Courses. - ACM, 2006. - C. 1

[12] Yasumuro, Y. et al. Consistent Presentation of Interactive Virtual Objects in Real Space with 3D Markers-Interactive Virtual Interior Design- //Digital Image Computing: Techniques and Applications, Proceedings of the VIIth Biennial Australian Pattern Recognition Society Conference. 2003. - C. $653-662$.

[13] Yemez, Y., Schmitt F. 3D reconstruction of real objects with high resolution shape and texture //Image and Vision computing. - 2004. - T. 22. - №. 13. - C. 1137 - 1153.

[14] Zhou, F., Duh H. B. L., Billinghurst M. Trends in augmented reality tracking, interaction and display: A review of ten years of ISMAR //Proceedings of the 7th IEEE/ACM International Symposium on Mixed and Augmented Reality. - IEEE Computer Society. - 2008. - C.193 - 202.

\section{References:}

[1] Afanas'eva, A. Osnovy sinteza fotorealistichnyh izobrazhenij [Elektronnyj resurs] // Kurs: Osnovy sinteza fotorealistichnyh izobrazhenij. URL: https://courses.graphics.cs.msu.ru/ course/ view.php?id=11.

[2] Blagoveshchenskij, I.A., Dem'yankov N. A.Tekhnologii i algoritmy dlya sozdaniya dopolnennoj real'nosti //Modelirovanie i analiz informacionnyh sistem. 2013. - T. 20. - №. 2. - S.129 138.

[3] Vizil'ter, Yu.V. Obrabotka i analiz izobrazhenij v zadachah mashinnogozreniya:Kurslekcijiprakticheskihzanyatij [Tekst] //M.:fizmatkniga. -2010.

[4] Makeev, S. N., Makeev A. N. Genezis ponyatiya rasshirennoj real'nosti//Uchebnyj eksperiment v obrazovanii. - S.8.

[5] Probujdopokupki:servisrazmeshcheniyatovarovvdopolnennojreal'nosti ARTOUCHER [Elektronnyj resurs]//ARNext.ru - Vsyo o dopolnennoj i virtual'noj real'nosti. URL: http://arnext.ru/interview/probuy-do-pokupki-servis- razmeshheniya-tovarov-v-dopolnennoy-realnostiartoucher-15718.

[6] Chang, B.T., Hoang F.N., Spicyn V.G. Raspoznavanie lic na osnove primeneniya metoda Violy-Dzhonsa, vejvlet preobrazovaniya i metoda glavnyh komponent//Izvestiya Tomskogo politekhnicheskogo universiteta. - 2012. - T. 320. - №.5.

[7] Bay H., Tuytelaars T., Van Gool L. Surf: Speeded up robust features //Computer vision-ECCV 2006. - Springer Berlin Heidelberg, 2006. - S. $404-417$.

[8] Bimber, O., Raskar R. Modern approaches to augmented reality //ACM SIGGRAPH 2006 Courses. - ACM, 2006. - S. 1.

Cook J. et al. Real-time photo-realistic augmented reality for interior design //ACM SIGGRAPH 2003 Sketches \& Applications. - ACM, 2003. - S. 1-1.

[9] Ivanova, A.V. Tekhnologii virtual'noj i dopolnennoj real'nosti: vozmozhnosti i primeneniyahttps://doi.org/10.17747/2078-8886-2018-3-88-107

[10] Bay, H., Tuytelaars T., Van Gool L. Surf: Speeded up robust features //Computer visionECCV 2006. - Springer Berlin Heidelberg, 2006. - S. 404 - 417.

[11] Bimber, O., Raskar R. Modern approaches to augmented reality //ACM SIGGRAPH 2006 Courses. - ACM, 2006. - S. 1

[12] Yasumuro, Y. et al. Consistent Presentation of Interactive Virtual Objects in Real Space with 3D Markers - Interactive Virtual Interior Design-//Digital Image Computing: Techniques and 
Applications, Proceedings of the VIIth Biennial Australian Pattern Recognition Society Conference. 2003. - S. 653-662.

[13] Yemez, Y., Schmitt F. 3D reconstruction of real objects with high resolution shape and texture //Image and Vision computing. - 2004. - T. 22. - №. 13. - S. 1137 - 1153.

[14] Zhou, F., Duh H. B. L., Billinghurst M. Trends in augmented reality tracking, interaction and display: A review of ten years of ISMAR //Proceedings of the 7th IEEE/ACM International Symposium on Mixed and Augmented Reality. - IEEE Computer Society. - 2008. - S.193 - 202.

\title{
ТЕХНОЛОГИЯ ИНТЕРАКТИВНОЙ ВИЗУАЛИЗАЦИИ В СРЕДЕ ДОПОЛНЕННОЙ РЕАЛЬНОСТИ
}

\author{
Даутбаева А. О., кандитат технических наук \\ Мырзамуратова А.А., магистр техники и технологии, \\ Бексейтова А.Б., магистр технических наук
}

Кызылординский университет имени Коркыт Ата, г. Кызылорда, Республика Казахстан

Анотация. Данная статья посвящена вопросам визуализации и обработки информации, в частности, улучшению визуализации трехмерных объектов с использованием технологий дополненной реальности и виртуальной реальности. Концепция дополненной реальности предлагает более продвинутый пользовательский интерфейс для визуализации благодаря сочетанию естественных способов управления визуализацией с целью объекта и визуализацией в реальном контексте.

Глобализация виртуальной реальности привела к вводу в научный оборот нового термина «дополненная реальность». Если текущие технологии пользовательских интерфейсов сфокусированы в основном на взаимодействии человека и компьютера, то дополненная реальность при помощи компьютерных технологий предлагает совершенствование интерфейса человека и реального окружающего мира.

Компьютерная графика воспринимается системой в синтезированном изображении в связи с воспроизведением условий монокулярного наблюдения, увеличением объема изображения, пространственного расположения объектов на линейную перспективу, препятствованием одних объектов другим, изменением характера теней и тона по полю изображения. Опыт наблюдения имеет большое значение для восприятия объема и пространства, благодаря чему пользователь «завершает»объемную структуру наблюдаемого представления. Таким образом, визуализация, предлагаемая дополненной реальностью в реальной среде, знакомой пользователю, способствует лучшему восприятию трехмерных объектов.

Ключевые слова: дополненная реальность, интерфейс, мобильные устройства, интерактивная визуализация.

\section{ТОЛЫҚТЫРЫЛҒАН ШЫНДЫҚ ОРТАСЫНДА ИНТЕРАКТИВТІ ВИЗУАЛИЗАЦИЯ ТЕХНОЛОГИЯСЫ}

Дәуітбаева А.О., техника ғылымдарының кандидаты

Мырзамуратова А.А., мехника және технология магистрі

Бексейтова А.Б., техника ғылымдарының магистрі

Қорқыыт Ата атындавы Қызыллорда университеті, Қызыллорда қ., Қазақсстан Республикасы

Андатпа. Бұл мақалада визуализация және ақпаратты өңдеу мәселелеріне, атап айтқанда, кеңейтілген шындық және виртуалды шындық технологиясын қолдана отырып,үш өлшемді объектілерді визуализация арқылы жақсартуға арналған. Толықтырылған шындық тұжырымдамасы объектінің мақсатымен мен нақты контексте визуализацияны басқарудың табиғи тәсілдерінің үйлесуіне байланысты визуализация үшін анағұрлым жетілдірілген пайдаланушы интерфейсін ұсынады. 
Виртуалды шындықтың жаһандануы ғылыми айналымға "толықтырылған шындық"деген жаңа терминнің енгізілуіне әкелді. Егер қазіргі қолданушы интерфейсі технологиялары негізінен адам мен компьютердің өзара әрекеттесуіне бағытталған болса, онда компьютерлік технологияның көмегімен кеңейтілген шындық адам мен нақты әлем интерфейсін жетілдіруді ұсынады.

Компьютерлік графика жүйе монокулярлық байқау жағдайларын жаңғырта отырып, кескіннің көлемін, объектілердің кеңістіктік орналасуын сызықтық перспективаға, кейбір объектілердің басқаларға кедергі келтіруіне, көлеңкелердің табиғатымен кескін өрісі бойындағы тонустың өзгеруіне байланысты синтезделген кескінде қабылданады. Байқау тәжірибесі көлемі мен кеңістікті қабылдау үшін үлкен маңызға ие, соның арқасында пайдаланушы бақыланатын көріністің көлемдік құрылымын «аяқтайды». Осылайша, пайдаланушыға таныс нақты ортада кеңейтілген шындық ұсынатын визуализация үш өлшемді нысандарды жақсырақ қабылдауға ықпалетеді.

Кілт сөздер: тольқтырылван шындық, интерфейс, мобильді құрылвылар, интерактивті визуализация 


\title{
ОҚУ ОРЫНДАРЫНЫН АҚПАРАТТЫҚ КЕНІСТІГІНІН КИБЕРКОРҒАУ САЛАСЫНДАҒЫ АЛДЫНҒЫ ЗЕРТТЕУЛЕРГЕ ШОЛУ ЖӘНЕ ТАЛДАУ
}

\author{
Ахметов Б.С. ${ }^{\mathbf{1}}$, техника ғылымдарының докторы \\ b_akhmetov@ntu.kz, https://orcid.org/0000-0001-5622-22233 \\ Лахно В. А. ${ }^{2}$, техника ғылымдарының докторы \\ lva964@nubip.edu.ua, https://orcid.org/0000-0001-9695-4543 \\ кыдыралина Л.M. ${ }^{3}, \mathrm{PhD}$ \\ lazzat_75@mail.ru, https://orcid.org/0000-0002-2836-0919
}

${ }^{1}$ Абай атындавы Қазақ ұлттық педагогикалық университеті, Алматы қ.., Қазақ̆стан Республикасы

${ }^{2}$ Биоресурстар және табиватты пайдалану ұлттық университеті, Киев қ.., Украина.

${ }^{3}$ Семей құаласының Шәкәрім атындавы университеті КеАҚ, Семей қ.. Қазаққстан Республикасы

Аңдатпа. Мақалада заманауи ЖОО-ның қауіпсіз ақпараттық білім беру ортасын қалыптастырудың алғы шарттары қарастырылған. Отандық және жетекші шетелдік зерттеулердің жарияланымдары талданды. Оқу орындарының ақпараттық кеңістігін кибер қорғау (КҚау) саласындағы алдыңғы зерттеулерге шолу жасалып, осы тақырып бойынша шыққан жарияланымдарға талдау жүргізілді. Жасалған талдау жоғары оқу орындарының КҚау жүйесін үздіксіз өзара инвестициялау міндеттерінде ШҚЖ үшін модельдерді одан әрі дамыту проблемасының өзектілігін растады. Ақпараттандыру нысандардың КҚау қатерлерінің моделін сипаттау үшін Петри желілерін қолдануға арналған зерттеулер нәтижелері бойынша жарияланымдарға талдау жасалды. Бұл жұмыстар осы міндетте айтарлықтай теориялық үлес қосса да, біздің ойымызша, авторлар ұсынған модельдерді, атап айтқанда АН-ді АҚ және КҚау бойынша ШҚИЖ-да және СЖда бағдарламалық жүзеге асыру біршама қиынға соғады. Бұл өз кезегінде қосымша зерттеулерді талап етеді.

Жалпы мақалада ақпараттық жүктемесі көп жұмыс орындары үшін қауіпсіздікті қамтамасыз ететін және мәліметтердің бірегейлігін сақтайтын мүмкіндіктер жайлы жан жақты келтірілген. Осы саладағы мамандар үшін мақала қажетті ақпараттарды бере алады.

Кїлт сөздер: киберққауіпсіздік, жовары оку орнының ақпараттық білім беру ортасы, моделдеу, Петри желісі, ақпаратты қоргау, жогары оқу орнының электронды ақпараттық білім беру ортасы, ддіс, модель.

Кіріспе. ТМД елдері ғалымдарының көптеген еңбектері мемлекеттік құрылымдардың, оның ішінде ЖОО-ның ақпараттық-коммуникациялық жүйелерінің (АКЖ) киберқорғау міндеттерін теориялық зерттеуге арналған: Р.Н.Акиншин [1], Б.С. Ахметов [2], Р.Г.Бияшев [3], О.В. Есиков [1], В.А. Лахно [4], R. Ortalo [5], P.Puhakainen [6].

Алайда, Қазақстанда және ТМД-ның басқа елдерінде бұл басылымдардың көлемі шектеулі немесе айтарлықтай аз, олар тек «жоғары оқу орындарындарын киберқорғау қажеттілігі» тақырыбындағы баяндамалардың тезистерімен ғана шектелген [6]. Теориялық нәтижелер мен зерттеу нәтижелері кейбір басылымдарда, эксперименттік мәліметтер немесе имитациялық модельдеу нәтижелері басқа басылымдарда берілген [7]. Зерттеудің жеке сегменті ЖОО үшін АҚау-ды және КҚау-ды қамтамасыз етудің аппараттық және бағдарламалық құралдарын құру міндеттеріне арналған [1].

Жарияланымдардың едәуір көп бөлігі, атап айтқанда, ЖОО КҚау жүйесі үшін қаржылай инвестициялаудың тиімді стратегияларын таңдауға арналған зерттеулер $[1,8,9]$.

АҚау және КҚау модельдерінің ішінде Гордон-Лоеба (ГЛ) моделі ең негізгі және кең таралған. Бұл модельдің мақсаты ақпаратты қорғауға инвестициялардың оңтайлы мөлшерін анықтауға байланысты міндеттерді шешу. 
ГЛ моделіндегі негізгі жағдай қарастырылып отырған ақпараттандыру нысаны үшін, атап айтқанда ЖОО АББО үшін АҚау-дың және КҚау-дың деңгейін анықтайтын осалдық функциясын енгізу және дамыту. Ақпараттық нысанның әртүрлі формалары болуы мүмкін: қолданушылар тізімі, бухгалтерлік есеп кітабы, стратегиялық даму жоспары, веб-сайт және т.б. Қауіпсіздікті арттыру құпиялылықты, тұтастықты, нақтылықты, сенімділікті, қолданушылардың авторизациясының қол жетімділігін және т.б. қорғау бағытында орын алуы мүмкін.

Зерттеу материалы және әдістері. Модель құрылымы бойынша статикалық болады. Демек, шешімдер мен нәтижелер бір уақытта пайда болады, ал динамикалық әсерлер, оның ішінде ақшаның уақытқа тәуелділігі ескерілмейді.

АҚау және КҚау құралдары мен әдістеріне инвестициялар жұмсау осалдықтың жеткілікті кіші және жеткілікті үлкен мәндерінде тиімсіз екенін ескере отырып, ГЛ моделінің авторлары, сондай-ақ ГЛ моделіне негізделген идеяларды дамытқан [2] бірқатар жұмыстарда келесі жағдайлар атап өтілген.

Көптеген авторлар нысандарды төмен, орташа және жоғары осалдық деңгейлеріне бөлуді басқарудың бірінші міндеті және бұл жобалаудың алғашқы кезеңдерінде жасалуы керек деп санайды. Алайда, ГЛ моделінің және оған ұқсас модельдердің авторлары оның кемшіліктерін атап өтті:

- шабуыл ықтималдығын және ақпараттық массивтердің осалдығын анықтайтын қарапайым процедура жоқ;

- ақпараттандыру нысанының қорғау периметрлерінің қауіпсіздігі мен киберқауіпсіздігінің бұзылуынан болатын потенциалды шығындарды анықтау қиынға соғады. (ЖОО АББО үшін бұл АҚау және КҚау периметрлері әлі де жеткілікті түрде шартты екенін ескереміз);

- Зерттеу нәтижелерін белгілі бір нысанға қатысты іске асырудың күрделілігі;

- шабуылдаушының қорғаныс үшін қосымша инвестициялар салу кезінде өзстратегиясын қалай өзгертетіні ескерілмеген, атап айтқанда, динамикалық режимде қарама-қарсы келудің талдауы жоқ.

ГЛ моделі кеңінен танылып және жарияланған кезден бастап он жыл ішінде көптеген жұмыстарда дамығанына қарамастан, қойылған сұрақтардың басым бөлігі бүгінгі күнге дейін шешілмеген болып отыр. Модель авторларының сөзсіз еңбегі - бұл міндетті алғаш рет мұқият қарастырып және осалдық функциясын анықтағаны, ақпараттық саладағы қарама-қарсы тұруды қарастырудағы басты мәселе. Функцияның түрін анықтау, динамикалық жүйенің осалдығын білдіреді, ақпараттық қарама-қарсы тұруды математикалық модельдеудегі басты мәселе және көптеген зерттеушілердің жұмыстары осы мәселеге арналды [3].

Егер біз міндеттің тарихына жүгінетін болсақ, онда екі тараптың қарама-қарсы тұруын бірінші рет екінші дүниежүзілік соғыстың соңында әскери жоспарлаудың математикалық негіздерін құру кезінде RAND Corporation мамандары мұқият қарастырды. RAND фирмасы жасаған екі тараптың қарсы тұру моделі тактикалық әскери операцияларды имитациялауға арналған Гросс моделі [10]. Осы модельге сәйкес, қақтығысушы тараптардың X және Y ресурстары бар, олардың қарама-қарсы тұру нәтижесі салынған ресурстардың айырмашылықтарына сызықтық тәуелді және сызықтық бағдарламалар есебіне әкелетін мақсатты функциямен анықталады.

Әскери операцияларды жоспарлау кезінде пайда болған Гросстың есебінің қарастырылған есептерден бірқатар айырмашылықтары бар. Біріншіден, мақсатты функция дискретті, өйткені қорғаныс арқылы өтудің немесе шабуылды жоюдың немесе қорғаныс санын анықтайды. Екіншіден, бұл өлшемдер қарама-қарсы күрестің әрбір эпизодында шабуылдаушы үшін де және сәйкес қорғанушы үшін де бірдей. 
Нысандардың біртектілігі есепті шешуді айтарлықтай жеңілдетеді, алайда қарсы күресу шарттарын шектейді. Алайда, Гросс моделінің басты кемшілігі - оның мақсатты функциясының сипаты үзік-сызықтық болып табылуында, ол әрине, нақты жағдайларға сәйкес келмейді. Осы себепті Гросс моделін оның қарапайымдылығын ескере отырып, мақсатты функцияны аппроксимациялау және бірінші жуықтауда нәтижелерді алу үшін ғана пайдаланады [11].

Ақпаратты қорғауға арналған шығындар көлеміне және КҚау-ға байланысты, қатерлерді іске асыру салдарынан болған шығындар деңгейін есептеуге мүмкіндік беретін тағы бір математикалық модель модельдер [4,12] жұмыстарда сипатталған. Мына зерттеу жұмыстарының [2,3] мақсаты, ықтимал бөлудің белгілі әдістерін қолдана отырып, ақпаратты техникалық қорғау кешенінің (АТҚ) тұрақтылығын бағалау болды.

Қорғауға немесе оны модернизациялауға қаржылай инвестициялар болмаған жағдайда, уақытқа қарамастан қорғалудың сенімділігі нөлге тең болады. Бұл модель қамтамасыз ету ықтималдығының неғұрлым тиімді қаржыландыруға тәуелділігін анықтауға мүмкіндік береді.

Модельді құрудағы негізгі қиындықтар бұзу нәтижелері туралы статистикалық мәліметтерді жинаумен байланысты (және қорғаудың бұзылу фактісінің қажеттілігі), өйткені мұндай қорғаныс жүйесі бұдан кейін қайталанып қолданылмайды. Осыған байланысты автор $[4,11]$ жеке қорғаныс жүйелерінің ықтималды сенімділігін бағалауға және оны бірнеше нысандарға орнатуға мүмкіндік беретін нақты бұзу әрекеттері негізінде АТҚ-ның ықтималды сенімділігін анықтау әдісін жасады (мысалы, бірнеше компьютерге антивирустық бағдарламаны орнату әрекетті ғана емес, сонымен қатар басқа компьютерлерді бұзу мүмкіндігіне кететін уақытты да қарастыруға болады) [2,13]. Бұл әдістің кемшілігі - бұл жағдайда жүйенің нақты бұзылуы салдарын талдау нәтижесінен алынатын АТҚ-ның тиімділігін білу қажеттілігі.

Зерттеулер нәтижесінде [4], авторлар АТҚ қасиеттерін анықтайтын параметр тек тұрақты шама ғана емес, сонымен қатар функция да да бола алатындығын көрсетті. Сонымен қатар, бұл функция бұзу әрекеттеріне және мұндай әрекеттер орын алған уақытқа байланысты тәуелді болады, мысалы, ақпараттандыру нысанының желісінде қолданушыны аутентификациялау процедурасы барысында парольдерді таңдау тактикасы кезінде $[9,14]$. Зерттеу нәтижелері бойынша, бұзу әрекеттерінің жиілігін есептеуге мүмкіндік беретін функциялар алынды.

Глушак-Новиковтың моделі [14] қорғаудың максималды деңгейін қамтамасыз ететін жүйенің компоненттері (нысандары) арасында қорғаныс механизмдерін оңтайлы орналастыруға бағытталған.

Ақпаратты жоғалтудың минималды тәуекелін қамтамасыз ететін қорғау механизмдерінің оңтайлы жиынтығын іздеу, аумақтық таратылған ақпараттандыру нысанның аудандық бөлімшелерінің жүйесі мысалында жүргізілген (автор банк бөлімшесінің мысалында қарастырды) [15]. Әрбір бөлімшедегі ақпарат көлемі потенциалды клиенттердің саны, атап айтқанда аудан тұрғындарының санына пропорционалды. Жекелеген қатерлерді іске асыру ықтималдығы, сондай-ақ қорғау механизмдерінің әрқайсысының құны мен тиімділігі сараптамалық бағалау әдісімен анықталады. Бұл жағдайда әрбір нысан үшін қатердің туындау ықтималдығы бірдей және тек қатердің түріне байланысты болады деп болжанады. Әрбір аумақтық бөлімшелер үшін қорғаныс элементтерінің әртүрлі комбинацияларын ескере отырып, бүкіл жүйеге келтірілген жалпы барлық шығындар (ол қауіптің дәрежесін сипаттайды) және әрбір бөлімше үшін қорғаныс элементтерінің оңтайлы жиынтығы есептеледі. Сонымен бірге қорғау жүйесінің жалпы құнына шектеулер енгізу шарттарын тексеру қарастырылған. 
Толық қауіпті есептеу кезінде әртүрлі қатерлерді жүзеге асырудан болатын шығын мөлшерін көрсететін теңдеулердің қиылысқан мүшелерінің мәні туралы міндет ашық күйінде қалады (бұл оқиғалар үйлесімді болып саналады) [5].

O.Е.Архиповтың жұмыстары тәуекелдерді бағалау және ақпараттық қауіпсіздікке салынған инвестициялардың тиімділігін зерттеу үшін "шабуыл-қорғау" экономикалық құндық модельдерін қолдану міндеттеріне арналған [1]. Осы модельдердегі тәуекелдің ықтимал параметрлерін анықтау үшін ақпарат саласындағы «шабуыл-қорғау» жағдайына тән мотивациялық-құндық және экономикалық-қаржы қатынастардың белгілі бір сипаттамалары қолданылады. Атап айтқанда, шабуылдаушы А (шабуылдаушы) кейбір I ақпараттық ресурстарға қатысты Т қаупін жүзеге асырған кезде пайда болатын жағдай В тарабына тиесілі.

Ақпараттық қатерді жүзеге асырудың экономикалық және шығындық сипаттамаларын талдау мен сандық бағалаудың нақты мүмкіндігі болған жағдайда, авторлар [3,8] еңбектерінде келтірілген модельдерді кез-келген нақты ұйымның тәуекелдерін есептеу үшін қолдануды ұсынады. Осы бағалаудың нәтижесін белгілі бір қосымша ақпарат болған кезде тәуекелдер менеджменті стандарттарының параметрлері мен ұсыныстарына сәйкес ұйымның ақпараттық қауіпсіздік жай-күйін зерттеу (аудит) жүргізу арқылы алуға болады, уақыт бойынша статикалық бағалауды қабылданған экономикалық-құндық шабуылдарды дамыту сценарийлеріне сәйкес уақыт өте келе өз мәндерін өзгертетін динамикалық түрде дамытуға болады [6].

«Шабуыл-қорғау» экономикалық-құндық модельдері нақты ұйым туралы нақты ақпарат негізінде осы ұйымның ақпараттық қауіпсіздігіне салынған қаражат көлемі жағынан жеткілікті ме екенін тексеруге мүмкіндік береді [5].

Ақпараттық жүйелерге жасалған кибершабуылдарды зерттеу В. А.Хорошконың [16] жұмыстарында көрсетілген. Кибершабуылдар кезінде қаскүнемдердің мүмкіндіктерін бағалау талдаудың ойын әдістерін пайдалана отырып жүргізіледі [11].

Ақпараттық салаға кибершабуылдаудың оңтайлы циклын рәсімдеу (шартты таңбалардың көмегімен модельді жазу) кезінде В.Нэш тұжырымдамасы қолданылады деп болжануда [16]. Бұл модельде қаржыландырудың оңтайлы шешімді таңдауға әсері ескерілмегенін айта кету керек, алайда зерттеушілер құрған талдаудың ойын әдістері жеке және топтық кибершабуылдарды бағалауға мүмкіндік беретінін көрсетіп отыр. Бұл ақпарат саласына мысалы, оқу орындарына жасалған кибершабуылдардан ақпараттың қорғалу деңгейінің кепілдендірілген және сенімді бағаларын алуға мүмкіндік береді [13].

Экономикалық қатынастар мен ақпараттық саланың, атап айтқанда білім беру саласының дамуы бәсекелестіктің күшеюіне, ақпарат көлемі мен құнының артуына, сондай-ақ ақпараттың жайылып кетуінен болған потенциалды шығындардың артуына, ақпараттық нысандар санының өсуіне (бұл әсіресе ЖОО АББО-да байқалады және қарқынды) және кибер-инциденттердің жиі болуына әкеледі. Бұл ретте екі тараптың: ақпаратты қорғау мен шабуылдаушы - қарама-қарсы тараптардың динамикалық өзара әрекеттесуін көрсете отырып, қарсы тұру жағдайларының шарттары да үнемі өзгеріп отырады.

Киберқорғау тараптарының стратегиясы мен тактикасының өзгеруі ақпараттық ресурстарға жаңа шабуылдар тудырады, олар бір жағынан қарсыластың ниетін көрсетеді, екінші жағынан шабуылдар немесе деструктивті араласудың өзге де әрекеттері бағытталған қорғаныстың әлсіз жақтарын көрсетеді.

ЖОО АББО-дағы КҚау-ды және АҚау-ды қамтамасыз ету тәсілдеріндегі өзгерістердің басқа себептері ақпараттың «ескіруіне», жаңа ақпарат пен қосымша ресурстарды енгізілуіне, нысандар арасында ақпараттық ресурстарды қайта бөлуге, олардың арасындағы жаңа байланыстардың пайда болуына байланысты факторлар болуы мүмкін. 
Ақпараттық саладағы екі тараптың антагонистік қарсы тұруы , әдетте қорғаушыға шабуылдаушының (хакердің) іс-әрекеттері мен қаржылай мүмкіндіктері белгісіз болғанымен сипатталады.

Сонымен қатар, шабуылдаушылар қорғаныс жүйесінің құрылымы туралы біраз түсінікке ие және қауіпсіздік жүйесінің ең әлсіз буындарын бұзуға өз күш-жігерін жұмсай алады. Бұл шабуылдаушыға өте тиімді.

Қауіп-қатерлердің әртүрлі түрлерін бұғаттауға қорғау ресурстарын бөлу белсенді режимде қарсыластың іс-қимылының алдын ала отырып, сондай-ақ мүмкін шабуылдардың бағыты айқын болған кезде қаржыландыруды кешіктіріп, атап айтқанда бейімделіп жүргізілуі мүмкін.

Ресурстарды динамикалық басқару қажеттілігі келесі себептерге байланысты:

- қарсыластың іс-әрекеті нұсқаларының белгісіздігі, атап айтқанда, ақпаратты алуға бағытталған күш-жігерінің бағыты және осы жұмыстың ауқымы, атап айтқанда бұзуға жұмсаған хакерлердің ресурстарының қаржы компоненттеріне де байланысты;

- уақыт өте келе қарама-қайшылықтың ішкі және сыртқы жағдайлары ақпарат құнының өзгеруімен, оның нысандар арасында бөлінуімен, қарсыластың шабуылдарының бағытының өзгеруі, жаңа шабуылдаушылардың пайда болуымен;

- ақпараттық жүйе күйінің өзгеруі (ЖОО АББО-сы дербес жағдай ретінде қарастырылады), атап айтқанда, шабуылдардың бағытын анықтағаннан кейін және қорғау тарапынан тиісті шаралар қабылдағаннан кейін оның ең әлсіз буынының өзгеруімен.

Ақпаратты қорғау жүйелерін математикалық моделдеу бойынша ғылыми жұмыстарды талдау, негізгі міндет қорғауды қаржыландырудың көлемін анықтауға бағытталғанын көрсетті.

Қаржыны қорғау нысандары арасында бөлу міндеттері кейбір жұмыстарда көрсетілген [14,15]. Сонымен қатар, қолданыстағы нәтижелер (модельдер) [8], шабуылдаушының мүмкін әрекеттері мен олардың салдары жүйенің көрсеткіштері мен сипаттамаларының өзгеруіне әсерін тигізетіні сирек ескереді.

Зерттеу нәтижесі мен талдау. Осылайша, зерттеліп отырған тақырыптағы жұмыстарға жүргізілген талдау шаруашылық қызмет субъектілері мен оқу орындарының ақпаратын қорғау үшін шектеулі қаржы ресурстарын тиімді пайдалану міндеті аса маңызды және маңызды бола түсетінін көрсетті [12].

Сонымен қатар, шабуылдаушы тараптың іс-әрекеттері мен қаржы ресурстарын белгілі бір ықтималдықпен ғана болжауға болатын белгісіздік жағдайында, теориялық ойын әдістерін пайдалану және қарама-қайшылық шарттарының өзгеру динамикасын ескере отырып қорғау нысандары арасында шектеулі ресурстарды оңтайлы бөлуді іздеу ақпараттың жайылып кетуінен болған қаржылай шығындарды барынша азайтуға мүмкіндік береді.

Компьютерлік жүйелер мен ақпараттық технологиялардың дамуы КҚау жүйесін инвестициялауды оңтайландыру бойынша жұмыстардың жеке тұжырымдамасын тудырды. Зерттеудің бұл тұжырымдамасы КҚау саласындағы инвестициялаудың рационалды стратегияларын анықтау есептерінде сараптамалық жүйелерді (СЖ) [2] және ШҚЖ-ны [8] кеңінен қолдануға негізделген. Біз осы салада көптеген жұмыстарды зерттеп, осы жарияланымдардың көпшілігінде $[7,9,11]$ жоғары оқу орнының КҚау жүйесін өзара қаржылай инвестициялаудың рационалды стратегиясын таңдау бойынша нақты шешімдерді қарастырмаған деген қорытындыға келдік.

Сонымен қатар, [2,3] және [11] жұмыстарының қорытындыларында КҚау-ға инвестициялауды басқарудың рационалды стратегияларын таңдау процедураларын автоматтандыру үшін СЖ-ны және ШҚЖ-ны қолдану кезінде нақты ұсыныстар берілмеген. Бұл жағдайлар жоғары оқу орнының КҚау жүйесін өзара қаржылай инвестициялаудың рационалды стратегияларын анықтау есептерінде ШҚЖ үшін жаңа 
модельдерді құру қажеттілігімен байланысты міндеттің туындауына себепші болды. Осы тақырып бойынша жасалған зерттеулердегі [5,6] авторлардың баяндаған тәжірибе мен тәсілдеріне, сондай-ақ зерттеу әдістемелері ұқсас авторлардың жұмыстарына $[10,13]$ сүйене отырып, осындай міндеттер класын шешуде жеткілікті тиімді тәсіл: бірнеше терминалды беті бар дифференциалдық сапа ойындары теориясының әдістерін қолдану деп айта аламыз [12]. Осылайша, осы тақырып бойынша зерттеулерге жүргізілген талдау жоғары оқу орнының КҚау жүйесін үздіксіз өзара инвестициялау есептерінде ШҚЖ үшін модельдерді одан әрі дамыту міндетінің өзектілігін растады. Бұл тұжырым инвесторлар үшін нақты ұсыныстар құру қажет болған кезде өте маңызды. Бірақ күрделі математикалық есептеулерді қолданудың қажеті жоқ, себебі есептеулердің көп бөлігі компьютерлік бағдарламалармен орындалады.

Мына жұмыстарда [4] АН-нің КҚау қатерінің моделін сипаттау үшін Петри желілерін қолдануға арналған зерттеулердің нәтижелері келтірілген. Бұл жұмыстар осы міндетінде айтарлықтай теориялық үлес қосса да, біздің ойымызша, авторлар ұсынған модельдерді, атап айтқанда АН-ді АҚ және КҚау бойынша ШҚИЖ-да және СЖ-да бағдарламалық жүзеге асыру (программалау) біршама қиынға соғады.

Кейбір зерттеу жұмыстарына [7,12] сүйене отырып, қатерлердің модельдерін АНнің қорғалуын бағалау міндетін өзектендіру кезінде қатерлерді көрсетудің көрнекі кестелік формасын қолдана отырып құруға болады. Бірақ жоғарыда көрсетілгендей, бұл тәсілмен қатерлердің моделін жасау көп еңбекті қажет етеді. Сонымен қатар, қатерлер санының өсуі, әсіресе КҚау саласында жұмыс тәжірибесі аз мамандар үшін мұндай кестені құрды қиындатады.

Петри (Петри-Марков) желілері шабуылдаушының модельдерін сипаттау үшін де сәтті қолданылды [9]. Алайда, авторлар шабуылдаушының моделін түзету мүмкіндігін, атап айтқанда, оны графтар теориясының негізінде құрылған модельдермен біріктіру арқылы түзету мүмкіндігін қарастырмады, бұл нақты АН үшін киберқорғау периметрлерінен (шекарасы) шабуылдаушының еңсеру процесіндегі күйлердің ауысуын дәлірек сипаттауға мүмкіндік берер еді.

Зерттеулерде $[1,16]$ әр түрлі АН үшін АҚ жүйесінің модельдері Петри желісінде алдын ала іріктелген қарапайым операциялардың тізбегі ретінде қарастырылған, олардың ішінде кибершабуыл да болуы мүмкін. Модельдер берілген уақыт аралығында әртүрлі шабуылдардың жүзеге асу ықтималдығын есептеуге мүмкіндік береді. Алайда, [2,10] зерттеулерде қарастырылған модельдер жаңа киберқатерлерді жүзеге асыру процесінде уақытқа байланысты сипаттамаларды есептеуге мүмкіндік бермеді.

Зерттеулерде [1,9] Петри желілеріне негізделген және ақпараттық жүйелерде (АЖ) қатерлерді іске асыру процестерін сипаттайтын және модельдер ұсынылды. Бұл модельдер АН-ді қорғаудың көптеген параметрлерін атап айтқанда, қатерлердің орындалу ықтималдығын, қатерлердің орындалу уақытын бағалауға мүмкіндік бергеніне қарамастан, шабуылдаушының іс-қимылдарының реті соңына дейін толық аяқталмаған. Атап айтқанда, бұл жұмыстарда әртүрлі кластарға жататын шабуылдар барысында АЖның жай-күйінің өзгеруі кезінде туындайтын қақтығыс жағдайларды шешу міндеті зерттелмеген. Бұл жағдай, біздің ойымызша, осы зерттеулердің практикада қолданылуына шектеу болады.

Қорытынды. Осылайша, қатерлерді анықтау мен талдаудың қолданыстағы әдістерін, Петри желілерін алгоритмдеу және визуализациялау негізінде шабуылдаушылардың модельдерін толықтыру нақты АН үшін қорғалу жағдайы мен жаңа қатерлерді болжаудың тиімді құралы бола алады. Бұл жаңа киберқатерлердің негізі қайда жатқанын және қандай салдар әкелетінін ұғуға мүмкіндік береді және болашақта әртүрлі ақпараттандыру нысандарының киберқауіпсіздігі мен АҚ қызметтерінің талдаушылары ұсынған тәсілдерді тиімді қолдануға болады. 


\section{Әдебиеттер:}

[1] Акиншин Р.Н., Ивутин А.Н., Есиков Д.О., Страхов И.А. Применение математического аппарата сетей Петри-Маркова для определения временных и вероятностных характеристик системы управления высоко нагруженными веб-порталами с повышенной отказоустойчивостью /Научный Вестник. - Москва, 2014, № 210. - С. 85 - 90.

[2] Ахметов, Б.С., Тукеев У.А. Технология ситуационного управления информационной безопасностью учебного процесса казну имени Аль - Фараби / Journal of Mathematics, Mechanics and Computer Science. - Алматы, 2009. - V. 63, № 4. - Р. 66 - 70.

[3] Бияшев, Р. Г., Амербаев В. М., Нысанбаева С. Е. Применение непозиционных систем счисления при криптографической защите информации. // Известия Национальной академии наук Республики Казахстан. - Алматы, 2005, № 3. - С. 84 - 89.

[4] Kartbayev, T., Akhmetov B., Doszhanova A., Lakhno V., Malikova F., Tolybayev Sh. Development of decision support system based on feature matrix for cyber threat assessment/ Intl Journal of Electronics and Telecommunications. - 2019. - V.65. № 4 - P. 545 - 550.

[5] Ortalo, R., Deswarte Y., Kaaniche M. Experimenting with Quantitative Evaluation Tools for Monitoring Operational Security // IEEE Transactions on Software Engineering. -1999. - V. 25. - P. 633 -650 .

[6] Puhakainen, P., Siponen M. Improving employees' compliance through information systems security training: an action research study (Улучшение соответствия сотрудников через обучение безопасности информационных систем: исследование исследования действия) // MIS Quarterly.2010. Vol. 34 Issue 4. - P .767.

[7] Campbell, R.H., Yan M., Sprabery R., Gopireddy B., Fletcher C.W.Attack directories, not caches: Side channel attacks in a non-inclusive world/IEEE Symposium on Security and Privacy. - 2019. - P. 888 - 904.

[8] Dawkins, J., Clark K., Manes G. A Framework for Unified Network Security Management: Identifying and Tracking Security Threats on Converged Networks /Journal of Network and Systems Management. - 2005. - V. 13, №. 3. - P. 253 - 267.

[9] Endler, M., Talavera L., Vasconcelos I., Vasconcelos R., Cunha M. The mobile hub concept: Enabling applications for the internet of mobile things// IEEE International Conference on Pervasive Computing and Communication Workshops. - 2015. - P.123 - 128.

[10] Ахметов Б. С., Бидайбеков Е.Ы., Казмагамбетов А.Г. Влияние методической системы обучения на разработку и применение средств информатизации в вузе / Международный конгресс конференций «информационные технологии в образовании». - Москва, 2003. - С. 112 - 113.

[11] Хуторской А.В. Человек и его изменение в телекоммуникационных системах / Материалы Всерос. науч.-практ. конф.- Москва, 2004. - С. 145 - 152.

[12] Chris D. Data Protection Law: An Overview /Congressional Research Service - 2019. - P. 1 $-27$.

[13] Ахметов Б., Яворский В.//Моделирование информационной образовательной среды вуза. - Москва, 2006. - С. 251.

[14] Котенко И.В., Юсупов Р.М. Перспективные направления исследований в области компьютерной безопасности / Защита информации. - Киев, 2006, №2. - С. 46 - 57.

[15] Atighetchi M., Adaptive Cyberdefenese for Survival and Intrusion Tolerance //Proccedins of 3 rd International Workshop Distributed Auto- adaptive and Reconfigurable Systems. - USA, 2003. - P. $74-84$.

[16] Korchenko A., Akhmetov B., Kazmirchuk S., Chasnovskiy Үe. Система оценивания рисков информационной безопасности /Ukrainian Scientific Journal of Information Security. Киев, 2017. - V. 23. Iss. 2. - P. $145-152$.

\section{References:}

[1] Korchenko, A., Akhmetov B., Kazmirchuk S., Chasnovskiy Ye. Sistema ocenivaniya riskov informacionnoj bezopasnosti /Ukrainian Scientific Journal of Information Security. Kiev, 2017. - V. 23. Iss. 2. - P. $145-152$. 
[2] Kotenko, I.V., YUsupov R.M. Perspektivnye napravleniya issledovanij v oblasti komp'yuternoj bezopasnosti / Zashchita informacii. - Kiev, 2006, №2. - S. 46 - 57.

[3] Akinshin, R.N., Ivutin A.N., Esikov D.O., Strahov I.A. Primenenie matematicheskogo apparata setej Petri-Markova dlya opredeleniya vremennyh i veroyatnostnyh harakteristik sistemy upravleniya vysoko nagruzhennymi veb-portalami s povyshennoj otkazoustojchivost'yu /Nauchnyj Vestnik. - Moskva, 2014, № 210. - S. 85 - 90.

[4] Atighetchi, M., Adaptive Cyberdefenese for Survival and Intrusion Tolerance //Proccedins of 3 rd International Workshop Distributed Auto- adaptive and Reconfigurable Systems. - USA, 2003. - P. $74-84$.

[5] Campbell, R.H., Yan M., Sprabery R., Gopireddy B., Fletcher C.W.Attack directories, not caches: Side channel attacks in a non-inclusive world/IEEE Symposium on Security and Privacy. - 2019. - P. $888-904$.

[6] Dawkins, J., Clark K., Manes G. A Framework for Unified Network Security Management: Identifying and Tracking Security Threats on Converged Networks /Journal of Network and Systems Management. - 2005. - V. 13, №. 3. - P. 253 - 267.

[7] Chris, D. Data Protection Law: An Overview /Congressional Research Service - 2019. - P. 1 $-27$.

[8] Endler, M., Talavera L., Vasconcelos I., Vasconcelos R., Cunha M. The mobile hub concept: Enabling applications for the internet of mobile things// IEEE International Conference on Pervasive Computing and Communication Workshops. - 2015. - P.123 - 128.

[9] Kartbayev, T., Akhmetov B., Doszhanova A., Lakhno V., Malikova F., Tolybayev Sh. Development of decision support system based on feature matrix for cyber threat assessment/ Intl Journal of Electronics and Telecommunications. - 2019. - V.65. № 4 - P. 545 - 550.

[10] Ahmetov, B.S., Tukeev U.A. Tekhnologiya situacionnogo upravleniya informacionnoj bezopasnost'yu uchebnogo processa kaznu imeni Al' - Farabi / Journal of Mathematics, Mechanics and Computer Science. - Almaty, 2009. - V. 63, № 4. - P. 66 - 70.

[11] Biyashev, R.G., Amerbaev V. M., Nysanbaeva S. E. Primenenie nepozicionnyh sistem schisleniya pri kriptograficheskoj zashchite informacii. // Izvestiya Nacional'noj akademii nauk Respubliki Kazahstan. - Almaty, 2005, № 3. - S. $84-89$.

[12] Hutorskoj, A.V. Chelovek i ego izmenenie v telekommunikacionnyh sistemah / Materialy Vseros. nauch.-prakt. konf.- Moskva, 2004. - S. 145 - 152.

[13] Puhakainen, P., Siponen M. Improving employees' compliance through information systems security training: an action research study (Uluchshenie sootvetstviya sotrudnikov cherez obuchenie bezopasnosti informacionnyh sistem: issledovanie issledovaniya dejstviya) // MIS Quarterly. 2010. Vol. 34 Issue 4. - P .767.

[14] Ortalo, R., Deswarte Y., Kaaniche M. Experimenting with Quantitative Evaluation Tools for Monitoring Operational Security // IEEE Transactions on Software Engineering. -1999. - V. 25. - P. $633-650$.

[15] Ahmetov, B.S., Bidajbekov E.Y., Kazmagambetov A.G. Vliyanie metodicheskoj sistemy obucheniya na razrabotku i primenenie sredstv informatizacii v vuze / Mezhdunarodnyj kongress konferencij «informacionnye tekhnologii v obrazovanii». - Moskva, 2003. - S. $112-113$.

[16] Ahmetov B., Yavorskij V.//Modelirovanie informacionnoj obrazovatel'noj sredy vuza. M oskva, 2006. - S. 251.

\title{
ОБЗОР И АНАЛИЗ ДОПОЛНИТЕЛЬНЫХ ИССЛЕДОВАНИЙ В ОБЛАСТИ КИБЕРЗАЩИТЫ ИНФОРМАЦИОННОГО ПРОСТРАНСТВА ОБРАЗОВАТЕЛЬНЫХ УЧРЕЖДЕНИЙ
}

\author{
Ахметов Б.С. ${ }^{1}$, доктор технических наук \\ Лахно В. А. ${ }^{2}$, доктор технических наук \\ Кыдыралина Л.M. ${ }^{3}, \mathrm{PhD}$ \\ ${ }^{1}$ Казахский национальный педагогический университет имени Абая, г. Алматы, \\ Республика Казахстан
}




\footnotetext{
${ }^{2}$ Национальный университет биоресурсов и природопользования, г. Киев, Украина

${ }^{3}$ Университет города Семей имени Шакарима, г. Семей, Республика Казахстан
}

\begin{abstract}
Аннотация. В статье рассматриваются предпосылки формирования защищенной информационной образовательной среды в современных университетах. Проанализированы публикации отечественных и ведущих зарубежных исследований. Обзор предыдущих исследований в области киберзащиты информационного пространства образовательных учреждений (CDS) и анализ публикаций по данной теме. Проведенный анализ подтвердил актуальность проблемы дальнейшего развития моделей СЭМ в задачах непрерывного взаимного инвестирования системы ВШЭ вузов. Анализ публикаций по результатам исследования использования сетей Петри для описания модели угроз объектов информатизации. Хотя данная работа вносит значительный теоретический вклад в решение данной задачи, на наш взгляд, программно реализовать модели, предложенные авторами, в частности, АН в ЭСД и СФ на АО и ФСА сложнее. Это, в свою очередь, требует дополнительных исследований. В целом в статье дается всесторонний обзор возможностей обеспечения безопасности и уникальности данных для информационно-емких рабочих мест. Для специалистов в данной области статья может предоставить необходимую информацию.
\end{abstract}

Ключевые слова: кибербезопасность, информационная образовательная среда вуза, моделирование, сеть Петри, информационная безопасность, электронная образовательная среда вуза, метод, модель.

\title{
REVIEW AND ANALYSIS OF ADVANCED RESEARCH IN THE FIELD OF CYBER PROTECTION OF INFORMATION SPACE OF EDUCATIONAL INSTITUTIONS
}

\author{
Akhmetov B.S, 1 doctor of technical sciences \\ Лахно B.A., 2 doctor of technical sciences \\ Kydyralina L.M, PhD \\ ${ }^{1}$ Kazakh National Pedagogical University named after Abai, Almaty city, \\ Republic of Kazakhstan \\ ${ }^{2}$ National University of Bioresources and Nature Management, Kiev city, Ukraine. \\ ${ }^{3}$ Sakarim University in Semey, Semey city, Republic of Kazakhstan
}

\begin{abstract}
Annotation. The article discusses the prerequisites for the formation of a secure information educational environment in modern universities. The publications of domestic and leading foreign studies are analyzed. Review of previous research in the field of cyber protection of the information space of educational institutions (CDS) and analysis of publications on this topic. The analysis confirmed the relevance of the problem of further development of SEM models in the tasks of continuous mutual investment of the HSE system of universities. Analysis of publications based on the results of the study of the use of Petri nets to describe the threat model of informatization objects. Although this work makes a significant theoretical contribution to solving this problem, in our opinion, it is more difficult to programmatically implement the models proposed by the authors, in particular, the AN in the ESD and $\mathrm{SF}$ at the JSC and FSA. This, in turn, requires additional research.

In general, the article provides a comprehensive overview of the possibilities of ensuring the security and uniqueness of data for information-intensive workplaces. For specialists in this field, the article can provide the necessary information.

Keywords: cybersecurity, university information and educational environment, modeling, Petrinets, information security, electronic information and educational environment of universities, method, model
\end{abstract}




\title{
БІЛІМ, ГУМАНИТАРЛЫК ЖӘНЕ ӘЛЕУМЕТТІК ҒЫЛЫМДАР СЕРИЯСЫ СЕРИЯ ОБРАЗОВАНИЯ И ГУМАНИТАРНО-СОЦИАЛЬНЫХ НАУК SERIES OF NATURAL, TECHNICAL AND AGRICULTURAL SCIENCES
}

\author{
Филология ғылымдары \\ Филологические науки \\ Philological science
}

FTAMP 17.07.41

https://doi.org/10.52081/bkaku.2021.v58.i3.082

\section{ҚАЗАҚ ПОЭЗИЯСЫНДАҒЫ АБЫЛАЙ ХАН БЕЙНЕСІ}

Жанбершиева Ұ., филология ғылымдарының кандидаты ulzhan1954@mail.ru, https://orcid.org/0000-0001-7662-0343

Кудайбергенова К.Т., гуманитарлық ғылымдарының магистрі, докторант kkunimzhan@mail.ru, https://orcid.org/0000-0001-6878-652X

Қорқыт ата атындавы Қызыллорда университеті, Қызыллорда қ.., Қазақстан Республикасы

Аңдатпа. Мақалада Абылай хан бейнесінің көркем әдебиетте сомдалуы қарастырылған. Қазақ әдебиеттану ғылымындағы Абылай хан, оның заманы жайлы тұжырымдар, ханға арналған толғаулар, дастандар, тарихи жырлар сараланып, анықталады. Абылай хан бейнесін жасаудағы ерекшеліктер ақын-жырауларға қатысты бірқатар дәйектерді келтіре отырып, хан образын ашудағы азаматтық ұстанымдары айқындалады. Сондай-ақ ғылыми тұрғыдан Абылай бейнесін жасаған шығармалар үш желіге бөлініп, ғалымдар пікірлері салыстырылады.

Мақалада Абылай хан туралы қазақ ғылымында жазылған фундаментальды зерттеулерге сүйене отырып, авторлар өздерінің көзқарастарын нақты айтып өткен. Сонымен қатар Абылай хан бейнесі жасалған тарихи жырлар, мифтік жырлар, ғұмырнамалық жырларға қатысты көзқарастарға шолу жасалған. Ұрпаққа рухани нәр беретін хан тұлғасын жинақтық бейне етіп қарастырған.

Хан бейнесі арқылы халқымыздың азаттық жолындағы күресі де назардан тыс қалмаған. Ұлт мақтанышы Абылай хан бейнесі шынайы ашылып, жан-жақты дәлелденіп, талданып көрсетілген.

Тірек сөздер: тарихи тұлва, тарихи жыр, вұмырнамалық жыр, Ресей отаршылдывы, хан тұлвасы, дастан, тарихи-этикалық бейне.

Kipicпе. Абылай хан бейнесі бір топ сүбелі еңбектерде жекелеген жанрлар бойынша кең көлемде зерттеліп сараланса да, бейне, бейнелік тұрғысынан зерттеу нысанынан тыс қалуы жұмыстың көкейтестілігін танытады.

Біз қарастырып отырған мәселеде тек бейне туралы жалпы түсінік бермей, қазақ әдебиеттану ғылымындағы теориялық негізде зерттелуін ескере отырып, Абылай хан заманы, оның атқарған ролін анықтап, тағы бір қырынан ашу көзделді.

Ақын-жыраулардың хан образын жасаудағы өзіндік қолтаңбасы зерттеу объектісінің өзектілігін көрсетеді және бүгінгі күннің зәру мәселесі болып табылады.

Әр дәуірдің ірі, іргелі оқиғалары, көрнекті тұлғалары тарихи тұрғыда нақты, дәлдікпен көріне қоймаса да, ақын-жыраулардың өз басы жағдайлары, жыр жолдарында кездесетін адамдармен қарым-қатынасы, олардың сыртқы һәм ішкі бейнесінің кейбір көріністері, сол замандағы бірқатар оқиғалар хақындағы деректерден анық байқалады. Мысалы, Асан жырламаса Жәнібек; Шалгез жырламаса Темір; Бұқар, Үмбетей, Тәтіқара жырламаса Абылай; Байтоқ, Жанұзақ, Махамбет жырламаса Жәңгір хан поэзия жолдарында қалмас еді. Тәтіқараның «Кеше қоңыраулы судың бойынан», Бұқардың «Ал, тілімді алмасаң» толғауларынан Абылай хан өмірінің кейбір деректерін, Үмбетейдің 
«Бөгенбай өлімін Абылай ханға естіртуінен» қалмақ пен қазақ арасындағы шайқас көріністерін тани аламыз. [1,7]

Әлем әдебиетінде тарихи деректік туындылар мен тарихи тұлғалар бейнесі әркез жасалып отырған. Оны заман көшіне қарай түрліше бұрмалауға да жол берілген. Бірақ тарихшы-ғалымдардың нақты деректері, зерттеулері арқылы тарихи тұлғалардың бейнесі әр кезде өз биігінде қалып отырған.

Философия мен әдебиеттің қиылысында қалыптасқан рухани мәдениет феномені көбінесе кеңейтілген түрде түсіндіріледі: кез-келген "терең" поэтикалық шығарма көбінесе "философиялық" деп аталады, олар өмір мен өлімнің жалпы мәселелеріне әсер етеді. Байланысты, бірақ біріктірілмейтін ұғымдарды ажырату керек - " философиялық поэзия "және" ғылыми поэзия", "Философиялық лирика "және "медиотативті лирика". Идея-жалпылауға әкелетін рефлексия поэзия философиясының негізі болып табылады [2].

Әр дәуірде ел басқарған әкімдердің ел алдындағы қызметін бейнелі сөзбен халқы жеткізетін болған. Хандар, батырлар, көсемдер, шешендер, өнер адамдарының азаматтық болмысы, әдебиет пен өнердегі бейнесі әр қырынан айқындалған деуге болады.

Абылай хан туралы әдебиеттану ғылымында айтылып жүрген пікірлерге сүйенсек, ханға арналған толғаулар, дастандар, тарихи жырлар, аңыздар өте көп. Оларды ғылыми сараптайтын болсақ, мынадай үш желіге құрылады.

1. Қазақ хандығының құлдырай бастаған кезінде ел басқарған Абылай бейнесі суреттелген шығармалар олардың тарихи оқиғалармен байланысын Ш.Уәлиханов жазып алған «Абылай туралы жыр», 1858 жыл.

2. Абылай бейнесін жасауда мифтік элементтердің қосылғаны, яғни Абылайдың дүниеге келуінде анасы түс көріп, Ғайыперен аян беруі немесе Абылай жорыққа шығарда Ақбура жорық жолына қарап жатса жеңіске жетеді. Абылайды халыққа Алла тағала жіберген қасиетті адам деген сияқты. «Ақатан» жыры.

3. Ғұмырнамалық жыр. Абылайдың өлер алдындағы Бұқар жыраумен бақиласуындағы үш өкініші:

- Қан көп төгілді, мен қан төкпесем, өзімнің қаным төгілер еді;

- Халқыма сәнді қала салдыра алмадым;

- Халық басы бірікпеді.

Академик Р.Бердібай: «Қазақ халқының сан буыны қысылғанда медет көріп, намыс кегі қайралғанда ұран етіп шақыратын да Абылай есімі болуы тегін емес. Ол жөнінде көне сөздердің көптігі соншалық, «Абылайнама» деп атарлық мол туындылар шоғыры жасалған. Орыс халқы тарихының болмыс-жырларының ең көбі Владимир дәуіріне арналған десек, қазақтың тарихи - эпикалық өлең жырларының аса көрнекті бөлігі де Абылай және оның айналасындағы батырларға, билерге, шешендерге бағытталған [3,4], дейді. Ғалымның осы пікіріне сүйенсек, ел бірлігі мен ынтымағын сақтауға ат салысқан Абылай хан бейнесі өз заманында да, бүгін де тарихи оқиғалармен байланысты болғанын аңғару қиын емес.

Академик В.В.Бартольд «XVIII ғасырдағы ең күшті Орта жүздің ханы Абылай болды» - десе [4,28]», Ш.Уәлиханов «Абылай ғасыры - қазақ ерлігінің ғасыры еді» $[5,127]$ деп баға берген. Ол үш жүздің ханы еді. Шоқан Уәлиханов Бұқар жыраудың Абылайға арнаған өлеңдерін жазып алып, алғаш пікірін айтса, Мәшһүр-Жүсіп Көпеев өз зерттеулерінде Абылай хан бейнесінің жасалуы туралы ой қозғайды. Ал, С.Сейфуллин Абылай хан туралы толғауларын талдап, баспаға жариялаған. Зерттеуші Сарбас Ақтаев өзінің «Дарабоз дана» кітабының алғысөзінде Абылайдың өмірбаяны мен сан-салалы қайраткерлік қызметін нақты құжаттар мен деректерге сүйене отырып, жазып шықты.

Абылай ханның көркем әдебиеттегі бейнесі прозада, поэзияда, драматургияда әр қырынан көрініс береді. Ханды да, қараны да қалыптастыратын қоғам, уақыт, заман десек, 
қазақ елінің ынтымағын, бірлігін сақтай білген Абылай хан бейнесі жасалған шығармалардың мәні ерекше.

Тарихи деректерге сүйене отырып, Абылай хан бейнесі жасалған шығармаларға әдеби-теориялық талдау жасап, қазақ поэзиясындағы көрінісін сөз етеміз.

Зерттеу әдістемесі. Абылай хан туралы жазылған ірілі - ұсақты толғау-дастандар арқылы кейінгі ұрпаққа үлгі боларлық Абылай хан бейнесіне көз жеткіземіз.

Абылай хан бейнесін жасауда Бұқар жыраудан бастап Үмбетей, Тәтіқара, Шәді Жәңгіров, М.Жұмабаев т.б. қалдырған жыр-дастандардағы хан бейнесіне тоқталып, даралық қолданысын көрсету. Қазақ әдебиетіндегі Абылай бейнесі жасалған шығармаларға, зерттеулерге талдау-жинақтау жасау әдістерін қолдана отырып, салыстыра қарастырдық.

Қазіргі қазақ әдебиетінің көркемдік өркендеуіне айрықша үлес қосып отырған жырдастандардағы Абылай хан бейнесінің көрінісі арқылы ұлттық өнердің ерекше өзіндік сипаты екшеленді. Қазақ поэзиясындағы Абылай хан бейнесін тақырыптық, тілдікбейнелік, көркемдік сипатын ашып, тұжырым жасау барысында салыстырмалытипологиялық, жинақтау, топтастыру, сипаттау әдістері қолданылды.

Нәтиже, талдау. Тарихи оқиғаларды суреттеу арқылы Абылай хан бейнесін сомдап, көркемдік табысқа жеткен шығармалар мол десек, ең алдымен Бұқар жырауды атаймыз. Оның толғаулары тарихи құжаттық мәнге ие. Ханның ақыл ой кеңесшісі ел бірлігін сақтаушы Бұқар жырлары нақтылы көзбен көрген оқиғалардан туған. XVIII ғасырдағы қазақ жерін басқыншы жаулардан қорғап дербес мемлекет құрудағы Абылай ханның әрекеттерін халық мүддесімен орайлас береді.

Қайғысыз ұйқы ұйықтатқан ханым-ай,

Қайырусыз жылқы бақтырған ханым-ай.

Үш жүзден үш кісіні құрбан қылсам,

Сонда қалар ма екен қайран жаным-ай,

деп, ханның ел басқарудағы жақсы істерін халық назарына ұсынады.

Бұқардың замандастары Үмбетей мен Тәтіқара ақын толғауларында Абылай хан бейнесі шынайы жасалған. Кеңес дәуірі тұсында Мағжан Жұмабаев, Мәжит Айтбаев, Д.Саурықұлы, Әбіш Кекілбаевтар арасында шын даналығы мен батырлығын ел мүддесіне лайық суреттеген.

Бұқардың «Абылай ханның қасында», «Ал тілімді алмасаң», «Ай, Абылай, Абылай», «Қазақтың ханы Абылай», «Ханға жауап айтпасам», «Басыңа біткен күніңіз», «Ай, Абылай сен он бір жасыңда», «Ал, айтамын, айтамын», т.б. толғауларында ханның ұстанған саясаты мен көрегендігі, алғырлығы мен бірлігі сипатталған. Халық болашағы мен тыныштығын сақтау, отарлау саясатына қарсы мәселе қозғаған. Дәуірінің айнасы іспетті бұл жырлардың бел ортасында Абылай бейнесі тұрады.

\section{Хан Абылай атандың, \\ Дүниеден шықпай мініңіз. \\ Алтын тақтың үстінде, \\ Үш жүздің басын құрдыңыз, -}

деп, әділ төре, білгір басшы, үш жүздің ұйытқысы екенін айта келіп, атақ пен даңққа халықтың қолдауымен жеткенін ескертіп, әділдік таразысынан жаңылмау керектігін ескертеді.

Абылайдың жеті жасынан бастап таққа отырғанға дейінгі барлық кезеңдеріне шолу жасап, оның өмірін халық тағдырымен бірлікте деп ой түйеді.

Ел иесі құт болса,

Халқы ала болмайды, -

деп, хан әділдігін, елдің құтты, бақытты болуымен ұштастырады. 
Бұқар жырау Абылайдың қамқоршысы ғана емес, қатал сыншысы да болған. Ерден елін тонап шабуға жөнсіз бұйрық берген Абылайға дау айтып тоқтатады.

Ханның жақсы болмағы,

Қарашаның елдігі, - десе,

Ресей отаршыларының қазақ даласының шұрайлы жерлеріне қоныстанғанын ханға ескертіп:
Өзің қонған Көкшетау,
Кәпір қала салды ойла,
Қарқаралы деген тауларға.
Қарқарасын шанышты ойла.
Көкорай шалғын көре алмай,
Шұбырып қазақ кетті ойла.
Нұраның бойы Ақмола,
Есілде бар Қараөткел
Екі өткелдің аузына
Тас қорғанды салды ойла.

Абылайға қарата айтқан толғауларын жырау диалогқа құрып, сұхбаттасады. Сөйтіп уақыт, заман сұрауларына жауап іздейді. Бұхар сөзі халықтың сөзі болып естіледі.

Ашуланба, Абылай,
Ашулансаң, Абылай!
Көтерермін көнермін,
Өкпеңменен қабынба,
Өтіңменен жарылма
Орыспенен соғысып,
Жұртыңа жаулық сағынба, - [6, 113]

деп, ханның тасыған көңілін басады. Абылай бейнесінің ерекше сомдалып берілуінің басты себебі де тар кезеңдегі ел бірлігін сақтауға ұйытқы болуы болар. Ханға қарата «орыспенен соғыспа», - дегенді әрдайым ескертіп отырады.

Ұлтының рухани адамгершілік қасиеттерін бойына жинақтаған Бұқар Абылайға: «Сенен бұрын жеті ханды желедім, кеше Еңсегей бойлы Ер Есімге де жолдас болдым, сен оның бір түстігіне де жарамайсың», - дегенмен Абылай Қытай мен Ресей сияқты қос алып мемлекеттің арасында оңтайлы саясат ұстауда Бұқарды қамқор ақылшысы деп бағалаған.

Бұқар өлеңімен сарындас келетін Үмбетей жырау мен Тәтіқара ақын Абылай және оның батырлары туралы жырларында Абылай хан бейнесі толыға түскен.

М.Әуезов: «Әдебиетте қалың елдің бұл қайғысы Абылай айналасынан шығады. Абылай маңына жиналады. Себебі сол ала-сапыран дәуірде қалың елдің «қайрандап жан қалама» деген «Қазы құрттай үміті, жалғыз ғана үміті Абылай басында қалған болатын. Ескі қазақ елдігін, ескі жұрттың тілегін, ту көтеріп бір арнаға жинаған Абылай болатын», $[7,143]$ - дейді.

Осы ойды дәлелдеу үшін Абылай ханның жорық жыршысы болған Тәтіқара ақын кей тұста Абылайды жақтаудан гөрі әшкерелеуші сыншы болып табылады. Ханның астам көңілін басарлық ауыр сөздер айтуға батылы жеткен.

Тәтіқараның «Кеше тоқыраулы судың бойынан» деп басталатын өлеңде Абылай ерлігі, елдің бағасын айта келе ханның көзқарасының өзгеруін сынайды.

Үш жүздің баласы

Ақылдасып, жолдасып,

Хан көтеріп еді,

Үш жүздің баласын

Бір баласындай көрмедің 
Ат құйрығын сүзіңдер

Аллалап атқа мініңдер

Хан талау қылып алыңдар!, - [8,18] деп, ханның астам көңілін басарлық ауыр сөздер айтқан.

«Кебеже қарын, кең құрсақ, Артық туған Абылай?»- деп басталатын өлеңінде Абылайдың ел басқарудағы қасиетін дәріптеуі оның келбетін аша түскен. Қытай әскерімен қақтығыс тұсында туған бұл өлеңде:

Артық туған Абылай,

Көтере көр бұл істі,

Жау жағадан алғанда,

Ит етектен алғанда,

Ер Абылай қорыққан жоқ. [9]

Абылай ханның бір жорығында жау өкшелеп куып келеді де, алдынан өзен кездесіп, қатты қысылады. Сонда Абылай: «Тілің қырқылғыр Тәтіқара бір айла тап» деген екен. Сол кезде ақын:

«Алдыңнан су, артыңнан жау қысқанда,

Ер жігіттің ерлігі осындайда», - [10]

деп, өзі бастап жауынгерлерді алып өтеді. Олжабай, Бөгенбай сынды батырлардың ерлігін жырлай отырып, Абылай бейнесін өмірлік шындықтан асып кетпей, мейлінше шынайы бейнелеуді мақсат тұтқан. Абылай оның батырларына айтылатын мадақ жырлар болып келеді.

Ақын, жыраулардың бейнелеу әдістерінде юморлық, сатиралық, трагедиялық, қаһармандық, романтикалық образдарға тән нышан-элементтер де көптеп кездеседі.

Жау жағадан алғанда,

Ит етектен алғанда,

Ер Абылай қорыққан жоқ,

Әншейін еңкейе беріп жылысты [ 11,12]

Қалмақпен шайқас кезіндегі Абылай әрекетін бейнелеуде Тәтіқара осылайша жеңіл ғана әжуамен сынап өтеді.

Абылай хан және XVIII ғасырдағы батырлар жайында жыр тудырушының бірі Үмбетей жырау. Абылай бейнесін жасаған ақын-жыраулар аз емес. Соның ішінде Үмбетейдің хан тұлғасын жасаудағы ерекшелігі өзгеше. «Бөгембайдың өлімін Абылай ханға естірту» атты ұзақ жоқтауында:

Жау қашты деп айғайлап, «Абылайлап» шапқанда,

Сол ерліктен хан болдың,

Әлем асқан жан болдың.

Барша әлемге даң болдың!

Ұмыттың ба соны, Абылай?! [12]

Бұл - негізінен кісі өліміне байланысты қаралы өлең, яғни, мұң-шер өлеңнің естіртуі. Бөгембай өлімін естірту арқылы батырдың жүріп өткен жолдарына тоқтала келе, Абылай ханды тәубаға келтіреді, тоқтамға шақырады.

Орта жүзде қатын көп,

Туатын кейін батыр көп, - дей келе,

Жасыңнан сырлас болған, 
Үлкен болса да құрдас болған

Батырың өтті Бөгембай, [13] - деп ой түйген. Жаугершілік заманда ел қорғаған, жауға шауып ту байлаған батырлардың есімін даңққа бөлеп, Абылай бейнесін тек қана ел мүддесінен көрсеткен.

Қазақ поэзиясында Абылай ханның адами болмысы көрініс табатын дастандар, тарихи өлеңдер, аңыз әңгімелер де мол. Мәселен, Шәді Жәңгіровтің «Тарихат», «Шыңғысханның тарихы», Мағжан Жұмабаевтың «Батыр Баян», Мәжит Айтбаевтың «Хан Абылай», Ә.Кекілбаевтың «Абылай хан» драмасы, Доспер Саурықұлы «Есенгелді» т.б. Бұл шығармаларды толық талдау үшін әрқайсысына жеке-жеке тоқталу керек. Сондықтан біз тек шолу ретінде атап өткенді жөн көрдік.

Шәді ақын «Тарихат» дастанында ханның бүкіл өмірін қамтып, әлеуметтік шежіресін береді. Абылай төре тұқымынан шыққан оғлан, текті, арғы тегі Жәнібек ханның кенже ұлы Жәдіктен тарайтынын баяндай келе, даналығы да, батырлығы да суреттеледі. Батырлар мен билер арасындағы беделі мен солардың ерекшеліктерін бағалай білген деп санайды.

Үш жүздің бірлігі мен азат өмірді аңсаған Абылай бейнесін халық түсінігіне лайық береді.

Жау жағадан алады, жау шабады,

Қазақтың бұзылмаса ынтымағы,

Басынан ажырамас берген бағы, -деуі ханның соңынан ерген елін болашаққа сеніммен қарауға шақырған өсиеті іспеттес.

Келесі М.Жұмабаевтың «Батыр Баян» поэмасында Абылайды алты алаштың басшысы, өз батырларының мүддесін қорғайтын, мәселені ақыл таразысымен шешетін жан бейнесінде суреттеген. Поэмада қалмақтарға алданып қалған қолды сабырға шақырып:

Ерлерін жиып Абылай ел ағасы,

Сұрайды: «Мынау істің не шарасы?»

Тұнжырай қалса-дағы хан Абылай:

«Қайту» - деп, сөздің болды пәтуасы, [14] - деген екен. Келтірілген

үзіндіден Мағжан ақынның Абылай заманы өте күрделі екенін еске алу арқылы Абылайдың ел мүддесін ұмытпайтын, қиыншылықты ақылмен шешетін жан екенін көрсете білген. Сөйтіп Мағжан Абылайға мағынасы терең, дәлелді сөздер айтқызып, мәртебесін көтереді.

Мәжит Айтбаев Абылай бейнесін төңірегіндегі батырлармен байланысты суреттейді. Жоңғарлармен соғыстағы Абылайдың күрес сахнасынан көрінуін ерекше жырлаған.

Доспер Саурықұлының «Есенгелді» дастанында Абылай маңындағы Қабанбай, Бөгенбай, Малайсары сияқты батырларды суреттей келе, Абылайды дәріптеп көкке көтереді.

Абылай ханға арналған эпикалық шығармалардың бәрінде сарбаздар жорықтарға аттанар алдында жер кіндігі Ұлытауда бас қосып, ұлардың етін жеуді ырымға айналдырады. Осы дастанда «Ұлытауға шықтың ба, ұлар етін жедің бе?» [15] - деген қанатты сөздің мәнін түсіндіреді.

Абылай хан бейнесін суреттеген дастан-поэмалардың бәріне ортақ желілер бар. Абылайдың балалық шағы, жетімдік көруі және Төле би қарауында Әбілмансұр атын өзгертіп Сабалақ атануы. Ерлік көрсетіп «Абылайлап!» ұрандап жауды жеңуі, Абылай атануы. Үш жүздің басын қосып, халықтың хан көтеруі. Міне, осындай тарихи оқиғалар мен деректерге сүйене отырып Абылайдың тарихи-эпикалық бейнесі шығарманың идеялық желісіне негіз болған. 
Қорытынды. Еліміздің тәуелсіздікке қол жеткізіп, егемендік алуы - XX ғасырдың соңғы шеніндегі елеулі оқиғалардың біріне саналады. Ежелден аңсаған еркіндік пен теңдікке қолымыздың жетуі - халқымыздың рухани мұрасын түгендеп, ұлтымыздың тарихы мен мәдениетіне, әдебиетіне қайта үңіліп, жаңаша саралап, өзіндік ой қорытуға да мол мүмкіндік туғызып отыр. Абылай хан бейнесі жасалған шығармалар аталған мұраларды игеру жолындағы игілікті бастама болары сөзсіз.

Халқымыздың азаттық жолындағы күресінде ұлт мақтанышы болған Абылай хан бейнесі көркем әдебиетте тарихи тұрғыдан шеберлікпен сомдалған. Ардақты хан, әйгілі қолбасшы, халық қадірлеген қымбат тұлға ел аузында жыр, дастан болып қалған. Оның айбын-айбарын, қаһармандық тұлғасын ақын-жырауларымыз асқан сүйіспеншілікпен бейнелеген. Елдің дербестігі мен тұтастығын сақтап қалуда ықпалды жыраулар қолдау көрсетіп, Абылайдың жиынтық образын еркіндік пен азаттықтың символына балайды.

Абылай аңсаған асқақ арманға ұлы мұратқа бүгінгі ұрпақ жетті. М.Әуезов атындағы Әдебиет және өнер институтының қолжазбалар қорында Абылай хан туралы он бес тарихи жыр сақтаулы. Абылай туралы әлі көптеген деректер ашылған жоқ. Оны танып білу үшін осы дүниелерді білу керек. Келешек магистранттар мен докторанттарды осы қымбат мұраны зерттеп, зерделеуде қыруар істер күтіп тұр.

\section{Әдебиеттер:}

[1] Ысқақов, Б. Абылай хан. - Алматы: Айқап, 1992. - 35 б.

[2] Пекелис, М.А., Антипов С.С. Философия поэзии размышления о поэзии: хронопоэтика. Часть III // DOI: 10.24411/2541-7673-2018-10524.

[3] Бердібай, Р. Әр жылдар, ойлар. -Түркістан: Тұран, 2007. - 630 б.

[4] Бартольд, В.В. История турецко-монгольских народов. - Москва, 1968, 5 том, стр. 338.

[5] Уәлиханов, Ш. Таңдамалы шығармалар жинағы. - Алматы: Санат, 1986. - 327 б.

[6] Абылай хан. Тарихи жырлар. 1 том. - Алматы: Жазушы, 1993. - 416 б.

[7] Әуезов, М. Әдебиет тарихы. - Алматы: Ана тілі, 1991. - 240 б.

[8] Қазақ әдебиетінің тарихы. 10 томдық - Алматы: Қаз ақпарат, 2004 - 3 т. - 520 б.

[9] Әуезов, М. Шығармалар. 50 томдық жинағы. - Алматы: Жібек жолы, 2005 - 13т. - 424

6.

[10] Бабалар сөзі. Қазақ фольклорының 100 томдығы. 29-том. - Алматы, 2014. - 457 б.

[11] Сыдиқов, Қ. Көркемдік өрнектер. - Алматы: Рауан, 1992. - 80 б.

[12] Сүйіншәлиев, Х. Қазақ әдебиетінің тарихы - Алматы: «Қазақстан» баспасы, 1967. 376 б.

[13] Мағауин, М. Ғасырлар бедері. - Алматы: Жазушы, 1991. - 4326.

[14] Жұмабаев, М. Батыр Баян. - Алматы: Ақжол, 1923. №374 саны.

[15] Тоғысбаев, Д., Сужикова А. Тарихи шығармалар. - Алматы: «Кітап» 2009. - 152 б.

\section{References:}

[1] Yskakov, B. Abylaj han. - Almaty: Ajkap, 1992. - 35 b.

[2] Pekelis, M.A., Antipov S. S. filosofiya poezii razmyshleniya o poezii: hronopoetika. Chast' III // DOI: 10.24411/2541-7673-2018-10524

[3] Berdibaj, R. Ar zhyldar, ojlar. -Turkistan: Turan, 2007. - 630 b.

[4] Bartol'd, V.V. Istoriya turecko-mongol'skih narodov. - Moskva, 1968, 5 tom, str. 338.

[5] Ualihanov, S.H. Tandamaly shygarmalar zhinagy. - Almaty: Sanat, 1986. - 327 b.

[6] Abylaj han. Tarihi zhyrlar. 1 tom. - Almaty: ZHazushy, 1993. - 416 b.

[7] Auezov, M. Odebiet tarihy. - Almaty:Ana tili, 1991. - 240 b.

[8] Kazaq adebietinin tarihy. 10 tomdyk - Almaty: Qaz aqparat, 2004 - 3 t. -520 b.

[9] Auezov, M. SHyg, 50 tomdyq zhinagy - Almaty: ZHibek zholy, 2005 - 13t - 424 b.

[10] Babalar sozi. Qazaq fol'klorynyn 100 tomdygy. 29-tom. - Almaty, 2014. - 457 b.

[11] Sydikov, R. Korkemdik ornekter. - Almaty: Rauan, 1992. - 80 b. 
[12] Syjinshaliev, H. Kazar adebietinin tarihy - Almaty: «Kazakstan» baspasy, 1967. - 376 b.

[13] Magauin, M. Fasyrlar bederi. - Almaty: ZHazushy, 1991. - 432b.

[14] Zhumabaev, M.. Batyr Bayan. Almaty: Akzhol, 1923. №374 sany.

[15] Togysbaev, D., Suzhikova A. Tarihi shygarmalar. Almaty: «Kitap» 2009. - 152 b.

\title{
ОБРАЗ АБЫЛАЙ ХАНА В КАЗАХСКОЙ ПОЭЗИИ
}

\author{
Жанбершиева Ұ., кандидат филологических наук \\ Кудайбергенова К.Т., магистр гуманитарных наук, докторант
}

Кызылординский университет имени Коркыт Ата, г.Кызылорда, Республика Казахстан

Аннотация. В статье рассматривается воплощение образа Абылай хана в художественной литературе. В казахском литературо ведении анализируются и определяются выводы об Абылай Хане, его времени, толгау, саги, исторические псалмы, посвященные хану. Особенности создания образа Абылай хана определяются гражданской позицией в раскрытии образа хана, приводя ряд цитат, касающихся акынов и жырау. Кроме того, с научной точки зрения произведения, создающие образ Абылай делятся на три сети, сравниваются мнения науки.

В статье, опираясь на фундаментальные исследования, изложенные в казахской науке об Абылай Хане, авторы подробно изложили свою точку зрения. Также представлен обзор взглядов на исторические псалмы, мифические псалмы, летописные псалмы, в которых создан образ Абылай хана.

Вокруг Абылай хана шешен-жырау анализирует и приводит литературно-теоретический анализ образа хана в поэмах Бухар, Умбетбей, Татикара.

Не осталась без внимания и освободительная борьба нашего народа в образе Хана. Образ Абылай хана, ставшего национальным символом, был раскрыт, как символ свободы.

Ключевые слова: историческая личность, историческая поэма, русская колония, личность хана, дастан, историко-этический образ, «Абылайнама».

\section{THE IMAGE OF ABYLAI KHAN IN KAZAKH POETRY}

\author{
Zhanbershieva U., candidate of philological sciences, professor \\ Kudaibergenova K.T., master of arts, doctoral student \\ Kyzylorda University named after Korkyt Ata, Kyzylorda city, Republic of Kazakhstan
}

Annotation. The article considers the embodiment of the image of Abylai Khan in belletristic literature. The Kazakh literature analyzes and determines conclusions about Abylai Khan personality and the time he lived, songs sung, sagas, historical psalms dedicated to the khan. The civic principles of revealing the image of Abylai Khan are defined, citing a number of arguments concerning the poets. Also, the works that scientifically created the image of Abylai are divided into three lines, and the views of the scientists are compared.

In the article, based on the fundamental research on Abylai Khan in Kazakh science, the authors clearly state their views. There is also an overview of views on historical songs, mythical songs, biographical songs with the image of Abylai Khan. He considered the personality of the khan, who gave spiritual nourishment to the descendants, as a collective image.

The orators around Ablai make a literary-theoretical analysis of the image of khan in the poems of Bukhara, Umbetbay, Tatikara.

The struggle of our people for liberation through the image of khan was not left unnoticed. The image of Abylai Khan, a staunch supporter of the nation, was revealed as a symbol of freedom and liberty.

Keywords: historical figure, historical poem, biographical poem, Russian colonialism, khan's personality, epic, historical and ethical image. 


\title{
STUDY OF THE PRAGMATICS OF CHINESE INTERNET LANGUAGE AND SLANG IN SOCIAL NETWORKS
}

\author{
Akhmetbek G., candidate of historical sciences \\ akhmetbek.gulzhan@mail.ru, https://orcid.org/0000-0003-0585-1923 \\ Kumashkyzy A., second year master's student \\ lingling@list.ru, https://orcid.org/0000-0001-5376-6841
}

\section{L.N. Gumilyov Eurasian National University, Nur-Sultan city, Republic of Kazakhstan}

\begin{abstract}
Annotation. The Internet provides a space for network users to communicate freely. The desire of network users to express their thoughts, imagination and self-knowledge is reflected in the slang on the Internet and social networks. The language of the Internet appeared as a product of the network, formed its own characteristics in the process of use and acquired its own pragmatic function. These qualities have made it an important tool of modern communication and a cultural carrier.The pragmatic approach to the recipient of information is an important function of any language communication. Although the root of Chinese Internet slang comes from Chinese, it gives a completely different meaning and character as a network language than literal, which requires a pragmatic study to understand. From the point of view of the speaker and the listener, people's speech actions are considered as social behavior governed by various social conditions. It is aimed at explaining that the use of special words in a particular environment can determine the meaning of the text, affect all aspects, and thus determine the pragmatic rules. Before using a slang word, any network user should pay attention to its meaning, as it can also have a negative connotation.
\end{abstract}

Keywords: Internet language; Internet slang; pragmatics; Chinese linguaculture; Chinese social network.

Introduction. With the development of computer technology, network languages gradually began to enter people's lives, then network linguistics appeared, research on network languages was conducted in different directions. Network languages have clear multimodal characteristics, network languages have images, symbols, words and other expressions, have achieved various pragmatic functions in the use of network language to achieve the purpose of communication.

The development of Internet language and social media slang in China has become such a new science. The network develops by showing the psychology of users, their inner nature, the indirect image of the problems in society, the voice that does not reach the right place.It is important not only to understand their literal meaning, but also to study their pragmatics, which in some cases can even help to prevent crime, to study the development of adolescents, to solve problems in society more quickly. Through this article, we want to review their pragmatics and give linguists a new direction in learning Chinese.

Literature review.Internet and social media slang (网络社交用语) - are also called "hot words (网络热词)", popular words, hit words (网络流行语), these are words that have a high frequency of use, mainly on the Internet and in the use of social software, and have new dictionaries that are widely distributed, giving new meanings in a certain period and language environment. As a lexical phenomenon, it arises in the context of online culture.It not only conveys and propagates a positive human spirit, but also serves as a moral tool for network users to identify the negative things that are happening in modern society. By studying the pragmatic use of these slangs, it is possible to know its true or figurative meaning, the state of society, the state of the people, the inner world of the informant [1]. 
In fact, until the end of the 19th century, Chinese scholars studied their language in isolation, despite foreign traditions and trends. [2,18 pp]. And in modern times it is important to study slang in combination with a foreign language, as discussed above.

Research materials and methods.At all stages of experimental research, we complied with the basic requirements:the pragmatic function represented in the network language is studied by analyzing the multimodal characteristics of the network language. Network slang is an attribute of natural language, ambiguity is one of the main characteristics of this language, qualitative analysis of Internet slang by studying the implementation of non-real language of interactive words and the pragmatic function of unknown language on the Internet, considering the context and language structure. The goal of striving, gaining popularity, and improving entertainment effects is to ensure the integrity of online communication by effectively avoiding negative information and sensitive issues while fully conveying meaning [1]. Theoretical analysis of content based on the study of the linguistic culture of Chinese slang on the Internet and social networks, descriptive interpretation and discovery of their features through the methods of statistical research.

There are 5 different ways to make words in Chinese. They are: with the help of an application (附加法); by combining (合成法); by doubling (重叠法); through consonance(变音 法); by abbreviation (简略法). [3,10pp]. The method of slang formation often uses the fourth and fifth methods, according to the form, Internet slang can be divided into 4 groups as follows:

1) Symbols: for example, half-opened parentheses ")))" "微笑" - means a smile, including smilies on social networks.

2) Numbers: 520 我爱你 - I love you, 9494 就是就是 - so ， 5555 鸣鸣鸣鸣（哭） cry，201314 爱你一生一世 - I love you all my life，7456 - 气死我了 - very much There are such notions as "I'm upset".

3) Letters (by abbreviation): abbreviated letters, JJ- 姐姐 - sister, GG- 哥哥- brother.

4) Hieroglyphs: 杯具 - 悲剧 - (beiju) tragedy, 洗具 - 喜剧 - (xiju) comedy, 餐具 - 惨 剧 - (canju) horror story, 酱紫 - 这样子 - (zhe yangzi) [1].

Research results and discussion.The work identifies the lexical-semantic and structural system of slang in the Internet and social networks, which has a significant impact on modern Chinese, especially the systematization of its peculiarities. From a disciplinary point of view, Chinese is an interdisciplinary subject involving Chinese language philology, applied linguistics, pedagogy, psychology, literature, and culture and art $[4,1 \mathrm{pp}]$. By studying the slang that has emerged as a result of this new phenomenon, we will look directly at the problem itself, addressing other issues in society, among young people.

As E. S. Karpov said: in the new online communicative space, the phenomenon of slang requires a place in the system, combining different properties and qualities, and pragmatically accumulates the most effective linguistic tools that help to realize communicative intentions. [5,4pp]. Although the slang used on the Internet and the slang used on social networks have the same history or reasons, their differences are obvious. The slang used in social software may not make sense, which is one of its features. Some netizens achieve their goal by writing different characters, numbers, one hieroglyph, using traditional hieroglyphs, or mispronouncing a sentence so that others do not understand their language.It is often used on social networks to make special connections with friends, not just on the Internet. For example, 你 (ni - you) is written separately with left and right keys 人+尔 as "人尔", so the Cyber police or administration of domain can't recognize it, when they need to do this; next example, 宁可高傲 的发霉，不去卑微的恋爱一《儜砢 g $\alpha$ ó 謸魡髮 $\mathrm{m}$ の 1 , 8. 去卑薇魡攣噯》 (ning ke gao ao de fa 
mei, bu qu bei wei de lian ai) which means I don't want to fall in love with a low status, even if I'm alone with my pride, in this sentence it replaced all the words with a symbol-numbertraditional hieroglyph; 我今天想跟她告白(wo jin tian xiang gen ta gao bai) - 《白告她跟想天今 我»: I want to express my love to her today, hereby by writing the sentence from back to front and so on examples want to express the game anonymously through the slang of the social network, which can only be understood by friends. This is not the case when using colloquial Internet language, because even if you speak traditional hieroglyphs, it sounds the same. And on social networks, slang users can immediately understand the metaphor of the person writing.Another example is the slang of the social network 在吗 (zai ma - are you here?), in terms of its pragmatic use, there is a violation of the grammar of the Chinese language when using such slangs, According to chinese researching site baidu baike: it means to ask if someone is in a certain place, it is a way of greeting, it is often used on social networks, because the interviewer must first answer this question, this slang is one of the most "disgusting" slang words of 2017. This is the most unpleasant way of greeting in the era of Chinese social media WeChat.Prior to the exchange of information, it is only a useful slang for the questioner, and the questioner must get an answer to “在吗?” before asking an additional information [6].

Network slang is a native language in the Internet environment and a product of the dissemination of network information. It has a variety of features, interactive, open, operational and hidden, which is a symbolic environment created by network users. Compared to the communicative language of our everyday life, the online language has its own characteristics, depending on the characteristics of its generation.

1. Oral features. The language of the Internet is the language used by netizens to express their feelings in the virtual world, which is expressed in writing, but due to the speed of the Internet, its essence is very close to the style of spoken language. Network users communicate on the Internet with obvious features, such as real-life conversations. The language of the Internet uses a lot of synonyms, even more than the spoken language of life. For example, "哇塞 (wa sai) - wow!", "呵呵 (he he) - hehe!" and more. In addition, many local dialects are used in online languages. Since dialects differ from Mandarin Chinese in pronunciation, intonation, and vocabulary, such words are rare in the dictionary. Therefore, in order to achieve dialectal resonance, charm, and humorous effects, network users often use homophony as a means of creating many uses for "new" slang. For example: "挤使(死)了(ji shi/si le) - I'm embarrassed", " 前面的银 (人 ) (qian mian de yin / ren) - the person in front" (Qingdao dialect).

2. Simplicity. Network slang is achieved by tapping the computer keyboard. To continue to synchronize with thought, online languages want to deliver the greatest amount of information in the shortest possible time, so online languages have a clear economic simplicity. According to the principle of brevity and speed, many network abbreviations are made by using the network language. One is the abbreviation of the capital letters in Chinese Pinyin. PPMM (漂漂美眉 (piao piao mei mei) beautiful lady), PMP (拍马屁 (pai ma pi) flattering, praise; GX (恭喜 (gong xi) greetings), JJ (姐姐 (jie jie) sister); another is the English abbreviation prefix, for example, GF (girl friend), PC (personal computer); other types - English or digital homophonic, for example U2 (you too - you too), 3Q (thank you (san Q/ 三 Q) - thank you), 7456 (气死我了 (qi si wo le) - very angry), 9494 (就是就是 (jiu shi jiu shi) so), 886 (拜拜喽 (bai bai lou) goodbye), 5201314 (我爱你一生一世 (wo ai ni yi sheng yi shi) - I will love you forever). From these examples, it can be seen that the transformation of online slang into existing language components is mainly reflected in the clear expression of the communicator's intentions, and that online chat adds humor and close communication to virtual online life [7,83pp]. 
Any statement contains two types of information: specific information to be conveyed and instructions on how the listener should receive it. In other words, what is said and how is said and how to understand the given content. Traditionally, linguistics deals with the first spectrum - the division of speech into parts of speech, taking into account its structure, etc. Relatively recently, linguists have turned their attention to the other side - the meanings that lie above the basic information [8]. Charles Bally called the first part a dictum and the other a modus: In the 20th century. Bally introduced the theory of modus and dictum into linguistics. Modus - (Latin Modus - size, method, image, type, rule), 1) philosophy. difference from an attribute - a term that refers to the properties of an object that are unique to it only in certain states - a property of an object; 2) in logic - one type of proof (for example, M. syllogisms) [9].

If we consider the pragmatic function of slang in the language of the Internet and social networks, they are divided into four:

1. Improves humor, entertainment, mood. The Internet slang language has become a means of communication for network users on the Internet communication platform. The relatively young age of the network users has made the online language viable. They have created many non-traditional, carefully thought-out, many open and interesting slang languages on the Internet, as well as a free and humorous communication context. The use of these slang languages has made the language of communication interesting, resourceful and easy. For example, "菌男 (jun - bacteria, nan - male) - 俊男 (jun - slender, nan - male)" and "震女 (mei moldy, nü - girl) - 美女 (mei - beautiful, nü - girl) »Slang for ugly men and women. On the one hand, these two words are used in the homonymous and opposite sense of "俊男美女 - a handsome man and a beautiful woman"; on the other hand, "菌 - bacteria" and "雼 - mold" can immediately remind people of expired and spoiled food, both of which have a strong ironic effect [10,60pp],

2. Write what you want and do not obey traditional prohibitions. The network is a virtual world. A network is a space where a user is "allowed" to start chatting with people they don't know and to communicate on the Internet. The most widely used on the Internet, such as "GG ( 哥哥 - ge ge - elder), MM (妹妹 - mei mei - sister), 大虾 (大侠 - da xia - hero), 菜鸟 (cai niao a low-level beginner)" established virtual interpersonal relationships through virtual names, making the dialogue seem kinder and closer than a real-life conversation. In real-life relationships, the profound effects of linguistic magic, such as "bad words call for evil" and "good words are half the battle," have forced people to avoid words such as evil for thousands of years, and people have used euphemisms for educational purposes. However, in the world of the Internet, people have broken the rules of real life by hiding the truth about themselves, humorously and exaggerating, and freely expressing what they want to say, making the communication between the two parties more natural. Even if you use forbidden words, there would be no significant loss. For example: 《如果多吃鱼可以补脑让人变聪明的话,那么你至 少得吃一对儿鲸鱼(说别人笨) - (ru guo duo chi yü ke yi bu nao rang ren bian cong ming de hua, na me ni zhi shao dei chi yi dui er jing yu) - If eating more fish makes your brain smarter, you should eat at least one or two whales (figuratively speaking, it's stupid).

3. Abstract signs - make up for the lack. In the Internet and social network communication, neither side can see each other. Compared to real interpersonal communication, it is only a picture, and online chat has the effect of a close connection, such as "seeing and listening to each other" and open communication. For example, the parentheses "))", $\bigodot_{-} \odot /$ (fear), etc. b. expresses mood by applying. Not only has the network changed the speed and quality of human information transmission, but it has also significantly enriched people's ways of communicating through social media expressions, creating a unique social networking language characterized by a large number of non-verbal emotions. Emotional smileys are used to clearly 
present and describe non-verbal information in everyday face-to-face communication, so that both parties feel as if they are hearing their voices and seeing each other.

4. Imagine freedom and strengthen it as an individual. Regardless of voice, speech style, and intonation, network communicators had to rely on their own language style and other factors to advance an individual in order to attract and identify the attention of others. The Internet provided users with the most free space to fully enjoy their imagination and creativity, which was free and individual, as there were no restrictions like in real social life. Compared to traditional written language, slang on the Internet and social media reduces external restrictions and allows full freedom of the author, the freedom of imagination is so full of clever and surprising words in the slang concepts they invent, thus maximizing the linguistic ingenuity of all. The various slangs on the Internet have provided a platform for network users to express their individuality, and the slang of individual network users has enriched the space of the online language. For example, 工作的最高境界就是看着别人上班,领着别人的工资 (gong zuo de zui gao jing jie jiu shi kan zhe bie ren shang ban, ling zhe bie ren de gong zi) - the highest level of employment is when you look at other people working and you get paid by others, that is, you get paid even if you don't work, which is often the case with managers or investments $[11,142 \mathrm{pp}]$.

In the online environment, the relative freedom of speech and the degree of participation of people have reached a level unmatched by any other media. Network users use the language of the Internet for political, social or educational-cultural, etc. agrees or disagrees with him by expressing his thoughts about the phenomena, makes jokes or ridicule, laughs or sneers, expresses resentment or anger, conveys to the world his moral standards and values in an unconventional and informal way. The "buzzwords" on the Internet are caused by the fact that network users pay high attention to a particular event and contribute to its spread, which in real life creates an "intense" impression.

Online linguistics courses offered by Chinese colleges and universities can effectively guide the development of online languages, cleanse negative languages, create a civilized and clean atmosphere, and allow the Internet languages to play a positive role in the development of modern Chinese. The principles of selection of teaching aids developed by them are as follows. 1) In order to keep up with the pace of language change on the Internet, it is necessary to monitor and analyze the latest phenomena of Internet language; 2) The selected content should be analyzed according to linguistic theory: 3) References to relevant books, textbooks and the latest research results; 4) The selected content is aimed at practical communication, applicability [11,28pp]. In this regard, other professionals, such as political scientists, linguists, culturologists, sociologists, sociologists, using the language of the Internet and social networks, which is hotly debated in their field research or textbook development, can be considered appropriate to use it as an "organic fertilizer". That is, through the emergence of the event behind it, pragmatic research, development in society, the impact can increase academic interest, focus on new issues, attract the right audience, achieve academic goals such as academic performance and access to knowledge.For philosophers, this topic is a new stage, a new part of the rapidly evolving linguistics that emerged in the age of the Internet.

In 2009, ".....你 (ni)...喊你回 (hanni hui)..." has become the most common slang sentence. No one knows who Jia Junpeng was or what Jia Junpeng did, only that someone posted a 12-digit message on the Internet saying, "贾君鹏，你妈妈喊你回家吃饭 (Jia Junpeng, ni ma ma han ni hui jia chi fan) - Jia Junpeng, your mother calls you to go home for dinner!" had become a "hit" in the Chinese Internet slang sentence. It later proved to be a well-planned online PR event aimed at compensating for the "World of Warcraft Cultural Crisis" caused by the website's workflow. [12,66pp]. 
When giving examples of popular slang phrases on the Internet, we need to pay attention to the following issues, otherwise it will not give a positive result.

- It is impossible to take a perceptive when quoting it. Doing so can lead researchers to focus on the superficial, dilute the main idea, and confuse it with the content of the main topic, so it should not be associated with appearance, surface meaning. In the process of learning it is necessary to get rid of the superficial phenomenon in time and try to understand its essence.

- When using it, do not quote unilaterally. If used in this way, it can lead to misconceptions, fail to develop students' ability to think critically, and negatively affect the realization of the right emotions, attitudes and values. Therefore, it is necessary to analyze the popular slang language used on the Internet objectively and not to go too far.

- The text should be considered in its entirety, not just a part: it is necessary to show the background of the events behind the slang on the Internet and social networks, so that researchers can understand the nuances of slang phrases online, reveal the meaning through full materials and draw conclusions based on it.Network users openly express their views and experiences on the Internet about the society, life and environment in which they live. Enthusiasm that you want to see in real life conveys a strong motivational force through new words online, evokes feelings of boredom and dissatisfaction, as well as expresses the appearance of your own consciousness through online slang. In China, emerging Internet slang is used in official newspapers or in the workplace. There are times when they change from one slang to another $[13,64 \mathrm{pp}]$.

On November 10, 2010, the Chinese slang word "给力" (gei li) became the headline of one of the three official media organizations of the People's Republic of China - "min" (ren min ri bao) (江苏给力"文化强省"), and netizens were happy to say "太给力了" (too strong/so great). And by the end of 2020, one of the most popular Internet slangs came from the word "奥 利给" (ao li gei) - the same "给力 / 给力噢" (gei li / gei li ao), that is, read the old slang from right to left and create a new " hit word "appeared. The word "奥利给" (ao li gei) came from the driver's "positive motivational quotes" during a live broadcast or video on a social network. The word also means wonderful and is rich in a variety of emotional colors, such as praise and applause as an interaction [14,211pp].

On December 4, 2020, it was selected as one of the "Ten Internet Slangs in 2020" published by the Chinese National Center for Monitoring and Research of Language Resources. In addition, the following Internet and social network slangs are included in this list:

- "逆行者 (ni xing zhe)" means a person who walks backwards, often referred to as a strong person who moves forward in times of danger, for example, the most beautiful "逆行者 a walker who goes against the wave" in the fight against the new pneumonia epidemic in 2020 . The innumerable "逆行者 - backwards" from ordinary people, who defended life with their own lives, are the symbols of the heroic spirit of the new era. If you do not understand its pragmatic function, you can think that this new slang is not a good word.

- 《秋天的第一杯奶茶 (qiu tian de di yi bei nai cha)», the first cup of milk tea in autumn. This means that in the fall, spouses, friends or family members give a gift of tea money to drink milk tea to take care of their loved ones, which is mainly 52.0 yuan ("520 I love you" consonant homonym - 我爱你 wo ai ni). Thus, during the quarantine security event, this word and the corresponding picture were posted on the whole social network, and relatives who could not leave the house expressed their condolences to each other. And if you don't do a pragmatic study, you will be amazed at the pictures of this tea, and the informant will feel left out of society, not understanding what he meant or what happened. 
-"云监工 (yun jian gong)", cloud observer. Initially, in the fight against the pneumonia epidemic, tens of millions of network users watched the construction site of China's Wuhan Huoshenshan and Leishenshan hospitals live around the clock as "cloud monitors".

- "夺冠 (duo guan)", winning the championship, this slang became famous thanks to the famous Chinese film "Winning the Championship". She is Chinese and she showed the strength of a generation of Chinese women volleyball players. The "female volleyball spirit" who contributed silently became the microcosm of the "Chinese spirit".

- "不约而同 (bu yue er tong)" is a coincidence, which literally means that the same opinion or action was made without prior consultation when speaking or acting. In 2020, due to the epidemic, netizens came up with a new meaning for the term: not to go to meetings, not to gather in groups - has become a common rule. Only by researching the new meaning can we find out what netizens want to say.

- "集美 (ji mei)", sisters (from the word 姐妹 jie mei), a popular name on the Internet, the host of the social network called "sisters" "集美 (ji mei)" live, which means It sounded close and pleasant to the audience, so netizens followed them and called their peers [8].

If we speak well, we can be happy a little bit, and if we get a lot of good speech, we can make the country better. If you do not speak well to the addressee carelessly, it can be at least annoying, and on the plus side, it can lead to stuttering and "death". Therefore, the ancients said that "one word makes a nation prosperous, and one word loses a nation." It is also important to be very careful when speaking in cyberspace today [15,2 pp].

Conclusion. In conclusion, the language of the Internet and slang words in social networks is a new cultural phenomenon that corresponds to time and cultural environment, and it satisfies the cultural psychology of modern people. The emergence and spread of Internet slang fully reflects the creativity and imagination of young people, expresses their own emotions and views, and reflects the many spiritual thoughts and values of today's youth. Network users realize their self-knowledge, individuality, independence and emotional satisfaction through the creation and use of slang phrases on the Internet and social networks, which in times of rapid economic and social development and the rise of Internet media as the most direct manifestation of recognition and individual cultural manifestations. There is a big gap between online social life and real social life. The online social network environment will be informal. Its forms are diversified and have the characteristics of oral speech. This form of social networking There are still many gaps in the development of social language on the Internet. From a pragmatic point of view, we should try to promote the standard and reasonable, sustainable, healthy development of online socialization by analyzing the language of the Internet and slang in social networks.

\section{References:}

[1] Baidu hanyu., Yuyong xue. 百度汉语：语用学。https://hanyu.baidu.com/zici/s?wd

[2] Kurdyumov, V.A. (2005) Kurs kitaiskogo yazyka. Teoreticheskaya grammatika. Tsitadeltrade: lada. P. 18.

[3] Abdyrakyn, N. (2010) Kazirgi kytai tilinin grammatikasy: oku kuraly. Kazakh university: Almaty. P. 10.

[4] Lin Yutang (2008). Shuo hua de yi shu. Yu yan yi shu: Xi’an. P. 1.

[5] Karpov, E.S. Internet-zhurnal. Funktsionirovanie slenga v diskurse. Internet-kommunikatsii: avtoreferat. P. 4.

[6] Baidu baike. 百度百科。https://baike.baidu.com/item/ $\% \mathrm{E} 5 \% 9 \mathrm{C} \% \mathrm{~A} 8 \% \mathrm{E} 5 \% 90 \% 97 /$ 9923403?fr=aladdin

[7] Blagaya, A.V. (2008) Uchebnik kitaiskogo yazyka. Nachalnyi kurs. Tsitadel-trade. P. 83.

[8] China Economic Net. 中国经济网：2020 年度十大网络用语发布。 
http://www.ce.cn/xwzx/gnsz/gdxw/202012/07/t20201207_36088821.shtml

[9] Bolshaya rossiiskayz entseklopediya. Большая российская энциклопедия (эл.) https://bigenc.ru/philosophy/text/2222316

[10] Kang Shiyong, Liu Hai (2003) Shi yong wang luo yong yu shou ce. Ji suan ji wang luo shu yu - shou ce: Shanghai. P. 60-121.

[11] Lin Gang (2017). Wang luo yu yan xue jiao chen: Beijing. P. 28-142.

[12] Wang Lei (2011) Xin hua wang luo yu yan ci dian. Hu lian wang luo - ying yong yu yan xue - ci dian: Beijing. P. 66.

[13] Shichko, V.F. (2014) Prakticheskaya grammatika sovremennogo kitaiskogo yazyka. Vostochnaya kniga. P. 64.

[14] Rakhimbekova, L.Sh. (1999) Povtory i ikh funktsii v sovremennom kitaiskov yazyke: Dis. ... kond. filol. nauk. MGLU. P. 211.

[15] Yang Yuling, Ying Chenjin (2011) Xian dai han yu yu fa da wen: Beijing. P. 2.

\title{
ҚЫТАЙ ҒАЛАМТОР ТІЛІ МЕН ӘЛЕУМЕТТІК ЖЕЛІДЕГІ СЛЕНГТЕРДІҢ ПРАГМАТИКАСЫНЫН ЗЕРТТЕЛУІ
}

\author{
Ахметбек Г., тарих ғылымдарының кандидаты \\ Кумашкызы А., 2-курс магистранты
}

\section{Л.Н.Гумилев атындавы Еуразия университеті, Нұр-Сұлтан қ.., Қазақсттан Республикасы}

Андатпа. Ғаламтор желі қолданушыларының еркін қарым-қатынас жасауына кеңістік қамтамасыз етеді. Желі қолданушыларының өз ойын білдіруге, қиялдауға және өзін-өзі тануға деген ұмтылысы ғаламтор және әлеуметтік желідегі сленгтер арқылы бейнеленіп, айқын көрінеді. Ғаламтор тілі желінің туындысы ретінде пайда болды, пайдалану процесі кезінде жеке дара сипаттамаларды қалыптастырып, өзіндік прагматикалық қызметке ие болды. Осы қасиеттер оны заманауи коммуникацияның маңызды құралы және мәдени тасымалдаушысына айналдырды. Ақпарат алушыға прагматикалық тұрғыдан дұрыс әсер ету кез келген тілдік коммуникацияның маңызды қызметі болып табылады. Қытай ғаламтор сленгтерінің түбірі қытай тілінен шыққанымен, тура мағынаға қарағанда желі тілі ретінде мүлдеп басқа мағына мен сипат береді, оны түсіну үшін прагматикалық зерттеуді қажет етеді. Ол сөйлеуші мен тыңдаушының көзқарасы бойынша адамдардың сөйлеу әрекеттері әр түрлі әлеуметтік шарттылықтармен басқарылатын әлеуметтік мінез-құлық ретінде қарастырылады. Белгілі бір ортадағы арнайы сөздердің қолданылуы, сол мәтіндегі мәнін айқындалуы, барлық аспектілеріне әсер етуі мүмкін екендігін түсіндіруге бағытталған және сол арқылы прагматикалық ережелерді анықтайды. Кез келген желі қолданушысы сленг сөзді пайдаланбас бұрын оның мән-мағынасына назар аударады, себебі ол негативті сипатқа ие болуы да мүмкін болып келеді.

Түйінді сөздер. Ғаламтор тілі; Интернет сленгі; прагматика; Қытай лингво мәдениеті; Қытай әлеуметтік желісі.

\section{ИЗУЧЕНИЕ ПРАГМАТИКИ СЛЕНГА В КИТАЙСКОМ ИНТЕРНЕТ-ЯЗЫКЕ И СОЦИАЛЬНЫХ СЕТЯХ}

\author{
Ахметбек Г., кандидат исторических наук \\ Кумашкызы А., магистрант 2 курса \\ Евразийский университет им. Л.Н. Гумилева, г.Нур-Султан, Республика Казахстан
}

\begin{abstract}
Аннотация. Интернет предоставляет пользователям сети пространство для свободного общения. Стремление пользователей сети выражать свои мысли, фантазию и самопознание отражено в сленге в Интернете и социальных сетях. Язык Интернета возник как продукт сети, сформировал свои особенности в процессе использования и приобрел свою прагматическую функцию. Эти качества сделали его важным инструментом современного общения и культурным
\end{abstract}


носителем. Прагматический подход к получателю информации - важная функция любого языкового общения. Несмотря на то что, корень китайского интернет-сленга происходит от китайского, он дает совершенно иное значение и характер сетевого языка, чем буквальный, для понимания которого требуется прагматическое изучение. С точки зрения говорящего и слушателя речевые действия людей рассматриваются как социальное поведение, регулируемое различными социальными условиями. Он направлен на объяснение того, что использование специальных слов в определенной среде может определять значение текста, влиять на все аспекты и, таким образом, определять прагматические правила. Перед тем как использовать сленговое слово, любой пользователь сети должен обратить внимание на его значение, так как оно также может иметь негативный оттенок.

Ключевые слова. интернет-язык, интернет-сленг,

прагматика,

Китайская лингвокультура,Китайская сочиальная сеть. 
FTAXP: 19.01.17

https://doi.org/10.52081/bkaku.2021.v58.i3.084

\title{
ШЕТЕЛ ЖӘНЕ ҚАЗАҚСТАН ЖУРНАЛИСТЕРІНІН ХАЛЫҚАРАЛЫК ҚАТЫНАСТАР МӘСЕЛЕСІН ЖАЗУДАҒЫ ҚҰҚЫКТЫК ЖАУАПКЕРШІЛІГІ
}

\author{
Есімова Г.А., әлеуметтік ғылымдар магистрі \\ gaukharai@bk.ru, https://orcid.org/0000-0003-0658-7984
}

Қорқыт Ата атындавы Қызылорда университеті, Қызыллорда қ., Қазақстан Республикасы

Аңдатпа. Мақалада халықаралық қатынастар саласының негізгі құрамдас бөліктеріне сипаттама беріліп, оның маңыздылығына тоқталады, сондай-ақ журналистердің халықаралық стандарттарға сәйкес кәсіби этика кодекстерін білуі, халықаралық заңнамалардың республикалық заңдарынан жоғары тиіс екендігінен хабардар болу қажеттігі баяндалады. Еліміздегі халықаралық журналистика саласының кенжелеп дамуына қандай кедергілер әсер етіп жатқандығы, бұл кемшілікті жою үшін журналистерге қойылатын талаптың жоғарылағандығы сөз болады. Сонымен қатар, тұрмыстық деңгейдегі стереотиптердің баспасөз бетінде көрініс табуы кей оқиғалардыңұлтаралық қақтығысты қоздыруға себепші болып, оның соңы құқықтық жауапкершілікке ұласатындығы жөнінде мысалдар келтіріледі.

Қазіргі таңда халықаралық қатынастар мәселесін шешудегі БҰҰ-ның маңызы, өзге үкіметтік емес ұйымдардың атқарып жатқан шаралары сөз етіледі. Қазақстанның халықаралық қатынастар саласындағы саяси ұстанымы - бейтарап, жаңа замандағы саяси «ойындар» алып державалардың мүддесіне орай ұйымдастырылып, соған сәйкес нақты позиция қалыптастыру қиынға соғады. Бұл өз кезегінде шетелдік медианы былай қойғанда, отандық БАҚ-тағы ақпараттардың өзара қарама-қайшылығын туындатады.

Кілт сөздер: халыққаралық қ̧атылнастар, құқықытық жауапкершілік, халыққаралыққ журналистика

Кіріспе. Халықаралық қатынастар тақырыбы саяси аренада да, бұқаралық коммуникация алаңында да байыптылық пен аса сақтықты қажет ететін құбылыс. Мемлекеттер арасындағы дипломатиялық байланыс кейде тұрмыстық этносаралық қақтығыстың әсерінен, сондай-ақ жалған ақпарат тарату салдарынан шиеленісіп жатады. Сондықтан бұл тақырыпқа қалам тербейтін журналист тереңінен ойлайтын, құқықтық жауапкершілікті сезінетін, саяси шолу жасауға қабілетті маман болғаны ләзім. Алдымен аталмыш салаға маманданған журналист ҚР Конститутциясының 4-бабында көрсетілгендей: «Республика бекіткен халықаралық шарттардың Республика заңдарынан басымдығы болады және халықаралық шарт бойынша оны қолдану үшін заң шығару талап етілетін жағдайдан басқа реттерде, тікелей қолданылады», - деген қағиданы басшылыққа алуы шарт [1].

Зерттеу материалдары мен әдістері. Халықаралық қатынастар объективті сипатқа ие. Осыған сәйкес халықаралық қатынастар саласы құрылымы, функциясы, даму процесі бойынша төмендегіше жіктеледі:

Саяси қатынастар. Саяси қатынастар саяси жүйе элементтерінің, ең алдымен мемлекеттің нақты саяси қызметінде көрініс табады. Бұл бағыт қауіпсіздікке кепілдік береді және қалған барлық қатынастарды дамыту үшін жағдай жасайды, өйткені бұл қатынас түрі ортақ мүддесін біріктіруші күш ретінде есептеледі.

Экономикалық және ғылыми-техникалық. Қазіргі жағдайда халықаралық қатынастардың бұл екі түрі іс жүзінде бір-бірінен ажырағысыз. Сыртқы саясаттағы, әлемдік сауда нарығындағы халықаралық бедел мемлекеттің экономикалық күшімен және ғылыми-техникалық әлеуетімен өлшенеді десек еш қателеспейміз. Экономикалық қатынастардың жай-күйі көбінесе өндірістің даму деңгейімен және мемлекеттердің 
өндіргіш күштерімен, экономиканың әртүрлі модельдерімен, табиғи ресурстардың болуымен және басқа да секторлармен айқындалады $[2,18]$.

Идеологиялық қатынастар - бұл жоғарыда атап көрсеткен саясиқатынастардың дербес бөлігі.Идеологиялық қатынастардың рөлі мен маңызы қоғамда идеологиялық рөліне байланысты өзгеріп отырады.Бірақ жалпы даму тенденциясы идеология рөлінің өсуімен, яғни идеологиялық қарым-қатынаспен тығыз байланысты.

Халықаралық-құқықтық қатынастар халықаралық қарым-қатынасқа негізделген құқықтық нормалармен ережелердің реттелуін көздейді. Халықаралық-құқықтық механизм екі тараптың өз мүдделерін қорғауға, өзара қарым-қатынасты дамытуға, жанжалдардың алдын алуға, даулы мәселелерді шешуге, бейбітшілік пен қауіпсіздікті қолдауға мүмкіндік береді.Халықаралық-құқықтық қатынастар әмбебап сипатқа ие және жалпыға танылған қағидаттар жүйесіне негізделеді. Халықаралық қатынастардың барлық түрлерін реттейтін жалпыға танылған нормалардан басқа, олардың арнайы бағыттарын реттейтін (дипломатиялық құқық, теңіз сауда құқығы, халықаралық төрелік, сот және т.б.)ерекше нормалары да бар.

Әскери-стратегиялық қатынас әскери күштерді жасақтауды, қажет болған жағдайда қайта бөлуді реттейтін халықаралық қатынастардың ауқымды саласы. Ядролық қару жасау мемлекеттердің одақтастық, конфронтациялық, кооперациялық-конфронтациялық әскери-саяси қатынастарының сипатын, ауқымын және қарқындылығын түбегейлі өзгертті $[3,102]$.

Мәдени қатынастар. Қоғамдық өмірдің жаһандануы, мәдениеттердің өзара кірігуі мен байытылуы, білім беру жүйесі, бұқаралық ақпарат құралдарының қарқынды дамуы бүгінгі таңда өзекті мәселеге айналды. Бұл қатынас түрінің дамуында көбінесе үкіметтік емес ұйымдар ерекше маңызға ие.

Халықаралық қатынастарға қатысты кез келген мәселені жазу журналистен үлкен жауапкершілікті қажет етеді. Бүгінгі таңда медиакеңістікке жіберілген кез келген ақпарат сол елдің айнасы іспетті. Екі елдің сыртқы байланысы, өзара әріптестік орнатуы ақпарат тарату платформасында қандай сипат алады, соған сәйкес саяси қатынастар да реттеліп отырады.

Зерттеу нәтижелері мен талқылаулар. Жалпылама алғанда, халықаралық қатынастардың шиеленісуіне кейде қалыптасқан қасаң қағидалар өз салқынын тигізеді. Мәселен, стереотиптердің қалыптасуының қайнар көзі - белгілі бір этнос туралы ойдан шығарылған, ақылға қонымсыз идеялар [4,16]. «Қауіпті постулаттар» деп аталатын мақалада саясаттанушы Қазақстанға қауіп-қатер төндіріп тұрған сыртқы факторларды (Батыстың зиянды ықпалы, Қытайдың демографиялық үстемдігінен туындайтын қауіп, араб шовинизмі) атай келіп былай дейді: «Ал, ескі құда Ресейдің мәдени-саяси иірімінің ішінде отырып, бір араққ̧а қ̧атты берілдік. Орыстың тікбақุай мінезі құала мәдениетінің негізіне салынып, құазақті сәлемін суық құабылдайтын денңгейге түсірді. Орыстың жейтін тамавы - шошқ̧аның жаясы қ̧азақтың мінезіне қыззzанбауды әкелді. Өйткені шошқ̧аның аталывы аналывын қыызванбайды. Қазақ арасында жеңіл жүріс, ажырасу көбейді. Орыс құызының, орыс әйелінің тасыр мінезі құазақ әйелін өзгертіп жіберді: құара санzа дейін көрінетін қыьсқ̧а көйлек киетін болды»».

Көріп отырғанымыздай, бұл үзіндіде автор мұсылмандардың теріс қабылдайтын «орыстар шошқаның етін жейді» деген жалпыға белгілі стереотипті пайдаланып (орыстардың мінезі қауырт, орыс келіншектері мен әйелдері тұрпайы), сол этностың негативті бейнесін одан әрмен өршітіп, тіпті абсурдқа дейін жеткізген. (Орыстың жейтін

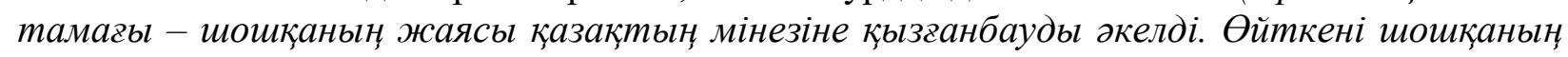
атальвъь анальвын қ̧ьззванбайды).

Ксенофобиялық теріс ұғым қалыптастырудың үйреншікті тәсілі - сатқын-этнос деген айдар тағып, оның арам пиғылы бар екенін көрсету. Мысалы, «...1992-1997 жылдар 
аралывында «Қайдасың Отаным - Ресей?» деп 1,6 миллион орыстардың көшіп кеткеніне кейбіреулер құатты қыынжылды. Ал туралыққ̧а келсек, біз қыынжылмай, құайта куануымызкерек. Себебі «қ̧асқырды қ̧анша бақ̧саң да, орманда қ̧арап ұлиды» дегендей олардың жүрегі Ресей деп совады. Олар еш уақытта Қазақстанда жаны ашыммаитынынын сол көшімен дәлелдеді. Мұндайлардан аман-есен, тыныш қ̧ана құтылганымызга куанайық.. Өйткені ел басына ауыр жавдай туа қъалса, бірінші болып сатқындық жасау солардан шызуы мүмкін» [5,43].

Газеттің бір оқырманы өзінің мақаласында осылай жазған. Редакция болса, ол хатқа салмақты да салиқалы түсініктеме бермеген. Егер редакция формальді түрде не шынымен мұндай пайыммен келісетін болса, онда БАҚ-ты ұлтаралық араздықты қоздыру үшін пайдаланып отыр деп айыптауға болады.

Кейде адамдар тұрмыстық деңгейдегі әңгімені баспасөз бетіне жариялауды батылдық санап, құқықтық жауапкершілікке тартылып жатады. Шетелдік психологтар осындай стереотиптердің теріс әсерін ерекше атап көрсетеді: «...стереотиптер әдетте жұқпалы ауруға ұқсас, себебі ондай қасаң қағидалар адамдарды талғамай, жалпылама бәріне бірдей дөрекі мінездемелік қорытынды баға береді. Кейде стереотиптер шындыққа сәйкес келгенімен, оның арты жамандыққа апаруы мүмкін, себебі сол халықтың кейбір өкілдерінің мінезі сөз болып отырған стереотиптерге мүлдем сәйкес келмесе де, оларға да сондай жаман атақ келеді» $[6,15]$.

Бұдан шығатын тұжырым, халықаралық қатынастар мәселесі жоғары толеранттылықты қажет ететін тақырып болғандықтан, кез келген айтылған не болмаса жазылған сөздің өзіндік салмағы болады. Ал мұндай орынсыз айыптаулар бүгінде біздің баспасөз бетінде де, электронды ақпарат құралдарында да өріп жүр. Сондықтан құқықтық жауапкершілікпен қоса, екі ел арасындағы саяси қарым-қатынасты күрделендірмеуді де ескерген жөн [7,36].

Халықаралық журналистер әрдайым журналист мамандығының элитасы болып саналды. Олардың қызметі ғаламшардың түрлі бұрыштарындағы адамдарды байланыстырады.Қандай да бір аймақ немесе мемлекет туралы материал жариялау журналистен тарих, мәдениет, қоғамдық өмірдің көптеген ерекшелігін білуді қажет етеді. Бұл ойымызды халықаралық журналист - Всеволод Овчинников, Александр Бовин, Генрих Боровик, Михаил Татарутой және өзге елдердің саяси, мәдени, қоғамдық дамуы туралы көптеген кітаптар дәлелдейді. Халықаралық қатынастар жүйесінде белгіленген нормалар мен кәсіби этика талаптарын терең меңгеру - осы тақырыпта жазатын журналистің басты міндеті $[8,54]$.

Қазақ журналистикасында халықаралық тақырып кенжелеу қалуының себебі де мамандардың кәсіби қызметінде үлкен жауапкершілікті қажет етуімен тығыз байланысты деп ойлаймыз. Екінші жағынан халықаралық қатынас көп қырлы болғандықтан, әсіресе оның саяси маңызы мен астарын айқындау - журналистке көп ізденуді міндеттейді.

Мемлекеттің қуаттылығы оның халықаралық бәсекеге қабілеттілігімен байланысты. Бұл экономикалық әскери әлеуетпен, табиғи және еңбек ресурстарымен, ғылым мен мәдениеттің даму деңгейімен, жоғары технологиялар саласындағы жетістіктермен, әлеуметтік тұрақтылық деңгейімен айқындалады $[9,18]$.

Біріккен ұлттар ұйымы -халықаралыққатынастарды тұрақтандыруға, жанжалдарды және мемлекеттер арасындағы конфронтацияны реттеуге арналған маңызды әмбебап ұйым. Сонымен қатар әлемдік саясатта белгілі бір рөл атқаратын мемлекетаралық өңірлік бірлестіктер арасында Африка бірлігі ұйымын, Америкалық мемлекеттер ұйымын, Еуропа кеңесін, Еуропалық Одақты, Тәуелсіз Мемлекеттер Достастығын (ТМД), Оңтүстік Шығыс Азия елдерінің Ассоциациясын (АСЕАН), Араб мемлекеттерінің лигасын (ЛАГ) және т. б. атап көрсету қажет [10]. 
Үкіметтік емес ұйымдар қандай да бір ортақ мақсаттарға қол жеткізу ісінде әр түрлі мемлекеттердің ерікті адамдарын біріктіреді. Мәселен, бұрынғы Кеңес одағының аумағындағы Хельсинки топтары сияқты әртүрлі құқық қорғау ұйымдары өте белсенді жұмыс істеген [11]. Үкіметтік емес қауымдастықтардың арасында ғалымдардың, қоғам қайраткерлерінің, саясаткерлердің халықаралық ұйымдарын атап өткен жөн. Табиғатты тиімді пайдалану және әлемдік даму перспективаларын қарастыруда түрлі елдердің өкілдерін біріктірген Рим клубы [12], осындай мақсаттағы Улаф Пальме комиссиясын да атап өткен жөн [13].

Қорытынды.Теориялық зерттеулерде бүгінгі күні барлық елдер үшін халықаралық экономикалық қатынастар үлкен рөл атқаратынын байқауға болады.Мұндай байланыстарды орнату және дамыту әрбір мемлекеттің әлеуетінің маңыздылығын сезінуі, өздерінің базалық шаруашылық бағыттарын дамытуына және ұлттық экономиканың ресурстық қажеттіліктерін қамтамасыз етуі үшін әлемдік шаруашылыққа кірігуіне ықпал етеді $[14,85]$.

Еуразия кеңістігіндегі алпауыт елдердің өзара тайталасқа түсуі кейбір елдердің саяси позицияларын нақтылауға мүмкіндік бермей отыр. Мәселен, Ресей мен Түркия арасындағы текетірестер, Сириядағы соғыс, Таяу Шығыстағы Сауд Арабиясының ислам дінінінрадикалды бағыттағы ағымдарға қолдау білдіруі секілді қазіргі таңда жүргізіліп жатқан векторлы саяси қадамдардың негізгі мәнін түсіну қиын. Сол себепті медианарықта да халықаралық қатынастар тақырыбы тұрақты көзқарас тудыра алмайды, халықаралық жағдайлардың әралуандығына байланысты әр елдің саяси ұстанымы өзгеріп отырады [15, 95].

\section{Әдебиеттер:}

[1] https://adilet.zan.kz/kaz/

[2] Ермичева, Е.В. Международно - правовые аспекты деятельности средств массовой информации. Автореферат диссертации на соискание ученой степени кандидата юридических наук. - Мосвка, 2003. - 24 с

[3] Кривчикова, Э.С., Колосов Ю.М.Действующее международное право в 3 - х тт. Сост. - М.: Московский независимый институт международного права, 1996 - 328 с.

[4] Жаз, бірақ ушықтырма - Журналистерге арналған жадынама - Алматы, 2010 - 60 б.

б.

[5] Психологиялық-филологиялық сараптаманы жасау әдістемесінде - Алматы, 2007 . - 70

[6] Прикладная конфликтология - Москва, 2006 - 23 с.

[7] Рихтер, А.Г. Массово-информационное право в грядущем веке. См.: сб. От книги до Интернета. Журналистика и литература на рубеже нового тысячелетия. - М.: МГУ, 2000. - 76 с.

[8] Ибрагимов, А.X. Перспективы международной информационной пропаганды. См.: сб. От книги до Интернета. Журналистика и литература на рубеже нового тысячелетия. - М.: МГУ, 2000. -43 c.

[9] Землянова, Л.М. Зарубежная коммуникативистика в преддверии информационного общества: Толковый словарь терминов и концепций - МГУ, 1999. $-98 \mathrm{c}$.

[10] https://kazakhstan.un.org/kk

[11] https://kk.wiki2.wiki/wiki/Moscow_Helsinki_Group

[12] http://www.myshared.ru/slide/424356/

[13] https://www.bbc.com/

[14] Международные стандарты профессиональной этики журналистов: учеб. - метод. пособие / сост. А. В. Байчик, Ю. В. Курышева, С. Б. Никонов. - СПб. : С.-Петерб. гос. ун - т, Высш. шк. журн. и масс.коммуникаций, 2012. -102 с.

[15] Оразбекова, 3.С., Жанабаев Е.Б.СМИ и международные конфликты на Евразийском пространстве. - Алматы, Қазақ университеті, 2017 ж. - 100 с.

\section{References:}


[1] https://adilet.zan.kz/kaz/

[2] Ermicheva, E.V. International legal aspects of mass media activity. Abstract of the dissertation for the degree of Candidate of Legal Sciences. Mosvka, 2003- - 24 s

[3] Krivchikova, E.S., Kolosov Yu.M. Current international law in 3 tt. Comp. - M.: Moscow Independent Institute of International Law 1996 - 328 p.

[4] Zhaz, birak ushyktyrma - Journalism arnalgan zhadynama - Almaty, 2010 - 60 b.

[5] Psychologiyalyk-philologiyalyk saraptamany zhasau adistemesinde - Almaty, 2007 - 70 b.

[6] Applied Conflictology - Moscow, 2006 - 23 p.

[7] Richter, A.G. Mass information law in the coming century. See: collection From books to the Internet. Journalism and literature at the turn of the new millennium. - Moscow: MSU, 2000. - $76 \mathrm{p}$.

[8] Ibragimov, A.H. Prospects of international information propaganda. See: collection From the book to the Internet. Journalism and literature at the turn of the new millennium. - Moscow: MSU, 2000. $43 \mathrm{p}$.

[9] Zemlyanova, L.M. Foreign communication studies on the eve of the information society: Explanatory Dictionary of Terms and Concepts - Moscow State University, 1999-98p.

[10] https://kazakhstan.un.org/kk

[11] https://kk.wiki2.wiki/wiki/Moscow_Helsinki_Group

[12] http://www.myshared.ru/slide/424356/

[13] https://www.bbc.com/

[14] International standards of professional Ethics of journalists: studies. - method. the manual / comp. A.V. Baychik, Yu. V. Kurysheva, S. B. Nikonov. - St. Petersburg : St. Petersburg State University, Higher School of Journalism. and mass. communications, 2012. - $102 \mathrm{p}$.

[15] Orazbekova, Z.S., Zhanabaev. E.B.Mass media and international conflicts in the Eurasian space - Almaty, "Kazakh University", 2017 zh. - 100 p

\title{
ПРАВОВАЯ ОТВЕТСТВЕННОСТЬ ЗАРУБЕЖНЫХ И КАЗАХСТАНСКИХ ЖУРНАЛИСТОВ В ОСВЕЩЕНИИ ВОПРОСОВ МЕЖДУНАРОДНЫХ ОТНОШЕНИЙ
}

Есимова Г. А., магистр социальных наук

Кызылординский университет имени Коркыт Ата, г.Кызылорда, Республика Казахстан

\begin{abstract}
Аннотация. В статье дается характеристика основных составляющих сферы международных отношений, подчеркивается ее важность, а также необходимость знания журналистами кодексов профессиональной этики в соответствии с международными стандартами, информированности о том, что международное законодательство должно быть выше республиканского. Речь идет о том, какие барьеры влияют на развитие международной журналистики в стране, какие требования предъявляются к журналистам для устранения этого недостатка.Вместе с тем, приводятся примеры того, как стереотипы бытового уровня находят свое отражение в прессе, иногда провоцируют разжигание межнационального конфликта, а в конечном итоге перерастают в правовую ответственность.

В настоящее время речь идет о значении $\mathrm{OOH}$ в решении вопросов международных отношений, о мерах, предпринимаемых другими неправительственными организациями. Политическая позиция Казахстана в сфере международных отношений - нейтральная, политические «игры» нового времени организованы в интересах крупных держав, в соответствии с которыми трудно сформировать четкую позицию.
\end{abstract}

Это, в свою очередь, порождает взаимное противоречие информации в отечественных СМИ, не говоря уже о зарубежных медиа.

Ключевые слова: международные отночения, правовая ответственность, международная журналистика 


\title{
LEGAL RESPONSIBILITY OF FOREIGN AND KAZAKH JOURNALISTS IN COVERING ISSUES OF INTERNATIONAL RELATIONS
}

Esimova G. A., master of social sciences

\author{
Kyzylorda University named after Korkyt Ata, Kyzylorda city, Republic of Kazakhstan
}

\begin{abstract}
Annotation. The article describes the main components of the sphere of international relations, emphasizes its importance, and also emphasizes the need for journalists to know codes of professional ethics in accordance with international standards, awareness that international legislation should be higher than republican. We are talking about what barriers affect the further development of international journalism in the country, what requirements are imposed on journalists to eliminate this shortcoming. At the same time, examples are given of how stereotypes of the everyday level are reflected in the press, sometimes provoke the incitement of an interethnic conflict, the end of which develops into legal responsibility.

Currently, we are talking about the importance of the UN in solving issues of international relations, about measures taken by other non-governmental organizations. The political position of Kazakhstan in the sphere of international relations is neutral, the political "games" of modern times are organized in the interests of giant powers, according to which it is difficult to form a clear position. This, in turn, generates a mutual contradiction of information in the domestic media when it comes to foreign media.

Keywords: international relations, legal responsibility, international journalism.
\end{abstract}




\title{
FEATURES OF SYNONYMS IN RELATION TO PREPOSITIONS IN CHINESE
}

\author{
Akhmetbek G., candidate of historical sciences \\ akhmetbek.gulzhan@mail.ru, https://orcid.org/0000-0003-0585-1923 \\ Zhenis A., second year master's student \\ aydanajenis@mail.ru,https://orcid.org/0000-0001-7013-9380

\section{L.N. Gumilyov Eurasian National University Nur-Sultan, Republic of Kazakhstan}

\begin{abstract}
Annotation. Vocabulary in any language is a complex system. Groups of words with synonymous relationship are known as synonyms. A language with a long history has rich vocabulary. Chinese is extremely rich in synonyms because of historical reasons. Each group of synonyms has the same or very close basic meaning. That's the basis of forming synonyms. The discrimination of synonyms plays an important role in communication and expression of ideas. It can improve one's language ability such as reading, writing and speaking. It can have different expressions of objective things and avoid repetition of the same word. So, it can make the Chinese conversation and writing livelier. It can avoid expressing too frankly. The correct use of synonyms can have a better effect on modification. In addition to mastering the general analysis methods, many people first language, cultural environment, and differences must also be considered. At the same time, the scope of synonyms can also be appropriately expanded, because many people whose mother tongue is Chinese do not think that they are synonyms or are not aware of words that are related in meaning so they may confuse and misuse them. Moreover, some idioms, phrases, etc. do not belong to the structure of words, and can also be included in the scope of synonym discrimination. There are many ways to distinguish synonyms, and the article distinguishes them from three aspects: semantics, grammar and pragmatics.
\end{abstract}

Keywords: Synonyms, prepositions, semantics, grammar, pragmatics

Introduction. The development of Chinese today has a very rich vocabulary, and some synonyms may even have more than ten. This is the result of Chinese constantly satisfying people's needs. For people whose first language is Chinese, the subtle differences between these synonyms do not require much explanation. Because in daily communication, different communication environments have clearly shown the difference between these synonyms. But for the foreigners who use Chinese as a second language, it is not easy to distinguish the differences between these synonyms and use them correctly. Through it, we can grasp the easy and difficult points in people's learning in time. By analyzing the ill sentences that foreigners appear in learning Chinese, it can be found that some of the causes of errors can be attributed to the failure to distinguish between synonyms[9,55 pp]. It is necessary to clearly explain the differences between synonyms, and to make the learners understand and use them. It is necessary to master certain synonym discrimination methods.

Generally speaking, Chinese words can be divided into two categories: content words and function words. Due to the essential difference between these two types of words, there are certain differences in the methods of distinguishing synonyms. And even if they are both content words and function words, the different sub-categories differ in their distinguishing methods $[11,138 \mathrm{pp}]$.

Literature review. The misuse of synonyms is a common mistake that learners often make in Chinese language learning and communication. Discrimination can be divided into three levels: semantics, grammar, and pragmatics, but the focus of each author is different. The first is the discrimination at the semantic level. Among them, Zhao Xin and Li Ying's discussion are relatively comprehensive, including the previous results and the methods they summarized in practice, such as the size of the reference range, the semantic strength, the number of semantic 
meaning items, the emphasis on the meaning of words, and the differences in semantic collocation aspect. The difference in the semantic level is the most important and will directly affect the communication. Therefore, most people will focus on the semantic level when discriminating.

However, it should also be pointed out here that the difference in semantics is the main one for content words, but not necessarily for function words, because the differences between function words are mainly in grammar. The second is the grammatical level. Zhao Xin and Li Ying believe that grammatical restrictions are mainly in grammatical features, composition distribution, and sentence patterns. The difference in composition distribution is the focus of their analysis. Zhang Lijuan and Li Fangfang believe that the analysis should be done in terms of part of speech, collocation objects and sentence-making ability. Wang Yingchun believes that from the perspective of semantics, verb synonym group and adjective synonym group mainly distinguish the use object and scope, and noun synonym group mainly distinguishes the combination ability and the scope of application object. In short, in the grammatical analysis, the main considerations are the combination distribution and the collocation relationship [2,109 pp].

The pragmatic analysis involves very little, because the differences in pragmatics are more complicated and difficult to grasp, and it also involves differences in culture and other aspects. Therefore, some scholars do not advocate allowing international learners to distinguish between style differences. But the basic pragmatic differences should still be mastered, otherwise there will be errors. Vocabulary teaching is the foundation of the second language, which runs through the entire time activities of the second language, and the discrimination of synonyms is the key and difficult point in vocabulary teaching. For learners, mastering a second language means mastering various usages of vocabulary [15,83 pp]. Mr. Hu Mingyang once pointed out: "If you have mastered the specific pronunciation and specific usage of words, even if you don't learn phonetics and grammar, the experience of acquiring your mother tongue is such a process[6,27 pp]." The main obstacles for second language learners. By analyzing the sick sentences of foreign learners, it can be found that although some sentences are not problematic from a grammatical point of view, they still do not conform to the language habits of Chinese. The main reason for this kind of problem is that foreign learners have not mastered the usage of words, and the most common problem among them is the confusion or misuse of synonyms.

Research materials and methods. As learners' vocabulary continues to expand, the above-mentioned problems will inevitably arise. Learners make more vocabulary errors than grammatical errors when using Chinese. Especially for learners at intermediate and advanced levels, insufficient vocabulary and inaccurate grasp of the meaning of words have become the bottleneck for the further improvement of Chinese proficiency [12,120 pp]. It can be seen that synonym discrimination plays a very important role in teaching Chinese as a foreign language. By distinguishing synonyms, not only can learners better grasp the usage of each word in comparison, but also can expand the vocabulary by establishing a synonym relationship network or an antonym relationship network, so that learners have a clearer understanding of the organization and system of Chinese vocabulary and a deeper understanding.

Research results and discussion. In the ontology research of Chinese, synonyms refer to words with the same or similar meanings. Among them, the words with exactly the same meaning are called equivalent words, such as《番茄-fanqie»、《西红柿-xihongshi»"tomatoes, tomatoes", «维他命-weitaming»、《维生素-weishengsu»"vitamins, vitamins" and so on. The meanings of equivalent words are exactly the same, which is actually a superfluous component produced in the development of language. Generally speaking, as time goes by, one of the equivalent words will gradually replace other words, which is a manifestation of the economic mechanism of language[5,232 pp]. For example, «维他命-weitaming»"vitamins" have now 
replaced《维生素-weishengsu» "vitamins" and are widely used in regular communication. There are some synonyms in use, the meaning will gradually produce subtle differences, and this difference may become greater and greater. For example, «演说-yanshuo»"speech" and《演讲yanjiang» "speech" were originally equivalent words, but now their collocation environment has been different. For example, «演讲比赛-yanjiangbisai»"speech contest" can be said, but «演说 比赛-yanshuobisai»"speech contest" cannot be said. Generally speaking, synonyms refer to words with similar meanings, that is, synonyms. For example: «愉快-yukuai»、《高兴gaoxing»"happy, happy", "«再-zai、又-you、还-huan»again, again, yet again" and so on. Mr. Guo Zhiliang pointed out: "The scope of the object of synonym discrimination in teaching Chinese as a foreign language is not only larger than the scope of the object of synonymous meaning discrimination, but also larger than the scope of the object of Chinese teaching[3,19 pp]. This is because many words (single syllable and multi-syllable), phrases, etc. with similar meanings will not be regarded as synonyms for people whose first language is Chinese, let alone use them wrongly, but some people often cannot distinguish them clearly. For example: «凭-ping 、根据-genju»"According to, basis", «应该-yinggai、该-gai»"should, should", etc. Therefore, Mr. Zhang Bo pointed out: "Learners will also be influenced by their mother tongue vocabulary knowledge to confuse certain Chinese words that are very distant in form, sound and meaning. In view of this, word discrimination in teaching Chinese as a foreign language should abandon 'synonymy' The scale provided by the research on Chinese ontology like 'similar meaning' truly transforms perspectives and distinguishes words based on the reality of inter language words being mixed. The object of discrimination is the 'easy to be confused [13,98 pp]'. And the object of discrimination is not limited to words. As long as the words and phrases that learners may confuse, they can fall into the scope of discrimination.

There are a large number of prepositions in Chinese. They serve as markers in sentences and are attached to the front of content words or phrases to form a "prepositional phrase". Chinese prepositions can be divided into many sub-categories according to their meanings, and each sub-category has its own characteristics and special usage. Although the position of the preposition is relatively fixed, when choosing which preposition to use, international learners are often not sure, and it is easy to make mistakes. This is because there are many words in prepositions that are similar in usage but not the same. Many sick sentences are caused by improper use of prepositions. Next, we will analyze the synonyms of prepositions from the three major aspects of word meaning, grammar and pragmatics by analyzing the sick sentences of foreign learners. But due to the part of speech of prepositions, the difference between them is mainly in grammar [1,113 pp].

When analyzing the meaning of words, semantic analysis is a simple and effective method that can help us accurately grasp, interpret, and understand semantics. Semantic analysis can highlight the similarities, differences and connections between word meanings. Although prepositions must be attached to content words or phrases to form prepositional phrases in order to be sentence components, different prepositions indicate different meanings, and due to the large number of prepositions in Chinese, differences should be considered when distinguishing synonyms or easily confused words the meaning indicated by the preposition[7,59 pp]. For example: 《因-yin、因为-yinwei、由于-youyu、为-wei、为了-weile»"cause, because, because, for, for" etc. means cause or purpose; «被-bei、给-gei、让-rang、叫-jiao、由-you、把-ba»"be, give, let, call, cause, take" etc. mean to act or receive; «对-dui、对于-duiyu、关于-guanyu、跟 -gen、同-tong、和-he»"to, for, about, follow, with" and so on indicate the object of concern. 
If the meaning of the preposition is not clear, it is easy to make mistakes. Such as the following sentence:

1)The exam will be changed from next Wednesday. «考试改从下星期三kaoshigaicongxiaxingqi san»

2)We all walked over on the bridge. «我们都在桥下走过去 womendouzaiqiaoxiazouguoqu»

3)We will leave at my home at five o'clock tomorrow morning. 《明天早上五点在我家 出发-mingtianzaoshangwudianzaiwojiachufa»

«在-zai»At: [+place or time point of the action] [-premises where an action passes] [-time starting point of an action]

«从-cong»From: [-place or time point of the action][+ The place where the action passes][+the time starting point of the action]

The reason for the errors in these sentences is that the meanings of the prepositions «在zai、从-cong» "in" and "from" do not clearly differ. The preposition «在-zai»"in" indicates where the action takes place or is performed, and also indicates the moment in time when the action occurs; the preposition «从-cong»"from" indicates the starting point of time, the source of the action and the place where the action takes place. Therefore, both the "in" in the example clause and the example clause should be replaced with «从-cong»"from", because the first means the place «桥-qiao»"bridge" where the action «走-zou»"goes" passes, and the second means the place where the action "flies away" triggers «我家-wojia»"my house". «从-cong»"From"in example 1) should be replaced with «在-zai»"in" because it means "next Wednesday" when the exam takes place. Therefore, it is necessary to clearly distinguish the meaning of each preposition and choose the appropriate preposition in accordance with the needs of expression.

4) A cute little girl ran to him. «一个可爱的小姑娘往他跑来-yi ge ke ai de xiao gu niang wang ta pao lai»

5)He calls home. «他在向家里打电话-tazaixiangjialidadianhua»

《往-wang»To: [+ Fixed and Clear Destination]

《向-xiang»To: [-Fixed and Clear Destination]

In the above sentence example, the structure «往-wang»"towards" with«向-xiang» "place" means" preposition + place". However, the noun "place" after "towards" indicates a fixed, predetermined and definite destination, for example, “this railway goes to Beijing”. «这条 铁路通往北京-zhetiaodalutongxiangyuanfang». The place for "towards" is not fixed, but there is a general direction, for example, «这条大路通向远方-zhetiaodalutongxiangyuanfang»."this road goes along the distance. Therefore, "towards" in the example sentence 4)should be replaced with "to", because it indicates the general direction of action of "running"; The «向-xiang»"to" in the example clause 5) should be replaced with «往-wang»"towards" because«打电话dadianhua»call up "action has the clear meaning of" home ".

As far as prepositions are concerned, the difference in grammar should be the main difference between two or more prepositions that are easily confused. Therefore, when distinguishing synonyms, we should grasp this degree, that is, the explanation of grammatical knowledge should be based on necessity, and the most important difference between the two should be displayed [4, $97 \mathrm{pp}]$. Most of the prepositions in Chinese are derived from verbs, so some words have both verbs and prepositions. Learners must first distinguish between 
prepositions and verbs of the same. Secondly, the meaning of each preposition is no single, and the usage of the prepositions also over lap each other.

6)The father said to his son: "We will come again next time." «父亲给儿子说：“我们下次再 来” -fuqingeierzishuo: "womenxiacizailai” »

7) Xiulin's child won the first place in the exam, and she was very happy for him. 《秀林的孩子 考试得了第一名，她给他很高兴-xiulindehaizikaoshidelediyiming, ta gei ta hen gao xing»

8)As soon as I sat down, the teacher asked me questions. 《我刚坐下来, 老师就给我提问wogangzuoxialai, laoshijiugeiwotiwen»»

The «给-gei»"give" in the example sentence 6) should be changed to «对-dui»"to", because the preposition "pair" introduces the object of the action "say", while the preposition «给-gei»"give" introduces the object of the action, it means the action Recipients, such as «给他打电话geitadadianhua»"call him". In Example 7), «给-gei»"give" should be changed to «为-wei»"for". Although both prepositions are the objects of introduction of actions, the "for" can be followed by 《高兴-gaoxing、着急-zhaoji、担心-danxin»"high happiness, anxiety, worry" etc. to express mood. Words, this kind of «为 -wei»"for" cannot use the preposition 《对-dui»"to". 《给 gei»"Give" in Example 8) should be changed to «对-dui»"to". The verb after «给-gei»"give" has the meaning of giving to the object, which means that the object of «给-gei»"Give" can be given some kind of benefit or damage through actions, such as «给他过生日 geitaguoshengri»"Birthday to him." The preposition "to" means facing and the following verbs are mainly verbs of the type and verbs related to the five senses and postures of a person.

9)I have never been angry, just sad for you. «我从来没有生气, 只是替你伤心 woconglaimeiyoushengqi, zhishitinishangxin»

10)Everyone is happy for this. 《大家都替这件事高兴-dajiadoutizhejianshigaoxing》

The prepositions «替-ti» "for" and «为-wei»"for" both indicate the object of the introduction of the action, but «为-wei»"for" can be followed by a mental verb that expresses the actor's own mood, while «替-ti»"for" cannot. Therefore, the «替-ti»"for" in Example 9) should be changed to «为-wei» "for", because the person who sent the action of "sad" is the person, not "you". The object after the preposition «为-wei»"for" must be a person and the object after "for" can be a thing besides. So, the «替-ti»"for" in example sentence 10) should be changed to «为-wei»"for".

Most prepositions can only be placed before the predicate, such as «对-dui»"to", «从cong» "from", «关于-guanyu»"about", etc. There are also a few prepositions that can be placed before or after the predicate, such as the prepositions «在-zai»"at", «向-xiang»"towards", «给gei»"give" and so on. For these prepositions, placing them in different positions will not only cause differences in semantics and grammar, but also have different pragmatic values. Therefore, it is correct for some sentences to be listed separately, but it is wrong if they are placed in a certain context[10,79 pp]. The reason for the error is not that does not conform to the grammatical rules, but that it does not follow the pragmatic rules. For foreign learners who are new to Chinese, the differences in semantics and grammar are the most basic and will directly affect communication. This can be seen from the following example sentence: 
13)The thing happened in Xiao Wang's house, so everyone outside knew it. «事情发生在 小王家里, 怎么外面的人都知道了-shiqingfashengzaixiaowangjia， zenmewaimianderendouzhidaole»

14)This kind of thing happened in Xiao Wang's house, and it may happen in Xiao Li's house. «这种事情在小王家发生, 也可能在小李家发生 zhezhongshiqingzaixiaowangjiafasheng,yekenengzaixiaolijiafasheng»

Example sentences 13) and the first half of 14) express the same meaning, but because the position of the preposition «在-zai»"in" is different, the emphasis of the two sentences is different. "in+location noun" is placed after the verb, and the focus of the sentence is on the location; "in+location noun" is placed before the verb, and the focus of the sentence is on the action. Example 13) emphasizes the location, that is, «小王家里-xiaowangjiali»"XiaoWang's house", so people outside should not know this. Example 14) emphasizes the action, the action remains the same, but the location can change, so the location can be 《小王家里xiaowangjiali»"Xiao Wang's house" or «小李家里-xiaolijiali»"Xiao Li's house". If you change the sentence to "Something happened in Xiao Wang's house, it may also happen in «小李家里xiaolijiali»Xiao Li's house." Although there is no grammatical error, it does not conform to the focus of the sentence. This means that the rules of pragmatics have not been followed and it is out of context [14]. The preposition «拿-na»"take" can introduce a few objects with actions such as《没办法-meibanfa» "no way"，《怎么-zenme»"how"，《开玩笑-kaiwanxiao»"joking" and «开 心-kaixin»"happy". For example:

15) Really can't help you. 《真拿你没办法-zhennanimeibanfa»

16) What can you do with me? «你能拿我怎么样-ninengnawozenmeyang»

17) Don't make fun of me. 《别拿我开玩笑-bienawokaiwanxiao»

This type of «拿-na»"take" has different meanings due to different occasions. 《拿...... 开 玩笑/开心-na...kaiwanxiao/kaixin»"Taking...joke/happiness" means treating the object as the object of "joking" and is often used in jokes between friends. But to be used between people in a general relationship, it has the meaning of disrespect and mocking each other. If the object after "taking" is a matter, it is often used in quarrels, thinking that "you" can't come up with any way to deal with "me", which is challenging.

It should be noted here that the difference in terms of content words is quite large, while the differences in function words are mainly concentrated in grammar. Therefore, the discrimination of pragmatic level is mainly based on content words, but since this article uses prepositions as an example to analyze synonyms, there is less discrimination of pragmatic words. For the analysis of the use of substantive words[8,43-45 pp].

Conclusion. The process of learners mastering a word can be divided into recognition, comprehension, memorization and use. Vocabulary teaching can include the following aspects: displaying words, explaining words, and guiding learners to practice, check and consolidate the memory. The discrimination of synonyms is a part of vocabulary teaching, so the learning of synonyms also needs to go through the above processes. Prepositions are only a small category of function words, and synonyms are not limited to this part of speech, so there are many ways to distinguish and analyze in actual teaching. For example, for adjectives, there will be differences in emotional color, stylistic color, and the weight of the meaning of the word; if it is a verb, it must be considered whether it can carry an object and what kind of object it can carry; in addition, there are also the number of meanings of the word and its ability. Whether it overlaps, what grammatical elements can be made, what sentence patterns can be used in, and so on. There are some differences that the synonyms in the preposition do not have. 


\title{
References:
}

[1] Chi Changhai (2002). Shijitongciyanjiu :Shanghai. P - 228

[2] Feng Li (2011). Tong yi ci bian xi yan jiu fang fa xin tan: Shenyang. P - 112

[3] Guo Zhiliang (1988). Dui wai han yu jiao xue zhong ci yi bian xi de ji ge wen ti.shi jie han yu jiao xue . P -124 .

[4] Gao Yujing (2005). Ye tan tong ti ci de bian xi: Kaifeng. P - 198

[5] Huang Borong ,Liao Xudong (2011) . Xian dai han yu : Beijing. P - 273

[6] Hu Mingyang (1997). Duiwaihanyujiaoxuederuoganwenti.yu yan wen zi ying yong. P - 65 .

[7] Jia Yande (1999). Han yu yu yi xue: Beijing.P - 94

[8] Liu Bao (2011). Dui wai han yu jiao xue Zhong de tong yi ci yan jiu zong shu : Sui ning

[9] Wei Meixi (2012). Lun dui wai han yu zhong tong yi ci jiao xue :Lanzhou. P - 55

[10] Wan Yiling (2010). Han yu ci hui jiao xue : Beijing.P - 115

[11] Ye Feisheng, Xu Tongqiang (1997) . Yu yan xue gang yao. P - 182

[12] Zeng Liying (2010). Han yu zuo wei di er yu yan de ci hui jiao xue : Beijing.

[13] Zhang Bo (2007). Tong yi ci,jin yi ci,yi hun xiao ci :cong han yu zhong jie yu de shi jiao zhuan yi.shi jie han yu jiao xue. $\mathrm{P}-297$

[14] Zhang Bodeng (2008). Ji yu Zhong jie yu yu liao ku de han yu ci hui zhuan ti yan jiu : Beijing

[15] GeBenyi (2004). Xian dai han yu ci hui gai yao: Beijing. P - 203.

\section{ҚЫТАЙ ТІЛІНДЕГІ ПРЕДЛОГ СӨЗДЕРМЕН ҚАТЫСТЫ СИНОНИМДЕРДІН ЕРЕКШЕЛІКТЕРІ}

\author{
Ахметбек Г., тарих ғылымдарының докторы \\ Жеңіс А., 2-курс магистранты
}

\section{Л. Н. Гумилев атындавы Еуразия ұлттық университеті, Нұр-Сұлтан құ., Қазақстан Республикасы}

Аңдатпа. Кез келген тілдің сөздік қоры күрделі жүйе болып табылады. Синонимдік қатынастары бар сөздердің тобы бізге синонимдер ретінде белгілі және ұзақ тарихы бар кез келген тіл сөздік қорына бай. Қытай тілі тарихи себептер бойынша синонимдерге өте бай. Синонимдердің әрбір тобы бірдей немесе өте жақын негізгі мағынаға ие,бұл синонимдердің пайда болуының негізі. Синонимдерді айыра білу коммуникацияларда және идеяларды білдіруде маңызды рөл атқарады. Мұндай қабілет оку, хат және сөйлеу сияқты тіл қабілеттерін жақсартады. Ол сонымен қатар объективті түсініктерді әртүрлі білдіруге және бір сөздің қайталануын болдырмауға мүмкіндік береді. Осылай қытай тілінде сөйлеу және хат жазу мәнері жанданады және қажет емес ашық ойды білдіруге жол бермеу жеңілдейді. Синонимдерді дұрыс пайдалану сөздерді түрлендірген кезде көмектесуі мүмкін. Сөйлеуді талдаудың жалпы әдістерін игеруден басқа көптеген адамдар сонымен қатар ана тілін, мәдени ортаны және мәдени айырмашылықтарды ескеруі тиіс. Сондай-ақ синонимдерді қолдану диапазоны тиісті түрде кеңеюі мүмкін, себебі ана тілі - қытай тілі болатын көптеген адамдар олар синонимдер болып табылатындығын ойламайды немесе мағынасы бойынша байланысты сөздерді білмейді, сондықтан оларды шатастыруы және дұрыс емес қолдануы мүмкін. Сонымен қатар кейбір идиомалар, сөз тіркестері және т.б. сөздердің құрылымына жатпайды және сонымен қатар синонимдерді қолдану диапазонына қосылуы мүмкін. Синонимдерді ажыратудың көптеген тәсілдері бар және мақалада оларды үш аспекті бойынша ажыратады: семантика, грамматика және прагматика.

Кілт сөздер. синонимдер, предлог сөздер, семантика, грамматика, прагматика 


\title{
ОСОБЕННОСТИ СИНОНИМОВ К ПРЕДЛОГАМ В КИТАЙСКОМ ЯЗЫКЕ
}

\author{
Ахметбек Г., кандидант исторических наук \\ Жеңіс А., магистрант 2 курса \\ Евразийский нацчиональный университет имени Л. Н. Гумилева, г. Нур-Султан, \\ Республика Казахстан
}

\begin{abstract}
Аннотация. Словарная база любого языка является сложной системой. Группы слов с синонимическими отношениями известны нам как синонимы, и любой язык с долгой историей имеет богатый словарный запас. Китайский язык чрезвычайно богат синонимами по историческим причинам. Каждая группа синонимов имеет одинаковое или очень близкое основное значение, это основа образования синонимов. Умение различать синонимы играет важную роль в коммуникации и выражении идей. Такое умение улучшает такие языковые способности, как чтение, письмо и устная речь. Оно также позволяет по-разному выражать объектные понятия и избегать повторения одного и того же слова. Таким образом оживляется речь и письмо на китайском языке и становится легче избегать нежелательно откровенных высказываний. Правильное использование синонимов может помочь при модификации слов. Помимо овладения общими методами анализа речи, многие люди также должны учитывать родной язык, культурную среду и культурные различия. В то же время диапазон применения синонимов также может быть соответствующим образом расширен, поскольку многие люди, чей родной язык - китайский, не думают, что они являются синонимами, или не знают слов, связанных по значению, поэтому могут путать их и неправильно использовать. Более того, некоторые идиомы, фразы и другое не относятся к структуре слов и также могут быть включены в диапазон применения синонимов. Есть много способов различать синонимы, и в статье их различают по трем аспектам: семантика, грамматика и прагматика.
\end{abstract}

Ключевые слова. Синонимы; предлоги; семантика; грамматика; прагматика 


\title{
Педагогика ғылымдары \\ Педагогические науки Pedagogical sciences
}

FTAXP 16.01.45

https://doi.org/10.52081/bkaku.2021.v58.i3.086

\section{ОРТА БІЛІМ БЕРУДЕ ҚАШЫҚТЫҚТАН ОҚЫТУДЫ ҰЙЫМДАСТЫРУДЫН ТИІМДІ ЖОЛДАРЫ}

\author{
Абадилдаева Ш., педагогика ғылымдарының магистрі \\ shyryn.abadildaeva@mail.ru,https://orcid.org/0000-0002-1128-8666 \\ Искакова А., педагогика ғылымдарының магистрі \\ aiko-1986-kz@mail.ru, https://orcid.org/0000-0001-5017-7128
}

Қорқыт Ата атындавы Қызылорда университеті, Қызылорда ққаласы.,Қазақсстан Республикасы

Аңдатпа: Жұмыста қашықтықтан оқытуды ұйымдастырудың тиімді жолдары туралы жанжақты ақпарат берілген. Жұмыс кіріспе, зерттеу материалдары, негізгі нәтижелер, алынған мәліметтерді талқылау, қорытынды бөлімдерден тұрады. Автор орта білім беруде қашықтықтан оқытудың маңызы, оны ұйымдастырудың тиімді жолдары, артықшылықтары мен кемшіліктеріне тоқталып, өз тәжірибесімен бөліседі. Қашықтықтан оқыту жағдайында білім алушылардың өзінөзі реттеуі, барлық оқушылардың жеке мүмкіндіктері мен қабілеттерін ескеру, саралап оқыту мәселелері, оқу тапсырмасы және тиімді кері байланыс жүргізудің жолдары жөнінде өз байламдарын келтіреді. Оқушылардың қашықтықтан оқыту жағдайында метатанымдық стратегиялардың тиімділігі көрсетіліп, өзін-өзі реттеуіне кеңестер ұсынылады. Оқушылардың жеке мүмкіндіктері мен қабілеттерін ескере отырып оқыту нәтижеге қол жеткізеді. Осы тұста Жаңа Зеландиялық педагог Нейл Варк Флеменгтің анықтаған білім алушылардың төрт типіне тоқталып, олармен жүргізілетін тиімді тапсырмалар және әдістер келтірілген. Сондақ-ақ, мақаладан «Оку тапсырмасына (үй тапсырмасына) қандай тапсырмалар берген тиімді және оның мөлшері қандай болу керек?» деген сауалға жауап аламыз. Ағымдағы жетістік пен күтілетін нәтиже арасындағы алшақтықты жойып, білім алушыға қолдау көрсетуде кері байланысты жүйелі қолдануды ұсынады.

Кілт сөздер: Қашықтықтан оқыту технологиясы, өзін-өзі реттеу, оқушылардың жеке мүмкіндіктері мен қзабілеттері, визуалдар, аудиалдар, кинестеттер, дигиталдар, дифференщация, оку тапсырмасы, тиімді кері байланыс.

Кіріспе. Қашықтықтан оқыту технологиясы - оқу процесі кезінде мұғалімдер мен білім алушылар арасында интерактивті өзара іс-әрекетте оқытылып, материалдың негізгі көлемін білім алушыларға жеткізуді қамтамасыз ететін, оқылған материалдарды меңгеру бойынша, сонымен бірге оқу процесі барысындағы білім алушылардың өз бетімен жұмыс істеуіне мүмкіндік беретін ақпараттық технология. Қашықтықтан оқыту - компьютерлік және телекоммуникациялық технологиялар арқылы оқытудың құралдары мен түрлері, білім беру процесінде үздік дәстүрлі және инновациялық әдістер қолданылатын, күндізгі және сырттай білім алу ретінде білімді қабылдау түрі болып табылады $[1,14]$.

Қашықтықтан оқыту кезіндегі білім берудің негізін жеке кесте бойынша өзіне ыңғай-лы жерде оқуға мүмкіндігі болатын, оқытудың арнайы құралдары жиынтығы өзінде бола отырып, электронды және қарапайым пошта, телефон арқылы оқытушылармен келісілген байланыс жасауына, сонымен қатар, күндізгі бөлімде де мүмкіндігі болатын, оқып үйренушінің мақсатқа бағытталған және бақыланатын қарқынды өзіндік жұмысы құрайды. Қашықтықтан оқыту білім жүйесі жоқшылыққа, географиялық немесе уақытша оқшаулануға қатысты себептермен, әлеуметтік қорғаны жоқ және дене бітімі жетілмеуіне байланысты білім мекемелеріне 
бару мүмкіндігі жоқ немесе өндірістік және жеке жұмыстары болу себебінен, ешкімнің окуға мүмкіндігін шектеуге болмайды деген гуманистік қағидаларға жауап береді $[2,53]$. Елімізде жоғары және орта білім беру ұйымдары аталғандардың ішіндегі уақытша оқшаулануға байланысты себеппен қашықтықтан оқытуға көшкені белгілі. Осы тұста мектепте ағылшын тілі пәні мұғалімі ретінде оқытудың қашықтық формасы турасында өз тәжірибеммен бөліскім келеді.

Қашықтықтан оқыту барысында төмендегідей аса маңызды сипаттарын анықтадым.

- Құрылымның ашықтығы. Жүйе ашық жүйе үрдісіне сәйкес құрылуы.

- Сәйкестілігі. Ақпараттық ресурстардың сақтау форматына сәйкес келуі.

- Кеңейгіштігі. Жүйенің құрылымы модульді болуы және жүйенің функционалды компоненттерін өсіруге мүмкіндік беруі.

- Жан-жақтылығы. Жүйенің көп функциялы және қолданыста жан-жақты болуы.

- Сенімділігі. Ақпараттар ресурстарын сақтау сенімділігі. Мүмкін болатын қауіптер әсерінен ақпараттардың жоғалмауы.

- Үлестірімділігі. Жүйенің әр түрлі желі конфигурациясы жұмысына бағытталуы (әртүрлі жедел жүйелерді басқаруға негізделген, мысалы, интернет).

- Өңдеудің қарапайымдылығы. Өңдеудің жылдам және тиімді болуы.

- Тасымалдануы. Жүйенің әртүрлі аппараттық - бағдарламалы тұғырнамада жұмыс істеуі.

- Қауіпсіздігі. Ақпараттық ресурстарды сақтау қауіпсіздігі.

- Көпмәнділігі. Жүйенің бірнеше қолданушылардың сұранысын қатар өңдеуі.

Зерттеу материалдары. Бұл жүйеге көшкенде оқушылардың өзін-өзі реттеуі аса маңызды аспект болып табылады. Себебі, реттелмеген әрекет мақсатқа жете алмайды, нәтиже де болмайды. Өзін-өзі реттеудің танымдық, әлеуметтік, аффективтік қырлары болады. Метатану термині оқушылардың саналы білім алуы мен ойлауын дамытуға ықпал ететін бірқатар үдерістерге қатысты қолданылады. Өзін-өзі реттеу ақыл-ой қабілеті емес және ол нақты академиялық көрсеткіштерге бағытталған дағды да емес. Өзін-өзі реттеу білім алуға, үйренуге өзіндік бағытталған үдеріс. Метатанымдық стратегиялар оқушыларды белсенді ойлауға итермелейтін оқыту тәсілі. Олар оқушыларды өз оқуын жоспарлауға, бақылауға және бағалауға үйретуді көздейді, өзін-өзі реттеуге мүмкіндік береді. Ол әлеуметтік тұрғыдан ақпаратты іздейді, оқуды басқара алады, қиындық пен кедергілер және оларды шешудің дұрыс жолын табады. Білім алушы аффективтік қырынан танымдық және метатанымдық аспекті бойынша ғана емес, сонымен қатар мотивациялық және мінез-құлықтық тұрғыда да белсенді болады.

Оқушылар алдына қойған мақсатқа жетуде бір-бірімен өзара баланысты бірқатар қадамдар жасайды.

1.Қажетті ақпаратты қалай есте сақтап қалуға болады?

2.Тапсырманы орындау үшін қандай стратегияны таңдап алуым керек? тиімсіз?

3.Қолданылған стратегиялардың қайсысы мәселені шешу үшін тиімді немесе

4.Тапсырманы орындауға қатысты менің қандай мүмкіндіктерім бар? секілді көптеген сауалдарға жауап іздейді. Джон Швеллердің «Когнитивті жүктеме» идеясында жұмыс жадысы, қысқа мерзімді және ұзақ мерзімді жады ұғымдарын зерделесек, бір мезетте оқушыға көп ақпарат беруден қашқақтау керек. Автор мейлінше ақпаратты бөлшектеп, қайта-қайта өңдеп, есте сақтау тиімді екендігін ұсынады. Оқушыға шамадан тыс тапсырма беру оң нәтиже бермейді. Э.Де.Бононың «Зияткерлік қақпан» әдістемесін басшылыққа ала отырып, «проблемаларды басқару» сәтсіздіктердің алдын алудың негізгі стратегиясы екеніне көз жеткізуге болады.

Оқушылардың метатанымдық және өзін-өзі реттеу дағдысын дамытуға арналған идеялар: 
1.Оқу. Мұғалімдердің метатанымдық аспекті бойынша кәсіби білімін жетілдіру бағытында қосымша әдебиеттер оқу.

2.Мониторинг. Оқушыны өз оқуын жоспарлаға, басқаруға, бақылауға, бағалауға үйрету.

3.Модельдеу. Метатанымды дамыту үшін мұғалімнің өз ойларын, идеяларын үлгі ретінде ұсыну.

4.Күрделілік деңгейі. Тапсырманың күрделілігін оқушының мүмкіндігіне сай таңдау арқылы метатанымды және өзін-өзі реттеуді қалыптастыру.

5.Коммуникация. Қашықтық жағдайында оқушыларды стилдері, қызығушылықтары, танымдық ерекшеліктеріне сай жұпқа, топқа біріктіріп, зерттеушілік жұмыстарға қатыстыру.

6.Жоспарлау. Оқушыға өз оқуын өзі тиімді ұйымдастыруға үйрету.

Өзін-өзі реттей алмайтын оқушыларға ұсыныс:

-кесте бойынша қолдау көрсету шаралары (синхронды, асинхронды хабарламалар мен үнпарақтар, бейне, аудио жазбалар, т.б.);

-жағымды кері байланыс орнату, сенім білдіру;

-аптасына бір рет онлайн кездесулер өткізу;

-зейінін шоғырландыру, эмоциясын бейтараптандыру, аудиал, визуал, кинестетиктерге арнап медитациялар, релаксация, қимыл-қозғалыс жаттығулары, т.б.

-өз күнін тиімді жоспарлауға қолдау көрсету;

-жұмыс орнын жайлы етіп орналастыруға бағыт беру;

-мессенджер, браузерлерді нақты мақсатқа сай қолдану жайлы түсіндіру;

-өзіне қажетті ақпараттармен жұмыстануға кеңестер беру т.б.

1.Маңызды емес мәселелерді оқудан қалай аулақтану керек?

А) Сұрақтарды шектеу.

2.Сұрақтарды оқып шығу. Нұсқауларға назар аудару. Негізгі сөздердің мәнін анықтау. Оқып отырған тақырыптың ұйымдастырылу деңгейін анықтау.

В) Тақырыпты айқындау.

3.Тақырыпты әр идеяны зерттелетін пәнмен салыстыру. Зерттелетін сұраққа қатысты идеяларды ғана есте сақтау. Тақырыптың дамуын қадағалау үшін сұрақтарды тағы бір рет қайталап оқып шығу.

С) Редакциялау.

Редакциялау барысында негізгі түйінді басты назарда ұстау үшін тақырыптың бастапқы сұрағына оралу.

Оқушылардың өз қабілетіне сенімділігі оларды оқуға ынталандырады. Атрибуция теориясы, егер оқушы табыстылық туа біткен тиянақталған қабілеттерге байланысты деп санайтын болса, онда олар сәтсіздікті өздерінің бақылауынан тыс болған нәрсе деп қабылдайды. Алайда, оқушылар ынталы жұмыс істеу нәтижесінде табысқа қол жеткізген кезде сәтсіздік дұрыс ақпараттың, дағдылардың, әдістердің, стратегиялардың болмау нәтижесі екенін түсінеді.

Қашықтықтан оқытуда барлық оқушылардың жеке мүмкіндіктері мен қабілеттерін ескеру маңызды. Жаңа Зеландиялық педагог Нейл Варк Флеменгтің пайымдауынша, білім алушылардың төрт типін көрсетеді [3,38]. Визуалдар - ұзақ мерзімді жады иелері, қолданатын сөздері, қол жистикуляциясы, жылдам оқуға қабілеттілігі, уақыт пен кеңістіктің қажеттілігі, бейне, сурет, графиктер, схемалы тапсырмаларды тез түсіну, ұсақ бөлшектерге назар аудару ерекшеліктерімен көзге түседі. Мұндай типті оқушылармен жұмыс жасауда қашықтан оқыту жағдайында бейнесабақтар, видеороликтер, электронды оқулықтар, субтитрі бар фильмдер, скриншоттар, фотошоп жасату, телефонда «flash card» орнатуды пайдалануға болады. Мен бұл типті білім алушыларға мәтін бойынша графикалық органайзердің әртүрін жасауды тапсырамын. 
Аудиалдар - баяу оқитын, сөз еркіндігі сақталған мұқият тыңдаушылар. Түсіндіруді ұнатады. Талқылау, пікірталастың шеберлері, диалог құруға икем, шешендік өнерге жақын. Музыка, сөздерді жақсы есте сақтайды. График, диаграммаларды шешу оларға қиынға соғады. Олармен жұмыста ортақ чаттар, аудио кітаптар, аудио жазбалар, онлайн сөздіктер, видео күнделік, аудио курстар жүргізу тиімді. Өз практикамда көбінесе мәтінді баяндап беруді тапсырамын.

Кинестеттер ақпаратты сезіну, жанасу, әрекет, қозғалыс арқылы алады. Олар әрекетті, тәжірибелік жаттығуларды жақсы есте сақтайды. Ақпаратты өз тәжірибесінде тексереді. Кинестеттер назарын шоғырландыру қиын, алаңдағыш келеді, оларға шынайы мысалдар, оқиғалар ұнайды. Оларға электронды энциклопедия, youtube видеохостингі, BBC және Discovery каналдары, үй жағда йы (еркін қозғалыс,үзіліс жасау) қолайлы ресурс көздері. «Stop-Keep-Start», “төрт апат” жаттығуына оқушылар қызыға қатысты. Өз тәжірибемде кинестеттерге сахналық көріністер дайындатамын.

Дигиталдар көп оқиды. Ойға, логикаға сүйенеді. Бірқалыпты, монотонды дауыс, көпшіл, ашық емес, бірақ бірден көп ақпаратты қабылдайды. Ойлануға уақыт қажет. Кеңістік, аудиокітаптар,уақыт,3D энциклопедиялар пайдаланады. Қашықтықтан оқыту процесі дигитал білім алушыларды шабыттандырады деуге әбден болады.

Жалпы әртүрлі типті оқушылармен жүргізілетін тиімді тәсілдерге тоқталсам. «Рифмус» данышпан үкілер» әдісі, «Лонгрид» жазу, «Қысқаша мазмұн» органайзері, «сәйкестендіру тесті», рөлдік ойындар, «суретті мозаика», ПОПС формуласы әдістерімен, әсіресе, маған «DEAL» әдісі арқылы сабақ жүргізген аса тиімді болды. Мұнда білім алушылар D-describe, E-explain, A-anallyse, L-links бойынша мәтінге талдау жасайды.

Білім алушының стильдерін анықтап қана қоймай, оларға білім беруді қабілеттері мен қызығушылықтарына орай ұйымдастырған жөн, яғни саралап оқытқан тиімді.

Дифференцация - оқушылардың қабілеттері, қызығушылығы, қажеттіліктері ескерілетін оқу үдерісін ұйымдастырудың формасы. Сараланған сабақ «Сабақ соңында оқушылар нені біледі? Оқушылар нені түсінеді? Оқушылар не істей алады?» деген сұрақтарға жауап іздейді.

Кэрол Ани Томлинсон: «Егер мұғалім барлық оқушылардың табысты оқуына жағдай жасау үшін жеке немесе оқушылардың шағын тобы үшін оқу мен оқытудың стратегияларын таңдаса, онда ол мұғалім дифференциацияны қолданады. Тағы да саралап оқытуды қолданатын мектептерде әрбір оқушыны жеке тұлға ретінде қабылдап, соған сәйкес оқыту қажеттігін түсінетін мықты көшбасшылар бар» деп тұжырымдайды [4.42]. Қашықтықтан оқыту барысында практикамда «Шоллер табақшасын» жиі қолданамын, сондай-ақ, сұрақ бойынша саралауда берілген деңгейлі сұрақтар ішінен қандай сұрақтарға жауап беретінін оқушылар өздері шешеді. Нәтиже арқылы саралауда барлық оқушыларға бірдей тапсырма берілгенімен, күтілетін нәтижелер әртүрлі болып отырды.

Ал қашықтан оқытуда пайдаланатын ресурстарды былай саралауға болады:

- тапсырманы орындау үлгісі;

- анықтамалық материалдар;

- алгоритмдер, жоспарлар, нұсқаулар, жадынамалар;

- көмекші сұрақтар, көмекші карточкалар;

- көмекші тапсырмалар, дайындық жаттығулары;

- жұмыс жоспары;

- ресурстарды жеңілдету немесе күрделендіру.

Қашықтан оқытуды ұйымдастыруда үй тапсырмасын берудің де өзіндік ерекшеліктері бар. Жасөспірімдерде танымдық, әлеуметтік және физиологиялық қажеттіліктер болады. Стенфорд университетінің ғалымы Клифтон В.Паркер үй тапсырмасының әсерінен оқушыда ұйқының бұзылуы, бас ауруы, асқазан ауруы, салмақтың кемуі сияқты аурулар пайда болатындығын, ал Гарвард университетінің 
ғалымы А.Даниелс оқушылардың 56 пайызында туындайтын стресс үй тапсырмасынан екенін зерттеп анықтаған.

Қазақстан Республикасының Білім және ғылым министрінің 2020 жылғы 1 сәуірдегі №123 бұйрығының 5-қосымшасында қашықтықтан оқыту шеңберінде білім алушылардың өзіндік жұмыстарын ұйымдастыру және оқу тапсырмаларын орындау жөнінде педагогтерге арналған әдістемелік ұсынымдар берген. Онда үй тапсырмасын орындау уақыты математика, физика, химия пәндерінде 15-40 минут аралығын, қазақ тілі мен әдебиеті, орыс тілі мен әдебиеті пәндерінде 10-30 минут аралығын, ал қазақстан тарихы, дүниежүзі тарихы биология, география,жаратылыстану, информатика, шетел тілі пәндеріне 15-25 минут уақыт аралығын қамтиды [5,39].

Үй тапсырмасын құрастыруда тапсырманың оқушы үшін ыңғайлы және мағынасы бар болуын ескеру өте маңызды. Тапсырманың белгілі бір мақсатқа бағытталып оқушының белгілі бір дағдысын, білімін жақсарту керек. Тапсырманы орындау үшін жұмсалатын уақыт пен ресурс алдын ала ойластырылады [6,28].

Үй тапсырмасын оқу тапсырмасы деп айту ұсынылған, ендеше оқу тапсырмасының оқушының академиялық жетістігіне әсері: «Төменгі сынып оқушыларына қарағанда жоғары сынып оқушыларының тапсырманы орындауға жұмсайтын уақыты мен оқушы жетістігінің корреляциясы жоғары мәнге ие» [8,41]. Кіші жастағы оқушылар үй ішіндегі назарды тартатын заттарға қарсылық білдіруі төмен, жоғары сынып оқушыларына қарағанда үй жағдайында назарын тапсырмаға шоғырландыруы қиын. Кей кіші жастағы оқушыларда тапсырманы тиімділікпен орындау дағдысы қалыптаспаған. Үлгірімі төмен оқушы үй тапсырмасын орындауға көп уақыт жұмсайды. Өз тәжірибемде өткен тақырып аясын кеңейтуге берілген тапсырмалар, өмірмен байланысты тапсырмалар, жоғары сыныптар үшін жоба жұмыстарын беремін. Оку тапсырмаларының түрлері - оқушының АКТ, медиа құралдары мен ғаламторды қолдану дағдыларын қажет ететін ақпараттық портфолиолар әзірлеу, отбасы дәстүрлері, шежіре ағашы сияқты ата-ананың қатысуын қажет ететін тапсырмалар, оқулыққа негізделген, оқушының қалауы бойынша берілетін тапсырмалар және жаңа тақырыпқа алдын-ала дайындалуға берілген тапсырмалар да өте тиімді.

Жақсы тапсырма мақсаты - оқушыда білімнің не дағдының қалыптасқанын көрсету, оқушы үшін маңызды бір жұмыс атқарғандай сезіну, тапсырманы орындағаннан кейін жақсы әсерде болу, мұғалім үшін тапсырма визуалды көркем құрастырылып, оқушыны орындауға шақырып тұратындай болу, тиімділігі - оқушы үйренуге, білімін ұлғайтуға және алған білімін демонстрация жасауына мүмкіндік жасау. Жақсы ұйымдастырылған тапсырманы оқушы да қызыға орындайды. Оку тапсырмасын орындаубаланың болашағына жасалған «депозит» деуге болады. Ол арқылы өмір сүруге қажетті білім алуды жоспарлау, тайм-менеджмент, басымдықты анықтау, өзін-өзі реттеу, өзіндік сенімділіктің артуы, дербес білім алу, өзіне жауапкершілікті алу, өмір бойы білім алу сияқты дағдыларды дамытуға көмектеседі.

Мұғалімдер үшін қашықтықтан оқыту индивидуализация, яғни жеке даралық қағидаттарын ажыратып берді:

- Уақытылы кері байланыспен қамтамасыз ету. Кері байланыс алған оқушы, кері байланыс берілмеген оқушыға қарағанда жақсы нәтиже береді [9,26].

- Окушылар тапсырмаларды жібергенде, «қателер бар ма? қатенің болу себебі қандай? осындай қатені болашақта жасамас үшін мен қандай көмек бере аламын? атап өтерліктей оқушы нені жақсы жасай алған?» сияқты сұрақтар төңірегінде ойланғанымыз абзал.

Ата-аналар үшін қашықтықтан оқыту - идентификациялық қағидатын ұстану, бұл дегеніміз:

- өзге біреудің тапсырманы оқушының орнына орындауын болдырмау; 
- баланың тапсырма орындайтын бөлмесінің жайлы болуын қағадалау;

- баланың өз бетінше орындалуын қадағалау;

- тапсырманың орындау жолын тек түсіндіріп, балаға мотивация беру;

- кейбір ұғымдарды өзінің білмейтінін жақсы қабылдау, ашуланбау;

- тапсырмаларды орындауды тым кешкі уақытқа қалдырмау;

- өзін үнемі позитивті ұстау.

Қашықтықтан оқытуда кері байланыс берудің маңызы өте зор. Оқу мен оқытудың сапасы тікелей кері байланысқа тәуелді. Орта білім беру ұйымдарында, яғни мектептерде кері байланыс беруге қолжетімді «Bilimland», «OPIQ.KZ», «iMektep», «Padlet», «GoogleClassroom», «Daryn.online» секілді платформалар ұсынылған. Бағалау оқушының көзімен «Мен қандай білім немесе дағдыны дамытқым келеді?», «Менің оған әлеуетім қандай?», «Енді не істеуім қажет?» деген сауалдарға жауап береді. Кері байланыстың оқу мен оқыту үдерісіне ықпалы аса зор. Танымдық бағытта «нені үйренеді?», ынталандырушылық бағытта «қалай үйренеді?» сауалдарына жауап береді. Қашықтық жағдайында кері байланысты жазбаша, ауызша, графикалық, аудио, видео түрінде беруге болады.

Төрт деңгейлі кері байланыс моделі - тапсырмаға берілген кері байланыс, тапсырманың жүзеге асырылуына берілген кері байланыс, өзін-өзі реттеуге берілген кері байланыс, жеке оқушыға берілген тұлғалық кері байланыс материал мазмұнын жүйелеуге мүмкіндік береді [7,31].

Тиімді кері байланыс оқушыларға өздерінің оқуының қай жерде екендігін түсінуге және танымдық жағынан енді қай бағытта даму керектігін айқындауға көмектеседі. Тиімді кері байланыс оқушы қолдана алатындай ақпараттан тұрады және өздерінің қабілетінің деңгейін және нені жасай алатындығына сенімділіктерін арттырады. Окушылар өздерінің түсінігінен тыс ақпараттарды қабылдай бермейді, дәлірек айтсақ, егер оларға кері байланыс тиімсіз болса, олар оны мұқият тыңдай бермейді. Сондықтан кері байланыс жасағанда, оны ұсынудың кей ережелерін білгеніміз жөн:

- позитивті болу;

- бағалаушы болмау;

- ынталандыруға ұмтылу;

- сыпайы болу;

- тең ұстау;

- сәттілікке бағыттау;

- мадақтау;

- ризашылық білдіру;

- тыңдай білу.

Өз тәжірибемде әрбір оқушының есімін атап, кері байланыс ұсынамын. Мысалы, «Аружан, таныстырылым жасауда тақырыпты ашуда кестені өте тиімді қолданғансың! Жақсы таңдау!» Жиі әрі жүйелі кері байланыс ұсыну, яғни күнделікті сабақтарда күннің белгілі бір уақытында, мысалы, сағат 11:00-12:00 немесе аптасына белгілі бір күнін нақтылап қоямын. Жедел кері байланыс ұсынуда тапсырманы орындауға берілген уақыт аясында дереу кері байланыс беріп отырылады. Теңгерімді кері байланыста «Мадақтау сэндвичіне» ұқсас басы, ортасы, аяғындағы критерийлерге сәйкес кері байланыс ұсынылады. Келесі түрі нақты кері байланыста «екінші абзацта айтылған ойлар тақырыптың мазмұнын жақсы ашып тұр» деген секілді нақты ұсыныстар келтіріледі. Позитивті кері байланыста «Екі жұлдыз, бір тілек» әдісін қолдануға болады. Сондай-ақ, ойлауды дамыту үшін сұрақтары бар кері байланыс ұсынамын. Мысалы, «тақырып бойынша тұжырымдаманы нақты келтіргенсіз. Осы тұжырымдаманы өмірмен байланыстыратын қандай мысалдар келтіре аласыз?»

Кері байланыс беру тәжірибесінің принциптері: 
- оқушының оқудағы өзін-өзі бағалауын жетілдіруне ықпал ету тәжірибесі;.

- оқыту мен оқу аясында мұғалім мен оқушының арасында, мұғалім мен оқушының өзара диалогын қалыптастыру тәжірибесі;

- сапалы өнімділікке қол жеткізуге ықпал ету тәжірибесі (мақсат, критерийлер, күтілетін нәтиже),

- ағымдағы жетістік пен күтілетін нәтиже арасындағы алшақтықты жоюға бағытталған тәжірибе.

- оқушыларға өз оқулары жайлы жоғары сапалы мәлімет беру тәжірибесі;

- позитивті, ынталандырушы және өзін-өзі бағалауға жетелу;

- мұғалімдерге оқушылардың оқуына қолдау көрсету үшін қажетті ақпарат ұсыну тәжірибесі $[10,128]$.

Жұптық не топтық кері байланысын эссе жазу тапсырмасында ұсынамын. Мұғалім нұсқаулығы бойынша ағылшын тілінде эссенің құрылымдарын түсіндіру, сілтемелерді қалай дұрыс қою, қорытындыны қалай құрылымдау, эссеге критерийлерді оқушылармен бірге құрастыру ұсынылған. Тапсырманы орындау қадамдары:

1-қадам: 10 минутта белгілі бір тақырыпқа эссе жазу.

2-қадам: Өз жұмысын сыныптағы басқа оқушыға кері байланыс немесе пікір алу үшін ұсыну.

3-қадам: Сыныптасының кері байланысы бойынша өз жұмысына толықтырулар мен өзгерістер жасау.

Бұл процестің артықшылықтары: күрделі оқу әрекеттерін кішігірім оқу міндеттеріне бөлу мүмкіндіктері, нақты оқу мақсатына жетуге бағытталған тапсырманы түрлендіріп орындау, тақырып бойынша жаңа білім мен қажетті дағдыларды (эссе жазу) жетілдіреді, құрдастарынан алған кері байланыс арқылы қолдау көру. Кемшіліктері: құрдастарының жұмысына пікір білдіруде бағалау критерийлерін назарға алмау, объективтен гөрі субъективтіліктің басым болуы, өзге жұмыстардан идеялар алу.

Мағжан Жұмабаев: «Баланың өзін емес, ісін мақта, мақтағанда да мақтауға тұрарлық ісін мақта»,-дейді. Қашықтықтан оқыту жағдайында оқушыларға тиімді кері байланысты қамтамасыз ету - бұл мұғалімнің сыни шеберлігі. Мұғалімдерге онлайн-кері байланыс дағдыларын жетілдіру үшін өмір бойы білім алу ұстанымын ұстану - қазіргі уақыттың ең өзекті мәселесі.

Негізгі нәтижелер. Қашықтықтан оқытудың маңыздылығы - білім берудің біртұтас ақпараттық жүйесін құру арқылы білім алушылардың білім деңгейін көтеру. Сонымен қатар әлемдік ақпарат кеңістігіне жол ашып, оқушылардың ғылыми және шығармашылық ізденістерін арттыра білсек, ұтар тұсымыз да сол болмақ. Бүгінде, информация өңдеу мен халықаралық деңгейде еңбек түрлерін бөлу әлемдік экономиканың ең негізгі ерекшеліктері болып отырған кезде, білім алу кез келген маманның жеке және кәсіби табысының негізгі көзі болып қала береді. Білімнің адамның жұмысқа түру мен өмір сүру деңгейіне тигізетін әсері бұрынғыға қарағанда анағұрлым күшейе бастады. Әрине, білімге қойылатын талаптар да өзгеріске ұшырады: әрбір жанның негізгі білімі мен оның тұрақты жаңарып отыруымен қатар қазіргі маман информациялық қорларды табысты пайдаланып, заң және экономика негіздерін де игеруі тиіс. Қазіргі мамандардан шығармашылық тұрғыдан ойлай білуі, соның негізінде шешім қабылдауы және өмір бойы оқып үйренуі талап етіледі.

Функциональдық дайындау тұжырымдамасынан жеке тұлғаны дамыту тұжырымдамасына ауысудың негізі тек приоритеттер ауысуы ғана емес, мұнда мамандарды мемлекетгік тапсырыс бойынша дайындаудан жеке тұлғаның талаптарын қанағаттандыруға көшу жүзеге асырылады. Жаңа тұжырымдама әрбір нақты адамның өз мүмкіндіктерін есепке ала отырып, соны іс жүзінде көрсету мен жетілдіру арқылы білім беруді жекелеп жүргізудің сипат алғанын көрсетеді. Бұл оқушылардың және 
мұғалімдердің өздерінің әртүрлі жеке мүмкіндіктеріне сәйкес алуан түрлі білім беру бағдарламаларын жасау арқылы іске асырылады. Білім беруді жетілдірудің осы бағытындағы маңызды фактор болып оқушылардың қазіргі және болашақта қолданылатын информациялық коммуникациялық технологияларды қолдану арқылы окуға деген өз ынтасын, мүмкіндігін, өздерінің жеке басының когнитивті іс-әрекет жасауға икемділігін қалыптастыру ісі саналады.

Алынған мәліметтерді талқылау. Қазіргі кезде адамзат дамуының ерекше артықшылығы - ақпараттық өркениетке көшу, адамдардың интеллектуалдық мүмкіндіктерін арттыратын есептеуіш техника мен ақпараттық технологиялардың жедел дамуы болып табылады. Қоғамды ақпараттандыру Қазақстан дамуының маңызды бағыттарының бірі болып саналады. Біздің еліміздегі үздіксіз білім беруді қарастыратын болсақ, осы сатылардың барлығында ақпараттандырудың әсерін көруге болады. Оның мақсаты - эффективтілікті радикалды және мамандарды даярлау сапасын дамыған елдердің деңгейіне көтеру.

Осы үрдісте келесі элементтер ерекше маңызды болды:

- техникалық құралдармен оқытудың педагогикалық әдістерінің приоритеттілігі;

- алгоритмдік білім мен ойлау стилінің өсуі;

- білім алушылардың информатика мен есептеуіш техника құралдарын меңгеру және қажеттеріне қарай жаңа ақпараттық технологияларды қолдану қабілеттіліктерін қалыптастыруы саналады.

Осының барлығы жеке тұлғаның ақпараттық мәдениет деңгейінің жоғарылауы мен дамуына әсер етуі керек. Осы тұрғыда үш деңгейді ерекшелеп көрсетуге болады: жалпы, кәсіби және жоғарғы логикалық. Адамдардың ақпараттық мәдениеті олардың еңбек қызметін анықтаушы факторы болып табылады. Акпараттык коғамға, қозғалысқа қарай оның рөлі арта түседі. Ақпарат бағалылығы да арта түседі. Адамның ақпараттық мәдениетінің қалыптасуы - оның күнделікті тіршілігіндегі білім, біліктерімен өз білімін жетілдіру кезінде жүзеге асады. Бұл - басқарылмайтын үрдіс. Әйтсе де, оның құрылымын анықтап, оқыту және тәрбие жүйесімен жеке тұлғаның ақпараттық мәдениетін бағытталған түрде дамыту кезінде күшейтуге, ұйымдастыруға болады. Тәжірибе көрсеткендей, оқытудың компьютерлік технологиясын келесі әдістерді қолдану аркылы жүзеге асыруға әсер етеді:

- ақпараттық әдіс, үйренушінің танымдық қызметін;

- компьютерлік модельдеу әдісі, мәліметтер базасы мен білімді, гипермәтіндерді қолдану арқылы білім алушының танымдық қызметін жүзеге асыру;

- автоматты оқыту және білімді бақылау әдісі, математикалық және логикалингвистикалық модельдерді қолдануға негізделген, танымдық кызметті дамытады;

- автоматтандырылған оқыту және білімді бағалау әдісі, автоматтандырылған оқыту жүйелерін, тестілеу жүйелері мен мультимедианы қолдануға негізделген, танымдық қызметті дамытады;

- ойындық әдіс, компьютерлік, іскерлік ойындарды, эксперттік жүйелерді қолдануға негізделген танымдык қызметті дамытады.

Білім беруде ақпараттық технологияларды сәтті тарату, сауатты қолдану және интенсивті дамыту бірнеше факторларға байланысты екендігі аныкталды:

- техникалық (компьютерлік) база жағдайы;

- ақпараттык жоне компьютерлік аймағындағы маман-оқытушылардың кәсіби дайындық деңгейі;

- басқа пән окытушыларының компьютерлік сауаттылығы және ақпараттық мәдениет дәрежесі;

- нақты аймақтағы ақпараттық технологияны дамыту тенденцияларына оқу жоспары мен бағдарламалар мазмұндарының сәйкес келуі. 
Қазіргі қойылатын талапқа сай жаңа технологиялар - берілетін білім деңгейінің кенейтілуінің және білім алушылардың білім дәрежесінің артуын талап етіп отыр.

Қорытынды. Қашықтықтан оқыту технологиясы білім берудің ортасында тұратын оқыту жүйесін құру мүмкіндігін береді. Бұл жүйеде оқытушы білім алушының жұмыстарын, жеке қызығушылықтары мен сұраныстарын ескереді. Білім беру жүйесінің ортасында білім алушы тұратынын ескерсек, оқыту жүйесі тұтасымен өзгереді. Оқытушы білім алушыға арналған өзіндік жұмыстарды ұйымдастырумен шұғылданады. Қашықтықтан оқыту технологиясын пайдалануда оқытушының рөлі арта түседі және өзгереді. Осымен байланысты қашықтықтан оқыту технологиясын қолданып жүргізілетін білім беру сапасын бақылауды дұрыс жүргізу және жүзеге асыру мақсаты туындайды.

Оқытудың сапасы мен құрылымы қашықтан оқыту мен дәстүрлі оқытуда бірдей немесе кейбір жағдайларда қашықтан оқыту сапасы жоғары болғанын тәжрибелер дәлелдеп отыр. Өз практикамыздан белсенділігі төмен оқушының өзі жауапкершілікпен тапсырмаларды бар ынтасымен орындап бергеніне көзіміз жетті. Дәстүрлі оқыту орталарына қарағанда жаңа электрондық технология оқушыны оқу процесіне белсенді қатыстырып қана қоймайды, сонымен қатар, дыбыстың, қимылдың, образдың және мәтіннің интеграциясы жаңа, мүмкіндіктері мол, әдеттен тыс оқу ортасын қалыптастырады, оның даму барысында оқу процесіне қатысатын оқушы саны да арта береді. Қашықтан оқыту жүйесінде қоданылатын бағдарламалер мен ақпаратты жеткізу жүйесінің инетрактивтік мүмкіндіктері, көптеген дәстүрлі оқу орталарында мүмкін болмайтын кері байланыс орнататын және икемдеп отырады, тұрақты көмек пен сұхбатты қамтамасыз етеді. Қазіргі заманғы компьютерлік телекоммуникация білім және түрлі оқулық ақпарат беруде, дәстүрлі оқу құраладарымен бірдей, ал кейде одан да әсерлі. Сондықтан қашықтықтан оқытудың мүмкіндіктерін пайдалану-уақыт талабынан туындаған қажеттілік. Оны жүйелі, мақсатқа бағыттай ұйымдастыру педагогтар шығармашылығы болып табылады.

\section{Әдебиеттер:}

[1] Полат, Е.С. Дистанционное обучение: Учебное пособие для вузов. - Москва, 2008. C.14-16.

[2] Демкин, В.П., Можаева Г.В. Технологии дистанционного обучения. - Томск, 2002. C.52-55.

[3] Fleming, N. Teaching and learning styles. - 2001. - C.139-141. DOI: 10.1002/ase.1777

[4] Tomlinson, C., The Differentiated Classroom: Responding to the Needs of All Learners, 2nd Edition. - 2014.

[5] ҚР Білім және ғылым министрінің Пандемия кезеңінде білім беру ұйымдарында, COVID-19 коронавирустық инфекцияның таралуына жол бермеу жөніндегі шараларды күшейту туралы. 01.04.2020. - C.39-42.

[6] Cooper, H., Robinson J., Patall E. Does Homework Improve Academic Achievement? A Synthesis of Research, 1987-2003. - 2006.

[7] Hattie, J., Timperley H. The Power of Feedback, Research Article. - 2007. DOI: $10.3102 / 003465430298487$

[8] Harris, C., Jorgianne C., Erika P. Homework Improves Academic Achievement. - 2006. september. DOI:10.3102/00346543076001001

[9] Robert, J., Jana S., Pickering J. Classroom Management That Works: Research-Based Strategies for Every Teacher. - 2007, september.

[10] Forman, I., Forman N. Java Reflection in Action. - 2004, October.

[11] Вайндорф-Сысоева, М., Грязнова Т., Шитова Ш.Методика дистанционного обучения. Учебное пособие. - Москва, 2017. - С.29-32. 
[12] Полат, Е., Бухаркина М., Моисеева М.В. Теория и практика дистанционного обучения.

- Москва, 2004. - С.312-314.

[13] Андреев, А., Солдаткин В. Дистанционное обучение: сущность, технология, организация. - Москва, 1999. - С.101-102.

[14] Демкин, В., Можаева Г. Технологии дистанционного обучения. - Томск, 2003. - С.7173.

[15] Рахимжанова, А., Нурбекова Г. Қашықтықтан оқытудың артықшылықтары. - Астана, 2014. - C.2-3. http://oldconf.neasmo.org.ua/node/2296.

\title{
References:
}

[1] Polat, E.S., Distancionnoe obuchenie: Uchebnoe posobie dlya vuzov. - Moskva, 2008. S.14-16.

[2] Demkin, V.P., Mozhaeva G.V. Tekhnologii distancionnogo obucheniya. - Tomsk, 2002. S.52-55.

[3] Fleming, N., Teaching and learning styles. - 2001. - S.139-141. DOI: 10.1002/ase.1777

[4] Tomlinson, S., The Differentiated Classroom: Responding to the Needs of All Learners, 2nd

[5] ҚR Bilim zhəne ғуlym ministriniң Pandemiya kezeңinde bilim beru ұjymdarynda, COVID-19 koronavirustyқ infekciyanyң taraluyna zhol bermeu zhenindegi sharalardy kүshejtu turaly. 01.04.2020. - S.39-42.

[6] Cooper, H., Robinson J., Patall E. Does Homework Improve Academic Achievement? A Synthesis of Research, 1987-2003. - 2006.

[7] Hattie, J., Timperley H. The Power of Feedback, Research Article. - 2007. DOI: $10.3102 / 003465430298487$

[8] Harris, C., Jorgianne C., Erika P. Homework Improves Academic Achievement. - 2006. september. DOI:10.3102/00346543076001001

[9] Robert J., Jana S., Pickering J. Classroom Management That Works: Research-Based Strategies for Every Teacher. - 2007, september.

[10] Forman, I., Forman N. Java Reflection in Action. - 2004, Ostober.

[11] Vajndorf-Sysoeva, M., Gryaznova T., SHitova SH.Metodika distancionnogo obucheniya. Uchebnoe posobie. - Moskva, 2017. - S.29-32.

[12] Polat, E., Buharkina M., Moiseeva M.V. Teoriya i praktika distancionnogo obucheniya. - Moskva, 2004. - S.312-314.

[13] Andreev, A., Soldatkin V. Distancionnoe obuchenie: sushchnost', tekhnologiya, organizaciya. - Moskva, 1999. - S.101-102.

[14] Demkin, V., Mozhaeva G. Tekhnologii distancionnogo obucheniya. - Tomsk, 2003. - S.7173.

[15] Rahimzhanova, A., Nurbekova G. Қаshуқтуқtan оқуtudyң artyқshylyқtary. - Astana, 2014. - S.2-3. http://oldconf.neasmo.org.ua/node/2296.

\section{ЭФФЕКТИВНЫЕ ПУТИ ОРГАНИЗАЦИИ ДИСТАНЦИОННОГО ОБУЧЕНИЯ В СРЕДНЕМ ОБРАЗОВАНИИ}

\author{
Абадилдаева Ш.К., магистр педагогических наук \\ Искакова А. Ж., магистр педагогических наук
}

Кызылординский университет имени Коркыт Ата, г.Кызылорда, Республика Казахстан

Аннотация. В данной работе дана подробная и всесторонняя информация об эффективных путях организации дистанционного обучения. Работа состоит из вступления, материалов исследования, основных результатов, обработки собранных материалов и итоговой части. Автор подробно останавливается на важности дистанционного обучения в среднем образовании, эффективных путях его организации, преимуществах и недостатках, а также делится своим 
опытом. Также автор выражает свое мнение и видение о саморегулировании обучающихся, учете возможностей и способностей всех обучающихся, вопросах дифференецированного обучения, учебных заданиях и проведении эффективной обратной связи в условиях дистанционного обучения. Будет продемонстрирована эффективность мета познавательных стратегий при дистанционном обучении и предложены рекомендации по саморегулированию. Обучение даст хорошие результаты только при учете личных способностей и склонностей учащихся. Также в статье можно найти ответы на вопрос «Какие виды заданий можно предложить в качестве учебных заданий (домашних заданий) и каковы должны быть их нормы?». Даются рекомендации к системному использованию обратной связи для поддержки обучения учащихся и устранению расхождений между текущим и ожидаемым результатом.

Ключевые слова: технология дистаниионного обучения, саморегулирование, личные способности и возможности обучающихся, визуалы, аудиаль, кинестеты, дигиталь, дифференциация, учебное задание, эффективная обратная связь.

\title{
EFFECTIVE WAYS OF ORGANIZING DISTANCE LEARNIG IN SECONDARY EDUCATION
}

\author{
Abadildaeva Sh. K., master of pedagogical sciences \\ Iskakova A. Zh., master of pedagogical sciences \\ Kyzylorda University named after Korkyt Ata, Kyzylorda city, Republic of Kazakhstan
}

Annotation. Work provides detailed and comprehensive information about effective ways of organizing distance learning. It consists of an introduction, research materials, main results, processing of the collected materials and the final part. The author dwells in detail on the importance of distance learning in secondary education, the effective ways of its organizing, advantages and disadvantages, and also shares her experience. The author also expresses her opinion and vision about self-regulation of students, taking into account the capabilities and abilities of all students, issues of differentiated learning, training tasks and conducting effective feedback in the conditions of distance learning. The effectiveness of meta-cognitive strategies in distance learning will be demonstrated and recommendations for self-regulation will be proposed. Education will give good results only when taking into account the personal abilities and inclinations of students. Also in the article you can find answers to the question "What types of tasks can be offered as educational tasks (homework) and what should be their norms?". Recommendations are given for the systematic use of feedback to support student learning and eliminate discrepancies between the current and expected result.

Keywords: distance learning technology, self-regulation, personal abilities and opportunities of students, visuals, audiles, kin esthetes, digital, differentiation, training task, effective feedback. 


\title{
IMPORTANT ISSUES OF THE CONTENT OF THE PHYSICS COURSE IN THE TRAINING OF FUTURE TECHNICAL SPECIALISTS IN HIGHER EDUCATIONAL INSTITUTIONS
}

\author{
Kozibay A.K., doctor of pedagogical sciences \\ k.anarbek@gmail.com https://orcid.org/0000-0002-4043-7771 \\ Zhanbekova G.I., doctoral student \\ gulnura08@list.ru https://orcid.org/0000-0002-7877-7085
}

Kazakh National Pedagogical University named after by Abai, Almaty city, Republic of Kazakhstan

\begin{abstract}
Annotation.The article presents new content areas in the traditional work program for the course of physics in the preparation of technical specialties in universities. The majority of physical education in the system of technical education and the systemic role of the physics course in the structure of technical training are noted. A number of problems and vulnerabilities in the practice of teaching physics were analyzed. The necessity of preserving the integrity of the logical structure of the physics course in the system of technical education, regardless of the direction of training, is noted. The article substantiates the inclusion of a complex of methodological knowledge in the traditional work program in physics, which forms ideas about the complex nature of the physical picture of the world. The structure of this complex is proposed. It is shown that the structure of the physical picture of the world can be represented in the form of two interrelated blocks: the scientific paradigm and scientific knowledge. The multi-level content of each block is revealed, corresponding to the logic of the development of scientific knowledge. A comparative analysis of the proposed approach to the formation of the course content is carried out. The article develops the structure and defines the content of the methodological educational complex of physical science, proposed for inclusion in the content of the physics course for the specialties of the technical bachelor's degree.
\end{abstract}

Keywords: technical education, physics course, methodological knowledge, mechanics, molecular physics and thermodynamics, electrodynamics, Maxwell's equations, quantum mechanics, nuclear physics.

Introduction. In the conditions of technological modernization of the country's economy, the labor market requires personnel with a universal set of competencies, an active civic position, interpersonal communication skills and systemic thinking[1]. The physics course is the main component in the curricula for the training of technical specialists in higher education institutions. Most disciplines of the technical cycle are based on certain fundamental scientific theories, primarily on the theory of physical science. Therefore, the physics course, which has the highest level of systematization of natural sciences and is built in accordance with the unified methodology of science, is able to regulate the process of organization and development of the entire spectrum of technical disciplines.

Literature review. The process of teaching physics in the preparation of bachelors contributes to students' understanding of the main role of physics in the system of scientific knowledge, mastering modern technologies of educational activity and methodology of systems thinking and thereby purposefully preparing them for effective activities in teaching disciplines of the technical cycle [2]. However, it should be noted that in the actual practice of teaching, the methodological complex of physical science is practically not considered when lecturing. The manifestation of this process was due to the transition to a three-level system of education and, as a result, a sharp decrease in the complexity of the physics course. Working curricula for the bachelor's system practically repeat the corresponding areas of the specialty, contain a large amount of theoretical material that teachers are trying to comprehend to students in a certain volume. Introduction of the course "special sections of physics" into the main part of master's 
programs in all technical specialties, the subject content of which is focused on the sections of physics that make up the main "gnosological space" of the corresponding field of technical knowledge $[3,4]$. The abundance of educational material of the physics course, mastered in the bachelor's system, leads to the splitting of knowledge, the lack of holistic ideas about the course. Strengthening the ideological orientation of the physics course within the framework of the priority of fundamental bachelor's training, reflected in the program documents, is one of the most important aspects of improving its content.

Research materials and methods. The expediency of the chosen strategy for improving the content of the course is confirmed by the results of a pedagogical experiment conducted at the Department of Natural Sciences of the Academy of Transport and Logistics over the past three years. A new type of education is being formed, and it depends on the efforts of modern scientists and teachers what its foundations, values and meaning will be [5]. Within the framework of this topic, we note the following results.

Firstly, the knowledge of students of a number of technical specialties of the engineering school of the university, laid down in the school physics course, was tested. Before starting the course, students were offered individual tasks consisting of seven tasks on all the main issues of the school course and three theoretical issues of ideological orientation. Students do not have enough methodological knowledge reflecting the system of ideas about the structure of physics as a science and an academic discipline. These results, ultimately, indicate a low level of formation of theoretical thinking, the ability to carry out operations of analysis, synthesis, generalization, systematization. For example, in $2020,56 \%$ of the total number of students ( 75 students) who passed the test showed positive results in solving the tasks. At the same time, only $25 \%$ correctly answered the question about the subject of physics, only $17 \%$ named the main physical theories and only $8 \%$ were able to specify the basic physical concepts from the proposed section of physics (which provides a summary of it).

Secondly, this study was revealed during a survey conducted among fourth-year students of selected specialties in order to determine their general attitude to the educational process for the entire academic cycle at the university. On the issue of interest to us, you can specify based on the following questions:

- Evaluate the level of teaching the course on a five-point system?

- To determine the priority of the disciplines included in the basic continuous training structure necessary for the successful formation of a specialist in your profile?

- Select sections and topics of the physics course based on the content of special disciplines included in the structure of basic continuous training (a list is provided); activities?

- Which five disciplines determine the success of your future professional and social

- Which five disciplines determine the formation of a research worldview?

The results of the survey reveal an obvious polarity in assessing the quality of teaching physics and attitude to the course itself: in general, positively assessing the quality of the organization of training at the Department of Natural Sciences and the level of teaching the course, students negatively evaluate the physics course, its role and significance in further education and life. Thus, $35 \%$ of the total number of students surveyed put physics in the first place in terms of teaching quality among 13-15 subjects, the average grade per subject for these indicators is 4.15 . It is obvious that an important role in the response to such a survey is played by the personal and professional activities of the teacher.

Since the physics course is the main academic discipline that has a priority influence on the formation of a specialist, then, in our opinion, the ideological orientation of the physics course. For example, $36 \%$ of future bachelors identified the ecology course as more fundamental than the physics course, and only $12 \%$ of students put physics first in the process of forming a scientific worldview. In addition, referring to the experience of technical colleges in the United 
States [6], where most of the physics course is distributed among graduate departments, he suggests creating special courses based on the physics course in accordance with the future specialty. Such a solution to the problem, in their opinion, removed unnecessary "superfluous" topics for a specialist of this profile. In our opinion, such a statement of the problem is unacceptable. The general scientific and methodological problems solved in the physics course in the bachelor's degree system are crucial both in the formation of a specialist of any profile and in the formation of a scientific worldview.

Research results and discussion. 6B07111 - technology of production and repair of rolling stock (code and classification of training areas: 6B071-Engineer and engineering. Code and group of educational programs: B065-motor vehicles) the working curriculum of the 135hour physics course for the specialty has been revised, which corresponds to a clear distribution of hours in the course for most technical specialties. It should be noted that we are not talking about a complete revision and modification of work programs. Special attention was paid to the integrity of the course based on the unification of all its sections around the basic methodological concepts, laws and principles, as well as the adequacy of modern principles of structuring scientific knowledge based on the internal logic of the development of physical science. Based on the results of this work, we decided to present the following modified software system for teaching a physics course.

"Mechanics" is the first part of the course, therefore, it is advisable to include two introductory lectures of a purely ideological orientation in its structure and introduce students to the principles of the organization of the educational process at the Department of Physics. The main questions of the introductory lecture: the scientific picture of the world as a philosophical category. The interrelation of the general scientific, natural scientific and physical picture of the world. Stages of evolution of the physical picture of the world $[7,8,9]$. Physics as a science. Scientific paradigm and structure of scientific knowledge of physical theory. Methods of physical research. Also, the following questions can be added to the main questions of the introductory lecture: the physics course is the theoretical basis for preparing bachelors in the field of education "technical sciences". The connection of the physics course with the disciplines of the specialty. Mechanics is the first part of physics and the whole of natural science. The subject of mechanics. The structure of the scientific theory of mechanics. Principles of systematization and structuring of the categorical and conceptual apparatus of mechanics (structural and logical graph of the scientific theory of mechanics). In addition, when presenting this section of physics, special attention should be paid to methodologically important issues: the nature of idealization in mechanics (a material point, a system of material points, an absolute solid, space, time); the form of causality in mechanics (mechanical or Laplace determinism); the concept of force as a dynamic characteristic of interaction; the dimensions of motion of classical mechanics and their relationship with the properties of space and time (momentum - with the homogeneity of space, momentum - with the isotropy of space and kinetic energy - with the homogeneity of time).

Section "Molecular physics and thermodynamics". When studying this section of physics, the following methodological issues require special attention: thermodynamic parameters-a new approach to the description of physical objects (compared with the characteristics of particles); methods of statistical and thermodynamic studies; microscopic and phenomenological approaches to the description of macro objects; statistical distribution laws (laws of the distribution of molecules by velocity and energy); ideological essence of the first beginning of thermodynamics; statistical significance of the second beginning of thermodynamics (necessity and direction of the passage of time), the second beginning of thermodynamics and the processes of evolution of the Universe; a synergetic approach to the description of nonequilibrium processes.

Physical concepts from the proposed section of physics (in which its summary is given). 
Secondly, this study was revealed during a survey conducted among fourth-year students of selected specialties in order to determine their general attitude to the educational process for the entire academic cycle at the university. On the issue of interest to us, you can specify based on the following questions:

- Evaluate the level of teaching the course on a five-point system?

- To determine the priority of the disciplines included in the basic continuous training structure necessary for the successful formation of a specialist in your profile?

- Select sections and topics of the physics course based on the content of special disciplines included in the structure of basic continuous training (a list is provided);

- Which five disciplines determine the success of your future professional and social activities?

- Which five disciplines determine the formation of a research worldview?

The results of the survey reveal an obvious polarity in assessing the quality of teaching physics and attitude to the course itself: in general, positively assessing the quality of the organization of training at the Department of Natural Sciences and the level of teaching the course, students negatively evaluate the physics course, its role and importance in further education and life. Thus, $35 \%$ of the total number of students surveyed put physics in the first place in terms of teaching quality among 13-15 subjects, the average grade for a subject on these indicators is 4.15. It is obvious that an important role in the response to such a survey is played by the personal and professional activities of the teacher.

Since the physics course is the main academic discipline that has a priority influence on the formation of a specialist, then, in our opinion, the ideological orientation of the physics course. For example, $36 \%$ of future bachelors identified the ecology course as more fundamental than the physics course, and only $12 \%$ of students put physics first in the process of forming a scientific worldview. In addition, referring to the experience of technical colleges in the United States [6], where most of the physics course is distributed among graduate departments, he suggests creating special courses based on the physics course in accordance with the future specialty. Such a solution to the problem, in their opinion, removed unnecessary "superfluous" topics for a specialist of this profile. In our opinion, such a statement of the problem is unacceptable. General scientific and methodological problems solved in the physics course in the bachelor's degree system are crucial both in the formation of a specialist of any profile and in the formation of a scientific worldview.

Section "Electrodynamics". Within the framework of this section, attention should be paid to the following issues: the empirical basis of scientific knowledge of electrodynamics; the theoretical basis of scientific knowledge in electrodynamics (creation of a unified theory of Maxwell's electromagnetic field); the physical essence of Maxwell's equations. When considering the first two questions, it should be particularly noted the heuristic value of mathematics in the interaction of empirical and theoretical foundations of scientific knowledge of physical theory $[10,11,12]$. In electrodynamics, this is obvious, and Maxwell's equations, being the mathematical expression of many empirical data (Coulomb, Ampere, Oersted Faraday experiments), contain much more information than the original data.

Section "quantum mechanics". In the study of quantum mechanics, methodological problems related to the dialectical nature of the development and content of physical theories and the interpretation of their results should be particularly noted. The interaction of scientific knowledge and the scientific paradigm is particularly evident here, when the growth of scientific knowledge leads not only to the expansion of the scientific paradigm, but also to a radical change in some basic concepts, ideas, principles [13]. In this section, the following questions require detailed explanation: empirical and theoretical prerequisites for the construction of quantum mechanics; Heisenberg uncertainty relation, probabilistic character of the description of the behavior of particles of the microcosm; the Bohr complementarity principle. Special attention 
should be paid to the philosophical category of causality in quantum mechanics and quantum mechanical determinism. The last question is of great gnosological importance for understanding the essence of quantum mechanics and should be considered in detail during lectures. It should be noted that determinism in quantum mechanics, despite its discrepancy with classical, laplastic determinism, is fully preserved, but it is necessary to explain the fundamental difference from the classical understanding.

Section "nuclear physics". In traditional teaching practice, there is little time left to study this section, and the lecture material is usually limited to basic data on the structure and characteristics of the nucleus, nuclear forces, types of radioactive decay and types of nuclear reactions. In our opinion, when studying this last section of the general physics course, it is necessary to emphasize the ideological significance of the course, pointing out that the development of science, the process of cognition is an endless process [15]. The program includes the following questions: hierarchy of matter structures; the main stages of the development of the physics of the nucleus and elementary particles; the role of conservation laws in nuclear physics; the quark hypothesis of the structure of matter, it is proposed to add gluons.

Conclusion. The article examines the issues of strengthening the ideological orientation of one of the main ways to improve the content of the physics course in the preparation of technical specialties of universities. The methodological complex of knowledge proposed for inclusion in the work programs is compiled according to the sections of the course that are mandatory for study in a certain volume in all specialties of the technical bachelor's degree. As already noted, the inclusion of methodological and ideological issues in the physics course program was carried out within the number of hours allotted for lectures. In this regard, some questions traditionally considered in the lecture course and aimed more at the development of memory than the development of thinking are offered for independent research. For example, in a traditional program, it is customary to use the bio-Savard-Laplace law to calculate the magnetic induction of fields of various configurations, mathematical conclusions of magnetic induction in the center and on the axis of circular rotation, magnetic induction formed by a segment of a straight conductor, etc. are considered. Since the calculation method is the same in all cases, it is enough to give one example, and offer students to study the remaining special cases independently (in all standard textbooks for technical universities, these examples are considered in more detail and require students to have certain mathematical skills). Some changes in the main volume of the lecture course, concerning ideological problems, predetermined changes in the nature of the course exams and assessment criteria. For example, about $40 \%$ of students cannot fully make the necessary conclusions for the exam due to their individual typological characteristics (low memory, low concentration of attention, etc.). In this case, they are offered methodological questions, the answers to which require a general orientation on the course, ultimately reflect the level of systemic knowledge. The results of the last exam showed that students accepted such an examination strategy as correct and, as a result, concluded that the academic performance of $15-25 \%$ of students was relatively high.

\section{Literature:}

[1] The state program for the development of education and science of the Republic of Kazakhstan for 2020 - 2025. //primeminister.kz/kz/gosprogrammy/kr-bilim-berudi-zhane-gylymdydamytudyn-2020 - 2025-zhyldarga-arnalgan-memlekettik-bagdarlamasy.

[2] State program of education development of the Republic of Kazakhstan for 2011 - 2020 Decree of the President of the Republic of Kazakhstan dated December 7, 2010 No. 1118

[3] Physics in the system of modern education (FSSO - 15): Proceedings of the XIII International Conference, St. Petersburg, June 1 - 4, 2015, vol. 1. - St. Petersburg: Publishing House of Fora-Print LLC, 2015. - $514 \mathrm{p}$. 
[4] Ozhevnikov, N.M. Crisis phenomena in the teaching of physics // Proceedings of the XIII International Conference, St. Petersburg, June 1-4, 2015 Vol.1. - pp. 14 - 16.

[5] Begalinov, A.S., Ashilova M. S., Begalinova K. K., On the image of higher education in the post-teen age: the formation and development of new order thinking. Science for Education Today, 2021, Vol. 11, No. 1, pp. $110-123$

[6] Alley, J. Physics in Undergraduate Engineering Education Report of a Survey // American Journal of Physics. - 2013. - V. 40, No. 8. - P. 1063 - 1069

[7] Concepts of modern natural science: Textbook / Bondarev V.P. - 2nd ed., reprint. and additional. - M.: Alfa-M, SIC INFRA-M, 2016. - 512 p.: ISBN $978-5-98281-262-9$.

[8] Klyagin, N.V. Modern scientific picture of the world [Electronic resource]: textbook. manual / N. V. Klyagin. - M.: Logos, 2014. - 264 p.

[9] Ilyin, V.A. History of physics [Text] : [textbook. manual for universities]. - Moscow: Academy, 2003. $-268 \mathrm{p}$.

[10] Vasiliev, A.N. Classical electrodynamics / A. N. Vasiliev. A short course of lectures: studies. stipend. 2nd ed., stereotypical. St. Petersburg: BHV - pEtersburg, 2010. $276 \mathrm{~s}$

[11] Electrodynamics: Textbook / I.F. Budagyan, V.F. Dubrovin, A.S. Sigov. - M.: Alf a - M: SIC INFRA - M, 2013. - $304 \mathrm{~s}$

[12] Electrodynamics: A textbook / I.I. Kalikinsky. - 3rd ed., reprint. and additional. - M.: SIC INFRA-M, 2014. - 159 p.

[13] Physics. Fundamentals of electrodynamics. Electromagnetic vibrations and waves: Textbook / S.I. Kuznetsov. - 4th ed., ispr. and additional. - M.: University textbook: SIC INFRA - M, 2015. - 231 p.

[14] Ivanov, M.G. How to understand quantum mechanics. - M. - Izhevsk: SIC "Regular and chaotic dynamics", 2012. $-516 \mathrm{p}$.

[15] Plotnikov, P.G., Plotnikova L.V. Some aspects of nuclear physics: Textbook. - St. Petersburg: NIU ITMO, 2016. -58 p.

\title{
ВАЖНЕЙШИЕ ВОПРОСЫ СОДЕРЖАНИЯ КУРСА ФИЗИКИ ПРИ ПОДГОТОВКЕ БУДУЩИХ ТЕХНИЧЕСКИХ СПЕЦИАЛИСТОВ В ВУЗАХ
}

\author{
Козыбай А.К., доктор педагогических наук \\ Жанбекова Г.И., докторант \\ Казахский Национальный педагогический университет имени Абая, г.Алматы, \\ Республика Казахстан
}

\begin{abstract}
Аннотация. В статье представлены новые содержательные направления в традиционной рабочей программе по курсу физики при подготовке технических специальностей в вузах. Отмечена большая часть физического образования в системе технического образования и системная роль курса физики в структуре технической подготовки. Был проанализирован ряд проблем и уязвимостей в практике преподавания физики. Отмечена необходимость сохранения целостности логической структуры курса физики в системе технического образования независимо от направления подготовки. Обосновано включение в традиционную рабочую программу по физике комплекса методологических знаний, формирующих представления о комплексной природе физической картины мира. Предложена структура этого комплекса. Показано, что структуру физической картины мира можно представить в виде двух взаимосвязанных блоков: научной парадигмы и научного знания. Раскрыто разноуровневое содержание каждого блока, соответствующее логике развития научного знания. Проведен сравнительный анализ предложенного подхода к формированию содержания курса. В статье разработана структура и определено содержание методологического образовательного комплекса физической науки, предлагаемого для включения в содержание курса физики для специальностей технического бакалавриата.
\end{abstract}

Ключевые слова: техническое образование, курс физики, методические знания, механика, молекулярная физика и термодинамика, электродинамика, уравнения Максвелла, квантовая механика, ядерная физика. 


\section{ЖОҒАРЫ ОҚУ ОРЫНДАРЫНДА БОЛАШАҚ ТЕХНИКАЛЫҚ МАМАНДАРДЫ ДАЙЫНДАУДА ФИЗИКА КУРСЫ МАЗМҰНЫНЫН МАНЫЗДЫ МӘСЕЛЕЛЕРІ}

Қозыбай А.Қ., педагогика ғылымдарының докторы Жанбекова Г.И., физика мамандығының докторанты

Абай атындагы Қазақ ұлттық педагогикалық университеті, Алматы қ.., Қазақ̆стан Республикасы

Аңдатпа. Мақалада жоғары оқу орындарында техникалық мамандарды даярлауда физика курсы бойынша дәстүрлі оқу жұмысының бағдарламасына жаңа мазмұнды бағыттар ұсынылды. Техникалық білім беру жүйесіндегі физикалық білімнің басымдылығы және техникалық мамандарды дайындық құрылымындағы физика курсының жүйелі болуы қарастырылды. Сонымен қатар, физиканы оқыту тәжірибесіндегі бірқатар мәселелер және осал тұстары талданды. Физика курсының логикалық құрылымының тұтастығын техникалық білім беру жүйесіндегі негізгі кәсіби бағыттағы қажеттілікті сақтау атап өтілді. Физика саласындағы дәстүрлі жұмыс бағдарламасына әлемдегі физикалық құбылыстардың, заттардың бейнесінің кешенді табиғаты туралы идеяларды қалыптастыратын әдіснамалық білім кешенін енгізу негізделген. Бұл кешеннің құрылымы ұсынылды. Әлемнің физикалық бейнесінің құрылымын өзара байланысты екі бөлім түрінде ұсынуға болатындығы көрсетілген: ғылыми парадигма және ғылыми білім. Ғылыми білімді дамыту логикасына сәйкес келетін әр бөлімнің түрлі деңгейлі мазмұны ашылды. Курс мазмұнын қалыптастыруға ұсынылған мәселелерге салыстырмалы талдау жүргізілді. Мақалада техникалық бакалавриат мамандықтарына арналған физика курсының мазмұнына енгізу үшін ұсынылатын физикалық ғылымның әдіснамалық білім кешенінің құрылымы жасалып және мазмұны айқындалды.

Кілт сөздер: техникалық білім беру, физика курсы, ддістемелік білім, вылыми парадигма, механика, молекулальқ физика және термодинамика, электродинамика, Максвелл теңдеулері, кванттық механика, ядролық физика 


\title{
ФОРМИРОВАНИЕ КОНЦЕПЦИИ НАРОДНОЙ ПЕДАГОГИКИ И ЕЕ ХАРАКТЕРНЫЕ ОСОБЕННОСТИ
}

\author{
Зубайраева 3.А. ${ }^{1}$, кандидат педагогических наук \\ zuhra-777@mail.ru, https://orcid.org/0000-0002-8695-0431 \\ Касимбекова Б.A. ${ }^{2}, \mathrm{PhD}$ \\ kasimbekova-b@mail.ru, https://orcid.org/0000-0002-7521-0286 \\ Аубакирова А.А. ${ }^{1}$, магистр педагогических наук \\ aubakirova_90_90_90@mail.ru, https://orcid.org/0000-0002-2251-6230 \\ Жакупова А.Б. ${ }^{1}$, магистрант \\ alfiya_dzhakupova@mail.ru,https://orcid.org/0000-0002-9321-4344 \\ Ишанова А.А. ${ }^{1}$, магистрант \\ aizhan_13.96@mail.ru, https://orcid.org/0000-0002-0614-7367
}

\footnotetext{
${ }^{1}$ Кокшетауский университет имени А. Мырзахметова, г.Кокшетау, Республика Казахстан ${ }^{2}$ Международный гуманитарно-технический университет, г. Чимкент, Республика Казахстан
}

Аннотация. Данная статья посвящена народной педагогике, которая является предметом изучения этнопедагогики, основанной, как и другие гуманитарные науки на национальных особенностях, традиционных ценностях народа. Статья отмечает значимость изучения народного творчества для оценки вклада каждого народа во всемирную культуру, в статье анализируется место и роль этонопедагогики среди других гуманитарных наук, а также исследуется народное творчество в контексте мировой культуры.

Кроме того, в статье четко разъясняется значение народной педагогики в сфере современного образования и особенности будущих специалистов.

Цель предлагаемой статьи - помочь студентам освоить народные традиционные методы воспитания молодого поколения и применять эти знания в школьных и внешкольных учреждениях. Будущие специалисты - студенты могут найти материалы, которые помогут им изучить традиционные взгляды на развитие гуманистического, умственного, экологического и правового, трудового и экономического, физического и эстетического воспитания. Они могут получить знания о прогрессивных и консервативных традициях, о возможностях применения народных методов воспитания в системе образования.

Таким образом, можно сказать, что в этой статье содержится много информации для будущих профессионалов.

Ключевые слова: этнопедагогика, народная педагогика, умственное воспитание, традиции и обычаи.

Введение. Имеется диалектическая связь между народной педагогикой и классической (научной) педагогикой. С одной стороны, педагогическая наука являет собой продолжение народной педагогики, она вбирает в себя лучшие практики народов по воспитанию и обучению. Наряду с этим народная педагогика как часть современной педагогической науки, определила многие инструменты влияния оружающей среды (природной и социальной) на формирование и развитие личности.

В педагогике заметно четкое дифференцирование инструментов воспитания: пословицы и поговорки могут быть направлены на формирование социально-этического облика молодых людей, загадки - на умственное развитие, песни - на эстетическое воспитание, сказки - на развитие каких-либо индивидуальных качеств. В народной педагогике преобладает живая практика воспитательных методов [1].

Народная педагогика, которая обозначает определенный уровень педагогических знаний и выявляет конкретный период духовного прогресса человечества стала основой для зарождения и развития педагогической науки. Однако появление художественной 
литературы не уничтожило устное творчество и педагогическая наука не отстранилась полностью от будней народа. Педагогическая наука и народная педагогика вступили в сложное взаимодействие и оказали взаимное влияние на развитие друг друга, создав общее пространство под названием педагогическая культура [2].

Материалы и методы. Разносторонняя жизнь народа, его борьба, его достижения стали основным и главным объектом исторических и гуманитарных наук, к которым относится и этнопедагогика, предметом изучения которой является народная педагогическая традиция. Изучение народного творчества играет большую роль в определении ценностей, которые вносит каждый народ в мировую культуру. развитию.

Изучая народное творчество, этнопедагогика способствует его возрождению и

Так как педагогическая культура пользуется народным творчеством, развивает его и является его неотъемлемой частью, это относится ко всем историко-педагогическим исследованиям.

В наше время обучение национальным ценностям является важным вопросом в воспитании молодежи. Это изложено в концепции воспитания в системе непрерывного образования Республики Казахстан: «Главная задача системы образования - создание необходимых условий для формирования, развития и профессионального становления личности на основе национальных и общечеловеческих ценностей; реализация прав ребенка на воспитание, образование и всестороннее развитие, сохранение родного языка, культуры, национальных обычаев и традиций, на информированность, укрепление здоровья» [3].

Со второй половины XX века начались процессы осознанного стремления к восприятию мира через изучение материалов народной педагогики, принадлежащей к конкретным этносам, этническому сообществу.Стремление к самоидентификации с помощью народной педагогики рассматривается как одно из основных качеств развития человечества во второй половине XX века. Заинтересованность, как отдельных людей, так и народов в целом в своей истории выражаются в разных формах: начиная от принятия древних традиций, изучения фольклора и прочего и заканчивая попытками создать свое, национальное государство.Осознанное изучение человека на предмет его принадлежности к конкретному народу, определение его особенностей предполагает рассмотрение педагогического аспекта, а также анализ мировоззрения изучаемого человека с помощью материалов народной педагогики [4,5].

Словарь по социологии дает следующее определение этносу: этнос (с греческого «ethnos» - клан, народ) - группа людей, исторически образовавшиеся на определенной территории, имеющие общие признаки, язык, культуру, психологические особенности и традиции. Появлению этноса способствует общность территории и ведение общего хозяйства. В процессе развития этноса общность территории как отдельный признак может исчезнуть. Этнос - определенная культурная целостность. Ему свойственна антитеза «мы - они», то есть, каждый этнос имеет этническое самосознание. Словарь политологии определяет этнос как людей, которые исторически сформировались как единый коллектив на определенной местности, имеющие общие особенности в языке, культуре, характере и осознающие свое единство [6].

Такие понятия как «этнос», «этнический» многие ученые определяют через понятие групповой идентичности. Л.Н. Гумилев, в свою очередь, определял этнос как коллектив, который обособляет себя от других коллективов и считал, что нет ни одного конкретного признака, определяющего этнос кроме тех случаев, когда можно выявить его через особенности языка, традиций и культуры [7].

Американские социальные психологи считают, что устойчивость (постоянство?) этнических характеристик в процессе развития индивида - или этническая константость - 
является элементом этнической идентичности. Этнические константы появляются в характере человека и в его сознании в возрасте 12-13 лет.

Направление жизненных стремлений индивида определяет его этническая группа и человек понимает, что этнокультурная идентификация стоит выше него и продолжит жить после него. Человек не выбирает свой этнос, а принимает как естественное. По мнению Ж.Ж.Наурызбая, этническая идентификация является одной из важнейших проблем, куда относится этническое самосознание, самобытность, национальныйхарактер, понимание принадлежности себя к определенной группе относительно «других». Этническая идентификация является народной педагогической идентификацией и формируется в социокультурной системе общества, считает ученый [8].

На формирование мировоззрения через материалы народной педагогики влияют учебно-воспитательные факторы. Не стоит забывать о влиянии биологических и других социальных факторах. Учитывая психологические и индивидуальные особенности личности, мы говорим, что большое влияние на формирование его мировоззрения через народную педагогику оказывают учебно-воспитательные факторы.О роли воспитания и обучения в процессе формирования мировоззрения посредством материалов народной педагогики высказались видные ученые.

С.Л. Рубинштейн отмечает, что воспитание - основной двигатель в формировании личности, который дает направление ее развитию. Он предлагает к понятию «воспитание» добавить «образование», так как в современных реалиях именно

образованию отведена ведущая роль в педагогике - воспитание личности осуществляется через образовательный процесс [9].

Результаты. Личность - это, прежде всего, социальный тип, который переносит качественные показатели определенной эры, класса, группы, нации. Нация проживает в среде, которая имеет элементы собственной народно-педагогической идентичности. В этой же среде осуществляется процесс формирования и развития личности. В ходе данного процесса на личность оказывают влияние особенности бытоустройства, традиций, материальной и духовной жизни нации. Национальные, этнические признаки отражаются не только через бытовые особенности, но и проявляются в народной педагогической идентичности отдельной личности.

Национальные особенности, в том числе и народная педагогическая идентичность - не врожденное качество. Они формируются вместе с развитием личности и его этнической социализацией под влиянием различных факторов. П.И. Кушнер пишет: «... Народно-педагогическая идентичность не является врожденным качеством человека. Она состоит из осознания очень ранних форм этнической общности и в соответствии с развитием общества проходит несколько этапов. Язык и традиции не передаются через механизмы наследственности. Язык, традиции и обычаи, вкусы передаются подрастающему поколению через подражание, воспитание, социализацию, через освоение интеллектуального и социального опыта».В данном случае этнос является обитателем среды и владельцем культуры, а культура понимается как один из антропогенных рельефов этой самой среды. Народно-педагогическая идентичность выделяется с помощью характеристик, которые отличают культуру каждого этноса от культур других этносов. Основой такой идентичности является периодичность этноса, самоидентичность и преемственность в развитии его культуры. Это рождает способность культуры влиять на другие этнические культуры. Народно-педагогическая идентичность должна сохраняться во всех сообществах, чтобы не отрываться от исторической судьбы народа [10].

Народно-педагогическая идентичность ориентирована на беспрепятственную самоидентификацию и самореализацию человека. Это взаимосвязь этноса и культуры. Несмотря на то, что между ними сохраняется некое расстояние, этнос защищает свою культуру, оберегает, развивает, возрождает. Культура - это простор для развития этноса, 
его защита, его сущность, а значит культура сохраняет этнос. Культуру сохраняют не считанные люди, а этнос. Этнос сможет сохранить себя только если сумеет сохранить свою самобытную культуру.Культура - это энергетическое поле, инструмент, защищающий этнос от поглощения другими и исчезновения; выделяющий от остальных этносов и в то же время помогающий взаимодействовать с ними.Общечеловеческие ценности обычно проявляются в образе этнической культуры. Эти ценности каждый этнос может найти в своей культуре и взаимодействовать с другими через эти ценности.

Народно-педагогическая идентичность формируется через социокультурную цепочку. Это своеобразные рычаги, с помощью которых достигается народнопедагогическая идентичность. Сюда мы можем отнести дошкольные учреждения, школы, национальные культурные центры и многое другое. При изучении мировоззрения через материалы народной педагогики нужно помнить об одной важной детали. Если человек, оторвавшийся от своих национальных корней, не считается полноценной личностью, то человек, воспитанный в духе этнической культуры, но не воспринимающий ценности других нации тоже является духовно неразвитым.

Учебно-воспитательные учреждения, как распространители национальной культуры и как связующее звено национальной культуры с общечеловеческой культурой должны научить детей ощущать биение сердца своего народа, беречь национальные ценности (язык, сознание и др.) как зеницу ока, развивать лучшие традиции и практики, понимать и уважать чужую культуру исоциокультурные потребности других этносов. Для этого необходимо осваивать новые, эффективные методы и инстуремнты воспитания, направленные на развитие гуманности, сознательности и высокой духовности.Так же необходимо пересмотреть содержание и структуру образования.

Знание обеспечивает целостность и преемственность культурного развития нации. Одно из главных условий при этом - познать родной язык и на его основе развивать национальное самосознание. Язык - это национальное достояние, которое удовлетворяет культурные требования этноса и воспитывает людей в национальных традициях. Освоение национального языка - путь к достижению духовной независимости. Обучение на родном языке является первичным условием формирования системы национального образования и воспитания. Язык каждой нации чётко отражает её территорию, историю и характер. Как говорил один из основателей казахской народной педагогики Магжан Жумабаев, казахский язык отражает и бескрайнюю степь, и безветренную тихую ночь, и стремительную, как ураган, историю, и степной быт, и неспешный, спокойный нрав нашего народа. Какова наша широкая степь, таков и язык - богатый и насыщенный.

Народно-педагогическая идентичность формируется стихийно в ходе социализации личности, определяет её принадлежность к конкретной этнической общине и описывет социальную природу человека. Народно-педагогическая идентичность - важный фактор, формирующий этнические общины и их социальную связь.Устойчивость идентификациипомогают человеку познавать самого себя и обеспечивают гармонию взаимоотношений между социумом и его личным «Я».

В определенной культуре проблемы развития личности были исследованы зарубежными психологами в пределах психологической антропологии. Первые исследования были связаны с отделением типа личности, называемой «основной личностью», которая является основной составляющей общества, имеющей конкретную культуру. После этого появилась концепция «модальной личности», которая являет собой основную характеристику определенного народа.

Как только ребёнок научится говорить, можно заметить как на его мышление повлияли устный народный фольклор: колыбельная, пословицы-поговорки, песни, легенды и сказки, которые он слушал и учил. Всё это впитывается и формирует в нём национальное самосознание и культуру. Национальные особенности выделяются в 
характере и поведении человека. К примеру, если казахам свойственны гостеприимство и радушность, то узбекам - обходительность и вежливость и т.д.

Сегодня эти традиции системно проанализировали К.Б. Жарыкбаев и С.М. Жакыпов [11].

Выводы. Многие современные исследования вопросовнародной педагогики приводят к следующей диаде: традиции - особенности личности. О.И. Дреев в своих трудах приходит к выводу о том, что в системе национальных традиций и обычаев выделяются два типа регулятора человеческого характера. Первый тип называется «традиционным» и действует через такие механизмы как подражание, убеждение и общественное мнение. Второй тип строится на основе внутренней, субъективной самостоятельности и активности [12].

Перед системой образования Республики Казахстан стоят высокие задачи по воспитанию сильного духом, образованного и культурного поколения, полностью впитавшего в себя ценности своего народа.

\section{Литературы:}

[1] Газизова, А.И., Закирова Н.Р. Характеристика средств татарской народной педагогики в формировании основных качеств интеллекта детей / Тенденции развития науки и образования. Научный журнал. - 2018, № 34. DOI: 10.18411/1j-31-01-2018-06

[2] Мустаева, Ф.А., Хабибова Н.Е. Педагогическая культура социального педагога в современных условиях развития отечественного образования // Казанский педагогический журнал. - 2020. - № 5 (142). - C.36-43. DOI: 10.34772/KPJ.2020.142.5.005.

[3] Концепция воспитания в системе непрерывного образования Республики Казахстан / приказ Министра образования и науки РК № 521 от 16 ноября 2009 года

[4] Батенева, E.В. Рефлексия как компонент профессионально-педагогической культу-ры педагога Педагогика. Вопросы теории и практики. Тамбов: Грамота, 2021. № 1. С. 111-115. DOI: $10.30853 /$ ped2 10005

[5] Христова, Е.А. Народная педагогика: историографические и теоретикометодологические проблемы: автореф. ... канд. пед. наук. - Москва, 1988. - 25 с.

[6] Психология общения [Текст]: энциклопедический словарь / Российской акад. образования, Психологический ин-т ; под общ. ред. А. А. Бодалева. - 2-е изд., испр. и доп. Москва : Когито-Центр, 2015. - 671, [1] с.; 27 см.; ISBN 978-5-89353-411-5

[7] Гумилев, Л.Н. Этносфера: История людей и история природы. - М., 1993. - 164 с.

[8] Жарыкбаев, К.Б., Наурызбаев Ж.Ж. Основы этнопедагогики и этнопсихологии: Программа курса для учащихся и студентов учебных заведений культуры./ К.Б. Жарыкбаев, Ж.Ж. Наурызбаев. - Алматы, 1994 - 15 с.

[9] Рубинштейн, С.Л. Основы общей психологии: учебное пособие. - Санкт-Петербург: Питер, 2007. - 713 с.: ил. - (Мастера психологии)

[10] Алымов, С.С., П.И. Кушнер и развитие советской этнографии в 1920-1950-е годы. М.: ИЭА, 2006. -278 c.

[11] Жарықбаев, Қ., Қалиев С. Қазақ тәлім-тәрбиесі. - Алматы: Санат, 1995. - 350 б.

[12] Дреев, О.И., Хамицаева З.А. Этнокультурная защита и проблема формирования гражданской идентичности / Материалы III Международной научной конференции Поликультурное образование как основа сохранения языкового наследия и культурного разнообразия человечества [Текст]. - Владикавказ: Изд-во СОГПИ, 2010. - С. 91 - 94.

\section{References:}

[1] Gazizova, A.I., Zakirova N.R. Harakteristika sredstv tatarskoj narodnoj pedagogiki v formirovanii osnovnyh kachestv intellekta detej / Tendencii razvitiya nauki i obrazovaniya. Nauchnyj zhurnal. - 2018, № 34. DOI: 10.18411/1j-31-01-2018-06 
[2] Mustaeva, F.A., Habibova N.E. Pedagogicheskaya kul'tura social'nogo pedagoga v sovremennyh usloviyah razvitiya otechestvennogo obrazovaniya // Kazanskij pedagogicheskij zhurnal. 2020. - № 5 (142). - S.36-43. DOI: 10.34772/KPJ.2020.142.5.005.

[3] Koncepciya vospitaniya v sisteme nepreryvnogo obrazovaniya Respubliki Kazakhstan / prikaz Ministra obrazovaniya i nauki RK № 521 ot 16 noyabrya 2009 goda

[4] Bateneva, E.V., Refleksiya kak komponent professional'no-pedagogicheskoj kul'tu-ry pedagoga Pedagogika. Voprosy teorii i praktiki. Tambov: Gramota, 2021. № 1. S. 111-115. DOI: $10.30853 /$ ped210005

[5] Hristova, E.A., Narodnaya pedagogika: istoriograficheskie i teoretiko-metodologicheskie problemy: avtoref. ... kand. ped. nauk. - Moskva, 1988. $-25 \mathrm{~s}$.

[6] Psihologiya obshcheniya [Tekst]: enciklopedicheskij slovar' / Rossijskoj akad. obrazovaniya, Psihologicheskij in-t ; pod obshch. red. A. A. Bodaleva. - 2-e izd., ispr. i dop. - Moskva : Kogito-Centr, 2015. - 671, [1] s.; 27 sm.; ISBN 978-5-89353-411-5

[7] Gumilev, L.N., Etnosfera: Istoriya lyudej i istoriya prirody. - M., 1993. - 164 s.

[8] Zharykbaev, K.B., Nauryzbaev Zh.Zh. Osnovy etnopedagogiki i etnopsihologii: Programma kursa dlya uchashchihsya i studentov uchebnyh zavedenij kul'tury./ K.B. ZHarykbaev, ZH.ZH. Nauryzbaev. - Almaty, 1994 - $15 \mathrm{~s}$.

[9] Rubinshtejn, S.L., Osnovy obshchej psihologii: uchebnoe posobie. - Sankt-Peterburg: Piter, 2007. - 713 s.: il. - (Mastera psihologii)

[10] Alymov, S.S., P.I. Kushner i razvitie sovetskoj etnografii v 1920-1950-e gody. - M.: IEA, 2006. -278 s.

[11] Zharyqbaev, Q., Qaliev S. Qazaq talim-tarbiesi. - Almaty: Sanat, 1995. - 350 b.

[12] Dreev, O.I., Hamicaeva Z.A. Etnokul'turnaya zashchita i problema formirovaniya grazhdanskoj identichnosti / Materialy III Mezhdunarodnoj nauchnoj konferencii Polikul'turnoe obrazovanie kak osnova sohraneniya yazykovogo naslediya i kul'turnogo raznoobraziya chelovechestva [Tekst]. - Vladikavkaz: Izd-vo SOGPI, 2010. - S. 91 - 94.

\title{
ХАЛЫҚТЫҚ ПЕДАГОГИКА ТҰЖЫРЫМДАМАСЫН ҚАЛЫПТАСТЫРУ ЖӘНЕ ОНЫН СИПАТТЫҚ ЕРЕКШЕЛІКТЕРІ
}

\author{
Зубайраева 3.A. ${ }^{\text {, }, ~ п е д а г о г и к а ~ ғ ы л ы м д а р ы н ы ң ~ к а н д и д а т ы ~}$ \\ Касимбекова Б.А. ${ }^{2}, \mathrm{PhD}$ \\ Аубакирова А.А. ${ }^{1}$, педагогика ғылымдарының магистрі \\ Жакупова А.Б. ${ }^{1}$, магистрант

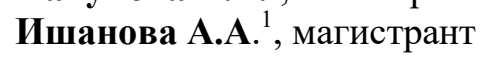

\footnotetext{
${ }^{1}$ А.Мырзахметов атындавы Көкиетау университеті, Көкшетау к.., Қазақстан Республикасы

${ }^{2}$ Хальққаральққ гуманитарльљқ -техникальқ университеті, Шымкент қ. Қазақстан Республикасы
}

Андатпа. Бұл мақала басқа гуманитарлық ғылымдар сияқты ұлттық ерекшеліктерге, халықтың дәстүрлі құндылықтарына негізделген этнопедагогиканың зерттеу пәні болып табылатын халықтық педагогикаға арналған. Мақалада әр халықтың әлемдік мәдениетке қосқан үлесін бағалау үшін фольклорлық өнерді зерделеудің маңыздылығы айтылады, сонымен қатар, этопедагогиканың басқа гуманитарлық ғылымдар арасындағы орны мен рөлі талданады, сондайақ, әлемдік өнер контекстінде халық шығармашылығы зерттеледі.

Ғылыми мақалада авторлар халықтық педагогиканың қазіргі білім беру саласындағы маңызы мен болашақ мамандардың ерекшеліктерін нақты түсіндірген.

Бұл мақаланың мақсаты - балашақ мамандарға жас ұрпақты тәрбиелеудің дәстүрлі халықтық әдістерін меңгеруге және бұл білімді мектепте және мектептен тыс мекемелерде қолдануға көмектесу болып табылады. Болашақ мамандар, яғни студенттер гуманистік, ақылойлық, экологиялық және құқықтық, еңбек-экономикалық, дене және эстетикалық тәрбиенің дамуы туралы дәстүрлі көзқарастарды зерттеуге көмектесетін материалдарды таба алады. Олар прогрессивті және консервативті дәстүрлер, білім беру жүйесінде халықтық тәрбиелеу әдістерін қолдану мүмкіндіктері туралы білім ала алады. 
Қысқаша айтқанда, бұл мақалада болашақ мамандарға арналған көптеген ақпарат бар деп айтуға болады.

Кілт сөздер: этнопедагогика, халықтық педагогика, ақыл-ой тәрбиесі, дәстүр мен әдетzұрып.

\title{
FORMATION OF THE CONCEPT OF FOLK PEDAGOGY AND ITS CHARACTERISTIC FEATURES
}

\author{
Zubairaeva Z.A. ${ }^{1}$, candidate of pedagogical sciences \\ Kasimbekova B.A. ${ }^{2}, \mathrm{PhD}$ \\ Aubakirova A.A. ${ }^{1}$, master of pedagogical sciences \\ Zhakupova A.B. ${ }^{1}$, master student \\ Ishanova A.A. ${ }^{1}$, master student \\ ${ }^{1}$ Kokshetau University named after A. Myrzakhmetov, Kokshetau, Republic of Kazakhstan \\ ${ }^{2}$ International Humanitarian and Technical University, Chimkent city, Republic of Kazakhstan
}

Annotation. This article is devoted to folk pedagogy. The article notes the importance of studying folk art for assessing the contribution of each nation to world culture, the article analyzes the place and role of ethono pedagogy among other humanities, and also examines folk art in the context of world culture.

In addition, the article explains the importance of folk pedagogy in the field of modern education, features and future specialists.

The purpose of this article is to help students master traditional folk methods of educating the younger generation and apply this knowledge in school and out-of-school institutions. Future specialists students can find materials that will help them study traditional views on the development of humanistic, mental, environmental and legal, labor and economic, physical and aesthetic education. They can gain knowledge about progressive and conservative traditions, about the possibilities of using folk methods of upbringing in the education system.

Thus, it can be said that this article contains a lot of information for future professionals.

Keywords: ethnopedagogy, folk pedagogy, mental education, traditions and customs. 


\title{
DEVELOPMENT OF THE INNOVATIVE POTENTIAL OF UNIVERSITY TEACHERS IN ADDITIONAL PROFESSIONAL EDUCATION
}

\author{
Yakubova D.E., master's student \\ nice_diva@bk.ru, https://orcid.org/0000-0002-7051-7668 \\ Saparkyzy Zh., PhD \\ 793@mail.ru, https://orcid.org/0000-0001-8784-2742
}

Kyzylorda University named after Korkyt Ata, Kyzylorda city, Republic of Kazakhstan

\begin{abstract}
Annotation. The article considers the theoretical foundations of the creation and understanding of the effectiveness of the development of innovative potential of teachers of universities with a personal point of view. The result of the innovation process in education is the application of innovations in theory and practice. Innovation in the education system is the introduction of innovations for the purpose of education, the transformation of new approaches and practices and forms of education, the introduction and dissemination of new pedagogical systems, the creation, development and implementation of new school management technologies. to meet the new requirements. The concept of an innovative educational process as a system of primary values characterizes it as spiritual production, and its product is not only the acquisition of new knowledge and values, but also the disclosure of the true strengths and abilities of students. Innovations in education are based on socially significant values: people, life, work, home land. This is considered as an indispensable condition for creating an effective model for the development of innovation potential of teachers of universities at the expense of using innovations in additional professional education. The basic concept of "innovative potential of university teachers" is defined. The purpose of this article is to consider the theoretical aspects of the development of innovative potential of teachers in the system of additional professional education.
\end{abstract}

Keywords: pedagogy, innovation, innovation potential, additional professional education, university teachers

Introduction. Nowadays the society of our country sets very high standards for the training and competence of university teachersand relevance of the research topic. Higher educational institutions, being the centers for the creation of innovative educational concepts, are constantly searching for the optimal way to form and develop creative qualities of a person [1]. Modern education should be based not only on disciplines, but also on the ways of thinking and functions of students. In the educational process, it is also important to develop the following qualities in students: creative activity, creative thinking, quick adaptation to changing market needs, the ability to evaluate, etc.An innovative approach to the professional and pedagogical activity of a university teacher is becoming a daily reality of an effective and competitive university [2].

These days, there is a need for the teachers who have a non-standard and an innovative approach to modern educational processes, who have creativity and who can think creatively, who can contribute to the development and change of society [3]. The task of any university is not only to train highly qualified specialists, but also to teach students to create new technologies in the educational process, to adapt them to the conditions of the production environment [4]. Currently, the high-quality training of university teachers for innovative activities is complicated by some inconsistencies in the system of professional retraining. Ensuring the readiness of university teachers for innovative activities, their ability to solve the problems of innovative education that arise in the structure and content of professional and pedagogical activities, the development of the teacher's innovative potential is one of the priority areas of work with teachers. all university levels [5]. 
A modern university teacher, not only competence and professional knowledge, but also openness to innovative changes, manifestation initiative and readiness to constantly improve and learn new things. Continuity of education at the faculty level, primarily turn, provides a system of additional professional education, which allows you to acquire the most relevant and demanded knowledge and skills, and thus improve the competence of an individual [6]. The peculiarity of the professional activity of a university teacher is that it consists of several interrelated types that have complex and common components. The versatility of a teacher's professional activity is expressed in his ability to combine different areas, to creatively perform several types of activities at the same time. The unity of theoretical and practical professional knowledge of the teacher and his competence, which is characterized by his readiness for teaching, self-development and improvement [7].

A individual abilities and resources of a higher school teacher that allow generating innovative ideas and behaviors, the ability to correlate the internal capabilities of the individual and the conditions of activity, analyze the situations of the modern educational space, transform traditional approaches into innovative teaching methods and technologies.It should be emphasized that designing and managing an innovation system by a university teacher is not an end in itself [8]. Ultimately, it should have access to practice, contribute to the development and self-development of an innovative culture of the individual. If we consider the development of the university's innovation system as a necessary component of managing the process of professional and personal development of a teacher and a student by creating favorable conditions for this, the most significant of them should be recognized as the presence of an innovation system in the university and an organized innovation space in the environment surrounding the subjects of innovative activity, created and functioning on a humanistic basis[9]. Therefore, a university teacher should remember about the social and personal meanings of innovative education and that the educational environment of the university in the unity of its main components acts as a complex form of organization of the fundamental factors of the student's personality development, her creative potential [10].

Ensuring the readiness of university teachers for innovative activities, their ability to address the issues of innovative education arising in the professional and pedagogical process' structure and content, the development of teachers' innovative potential has become one of the priorities teachers' work [11]. The purpose of this article is to consider the theoretical aspects of the developing theteachers' innovative potential in additional vocational education. This goal requires the solution of the following tasks:

-to identify and describe the features of the developing the university teachers' innovative potential in the system of additional professional education;

-to highlight the central tools for developing the innovative potential of university teachers in additional professional education through the use of innovations in pedagogical process;

Based on the sources for the system of professional retraining and advanced training of scientific and pedagogical staff, it is possible to highlight this system's main characteristics. According to them, in recent years, the system of professional retraining and advanced training of scientific and pedagogical staff has undergone various changes and updates in the selection of forms, methods and technologies of teaching, revision of the content [12].

According to scientists (L.S. Vygotsky, A.N.Leontiev, S.L. Rubinstein, etc.) "any ability must be formed and developed in the appropriate manner" [13]. N.E. Kopytova stated that "in professional process, the innovative qualities of a university teacher can be seen as his ability to combine different areas, such as the ability to perform several activities creatively at once. In connection with the implementation of different types of professional activities, a university teacher performs various functions that can be divided into two blocks: 
1) traditional: educational and technological, educational and humanistic, communicative and organizational and research functions;

2) innovation: creative development, constructive design, innovation and entrepreneurial activity [14].

The professional innovative activity of the university teacher was carried out by E.A. Rogacheva, who believes that this activity is "an integral part of the university's professional processwhichis aimed at achieving innovative results" [15].

Research method. In the XXI century, a university teacher must be able to organize all types of pedagogical process in a non-standard way, using a variety of innovative approaches, using their own and creative solutions. This can be done by stimulating and updating the internal motivation of the university teacher, and is one of the prerequisites for the development of teacher's innovative qualities.

The innovative potential of a teacher is a combination of the sociocultural and creative qualities of an individual, which means the teacher is ready to improve his professional and pedagogical activities, as well as the presence of internal tools and methods that ensure this training.The innovative activity of a teacher is a prerequisite for his professional development.Key innovative competence is one of the most important tasks facing the system of advanced training of scientific and pedagogical personnel.

To implement the innovation process in higher education, it is necessary to develop the infrastructure of the innovation system of the university as a set of subjects of the innovation activity of the university, which contributes to the implementation of activities, including the provision of services to universities. creation and sale of innovative products. The infrastructure of the university's innovation system, including student structures, technology transfer centers, innovation and technology centers, technology parks, business incubators, commercialization offices, innovation training centers, innovation-active departments, laboratories, etc.

It is very important to take into account the individual approach to each teacher, to allow them to choose innovative solutions when designing the professional direction of teacher training and professional development in higher education. Creating the motivation for innovative process can be done by attracting creative ideas, arousing interest in innovative topics, formulating innovative problems, creating conditions for complete freedom forthe innovation process.Innovative learning is the process and result of such educational and educational activities that stimulate innovative changes in the existing culture, social environment.

Analysis. As part of the research strategy, 25 teachers were interviewed during the data collection. The survey was conducted using the survey method, which was done by using the Google Forms platform. The purpose of using this method is to determine the innovative skills of university teachers in additional education.

The survey included the following questions:

1. What do you think of innovation in education?

2. Do you have innovative potential?

3. What is the impact of developing the teachers' innovative potential?

4. What are the difficulties in the application of innovations in vocational education?

According to the results of a survey among teachers, the majority of teachers have a full understanding of "innovations in education" (Figure 1).

The results of the first question of the survey (What do you think of innovation in education?) show that 15 teachers have fully mastered innovation in education. As for the rest of the participants, 5 teachers said that they know the meaning of innovation, but do not practice it every day, while the other 5 teachers are not familiar with innovation in education at all. 


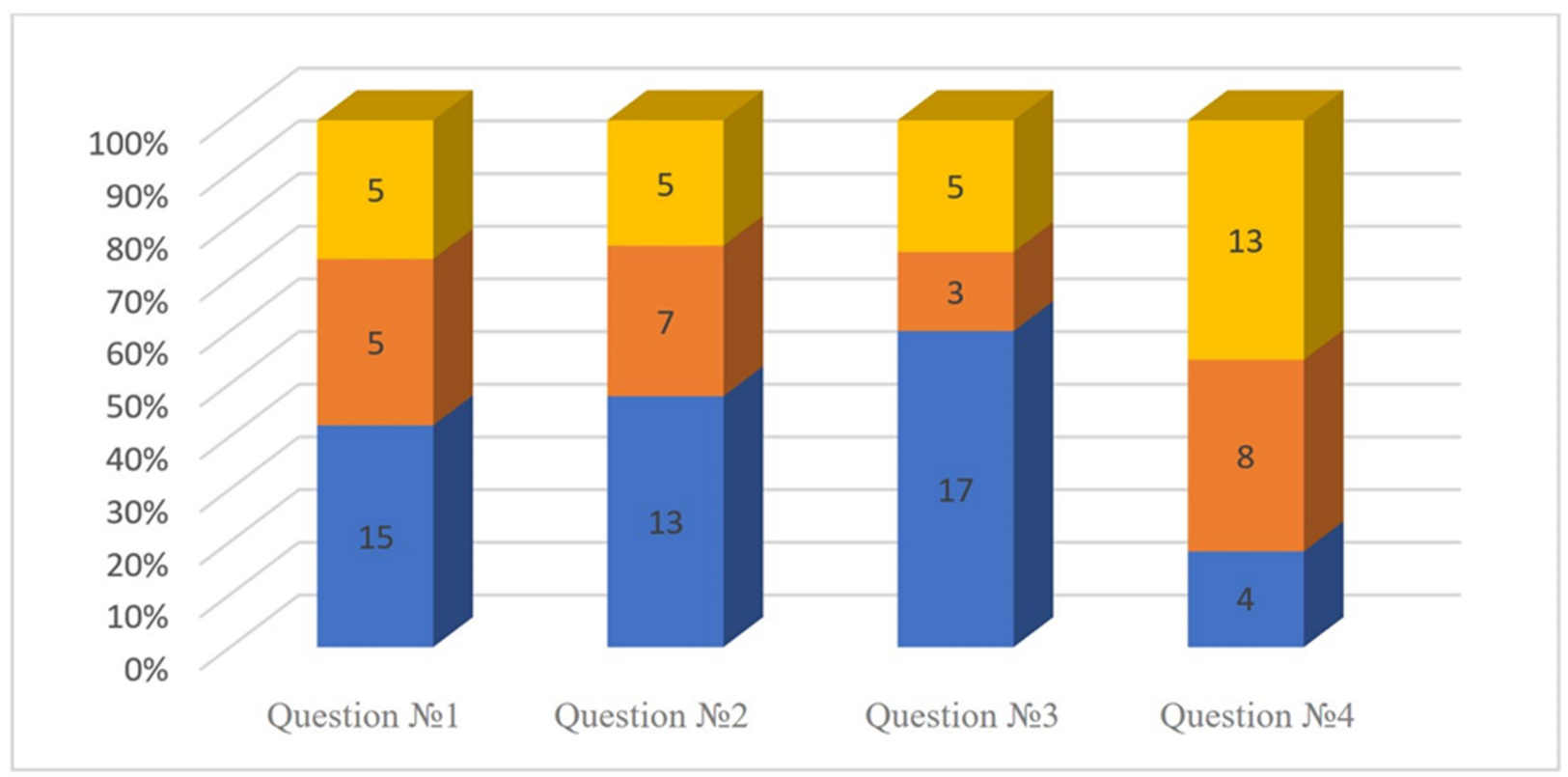

Diagram 1: Results of a survey among teachers [created by the author]

Conclusion. To the second question of the questionnaire (Do you have innovative potential?), 13 teachers answered "I have innovative potential", 7 of them answered "I do not have innovative potential", and 5 other teachers stated that they struggled to answer.

\section{Literature:}

[1] Абдалина, Л.В. Основные характеристики инновационного потенциала личности современного специалиста [Текст] / Л.В. Абдалина // Вестник Воронежского государственного технического университета. 2013. Т. 9, № 3 - 2. стр.131 - 134.

[2] Вербицкий, А.А. Преподаватель вуза в контексте реформы образования [Текст] / А.А. Вербицкий // Вестник Воронежского государственного технического университета. 2013. Том 9. № 5 - 2. С. 4 - 10 .

[3] Миронова, И.В. Педагогические условия развития инновационного потенциала преподавателя вуза в системе дополнительного профессионального образования [Текст] / И.В. Миронова // Педагогический журнал. 2018. Том 8. № 3А. С. 155 - 164.

[4] Копытова, Н.Е. Инновационные компетенции преподавателя вуза [Текст] / Н.Е. Копытова // Психолого-педагогический журнал Gaudeamus. 2013. №1 (21). C. 28 - 33.

[5] Рогачева, Е.А. Профессиональная деятельность современного преподавателя вуза: инновационный контекст [Текст] / Е.А. Рогачева // Вестник Ставропольского государственного университета. 2012. № 1. С. 146-150.

[6] Закон Республики Казахстан [Текст] / Об образовании \\Алматы 2008 с.

[7] Обращение Н.А. Назарбаева к народу Казахстана. [Текст] / Обращение Президента Казахстана \\ - 2050 г. Астана 2014.

[8] Закон Республики Казахстан [Текст] / Об образовании // Астана 27072007 № 319 -III.

[9] Бузаубакова, К.Ж. [Текст] / Формирование инновационной педагогической подготовки. Алматы. Писатель 2006, 258 - с.

[10] К.Р. [Текст] / Государственная программа развития образования // на 2011 - 2020 годы.

[11]Пригожин, А.И. [Текст] / Инновации: стимулы и препятствия социальных проблем инноваций.$/ /$ - М .: Политиздат. $-271 \mathrm{c.}$

[12]Медведев, В.П. [Текст] / Инновации как средство обеспечения конкурентоспособности организации .// - М .: Магистр. -159 с. 
[13] Исследовательские университеты США: механизм интеграции науки и образования [Текст] / под ред. Проф.//V.В. Супян. - М .: Мастер, 2009- 399 с.

[14] Кругликов, Г.И. Методика профессионального обучения с мастерской: учеб. Пособие для студентов высших учебных заведений. Учреждения [Текст] /Г.И. Кругликова. - 2-е изд., Стер. - М .: Издательский центр «Академия», 2007.

[15] Современные педагогические технологии в дополнительном образовании [Текст] / Нормативно-методическая статья // Внешкольн. - 1999, №7 - 8. - С. 37.

\title{
References:
}

[1] Abdalina, L.V. Osnovnye harakteristiki innovacionnogo potenciala lichnosti sovremennogo specialista [Tekst] / L.V. Abdalina // Vestnik Voronezhskogo gosudarstvennogo tekhnicheskogo universiteta. 2013. T. 9, № $3-2$. str.131 - 134 .

[2] Verbickij, A.A. Prepodavatel' vuza v kontekste reformy obrazovaniya [Tekst] / A.A. Verbickij // Vestnik Voronezhskogo gosudarstvennogo tekhnicheskogo universiteta. 2013. Tom 9. № 5 2. S. $4-10$.

[3] Mironova, I.V. Pedagogicheskie usloviya razvitiya innovacionnogo potenciala prepodavatelya vuza $\mathrm{v}$ sisteme dopolnitel'nogo professional'nogo obrazovaniya [Tekst] / I.V. Mironova // Pedagogicheskij zhurnal. 2018. Tom 8. № 3A. S. $155-164$.

[4] Kopytova, N.E. Innovacionnye kompetencii prepodavatelya vuza [Tekst] / N.E. Kopytova // Psihologo-pedagogicheskij zhurnal Gaudeamus. 2013. №1 (21). S. 28 - 33.

[5] Rogacheva, E.A. Professional'naya deyatel'nost' sovremennogo prepodavatelya vuza: innovacionnyj kontekst [Tekst] / E.A. Rogacheva // Vestnik Stavropol'skogo gosudarstvennogo universiteta. 2012. № 1. S. $146-150$.

[6] Zakon Respubliki Kazahstan [Tekst] / Ob obrazovanii \ Almaty 2008 s.

[7] Obrashchenie N.A. Nazarbaeva k narodu Kazahstana. [Tekst] / Obrashchenie Prezidenta Kazahstana \ - 2050 g. Astana 2014.

[8] Zakon Respubliki Kazahstan [Tekst] / Ob obrazovanii // Astana 27072007 № 319 -III.

[9] Buzaubakova, K.Zh. [Tekst] / Formirovanie innovacionnoj pedagogicheskoj podgotovki. Almaty. Pisatel' 2006, $258-\mathrm{s}$.

[10] K.R. [Tekst] / Gosudarstvennaya programma razvitiya obrazovaniya // na 2011 - 2020 gody.

[11] Prigozhin, A.I. [Tekst] / Innovacii: stimuly i prepyatstviya social'nyh problem innovacij .// M .: Politizdat, $-271 \mathrm{~s}$.

[12]Medvedev, V.P. [Tekst] / Innovacii kak sredstvo obespecheniya konkurentosposobnosti organizacii .// - M .: Magistr. $-159 \mathrm{~s}$.

[13] Issledovatel'skie universitety SSHA: mekhanizm integracii nauki i obrazovaniya [Tekst] / pod red. Prof. //V.B. Supyan. - M .: Master, 2009-399 s.

[14] Kruglikov, G.I. Metodika professional'nogo obucheniya s masterskoj: ucheb. Posobie dlya studentov vysshih uchebnyh zavedenij. Uchrezhdeniya [Tekst] /G.I. Kruglikova. - 2-e izd., Ster. - M .: Izdatel'skij centr «Akademiya», 2007.

[15] Sovremennye pedagogicheskie tekhnologii $\mathrm{v}$ dopolnitel'nom obrazovanii [Tekst] / Normativno-metodicheskaya stat'ya // Vneshkol'n. - 1999, №7 - 8. - S. 37.

\section{РАЗВИТИЕ ИННОВАЦИОННОГО ПОТЕНЦИАЛА ПРЕПОДАВАТЕЛЕЙ ВУЗОВ В ДОПОЛНИТЕЛЬНОМ ПРОФЕССИОНАЛЬНОМ ОБРАЗОВАНИИ}

\author{
Якубова Д. Э., магистрант \\ Сапаркызы Ж., доктор PhD \\ Кыззылординский университет имени Коркыт Ата, г.Кызылорда, \\ Республика Казахстан
}

\begin{abstract}
Аннотация: В статье рассматриваются теоретические основы создания и понимания эффективности развития инновационного потенциала преподавателей вузов с личностной точки зрения. Это рассматривается как необходимое условие для создания эффективной модели
\end{abstract}


развития инновационного потенциала преподавателей вузов за счет использования инноваций в дополнительном профессиональном образовании. Результатом инновационного процесса в образовании является применение нововведений в теории и на практике. Инновация в системе образования - это внедрение нововведений в целях образования, преобразование новых подходов и практик и форм обучения, внедрение и распространение новых педагогических систем, создание, развитие и внедрение новых технологий управления школой. чтобы соответствовать новым требованиям. Концепция инновационного образовательного процесса как системы первичных ценностей характеризует его как духовное производство, а его продуктом является не только приобретение новых знаний и ценностей, но и раскрытие истинных сильных сторон и способностей учащихся. Инновации в образовании основаны на социально значимых ценностях: человек, жизнь, работа, Родина. Определено основное понятие «инновационный потенциал преподавателей вуза». Целью данной статьи является рассмотрение теоретических аспектов развития инновационного потенциала учителей в системе дополнительного профессионального образования.

Ключевые слова: педагогика, инновачия, инновационный потенциил, дополнительное профессиональное образование, преподаватели вузов

\title{
ҚОСЫМША КӘСІПТІК БІЛІМ БЕРУДЕ ЖОО ОҚЫТУШЫСЫНЫҢ ИННОВАЦИЯЛЫК ӘЛЕУЕТІН ДАМЫТУ
}

\author{
Якубова Д. Э., магистрант \\ Сапарқызы Ж., доктор PhD \\ Қорқыыт Ата атындавы Қызыллорда университеті, Қызылорда қ., \\ Қазақ̆стан Республикасы
}

\begin{abstract}
Андатпа: Мақалада ЖОО оқытушысының жеке көзқарас тұрғысынан инновациялық әлеуетін дамытудың тиімділігін құру мен түсінудің теориялық негіздері талқыланады. Қосымша кәсіптік білім беруде инновацияларды қолдану арқылы университет оқытушысының инновациялық әлеуетін дамытудың тиімді моделін құрудың негізгі алғышарты ретінде қарастырылады. Білім берудегі инновациялық үдерістің нәтижесі теориялық және тәжірибелік жағынан жаңалықтарды қолдану болып табылады. Білім беру жүйесінде инновация білім беру мақсатына жаңалықтар енгізу, жаңа мазмұнды жаңа тәсілдер мен тәжірибелер және білім беру формаларын қайта жасауды, жаңа педагогикалық жүйені енгізу және таратуды,басқарудың жаңа технологияларын жасауды, дамытуды және мектеп жаңа білім беру бағытын ұстанғанда, оның мақсаты, мазмұны, әдісі жаңа талаптарға сай болуын жобалайды. Инновациялық білім беру үдерісінің бастапқы құндылықтар жүйесі ретіндегі түсінік оны рухани өндіріс ретінде сипаттайды, ал оның өнімі тек жаңа білім, құндылықтарды меңгеру емес, сонымен қатар оқушылардың шынайы күші мен әрекеттік қабілеттіліктерін ашу болып табылады. Білім берудегі инновациялар әлеуметтік маңызды құндылықтарға негізделеді, олар: адам, өмір, еңбек, Отан. «ЖОО оқытушысының инновациялық әлеуеті» негізгі тұжырымдамасы анықталады. Бұл мақаланың мақсаты - қосымша кәсіптік білім беруде мұғалімнің инновациялық әлеуетін дамытудың теориялық аспектілерін қарастыру.
\end{abstract}

Кілт сөздер: педагогика, инновачия, инновациялық әлеует, қосымша кәсіби білім, ЖОО оқытушылары 


\title{
CLUSTERS AS A SUBJECT OF MODERN ECONOMY
}

\author{
Smagulova Zh.B., master of economics \\ zchanna_555@mail.ru, https://orcid.org/0000-0002-3800-7983 \\ Mukhanova A.E., candidate of economics sciences \\ aia_mukanova@mail.ru, https://orcid.org/0000-0001-9332-2591 \\ Kyzylorda University named after Korkyt Ata, Kyzylorda city, Republic of Kazakhstan
}

\begin{abstract}
Annotation. The article is devoted to the analysis of clusters as a new factor of increasing competitiveness in the modern economy. The initial preconditions for the formation of clusters are described (the presence of competitive enterprises, presence of competitive advantages for cluster development in region, geographical concentration, an extensive selection of participants, existence of links and interactions between cluster entities). The characteristic features of clusters are given (the possibility of research and development; qualification of the workforce; improvement of labor potential, collective vision and leadership; proximity of suppliers and connections with them; availability of capital; access to specialized services; associated structures; intensity of network formation; entrepreneurial energy; innovation and training). The general features of cluster formations are characterized (presence of critical mass; specialization of firms on various aspects of the value chain; mainly horizontal structure of relations and regulation) The classification of clusters is given (by territorial coverage, by stage of cluster development, by degree of products novelty, by role in the system of exchange and use of knowledge, by presence and degree of development of elements in cluster structure, by level of aggregation of cluster participants, by nature of the industry of enterprises participating in the cluster). The models of cluster formation (Italian, Japanese, Finnish, North American, Indian-Chinese, etc.) are highlighted.
\end{abstract}

Keywords: cluster, economic competitiveness, innovation

Introduction. Maintaining the competitiveness of the national economy is among the primary tasks of any state. Economic processes in the modern world are under the influence of destabilizing factors at micro and macro levels, which encourages economic entities to look for new forms of economic activity to adapt to changing conditions and maintain their competitiveness. Currently, many countries are implementing investment and innovation policies, as well as regional economic policy, based on the concept of cluster development, the essence of which is to increase the competitive advantages of geographically close economic entities. The competitive potential of such geographically close economic entities is based on their effective interaction with each other, the joint use of technologies, innovations, highly qualified personnel, specialized services, infrastructure, etc. within the same cluster. Clustering of the economy is becoming an important tool for both regional development in general and stimulating innovative development [1].

The purpose of the article is to consider the features of clustersas an important factor of economic development in the context of modernization.

Material and methods. To achieve this goal, such research methods were used as the analysis of literary sources and documents in order to study the problem and determine the theoretical and methodological foundations of research; concretization, induction and deduction of theoretical knowledge; abstraction, classification and systematization of theoretical and experimental data on the research problem. 
Resultsofresearch. The cluster as an object of economic agglomeration of interconnected enterprises in a certain territory has been known since the days of handicraft production [2]. At the same time, economic science owes the origin of the cluster approach (1830-1890) to A. Marshall, who himself called them localized industries [3].

Subsequently (1890-1950), the name "industrial districts" became widespread in the literature [2]. The most popular term currently - "cluster" appeared much later. It is believed that the concept of "cluster" was introduced into the theory of economic relations by M. Porter [4]. He used the term "cluster" to analyze the structure and effectiveness of economic relations in industries and organizations. Analyzing the competitiveness of the company, he focused on its economic environment. Currently, the cluster is considered as a separate economic system, an integrated structure that have a significant impact on the development of both state industrial policy and the economy as a whole [2].

Clusters can be identified as a group of firms participating in a particular market, united on the basis of long-term agreements in order to effectively use resources and characteristic advantages for the collective implementation of entrepreneurial projects. By applying mainly horizontal connections, specialization and complementing each other, they gain the opportunity to achieve higher results. One of the distinctive features of the cluster can be considered targeted entrepreneurial activity, since within the cluster not only production and innovation businesses are combined, but also integrated product quality management and service. Combining the efforts of entrepreneurs, management bodies, subjects of investment and innovation activities in a particular territory brings significant success in the competitive struggle, promotes the rationalization of production and market processes, the redistribution of risks and the implementation of flexible policies necessary in a rapidly changing modern environment.

It should be emphasized that clusters form the conditions for attracting investments, since initiative, innovation, integration, information and interest, which are important for their organization, are considered significant points for the interest of participants.

The introduction of cluster technologies for merging companies contributes to the growth of business structures business activity, improvement of the investment climate in the country and its regions, development of social, economic, information and integration systems, giving impetus to more intensive improvement of entrepreneurship, attracting investment and economic growth of the country.

Developed clusters have five fundamental characteristics, of which the first three can be considered as the starting prebases for clustersformation [5].

1. Presence of competitive enterprises. The main condition for cluster development is the presence of enterprises that are competitive in the market within the cluster. The concentration of employment in enterprises can be one of the conditions for formation and development of a cluster. As an indicator of competitiveness, the level of productivity of enterprises and sectors included in the cluster, the level of goods and servicesexports, and economic ratings of companies' activities (for example, profitability and shareholder value) are considered.

2. Availability of competitive advantages in the region for cluster development. For example, a good geographical location, access and availability of natural, specialized and working resources, suppliers of components and services, suitable educational institutions and educational programs, organizations conducting research and development (R\&D), the necessary infrastructure, etc. As an indicator of competitive advantages, we can consider the high level of attracted foreign investment at the level of enterprises or sectors included in the cluster.

3. Geographical concentration. The central participants of the clusters are located in geographical proximity to each other and have the potential for active interaction. The geographical range may vary depending on type and characteristics of cluster, including one or more regions of the state. 
Various data characterizing the high level of region specialization can be presented as indicators of geographical concentration.

4. An extensive selection of participants and the presence of a "critical mass". A cluster may

consist of companies producing final goods and services, often exported abroad of a country or region, systems of suppliers of components, equipment and services, including professional educational institutions, research institutes and similar supporting associations. As indicators, high employment level in enterprises and sectors, as well as the number of companies and organizations belonging to these sectors and included in the clustercan be identified.

5. The existence of links and interactions between the cluster subjects. An important factor in the success of cluster development is the presence of working relationships and coordination of efforts between cluster members. These relationships can have all kinds of nature, include formalized relationships between the parent company and suppliers, between suppliers themselves, partnerships with suppliers of equipment and specialized services, links between companies, universities and research institutes in the framework of cooperation in the implementation of joint R\&D and educational programs [5].

The characteristic features of clusters can be reduced to ten indicators: 1 . the possibility of research and development; 2. workforce qualifications; 3. improvement of labor potential, collective vision and leadership; 4. proximity of suppliers and connections with them; 5 . availability of capital; 6 . access to specialized services; 7 . associated structures; 8 . intensity of network formation; 9. entrepreneurial energy; 10. innovation and training [6].

World practice demonstrates the role of clusters in economic development and increasing the competitiveness of regional and national economies, which is associated with their ability to combine scientific, educational and production potential, ensuring the competitiveness of enterprises, research organizations and educational institutions, having a multiplicative effect on the economy development, contributing to attracting investment and creating new jobs, namely:

1) the effect for cluster enterprises: increasing labor productivity, increasing profits, expanding sales markets, attracting investors, introducing modern technologies and innovations due to internal competition between cluster manufacturers;

2) effect on public authorities: budget increase, reduction of unemployment benefits, infrastructure development;

3) the effect on the regionaleconomy: the growth of the gross regional product, investment volumes, exports of high-tech products, employment and welfare of the population, etc [7].

All cluster formations have certain common features:

- the presence of a critical mass of firms and institutions located next to each other in the same geographical area and specializing in a set of interdependent economic activities;

- combination of spatial proximity with organizational, cultural proximity of firms, as well as proximity based on learning processes and knowledge exchange;

- specialization of firms on various aspects of the value chain - their complementarity is connected with this. Firms are integrated into the external division of labor, covering the entire process of economic relations from outgoing costs and suppliesto the release of the finished product;

- in addition to relations related to the production chain, firms are embedded in dense networks of social and cultural interdependencies unrelated to commercial activities, which provides opportunities for mutual learning, knowledge acquisition and strengthens cooperation based on mutual trust;

- the presence of a relatively evenly distributed decision-making process with the absence of a clear vertical hierarchy, i.e. a predominantly horizontal structure of relations and regulation; 
- gradual consolidation of the institutional structure, which means the emergence of public and private institutions and organizations capable of supporting the growth of the cluster by providing affordable services and putting forward certain initiatives [8]. In table 1 the main types of clusters are described (Table 1).

Table 1 - Classification of clusters

\begin{tabular}{|c|c|c|c|}
\hline $\begin{array}{l}\text { Authorsofthecl } \\
\text { assification }\end{array}$ & $\begin{array}{l}\text { Classification } \\
\text { feature }\end{array}$ & Selected types of clusters & Examples of clusters \\
\hline Porter M. & $\begin{array}{l}\text { By territorial } \\
\text { coverage }\end{array}$ & $\begin{array}{l}\text { National (extra-spatial) } \\
\text { Regional (linked to a } \\
\text { specific region) } \\
\text { Local (located in a specific } \\
\text { city) }\end{array}$ & $\begin{array}{l}\text { 1) Information Technology Cluster } \\
\text { in Israel } \\
\text { 2)Automotive cluster of Styria } \\
\text { (Austria) } \\
\text { 3)Entertainment Industry Clusterin } \\
\text { Hollywood (USA) }\end{array}$ \\
\hline $\begin{array}{l}\text { Andersson T., } \\
\text { Schwaag S. }\end{array}$ & $\begin{array}{l}\text { By cluster } \\
\text { development } \\
\text { stage }\end{array}$ & $\begin{array}{l}\text { "Precluster", or agglome- } \\
\text { rate } \\
\text { Nascent cluster } \\
\text { Developing cluster } \\
\text { Mature cluster } \\
\text { Transformingcluster }\end{array}$ & \\
\hline $\begin{array}{l}\text { Carlos A. } \\
\text { Carvaja, } \\
\text { ChihiroWatana } \\
\text { be }\end{array}$ & $\begin{array}{l}\text { According to } \\
\text { the degree of } \\
\text { products } \\
\text { novelty }\end{array}$ & $\begin{array}{l}\text { Industrialcluster } \\
\text { Innovation Cluster }\end{array}$ & $\begin{array}{l}\text { 1)Wine Cluster of California (USA) } \\
\text { 2)Bangalore ICT Cluster (India) }\end{array}$ \\
\hline $\begin{array}{l}\text { MehtaDh., } \\
\text { Shukla P. }\end{array}$ & $\begin{array}{l}\text { By size, based } \\
\text { on the level of } \\
\text { profit } \\
\text { from exports }\end{array}$ & $\begin{array}{l}\text { Small } \\
\text { Middle } \\
\text { Large }\end{array}$ & $\begin{array}{l}\text { 1)Entertainment Industry Cluster in } \\
\text { Hollywood } \\
\text { 2) Automotive Industry cluster in } \\
\text { Styria (Austria) } \\
\text { 3) Carpet cluster in Dalton (USA) }\end{array}$ \\
\hline OECD & $\begin{array}{l}\text { On the role in } \\
\text { the system } \\
\text { ofexchange and } \\
\text { use } \\
\text { ofknowledge }\end{array}$ & $\begin{array}{l}\text { Clusters based on a } \\
\text { scientific basis } \\
\text { Clusters of "intensive size" } \\
\text { Clusters of suppliers } \\
\text { Clusters of specialized } \\
\text { manufacturers }\end{array}$ & $\begin{array}{l}\text { 1)Pharmaceuticals, aerospace } \\
\text { industry } \\
\text { 2) Automotive industry, } \\
\text { food industry } \\
\text { 3) Logging 4) Manufacturers } \\
\text { of computer hardware components }\end{array}$ \\
\hline Bondarenko V. & $\begin{array}{l}\text { By the level of } \\
\text { aggregationof } \\
\text { cluster members }\end{array}$ & $\begin{array}{l}\text { 1) Clusters with a regiona- } \\
\text { lly limited form of econo- } \\
\text { mic activitywithin related } \\
\text { sectors } \\
\text { 2) Clusters with vertical } \\
\text { production links in narrow } \\
\text { fields of activity } \\
\text { 3) Industry clusters in } \\
\text { various types of production } \\
\text { with a high level of } \\
\text { aggregation }\end{array}$ & $\begin{array}{l}\text { 1) Software cluster in Boston (USA) } \\
\text { 2) Ski shoe cluster in Montebelluna } \\
\text { (Italy) } \\
\text { 3)Chemical cluster in Texas } \\
\text { (USA) }\end{array}$ \\
\hline $\begin{array}{l}\text { The concept of } \\
\text { cluster policy } \\
\text { in the Russian }\end{array}$ & $\begin{array}{l}\text { By the nature of } \\
\text { the industry of } \\
\text { the }\end{array}$ & $\begin{array}{l}\text { Process clusters } \\
\text { Discrete clusters } \\
\text { Innovation clusters }\end{array}$ & $\begin{array}{l}\text { 1)Chemical, pulp and paper, } \\
\text { metallurgical clusters } \\
\text { 2) Automobile cluster, aircraft and }\end{array}$ \\
\hline
\end{tabular}




\begin{tabular}{|l|l|l|l|}
\hline Federation & $\begin{array}{l}\text { enterprisespartic } \\
\text { ipatingintheclus } \\
\text { ter }\end{array}$ & $\begin{array}{l}\text { Tourist clusters } \\
\text { Transport and logistics } \\
\text { clusters }\end{array}$ & $\begin{array}{l}\text { aircraft engine cluster } \\
\text { 3) Cluster of biotechnologies, } \\
\text { cluster of information technologies, } \\
\text { cluster of new materials } \\
\text { 4) Tourist cluster } \\
\text { 5) Transport and logistics cluster }\end{array}$ \\
\hline \multicolumn{2}{|l}{ Note - based on the source [2] } & \\
\hline
\end{tabular}

A significant role in the creation of clusters in most countries is played by the state. Even in countries with highly developed economies, the scale of the task of building large cluster structures and the high cost of such projects require the participation of the state as a pioneer supporting cluster initiatives of business and sharing specific risks with it. In addition, the most important task of the state, together with leading experts, is the institutionalization of clusters as part of the national innovation and economic systems. Without this, it is difficult to talk about the normal integration of clusters into the structure of modern economy.

An equally important function of the state is the development of cluster policy. It is understood as a unified system of state and social mechanisms for supporting both existing clusters and initiatives for their formation. The aim of cluster policy is to ensure a sufficient level of competitiveness of both individual enterprises and the regions in which they are formed. That is why, in the understanding of regional authorities, clusters are "growth points" of the regional economy, providing high rates of creation and commercialization of innovations.

The cluster policy of different states differs significantly from each other, focusing on the specifics of the regulatory framework, the conditions and principles of doing business and specific country risks. For example, Germany, the USA and Scotland invest significant resources in stimulating cluster integration, while countries such as France and Russia prefer a targeted approach involving support for specific projects in priority areas of technology development [9].

World experience conditionally identifies six models of cluster formation.

1. Italian: a large number of small firms united in various associations to increase competitiveness. The model is applicable for products of low technological level with a high degree of differentiation and fluctuations in demand.

2. Japanese: formed around a leading company with large-scale production, integrating a mass of suppliers at various stages of the chain. It is applicable for the production of technologically complex products. Product development requires high fixed costs, which can only pay off with a large volume of sales.

3. Finnish: characterized by a high level of innovation, supported by a powerful research and development sector, a developed education system. The internationalization of business is characteristic. It is most applicable for small compact countries, relatively scarce in natural resources and export-oriented.

4. North American: characterized by pronounced competition between enterprises, applicable if the production process does not involve the establishment of close relationships. Due to competition between suppliers in the cluster, as well as due to mass production at the parent company, a low cost of the final product is achieved.

5. Indo-Chinese: the key role is played by the state. The main focus is on foreign investments, they bring modern technologies and give access to world markets.

6. Soviet: market relations and competition are minimized, production is concentrated on large firms. It is applicable in the raw materials industries of regions with low population density and poor development [10].

Conclusion. In conclusion, we can say that clusters play the role of growth points for the modern economy. Cluster policy is effective for increasing the level of competitiveness of 
individual regions or the country as a whole. The cluster contributes to the achievement of a specific economic effect and enhances the competitive superiority of individual companies and industries in the modern world

\section{References:}

[1] Бахшян, Э.А. Кластеры в современной экономике: сущность, характерные черты и генерируемые эффекты // Теоретическая и прикладная экономика. - 2019, № 1. - C. 64-74. DOI: 10.25136/2409-8647.2019.1.28209 URL:https://nbpublish.com/library_read_article.php?id=28209

[2] Бабкин, А.В., Новиков А. О. Кластер как субъект экономики: сущность, современное состояние, развитие // Научно-технические ведомости Санкт-Петербургского государственного политехнического университета. Экономические науки. - 2016, №1 (235). URL: https://cyberleninka.ru/article/n/klaster-kak-subekt-ekonomiki-suschnost-sovremennoe-sostoyanierazvitie.

[3] Маршалл, А. Принципы экономической науки. Т. 3. М.: Прогресс. - 1993. 351с.

[4] Porter, M.E. The Competitive Advantage of Nations. NewYork: FreePress. - 1990.

[5] Буга, А.В., Кудряшов В.С. Эффективность кластерного подхода в развитии региональной экономики // Экономика и управление. - 2017, № 3 (137)

[6] Кудряшов, В.С. Анализ развития экономики европейских стран на основе кластерного подхода //Дизайн. Материалы. Технология. - 2012, № 3 (23).С. 105-107.

[7] Савзиханова, С.Э. Роль кластера в развитие экономики региона и повышение его конкурентоспособности // Российское предпринимательство. - 2014, №15 (261). URL: https://cyberleninka.ru/article/n/rol-klastera-v-razvitie-ekonomiki-regiona-i-povyshenie-ego-

konkurentosposobnosti.

[8] Рассадина, А.К., Роль кластеров в современной экономике: зарубежный опыт // Вестник Московского университета. Серия 6. Экономика. 2014. №5. URL: https://cyberleninka.ru/article/n/rol-klasterov-v-sovremennoy-ekonomike-zarubezhnyy-opyt.

[9] Голов, Р. Локализация становится инструментом формирования кластерной политики //Российская газета. - 2017. Спецвыпуск, № 149 (7315). URL:https://rg.ru/2017/07/07/kak-formiruetsia-i-realizuetsia-klasternaia-politika.html

[10] Исследование и анализ мирового опыта кластерной политики и её адаптация к условиям образовательной среды Москвы. 2012. URL:https://files.mai.ru/site/cluster/concept/ issledovanie-i-analiz-mirovogo-opyta-klasternoj-politiki.pdf.

[11] Мямлин, А.П. Синдром кластера // ПСЭ. - 2013, №2 (46). URL: https://cyberleninka.ru/article/n/sindrom-klastera.

[12] Городничая, Е.И. Зарубежный опыт государственного стимулирования формирования кластеров // Вестн. Моск. ун-та. Сер. 6. Экономика. - 2010, № 1.

субъект

[13] Бабкин, А.В. Интегрированные промышленные структуры как экономический

рынка: сущность, принципы, классификация // Вестник Астраханского государственного технического университета. Серия «Экономика». - 2014, № 4. - С. 7-23.

[14] Караева, Ф.Е., Шогенова 3. Х. Региональный кластер: сущностные подходы к определению //Петербургский экономический журнал. - 2013, №1. URL: https:/cyberleninka.ru/ article/n/regionalnyy- klaster-suschnostnye-podhody-k-opredeleniyu.

[15] Монастырный, Е.А., Инновационный кластер // Инновации. - 2006, №2. URL: https://cyberleninka.ru/article/n/innovatsionnyy-klaster.

\section{References:}

[1] Bahshyan, E.A. - Klastery v sovremennoj ekonomike: sushchnost', harakternye cherty igeneriruemyeeffekty // Teoreticheskaya I prikladnaya ekonomika. - 2019, № 1. - S. 64-74. DOI: 10.25136/2409-8647.2019.1.28209 URL: https://nbpublish.com/library_read_article.php?id=28209

[2] Babkin, A.V., NovikovA., O. Klaster kak sub"ektekonomiki: sushchnost', sovremennoesostoyanie, razvitie //Nauchno-tekhnicheskie vedomosti Sankt-Peterburgskogo 
gosudarstvennogo politekhnicheskogo universiteta. Ekonomicheskie nauki. - 2016, №1 (235). URL: https://cyberleninka.ru/article/n/klaster-kak-subekt-ekonomiki-suschnost-sovremennoe-sostoyanierazvitie

[3] Marshall, A. Printsipy ekonomicheskoi nauki. T.3. M.: Progress. - 1993. - 351 s.

[4] Porter, M.E. The Competitive Advantage of Nations. New York: Free Press. - 1990.

[5] Buga, A.V., Kudryashov V.S. Effektivnost' klasternogopodhoda v razvitii regional'noj ekonomiki // Ekonomikaiupravlenie. - 2017, № 3 (137)

[6] Kudryashov, V.S. Analiz razvitiya ekonomiki evropejskih stran na osnove klasternogo podhoda // Dizajn. Materialy. Tekhnologiya. - 2012, № 3 (23). - S.105-107.

[7] Savzihanova, S.E. Rol' klastera v razvitie ekonomiki regionaipovyshenie ego konkurentosposobnosti // Rossijskoe predprinimatel'stvo. - 2014, №15 (261). URL: https://cyberleninka.ru/article/n/rol-klastera-v-razvitie-ekonomiki-regiona-i-povyshenie-ego-

konkurentosposobnosti.

[8] Rassadina, A.K. Rol' klasterov v sovremennoj ekonomike: zarubezhnyj opyt // Vestnik Moskovskogo universiteta. Seriya 6. Ekonomika. - 2014, №5. URL: https://cyberleninka.ru/article/n/rolklasterov-v-sovremennoy-ekonomike-zarubezhnyy-opyt.

[9] Golov, R. Lokalizaciya stanovitsya instrumentom formirovaniya klasternoj politiki // Rossijskaya gazeta. 2017. Specvypusk, № 149 (7315). URL: https://rg.ru/2017/07/07/kak-formiruetsia-irealizuetsia-klasternaia-politika.html

[10] Issledovaniei analiz mirovogo opyta klasternoj politiki I eyo adaptaciya $\mathrm{k}$ usloviya mobrazovatel'noj sredy Moskvy. - 2012. URL:https://files.mai.ru/site/cluster/concept/issledovanie-ianaliz-mirovogo-opyta-klasternoj-politiki.pdf

[11] Myamlin, A.P. Sindrom klastera //PSE. - 2013, №2 (46). URL: https://cyberleninka.ru /article/n /sindrom-klastera (data obrashcheniya: 20.09.2021).

[12] Gorodnichaya, E.I. Zarubezhnyj opyt gosudarstvennogo stimulirovaniya formirovaniya klasterov // Vestn. Mosk. un-ta. Ser. 6. Ekonomika. - 2010, № 1.

[13] Babkin, A.V. Integrirovannye promyshlennye struktury kak ekonomicheskij sub"ekt rynka: sushchnost', principy, klassifikaciya // Vestnik Astrahanskogo gosudarstvennogo tekhnicheskogo universiteta. Seriya «Ekonomika». - 2014, № 4. - S. 7-23.

[14] Karaeva, F.E., Shogenova Z.H., Regional'nyjklaster: sushchnostnye podhody k opredeleniyu // Peterburgskij ekonomicheskij zhurnal. - 2013, №1. URL: https://cyberleninka.ru/article/n/regionalnyy-klaster-suschnostnye-podhody-k-opredeleniyu.

[15] Monastyrnyj, E.A. Innovacionnyj klaster //Innovacii. - 2006, №2. URL: https://cyberleninka.ru/article/n/innovatsionnyy-klaster.

\section{КЛАСТЕРЛЕР ЗАМАНАУИ ЭКОНОМИКАНЫН СУБЬЕКТІСІ РЕТІНДЕ}

Смагулова Ж.Б., экономика магистрі

МухановаА.Е., экономика ғылымдарының кандидаты

\section{Қорқыыт Ата атындавы Қызылорда университеті, Қызылорда қ.,Қазақстан Республикасы}

Аңдатпа. Мақалада кластерлер заманауи экономиканың бәсекеге қабілеттілігін арттырудың жаңа факторы ретінде қарастырылған. Кластерлерді қалыптастырудың алғышарттары сипатталған (бәсекеге қабілетті кәсіпорындардың болуы, өңірде кластерді дамыту үшін бәсекелестік артықшылықтардың болуы, географиялық шоғырлану, қатысушылардың кең таңдауы, кластер субъектілері арасындағы байланыстар мен өзара іс-қимылдың болуы). Кластерлерге тән белгілер келтірілген (зерттеу және даму мүмкіндігі; жұмыс күшінің біліктілігі; еңбек әлеуетін жетілдіру, ұжымдық пайымдау және басшылық ету; капиталдың болуы; мамандандырылған қызметтерге қол жеткізу; қауымдасқан құрылымдар; желілерді қалыптастыру қарқындылығы; кәсіпкерлік энергия; инновациялар және оқыту). Кластерлік құрылымдардың жалпы белгілері сипатталған (шекті массаның болуы; қатынастар мен реттеудің көлденең құрылымы; институционалдық құрылымды біртіндеп тығыздау және тағы да басқалар) Кластерлердіңклассификациясы келтірілген (аумақтық қамту бойынша, кластердің даму кезеңі бойынша, шығарылатын өнімнің жаңашылдығы дәрежесі бойынша, білімді алмасу және пайдалану жүйесіндегі рөлі бойынша, кластерлік құрылым элементтерінің болуы және даму 
дәрежесі бойынша, кластерге қатысушыларды агрегаттау деңгейі бойынша, кластерге қатысушы кәсіпорындар саласының сипаты бойынша). Кластерлерді қалыптастыру модельдері анықталды (итальян, жапон, фин, Солтүстік Америка, Үнді-Қытай, тағы да басқалар)

Кілт сөздер: кластер, экономиканың бәсекеге қ̧абілеттілігі, инновациялар

\title{
КЛАСТЕРЫ КАК СУБЬЕКТ СОВРЕМЕННОЙ ЭКОНОМИКИ
}

Смагулова Ж.Б., магистр экономики

МухановаА.Е., кандидат экономических наук

Кызылординский университет имени КоркытАта,г.Кызылорда, Республика Казахстан

\begin{abstract}
Аннотация. Статья посвящена анализу кластеров как нового фактора повышения конкурентоспособности в современной экономике. Описаныстартовые предпосылки для формированиякластеров (присутствие конкурентоспособных предприятий, наличие в регионе конкурентных преимуществ для развития кластера, географическая концентрация, обширный выбор участников, существование связей и взаимодействия между субъектами кластера). Приведены характерные признаки кластеров (возможность исследования и развития; квалификация рабочей силы; совершенствование трудового потенциала,коллективное видение и руководство; соседство поставщиков и связи с ними; наличие капитала; доступ к специализированным услугам; ассоциирующиеся структуры; интенсивность формирования сетей; предпринимательская энергия; инновации и обучение). Охарактеризованы общие черты кластерных образований (наличие критической массы; специализация фирм на различных аспектах стоимостной цепочки; преимущественно горизонтальная структура отношений и регулирования; постепенное уплотнение институциональной структуры и др.) Приведена классификация кластеров (по территориальному охвату, по стадии развития кластера, по степени новизны выпускаемой продукции, по роли в системе обмена и использования знаний, по наличию и степени развития элементов кластерной структуры, по уровню агрегации участников кластера, по характеру отраслипредприятий-участников кластера). Выделены модели формирования кластеров (итальянская, японская, финская, североамериканская, индийско-китайская, т.д.)
\end{abstract}

Ключевые слова: кластер, конкурентоспособность экономики, инновачии 


\title{
КАЗАҚСТАНДАҒЫ ПАНДЕМИЯ САЛДАРЫ: ЭКОНОМИКАЛЫК ЖАҒДАЙ ЖӘНЕ ДАМУ МУМКІНДІКТЕРІ
}

\author{
Шильманова А.М., экономика ғылымдарының кандидаты \\ altynsh@mail.ru, http://orcid.org/0000-0001-8376-1275 \\ Жайшылық А.П., докторант \\ aiko_93a@mail.ru,https://orcid.org/0000-0002-3707-5482
}

Қызылорда «Болашақу» университеті, Қызылорда құаласы, Қазақсстан Республикасы

Аңдатпа. Мақалада жаһанды жаулаған Covid-19 пандемиясы салдарынан пайда болған күрделі экономикалық жағдай баяндалған: кедейлердің жағдайы нашарлауы аясында байлардың табысының өсуі орын алу мүмкіндігі аталды. Экономиканың түрлі салаларындағықұрылымдық өзгерістер мазмұндалған. Сарапшылардың талдаулары келтірілген: көмірсутектер нарығындағы, ауыл шаруашылығындағы, құрылыс саласындағыахуал, халыққа көрсетілген қызметтер көлемі, тұтынушылық талап-тілектері сараланған.Мұнай бағасының Қазақстандағы өнеркәсіп өндірісіне әсері, Қазақстанның ЖІӨқалыптастыруға ауыл шаруашылығының қосқан үлесі, Құрылыс жұмыстары көлемінің өзгеру динамикасы, Халықтың қаржылай шығыстарының құрылымы келтірілген.

«Қарапайым заттар экономикасы» және «Бизнестің жол картасы» бағдарламаларының маңыздылығы аталған.

Жаңа әлемдік тәртіпті қалыптастыру жағдайында жүйелік реформаларға, Ұлт жоспары мен Бес институционалдық реформаға негізделген қуатты серпін қажеттігі аталып, экономикалық дамуға бағытталған стратегиялық мақсат нақтыланған.Қолайлы экономикалық жағдай қалыптасқан жағдайда Қазақстан дағдарысқа дейінгі деңгейге оралып, 2022 жылы қалыпты өсу траекториясына жететіні болжанған.Doing Business рейтингінде Қазақстанның позициясын жақсарту үшін жүйелі жұмыстар жүргізілу мүмкіндігі қарастырылған.

Кілт сөздер: пандемия, экономикалық жавдай, құрылымдық өзгерістер, даму мүмкіндіктері.

Kipicпе. Covid-19 пандемия қоғамдық өмірде көптеген үдерістердің жүруін жылдамдатты: жаңа ғылыми-технологиялық және әлемдік шаруашылық әрекеттерінтездете отырып, әлемдік экономикадағы құрылымдық өзгерістерге әкелді.

Пандемия тудырған дағдарыс және одан кейінгі локдаун әртүрлі салалардағы шаруашылық әрекеттер қарқынының төмендеуіне және азаматтардың еркін қозғалысының шектелуіне әкелді.

Жалпы экономикалық дамуыда оң үрдіс байқалғанымен, бүгінгі ахуал әлі де күрделі. Сондықтан, мемлекет басшысы Қ.Тоқаев«Қарапайым заттар экономикасы» және «Бизнестің жол картасы» бағдарламаларының мерзімін 2022 жылға ұластыру туралы шешім қабылдады.

Қазақстанда орта мерзімді экономикалық саясат айқындалып, 2025 жылға дейінгі дамудың Ұлттық жоспары және Мемлекеттік жоспарлаудың жаңа жүйесі қабылданды.

Экономикаға тікелей инвестиция тарту ісін жалғастырудың жаңа тәсілі ретінде «Стратегиялық инвестициялық келісім» ұғымы енгізілді [1]. Бұл, өз кезегінде, мемлекеттік бастамаларды реттеу үшін аса маңызды.

Материалдар және зерттеу әдістемелері. KPMG (аудиторлық, салықтық және консультациялық қызметтер көрсететін халықаралық фирмалар желісі) деректері бойынша ең осал тұстар азық-түлік емес бөлшек сауда, авиация, мұнай-газ, тау-кен өндіру, көлік, энергетика және коммуналдық секторлар болып табылады. 
Қазір барлық қазақстандық кәсіпкерлік субьектілері өздерінің айналым қаражатын оңтайландырудың, дағдарысқа қарсы іс-қимыл жоспарын әзірлеудің және енгізудің ісшараларын қолға алуда, ақша қаражатынқажетсінетін инвестициялық жобаларды кейінге қалдырып, оларды іске асырудың шығыны аз болатын нұсқаларын қайта қарастыруда.

Соңғы жылы қалыптасқан жағдай Қазақстандағы теңсіздікті күшейтті, бұл әлеуметтік қорғаудың жүйесініңәлсіздігіменкүрделене түсті. Осылайша, Human Rights Watch (бүкіл әлемде адам құқықтарының бұзылуы туралы тергеу жүргізетін және мәлімдейтін)ұйымыныңкедейлік пен теңсіздікті зерттеушлері «егер үкімет карантин кезінде және одан кейін шұғыл түрде қаржылық көмек көрсетпесе және кеңейтпесе, кедейлікке тап болған көптеген қазақстандықтар ауыр зардап шегуі мүмкін» деп болжады [2].

ЮНКТАД (United Nations Conference on Trade and Development - БҰҰ Бас Ассамблеясының органы) өкілдерінің пікірінше, әлемдік экономиканы «V» немесе «U» қалпына келтіру емес, «К» нысанындағы қалпына келтірукезіндекедейлердің жағдайы нашарлауы аясында байлардың табысының өсуі орын алады, бұның соңы теңсіздіктің өсуіне әкеледі [3].

Қазақстан Республикасы Президентінің жанындағы Қазақстан стратегиялық зерттеулер институтының экономиканы жоспарлы қалпына келтіру факторы ретінде экономиканың нақты секторынажәне пандемияның Қазақстандағы қызмет көрсету саласына әсеріне сараптамасы жасалған.

Зерттеу нәтижелері және оларды талқылау. 2020 жылы әлемдік экономика 4,3 пайызға қысқарды, бұл 2009 жылғы әлемдік қаржы дағдарысы кезіндегіден екі жарым есе артық. Біріккен ұлттар ұйымының Дүниежүзілік экономикалық есебіне сәйкес, 2021 жылы күтілетін қалыпты қалпына келтіру 4,7 пайыздық көрсеткіш өткен жылғы шығындарды өтей алмайды (1-Сурет) [4].

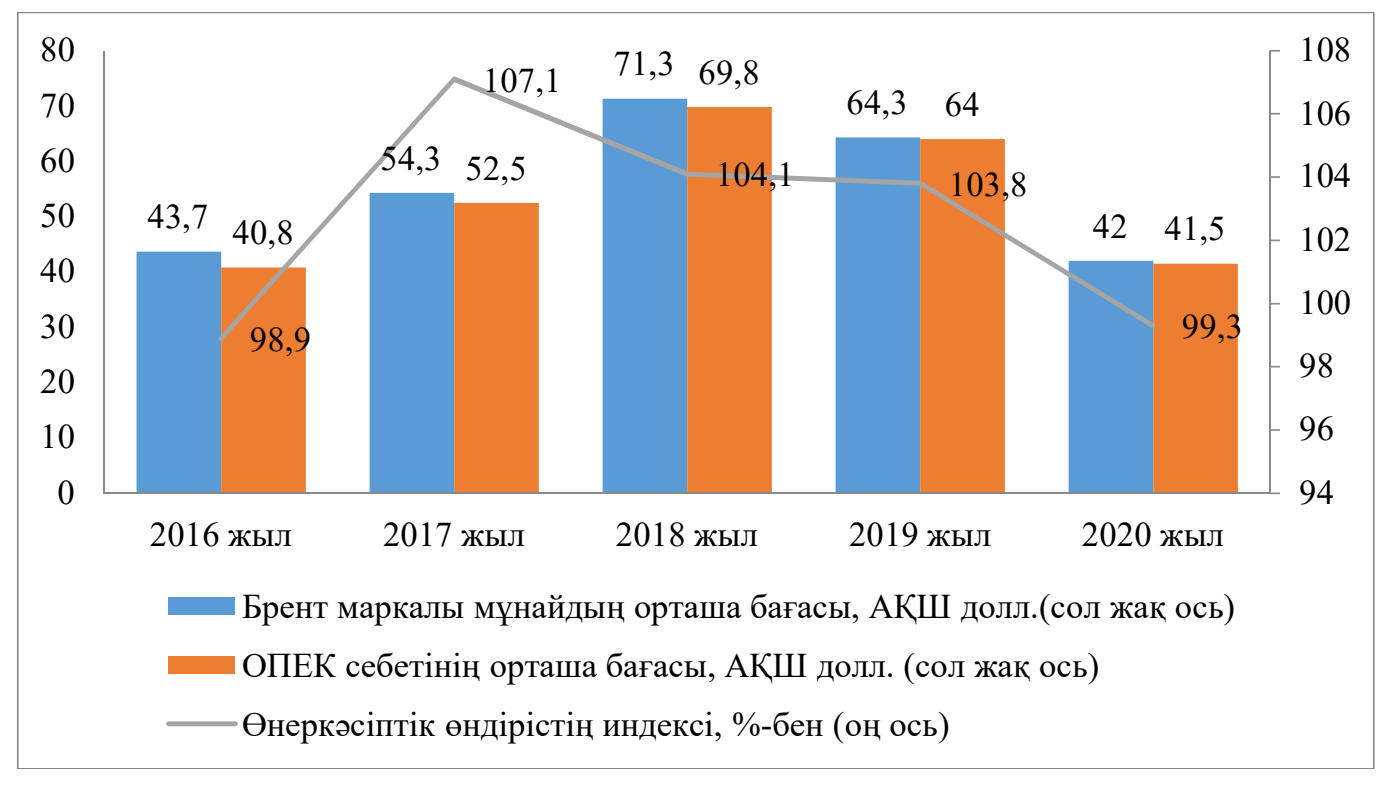

\section{1-Сурет - Мұнай бағасының Қазақстандағы өнеркәсіп өндірісіне әсері [7,8,9]}

Қазақстан экономикасының нақты секторы экономикалықөсудің негізгі, макроэкономикалық тұрақтылықтың негізі және қоғамдық жүйелердің тұрақты жұмыс істеуінің кепілікөзі десек, ол ұлттық жалпы ішкі өнімнің 38,6\%-ын қалыптастырады. Бұл ретте, мұнай-газ саласының кәсіпорындары мемлекеттік бюджетке салық түсімдерінің басым үлесін қамтамасыз ететіні белгілі [5]. 
Былтырғы жылы коронавирустық инфекция пандемиясының өршуі кезінде, көмірсутектер нарығындағы ахуал салдарынан Қазақстандағы өнеркәсіп өндірісі 2019 жылғы көрсеткішке қарағанда, 99,3\%-ға дейін төмендеді

Алайда, өңдеу өндірісінің тұрақты өсуіне байланысты өнеркәсіптік өндіріс индексінің күрт төмендеуіне жол берілмегенін атап өткен жөн. Өңдеу өнеркәсібіндегі өнеркәсіптік өндіріс индексі өткен жылы 103,9\%-ға дейін өсті, ал мұнай бағаларының әсер ету арнасы тау-кен өнеркәсібі көрсеткішінің 96,3\%-ға дейін төмендеу факторына айналды.

Экономиканың нақты секторының маңызды саласы - ауыл шаруашылығында, былтырғы жылы өндіріс көлемінің өсуі байқалды. Мемлекет тарапынан көрсетілген қолдау аясында осы бағыттағы өнімдер мен қызметтердің жалпы өндірісінің нарықтағы сұранысы өсті (2-Сурет).

Өндіріс көлемінің 21,2\%-ға ұлғаюы республиканың жалпы ішкі өнім құрылымындағы ауылшаруашылығының үлесін 2020 жылдың қорытындысы бойынша 5,3\%-ғадейін жеткізуге мүмкіндік берді.

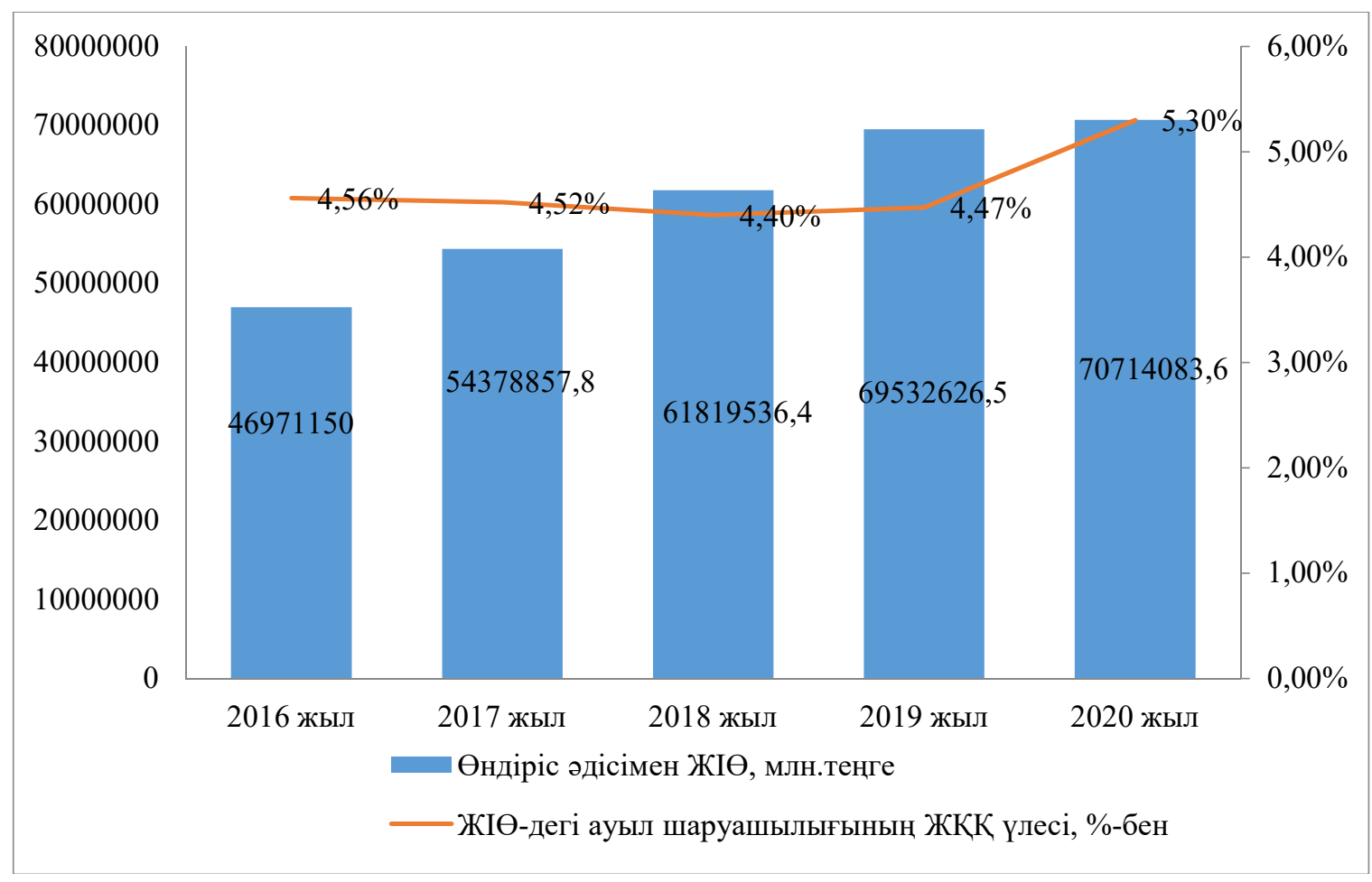

\section{2-Сурет - 2016-2020 жылдар аралығындағы Қазақстанның ЖІӨ қалыптастыруға ауыл шаруашылығының қосқан үлесі $[7,8,9]$}

Елдің ЖІӨ-не құрылыс секторының үлесін 6\%-ға дейін тұрғын үйді пайдалануға беру көлемінің ұлғаюы қамтамасыз етті. Енгізілген шектеу шараларына байланысты 2020 жылы құрылыс жұмыстары көлеміні өзгерді (3-Сурет). 


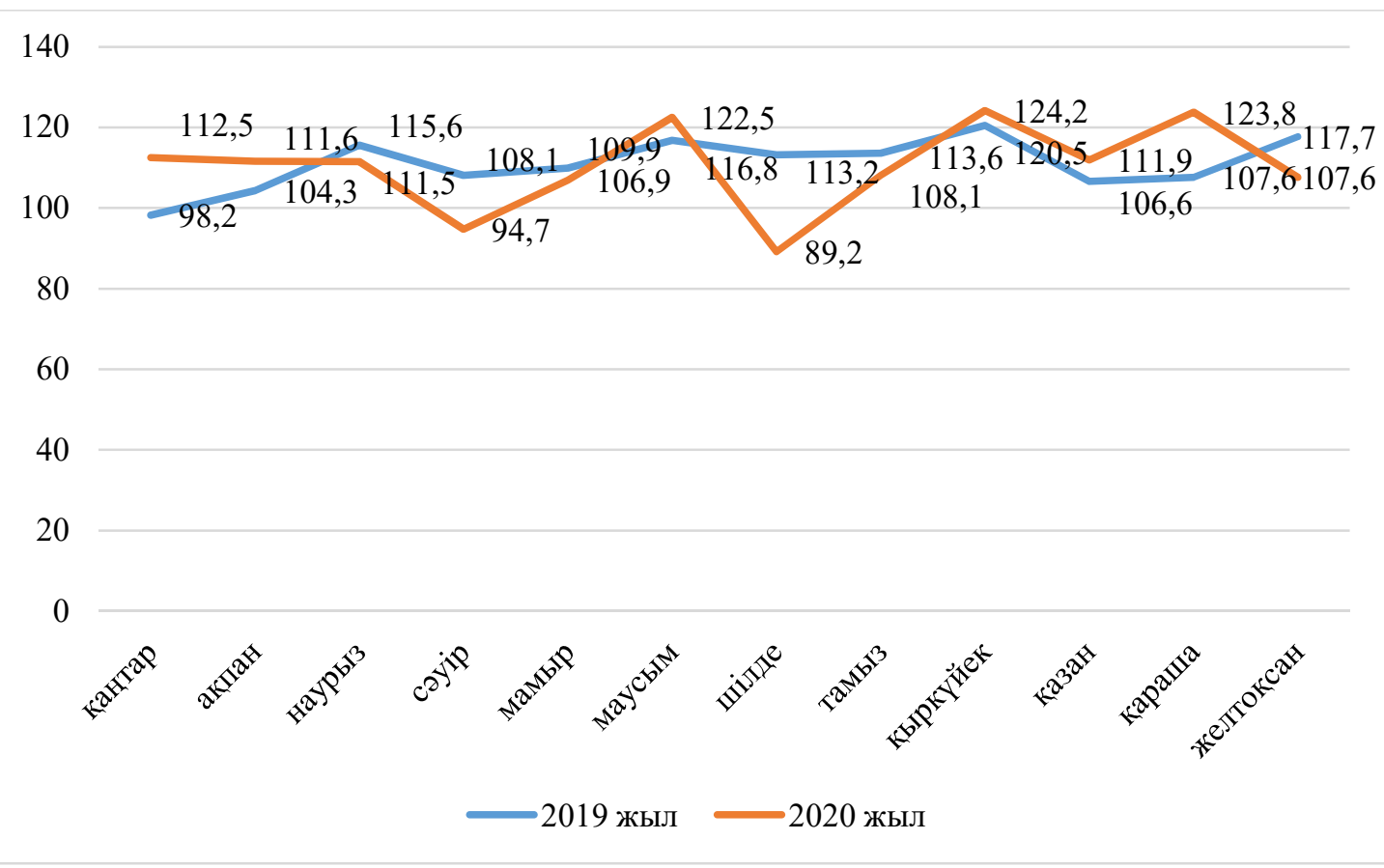

\section{3-Сурет - Құрылыс жұмыстары көлемінің өзгеру динамикасы \%-бен [7,8,9]}

Қатаң шектеулер кезеңінде тұрғын үйлерді пайдалануға берудің төмендегені байқалды. Дегенмен, 2020 жылы 15,3 млн. м² астам тұрғын үйді пайдалануға беру мүмкін болды, бұл 2019 жылмен салыстырғанда 16,8\%-ға артық.

Өңдеуші өнеркәсіптің орнықты болуы, ауыл шаруашылығы мен құрылыс секторындағы өсу қарқыны сыртқы әсерлердің ел экономикасына ықпалын бәсеңдетуге мүмкіндік берді.Қашанда тауарлар өндірісі Қазақстанның экономикалық саясатының аса маңызды басымдығы болып қала береді.

Бұл ретте, аталған салалар көрсетілетін мемлекеттік қолдау аясында,алдағы уақытта,ұлттық экономиканы жоспарлы қалпына келтіруді қамтамасыз етері сөзсіз. Осылайша, тұрғын үйді пайдалануға берудің оң серпіні ағымдағы жылдың алғашқы тоқсанында жалғасын тапты, ауыл шаруашылығындағы жалпы өнім 12 аймақта ұлғайды. Бұған қоса, өңдеуші өнеркәсіптің бірқатар салаларында да оң динамика байқалады. Нақты сектордың осы бағыттарында өндіріс көлемін одан әрі ұлғайту шаралары мұнай бағасын дағдарысқа дейінгі деңгейге келтірумен қатар ұлттық экономиканы «жандандыру» факторына айналады.

Экономикалық құлдырау халықтың кірісімен тауарларға деген сұраныстың қысқаруына,сондай-ақ халыққа ақылы қызмет көрсетусекторының баяулауына әкелді.

Халыққа көрсетілген қызметтер көлемі өткен жылы іс жүзінде шағын салалардыңедәуір бөлігінде төмендегені белгілі. Сонымен қатар, 2020 жылдың алғашқы 9 айындаақылы қызметтер көлемінің өсуіне негізінен жылжымайтын мүлік саласындағы операциялардың өсуі $(+51,2 \%)$ мен ақпараттық қызмет көрсету $(+30,1 \%)$ есебінен қол жеткізілді.

Айта кетерлік жайт, халықтың тұтыну белсенділігінің оң серпін алуына 2020 жылы нақтыжалақының (+7,3\%) өсуі де ықпал етті.

Халыққа ақылы қызметтердің бағасы орташа алғанда өткен жылға қарағанда 2020 жылы екіесе баяу өсті. Өткен жылдың сәйкес кезеңімен салыстырғанда қызметтерге тұтыну бағаларының индексі 3,3\%-ды құрады (2019 жылдың қаңтар-желтоқсанында бұл көрсеткіш 1,2\%болған). 
Кейбір салаларда баяулау одан да елеулі деңгейде болды. Мысалы, шипажайсауықтыру секторының және мәдениет пен ойын-сауық ұйымдарының көрсеткен қызметтеріне бағаныңөсу қарқыны, керісінше 1,8\% баяулап, тиісінше жылдық мәнде 4,1\%-ды көрсетті. Тамақтану және орналасу секторында да осыған ұқсас динамика байқалды - бағаның өсуі 2019 жылғы6,8\%-дан 4,7 дейін дейін төмендеді.

Ел тұрғындары, әсіресе қатаң карантин кезеңінде, өз тұтынушылық талап-тілектері мен талғамдарынбелсенді түрде қайта құрылымдады.Мысалы, 2020 жылдың 3-тоқсанында өткен жылғы осы кезеңмен салыстырғанда, халыққаражатының құрылымында неғұрлым қымбат тауарлар мен қызметтер түріндегі шығындарең аз көрсеткіш берді, ал азықтүліктің сатып алулардағы үлесі айтарлықтай өсті.

Өткен жылмен салыстырғанда азық-түлік тауарларына жұмсалған шығындардың үлес салмағы 49,9\%-дан 54,3\%-ға дейін көтерілді. Қызмет көрсету секторының шектеулі қызметі нәтижесінде халық арасында оған жұмсалатын шығыстар - 19,2\%-дан 14,7\%-ға дейін қысқарды. Алайда, карантиндік шектеулердің шыңында, яғни 2-ші тоқсанда, халықтыңжалпы көлеміндегі азық-түлікке жатпайтын тауарларға жұмсаған қаражатыаздап қысқарғаннан кейін,жыл соңына қарайқалпына келу өсімін көрсетті (4-Сурет).

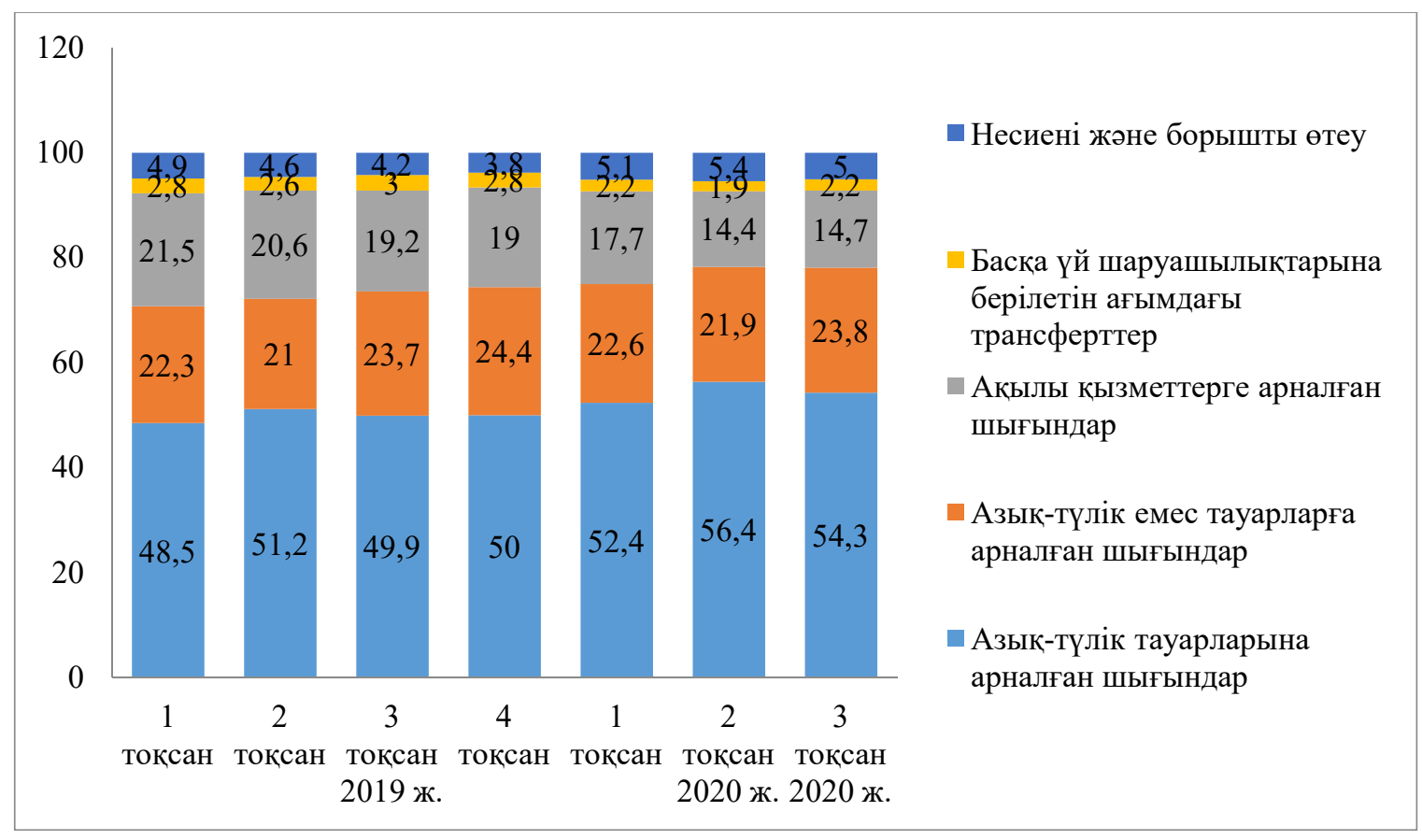

\section{4-Сурет - Халықтың қаржылай шығыстарының құрылымы (\%)}

Осылайша, қызмет көрсету саласындағы жағдай елдегі эпидемиологиялық жағдайдың дамуына және вирустың таралуын болдырмау үшін енгізілген шектеулердің сипатынажәне халықтың экономикалықәл-ауқатымен анықталды [6].

Қорытынды. 2018 жылы қабылданған 2025 жылға дейінгі Стратегиялық даму жоспары елдің үшінші жаңғыру процестерін іске қосып, сол арқылы экономиканың сапалы өсуі мен өмір сүру деңгейін жоғарылату міндеттерін айқындады.

Әлемде қалыптасқан жағдай және оны ауыздықтау шаралары соңғы жүз жылдағы ең ауыр ауқымды дағдарысқа алып келді. Осылайша пандемия мен жаһандық рецессияның ажырамас әсері Қазақстан дамуының негізгі сценарийін түбегейлі өзгертіп, «жаңа болмысты» қалыптастырды. 
Жаңа әлемдік тәртіпті қалыптастыру жағдайында жүйелік реформаларға, Ұлт жоспары мен Бес институционалдық реформаға негізделген қуатты серпін қажетболды. Осы орайда, Қазақстан Республикасының 2025 жылға дейінгі Ұлттық даму жоспарын басшылыққа алынып, оны іске асыру бойынша қажетті шаралар қабылданған болатын.

Ұлттық даму жоспарында: «2025 жылға дейін дамудың жаңа моделіне көшуде «қайта оралмайтын нүктеден» өту қажет» - делінген, яғни дамудың жаңа моделін қалыптастыру 7 негізгі қағидатқа негізделеді:

- игіліктер мен міндеттерді әділ бөлу;

- жеке кәсіпкерліктің жетекші рөлі;

- әділ бәсекелестік, кәсіпкерлердің жаңа буыны үшін нарықтар ашу;

- өнімділіктің өсуі, экономиканың күрделілігі мен технологиялығын арттыру;

- адами капиталды дамыту, жаңа типтегі білім беруге инвестиңиялар салу;

- экономиканы "жасылдандыру", қоршаған ортаны қорғау;

- мемлекеттің негізделген шешімдер қабылдауы және олар үшін қоғам алдындағы жауапкершілік.

Аталмыш жоспардың «Әртараптандырылған және инновациялық экономика құру» атты 8-жалпыұлттық басымдығының мәні: кәсіпкерлердің экономикалық белсенділігін ынталандыруға және дамытуға, жеке меншік пен бәсекелестікті тиімді қорғауға бағытталған кәсіпкерлікті дамытудың «жаңа күн тәртібі» енгізілуінде. Мұндағы негізгі нәтиже бәсекеге қабілетті отандық кәсіпорындарды қалыптастыру болады [10].

Сарапшылардың пікірінше, қолайлы экономикалық жағдай қалыптасқанда Қазақстан дағдарысқа дейінгі деңгейге 2021 жылдың екінші жартысында оралып, 2022 жылы қалыпты өсу траекториясына жете алады. Сонымен, биыл экономика 3,5-4\% деңгейінде өседі деп күтілуде, келесі жылы қалыпты өсім 2-2,5\% құрайды.

Құрылыс индустриясы қазақстандық экономиканың қозғаушы күші болып қала бермек:мультипликативті ықпалы зор.Осы салаға енгізілген 2,2 трлн. теңге көлеміндегі инвестиция арқылы 17 млн. м² құрайтын тұрғын үй пайдалануға беру жоспарланып отыр [11].

Өндіріс саласында шикізаттық емес салаларды, шағын және орта бизнесті қолдау мен дамытуға баса назар аударылады. ЖІӨ-ге қатысты шағын және орта бизнес үлесін 30\%, ал 2025 жылға қарай - 35\% дейін жеткізуге бағытталған стратегиялық мақсат қойылды. Бұл бағытта «Қарапайым заттардың экономикасы» бағдарламасына ерекше назар аударылады.Осы мақсаттарға жалпы көлемі, кемінде, бір триллион теңге қаржы бөлінді. Қаражаттарөңдеу өнеркәсібі және қызмет көрсету, агроөнеркәсіптік кешендегі өндіріс және қайта өңдеу бағыттары бойынша жүзеге асырылады. 2021 жылы ет, сүт өңдеуге, астық пен майлы дақылдарды терең өңдеуге және т.б. бағыттармен байланысты 40 инвестициялық жоба жүзеге асырылуда [12].

«Атамекен» Ұлттық кәсіпкерлер палатасының қатысуымен «Бастау» бағдарламасынан өткен өзін-өзі жұмыспен қамтыған және жұмыссыз адамдарға жеңілдікпен несие беру үшін микроқаржы ұйымдарын құру да оңтайлы ықпал етуде. Тағы бір назар аударатын бағыт - қайта қалпына келетін энергия көздерін дамыту. Қазіргі уақытта электр энергиясының жалпы көлемінде қайта қалпына келетін энергия көздерінің үлесі 2\% асты. Осы орайда, Мемлекет басшысы кеңейтілген отырыста Қазақстан Республикасы Үкіметінің алдына бірқатар негізгі міндеттерді қойды.

Сонымен қатар, Doing Business рейтингінде Қазақстанның позициясын жақсарту бойынша жүйелі жұмыстар жүргізілуде: 2025 жылға қарай осы рейтингте алғашқы 20 елдің қатарына ену мақсаты қойылған. Сонымен қатар, мемлекеттік жоспарлаудың жаңа жүйесі аясында қазіргі таңда кәсіпкерлікті дамыту тұжырымдамасын қалыптастыру жұмыстары жүргізілудежәне пандемиядан кейінгі кезеңде шағын және орта бизнесті дамытудың негізгі тәсілдері мен қағидаттары пысықталуда. 


\section{Әдебиеттер:}

[1] Мемлекет басшысы Қ.Тоқаевтың «Халық бірлігі және жүйелі реформалар - ел өркендеуінің берік негізі» аттыҚазақстан халқына Жолдауы. https://www.akorda.kz/kz/memleketbasshysy-kasym-zhomart-tokaevtynkazakstan-halkyna-zholdauy- 183555

[2] Казахстанскую экономику в постпандемический период обсудили в Клубе молодых экспертов при Сенате. https://www.inform.kz/ru/kazahstanskuyu-ekonomiku-v-postpandemicheskiyperiod-obsudili-v-klube-molodyh-ekspertov-pri-senate_a3792338

[3] https://gsb.nu.edu.kz/kz/n/2/a-postpandemic-world-what-awaits-the-economy-of-kazakhstan

[4] http://www.eurasiancommission.org/kk/nae/news/Pages/30-11-2020-1.aspx

[5] Экономиканың нақты секторы - экономиканы жоспарлы қалпына келтіру факторы. http://kisi.kz/images/KAZISS_SARAPTAMA/25-08-qaz.pdf

[6] 2020 жылы COVID-19 пандемиясының Қазақстандағы қызмет көрсету саласына əcepi.http://kisi.kz/images/KAZISS_SARAPTAMA/16-06-2021-2.pdf

[7] https://stat.gov.kz/

[8] https://www.opec.org

[9] https://www.statista.com/

[10] Қазақстан Республикасының 2025 жылға дейінгі Ұлттық даму Жоспары. https://adilet.zan.kz/kaz/docs/U1800000636

[11] Қазір экономиканы COVID-19 дағдарысына дейінгі қалпына келтіру міндеті тұр. https://www.inform.kz/kz/kazir-ekonomikany-covid-19-dagdarysyna-deyingi-kalpyna-keltiru-mindetitur-asel-benova a3745608? fbclid=IwAR28TLeOfrhEI8VTTIv NBzATQTim86hg5orA0YDkicsOteW0Tt1oSxIenFM

[12] Как будут поддерживать бизнес в постпандемический период.https://inbusiness.kz/ru/last/kak-budut-podderzhivat-biznes-v-postpandemicheskij-period

\section{References:}

[1] Memleket basshysy Қ.Тоқаevtyn «Halyq birligi zhane zhujeli reformalar - el erkendeuinin berik negizi» atty Kazakhstan halqyna Zholdauy.https://www.akorda.kz/kz/memleket-basshysy-kasymzhomart-tokaevtynkazakstan-halkyna-zholdauy-183555

[2] Kazahstanskuyu ekonomiku v postpandemicheskij period obsudili v Klubemolodyhekspertovpri Senate.

https://www.inform.kz/ru/kazahstanskuyu-ekonomiku-v-postpandemicheskiy-period-obsudili-v-klubemolodyh-ekspertov-pri-senate_a3792338

[3] https://gsb.nu.edu. $\overline{k z} / \mathrm{kz} / \mathrm{n} / 2 / \mathrm{a}-$ postpandemic-world-what-awaits-the-economy-of-kazakhstan

[4] http://www.eurasiancommission.org/kk/nae/news/Pages/30-11-2020-1.aspx

[5] Ekonomikanyn naqty sektory - ekonomikany zhosparly qalpyna keltiru faktory. http://kisi.kz/images/KAZISS_SARAPTAMA/25-08-qaz.pdf

[6] 2020 zhyly CŌVID-19 pandemiyasynyn Kazakhstandagy kyzmet korsetu salasyna aseri.http://kisi.kz/images/KAZISS_SARAPTAMA/16-06-2021-2.pdf

[7] https://stat.gov.kz/

[8] https://www.opec.org

[9] https://www.statista.com/

[10] Kazakhstan Respublikasynyn 2025 zhylga dejingi Ulttyqdamu Zhospary. https://adilet.zan.kz/kaz/docs/U1800000636

[11] Kazir ekonomikany COVID-19 dagdarysynadejingi qalpyna keltiru mindeti tur. https://www.inform.kz/kz/kazir-ekonomikany-covid-19-dagdarysyna-deyingi-kalpyna-keltiru-mindetitur-asel-abenova_a3745608?fbclid=IwAR28TLeOfrhEI8VTTIvNBzATQTim86hg kicsOteW0Tt1oSxIenFM

[12] Kak budutpodderzhivat' biznes $\mathrm{v}$ postpandemicheskij period. https://inbusiness. $\mathrm{kz} / \mathrm{ru} /$ last/kak-budut-podderzhivat-biznes-v-postpandemicheskij-period 


\title{
ПОСЛЕДСТВИЯ ПАНДЕМИИ В КАЗАХСТАНЕ: ЭКОНОМИЧЕСКОЕ СОСТОЯНИЕ И ВОЗМОЖНОСТИ РАЗВИТИЯ
}

\author{
Шильманова А.М., кандидат экономических наук \\ Жайшылык А.П., докторант \\ Кызылординский университет «Болашак», г.Кызылорда, Республика Казахстан
}

\begin{abstract}
Аннотация: В статье изложена сложная экономическая ситуация, вызванная глобальной пандемией Covid-19: вероятность увеличения доходов богатых за счет ухудшения положения бедных. Приведены структурные изменения в различных секторах экономики. Дан анализ экспертов: анализируется ситуация на рынке углеводородов, сельского хозяйства, строительства, объем услуг, оказываемых населению, потребительский спрос.Описано влияние цены нефти на промышленное производство в Казахстане, доля вклада сельского хозяйства в формирование ВВП Казахстана, динамика изменения объемов строительных работ, структура финансовых расходов населения.

Отмечена важность программ «Экономика простых вещей» и «Дорожная карта бизнеса».

Отмечена необходимость сильного импульса на основе системных реформ, Плана нации и пяти институциональных реформ в контексте формирования нового мирового порядка, уточнена стратегическая цель экономического развития.Ожидается, что при благоприятных экономических условиях Казахстан вернется к докризисному уровню и выйдет на траекторию умеренного роста в 2022 году. Предусматривается возможность улучшения позиции Казахстана в Рейтинге Doing Business при планомерной работе.
\end{abstract}

Ключевые слова: пандемия, экономическая ситуация, структурные изменения, возможности развития.

\section{CONSEQUENCES OF THE PANDEMA IN KAZAKHSTAN: ECONOMIC CONDITION AND DEVELOPMENT OPPORTUNITIES}

\author{
Shilmanova A.M., candidate of economic sciences \\ Zhaishylyk A.P., doctoral student \\ Kyzylorda University "Bolashak", Kyzylorda city, Republic of Kazakhstan
}

\begin{abstract}
Annotation. The article emphasizes obstacles of economic situation caused by the global Covid19 pandemic: such as an increase in the income of the rich at the expense of the worsening of the situation of the poor. Structural changes in various sectors of the economy are presented. The analysis of experts is illustrated: the situation on the market of hydrocarbons, agriculture, construction, the volume of services provided to the population, consumer demand is analyzed. Also, there is discussed the influence of the price of oil on industrial production in Kazakhstan, the share of the contribution of agriculture to the formation of Kazakhstan's GDP, the dynamics of changes in the volume of construction work, the structure financial expenses of the population.

The importance of the programs "Economy of Simple Things" and "Business Roadmap" was noted.

The need for a strong impulse based on systemic reforms, the Plan of the Nation and five institutional reforms in the context of the formation of a new world order was noted, the strategic goal of economic development was clarified. It is expected that, given favorable economic conditions, Kazakhstan will return to the pre-crisis level and enter the trajectory of moderate growth in 2022 . There is investigated the possibilities of improving the position of Kazakhstan in the Doing Business Rating through systematic work.
\end{abstract}

Keywords: pandemic, economic situation, structural changes, opportunities for development 


\section{ҚОЛЖАЗБАЛАРДЫ РӘСІМДЕУ ЖӨНІНДЕ АВТОРЛАРҒА АРНАЛҒАН НҰСКАУЛЫҚ}

«Қорқыт Ата атындағы Қызылорда университетінің Хабаршысы» журналында мақала жариялау үшін дайын ғылыми жұмысты автор(лар) Vestnik.korkyt.kz сайтындағы Онлайн мақала жіберу жүйесі арқылы, арнайы нұсқаулықты пайдаланып жіберуге болады (сонымен қатар, e-mail: khabarshy@korkyt.kz электронды поштасы арқылы қабылдау да қосымша жүргізіліп отырады). Мақала Word форматында Times New Roman шрифтінде жазылуы қажет. Жарияланым тілдері - қазақша, орысша, ағылшынша.

Журналда жариялау үшін жұмыс мәтінін ұсына отырып, автор өзі туралы барлық мәліметтердің дұрыстығына, мақалада плагиат пен әдебиеттерді заңсыз алып пайдаланудың басқа түрлері жоқтығына, пайдаланылған барлық мәтін, кестелер, сызбалар, суреттердің тиісті түрде рәсімделуіне кепілдік береді.

Қолжазбада жаратылыстану, техникалық, ауылшаруашылық, гуманитарлық және әлеуметтік ғылымдар саласындағы білім берудің өзекті мәселелері бойынша ғылыми зерттеулердің нәтижелері болуы керек. Мақаладағы дәйексөз тізімінде тек рецензияланған әдебиет көздері болуы тиіс.

Қолжазбада жаратылыстану, техникалық, ауылшаруашылық, гуманитарлық және әлеуметтік ғылымдар саласындағы білім берудің өзекті проблемалары бойынша ғылыми зерттеулердің нәтижелері болуы тиіс.

Мақала құрылымы мен безендірілуі:

1. Мақала көлемі 8 беттен аспауы тиіс.

2. Мақаланы құру схемасы (беті - A4, кітаптық бағдар, туралау - ені бойынша. Сол жақ, үстіңгі және төменгі жақтарындағы ашық жиектері - 2,5 см, оң жағында - 2,0 см. Шрифт: тип - Times New Roman, өлшемі (кегль) - 12)

- МРНТИ индексі - бірінші жолы, жоғарыдан, сол жақта (http://grnti.ru).

- DOI индексі;

- Мақала атауы - ортасына қалың қаріппен.

- Автордың (лардың) аты-жөндерінің бірінші қарпі мен тегі - ортаға.

- Ұйым, қала, елдің толық атауы (егер авторлар түрлі ұйымдарда жұмыс істесе авторлардың тегінің жанына бірдей таңба және тиісті ұйымды қою қажет, авторлардың электронды поштасы, орсид номері түсуі қажет) - ортаға, курсив.

- Андатпа түп нұсқа тілінде (150-300 сөз; мақала құрлымын сақтай отырып), өлшемі (кегль) -11

- Кілт сөздер - қазақ, орыс, ағылшын тілдерінде (3-5 сөз/сөз тіркестері), өлшемі (кегль) 11.

- Негізгі мәтін (аралық интервал - 1, «азат жол» - 1,25 см) құрылымы:

1) кіріспе: тақырыптың таңдалуын негіздеу, тақырыптың немесе мәселенің өзектілігі, объектіні, тақырыпты, мақсаттарды, міндеттерді, әдістерді, тәсілдерді, гипотезалар мен жұмыстың маңыздылығын анықтау.

2) әдебиетке шолу: шетел авторларының ағылшын тіліндегі зерттеліп отырған тақырыбы бойынша іргелі және жаңа еңбектер, осы еңбектерді олардың ғылыми үлесі тұрғысынан талдау, сондай-ақ өз мақаласында толықтыратын зерттеудегі олқылықтар қамтылуға тиіс. Жұмысқа қатысы жоқ көптеген сілтемелердің болуына немесе автор өз жетістіктері туралы орынсыз пікірлер, алдыңғы жұмыстарға сілтемелер жасауына тыйым салынады.

3) зерттеу материалдары мен әдістері: материалдар мен жұмыс барысы сипаттамасынан, сондай-ақ пайдаланылған әдістердің толық сипаттамасынан тұруы тиіс. Бұл бөлімде мәселенің қалай зерттелгені сипатталады: бұрын жарияланған белгіленген рәсімдерді қайталамай-ақ егжей-тегжейлі ақпарат; материалдар мен әдістерді пайдалану кезінде жаңалықты міндетті түрде енгізе отырып, жабдықты (бағдарламалық жасақтаманы) сәйкестендіру және материалдарды сипаттау қолданылады. Кестелер, суреттер айтылғаннан 
кейін орналастырылуы керек. Әр иллюстрациямен жазу (өлшемі (кегль) - 11) болуы керек. Суреттер анық, таза, сканерленбеген болуы керек. Мақалада мәтінде сілтемелер бар формулалар ғана нөмірленеді. Жалпыға мәлім аббревиатуралар мен қысқартуларды қоспағанда, барлық аббревиатуралар мен қысқартулар мәтінде бірінші рет қолданылған кезде ашып жазылуы тиіс. Мәтінде сілтемелер тік жақшада көрсетіледі. Сілтемелер мәтінде қатаң түрде нөмірленуі керек. Мәтіндегі әдебиетке бірінші сілтемеде [1], екіншісі - [2] және т. б. нөмірі болуы тиіс. Мақаланың негізгі мәтініндегі кітапқа сілтеме пайдаланылған беттерді (мысалы, [1, 45 бет]) көрсетумен қоса берілуі тиіс. Жарияланбаған жұмыстарға сілтеме жасауға жол берілмейді. Лицензияланбайтын басылымдарға сілтеме жасауға жол берілмейді.

4) нәтижелер / талқылау: зерттеу нәтижелерін талдау және талқылау келтіріледі.

5) қорытынды/қорытындылар: осы кезеңдегі жұмысты қорытындылау; автор айтқан ұсынылған тұжырымның ақиқатын растау. Қорытындылар белгілі бір ғылыми саладағы зерттеу нәтижелерін жалпылау үшін, ұсыныстарды немесе одан әрі жұмыс істеу мүмкіндіктерін сипаттай отырып қолданылуы керек. Жұмысты қаржылық қолдау туралы ақпарат бірінші бетте сілтеме түрінде көрсетіледі

6) әдебиеттер тізімі (өлшемі (кегль) - 11): әдебиеттер тізімі алфавиттік ретпен ұсынылады, тек мәтінде келтірілген жұмыстар. Әдебиеттер тізімінде кириллицада ұсынылған жұмыстар болған жағдайда әдебиеттер тізімін екі нұсқада ұсыну қажет: біріншісі түпнұсқада, екіншісі - романизацияланған алфавитпен (транслитерация).

Романизацияланған әдебиеттер тізімі келесі түрде көрінуі керек: автор (лар) (транслитерация) $\rightarrow$ (жақшадағы жыл) $\rightarrow$ транслитерацияланған нұсқадағы мақала атауы [мақала атауын ағылшын тіліне квадрат жақшамен аудару], орыс тіліндегі дереккөздің атауы (транслитерация немесе ағылшын атауы-бар болса), ағылшын тіліндегі белгілері бар.

Мысалы: Chicago Style бойынша: Gokhberg L., Kuznetsova T. (2011) Strategiya-2020: novye kontury rossiiskoi innovatsionnoi politiki [Strategy 2020: New Outlines of Innovation Policy]. Foresight-Russia, vol. 5, no 4, pp. 8-30.

ГОСТ бойынша: Кохберг Л., Кузнецова Т. Стратегия-2020: новые контуры российской инновационной политики // Foresight-Russia. - T. 5, № 4. - C. 8-30.

Қазақ және орыс тілдеріндегі әдебиеттер тізімін рәсімдеу стилі ГОСТ 7.1-2003 сәйкес: «Библиографическая запись. Библиографическое описание. Общие требования и правила составления». Романизацияланған әдебиеттер тізімін, сондай-ақ әлеуметтік-гуманитарлық бағыттарға арналған ағылшын (басқа шет) тіліндегі дереккөздерді безендіру стилі-American Psychological Association (http://www.apastyle.org/), жаратылыстану және техникалық бағыттар үшін-Chicago Style (www.chicagomanualofstyle.org).

Авторлар туралы мәліметтер: (автордың(лардың) аты-жөні, ұйымның толық атауы, қаласы, елі, байланыс деректері: телефоны, эл.пошта) 3 тілде (мақаламен бірге жіберілуі қажет). Сонымен қатар, мақаланы журналда жариялау төлемін растайтын құжат. Төлем сараптамадан өткеннен кейін ғана жүргізіледі (қараңыз. http://korkyt.kz/vestnik). «Қорқыт Ата атындағы Қызылорда университетінің Хабаршысы» журналында мақалаларды жариялау үшін ақы төлеу. Қорқыт Ата атындағы Қызылорда университетінің қызметкерлеріне - 5000 теңге, магистранттары мен докторанттарына - тегін), өзге ұйымдардың авторларына - 5000 теңге (төлемақы жөнінде өзгерістер болуы мүмкін).

Университеттің мекен-жайы: 120014, Қазақстан Республикасы, Қызылорда қаласы, Әйтеке би көшесі, 29а. Қорқыт Ата атындағы Қызылорда университеті, бас ғимарат, каб. 303, тел. 8(7242) 27-60-27

«Қорқыт Ата атындағы Қызылорда университеті» КеАҚ

Реквизиттер: Қазақстан Халық банкі АҚ.

PHH 331000037638

БИН: 960540000620

БИК НSBККZКХ

ИИК KZ276017201000000125

КБЕ-16. 
Кудияров Р. И., Дямуршаева Э.Б., Сауытбева Г.З., Дямуриаева Г.Е.

Арал өңірінің жылыжайларында қызанақ өсіру үшін бейімделген аз көлемді технологияны қолдану тиімділігі

Баринов В.Э., Длимбетов М. К., Кенжебаев С. $А$.

Қазақстанның Оңтүстік батыс аймағына ірі қара малының биологиялық бейімделу ерекшеліктері

Есімов Е.К., Султанбекова П.С., Шаянбекова Б.Р., Омаров Қ.Ә., Буланбаева П.У.

Оңтүстік аймақта ауыл шаруашылығын орналастыру және дамытудың негіздері мен әлеуметтік-экономикалық нәтижелері

Длимбетов М. К., Кенжебаев С. А.

Қазақстанның Оңтүстік-батысы жағдайында ірі қара малынның өсімін молайту қабілеті

ЖАРАТЫЛЫСТАНУ ЖӘНЕ ТЕХНИКАЛЫК ГЫЛЫМДАР СЕРИЯСЫ

Сейтмұратов А.Ж.

Физика-математика ғылымдары

Бисызықты заң бойынша қозғалмалы үстеме жағдайындағы жазық есептер тобы Алпысов А.К., Сейтханова А.К., Абишова И.Ш.

Құрылымы әртүрлі теңдеулер мен теңсіздіктерді шешудің типтік кластар әдісі 46

\section{Химия ғылымдары}

Балықбаева Г.Т., Тапалова А.С., Абызбекова Г.М., Еспенбетова Ш.О., Арынова K.U.

Бейорганикалық химия мәселесі - оқыту негізі

Үркімбаева П.И.

Акрилаттар негізіндегі жаңа дифильді сополимерлердің синтезі және 74 сипаттамалары

\section{Биология ғылымдары}

\section{Ибадуллаева С.Ж.}

Қызылорда облысының тұрғындарында жалпы ақуыз концентрациясының функционалдық өзгерістері

Ауезова Н.С., Ибраева С.С.

Стевия сығындысымен дайындалатын сүтқышқылды өнім алудың мүмкіндігі

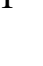




\begin{tabular}{|c|c|}
\hline $\begin{array}{l}\text { Курбаналиев Б.Б., Жумагулов Ж.Б., Сапарбаев Е.Т., Черикбаев Р.К. } \\
\text { Техникалық сервис орталықтарындағы мәселелер мен инновациялық қызмет } \\
\text { түрлерінің перспективасы }\end{array}$ & 127 \\
\hline \multicolumn{2}{|l|}{ Ақпараттама, есептеу техникасы және басқару } \\
\hline $\begin{array}{l}\text { Дәуітбаева A.O., Мырзамуратова А.A., Бексейтова } \boldsymbol{A . Б} \text {. } \\
\text { Толықтырылған шындық ортасында интерактивті визуализация технологиясы }\end{array}$ & 137 \\
\hline $\begin{array}{l}\text { Aхметов Б.С., Лахно В.А., Кыдыралина Л.М. } \\
\text { Оқу орындарының ақпараттық кеңістігінің киберқорғау саласындағы алдыңғы } \\
\text { зерттеулерге шолу және талдау }\end{array}$ & 143 \\
\hline \multicolumn{2}{|l|}{ БІЛІМ, ГУМАНИТАРЛЫК ЖӘНЕ ӘЛЕУМЕТТІК ҒЫЛЫМДАР СЕРИЯСЫ } \\
\hline \multicolumn{2}{|l|}{ Филология ғылымдары } \\
\hline $\begin{array}{l}\text { Жанберииева Ұ., Кудайбергенова К.T. } \\
\text { Қазақ поэзиясындағы Абылай хан бейнесі }\end{array}$ & 152 \\
\hline $\begin{array}{l}\text { Aхметбек } \boldsymbol{\Gamma} \text {., Kумашкызы } \boldsymbol{A} \text {. } \\
\text { Қытай ғаламтор тілі мен әлеуметтік желідегі сленгтердің прагматикасының } \\
\text { зерттелуі }\end{array}$ & 160 \\
\hline $\begin{array}{l}\text { Eciмoва } \boldsymbol{\Gamma} . \boldsymbol{A} \text {. } \\
\text { Шетел және Қазақстан журналистерінің халықаралық қатынастар мәселесін } \\
\text { жазудағы құқықтық жауапкершілігі }\end{array}$ & 169 \\
\hline $\begin{array}{l}\text { Axметбек } \Gamma \text {., Жеңіс } \boldsymbol{A} \text {. } \\
\text { Қытай тіліндегі предлог сөздермен қатысты синонимдердің ерекшеліктері }\end{array}$ & 175 \\
\hline \multicolumn{2}{|l|}{ Педагогика ғылымдары } \\
\hline $\begin{array}{l}\text { Абадилдаева Ш., Искакова } \boldsymbol{A} \text {. } \\
\text { Орта білім беруде қашықтықтан оқытуды ұйымдастырудың тиімді жолдары }\end{array}$ & 183 \\
\hline $\begin{array}{l}\text { Қозыбай } \boldsymbol{A . K . , ~ Ж а н б е к о в а ~} \boldsymbol{\Gamma . И .} \\
\text { Жоғары оқу орындарында болашақ техникалық мамандарды дайындауда физика } \\
\text { курсы мазмұнының маңызды мәселелері }\end{array}$ & 194 \\
\hline $\begin{array}{l}\text { Зубайраева З.А., Касимбекова Б.А., Аубакирова А.А., Жакупова А.Б., Иианова } \\
\text { А.А. } \\
\text { Халықтық педагогика тұжырымдамасын қалыптастыру және оның сипаттық } \\
\text { ерекшеліктері }\end{array}$ & 201 \\
\hline $\begin{array}{l}\text { Якубова Д. Э., Сапарқызы Ж. } \\
\text { Қосымша кәсіптік білім беруде жоо оқытушысының инновациялық әлеуетін } \\
\text { дамыту }\end{array}$ & 208 \\
\hline Экономикалық ғылымдар & \\
\hline $\begin{array}{l}\text { Смагулова Ж.Б., МухановаА.E. } \\
\text { Кластерлер заманауи экономиканың субъектісі ретінде }\end{array}$ & 214 \\
\hline 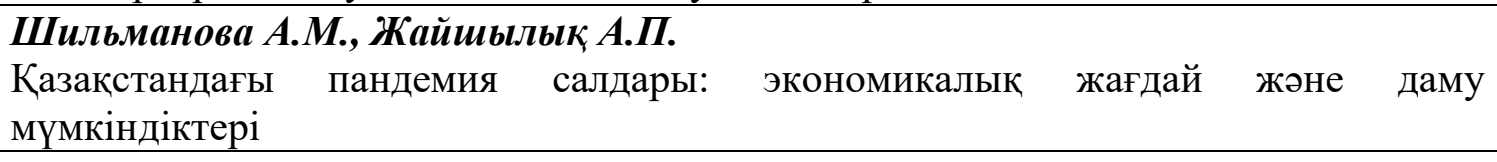 & 222 \\
\hline
\end{tabular}




\section{СЕРИЯ СЕЛЬСКОХОЗЯЙСТВЕННЫХ НАУК}

\section{Сельскохозяйственные науки}

\section{Кудияров Р.И., Дямуршаева Э.Б., Сауытбева Г.З., Дямуриаева Г.Е.}

Эффективность применения адаптированной малообъемной технологии для выращивания томата в теплицах Приаралья

Баринов В.Э., Длимбетов М.К., Кенжебаев С.А.

Биологические признаки приспособление мясных пород скота в условиях Юго Запада Казахстана

Есимов Е.К., Султанбекова П.С., Шаянбекова Б.Р., Омаров К.А., Буланбаева П.У.

Основы и социально-экономические результаты размещения и развития сельского хозяйства в Южном регионе

Длимбетов М.К., Кенжебаев С.А.

Воспроизводительные способности мясных пород скота в условиях Юго-Запада Казахстана

\section{СЕРИЯ ЕСТЕСТВЕННЫХ И ТЕХНИЧЕСКИХ НАУК}

\section{Физико-математические науки}

\section{Сейтмұратов А.Ж.}

Класс плоских задач о воздействии подвижных нагрузок при нелинейном законе Алпьсов А.К., Сейтханова А.К., Абишова И.Ш.

Типовые классовые методы решения уравнений и неравенств с различными 53 структурами

\section{Химические науки}

Балыкбаева Г.Т., Тапалова А.С., Абызбекова Г.М., Еспенбетова Ш.О., Арынова 63 K.U.

Проблемы неорганической химии основа обучения

Уркимбаева П.И.

Синтез и характеристика новых дифильных сополимеров на основе акрилатов

\section{Биологические науки}

\section{Ибадуллаева С.Ж.}

Функциональные изменения концентрации общего белка у жителей

Кызылординской области

Ауезова Н.С., Ибраева С.С.

Возможность производства молочных продуктов с экстрактом стевии

Технические науки

\section{Танжарыков П.А., Сарабекова У.Ж., Жиенбекова Ж.Е., Жұмабек Ж.}

Производственные риски в нефтегазовой отрасли

Титов М.М., Еримбетов К.А.

Разработка дорожного покрытия на основе промышленных отходов

Мустафаев М.Г., Бекжанов С.Ж., Дуйсембеков Б.А., Култасов Б.ШІ, Шарипова

H.E.

Результаты предварительных испытаний зерноуборочного комбайна ловол GM-80 
Курбаналиев Б.Б., Жумагулов Ж.Б., Сапарбаев Е.Т., Черикбаев Р.К.

Проблемы технического сервиса и перспективы инновационных методов

Информация, компьютерные технологии и управление

Даутбаева А. О., Мырзамуратова А.А., Бексейтова А.Б.

Технология интерактивной визуализации в среде дополненной реальности

Ахметов Б.С., Лахно В.А., Кьдыралина Л.М.

Обзор и анализ дополнительных исследований в области киберзащиты

информационного пространства образовательных учреждений

\section{СЕРИЯ ОБРАЗОВАНИЯ И ГУМАНИТАРНО-СОЦИАЛЬНЫХ НАУК}

\section{Филологические науки}

Жанбершиева Ұ., Кудайбергенова К.Т.

Образ Абылай хана в казахской поэзии

Ахметбек Г., Кумашкызы $А$.

Изучение прагматики сленга в китайском интернет-языке и социальных сетях

Есимова $\Gamma$. $A$.

Правовая ответственность зарубежных и казахстанских журналистов в освещении вопросов международных отношений

Ахметбек Г., Жеңіс $A$.

Особенности синонимов к предлогам в китайском языке

\section{Педагогические науки}

Абадилдаева Ш.К., Искакова А.Ж.

Эффективные пути организации дистанционного обучения в среднем образовании

Козыбай А.К., Жанбекова Г.И.

Важнейшие вопросы содержания курса физики при подготовке будущих технических специалистов в вузах

Зубайраева З.А., Касимбекова Б.А., Аубакирова А.А., Жакупова А.Б., Иианова A. $A$.

Формирование концепции народной педагогики и ее характерные особенности

Якубова Д. Э., Сапаркызы Ж.

Развитие инновационного потенциала преподавателей вузов в дополнительном профессиональном образовании

\section{Экономические науки}

Смагулова Ж.Б., МухановаА.Е.

Кластеры как субъект современной экономики

Шильманова А.М., Жайшылык А.П.

Последствия пандемии в Казахстане: экономическое состояние и возможности 


\section{CONTENT}

\section{SERIES OF AGRICULTURAL SCIENCES}

\section{Agricultural science}

\section{Kudiyarov R.I., Dyamurshayeva E.B., Sauytbayeva G.Z., Dyamurshayeva G.E.}

The effectiveness of the adapted low-volume technology for growing tomatoes in greenhouses in the aral sea regionannotation

Barinov V.E., Dlymbetov M.K., Kenzhebaev S.A.

Biological signs adaptation of meat breeds of livestock in the conditions of southwest kazakhstan

Yessimov E.K., Sultanbekova P.S., Shayanbekova B.R., Omarov K.A., Bulanbayeva P.U.

Fundamentals and socio-economic results of the placement and development of agriculture in the southern region

Dlymbetov M.K., Kenzhebaev S.A.

Reproductive abilities of meat breeds of livestock in the conditions of South-West 41 Kazakhstan

\section{SERIES OF NATURAL AND TECHNICAL SCIENCES}

\section{Seitmuratov A.Zh.}

Physical and mathematical sciences

Class of plane problems on the effect of moving loads under a nonlinear law

Alpysov A.K., Seytkhanova A.K., Abishova I.Sh.

Typical class methods for solving equations and inequalities with different structures

\section{Chemical sciences}

Balykbaeva G.T., Tapalova A.S., Abyzbekova G.M., Espenbetova Sh.O., Arynova K.Sh.

Inorganic chemistry problem-based learning

Urkimbaeva P.I.

Synthesis and characterization of acrylate-based diphilic copolymers

\section{Biological Sciences}

\section{Ibadullayeva S.Zh.}

Functional changes in the concentration of total protein in residents of the kyzylorda region

Auezeva N.S., Ibraeva S.S.

Possibility of production of dairy products with stevia extract

Technical science

Tanzharykov P.A., Sarabekova U.Zh., Zhienbekova Zh.E., Zhumabek Zh.

Production risks in the oil - gas industry

Titov M.M., Yerimbetov K.A.

Development of road surface based on local raw materials and industrial waste

Mustafaev M.G., Bekzhanov S.Zh., Duisembekov B.A., Kultasov B.Sh., Sharypova N.E.

Preliminary test results grain harvester lovol GM-80

Kurbanaliev B.B., Zhumagulov Zh.B., Saparbayev E.T., Cherikbaev R.K.

Problems of technical service and innovative methods perspective 


\begin{tabular}{|c|c|}
\hline Informatics, computer engineering and management & \\
\hline $\begin{array}{l}\text { Dauitbayeva A.O., Myrzamuratova } A . A ., \text { Bexeitova } A . B . \\
\text { Interactive visualization technology in augmented reality }\end{array}$ & 138 \\
\hline $\begin{array}{l}\text { Akhmetov B.S., Lakhno V.A., Kydyralina L.M. } \\
\text { Review and analysis of advanced research in the field of cyber protection of information } \\
\text { space of educational institutions }\end{array}$ & 143 \\
\hline \multicolumn{2}{|l|}{ EDUCATION, HUMANITIES AND SOSIAL SCIENCES SERIES } \\
\hline \multicolumn{2}{|l|}{ Philological science } \\
\hline $\begin{array}{l}\text { Zhanbershieva } \text { U., Kudaibergenova K.T. } \\
\text { The image of abylai khan in kazakh poetry }\end{array}$ & 152 \\
\hline $\begin{array}{l}\text { Akhmetbek G., Kumashkyzy } \boldsymbol{A} \text {. } \\
\text { Study of the pragmatics of chinese internet language and slang in social networks }\end{array}$ & 160 \\
\hline $\begin{array}{l}\text { Yessimova G.A. } \\
\text { Legal responsibility of foreign and kazakh journalists in covering issues of international } \\
\text { relations }\end{array}$ & 169 \\
\hline $\begin{array}{l}\text { Akhmetbek G., Zhenis } \boldsymbol{A} \text {. } \\
\text { Features of synonyms in relation to prepositions in chinese }\end{array}$ & 175 \\
\hline \multicolumn{2}{|l|}{ Pedagogical sciences } \\
\hline $\begin{array}{l}\text { Abadildaeva Sh.K., Iskakova } \boldsymbol{A . Z h} \text {. } \\
\text { Effective ways of organizing distance learnig in secondary education }\end{array}$ & 183 \\
\hline $\begin{array}{l}\text { Kozibay A.K., Zhanbekova G.I. } \\
\text { Important issues of the content of the physics course in the training of future technical } \\
\text { specialists in higher educational institutions }\end{array}$ & 194 \\
\hline $\begin{array}{l}\text { Zubairaeva Z.A., Kasimbekova B.A., Aubakirova A.A., Zhakupova A.B. } \\
\text { Formation of the concept of folk pedagogy and its characteristic features }\end{array}$ & 201 \\
\hline $\begin{array}{l}\text { Yakubova D.E., Saparkyzy Zh. } \\
\text { Development of the innovative potential of university teachers in additional professional } \\
\text { education }\end{array}$ & 208 \\
\hline \multicolumn{2}{|l|}{ Economic Sciences } \\
\hline $\begin{array}{l}\text { Smagulova Zh.B., Mukhanova A.E. } \\
\text { Clusters as a subject of modern economy }\end{array}$ & 214 \\
\hline $\begin{array}{l}\text { Shilmanova A.M., Zhaishylyk A.P. } \\
\text { Consequences of the pandema in kazakhstan: economic condition and development } \\
\text { opportunities }\end{array}$ & 222 \\
\hline
\end{tabular}




\section{Қорқыт Ата атындағы \\ Қызылорда университетінің ХАБАРШЫСЫ}

\section{ВЕСТНИК \\ Кызылординского \\ университета имени \\ Коркыт Ата}

\author{
BULLETIN \\ of the Korkyt Ata \\ Kyzylorda \\ University
}

\author{
1999 жылғы наурыздан бастап шығады \\ Издается с марта 1999 года \\ Published since March 1999
}

\author{
Жылына төрт рет шығады \\ Издается четыре раза в год \\ Published four a year
}

Редакция мекенжайы: 120014, Қызылорда қаласы, Әйтеке би көшесі, 29 «А»,

Қорқыт Ата атындағы Қызылорда университеті

Телефон: (7242) 26-17-95 Факс: 26-27-14

E-mail: khabarshy@korkyt.kz
Адрес редакции: 120014, город Кызылорда, ул. Айтеке би, 29 «А»,

Кызылординский университет им. Коркыт Ата

Телефон: (7242) 26-17-95 Факс: 26-27-14

E-mail: khabarshy@korkyt.kz
Address of edition: 120014, Kyzylorda city, 29 «A» Aiteke bie str., Korkyt Ata Kyzylorda University

Tel: (7242) 26-17-95

Fax: 26-27-14

E-mail: khabarshy@korkyt.kz

\title{
Құрылтайшысы: Қорқыт Ата атындағы Қызылорда университеті Учредитель: Кызылординский университет им. Коркыт Ата Founder: Kyzylorda University named after Korkyt Ata
}

Қазақстан Республикасының Ақпарат және қоғамдық келісім министрлігі берген 3032-Ж бұқаралық ақпарат құралын есепке алу куәлігі (№ KZ 75VPY00039225 25-тамыз, 2021 ж), 14-маусым, 2002ж.

Техникалық редакторы: Абуова Н.А.

Компьютерде беттеген: Кулманова С.А.

Теруге 05.10.2021 ж. жіберілді. Басуға 19.10.2021 ж. қол қойылды. Форматы $60 \times 841 / 8$. Көлемі 15,75 шартты баспа табақ. Индекс 76077 . Таралымы 300 дана.

Тапсырыс 0138. Бағасы келісім бойынша.

\author{
Сдано в набор 05.10.2021 г. Подписано в печать 19.10.2021 г. Формат 60 × 841/8. \\ Объем 15,75 усл. печ. л. Индекс 76077. \\ Тираж 300 экз. Заказ 0139. Цена договорная.
}

\footnotetext{
Жарияландан мақала авторларының пікірі редакция көзқ̧арасын білдірмейді. Мақ̧ала мазмұнына автор жауап береді. Қолжазбалар өңделеді және авторва қайтарылмайды. «ХАБАРШЫДА» жарияланван материалдарды сілтемесіз көшіріп басува болмайды. 